(1)

W

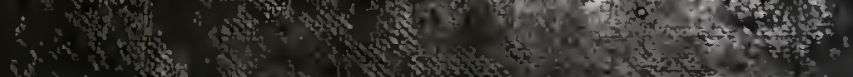

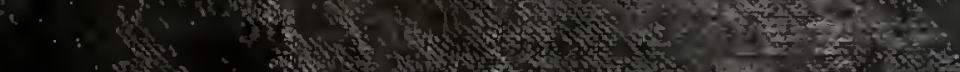

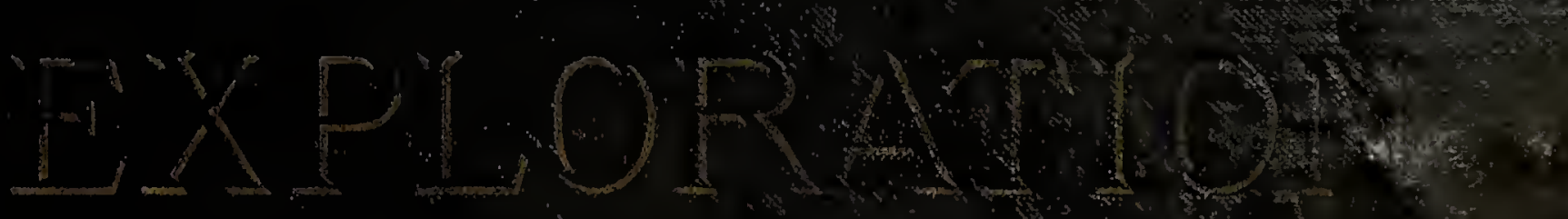

C)
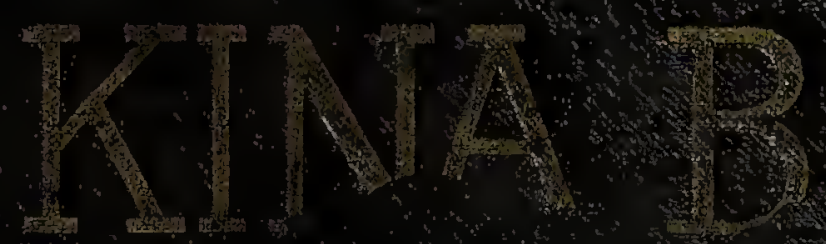

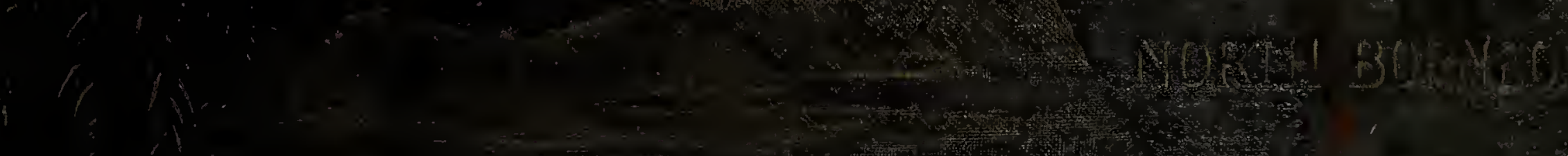

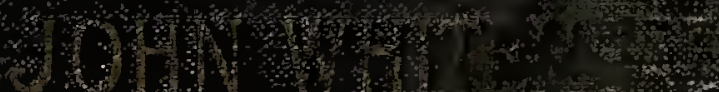

2. sinen 


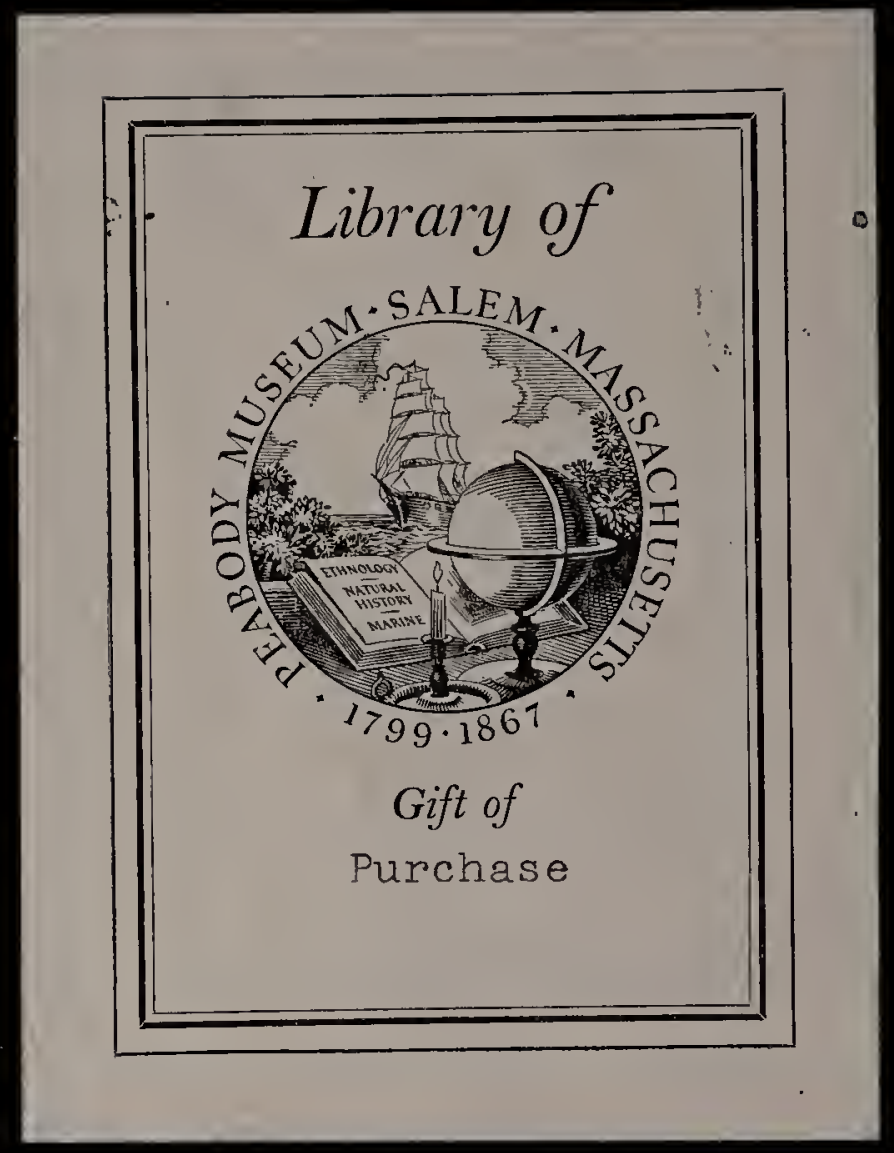




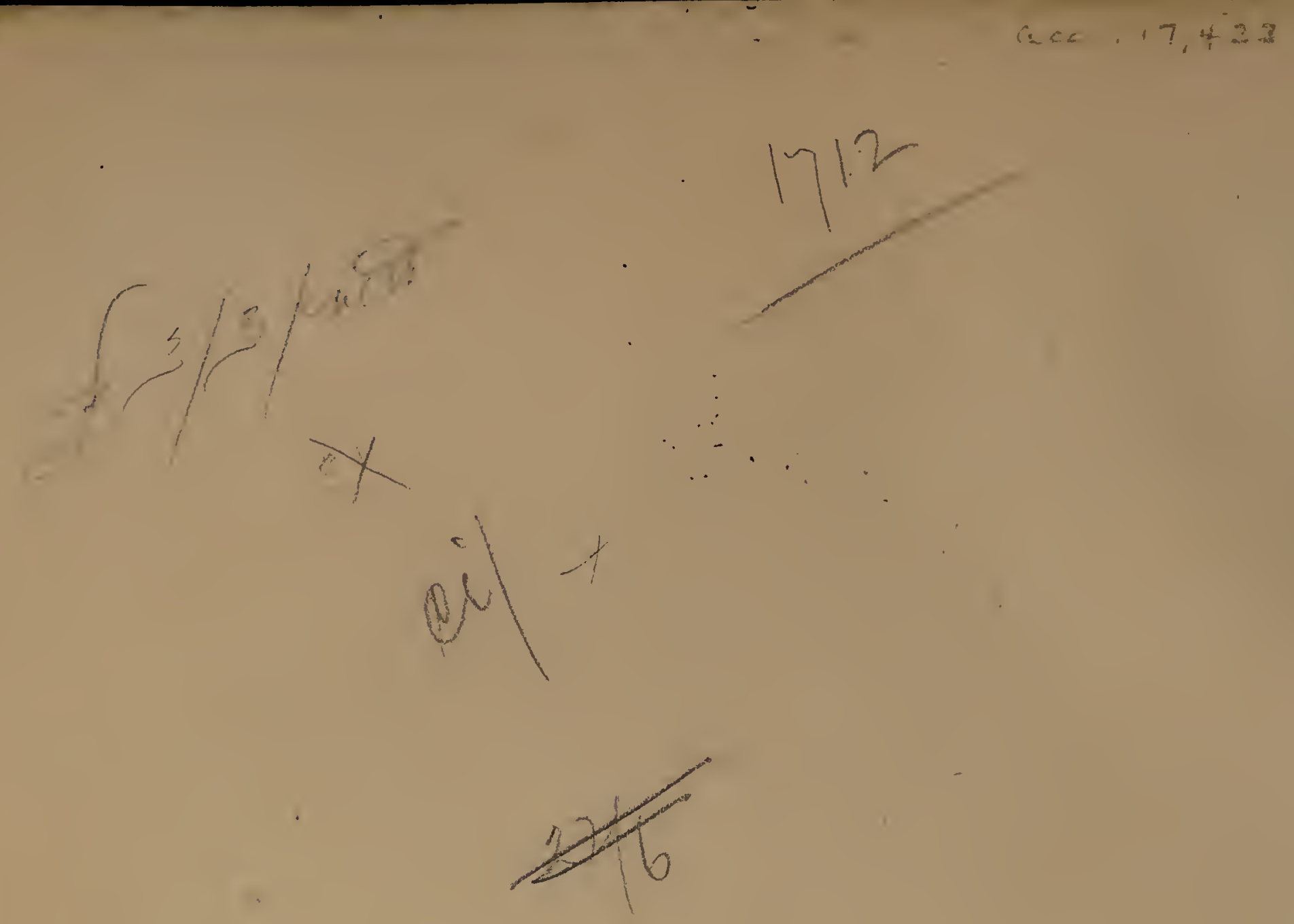

$10 / 6$ 



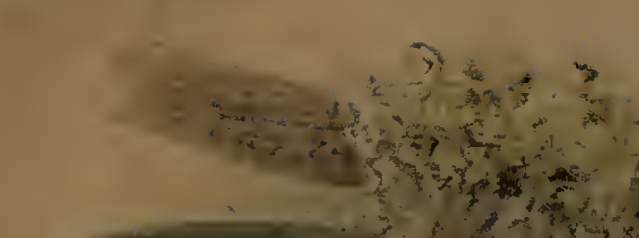

th

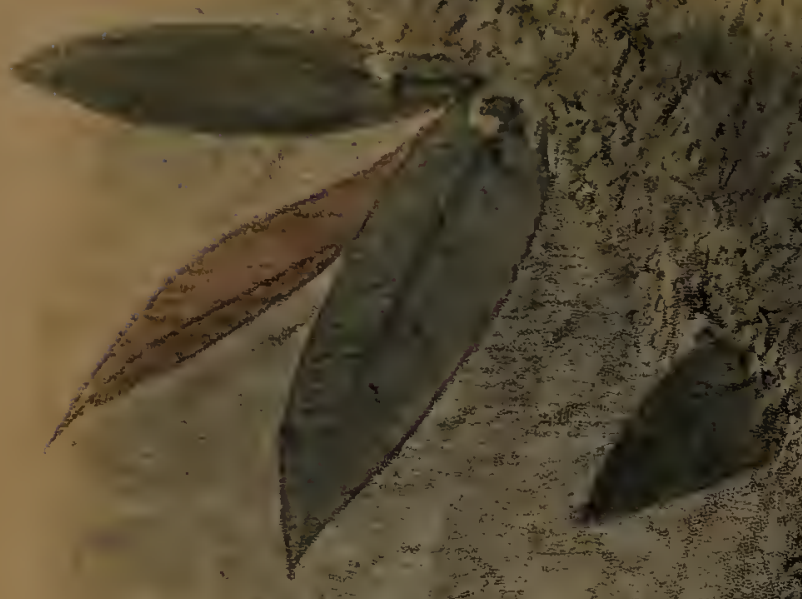

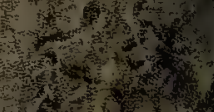

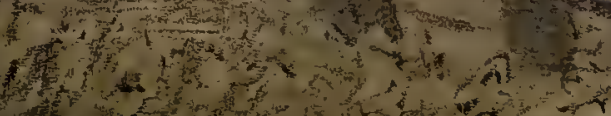

5

- $21 \mathrm{TSt}$

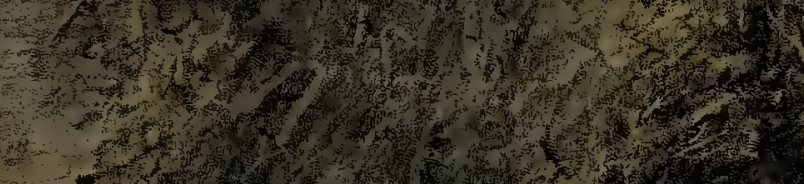
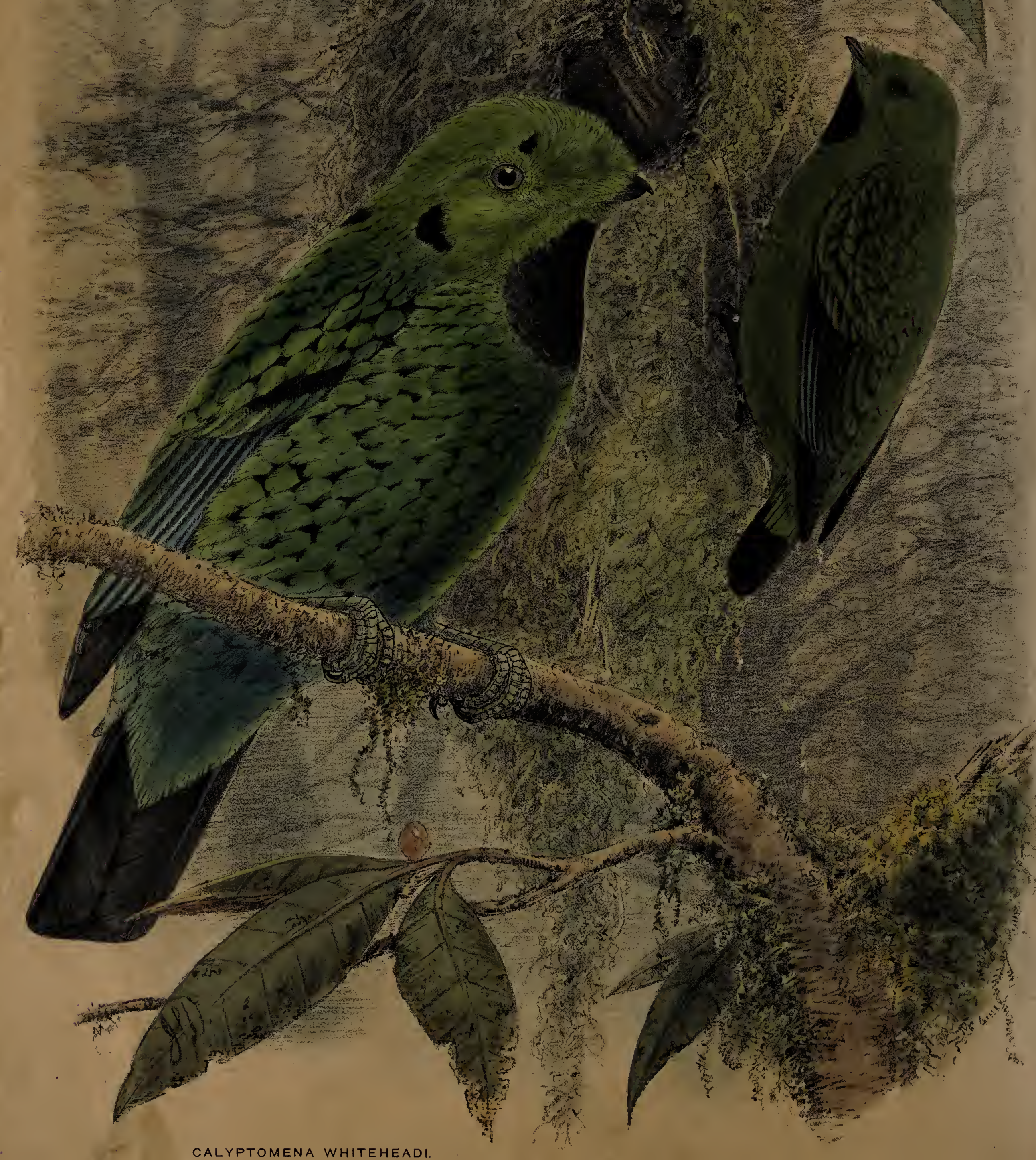

CALYPTOMENA WHITEHEADI. 


\section{EXPLORATI0N}

\section{$\mathrm{OF}$ \\ MOUNT KINA BALU, NORTH BORNEO.}

BY

J OHN WHITEHEAD.

WITH COLOURED PLATES AND ORIGINAL ILLUSTRATIONS.

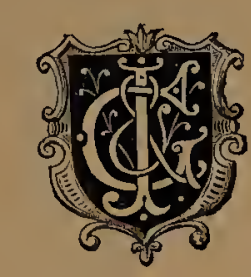

L ON DON :

GURNEY AND, JACKSON, 1 PATERNOSTER ROW, E.C. (Successors to JOHN VAN VOOHST.)

1893.

[All rights reserved.] 
5 


\section{N TR O D U C T.I $0 \mathrm{~N}$.}

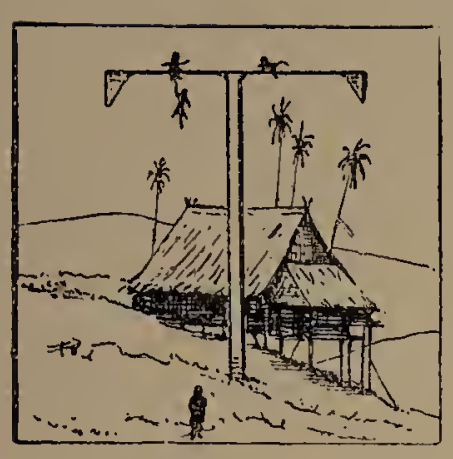

HE chief aim of my Eastern travels was, as the title of this volume proclaims, "The Exploration of Mount Kina Balu," in Northern Borneo. This great mountain had hitherto been visited by Messrs. Low, St. JoHv, and Burbidge, for the purpose of botanical investigation-so for the zoologist it was as yet a virgin field. My primary object in undertaking these expeditions was ornithological; but I trust that my readers will not be overburdened with accounts of Tropical bird-life, as I have endeavoured-I hope not in vainto make this volume otherwise interesting.

The success that attended these expeditions may be gauged by an examination of the Appendix, which contains an almost complete account of the collections, with descriptions of the new species obtained.

Besides visiting North Borneo I spent several months in the interesting islands of Java and Palawan, and made an expedition into the State of Malacca, being absent from England nearly four years.

The exploration of the mountainous interior of most tropical islands is by no means an easy task. In the first place, the means of communication are almost nil. After the level coast plains are left the slow-travelling buffalo is no longer useful, and man himself becomes the beast of burden; and of all beasts, he is perhaps the most difficult to manage. The highway from the coast is generally up the river-courses, which are choked with boulders, and have to be crossed and recrossed as many as ten or fifteen times a day. The fords are often dangerous and at times impassable, owing to the deluges of rain which fall on the mountains. Progress is therefore slow indeed, and is at times brought to a complete standstill. Food can be procured only with the greatest difficulty, and the further the coast 
is left behind the greater does this difficulty become, until when the villages of the mountaineers are reached it is impossible to purchase rice in quantity even directly after the harvest. This necessitates the conveyance of a tremendous amount of baggage from the coast if the expedition is to remain any length of time inland, which to be zoologically successful it must do.

The equatorial regions are noted for their great rainfall; but that of the equatorial mountain regions may be said to be almost continuous, averaging perhaps six hours out of every twelve of daylight; the nights, however, are generally clear and cold.

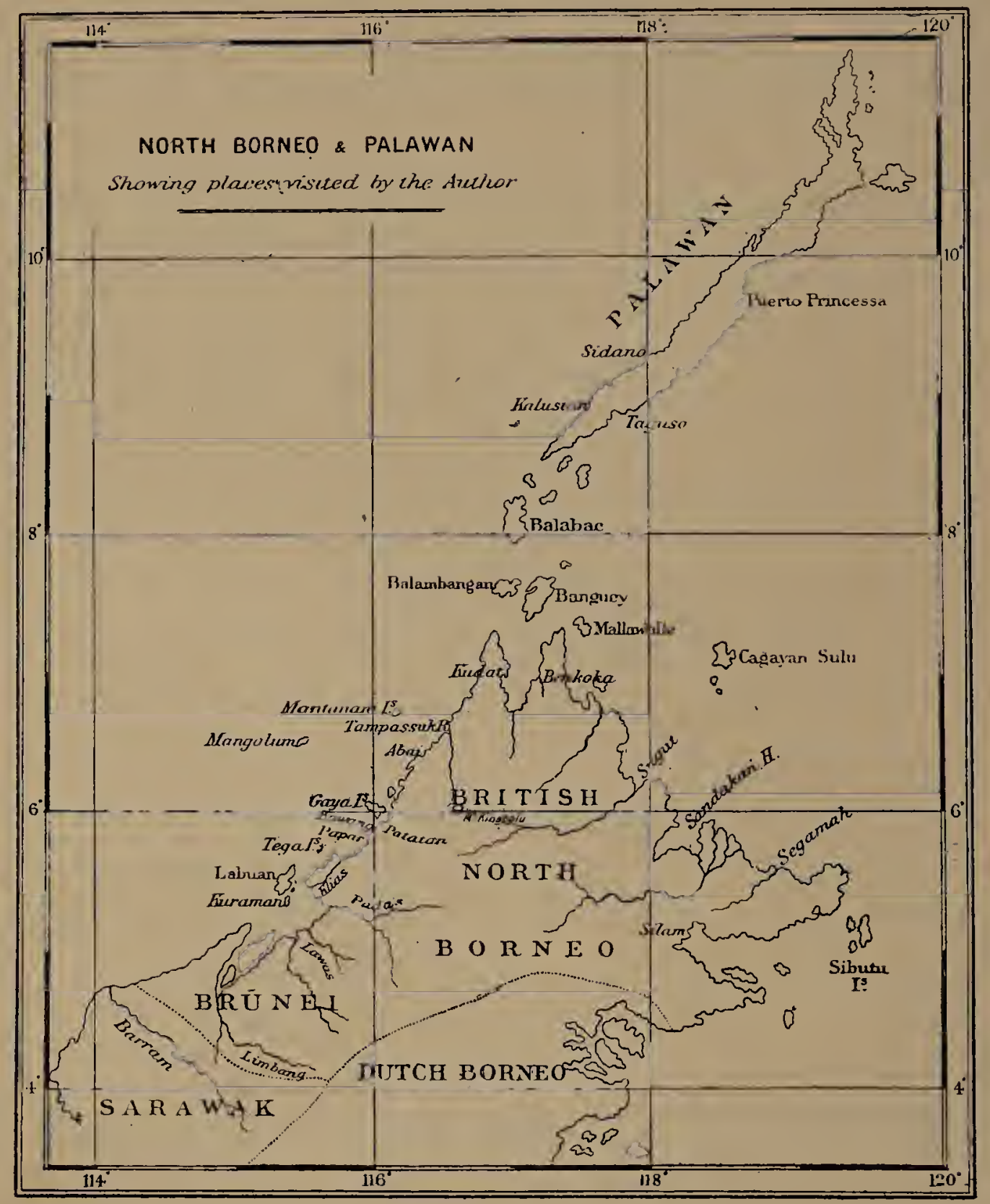

The utter indifference shown by the aborigines of these countries as regards the value of time is often more than annoying-to-day, to-morrow, or the next day being all the same to them. Then, again, their curious superstitions at times make them openly hostile to 
the traveller's progress, added to which a hundred petty troubles bar his path in every direction. Still these very difficulties make success when attained infinitely sweeter. My failure to reach Kina Balu on two occasions was due to the disturbed state of the inland tribes and the punitive police expeditions sent against them by the British North Borneo Company.

The accompanying map will give my readers some idea as to the positions of the localities visited by me in North Borneo and Palawan.

I must apologize for the somewhat cumbersome shape of my volume, but I have sacrificed the size for the illustrations, finding it impossible to give topographical drawings on a much smaller scale. The numerous illustrations are from my water-colour sketches made in Borneo and lithographed by myself. I have perhaps given rather too many of Kina Balu, but they will, I feel, assist the reader's imagination of the districts traversed more than pages of descriptive letterpress.

The figures (opposite page 56) of the three reptiles I have copied from Dr. Mocquard's memoir, published in Paris in the 'Nouvelles Archives du Muséum,' 3e série, ii. The first eight figures in the illustration (opposite page 184) of the new beetles are copied from Mr. Waterhouse's 'Aid to the Identification of Insects,' vol. ii. pls. 186, 187; no. 9 is from the 'Proceedings of the Zoological Society', by kind permission; the last three are original drawings.

'The attitudes of several of the birds have been taken from drawings in the 'Ibis' by Mr. J. G. Keulemans.

Our success is greatly due to the assistance of others-mine was no exception to this rule; and to many kind friends, both at home and in the "Far East," I beg to tend my most grateful thanks for kindnesses shown me in the past. As far as the publication of this volume is concerned, Mr. H. E. DrEsser deserves my best thanks for the trouble he has taken in correcting the proof-sheets.

In conclusion, I must crave the indulgence of my readers, and trust that they will take a lenient view of this my first literary effort, for I myself am conscious of my many literary shortcomings. Fssentially and by choice a "field naturalist," I find it far easier to explore an unknown tract of country than to write an account of my researches.

Bickley, Kent, 10th May, 1893.

JOHN WHI'TEHEAD. 



\section{O N T E N T S.}

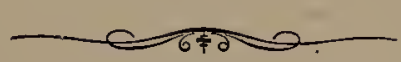

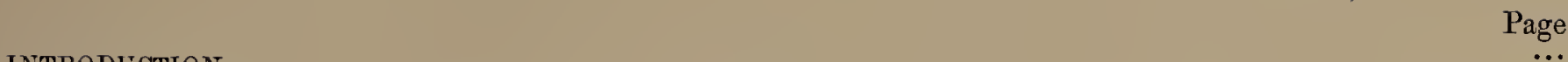
INTRODUCTION LIST OF PLATES LIST OF WOODCUTS . . . . . . . . . . . . . . . . . . . . . . . . . xii

\section{CHAPTER I.}

VOYAGE TO SINGAPORE.-SINGAPORE.--START FOR MALACCA.—ALOR-GAJAH.—ANTS.—EASTERN

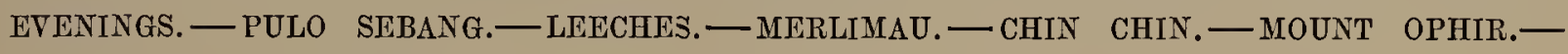
PADANG BATU.—RETURN TO SINGAPORE. . . . . . . . . . . . . . . . . . .

\section{CHAPTER II.}

START FOR BORNEO.—LABUAN.—PULO GAYA.—THE S.S. "SPANIEL" ON A REEF.—ON ANOTHER REEF.—REACH SANDAKAN. - RETURN TO PULO GaYa. - EXPEDition to KiNa. BALU

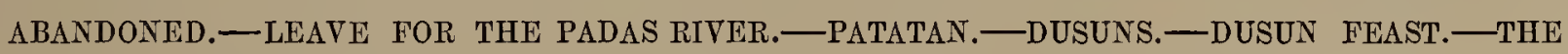
OMEN. - THE KAWANG AMOK. - RETURN TO SANDAKAN WITH THE WOUNDED. - DE FONTAINE'S DEATH. - RETURN TO LABUAN.-PADAS RIVER. - MEMPAKOL. - MANGROVE SWAMPS.—JOURNEY UP THE PADAS.-MOSQUTTOES.-ORANG SUNGEI.-MURUTS.—MUSIC. —CAMP ABOVE THE RAPIDS.- -WANT OF RICE.-RETURN TO LABUAN.—COAL POINT.BIRDS.—WALKING-FISH.—CRABS.-INSECTS . . . . . . . . . . . . . . 19

\section{CHAP'TER III.}

SAIL FOR KUDAT.—BENKOKER RIVER.-OBTAIN A HOUSE.-FAREIGH, THE NEGRO.-BIRDS.ORANG SUNGEI. - MAMMALS. - CROCODILES. - PIGS. - CROCODILE'S NEST. - BANDEIRA'S AMOK.—START FOR KUDAT.—HORNBILL'S NEST.—BEES.—BUTTERFLIES.-SCARCITY OF INDIVIDUALS. - LOW RATE OF INCREASE. - NESTING-HABITS IN THE TROPICS. - FEVER. —WET SEASON SETS IN.-RETURN TO LABUAN . . . . . . . . . . . . . . 41 


\section{CHAPTER IV.}

START FOR KINA BALU.-VIEW OF THE MOUNTAIN FROM ABAI.-DATU TUMANGGONG.-CATTLE-

LIFTING.-START FOR THE TAMPASSUK.-BUFFALOES.—THE DATU'S HOUSE.-BAJOWS.ILANUNS. - FAIL TO FIND PORTERS.-THE TAMPASSUK PLAIN.-DISTURBED STATE OF THE DUSUNS INLAND.-RETURN TO ABAI.-DYAKS.—SULUS.-ARRIVAL OF THE ' KIMANIS.'RETURN TO LABUAN.-THE LAWAS RIVER. - BRUNEIS. - KADYANS. - MURUTS. - VISIT SI'LALANG'S VILLAGE.- HIS TROPHIES.—HEAD-HUNTING.—VISITED BY MURUTS.—BURIAL CUSTOMS.—TATTOOES.-CAVES.—BARK JACKETS.—SUMPITANS.—LUKUTAN RIVER.—COAST TO BATU-BATU.-WANT OF FELLOW-FEELING AMONGST NATIVES.—VOYAGE TO PULO TEGA.NICOBAR PIGEONS.-RETURN TO LABUAN.-VISIT BRUNEI . . . . . . . . . . 57

\section{CHAPTER V.}

YOYAGE TO JAVA.-BATAVIA.-CHINESE IN JAVA.-DUTCH CUSTOMS.-SOURABAYA.-PERMIT TO RESIDE IN JAVA.-JAVAN HIGHLANDS.-TOSARI.-EUROPEAN RESEMBLANCE.-CABBAGEGARDENS.-THE BROMO VOLCANO.—BIRDS.—VISIT TO THE CRATER OF THE BROMO.—LEAVE FOR LAWANG. - PITTA CYANURA. - SINGOSARI. - THE TEMPLE OF BOROBUDDAH. SEMARANG.-CRETURN TO LABUAN . . . . . . . . . . . . . . . . . .

\section{CHAPTER VI.}

MY THIRD START FOR KINA BALU.-DATU TUMANGGONG AGAIN ASSISTS TO THE TAMPASSUK ONLY, —SULTAN PAITAILAN.—OUR INTERPRETER.-GHINAMBUR.—DUSUNS.—FORDING THE RIVER. —BUFFALOES BECOME USELESS.—ANOTHER SULTAN.—SINOROB.—MELANGKAP.—MOUNTAINOUS SURROUNDINGS.-DUSUN HOMES.-CUSTOMS.-COSTUME.-CROHS.-MARKETS.TRAPS. - HOUSEHOLD UTENSILS.-MUSICAL INSTRUMENTS.—WLAPONS.—HOSPITALITY.— IIEALTII. — RELIGION. - HEAD-HUNTING. — MARRIAGE.—BURIAL.—DOMESTIC ANIMALS.LAND.- PAYING PORTERS.—THE SULTAN GUIDES US TO KINA BALU (?).- OUR CAMP.RAMBLES ON THE MOUNTAIN.—BIRDS.-BUTTERFLIES.-FRUG-HUNTERS.-RETURN TO MELANGKAP. - THE POLL (TAX) COW.- WANT OF RICE.-REIURN TO TIIE COAST.PURCHASE A BOAT TO RETURN TO LABUAN.—ZOOLOGICAL RESULTS OF THE EXPEDITION . . 97 


\section{CHAPTER VII}

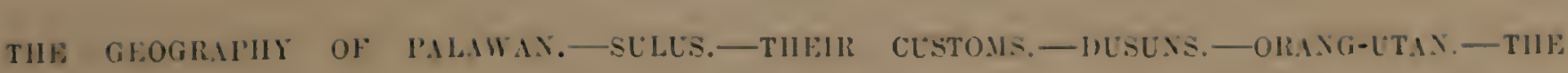

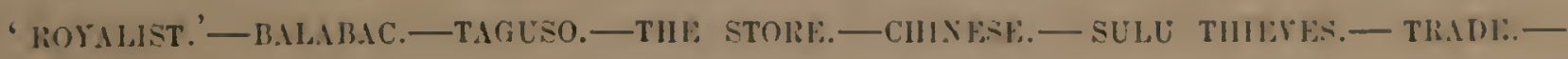

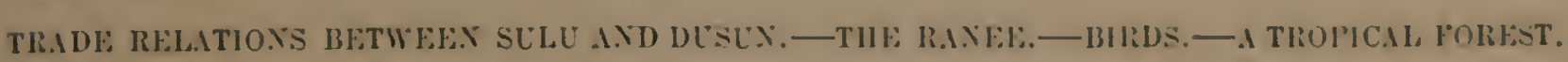

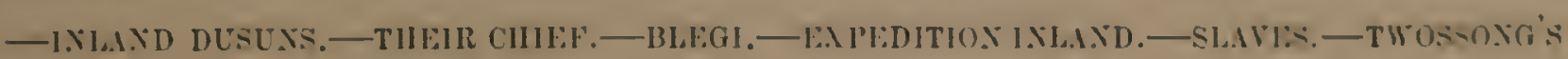
PENDETTA. - RETUR TO BLEGI - MEGAPODE. - HEREDITART RLEAHANCE OF HUT-

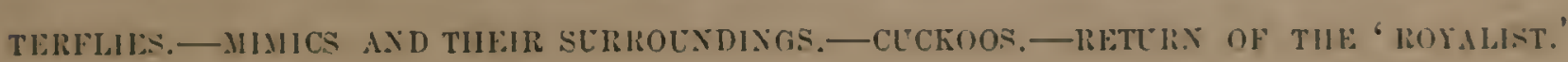
-Visit the conthik colst . . . . . . . . . . . . . . . . . . . 1.27

\section{CHAP'IER VIII.}

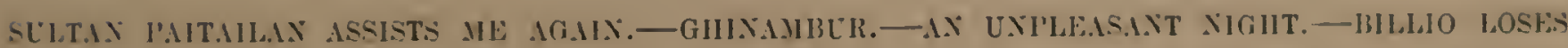

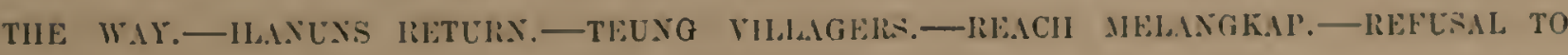

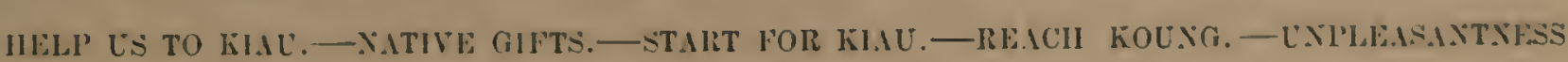

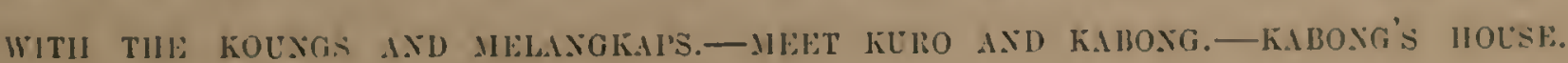
-BLSINISS-LIKE KIALS-START FOR SUMMIT.-FOREST CAMP-LIFE IN SUNLLSS HOLA.-

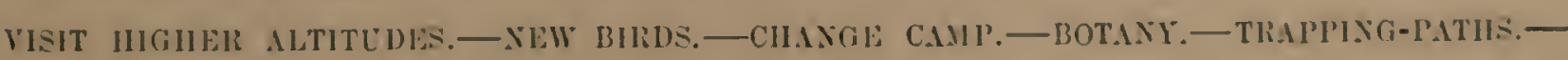

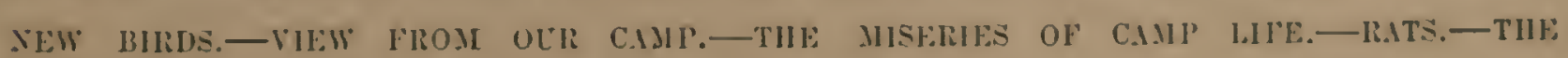

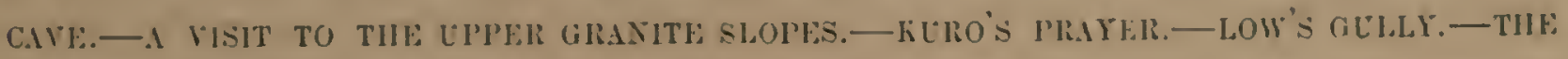

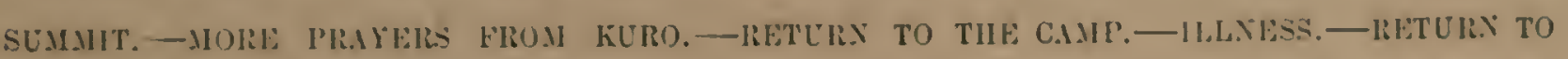

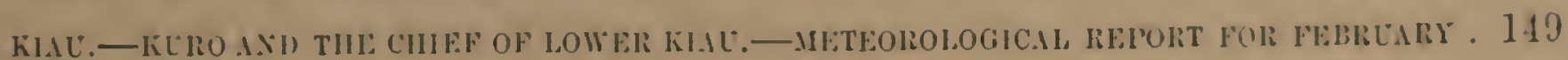

\section{CHAPTER IA.}

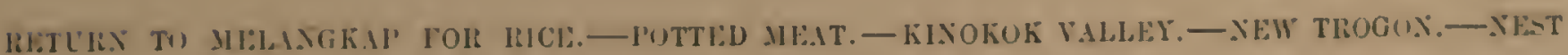

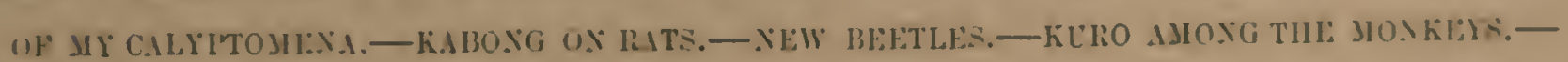

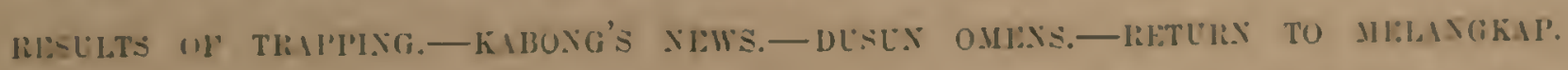

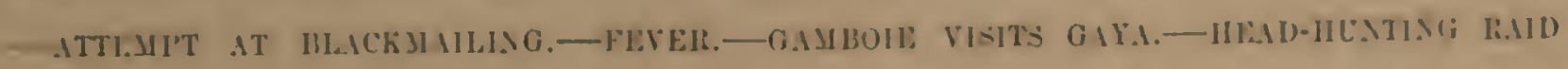

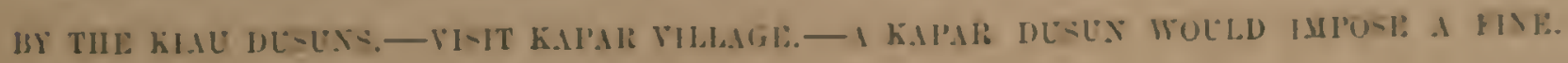




\section{APPENDIX.}

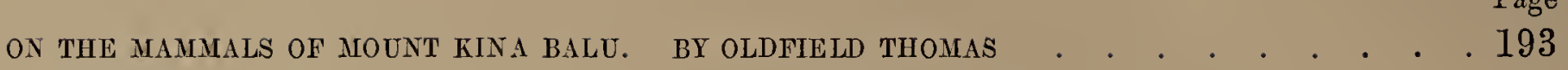

ON THE BIRDS OF NORTH BORNEO. BY DR. R. B. SHARPE AND MR. JOHN WHITEHEAD • . . 200 ON THE BIRDS OF PALAWAN. BY JOHN Whitehead . . . . . . . . . . . . . . 249

NOTES ON A COLLECTION OF BIRDS FROM EASTERN JAVA. BY JOHN WHITEHEAD . . . . . 258

RECHERCHES SUR LA FAUNE HERPÉTOLOGIQUE DES ÎLES DE BORNÉO ET DE PALAWAN. PAR

M. F. MOCQUARD . . . . . . . . . . . . . . . . . . . . . . . 264

SUR UNE COLLECTION DE REPTILES ET DE BATRACIENS DES ÎLES BORNÉO E'T PALAWAN. PAR

F. MOCQUARD . . . . . . . . . . . . . . . . . . . . . . 285

SUR LES POISSONS DES EAUX DOUCES DE BORNÉO. PAR M. LÉON VAILLANT. . . . . . . . . 286

DESCRIPTIONS OF SOME NEW SPECIES OF LAND-SHELLS FROM BORNEO. BY EDGAR A. SMITH • . 287

LIST OF THE LAND-MOLLUSCA COLLECTED BY MR. JOINN WHITEHEAD IN PALAWAN DURING 1887.

BY LIEUT.-COL. H. H. GODWIN-AUSTEN, F.R.S., F.Z.S., ETC. . . . . . . . . . 288

LIST OF FRESHWATER AND BRACKISH-WATER SHELLS COLLECTED BY MR. JOHN WHITEHEAD

in THE ISLAND OF PALAWAN IN 1887. BY LIEUT.-COI. H. H. GODWIN-AUSTEN,

F.R.S., F.Z.S., ETC. . . . . . . . . . . . . . . . . . . . . . . 288

ON NEW GENERA AND SPECIES OF COLEOPTEROUS INSECTS FROM MOUNT KINA BALU, NORTH

BORNEO. BY H. W. BATES, F.R.S., F.Z.S. . . . . . . . . . . . . . . . 289

DESCRIPTIONS OF COLEOPTERA COLLECTED BY MR. JOHN WHITEHEAD ON KINA BALU, BORNEO.

BY THE REV. H. S. GORHAM, F.Z.S. . . . . . . . . . . . . . . . . . 296

DESCRIPTIONS OF SLXTEEN NEIF BUTTERFLIES FROM KINA BALU. BY H. GROSE SMITH • . . 300

DESCRIPTIONS OF NEW SPECIKS OF RHYNCHOTA. BY W. L. DISTANT . . . . . . . . . . 306 


\section{LIST OF PLATES.}

CALYPTOMENA WHITEHEADI

(Frontispiece)

MOUNT OPHIR, MALACCA

Facing page

BRUNEI HOUSES (LABUAN)

KINA BALU, FRON GAYA ISLAND . . . . . . . . . . . . . . . . . . . . . . . 24

FISHERAIEN, NORTH BORNEO . . . . . . . . . . . . . . . . . . . . 30

STOPAROLA CERVINIVENTRIS AND PERICROCOTUS CINEREIGULA . . . . . . . . . . . . 40

"BOUKAR."- -IIY HOME ON THE BENKOKER . . . . . . . . . . . . . . . . . . 42

LEAF-MIMICKING INSECTS, ETC. • . . . . . . . . . . . . . . . . . . . . 50

NEW REPTILES . . . . . . . . . . . . . . . . . . . . . . . . 56

KINA BALU FRON THE TAMPASSUK PLAIN . . . . . . . . . . . . . . . . . . . 58

HINDOO IDOL: SINGOSARI, JAVA.-DATU TUMANGGONG'S HOUSE, TAMPASSUK . . . . . . . . 62

JUURUT WOMAN AND MIURUT WARRIOR (LAWAS RIVER) . . . . . . . . . . . . . 70

NATIVE DECORATIVE WORK . . . . . . . . . . . . . . . . . . . . . 76

CORYTHOCICHLA CRASSA AND HEMIXUS CONNECTENS . . . . . . . . . . . . . . 84

THE SEMEROE (FROM LAWANG), JAVA . . . . . . . . . . . . . . . . . . . 92

CHLORURA BONELNSIS, CRYPTOLOPHA XANTHOPYGIA, AND STAPHIDIA EVERETTI . . . . . 96

KINA BALU, FROM MELANGKAP VILLAGE . . . . . . . . . . . . . . . . 104

DUSUNS (KINA BALU) . . . . . . . . . . . . . . . . . . . . . . 106

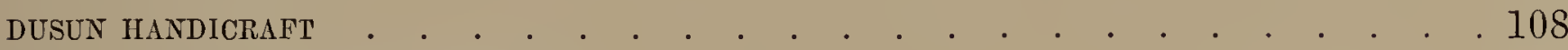

NEW BUTTERFLIES FROM KINA BALU . . . . . . . . . . . . . . . . . . . 118

KINA BALU, FRON NEAR MELANGKAP . . . . . . . . . . . . . . . . . 120

KADYAN WOMAN (LABUAN) AND SULU ISLANDERS (PALAWAN) . . . . . . . . . . . 128

SUlu graves, PalawaN . . . . . . . . . . . . . . . . . . . . . 130

BUKIT KALAMUTAN, PALAWAN . . . . . . . . . . . . . . . . . . . 140

DISTASTEFUL AND MINICKING BUTTERFLIES . . . . . . . . . . . . . . . 142

ORIOLUS VULNERATUS AND PRIONITURUS CYANEICEPS . . . . . . . . . . . . . . 146

SUMMIT OF KINA BALU (8000 FEET), s.W. . . . . . . . . . . . . . . . . 166

VIEW FROM KINA BALU ( 8000 FEET), S.E. . . . . . . . . . . . . . . . 166

KINA BALU FROH THE KINOKOK (FRON S.W.) . . . . . . . . . . . . . . . . 180

IARPACTES WHITEHEADI . . . . . . . . . . . . . . . . . . . . . . 182

NEW KINA BALU BEETLES . . . . . . . . . . . . . . . . . . . . . 184

THE "MANTOK" AND THE "NAMPUNGHER" . . . . . . . . . . . . . . . . . 196 


\title{
LIST OF WOODCUTS.
}

ERRA'TA.

Page 95, line 14, for Gurong read Gunong.

" 119, „ 25, for from Melangkap read to Melangkap. 


\title{
EX P L O R A T I O N
}

\section{$\mathrm{OF}$ \\ MOUNT KINA BALU, NORTH BORNEO.}

\section{CHAPTER I.}

\begin{abstract}
VOYAGE TO SINGAPORE. — SINGAPORE. - START FOR MALACCA. — ALOR-GAJAH. - ANTS. — EASTERN EVENINGS.-PULO SEBANG.-LEECHES.-MERLIMAU.-CHIN CHIN.-MOUNT OPHIR.-PADANG BATU.—RETURN TO SINGAPORE.
\end{abstract}

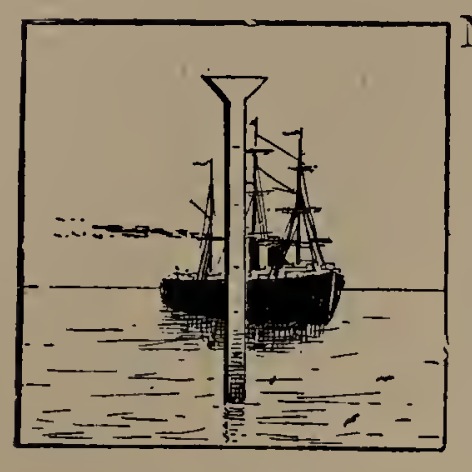

N October 1884 the good ship 'Khedive' sailed from Tilbury laden with a human freight, to be discharged during her voyage over nearly half the world. Amongst the passengers were healthseekers for Gibraltar and Malta, soldiers for Egypt and Aden, planters and merchants for India and the Straits, and a few bent on seeking adventure in strange lands; to the latter category I myself belonged, and will ask my readers to follow me in my peregrinations.

What was the primary cause of my visit to Borneo I have by this time forgotten : perhaps I was inspired by that interesting volume, 'The Forests of the Far East,' in which Mr. Spencer St. John gives an account of his interesting expeditions to the mountain of Kina Balu, this mountain up to the date of my exploration having refused to render an account of its ornithological treasures.

Well! we have started-waving hands and distant cheers are all that we can see and hear of friends that perhaps many of us will never meet again. In a few hours, causes over which we have no control reduce many of us to a state of woe-begone helplessness : the Bay of Biscay was indeed unkind. On the fifth day of our voyage Gibraltar is reached just before sunset; after a few hours' stay we enter the gates of the Mediterranean 
and leave the grim-looking rock far behind. Malta and Port Said are visited in their turn. It is in Egypt that the outward-bound traveller meets with the first strong contrast to things European-the bright clear sky, the sea-like desert, Arabs and other dark-skinned races, camels, and many other objects so different to our northern surroundings. In the early morning a party of us went on shore; we visited a native outdoor school, the little boys of which were dressed in gaudy colours; some were negroes, others nasty soreeyed Egyptians. In the desert a short distance from the town we watched some boys catching birds; a net was hidden in the sand, which, when pulled, covered a pan of water and some tufts of grass, the only lure necessary in this parched-up land: when we left it was going hard with both Larks and Linnets.

Slowly the steamer proceeds through the canal until nightfall, when the regulations force us to "tie up." To-day we have passed many objects of interest-the tints and form of the sea-like desert; thousands of Flamingoes stretching in pink bands across the horizon; Pelicans and other birds are numerous; and towards evening I saw a solitary Jackal skulking along the bank. At Suez some of our energetic countrymen played a cricket-match; others rode donkey-races, on mounts hardly worthy of their names *. 'The heat of the Red Sea was sufficiently unpleasant; in my cabin the thermometer registered $93^{\circ}$; and a gentleman who went below in search of a cigarette returned to his friends on deck with hardly a dry stitch to his back.

We reached Aden in the early morning, and as soon as the sun had risen our steamer was beset by dozens of Somali urchins in tiny canoes; they are bright little rascals, diving with facility after the coins thrown overboard, accompanying their aquatic feats by a ceaseless chorus of "I dive! I dive!" These boys haunted the steamer during the whole day. We were boarded by representatives of several African races with their various articles of merchandise-animals' skins and horns, ostrich eggs, and many other products of the desert. Most noticeable, perhaps, of all races are the Aden Jews, with their dirty loose white garments and long greasy ringlets hanging down to their shoulders; the chief commerce of these people seems to be in ostrich feathers of various qualities. Most of the passengers visited the Tanks: the writer and a friend explored first the sea-shore, where pretty shells were to be found; here we also noticed a Little Bittern sitting on the rocks. The ornithology of Aden is, however, more interesting than one would suppose such a parched-up spot could be. Hundreds of Egyptian Vultures sit about in perfect safety, allowing one to walk within a yard or two of them; various species of Kites with other birds of prey abound, and several kinds of sea-birds are plentiful.

Early the next morning once more we headed eastwards. It will be eight days before our next port Colombo is sighted; this is the longest part of the voyage out of sight of land-weary work for most of us. Our human cargo is, I notice, becoming more bellicose day by day; some of the ladies as we near our goal can only just tolerate each other; a few more clays, and I fear a veritable explosion would have taken place; but no! Colombo is in sight with its dark coconut-palm-fringed shore, and saves the ship from such dire calamity. During this run we got into strong currents, which carried the 'Khedive'

* Suez donkeys are named after the celebrities of the day-statesmen, actresses, \&c. \&c. 
somewhat out of her bearings; but fancy-dress balls, theatricals, bull, athletic sports, and other games have amused and kept within bounds the tempers of the 'Khedive's' cargo.

The absence of life on this vast expanse of water had not a very exhilarating effect on * my mind; except a few flying-fish that were disturbed as the monster ship rushes on its course and flitter away, until exhausted they drop once more out of sight, there is absolutely nothing to prove the existence of this teeming animal kingdom over many thousands of square miles.

At Colombo, as nearly all the passengers are bound for India, the minority-some thirty or forty only - have to change their ship. At this port true Eastern life may be said to begin. When in after years I visited the large towns of Java, I found the order of things but little different; here, for the first time, the sight was gladdened by gaudy butterflies, large gaily-coloured lizards, and birds, whose first cousins I afterwards met in Borneo. I am afraid I shall weary my readers, before I finish my task, with birds ; but if ever any of them should visit Colombo they must notice the Crows, whether they will or no, as they are so obtrusive in their habits. These birds will enter your bedroom windows in the morning and steal what they fancy; in the streets they wait on the house-tops for jobs as scavengers. But it is in the harbour that they seem to enjoy themselves most; perched high in the rigging they watch the galleys for scraps, picking out of the sea any refuse that may be thrown overboard. When the 'Khedive' was in Colombo a young Crow had the misfortune to fall into the sea; his friends gathered round, and by cawing attracted the attention of some natives, who went to its succour; immediately the Crows saw their relation safe they ceased all further signs of anxiety.

We had a delightful passage to Penang: the ship is now comparatively empty, so there is now what one misses most on board ship, viz. plenty of room. At Pulo Penang we drop still more of our passengers, mostly Sumatra tobacco-planters, who, to judge from their conversation, are men that enjoy life, many of them having made their fortunes in a few years; but times have changed since then with tobacco-planters.

Penang has an air of real prosperity about it; it seems full of busy people, and is a port second only to Singapore in the Straits Settlements. A few hours only at this port and we pass into the Straits of Malacca, a shallow muddy sea. Our outward journey is now nearly at an end; to-night we pass the lights of Malacca, the next morning we enter the harbour of Singapore, where still more of our passengers disembark, myself amongst the number. A kind friend met me on the quay, and for several days I enjoyed his hospitality. One thing that first strikes the etiquette-loving Western races is the hospitality and freedom which exists amongst the white population of the East: wherever you go you are always received with a kindness that is surprising to your colder Western mind. What the chief causes of such different feelings displayed by Europeans to one another in the East and West are, I do not know-unless it be the feeling of hospitality induced by meeting a fellow-countryman in a strange land and amongst alien races and surroundings.

Singapore is, strictly speaking, a Chinese town, and there the Chinamen have more freedom than in any other part of the world, their own country not excepted; and accordingly their manners (?) and customs are little, if at all changed. In Java and the 
Philippines, where the Chinese are not nearly so numerous owing to restrictions put upon them by the Dutch and Spanish governments, you may notice changes in their dress, and in their manner they are decidedly more courteous to Europeans. The Dutch and Spaniards keep the Chinese from overrunning their colonies, and in that way benefit the native. We welcome the Chinese and swamp out the hereditary owners of the soil. The result of this toleration in Singapore to the pig-tailed Celestials has been to give more scope to their secret societies, and therefore an impetus to riotous behaviour, which has at times had serious results to the very nation which protects and pampers them.

Street riots used to be not an unusual occurrence in Singapore, during which it would be dangerous for a European to drive through the town, where he would receive a warm reception of stones and brickbats. These little peculiarities of the Chinese are generally brought about by some edict issued by the governing powers for the good of the community at large; that does not quite suit Johnnie, so he holds a meeting, and makes the streets of Singapore impassable for a day or two. There is no denying the fact that the Chinese are the life and soul of Eastern commerce and are an absolute necessity to the building-up of our Eastern colonies, but at the same time they should be treated by our ruling powers with great firmness.

As servants these peculiar people are most useful, nearly all the domestics in Singapore being Chinese ; they are one and all called "boys," though many are old boys indeed. Your boy does all the marketing, cooking, washing, and performs a hundred other duties; but for all their usefulness I love them not. Honesty and truthfulness are traits that seldom exist in a Chinaman; they will rob the unsuspecting " $\mathrm{Mem}$ " in a thousand ways: a bachelor master must be as good as an account at the bank to most Chinese servants. As Mr. Thomas Plush celebrates his mistress's evenings out by balls below stairs, so John Pigtail holds gambling-parties up to all hours at night, for which probably you yourself have provided the counters; and, finally, after many years in your service, you will find all kindness has failed to make the least impression on the mind of your placidfaced domestic: give him a chance, and, if the stakes are sufficient, he levants.

The wealthy Chinese merchants are swells indeed; they drive out of an evening in the best turned-out carriages, and may be seen sitting, fat and contented, bedecked in mauve and other coloured silks, watching the-to them-idiotic Englishmen playing cricket and other games. They live in large houses surrounded by high walls, with their harems, where they eat the best of food, get fat, and rich by speculation. Many of the wealthy Chinese have been for generations in Singapore, and have shaken off many of their country ties. Most of the vegetables are grown by Chinamen, and they are without doubt wonderful gardeners. Poultry and ducks, especially the latter, they rear in thousandsa small bamboo enclosure will be so stocked that the ground is as though paved with a tumbling mass of quacking ducks.

Chinese cemeteries are curious, but I should imagine expensive, each defunct Chinaman requiring a large space, which is built round in a semicircle, in the centre of which is a granite tablet; on it is deeply cut an inscription in Chinese in letters of various colours and sizes. Some of the hill-sides in Singapore are covered with these graves, which later on will be opened and the bones packed off to China. 
The Malays and Javanese chiefly fill the posts of coachmen; Klings do most of the road-mending, tailoring, and washing, and Chitties the money-lending. It is perhaps only from the natives of India that the Chinese meet with any competition in their commercial pursuits. The Europeans have their bungalows some distance away in the suburbs, many of their gardens being beautifully planted with palms and other tropical plants. The clerks employed in offices club together and live in small communities. The hotels were decidedly uncomfortable, not one of them coming up to those of Java.

Thus it is in Singapore that a number of different types of the human race are collected together-with a variety of colour and style of costume which adds life and beauty to the scene, and is at the same time comfortable to the wearers: so different to our colder northern latitudes, where pale thoughtful faces peep out of dark-coloured garments, making our cities appear in perpetual mourning. The struggle for existence being less severe with these children of the sun-food, chiefly rice and fish, being abundant, and fuel only required for cooking-purposes-they have few troubles to worry them; with a few cents to spare they are happier indeed than any millionaire.

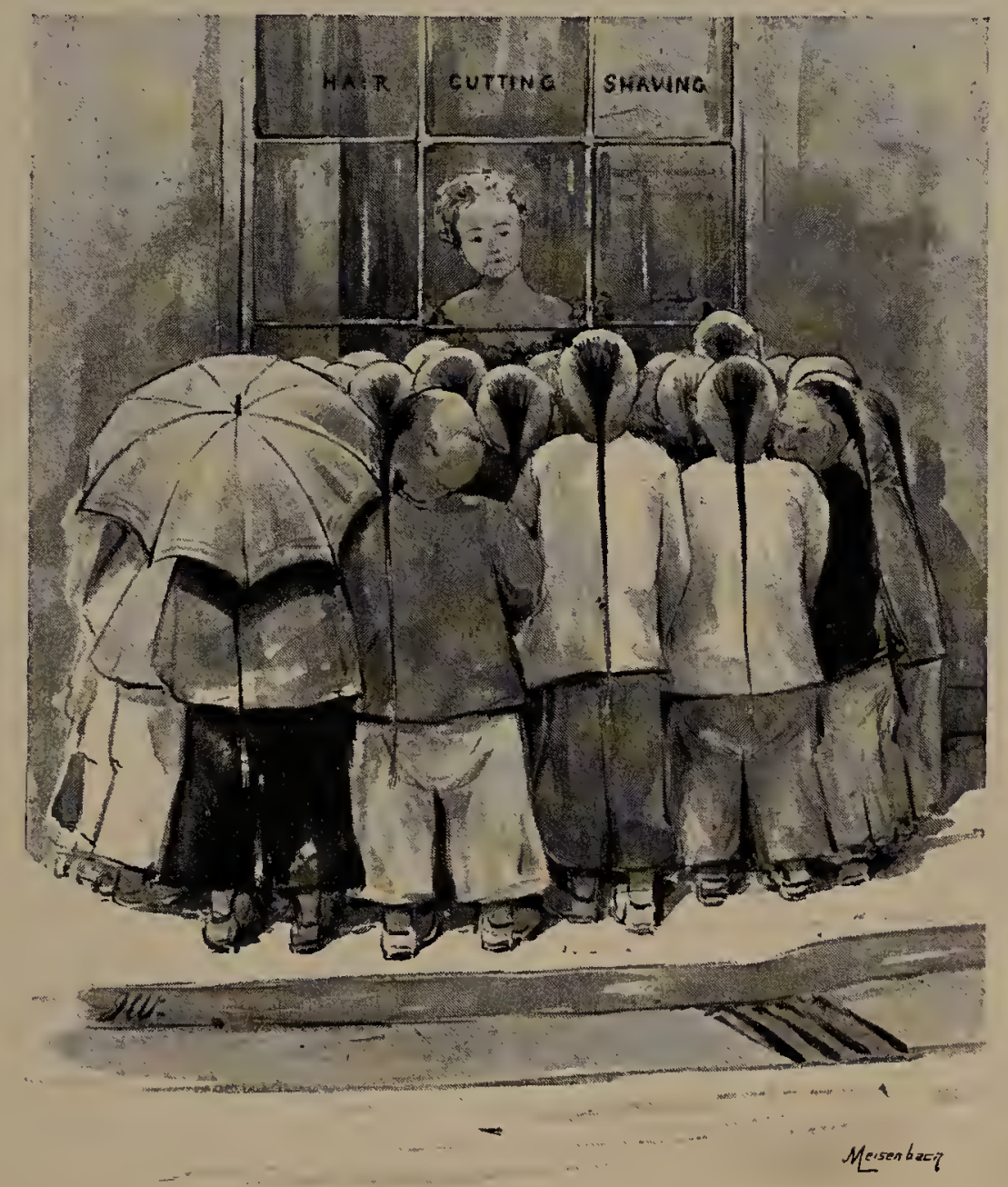

CHINESE ADMIRATION.

In a thoroughfare that I often passed through some enterprising barber had imported a most magnificent block; it was, I remember, the waxen bust of a lovely female, with 
delicate pink cheeks, a wealth of golden hair, and a bodice of crimson satin. This, I suppose the first introduction of European art of its kind, was the object of adoration to many dozens of Chinese. Whenever we passed that shop a crowd of Celestials were to be seen gazing with admiration at perhaps their ideal of feminine loveliness. However, the Chinese admiration did not save the business; for some time after when I passed the barber's shutters were up, and that block, the pride of the Singapore coolies, had gone with the business.

A visit to the Governor of the colony is one of the duties of a would-be resident in Singapore. Sir Cecil Smith, who was at the time of my visit Acting-Governor, received me with kindness, taking a keen interest in my natural history pursuits. Owing to the wholesale slaughter of birds for the London and Paris markets, in Malacca, the Government passed a law forbidding any furthur destruction. As I wished to visit Malacca in order to inure myself to forest travel, and thought it best to begin as easily as possible, no place was more suitable for my purpose. So at my request Sir Cecil Smith kindly granted me permission to make a collection.

One or two days were necessary to buy provisions and other necessaries for a three months' trip to Malacca. Now, whilst on the subject of provisions, I cannot help saying a few words to express my disgust at the want of legislature that is absolutely necessary to prevent people being occasionally poisoned by eating tinned foods. In the first place, all tins containing food ought to bear a date stamped in the metal; that date being the day when the tin was soldered down. Now it is impossible to tell what you are buying, there being no mark to guide you. The gases which accumulate blow out the ends of the tins; this at present affords the only means of guessing what the contents may be like. I have seen tins of soup when pricked squirt up like little fountains of impurity; I have heard of anchovies that burst their bottles and stuck on the ceiling, of tinned lobster that poisoned the partakers thereof; and all this because people are allowed to sell in 1892 provisions that were potted-well! who knows when; yet if a shopkeeper were to expose meat that we can both see and smell is bad, he is had up at once for "exposing meat unfit for human food." These remarks do not apply to the European houses in Singapore, as provisions from these depots are nearly always fresh; but unfortunately all that is not disposed of when fresh is sold to the Chinese, who may get rid of them perhaps before they explode. To remedy this I would suggest that a small tax be imposed on all tinned food. The profit from this tax would amply repay the official surveillance necessary for the correct dating of all tins. Such a tax would in no way interfere with the poorer classes, as they seldom consume such provisions. Foreign exporting countries might possibly be forced to follow such a regulation, as doubtless dated tins would have a larger sale than undated ones.

My next job was to find a Chinese servant, which I did in one Ah Hing. As he spoke English fairly well, I am afraid it retarded my knowledge of Malay considerably.

We embarked, my Chinaman and I, on board one of the small coasting-steaners which run between the port of Singapore and the small coast-towns on the Peninsula. 'The sea was luckily quite smooth, or it would have been a most horrible voyage. We ought to have left Singapore early in the day, but, with true Eastern unpunctuality, we did not start 
until some hours after the appointed time. The coast for the most part was bordered with mangrove-swamps, in which and amongst the numerous small islands, used to lurk everwatchful pirates, to pounce on unprotected Chinamen, robbing and murdering occupants of small boats; for which crime some seven men were hanged a few weeks before we arrived in Singapore. In the early morning the little steamer cast anchor off the town of Malacca, the sea being so shallow that even small craft have to anchor some distance from the shore, communication with which is carried on by means of lighters and sampans.

Malacca is, we are told, an old Portuguese 'settlement, dating back probably to the early part of the sixteenth century; the ruins of the forts and gates alone remain as emblems of the past. The inhabitants, as might be expected, are chiefly Chinese; but there are also a good many half-castes, who call themselves Portuguese; Malays are also numerous. The houses are one-storied tiled dwellings of bricks and plaster, the water's edge being fringed with pile-dwellings. A note of introduction to the Hon. Dudley Hervey, the Resident of Malacca, was sufficient to ensure a kindly reception, and as this gentleman's tastes take a zoological turn, we soon became friends. Mr. Hervey had a few interesting pets, amongst them a porcupine which lived in a large box, one of the most evil-minded little animals I have ever seen. Whenever the box was tapped the porcupine would back itself viciously into the sides, trying, no doubt, to spear with its quills the hands of its visitors. Mr. Hervey showed me a collection of birds that had been found in a Chinaman's possession and confiscated, the law about the export of bird-skins being in force. In this collection were skins of three species of Pittas or Ground-Thrushes, birds bedecked with all the colours of the rainbow. I wondered if I should have the luck to meet with any of these gems of bird-life; but as long as I remained in Malacca I was doomed to disappointment.

The following day I looked about for a bullock-waggon to convey my belongings to Alor-Gajah, where there is a government bungalow, built expressly for officers desiring a change. Now travelling in the East means taking everything with you, or going without; bedding and cooking-utensils, besides my collecting-boxes, with the Chinaman added, soon filled the cart, and we started. 'The distance between Malacca and Alor-Gajah is only some fifteen miles, but with bullocks this means the best part of a day's journey. We drove for some distance through flat swampy rice-fields, which at this season of the year were becoming bright emerald-green; there were few signs of forest, most of the trees having been felled for tapioca-planting. It was pitch dark when the bullock-cart arrived at the Alor-Gajah Rest House. The house was in a bad state of repair, the roof leaky, and somehow I felt uncomfortable and lonely on this my first night away from civilization. This was my first introduction to a lengthened course of chicken and tinned food, and my first real experience of mosquitoes. I remember going to sleep with a heavy heart, and thinking what a fool I was to venture into such a place; but how soon do we become accustomed to such a solitary existence! a few years later I lived for over six months at a time without feeling the want of companionship.

The Rest House was a roomy building of wood, thatched with palm-leaves, and on one side a large verandah, under which we lived. 'The country round about is fairly well covered with trees, but there is no old forest; emerald-green rice-fields surround the hill on which the house is built, and a few distant forest-covered hills complete the scene. 
My servant in the first few days showed his dislike to travel: when we arrived at a fresh station he would sit down and wait, doing nothing, until I called him for my meals; then he would appear downcast and sorrowful, saying that there was "no wood, no water, no nothing," evidently expecting to find all these necessaries ready. For Eastern foresttravel a Chinaman is almost useless, he can never adapt himself to forest life and never will ; it is far better to have an inferior servant at once in a native, break him into your ways, and he will always be willing to make the best of everything, besides using his own natural instincts to make everything he finds about him as useful as possible. I always found that a Chinaman required a native to wait upon him, and another to carry his baggage when on the march, so I cannot recommend them to any traveller who expects to rough it. I engaged a Malay to guide me to the forests and help to carry my gun and net; but he generally used to lead me to the most unlikely spots, so I concluded he did not quite understand what I wanted, as I was unable at this time to speak more than a few words in Malay, the chief reason being my Chinaman's knowledge of English.

My first victim in the East was a beautiful pearly-grey Drongo Shrike (Buchanga leucogenys). This genus is well known among ornithologists from its pugnacious habits, especially during its nesting-season, when a pair of Drongos will attack in the air the largest Hawks, and drive them out of the vicinity of their nests. Lovely species of birdlife came before my delighted eyes day by day: Trogons (Harpactes diardi and duvaucelli) with their crimson breasts like balls of fluff, so soft are these splendid creatures, but with a skin so tender that the most delicate of taxidermal fingers can hardly perform the last rites without tearing them. Though ornamented with the brightest of crimson breasts, and fairly large birds, Trogons are hard to see, their backs being brown and leaf-like in colour, and when perched quiet and motionless high in some forest tree they may easily remain unnoticed. I have known experienced Bornean natives, with eyes as sharp as needles, fire at a bunch of dead leaves, thinking they were firing at a 'Trogon.

Honey-suckers, Kingfishers, Gapers, Irenas, all birds of brilliant hues, were continually being collected; butterflies in all their splendour disported themselves in the more open forest-paths or round the higher branches of some flowering tree. Other families of insect-life were in thousands, with a variety of both form and colour that would astonish a collector in temperate climes. Most numerous perhaps of all groups, both in quantity and variety, are ants. Oh! what troublesome mischief-working little pests they are; nothing is safe from their depredations. A bird-skin is a perfect windfall to them: the feathers are cut off in lanes, and in a few hours the delight of my day's expedition would be rendered utterly useless. On one occasion a large box of butterflies had been safely packed away in one of those splendid air-tight boxes that one takes out from home; the next day there was a perfect stream of little slowly-crawling red rascals making their way in and out of that box, and when I opened it, to my horror over eighty fine specimens were minus either body or head. I never trusted such boxes again, and nothing but isolation in kerosene oil, or some mixture equally objectionable to them, will save anything they can possibly destroy. In the low scrub, and especially in the gardens of Singapore, a wiry, long-legged red ant makes its nests in the trees, by binding the leaves together in a large ball. In this ant we meet with the acme of pluck and ferocity : a tap on that curious-looking ball of leaves brings out ant- 
warriors in their hundreds; they make the leaves rattle as if challenging the intruder; they have not the least hesitation in attacking anything that comes within reach, when they will nip on with jaws like red-hot pincers, that still remain firmly fixed long after the body has been pulled off. When I used to find these ants in possession I always gave them a wide berth, not even daring to pick up a bird if it fell too near their nests.

'Then, again, there are industrious ants, who turn their attention to one's garments and provisions ; they bit out all the sewing of one of my coats, bored holes in a felt hat until it looked like a cullender, marched up in processions on to the breakfast-table and carried off my food from under my very nose. Being short of leg, and therefore travelling over the ground somewhat slowly, they are assisted by a long-legged black ant, which seems to act as a scout: he quickly covers a good deal of ground in search of forage, which, when found, he closely examines. Knowing evidently his weakness as a labourer, he quickly disappears to return shortly with a gang of red rascals, who soon cut up and carry off the prize. The black scouts are very partial to sugar and water, with which they will blow themselves out like transparent miniature balloons. Perhaps the worst of tropical ant-pests are the wellknown white ants or 'Termites; their depredations on all wood-work are too well known to all readers of tropical travel. When I tell you that you may suddenly find your feet going through the floors of your best rooms, or that some article of furniture will crumble away in your hand, it will serve to give you an idea of the quiet destruction that millions of these soft-bodied insects are carrying on day by day. In the forests of Malacca, before the sun is too powerful, or in some deeply-shaded spot, an army of Termites, marching four or five abreast in most perfect order, may be often met with. On close inspection it will be found that the army is composed of apparently two kinds of insects; they are, however, the progeny of one mother, only differently developed, and are the workers and soldiers of the nest. Each worker, it will be noticed, is carrying a ball of mud or rotten wood, which will be used for enlarging or repairing the nest, a large conical structure, often six feet high, of mud, baked as hard as a rock by the sun. I often amused myself by obstructing these armies, when the workers would be thrown into confusion; the soldiers would collect together and wag their great heads from side to side, but I fancy fighting is not their forte. When we are told, speaking of the curious bag-like female, that "her fecundity is prodigious; she is supposed to lay more than $31,000,000$ eggs in a year," I shall lềave you, reader, to form your idea as to the amount of work done by these Termites in a tropical forest. I always noticed when they attacked wood in houses or in other dry situations they saturated it first with moisture, for which purpose their bladder-like bodies seem well adapted. In the forests there are many species of ants which live in small communities of less than a dozen, which are extraordinary on account of their protective armour. I noticed one species in particular that had a perfect little three-pronged grappling-iron-like weapon sticking out from the thorax, which stuck into my fingers when I picked the insect up. So it would seem that those speciés which do not protect themselves by their numbers are themselves protected by some weapon-like growth, which would make the wearers a disagreeable morsel to either lizard or bird.

The most interesting and lively time in a great tropical forest is the early morning at sunrise and about an hour before sunset. During the heat of the day even the very 
butterflies are found in shady paths, or in the cool beds of half-dried-up streams, sipping moisture through the damp sand.

Most mammals seek their food at night, monkeys and squirrels being the chief exceptions; and it is only after the sun's declining rays reach high into the vault of the heavens, when the cicadas fill the air with their discordant music, and the Nightjar may be seen disporting himself high in the sun's departing rays, that the timid deer and lordly tiger leave their lairs-the one to munch the tender grass, the other to destroy some unsuspecting victim. To be successful as a big.game hunter in the Malay Archipelago requires a good deal of perseverance and night work, also a skin that bids defiance to mosquitoes. Larger animals are seldom met with during the day, owing to the density of the underwood in the places they frequent; if by chance you should disturb a deer or pig, they are out of sight in a moment, the crashing of the underwood being often the only indication you have of their near presence. As I did not visit these lands for the purpose of collecting hides and horns for my trophies, but rather the more lasting beauties of the East, and especially, if possible, to add some little everlasting stone to that ever-increasing cairn of human knowledge- - so, if my readers expect to follow me to a field of carnage and "acres of meat," they will, I am afraid, be disappointed.

Well! to return to our Eastern evenings. Most striking perhaps at this period of the day are the huge fruit-eating Bats (Pteropus), which issue forth in hundreds from some quiet spot in the forest, where they have been hanging head downwards all day in the topmost branches of some tree. Slowly they flap their noiseless way to some fruit-bearing forest tree, or perhaps make a descent on some Malay's garden, where they will meet in a shrieking fighting mass, and before the sun's light again appears not a leaf or a berry will be left. Besides these fruit-eaters, there is a multitude of insectivorous bats which flitter close by like spirits on silent wings.

Of the bird world many species of Swifts and Swallows fly low, and dipping, drink the water of some tank or pond; Herons utter a few hoarse croaks before seeking some wellknown pool where frogs and fish will later suffer. Most interesting to me were the Nightjars (Iyncornis temmincki), which exactly at ten minutes past six might be seen flying high in the last rays of the setting sun, uttering a pretty whistling note, "Teta bow, teta bōw." So well timed was their flight, that I knew the time withont looking at my watch. After ten minutes' flight this Nightjar descends to the earth, and may be seen flitting over the rice-fields, now and then soaring up after its insect prey, or sitting on some dead bough or post, where its pretty note is changed to a frog-like croak. A few minutes before sunrise this bird takes another flight high into the sky, when Teta bow is heard for a few minutes, then quietly he drops to mother earth, where, drowsy and silent, he will remain under some friendly shelter from the sun's all-powerful rays until nature tells him it is time to be up and doing.

A dull brown butterfly (Amathusia phidippus) might be seen taking a short flight beneath the spreading trees. This insect has a very disagreeable odour, which is no doubt protective. Thousands of minute insect forms, from ugly ichneumons and blundering beetles to fairy gauze-winged flies, seek to dash their brains out against the first lamp seen, or struggling, stick with tiny kicking legs in any oil that has not been cleaned away; and 
then it is that the mosquito will introduce herself to any uncovered inch of flesh that she can find, and will continue her visits as long as you remain in the land, or bloated fall an easy victim of your vengeance. Some evenings hundreds of winged ants would swarm over everything, seeking to destroy themselves in my soup, or getting squashed in between the pages of my books, where many remain to-day pressed examples of their folly.

Then it is that the gecko lizard, who performs a feat worthy of our greatest acrobats by walking all over the ceilings on his sucker-formed toes, reaps a rich harvest as he stalks and races after many idiotic moths and flies that bump about the walls and roof, "chuck chucking "with delight at their innate foolishness. Such, reader, is the effect on the animal kingdom when that all-powerful luminary of ours disappears for a short space of time below the horizon: when the morning draws nigh, and as soon as the sun has tipped the highest hills with his golden light, those that are left in this struggle for life will take a last sip at the cool flowing stream-our Nightjar will give one more Teta $b \bar{o} w$, the satisfied gecko will seek his lair in the thatch, and all that is left of this multitude which attended the ball of the night will be hushed and hidden, until the evening arouses them once more to continue their frolics: this, my friends, is the ever recurring tropical drama, the actors of which are legion. I always looked forward to this period of our day, and seldom went indoors until pitchy darkness hid everything from my view.

The early morning is the best time for collecting-birds are then feeding and more lively; sometimes in an early morning ramble I would collect sufficient birds to keep me busy for the rest of the day. Unfortunately, in Malacca I had no bird-skinner with me, so had to do all the preparing myself; but as none of the Malacca birds are rare it did not matter much.

Towards the end of December I changed my locality, going some few miles further on to the police-station of Pulo Sebang. This station consists of a few Chinese and Malay huts, the only building worthy of the name being the police-station. In Malacca these stations are fitted up with a room for travelling officials. Mr. Hervey had kindly given me a letter to the various superintendents authorizing me to occupy this room, so I was fairly comfortable. The police are Malays, generally five or six in each station; they are armed and patrol the roads, and are, I should imagine, a useful body of men. The sergeant of Pulo Sebang was an amusing fellow; he once shot a tiger from the verandah of lis house, and when he could meet with an audience willing to listen to this exploit, he would act the whole thing splendidly, rolling over on the ground, growling and pawing the air, in imitation of the wounded tiger. Tigers seemed fairly common in Malacca-attracted, no doubt, by the herds of wild pigs which root up the tapioca-plantations. I went one day with the police-sergeant to see a freshly killed Sambur stag that had been destroyed by one of these beasts; only a pound or two of meat had been eaten from the rump, the rest being left to rot. I felt a pang of sorrow to see so much good meat wasted, as in those days I could not buy any. Several times I saw tracks in the vicinity of the station, and a few native cattle were killed, so I am sure that with a little perseverance a shot might be obtained.

At the time of my visit to Malacca tapioca had been so over-produced that the price had dwindled away, leaving little or no profit to the producer; so that large plantations 
were either being worked with too few coolies, insufficient to cope with the rapidly growing jungle, which in the East quickly takes possession of neglected clearings, or entirely neglected. These plantations form splendid haunts for pigs, and become soon so thick and entangled that it is almost impossible to move about. Tapioca is the produce of a large tuber, which grows some few inches under the soil, from a slender knotted plant about five feet high, the foliage consisting of a few straggling five-parted leaves. The entire cultivation of tapioca was in the hands of the Chinese. 'The felling and burning of a huge forest looks a herculean task; when this has been accomplished, the plants have to be carefully hoed and kept clean, or else the ever encroaching "lalang grass" would soon smother them; they, however, grow very fast, attaining maturity in about six months.

My stay at Pulo Sebang was short, as birds were scarce; but amongst those obtained were several interesting species. A very large Swift (Hirundinapus giganteus) was especially remarkable, having all the tail-quills partly denuded of web and as sharp as needles. This fine bird, though common, is difficult to obtain, as most of the day it flies high out of the reach of powder and shot; but towards evening a shot may be obtained as it dashes by to drink in some open pond or tank. I was also pleased to see some Hornbills flying about, and was first attracted by the loud noise they made with their wings, though at the time they were some distance off. Here also I met with perhaps that most loathsome pest the jungle leech. These disgusting creatures take up their position in the jungle-paths, ready to fasten on to the first passer by: when it happened to be myself, they bored through my thin clothes, either fixing on to my legs or working up to my stomach-there becoming surfeited they dropped off; it is only then that one feels the least pain. Soon your clothes become saturated with blood trickling from an almost imperceptible wound. The bite of these leeches is slightly poisonous, and causes irritation for weeks afterwards, and if you are not in good health develops into nasty sores. There are two species-a dirty brown terrestrial leech and an arboreal one, striped with green and yellow : the latter species fastens on to any part of your body as you brush by the branches that overhang the paths. When I tell you that some paths simply swarm with leeches, and that I have picked from thirty to forty off my boots (doing their best to get up my legs) during a short walk, you can form some idea what a source of annoyance they must be. It is only by wearing thin loose canvas stockings tied over your trousers below the knee that you stand a chance of being free from their bloodthirsty attacks. The ground leeches are about two inches long and rear straight on end, turning their pin-pointed heads quickly in all directions when they feel the thud of a footstep on the path. Whenever I offered them a stick that I had previously touched with my hand they fastened to it in a moment, though refusing to notice the untouched end.

One day during my rambles I heard the plaintive howls of some animal, which, when I approached, proved to be a wretched dog, which had been tied up close to a piece of bamboo, and the bamboo to a large creeper. The poor animal was half-starved and nearly mad for want of water, and, judging by the state of the ground, had been there some days. This was the kindly act of some Malay or Chinaman. I noticed in Malacca several dogs running about with short bamboos fastened to their necks, so perhaps they had narrowly escaped a slow death by starvation. Unowned, half-wild dogs are so numerous round the outskirts 


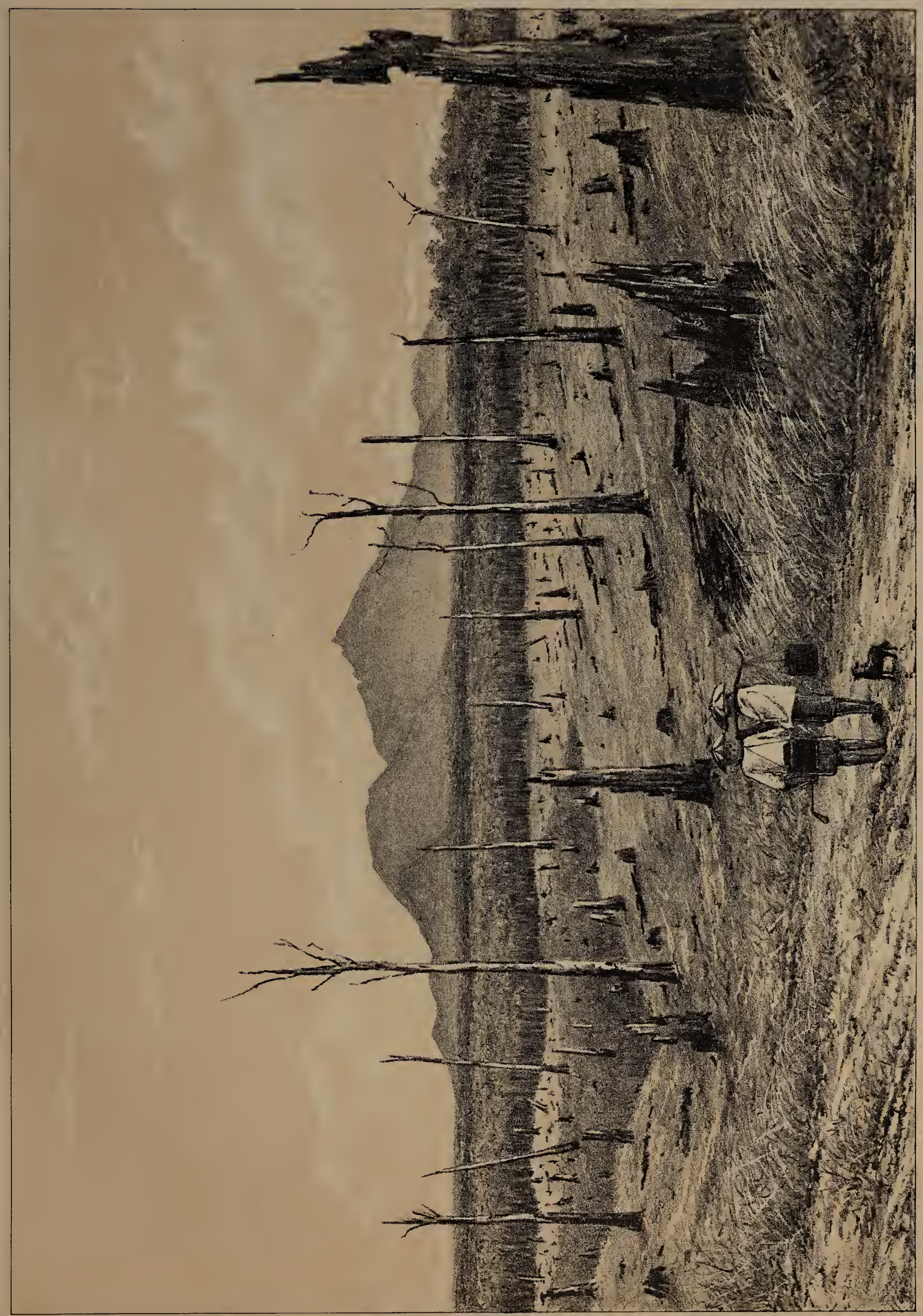



of Eastern towns, that it has been found necessary to devote several days in the course of the year to their destruction.

On the 26th of January I left before daybreak with a bullock-cart for Bantam Malacca, intending afterwards to visit Mount Ophir. When we had proceeded about two miles, a huge tree that had fallen right across the road barred all further progress. As there was only one Malay chipping at it, who informed us that it would take at least two days to reopen the road, we returned by the same route in two days to Malacca. In a few days we started for Merlimau; from this station a fine view of Mount Ophir is obtained. This mountain is the "Gunong Ladang" of the Malays, and forms the chief topic of several songs, which I heard sung years afterwards by my bird-collectors in Borneo. The accompanying illustration is a sketch of this mountain from a tapioca-plantation. 'In the distance is the virgin forest, the charred remains of many forest giants which are too large or too tough are left standing; the only part planted is the dark patch in the middle distance on the left-hand side.

Merlimau is the best locality I have as yet visited for collecting-purposes, there being a good deal of virgin forest about; besides it is only a short walk from the sea-coast, which affords plenty of interest. In the forest one day I disturbed two small Bats that had taken up their quarters in an old disused ants' nest; the nest was fixed to a creeper and hung down like a bell, forming a snug dwelling for the Bats. I also met with two curious animals, one known as the Flying-fox (Pteromys melanotis): it is covered with rich rustybrown fur and has a long tail; on both sides of the body, from the thumb to the feet, is a thin membrane of skin, which, when this animal wishes to reach another tree, by stretching open its four legs it expands, forming a parachute. In this manner it sails through the air to the base of some distant tree, which it ascends with the activity of a monkey. The other animal is known as the Flying Lemur (Galeopithecus volans); it is a beautiful creature, with the softest of marbled-patterned fur. In habits it is similar to the last species, but is almost tailless, with shorter limbs and not nearly so active. The pattern of the fur is highly protective, making the animal assimilate well with the tree-trunks to which it clings.

The forests here seem to be overrun with wild pigs, and several times I came across large herds; the Chinese catch them in pitfalls. On the coconut-palms round about the station Flying Lizards (Draco? sp.) were numerous. These interesting little reptiles have the ribs greatly lengthened and connected by a tough membrane, which acts as a parachute (see illustration, page 56, fig. 1). As soon as the Malay boys saw I was desirous of catching them, they began to climb the palm-stems after the lizards, which would attain the greatest height possible before sailing off to the foot of another palm. In three or four flights they generally landed on the ground and were easily captured. In this manner we caught several specimens of both sexes; the male is adorned with a curious yellow pouch under the chin, which he can inflate and thrust forward at will. When hunting these lizards, a female settled close to a male, which began at once to inflate his pouch as if pleased. I kept several of these little reptiles alive for a few days, but they refused all food and were very vicious to one another; they also possess the power of changing colour from green to blue, or almost dark black. 
Merlimau is an unhealthy place in the neighbourhood of mud-swamps. Here I first felt the effects of the climate, on some days being scarcely able to drag myself about.

The Malays are much cleaner than the Chinese, their houses being built on piles, and the ground beneath is kept neatly swept; but the dirty Chinaman, who will not take a lesson, builds his house on the ground, round which he digs a shallow trench, which becomes full of filth, and emits a stench that would be fatal to anyone but the owner.

On the 17th of February we left Merlimau for Chin Chin. On this journey we left the splendid high roads, which are a credit to the Colony, and followed a track through Chinese plantations; the cart jolted about to such an extent that many things were thrown out. At mid-day we had only accomplished twelve miles of our journey, and it was past seven at night before our weary oxen reached the station. On the road, while walking ahead of the cart, I noticed a suspicious-looking brown leaf that had fallen across a green one; but knowing that some butterflies closely resemble dead leaves, I caught it in my net: as the expected flutter did not come, "done again" passed through my mind as I proceeded to throw the leaf out of my net, when to my surprise the dead leaf became suddenly transformed into a grasshopper arrangement, which walked on to my fingers; so perfect was the disguise that I should have thrown the insect away if it had not fastened on to my hand. As if to make the resemblance closer to a dead leaf another specimen, which I caught a few minutes afterwards, had a small transparent window in the leaf-like development on the back, as if to better imitate the holes in decayed leaves. I have figured this grasshopper opposite page 50, fig. 3, with several other wonderfully formed insects.

At Chin Chin birds were almost extinct, owing to the destruction caused by a foreigner, who boasted that he had sent several millions of birds' skins to the markets of London and Paris for millinery purposes. The law passed by the Government caused this man to leave the State of Malacca; but as he only went to the other side of a boundary stream into the State of Johore, it did not make much difference to him. As this collector was living but a short distance from the station, I walked over to see him one afternoon; he showed me a great many beautiful but badly skinned birds; there were also several large boxes of wings and heads of victims spoilt in skinning. He employed, he told me, fifty-two Malays, who went off into the forests for a month at a time. I suppose this man did more harm in a month than any genuine collector does in four or five years; and that not a specimen of all this fearful slaughter caused more than a few days' pleasure to some fashionable woman, while scientific collections with care may last for ever, besides being necessary to our knowledge. So much has been written on this subject, but apparently without success; women will no doubt continue to wear anything they think becomes them, regardless of the suffering caused to many thousands of creatures that have as much right to be in the world as they have.

Not far from the house was a muddy stream, in which were numbers of enormous Monitor Lizards (Varanus, sp. ?). These reptiles attain a length of over six feet and a girth of $18 \frac{1}{2}$ inches; they feed on fish, but also on birds. In Borneo they used to take up their abode in some hollow tree, not far from a poultry-yard; soon you began to miss your chickens, until one day the hens would be in such a state of excitement, that on going to look one of these huge reptiles would be discovered in the middle of the farmyard, where, 
if possible, a charge of shot should end his career. The tail is like a whip, and would be sufficient to cause a nasty wound. When I shot these monsters my Chinese boy was delighted; he carefully preserved the gall-bladders for medicine. In the same stream numbers of Malays used to fish for a peculiar broad-headed, barbuled mud-fish, which rose to a small frog; one old man lent me his rod, but I did not succeed in catching any. After each fish caught he spat on the bait, either to give it a flavour or for luck, I cannot say which. I also noticed one of those peculiar little Herons (Ardetta sinensis), which scek to evade observation by standing up with neck and beak in the air, and thus imitate the reeds amongst which they settle. If I had not previously flushed this bird I might have passed it by within a yard or two unnoticed. The rainy season seems to have set in, as day after day it does nothing but rain; and though I hear from Mr. Hervey that the house he ordered to be built for me on Mount Ophir is finished, I dare not venture to start. During my walks I found one of those peculiar insects known by the name of Lantern-flies, Hotinus (see drawing of a Bornean species opposite page 50). These insects are difficult to collect from their habit of settling out of reach on the trunks of trees; when you attempt to approach they work slowly round the tree. If, however, you make a swoop at them with a butterfly-net, it is a hundred to one that you miss them, as they give a powerful jump and open their wings to settle still higher on another tree. On the 20th February I made several attempts at different times in the day to secure one of these flies; he had a gorgeous red nose and bright blue wings, and always returned to one particular tree. These attempts were continued day by day, at the rate of three or four shots a day, until the 25th of the month, on which date I left for Mount Ophir. On my return on the 4th of March, the first thing I did was to go and see if that fly was still in existence, and there sure enough he was sitting on the same tree, almost out of reach as usual ; once I tried, but with a jump he was far away, but on returning I caught him. This peculiarity of frequenting one particular spot I have often noticed amongst insects: the large wood-boring bees will settle for weeks on the same stick in a row of palings, though they have no intention of making a hole in it. My Bornean natives were very clever with the Lantern-flies, catching them with hair nooses fastened on a thin bamboo.

On the 25th February we left for Mount Ophir, the weather having cleared up ; the same evening we arrived at the campong of a Malay chief, who lent us a shed to sleep under. The next morning we started with twelve Malays, who carried our baggage and food, soon after daylight. The path led through native gardens and old forest-clearings until the foot of the mountain was reached; where we rested for an hour at mid-day and enjoyed a refreshing bath in a cool stream. After a light repast we again commenced our journey; the path became at once steep and slippery, swarming with leeches, so that both eyes were required to prevent nasty falls; on the way we passed a large wooden tiger-trap. It was not until 4 P.M. that we reached the spot known as the Padang-batu, or Field of Stone, quite done up with fatigue; if I had believed the Malays I do not think that we should have reached our camping-ground that night, as they kept telling us it was ever so much farther on. When we saw the sheds that the Malays had built for us-which the chief told me took eighteen men six days to build,-we were surprised: any six natives in Borneo would have finished the whole job in a few hours. 
As soon as the Malays reached the camp they began to be unruly, clamouring for biscuits and brandy: they sat still until it was nearly pitch dark without attempting to cut a stick of fire-wood or make the least provision against the cold of the night, and not until they were chattering with cold did they move.

The following morning nine of them, I am glad to say, returned home, three remaining with me. Everything was enveloped in mist, and when I ascended to the summit of the mountain, only about an hour's scramble from the encampment, I saw absolutely nothing of the surrounding country. On the way up to the summit I found a large Tarantula spider, which I dug out of her hole, but I did not see either bird or butterfly. The absence of animal life was, however, well compensated for by the vegetable kingdom. Pitcher-plants (Nepenthes) were so numerous that at times we had to cut our way through them. I noticed some four or five species- $N$. sanguinea, rafflesiana, ampullaria, albo-marginata, and a new one still undescribed, the large $N$. sanguinea being especially remarkable. The low weather-beaten trees were covered with mosses; tree-ferns about eight feet high grew plentifully in a deep gap between the two highest peaks, in vegetable mould several feet deep.

The next morning I sent the Chinaman to the summit (which I am told is about 4000 feet above the sea-level) with two Malays whilst I busied myself making a sketch of the distant country. In the afternoon I went for a stroll along the Padang-batu to a smatl stream, where I shot one of those peculiar Eastern Cuckoos, with a beautiful pearly grey back and bright red beak (Zanclostomus javanicus); the only other bird collected at this camp was a species of Bulbul, which the Malays called Bura Bura (Hemixus cinereus), otherwise I did not see another bird; butterflies were represented by one common white and yellow species, Delias orphne.

The Chinaman tells me tales in the evenings about the war his countrymen are now carrying on with the French; and how the Chinese have put "cannons under the sea (torpedoes), and when the French steamboats came, bang! and make finish everything."

1st March.-We followed the course of the stream down to the forest: the palms and trees were magnificent; added to this the stream formed many waterfalls as it tumbled over the precipitous rocks; the whole scene was like a glimpse into fairy-land, which so delighted me that I could not bring myself to turn back, much to the disgust of my two Malay followers, who tell me that they would not do this sort of work for $\$ 5$ a day. Most remarkable of all palms in the forests are those extraordinary long rattan-canes.

These canes grow in tropical forests like long thin ropes, climbing to the tops of the highest trees, when they often fall to the ground; after running along for some distance they clutch hold of a branch or creeper, and gradually, with help of the wind and their string-like tentacles, attain a great height; this climbing process may be gone through several times, until looking up you may be puzzled to find out where these extraordinary forest ropes begin or end; some canes must be over olle hundred yards long. The way this climbing is accomplished is interesting: the cane has at its end a palm-like tuft of leaves, each leaf is provided with a bare wire-like rib, some four feet long, which hangs loosely swaying in the wind; this gradually tapering wire-like tentacle is covered with circles of thorny teeth, pointing inwards and about an inch apart, so that wherever they are blown 
they become firmly fixed; soon another puff of wind sends a few more hooks over the branch, until the cane is firmly held. As the growth of this creeping palm is very rapid it is easy to account for the height they attain, their object always being to breathe the fresh air and bask in the sun's rays at the top of the forest roof. The wire-like continuation of the leaf is often a great nuisance in the forest-paths: without the least warning one's hat is suddenly taken off, and on looking round is to be seen dangling at the end of one of these strings some feet above you; besides, they give plenty of work in mending clothes and nets.

The best sorts of cane, however, form a valuable article of commerce, and find their way into this country, where they are used chiefly for chairs ; but in the tropics everything is tied with rattan, in the same way as we use string.

2nd March.- The three Malays have begun to grumble, also the Chinaman, and want to return to-day; but I have resolved to stay until to-morrow, so I left them at our camp doing nothing but stuffing themselves with rice, which seems to be the kind of work most congenial to them. I enjoyed a ramble among the rocks, but it was not productive as far as my collections were concerned; in fact there are no birds about the summit of this mountain-it is not high enough to have species peculiar to it, and I have no doubt the forest birds think they are better off lower down.

The moon has been at its best the five nights we slept at the Padang.batu, which was lucky, as the wind prevented me using candles. The mists and clouds at night wet everything through, and were far too cold to be pleasant, so I was not surprised at the Malays grumbling.

The next morning we left for the lowlands, and after a weary tramp in the broiling sun reached the chief"s house at 3.30 P.м. ; then a jolting bullock-cart carried us to Chin Chin. The China boy is quite done up, and no doubt will retire from forest travel as soon as I reach Singapore. On the way down from Mount Ophir I saw a wonderful gathering of pale yellow millipeds, about six inches long; they were in a mass, one on the top of the other, which must have numbered several hundreds, and reminded one of a huge dish of macaroni.

On the 4 th we left for Kesang, ten miles distant; the next day for Malacca, when we had a weary journey in a bullock-cart, with little to eat; at last, as it was getting late, and we had still seven miles to do, I walked into the town, and was, luckily, just in time to share dinner with Mr. Hervey. We were getting hard up for food at Chin Chin, most of my provisions being finished; and as my boy told me one day " if we stop here longer, Sar, we make all chickens finish," so this caused my return sooner than I expected. After waiting until the 8th of the month, we left by the SS. 'Benmore' for Singapore. The behaviour of a fat half-caste Portuguese school-girl, who was being teased and flirted with by some six Eurasian Singapore clerk's, prevented all chance of sleep that night.

The results of my trip to Malacca were insignificant: I collected only one hundred and fifty birds and some four hundred butterflies; but this being my first experience, and as I was without native collectors, was by no means time wasted, and served me in later years, during my most successful expeditions in Borneo.

Of course Malacca is a well-civilized State, with excellent roads; a bullock-cart may 
be hired from place to place, making travelling comparatively easy. Malacca is well known for its Snipe-shooting; but to me there was not much pleasure in trying to balance myself on the narrow banks that divide the rice-fields into small spaces of from a few yards to several acres in extent, and occasionally slipping into the filthy black mud up to one's ankle or knee, besides the broiling sun, which makes these, the favourite haunts of the Snipe, stink with foul exudations, and they are in every way productive of malarial fever. Before closing this chapter, I feel it my pleasurable duty to express my thanks to Mr. Dudley Hervey for the many kindnesses shown to me during my visit.

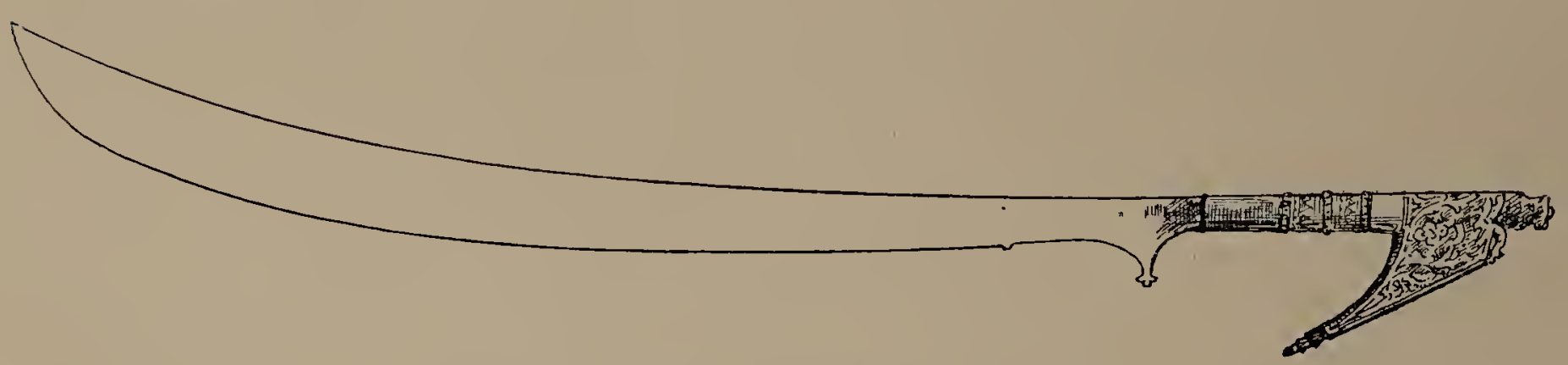

SAMBAS DYAK SWORD. 


\section{CHAPTER II.}

START FOR BORNEO.-LABUAN.-PULO GAYA.-THE S.S. "SPANIEL" ON A REEH.-ON ANOTHER REEF.

—REACI SANDAKAN.-RETURN TO PULO GAYA.-EXPEDITION TO KINA BALU ABANDONED.LEAIVE FOR THE PADAS RIVER.-PATATAN.-DUSUNS.-DUSUN FEAST.-THE OMEN.-THE EAWANG AMOK.-RETURN TO SANDAKAN WITH TIE WOUNDED.-DE FONTAINE'S DEATH.-RETURN TO LABUAN.-PADAS RIVER.-MEMPAKOL.-MANGROVE-SWAMPS.-JOURNEY UP THE PADAS.MOSQUITOES.-ORANG SUNGEI.-MURUTS.-MUSIC.-CAMP ABOVE THE RAPIDS.-WANT OF RICE. —RETURN TO LABUAN.-COAL POINT.-BIRDS.-WALKING-FISH.-CRABS.-INSECTS.

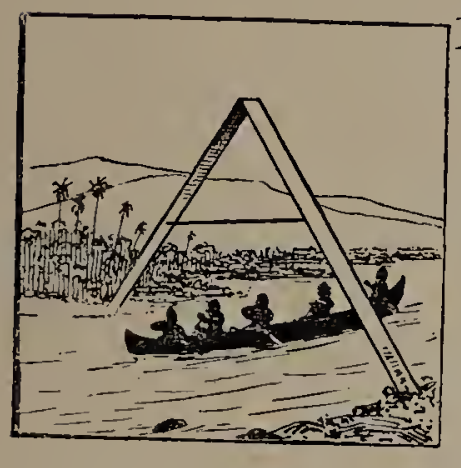

FTER waiting in Singapore until the 1st of April for a ship to North Borneo, we left in a small Chinese trading-steamer. The SS. 'Spaniel' was the name of one of the filthiest and most uncomfortable boats I was ever on board of, although the passagemoney was equal to the fares charged by the finest liners. The cabins were so small and dirty that in such a hot climate it required courage to go into them; so with one accord all the European passengers camped on deck, or rather on top of the deck-house, where we were almost on a level with the top of the fumnel, and were exposed to the soot and fine ash until everything was black. For three days I was a martyr to sea-sickness and lay on a table surrounded by the dirty Chinese cargo-clerks; I also had several slight attacks of fever, the result of my Malacca experiences. The voyage was longer than it ought to have been, our captain at times not knowing quite where he was, this being his first voyage. We passed close to the island of Sirasan, on which some years later this dirty old 'Spaniel' was wrecked. On the afternoon of the fourth day we steamed into Labuan harbour.

Labuan is the name of the island on which the small town known as Port Victoria is built; the island itself is only some 19,000 acres in extent, and is for the most part flat or undulating, except at the most northern point, where it is slightly hilly. The chief value of the island is its safe anchorage and its coal deposits, which at the time of my visit had been abandoned to rack and ruin, owing to the failure of the company ivorking them. These coal-mines, however, were re-opened some years ago; how they are now getting on I am unable to say.

As usual in our Malayan colonies, the Chinaman is strongly "en évidence," absorbing all the trade and work within his reach, sending his coasting-steamers to Palawan, Sulu, 
and the Bornean ports for the purpose of collecting the valuable jungle-products from these islands; they also, as in Singapore, farm the opium, tobacco, spirits, and the pawnbroking from the Government; these farms are put up to auction, the purchaser keeping his own spies to guard his interests. The farming-out of imposts is, I think, an objectionable practice, especially with regard to the necessaries of life.

In Labuan it is often impossible to buy fish, as there can be no object to the native fishermen in supplying the fish-market at the low prices paid by the Chinese, who retail it often at exorbitant prices; consequently most of the fish caught is not brought into the market, but sold amongst the natives themselves, or a quantity sufficient only for the household wants is captured. The Chinese also do a good deal of vegetable-growing and pig-rearing.

Labuan is noted for its fruit-gardens, in which quantities of oranges, mangoes, mangosteens, pine-apples, and pisangs (East-India name for bananas) are grown, besides numbers of other sorts of fruits peculiar to the East. Coco- and betel-nuts, the most necessary articles to the aborigines, are also largely cultivated : a coco-nut tree in full bearing brings in about one dollar a year to the orvner. The sago-palm is also freely cultivated in suitable localities.

This island was at one time covered with virgin forest, but frequent fires have long since destroyed all the timber; the dead stumps of the most durable trees still remain standing, bleached white by the sun. Whenever the land is not under constantcultivation, it soon becomes covered with a species of sword-grass, called by the natives "Lalang"; this grass, when once it takes possession, soon smothers all other growths, being itself killed only by the shade of large trees : setting fire to it seems only to strengthen the roots, which spring up the ranker with the next rain.

Besides the Chinese, several Bornean aborigines have settled in the island; they are called Kadyans, Bruneis, or Brunei Malays, and occasionally Sarawak Dyaks visit it.

The Kadyans are Mohammedans by faith; they make good colonists, occupying themselves with agriculture, forming gardens in which they grow quantities of vegetables, also sugar-cane and ceri-leaves, to be sold in Port Victoria. The dress of the women is rather pretty (see illustration, page 128), consisting of a loose dark blue skirt, a jacket of the same material, ornamented at the wrists for some distance up the sleeve with strips of red and white cloth, and numerous silver bell-like buttons. 'Their hair is twisted in a knot at the back of the head, covered generally by a red handkerchief. The men dress in the usual Malay style, loose trousers and coat. Amongst the Kadyans I formed my trusty contingent of hunters and servants, and found them most trustworthy and intelligent, hardworking and willing to please; and to them I owed much of my success hereafter. The Kadyans generally leave the main island owing to the persecutions of the head-hunting Kyans and Muruts, or the squeezing of the ever tax-collecting Brunei nobles; once settled in Labuan they seldom return home.

The Bruneis or Brunei Malays are deserters from the once far-famed town of Brunei on the main island. In Labuan they have more freedom than in Brunei, so generally settle down for good. Their houses are built on piles over the sea (see illustration opposite): being by nature a sea-loving race, and occupying themselves with fishing, this is perhaps the most 


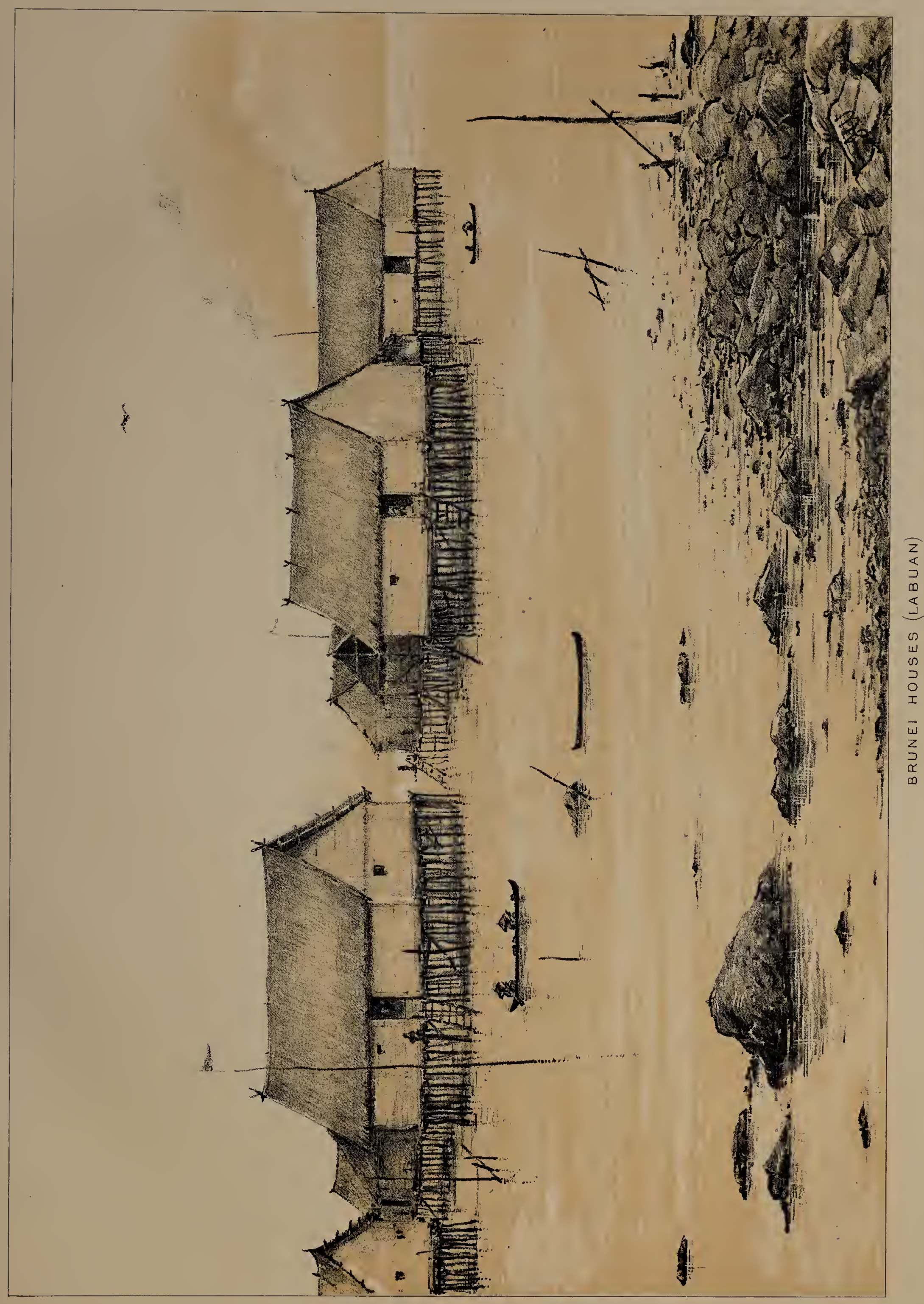



suitable and cleanly situation they could choose, though probably first adopted as a means of greater security from their numerous enemies. The Bruneis are also well known in the East as experts in the art of working metals.

The Sarawak Dyaks are only visitors to Labuan, using that island as their head-quarters when they come to the North Bornean rivers in search of gutta-percha or rattan-canes. The Dyaks are a fine race of men, short of stature, clear-skinned, often with good features ; they are, however, fond of fighting and bloodshed, cutting off heads being their greatest pleasure. For the most part they retain their native dress, a band of cloth round the loins known as a chawat. Their teeth are blackened and ornamented with small gold stars let into the enamel; their ears are bored all round the rim with numbers of holes into which fine brass wire rings are inserted,--both most painful operations; but it is astonishing what pain mankind will suffer, only to be fashionable! As the Dyaks do not inhabit the parts of Borneo visited by me, I shall not write further about them; but of their somewhat nearly allied tribe the Muruts I shall be able to say something later on. I prefer to write more about Labuan in the chronological order of my visits; so we will return to the narrative of the ill-fated 'Spaniel.'

On the 9 th we started northwards once more, passing the islands of Pulo Tega about mid-day; during the afternoon we entered the most splendid natural harbour of Pulo Gaya. 'The 'Spaniel' was getting along first rate until suddenly she ran well on to a coral-reef; the reason of this mishap being that one of the kerosene-oil tins which acted as beacons had fallen off its tripod stand, and the authorities on shore had neglected to replace it, so I do not think we could blame our captain. Anchors were let go in all directions, engines backed, but all to no purpose-the 'Spaniel' evidently was fast, and meant stopping. We landed at the end of some hundred yards of rickety nebong pier, which is necessary for connection with the shore, the coral-reefs preventing vessels of even light draught approaching closer, our dirty little steamer forming an interesting proof of this fact.

The Resident of Pulo Gaya kindly invited the few European passengers to visit his bungalow, which was perched on the top of a steep hill, added to which the broiling sun made the ascent no easy task. It was not until late when we returned to our steamer: it being now low tide the corals were above water round nearly half the ship; but to me this more stable state of things was quite a relief, and I passed a comfortable night. The coolies were busy nearly all night shifting the cargo to the stern; this eventually, with the aid of stern-anchors and the donkey-engine, helped the vessel off, when she triumphantly came alongside the pier-head shortly before mid-day. That same evening we left for Sandakan, steaming along a mountainous coast; but the hills inland were so hidden by the clouds that we were unable to get a glimpse of them until almost opposite the mountain of Kina Balu, when a rift in the clouds disclosed for a few minutes to our wondering eyes the summit of this truly magnificent mountain. I was so struck by its appalling height that I almost feared that the work of ascending to its rocky summit would be more than I could accomplish; but years later when camped far above the clouds we were able to watch the steamers, perhaps this very boat, as they plied between the Bornean ports.

The 'Spaniel' was now going well, and it was not until the following morning that we had another mishap, which might have proved serious. On passing the island of Banguey 
the captain took the safer or outside course, but, before he had proceeded many miles, ran his ressel on to another coral-reef: this time, however, the sea buinped her a good deal, and if the wind had got up she would have soon had a hole knocked in the bottom; but after two hours of full steam ahead varied by full steam astern, we were enabled once more to continue our voyage.

The coral-reefs round the coast of North Borneo are so numerous that it is a common occurrence for vessels to touch once or twice in a voyage: these reefs are so dangerous in the Mallawalle passage during daylight, as there is neither beacon nor buoy to steer by, that captains have to thread their way amongst them with the greatest caution; of course after dark the passage is next to impossible. The reefs grow up like walls within a few feet of the surface of the sea, so that a ship might sound twenty fathoms, while the next cast of the lead would be less than two; but luckily their composition is soft, and unless the weather is rough little harm is done.

Our voyage was now drawing to a close, and on the morning of the 10 th we entered the fine harbour of Sandakan: no one could have been more relieved than myself to bid good-bye to the dirty little 'Spaniel.' The Chinese steamship owners do not care about European passengers, as they require a large space at their disposal and waiting upon, whereas Chinese passengers will crowd together and be contented with very little. Perhaps this in some way accounts for the high passage-money and want of accommodation.

In Sandakan we put up at the Rest House, a most comfortable little house, under the able management of Mr. Bailey. I believe that this house has since been given up, and that visitors have now to stop at an hotel under Chinese management.

Sandakan is the chief port of North Borneo and the seat of government; in those days it was decidedly a most unpretentious-looking place. The small township is built partly on the slopes of some steep sandy hills that run down close to the sea, and partly, after the Brunei fashion, on piles over the sea. It is, I believe, one of the healthiest spots in North Borneo, the forest being cleared away for some distance inland; but the hills I fancy are rather too steep to build on without a heavy expenditure for levelling and building roads, the sandy soil being easily cut up by the heavy rains : if there is a future for it this difficulty will not be easily overcome. Even at the present time the Government were building substantial piers over the shallower parts of the coast for Chinese shops, it being apparently easier to build over the water than on the land. The town consisted of wooden buildings, in one or two cases roofed with galvanized iron; the chief buildings were the Government offices and a few brick shops. The usual collection of tumble-down leaf shanties, mostly built on piles, formed the native quarter ; this part of Sandakan has since been burnt down, and no doubt replaced by buildings more suitable to the dignity of the capital of British North Borneo. The European part of the community had perched their bungalows on the hills some little distance from the town, where fresh breezes would be more plentiful. 'There were in those days some fifteen Europeans in Sandakan, chiefly in the employ of the Company,- - this was in the year 1885; but of late years their numbers have, I believe, been greatly augmented and again decreased. Besides the Chinese, who, as usual, predominate, there are numbers of Sulu Islanders and other native races that visit Sandakan in their prahus on trading-expeditions. 
I risited Sandakan because I knew of no other place at the time where one could find accommodation, and that by my meeting the Company's officials I should be able to gain some knowledge of the country. My stay was short, as I again left for Pulo Gaya on the 2 Sth, where I expected to meet a man that I had engaged in Labuan with a native contingent, who was to act as my guide to Kina Balu.

However, during the few days I remained in Sandakan I used to ramble about in the forests and made a small collection of birds-one of the first being that extraordinary longtailed white Paradise Flycatcher (Terpsiphone affinis), also a handsome green-breasted Partridge (Rollulus rouloul); though very common in collections, this is indeed a beautiful little bird, with a hair-like crest on the top of its head, and bright coral-red beak and feet; the small green Cock-of-the-Rock (Calyptomena viridis) and many other interesting species were collected. In one of these early morning rambles I had the good fortune to be a spectator of one of nature's curious dramas. Whilst standing still I saw what I took to be a small red bird settle on a tree-stump; after waiting a few minutes one of those long green whip-snakes began to ascend the tree by the aid of the small branches; the red bird, which proved to be a tree-fiog, croaked in alarm, but seemed quite unable to use its powers of escape. Slowly the snake twined up the stem; the tree-frog, knowing its last moments were near, seemed perfectly petrified with fear, and in one of its feeble jumps the snake sprang at it and caught it by the hind legs : the snake hung half its length in the air with the croaking frog in its jaws. Having a natural antipathy to snakes I shot it in this position, when it immediately relaxed its hold of the frog, which dropped to the ground. "Just what I have been waiting for," said the snake's spouse as she seized the poor little wretch before it had reached many feet on the stem of a neighbouring tree; the little frog, however, stuck so firmly to the tree with its peculiar sucker-like toes, that I was able to approach near enough to administer a rap on the head to the snake, and so ended this unequal conflict.

That snakes hunt in pairs there is little doubt: a friend in Sandakan showed me a snake eleven feet long that he had shot in the forest, whilst on its way to attack his dogs, which were at the moment busy worrying its companion.

In Sandakan I made the acquaintance of Captain de Fontaine, Captain of the Police Force; he showed me a most interesting collection of native arms and armour, many of which he had himself taken in mortal combat in the various police raids against the aborigines. The next time I met this unfortunate gentleman it was under very different circumstances.

On the 28th April I returned to Pulo Gaya by the SS. 'Banca'; though a decided improvement on the 'Spaniel,' even on this ship, but for the captain, things would have been bad indeed. The cabins are generally used for the smoking of that foul-smelling drug, opium, and unfit for anyone but Chinamen.

The officer in charge of Pulo Gaya kindly invited me to spend a few days with him while waiting for my followers from Labuan; but it was not until the Sth of May that they arrived, so I amused myself in rambling about the island and in examining the coral-reefs. Pulo Gaya, or Gaya Island, is situated about the centre of the Company's possessions on the west coast, and is well chosen on account of its harbour, which is almost enclosed by 
high hills and islands. The village consists of a few Chinese shops, built in a row facing the sea on a few acres of flat land, about the only level space in the island. But I do not think that "Town lots" in Pulo Gaya would be a successful speculation, as years later when I visited the place the shops looked decidedly the worse for wear and had not increased in number. At one time the Chinese opened a small sago factory, but they shortly abandoned this business. The Government buildings are perched on the top of a hill, and are built of the usual materials employed in this country, attaps and kâjangs, the latter being flat mats of threaded palm-leaves, which form capital walls to a house when nailed over a wooden framework. In Gaya one of the Company's officers reigns and has jurisdiction over some hundreds of square miles on the mainland opposite, most of which has seldom, if ever, been visited. Gaya is, I should think, a most unhealthy place; it is certainly a very hot one, being sheltered from most winds; if a good site for a town could be chosen on the main island where steamers could touch, it would be a good move to abandon Gaya for more reasons than its unhealthy position. The Company's officers see little or nothing of the people they are supposed to be ruling, as few natives would trouble to come over to the island to have their disputes settled; and for the same reasons they do little trade. It is, however, a suitable depot for prisoners, and there were rumours that at one time the jail would have to be enlarged in order to accommodate the large percentage of the popnlation which it was found necessary to admonish by a little holiday at Government expense.

From the Government bungalow, in the early morning and evening, one of the finest views of Kina Balu is to be obtained. During the day, soon after nine o'clock, this mountain is nearly always hidden in clouds. We made several pleasant boating expeditions round Gaya Island, and on one occasion we pulled up one of the large bamboo basket fishtraps, to see if we could find our dinner. The basket was full of fine fish, so the Government levied tax ; in taking one of the fish out the native boatman suddenly cried out with pain, a small fisl about eight inches long having bitten him through the finger; on picking. up this fish later on $I$ found that it had teeth like a rat, so $I$ offered it the wooden stem of a match, which it cut through with one bite as if with a knife. We visited several small islands on which numbers of Pigeons (Carpophaga genea et bicolor) had taken up their abode for the time; these birds are always numerous on the smaller islands off the coast of Borneo, where no doubt they are seldom molested. In the afternoon we were overtaken by a terrific thunderstorm, accompanied by a deluge of rain, which soon ended our day's enjoyment.

One of the common birds on this island was a Tree-Swallow (Artamus leucorhynchus). This bird is called a Tree-Swallow from its habit of flying about after the manner of Swallows, and frequently resting on the branches of dead trees; but I should think that, from its mode of nesting and its eggs, it is much more nearly allied to the Shrikes. The TreeSwallows are most disagreeable little birds; they sit in families of four or five, huddled close together on the bare branches of some dead tree, and attack every other species that come near this spot; their note is a ceaseless disagreeable sharp chatter.

On the 7th May my men arrived from Labuan, so I hoped to be able to start on the following morning; but somehow I had little hopes of success-the dry season being far 


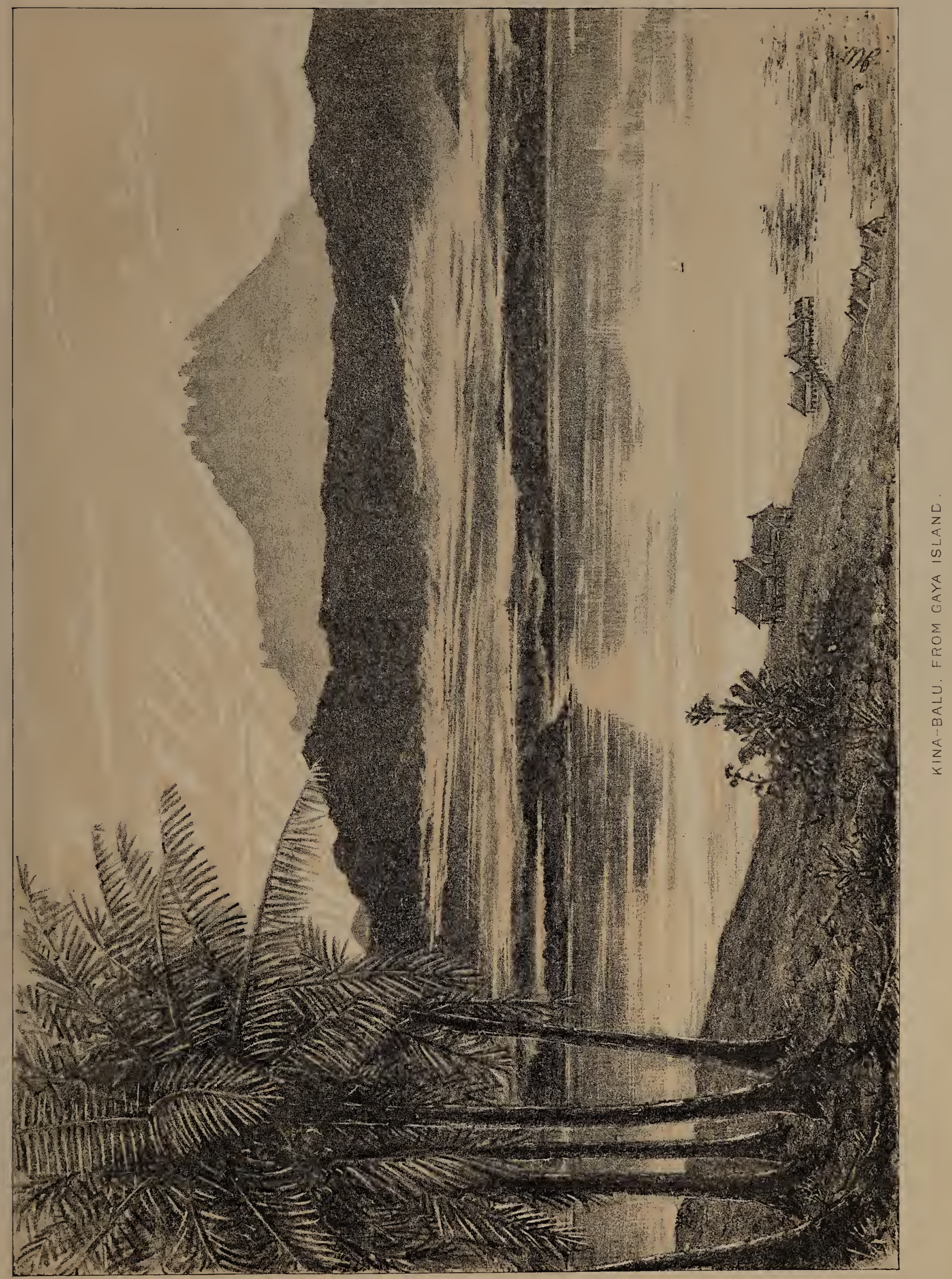



advanced, and, as far as my little knowledge of Eastern travel went, I could not see how we were going to protect our goods from the drenching rains. When the morning came and I had said good-bye to my kind host at the pier-head, we espied two steam-launches entering the harbour with De Fontaine, all the orang puteh of the west coast, and a small army of Dyak and Sikh police on board. We were informed that several tribes about the foot of Kina Balu had been misbehaving themselves after their manner, by collecting a few heads to celebrate their harvest thanksgiving; but unfortunately for me they had, I believe, attacked a village that had tendered its nominal allegiance to the Company, so it was considered necessary to send this expedition against them. This was a great blow to all my preparations, but I believe it was for the best, as, judging from my experience when I did reach that mountain some two years later, I am sure that the preparations made by my guide would have been fatal to any chance of success; so I was advised to try the Padas River, and started in that direction the following morning. After coasting a few miles the wind blew so hard in our faces that the two rotten little prahus made no progress and began shipping water freely, so we sought shelter in one of the rivers. All the North Bornean rivers have sand-bars across the mouths, which makes them difficult and often dangerous to enter: on this occasion the first prahu shipped a wave over the stern, which, however, did not do much harm; the natives in the other one jumped out and helped their boat over the bar, without getting water into her. Much to our surprise we noticed the steam-launches pass us, evidently having abandoned their expedition to Kina Balu for the time being. After a sharp shower we commenced rigging up a small shelter until the wind abated. The Company's officer in charge of the district hearing that two white men were encamped a short distance off, kindly sent us an invitation to share his hospitality; this we gladiy accepted, as there were sufficient sandflies and mosquitoes at that camp to keep a regiment awake; so leaving our boats in charge of the men we struck inland for his house. After wading through a mud-swamp we reached the splendid open plain of Patatan, and before we had gone far we met our future host coming to wclcorne us.

I remained in Patatan two days, and for the first time visited some of the Bornean aborigines. The Dusuns, as the inhabitants of this district are called, are a hard-working lot of people, devoting their time almost entirely to rice-cultivation. The rice grown by them is called swamp-rice, to distinguish it from hill-rice. The different states of rice are denoted by the natives by three separate terms-in the fields it is known as paddi, unboiled as bras, and boiled as nasi. The plain of Patatan is well suited to the cultivation of this cereal, and the inhabitants make the most of their good fortune; the ground is turned over by a rude plough drawn by buffaloes, and after the harvest they have often a good deal to barter to their less fortunate, but I must say often more lazy, brethren. The Bajows of the Tampassuk plains could raise enough rice for nearly the whole of North Borneo; but they are much too idle to plant more than their household needs, and when the crop fails they have to buy from the more industrious Dusuns; consequently the Patatan Dusuns are better off than any Bornean tribe I visited. Besides rice they have large coconut-plantations; betel-nut and other fruits are also cultivated on the small hills that stud the plain. Their only trouble is an occasional flood, when many cattle are washed away and other damage done. 
Some of the Dusun houses are very large: one house I visited belonging to the head of the tribe, a lady, was over eighty yards long, but so dark and gloomy inside that it was difficult to see. We sat for a short time on some boxes in the centre of a curious crowd of Dusuns, the Resident explaining to our hostess that I had come to see her house and was visiting Borneo for the purpose of collecting birds; this was entirely beyond their comprehension, as to their minds a bird without its flesh would be perfectly useless. The lady seemed very anxious to have one of the Company's flags presented to her, which my friend promised. On our way home we came across a peculiar carred wooden figure which was placed as a landmark; we also noticed two or three curiously painted wooden tombs, like boxes. The Dusuns, as far as European ideas go, have no religion, though believing in a spiritual existence hereafter: most of their ghosts live on the top of Kina Balu; they fear evil spirits, and have many curious rites, to which I will refer later on after visiting that mountain. The next day we took a long walk, and on our way home visited a house in which a marriage was being celebrated. The house was a long one and crowded with natives, all dressed in their best-natives in Borneo, like ourselves, having a Sunday suit. They were all-women, men, and children-more or less intoxicated, and were very jolly. Drink often improves a Dusun-he loses his shyness and welcomes his friends most heartily. We were requested to join in the feast, and being hungry we did so ; but the meat-buffalo—was far too tough, and a little went a long way towards satisfying our liunger. The liquor was, however, flowing like water; it is called arrack, and is made by fermenting rice : this I did not care about either, it being evidently an acquired taste. Most of the men were clean healthy-looking fellows, with smooth good-tempered faces, and some were decidedly good-looking; they were dressed in short loose trousers and jackets of dark blue cloth, their head-covering being a red or blue handkerchief twisted turban fashion; the unmarried men having long hair. The women also wear knickerbockers and a sort of Eton jacket, and round their waists are wound innumerable coils of blackened rattan-cane, strung with metal rings and small brightly-polished cylinders of steel. Their coiffure is simple, being a knob of hair on the top of the head stuck through with a long pin either of brass or bone; some had many bracelets of brass wire on their arms. Their best holiday hats are most curious, being like the roof of a small Chinese pagoda, beautifully plaited with coloured straws of red, yellow, and black; at the extreme point of the. pagoda is a tuft of feathers. I think if I had to award the apple of Paris to the beauties of Borneo, the Patatan ladies would stand the best chance of receiving it. Now that I have described our company, I will proceed with the entertainment. This feast had already-when we arrived-been going on for about forty-six hours, and would probably continue another eighteen, making a three days' ball. 'The great enjoyment after drinking seems to be dancing on these occasions. The dancers consist of three persons-two women, one at each end of the long house, and a man, who seems to do much as he likes. The women have little to do, merely posturing, holding out their arms at full length and slowly turning their hands up and down; their feet are slowly moved without changing their place on the floor during the whole dance. 'The man, however, careers up and down the house with a huge grass appendage tied to his back with bits of jingling metal and horn fastened to it; with bounds accompanied by fiendish yells like a roaring maniac, he remains dancing a sort 
of break-down before one of his partners for a few moments, then with a bound he is off to the other end of the house: as this is considered really hard work, there are numerous intervals during the performance, which are occupied in administering potations to the supposed exhausted male performer. The music consists of gongs beaten in unison, and the beating of the native tom-tom. The long Dusun houses are well suited to such entertainments, one side being clear from end to end and covered with elastic planks of unrolled bamboo; as usual, the building is erected on piles. The other half of the house is divided into many small cubicles (like a school dormitory); these are the private apartments of the various inhabitants.

On the following morning we left Patatan after having spent a most enjoyable visit. We embarked once more in the rotten little prahus and set sail; but the wind soon changed to an unfavourable quarter, so our progress was slow. All Bornean natives are of course ignorant and therefore superstitious, but to-day a curious coincidence happened: several heavy drops of rain fell on us and on the sea around without any clouds being visible; the men began to talk to one another, and when we inquired what they were conversing about, they told us it was a most unlucky sign, and that some people were being killed at the moment: however, we laughed at their fears; but it was only a few hours later that we learned that their curious omen was actually going to prove true. At last we reached some small islands known as Pulo Danarwan; here we found the steam-launches anchored, and judged by the faces of the natives on board that something serious had taken place. A Dyak policeman had just arrived with bad news; he told us that Dr. Fraser had been shot dead, Captain de Fontaine wounded beyond hope of recovery, the Jemadhar and two other officers killed, and eight police wounded, some severely. The Dyak himself seemed in great glee, his legs being splashed with blood, and he exhibited his sword to some of his admirers. As I was not at Kawang, where this unfortunate affair took place, and as it has to do with my tale, I copy extracts from 'The British North Borneo Herald' of June 1st, 1885:- "It appears that on the 10th inst. ... that Captain de Fontaine . . with a party of constabulary arrived at Kawang, which was selected as the most convenient and direct point of departure for an expedition to the village of a Murut chief, one Bandurong.

"Messengers were sent to Papar to bring in 50 Dusuns to act as carriers for the party, but only 30 came, and the Bajow headmen of Kawang were asked to supply the deficiency. The headmen reluctantly promised to use their influence, but it was plain that the service was very unpopular with the people, and thereupon the Resident announced that a fine would be imposed if the requisition were not complied with. The Bajows of the coast are noted cattle-robbers, and the Dusun carriers from Papar recognized a buffalo which had recently been stolen and laid their case before the Resident, who ordered the buffalo to be returned to its owners. This action, though of course unavoidable, had a tendency to further augment the ill-feeling brought about by the demand for baggage-carriers. Amongst the Bajows were recognized the noted cattle-thieves, Sahat and Bagul Putel.

"Orang Kaya Awang, an agent of Pangeran Roup, who has been influenced by persons in Brunei, was also seen going about amongst the villagers . . . . On the 12th instant, as it was found impossible to obtain the required number of baggage-carriers, it was proposed to defer the departure of the expedition pending further communication with Papar. The 
stores were ordered to be put back in the house of the Datu of the village, and the men of the Constabulary were 'dismissed.'

"The Europeans and the officers of the Constabulary were standing about under a tree in a large plain near the village, when two men came up with muskets in their hands and entered into an apparently friendly conversation with Dr. Fraser. Without any warning one of the men suddenly discharged his musket, killing the Doctor instantaneously; an alarm was occasioned. Seven Bajows, friends of the two men alluded to, and including Orang Kaya Awang and the two cattle-thieves above mentioned, at once 'amoked,' and speared fatally Jemadhar Asa Singh, Sergeant-Major Narain Singh, and Private Jendah Singh; they then endeavoured to escape by rushing across the plain towards the jungle, when Captain de Fontaine in the most plucky manner pursued them. All this happened in the space of a few minutes only, and no one had time to support Captain de Fontaine before he tripped up and fell on the ground, when the Bajows turned on him and inflicted no less than nine spear wounds on different parts of his body, three of his assailants falling, however, to his revolver. By this time the Sikhs, who were at some little distance off, had seized their rifles and opened fire, killing three others of the Bajows and wounding the remaining two, who succeeded in making good their escape to the jungle . . . . . None of the Bajow villagers took part in the disturbance, with the exception of the nine amokers, and consequently no punishment was inflicted on the village; but the chief, Datu Dullah, accompanied the Resident to Gaya. It was found that eight privates were wounded, some of them severely. Until further intelligence is received, it is impossible to say whether the treacherous attack was premeditated, or whether, as some think, the first gun went off by accident, giving rise to the panic which had such sad results; under the circumstances, therefore, we deem it right to refrain from comment."

Later news settled all doubts as to the premeditation of this "amok." The Bajows, whether seven or nine in number, prepared the day before with their Hadjis (or Mohammedans who have made the pilgrimage to Mecca) for almost certain death; and though dreadful were the consequences of their sudden and to our ideas most treacherous attack, one cannot but feel that these men were little less than heroes. I must say I always view such deeds from the natives' side as well as that of the European, and that I cannot help regarding these seven Bajows, who attacked, after their mode of warfare, no less than eighty men better armed than they were, as "braves" indeed. Whether aborigines, when they attack Europeans by such sudden and to our minds such treacherous modes, are justified or not, the reader must decide for himself; but when the civilizing (?) white man goes into countries to which he has not the least right in the world, armed with weapons of the most improved pattern and other Christian-like inventions for the improvement. of his dark-skinned brethren, I will ask, What other mode of fighting is left to them? No doubt these Bajows imagined that this expedition had intentions on their lives and property, so they attacked it in the only way left open to them with the least chance of success, and that chance slight indeed.

The steam-launches now neared the opposite coast, but it was not until late in the afternoon that the dead and wounded were brought from the shore in canoes. Seeing the fearful plight poor De Fontaine was in, I offered my services to the Resident to nurse 
him as far as Sandakan, which few of us entertained the slightest hopes of him reaching alive. It was not until late that we were able to start, the two remaining officers being busy with their despatches, which we were to take to Sandakan, until midnight.

In the cabin of the 'Kimanis' the Resident discussed his future actions: his fellow officer was for returning on the morrow and burning the Bajow village; here I regret that I expressed my opinion that as the actual culprits had suffered the extreme penalty for their crime, it would be a somewhat useless action, besides it could be easily carried out at another time if necessary. I mention this fact as some years later I received a communication from one of the Company's officials, and, amongst other charges, was that by following my advice on this occasion the affairs of the Kawang Bajows were still in an unsettled state; and "yet the very mouth-piece of the Government distinctly states that " none of the Bajow villagers took part in the disturbance . . . . a and consequently no punishment was inflicted on the village." Later on, however, they were ordered to pay a fine, which I am doubtful if they ever did, most of the Bajows leaving their village for good.

It was not until midnight on the 12th that the 'Kimanis' left with De Fontaine and eight wounded Sikhs on board, one of the Company's officers being in charge of this floating hospital. On the horrors of the next three days and nights I will not dwell : several times we thought De Fontaine's end had come--but no, he must still suffer and finish this last terrible journey : at times even the sea was rough, and, as if to make his agony the greater, our steamer's machinery broke down close to the island of Malawalli for several hours; the very sun baked our suffering wounded: a few more days of such a voyage would have turned my hair grey. Several of the Sikhs were severely wounded, one had a bullet-hole right through his chest: it was wonderful to see with what fortitude these brave fellows bore their sufferings, with hardly a murmur; later on all these men recovered in the hospital of Sandakan.

Poor De Fontaine reached Sandakan on the morning of the 15 th at 3 P.M. ; there he lingered on until the evening of the 17 th, when kind Death relieved him from further suffering. On the following evening we saw the last rites performed over one we had almost learned to love in his dire affliction, and many an eye was dimmed ere we turned from his last resting-place. He was buried beside the late Frank Hatton, who met with his death by the accidental discharge of his rifle. On the 19th I returned to Labuan, the events of the last few days having a very depressing effect ; here my second Chinese servant refused to go any further, having seen rather more than he cared about in his short risit to North Borneo, so I had to employ a native who knew little or nothing of his duties. On the 1st June we sailed across to the Padas River, landing at Mempakol: there I waited two days for the officer in charge, who intended to make a long stay inland, travelling by the same river; but as he did not seem quite certain as to the day of his departure, we did not wait any longer.

Mempakol is one of the Company's stations on the sea-coast, not far from the embouchures of the Padas River; it consists of a few Chinese shops and a sago factor 5 , also in Chinese hands. The village is built close to the sea on a narrow sandspit, and at the back is, at low water, a filthy stinking mangrove-swamp ; the whole country round about is swamp for miles, and a more depressing and unhealthy-looking place I have seldom seen. The officials of the Company who are doomed to this place of exile must have a sorry time 
indeed, and nearly all are victims, as might be expected, to malarial fever. During my short visit I watched two fishermen for some time in the early morning fishing with a large net, which was lowered into the sea by means of two long poles and ropes: when the fish, mostly grey mullet, swim in shoals over the net they are easily seen by the two men from their high perches; the net is quickly raised and an assistant collects the spoils with a landing-net. While I was sketching the accompanying illustration quite a number of fish were captured, and immediately purchased by the Chinese coolies, who seemed more anxious about the fish than the fishermen themselves.

When visiting Mempakol for the first time a stranger would wonder to himself why such a miserable site had been selected for the few shops, Government buildings, and native hovels which compose this station; but as it commands the entrance of the Padas and Kilias Rivers, where the sago industry is extensively carried on, the flat swampy nature of the country being suited to the cultivation of this useful palm, and employing a large population, the duties on exports and imports are considerable; it also has the advantage of close proximity to Labuan, that island being about one hour's sail distant: but for all these advantages a more miserable and unhealthy spot I have seldom seen.

We made an early start from Mempakol, sailing up one of the many channels of the mouth of the Padas River until we came to a "Keelong," or native stake fish-trap, in which the two owners were busily engaged collecting the fish. The "Keelongs" are made of fences of thin laths of wood stretching out into the shallower parts of the sea for over one hundred yards, like salmon stake-nets, and end in an enclosure which the fish unknowingly enter when trying to pass the slender wooden fence that bars their passage; so cleverly arranged is this enclosure that the more a fish seeks to escape the further it enters its prison. The natives were collecting their captives in the inner enclosure by means of a long piece of "Keelong" fence, which one of them by diving fixed to the bottom close round the sides, then by gradually narrowing the space they were able to roll the fish up in the mat-like fencing and lift all out together: sometimes small sharks and crocodiles up to nine feet long get in to these traps, when they must prove a disagreeable surprise to the man who does the diving. We purchased for a few cents some fine fish for ourselves and our boat's crew, on which we breakfasted, at the landing-stage of some Brunei houses. During this repast an amusing incident happened. A child-perhaps three years old-had been doing its best to make things as unpleasant as possible for its mother by shrieking, when the woman losing all patience chucked the little urchin out of the door into the water below; after a good deal of spluttering, the child swam to one of the many piles on which these houses are built, where it remained clinging until in a better temper. Such treatment may seem strange to us; but Brunei babies can swim and, some say, smoke when only a few months old, so a plunge into the water is in reality no punishment at all. I never once saw natives ill-treat their children, and it is seldom that they require to correct them: these children have very little devilment in their characters, quite unlike the British youth; so noticeable is this fact that my native followers often used to tell me how "bâniak jăhat" (very wicked) the white man's offspring were. After our repast we again rowed the prahu up stream, where the channels were so numerous, and often almost closed with overhanging vegetation, that it was at times difficult to find the right way. 


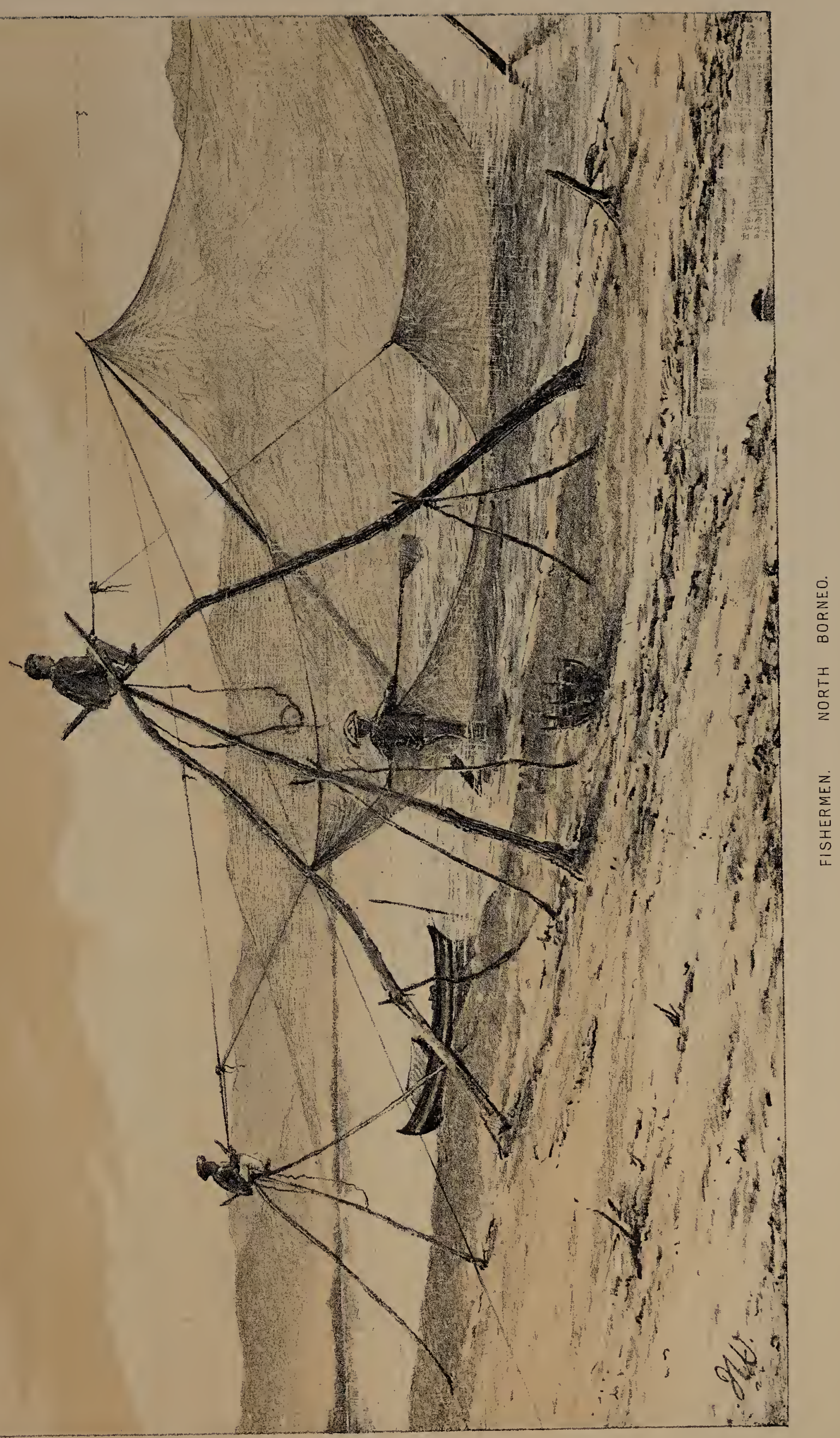



The vegetable growth on the banks and many small islands of the Padas River was most interesting to me, this being the first time I had ascended a great tropical river. The first few miles are thickly covered with mangrove-swamps; the mangroves are much stunted on the edge of the swamp, but in suitable backwaters they form quite a forest of forty to fifty feet in height: these trees only exist in salt or brackish water, where their many-branched roots at low water form a most remarkable sight. Mangroves (Rhizophora) are amongst the first rank of the land-reclaimers; so important is the work performed by them, that the remains of old swamps may now be dug up many miles inland; this I especially noticed on the shallow muddy coast of Malacca, which in time will possibly be again joined to the opposite coast of Sumatra by the aid of these shrubs ; and wonderfully is their work performed.

As it would be impossible for the edge of the swamp to encroach much on the sea without some special arrangement for its increase, the mangroves drop roots from their branches, which soon become firmly fixed in the soft mud, and thus give great stability to the trees, that otherwise could hardly withstand the force of wind and tide; the seeds, we are told by botanists, "have the peculiarity of germinating whilst still attached to the parent branch, a long thick radicle proceeding from the seed . . . extending rapidly downwards, till the fruit falls off into the mud, into which its club-like form enables it to penetrate." The root-branches also serve another important function: they collect and hold together mud, sand, and any alluvial debris that may be washed amongst them either by the river or sea ; by gradual encroachments the tide-way is lessened, and when the water is not sufficiently brackish for their need the mangroves die off, giving place to other member's of the vegetable kingdom that closely follow up the inland fringe of these swamps.

A mangrove-swamp forms a secure retreat for many species of birds, mostly belonging to the two families of Herons and Sandpipers: in the Bornean swamps I noticed several common European species-Redshanks, Godwits, Wood and Common Sandpipers, Turnstones, and several species of Eastern Plovers; needless to say they form splendid places for crocodiles, myriads of crabs and Jumping Johnnies (Periophthalmus koelreuteri), not forgetting mosquitoes. The only use to which mangroves are put by the natives is the procuring of salt from the seeds and roots by burning.

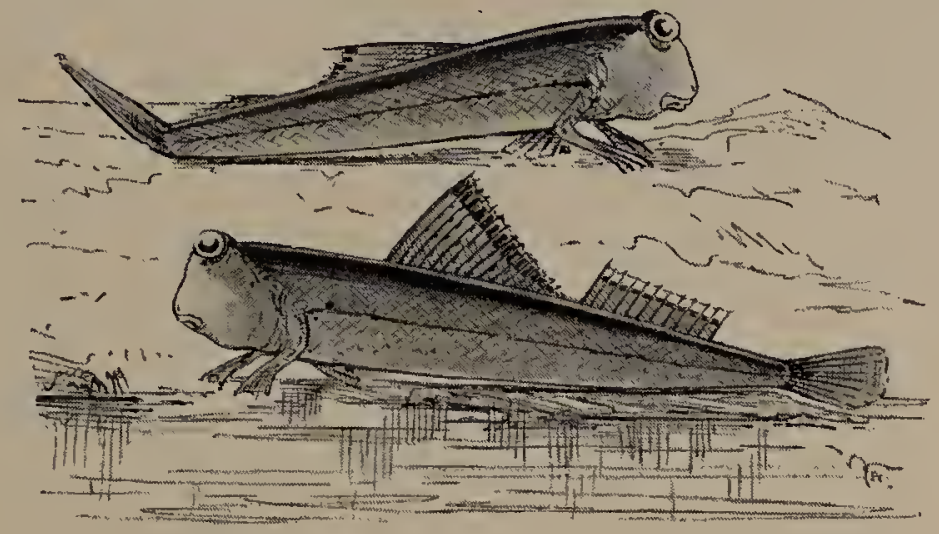

JUMPING JOHNNIES.

Next in order come huge beds of Nipa palms ( $N$. fruticans); this growth continues as long as the water is sufficiently brackish, and on the Padas River one might paddle for a day without reaching the next or forest vegetation. 'The roots of the Nipa are firmly held 
together, forming huge hummocks mixed with mud, which are exposed for half the tide ; so strongly bound together do they become that when a sudden rush of water detaches a mass of these palms they may be met with, floating erect, miles out at sea. The value of this palm to the Borneans is great; by collecting the leaves before fully opened, they are bound on a lath of nebong, and, after remaining pressed until dry, form splendid cool and waterproof roofs to their houses. Attaps, as this manufacture is called, are, however, considered superior when made of sago-palm leaves. The Nipa also supplies, when young, a covering for cigarettes, and is made into splendid waterproof mats called "kâjang," which are utilized for awnings for boats and for walls of houses, and I believe a coarse sugar is made from it. On one occasion I visited a breeding-place of the Darter or Snake-bird (Plotus melanogaster), which was situated in an unfrequented channel in this huge Nipa-swamp. These curious birds are a species of Cormorant, and are fairly common in the tide-ways of most Bornean rivers; they may often be seen sitting motionless on some dead log, but as your boat gets nearer the Darter glides into the water without the least splash and vanishes; perhaps if your eyes are sharp enough you may detect a snake-like head close to the bank as the bird proceeds up stream without the least sign of its body above the surface. During the breeding-season these birds collect in numbers, nesting on some low mangrove-trees; in the "rookery" visited by me there were about fifty nests ; about the middle of November some four or five white eggs are laid, which become much discoloured, like those of the Grebe, before they are hatched. The Darters were not the only inhabitants of this secluded spot, for hundreds of Fruit-Bats (Pteropus) were dangling at the ends of the Nipa palms, passing away their day by chattering or screaming or perhaps discussing their last night's raid on some poor native's fruit-garden. These Bats seem to court the full glare of the sun, keeping up a gentle fluttering motion with one wing as though fanning themselves. Every now and then some dozens would fly off as we approached too near, making a loud rattling noise with their wings, seeking to find some new resting-place, when the screaming and chattering would be increased by their companions, who did not wish to be disturbed by fresh claimants to their palm-stem; I noticed that as they flew between us and the mid-day sun their mouths were kept open as if panting for breath.

My European guide, to whom we will in future allude as W. S., while we were paddling up one of the narrow channels suddenly exclaimed "Hay Halligator!" and immediately opened fire with his rifle: the crocodile, a huge beast, was basking on a log when his siesta was thus rudely interrupted; with a jump into the air and a splash that sent the water far and wide, he disappeared from our view; whether he was hit or not I am unable to say. 'The natives have peculiar ideas about these reptiles, which are called "Buaia" by them. They say that if a crocodile is not shot at or worried by man, it seldom does any harm, but if you make enemies of them they always kill you when they have the chance. Whether this is crocodilian etiquette or not I am unable to say; but, if possible, I should never give them a chance of proving it, and always treat them to a bullet when I have the opportunity.

Towards evening we began to near the confines of this huge swamp; the Nipa now gradually gives way to other claimants of the soil, and forest trees, mingled with the tall- 
stemmed Nebong palm, which is surmounted with a graceful plume-like tuft of foliage, formed one of nature's most beautiful gardens; the reason of this change was that the water is now too sweet for the brackish-loving Nipa. Here we began to notice signs of animal life: flocks of screaming Parrots (Palcoornis longicauda) flew overhead; large longtailed red monkeys here, too, found a home, at night holding howling parties, which were only broken up by a charge of shot aimed in the direction from whence the hideous sounds proceeded.

At 5 P.M. we landed on the low banks, which were not more than a foot above the water, and cooked our evening meal; but the mosquitoes were in such force that we were glad to return to the prahu. As it was impossible to sleep in such a place, our boatmen preferred to paddle on until we reached the first native house; there we stopped for the night, the men being much fatigued with their long day's work. I decided to sleep in the prahu; and though I carefully hung my mosquito-net, some dozens managed to enter, preventing all chance of sleep. For forest travel a mosquito-net is an absolute necessity, not only for insects, but as a preventive from damp and fever: this net should be made of coarse thin trade-cloth known as grey shirting, by the natives as "Blatchu;" the size should not be larger than seven feet by four, with no side entrance, as this is a weak point by which mosquitoes always enter. Mosquitoes are, without exception, the worst pests a traveller has to put up with-constant everywhere, both night and day; a small black insect banded with white is especially venomous, attacking one's wrists and ankles in broad daylight. The Padas River was the worst district I visited in Borneo for these bloodsucking insects. During the day thousands of minute black sand-flies would crawl up your legs and arms and in your hair, causing great irritation by their bites; the flat and swampy nature of the country is no doubt the cause of such an extraordinary abundance.

The next morning we were off by daybreak. The surrounding country is now more open, with frequent plains of coarse grass mingled with clumps of forest; the Padas is a fine stream, quite one hundred yards broad, but the scenery is not nearly so beautiful as it was lower down.

When we landed to boil water for our breakfast, we were, as usual, soon driven away by mosquitoes. In a clump of trees I was delighted with two very small squirrels (Sciurus exilis). These little animals were very tame, allowing me to approach within two or three yards; but they always managed to avoid my butterfly-net, with which I was trying to secure them, by dodging round the tree-trunk; they belong to a small group of pygmy squirrels, and are no bigger than a large-sized mouse, feeding apparently on the bark of large trees, which have their trunks often much bitten by these little animals.

On the 5th we arrived at Gadong, at the time of our visit the only station of the Company on this river. The garrison consisted of eight Sikh police, who were living in a tumble-down native house; here we decided to rest for the day, as our boatmen had had a very hard pull since we left Mempakol, the mosquitoes at night spoiling their rest. In the afternoon I visited the house of a native chief, who showed me some beautifully-cast brass cannons, or, as they are called, "badils;" they were covered with ornamental work and with well-executed models of crocodiles for the handles, which most of these badils have over the swivel, and mounted so as to command the river in front of the house. 
These guns were used at one time on the coast as money, and are employed for this purpose still in out-of-the-way places; they are valued by weight, ornamentation going for nothing. I bought one of these weapons on this river (see illustration, p. 76), but should not care to fire it off, as it would be decidedly more dangerous to the person who fired it than to the mark aimed at.

An early start next morning took us past similar scenery, but native houses were more plentiful, there being one about every mile. The inhabitants of this part of the river are different from the Bruneis, though also Mohammedans, and are called "Orang Sungei" or River-men; these people are probably the real inhabitants with a strong strain of Brunei blood in their veins, who have been conquered centuries ago by the Brunei Malays and forced to follow Islam. The Orang Sungei do most of the agricultural work, growing rice and various fruits, such as Durians, Jack-fruit, and Pisangs; they also rear numbers of fowls. In the afternoon we reached the house of the Orang Kaya Sahabandah, where, as it was getting late, we decided to stop the night. Here we were evidently unwelcome guests, the people asking three and four times their value for fowls and eggs, which we refused to pay. On the following, day we again proceeded up stream, leaving at the house of one of the Company's subsidized chiefs part of our baggage, the prahu being too heavily laden to pass over the first rapids which we should meet with before our next camp, which was beyond the limit to which Mohammedans go on this river.

The populations of the Padas and most other Bornean rivers are clearly defined by the streams themselves. The estuary is occupied by Bruneis, who prepare fish and salt, to be bartered for other goods with the Orang Sungei; they also often have trading-prahus for collecting jungle-produce from the same people. The Orang Sungei act as middlemen, collecting jungle-produce from the Muruts, and extend up to the first rapids; these they seldom pass, as their prahus are too big, and the country becomes hilly and unsuitable to their mode of agriculture, the land best suited to them being flat, where they can raise large quantities of sago, but at the same time subjected, I should fancy, to terrible floods. Beyond the rapids you find yourself among the more uncivilized tribes on this river-the Muruts; they seem very little removed from the Dyaks. These people cultivate the hills by cutting and burning the forests, when they plant rice known as hill-paddi, which is, in my opinion, preferable to the swamp-rice. Here, as elsewhere on the Padas, a great many natives have left their campongs on account of a perfect plague of rats which devoured their crops, and they were continually asking whether we had brought any rat-poison with us. The Muruts also are great pig-hunters, and collectors of various gums, rattans, wax, and other forest-produce, which costs them a great deal of labour, and for which they do not receive one-hundredth part of the value in barter with the Orang Sungei. Then, as we go further inland to the watershed of these great rivers where they become tiny trickling streams, we find man but little removed from the higher apes, living all his life in the forests, neither sowing crops nor building villages, but still with enough intelligence to collect the produce of the forest, which is passed from hand to hand until it reaches our homes in this far-off country in the shape of cane-chairs and varnishes; thus commerce, like the river, stretches out her feelers until they become so fine as to be hardly recognizable. 
We camped shortly before dark at a Murut village consisting of four or five small houses; the inhabitants were a most miserable half-starved lot of people, several deformed, and many suffering from bad sores. The Malay language is now no longer useful, the Murut not troubling himself to learn other tongues like the Orang Sungei, who can often speak four or five Bornean dialects.

Here we met our friend the officer in charge of the Mempakol station, who for brevity we shall allude to in future as Mr. D., he having passed us in his lighter canoe shortly after our leaving Gadong. In the evening Mr. D. hoisted the Company's flag on a high bamboo for the first time so far up the Padas River amidst (I suppose I must say) lusty cheers from the few Muruts assembled, who never cheer in our sense of the word, and probably had a very faint idea of what this ceremony portended.

'The house in which we passed the night was a tumble-down Murut dwelling, consisting inside of an open space in front of a few wooden stalls, the private apartments of the owners, who, like the Dusuns, live several families in one house. Mr. D., W. S., and myself occupied the open space or public apartment, where we passed an unpleasant night, the chief reason of our disturbed slumbers being the numerous Murut dogs, which are always present in native houses other than Mohammedans. 'These dogs kept up frequent fights between our mosquito-nets, round which they were prowling in hopes of picking up anything eatable, which in a Murut dog's menu consists of boots and anything that has even a flavour of nourishment about it. The Muruts asked us for rat-poison, their crops, like those of the people lower down this river, being destroyed by these animals.

After our evening meal we sat talking to our curious hosts, when a Murut outside began to play on a small reed-pipe. W. S., always to the fore, called him in, and began to try to play on the instrument in the usual way; but, after several attempts, no sound issued forth "to calm the savage breast," so he returned the pipe to the Murut musician and begged him to perform. Much to my surprise, and to the disgust of W. S., our musician took a small ball of tobacco from his girdle and proceeded to plug up one nostril; in the other he placed the pipe, and continued to play as before; this novel way of performing with a pipe no doubt deterred W. S. from further practice on native instruments. The Murut played really well; perhaps the flat open nostrils of these people are well suited for such a performance.

9th June.-This morning we changed our prahu for two Murut canoes, as the rapids before us were impassable with anything else, and we left two of our boatmen with most of the provisions at the Murut village. We also hired a Murut as guide, but he proved utterly useless. About mid-day, after passing many rapids, we camped on a suitable open sandy spot, where we erected a small shelter. In the evening I shot several Fruit-Bats for our Murut guide, on which he made a good dinner. We hear Argus Pheasants crying out close to the camp in the mornings, for which our men set dozens of snares but never caught one. The hills run steeply down close to the river, making it most difficult to get about; the forest is dense and full of leeches. Our Murut led us over miles of mountains in search of imaginary Orang-Utans or Mias, as this animal is called by them, and as we were fools enough to follow him, several days were wasted in this unprofitable way; 
however, I caught numbers of fine butterflies as they settled to drink on the wet sand, the finest being a most gorgeous insect of spangled green and black, the hind wings of bright iridescent blue, with spoon-shaped tails (Papilio arjuna). The fine Papilios, which are often difficult to catch, fall easy victims to this simple method-by catching some of the common species and placing them in an open place on the wet sand, a few with their wings open, nearly every butterfly on passing, seeing these butterflies, will immediately settle amongst them; and so fearless do they become that insects which you often can hardly approach will allow themselves to be touched with your fingers.

Rain is now a daily occurrence, and most of my scanty wardrobe is wet through, there not being sufficient sun on some days to dry my clothes; so to-day (13th) I am " downcast and damp," at least my clothes are all wet through and are hanging in a row in front of the camp. Camp-life is at times miserable, especially before the sun gets up, when everything is more or less damp. Some animal in the night bit several large holes in my hat; as it could hardly be nutritious, I conclude it was wilful destruction on the part of the unknown marauder. Our Murut says that he must return to the bosom of his family as he has work to do, so I willingly paid him his wages, as this Mias-hunting is a delusion. By the same canoe that took him home, I sent W. S. to see how the two men we had left in charge of our rice and other provisions were getting on: in the evening he returned with the news that there was only sufficient rice to last for five days; as we had left nearly a sackful only five days ago with two men, they could not possibly have eaten this amount. Whether they gave my rice to the Muruts or otherwise disposed of it, I am unable to say; but from what I afterwards discovered respecting the characters of certain members of this expedition, I need no longer be in the least doubt that it was disposed of to. force my return to the coast, all well knowing that these half-starved Muruts had none to sell, and, being on monthly wages, it suited their purpose. This unfortunately forced my return to Labuan earlier than I intended; but it taught me one lesson, that if I would travel in this country I must learn Malay, as otherwise I should be a prey to my employés, who would be constantly doing everything in their power to cause my return to quarters more comfortable to them.

14th.-We left our miserable camp and reached the house of the chief where I had left some of my baggage on the voyage up stream. On the following day I shot my first new Bornean bird-Dendrophila corallipes; this was a small red-legged Nuthatch, specimens of which at the time were lying in state in one of the glass-topped boxes of the South Kensington Museum mingled with a number of its near ally, $D$. frontalis.

The Datu in whose house we are stopping shows us that he would sooner have our room than our company, so I am resolved that he shall be quit of us as soon as possible. I am rather sorry to leave so soon, as I find quite a number of birds and butterflies about this neighbourhood. I am also sorry for the Datu, as he is in a most unfortunate position, being married to several ladies who will not live peaceably under one roof, so he has to divide his attentions between two houses; and if by any undue preference he excites the jealousy of these ladies, he receives a warm reception, having various articles of crockery thrown in his direction. I am truly sorry for him, so left as soon as possible. It now rains in torrents every day, and this continual river-work is therefore almost unbearable; 
besides, continued sitting still in the boat is most unhealthy work: several times when we attempted to walk along the river-banks the slushy paths were up to our knees in water and mud. I am now beginning to be quite doubtful of ever doing anything in this country, and at times almost make up my mind to return home. During the whole time we were on the Padas River we seldom got a night's rest for mosquitoes, my men being quite done up, having no nets.

On the evening of the 17 th we again were amongst the mangrove-swamps; and just as our prahu reached the sea it became firmly fixed in the mud; as the tide was receding, we had to remain there until morning. At 9 A.M. we arrived at Mempakol; and thus ended the most uneventful and worst managed expedition I have ever made: in fact, I must apologize to my readers for recounting this part of my history ; but it will give them some idea of what a naturalist has to endure, and to any intending traveller one of the many ways in which he may be duped.

For the next few weeks after my return to Labuan I was laid up with slight attacks of fever, and so was my native servant, who in a very few days after my return went out "on the spree" and neglected to turn up for a day. When I sent after him, he told my messenger that he would come back on the morrow; but on his arrival he found another carrying on his occupation. Natives and Chinese servants are very fond of leaving in this abrupt manner, generally waiting until their month's wages have been paid, so it is best to pay them shortly after their money is due.

The small town of Port Victoria is composed of a row of one-storied Chinese brick shops, with the usual collection of native "attap" dwellings in the outskirts. The Government office is a fine roomy wooden building; but there is an air of neglect about this small town, which is perhaps to be accounted for by the fact that, since the coal-mines were abandoned, trade is not nearly so brisk; then Chinese shop-keepers are naturally a slovenly lot of people, taking little or no interest in the outward appearance of their business premises. The harbour is better than most others in Borneo; with the assistance of a few feet of nebong pier large steamers can unload within a few yards of the shops. During one of my visits to Labuan I visited Coal Point, the scene of the Oriental Coal Company's workings. It was indeed a sorry sight: thousands of pounds worth of machinery lay about in all directions, often a mass of rust, and of course all woodwork was long since destroyed; most of the brass fittings had been cut away or unscrewed from the engines and other plant by, it was supposed, Bruneis from the mainland, who must have thought the white men big fools to leave so much valuable metal about-in which they were not far wrong, as I believe most of this wilful waste was due to certain Government claims on the property.

In Labuan I amused myself collecting birds, and in making short expeditions to some of the small islands which form the Labuan group. The commonest species of birds in the island were three sorts of Paddi-birds, which at the moment are busy proving one of Darwin's great doctrines-_" the survival of the fittest." The commonest species of Paddibird at present is Munia brunneiceps; this species has almost extirpated a once commoner species, $M$. fuscans, a much smaller bird, but in habits identical with the other bird, and thus perhaps competing slightly with it. Of late years one of the Gorernors of Labuan 
introduced the Java Sparrow (Padda oryzivora), which in time, no doubt, will prove as beneficial on a smaller scale to the Bornean native as rabbits have in Australia!

The Java Sparrow is well known to all of us, often being imported into this country by bird-dealers. In Labuan, the original pair or pairs imported have increased at a prodigious rate, and now form large flocks, and no doubt in time will exterminate the weaker race (M. Urunneiceps). The Sarawak Dyaks often purchase Java Sparrows in Labuan to take home with them; if a few pairs attain their liberty the Dyaks will have the honour of adding one more enemy to their paddi-fields.

I also shot numbers of Doves (Turtur tigrina), and a small Green Pigeon (Treron vernans) affords excellent sport in the evenings, dashing past the shooter in large flocks. There are also one or two species that frequent the precincts of your divelling. First, perhaps one of the most elegant in its movements of birds, is a small Fan-tailed Flycatcher (Leucocerca javanica), which hops about on the ground, below the shady mango-trees, with its wings almost touching the ground, and its black and white tail spread out like a Turkey, uttering every now and then its pretty note "kip-kip-pě-whe-ēk." In the mango-trees it builds a pretty cup-shaped nest, bound to a slender dead branch by means of spiders' web. Then there is the well-known Dial-bird (Copsychus amonus) with its Magpie-like plumage, which delights one with its singing. Prettiest of all is the dark metallic-blue-throated Sunbird (Nectarinia pectoralis), which often hovers under the verandah in search of insect prey : this bird builds a pretty pendent nest of dead leaves and grass, bound together with spiders' web; the entrance is from a small roofed hole in the side; at the bottom a long streamer of leaves was left hanging loosely, which helped the nest to escape my observation on several occasions, resembling as it did the collections of rubbish that are spun together either by caterpillars or ants. At the foot of the low hill on which my Labuan house was built the shore was fringed with coconut- and sago-palms, and beyond this a mangroveswamp, which though an unhealthy place to visit, was nevertheless teeming with animal life. Most noticeable of the inhabitants of these swamps are numbers of small fish which spend more of their time out of the water than in it: they are called by sailors "Jumping Johnnies," from their curious habit of hopping about on the mud; for this dual existence they are provided with specially convertible tails and pectoral fins, which, when out of the water, act as legs (p. 31-illustration), so that they walk about with ease; when, however, excited by my approach, the tail is twisted round and is used for jumping with, acting as a lever. It is a curious sight to see dozens of small fish hopping about on the mud: at the edge of the water they are more plentiful, when, if disturbed, they can escape into the sea; but they do not seem to care about diving, preferring to hop along on the surface to some rock, on which they sit. I found them difficult to catch, except with a hook baited with a fly, when some dozen would bob along on the mud in eager pursuit of this bait. The mangroves are also the homes of many varieties of crabs: some are provided with one huge claw as big as themselves, coloured bright red or yellow; these seem to be the Dyaks or fighting men of this inud colony; they are about two inches long, and live in round holes burrowed deep in the mud: at low tide they swagger about seeking to fight one another, one crab driving another from the entrance of its burrow; when the vanquished one thinks it has been driven far enough it executes a flanking movement and bolts home. What 
the use of this large brightly-coloured claw is I am unable to say, unless it, when folded across the front of the crab, successfully blocks up the burrow; they have also a tiny feeding-claw with which they shovel the green slimy weed to their mouths. There is another species with eyes sticking out from its head like the antennæ of a butterfly: this species is beautifully adorned with cobalt-blue; its whole occupation seems to be to eat as much greeu weed as possible, and it is a true vegetarian, and indignantly thrust away a piece of raw beef with which I was fishing. In the deeper pools amongst the mud may at times be seen a curious large boiled-looking lobster : this crustacean is very shy, moving about and vanishing into the mud on the least sign of alarm. I several times made collections of some of the little warrior crabs, which I put in a tin pot to carry them; but the battle waged in this small space was so fierce that some seventy claws and legs were ownerless before I got back to my house. Insects of course we have in Labuan in plenty. The large bronze-blue-winged carpenter-bee bores neat holes into the poles of the bungalow, and, as I remarked before, has a particular spot on which it rests; one bee I noticed for over a month always settled on the top of a bamboo-paling with no intention of boring a hole in it. The well-known mason-wasps build large edifices of mud on the poles which support the roof, filling the three cells into which these lumps of corv-dung and mud are divided with benumbed caterpillars and spiders, which live to be slowly devoured by the fat maggots or pupæ of the wasp. Ant-lions drill hundreds of small pitfalls below the house, into which numerous ants are always tumbling.

The rains are now nearly over, and we may expect a month or two of fine weather before the longer wet season sets in, which commences towards the middle of October and lasts until the middle of January ; but the same dates do not apply to more than a few hundred miles of any territory in the Archipelago-a range of mountains in some islands causes the wet season on one coast, while the other hardly gets a drop of rain.

I had now two servants-a native, named Jumbol, as cook and general servant; and a boy of about ten years old, who was a frieud of Jumbol's : a dirtier urchin never breathed; he neither washed nor combed his hair, and was covered with that most disagreeable skin-disease " kürrup." I do not know why I ever accepted his services, but somehow his monkey-like appearance was interesting. I even made a drawing of him (see illustration facing p. 42), which took some time, as he seldom sat still, and one day wanted to wear a Turkish fez, another his dirty mop of hair would be tied up with rag, which suited him best. This boy fetched wood and water, and was named Boukar. The best and most faithful follower I had was a Kadyan named Nyhan; this man acted as my bird-collector, and remained in my service until I returned home.

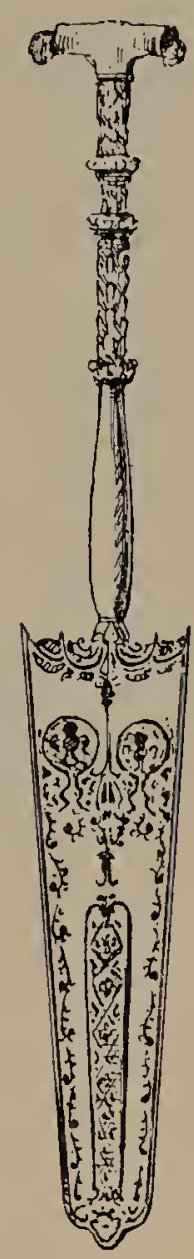

KADYAN WOMAN'S PADDLE. 





\section{CHAP'TER III.}

SAIL FOR KUDAT.-BENKOKER RIVER.-OBTAIN A HOUSE.-FAREIGH, THE NEGRO.-BIRDS.-ORANG SUNGEI.-MIAMMALS.—CROCODILES.-PIGS.—CROCODILE'S NEST.-BANDEIRA'S AMOK.-START FOR KUDAT.-HORNBILL'S NEST.-BEES.-BUTTERFLIES.—SCARCITY OF INDIVIDUALS. - LOW RATE OF INCREASE.-NESTING-HABITS IN THE TROPICS.-HEVER.-WET SEASON SETS IN.RETURN TO LABUAN.

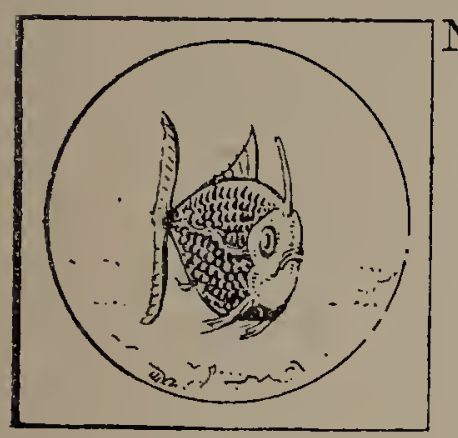

$\mathrm{N}$ the 24th of August I left Labuan for Kudat-the Company's station on Marudu Bay-where the Resident of the West Coast resides, taking the three natives mentioned as my servants. I thought it would be best to dispense with European assistance, seeing what a farce my Padas expedition had turned out; and as none of my followers could speak a word of English, it would be necessary for me to learn sufficient Malay to make myself understood.

On the 27 th of August we arrived in Kudat, where we remained trying to get a boat to take us across to the Benkoker River until the 31st. At Kudat the Resident showed me great kindness, inviting me to live in his bungalow during my stay, and assisting me in arranging my trip to Benkoker, which river flows into Marudu Bay opposite Kudat. Kudat in 1885 looked anything but a prosperous port of the young colony; a greater part of the town was built of attap houses over the sea on piles, and on a sardspit between the sea and a swamp, but nearly all were tenantless and dropping to pieces, two Chinese brick shops being the only buildings worthy of the name. The Government bungalow was a fine substantial building, both cool and comfortable, being built with expectations of great things, which up to the present have not been realized. Kudat was expected by its builders to be a place of great importance, being in a splendid bay with deep water close in shore ; but I believe one of the chief reasons of its early decay was the cholera and smallpox epidemic, a few years before I saw this station. However, the trade will have to be brisk to make the place attractive, as the water obtainable some distance from the town site is both scanty and brackish; it may seem absurd, but it is, I believe, a fact that Kudat was built before its founders looked for fresh water, which they never found, after boring in various directions. Since my visit in 1885 it received a fresh start with the tobacco industry, which I believe is now on the wane. The country round about is covered with forest and is mountainous. 
On the 31st of August we left for the Benkoker River, which was reached after a few hours' sail ; the tide being suitable we had no difficulty in passing the sand-bar, which seems ever present across the embouchures of Bornean rivers: we passed into calm water and proceeded up stream, having no definite idea as to where we were going to settle for the next month or two; on our way up the river we saw two Crocodiles, some Darters, Herons, and other birds; but as shooting out of boats is most unsatisfactory, I was not on the look out. A little further on we passed the now flattened remains of some large houses which had been built by the Company for a number of Hakka Chinese, who were enticed over to Borneo by dreams of land grants and other privileges, these people being chiefly agriculturists; but however good they might be at growing vegetables, as it was impossible to find a market for their produce they were unable to earn their livelihood, and when the rains came the river overflowed its banks level to the floors of their houses, added to which fever and other climatic complaints soon killed or dispersed this disastrous little colony. A short distance further on we passed some natives on the left bank busy making attaps for the newly-opened station on Banguey Island; we little thought at the time that one of these peaceful-looking individuals was to be the cause of a most dreadful tragedy before a few weeks had passed over our heads. Shortly after passing these attap-makers we were hailed by a negro in broken English; he, hearing I intended to stop on the river some time, offered to sell me his house, as he said he was going elsewhere after attaps : the hut being fairly clean though small, and I was undecided as to my future movements, I thought this would be a suitable place to begin with. The price asked by Fareigh, the negro, was six shillings, which I agreed to pay when I left; but I afterwards found out that this black gentleman had no claim to the house at all, and that it belonged to some natives who had gone to work in their paddi-fields higher up the river, so I waited until they returned, when I paid them for the use of their little dwelling (see illustration opposite). In this house we lived until the 17th of November; it was built in the usual style, about five feet above the ground on posts, the sides and roof made entirely of attaps, in size about twenty-five feet by ten; with the help of a few rattan mats, boxes, and my folding camp-bed, my division of the house soon looked quite comfortable; the three boys had the rest, which was divided off with attaps, using it as a kitchen and sleeping-apartment, and for everything else as a matter of fact. We had no door to close at night, but pulled up the ladder by which we entered and placed it across the entrance. The forest extended to within a few yards of our dwelling, which was very convenient, as often one has to walk miles to suitable collecting-grounds, which in the tropics means a good deal of labour; the river flowed past our frontage, so we had no difficulty in obtaining wood and water for our daily use, this occupation falling to "Boukar, the Dirty." On both sides were houses of the Orang Sungei, surrounded with maize-plantations and a few acres of sweet-potatoes.

Fareigh, the negro, reigned like a king over the people; unfortunately they are all afraid of him, believing him to be, through his own representations, one of the Company's servants: his chief occupation was buying attaps, or acting as middleman between the Kudat and Banguey coolies and the Benkoker people, who could have managed better without him; he also did a good deal of trading in beeswax and rattans, cheating his clients in every possible way. I have never come into contact with the great African negro 


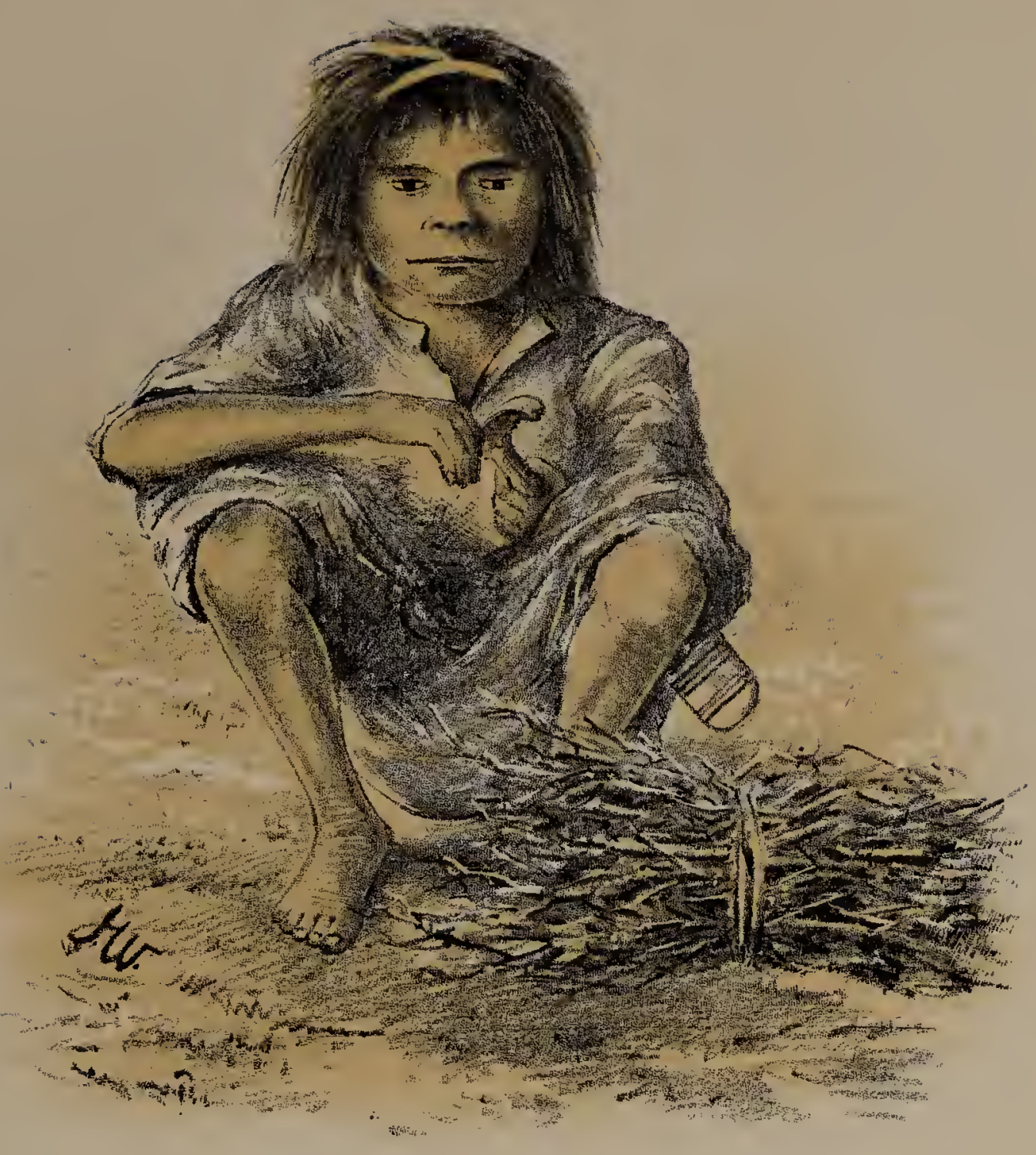

BOUKAR

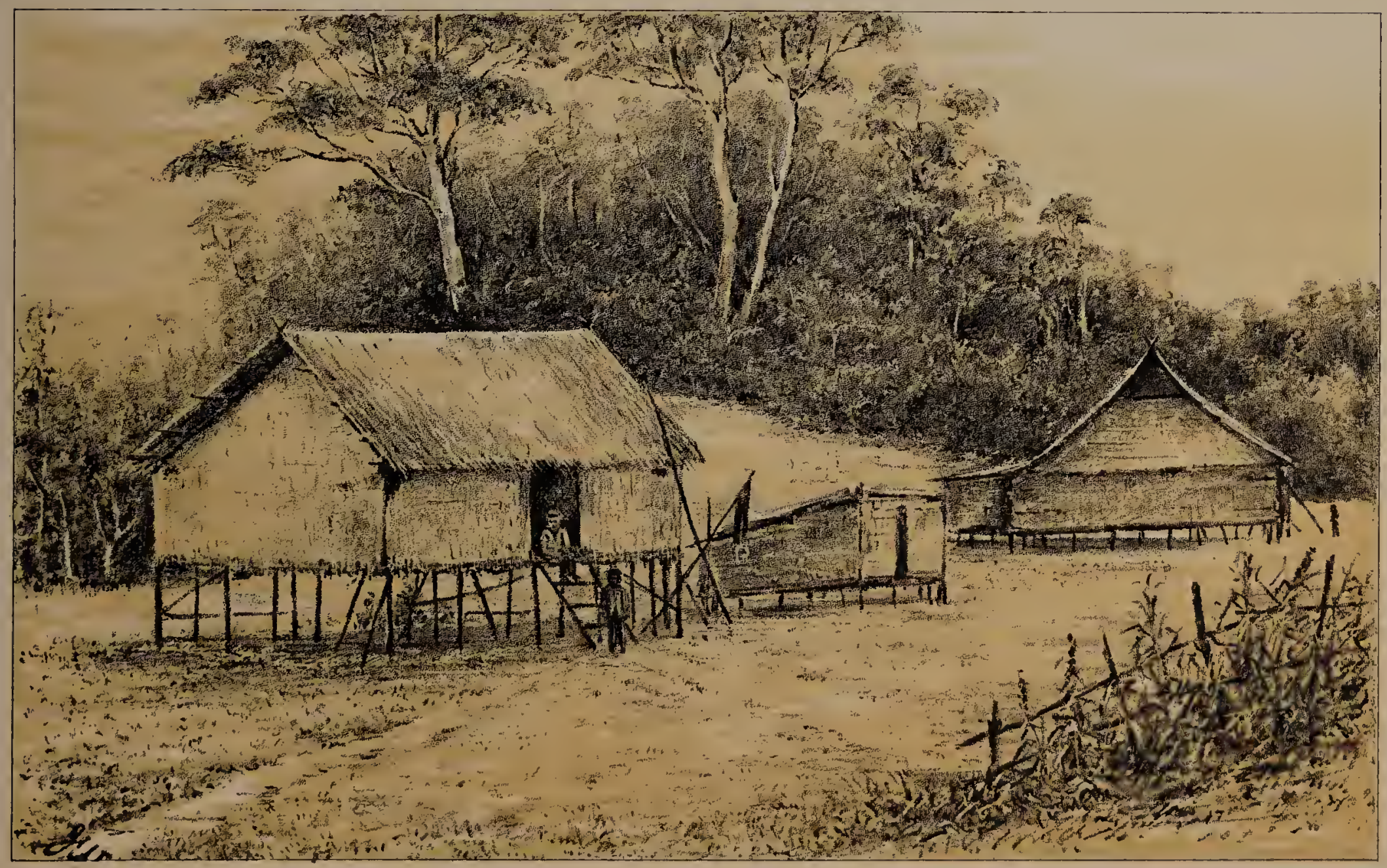



races; but from what I saw of this single specimen, I should conclude that it is possible for them one day to take a high position among nations, adapting themselves easily to western civilization, and perhaps surpassing even the Chinese in general swindiling.

Somehow, whenever I turned up unexpectedly, Fareigh was always to be found sitting comfortably in my house; later on I found out that he used to watch me go to the forest, when he would make his morning call and demand his breakfast, threatening to thrash the boy left in charge unless he complied with his wishes. However, the next time I met my negro acquaintance I told him if ever he entered the house again I would give him a most awful thrashing-which, by the way, I should have been totally unfit to carry out, as he was considerably over six feet and big in proportion, but a thick stick across his shins would have made some impression, I have no doubt. One branch of this man's business was very lucrative: he would confiscate the krises of the Orang Sungei, abont the only article of value they possessed, on the slightest pretext, and the next time he went over to Kudat would give them to the police; but not quite understanding this mode of procedure, the first time I went over to Kudat I inquired of the police about these weapons, and requested them to visit the Chinese pawnshop, where, as I expected, Fareigh had pawned them. These sort of superior-minded men do an immense amount of harm amongst the ignorant natives, and especially when their range of rascality is far away from Government control: unfortunately the territory of the Company is so great, its officers so few, and the means of communication so bad, that those in charge of districts larger than most English counties seldom visit parts of these districts once in several years; and when they do so, the natives have either forgotten their wrongs or avenged them after their own custom. If I had not made the Resident aware of Fareigh's misdoings, he would, no doubt, be king of the Benkoker to-day, ruling by his pretended connection with the Company, and frightening the ignorant by his threats, size, and ugliness, unless some native more plucky than the rest had cut him down with his kris, which would probably have got the whole community into trouble with their supposed government, and certainly brought death to their deliverer from this swindling bully. I am happy to state that when I last inquired after this negro, a year or so later, he had overstepped the limit by swindling the Government, and was then enjoying board and lodging at the Company's expense, and was not allowed to visit the Benkoker after his release.

The proximity of both forest and river made our dwelling very convenient ; I purchased a dug-out or canoe from some natives in which we could make expeditions on the river, so we were able to move about freely, and commenced collecting in real earnest. The forest mostly grew in broad strips along the sides and tops of the low hills, which had been left by the Orang Sungei and Dusuns, being considered by them unsuitable for maize or rice plantations; the country was mostly covered with close impenetrable jungle which had sprung up in a few months after the harvest. These jungles formed lairs for quantities of huge pigs, deer, and often wild cattle. In the forests we found numbers of beautiful birds, including Argus Pheasants (A. grayi), Jungle Partridges (Arborophile charltoni), some six species of Hornbills, including the large Malayan species Buceros rhinoceros, and a solid knob-billed bird (Rhinoplax vigil), Forest Kingfishers, Bee-eaters, Sun-birds, Trogons, Barbets, all birds of the brightest colours, on some of which Nature seems to have bestowed? 
every colour she is possessed of. So abundant were the species of Woodpeckers that we collected no less than thirteen species on this river alone. We also collected two rare species of Pittas (P. baudi and P. ussheri). The head of the first is bright silvery blue, bordered by a black band, the back vermilion, throat white, the breast dark blue with copper reflections; the second species has a black head and throat, purple and blue back, and crimson breast: such beautiful creatures were well worth coming to Borneo to see.

On one or two occasions after the tell-tale leaves and twigs had been soddened by the heavy rains, I approached unexpectedly within a few yards of an Argus Pheasant, which was off like a flash and out of sight. My collector Nyhan shot a cock and two hens, and a splendid male we caught in a snare, but. before we visited the trap it was totally spoiled by a wild cat. As neither the Orang Sungei nor Dusuns are trappers or hunters, like the Murut and Kina-Balu Dusuns, ground birds were fairly plentiful; several times we came across the parade or plumage-displaying grounds of the cock Argus, which are neatly swept circles of about two yards in diameter, where the cock displays his somewhat ungainly though beautifully marked plumage to his admiring spouse. The cry of this Pheasant is very loud, and sudden noises, such as thunder, the crash of falling forest trees, and even the explosion of a gun, cause them to cry out with a voice that resounds far and wide, as if such noises gave them pleasure : the firing of a gun disturbs forest birds but little.

Pittas are shy and difficult to collect until you begin to understand them. Pitta ussheri, though rare in collections, was here fairly common. They frequent the ground and fallen trunks of trees, seldom using their wings, but proceeding over the ground at a great pace by hopping. After we learnt to imitate their peculiar whistle-which begins almost imperceptibly, increasing in volume until quite loud, when it suddenly ceases-it was not difficult to attract the birds within easy shot. Though adorned with the brightest of colours, this Pitta is difficult to see, frequenting the gloomy parts of the forest, where, with its back towards you, it will remain motionless and unnoticed; even the scarlet breast does not attract attention amongst the dead leaves and husks of forest fruits which cover the ground and equal it in brightness. The only two specimens of Pitta baudi collected were shot by myself, though Nyhan blew another to pieces-a very common fault with most native collectors, who, though born sportsmen and naturalists, are apt to get excited over the rarest species, which they often totally destroy. It was one early morning soon after daylight that I shot my first specimen of this beautiful species. Seeing a bird hopping about an old rotten tree-trunk, I took a most careful pot-shot, but to my sorrow I found no Pitta lying on its back when I approached the dead ling. After searching around for over an hour, and bewailing this misfortune, we were returning home, when amongst the roots of a large tree lay this gem of bird creation on its back. I sat down and stroked it, put every feather in its place, brushed the ants off, which had already found my prize, and gazed upon one of the most lovely Eastern birds-satisfied with all the world.

As soon as we were settled on the Benkoker, we were visited by numbers of the Orang Sungei, who generally came to be cured of their various ailments: some were decrepit old men bent nearly double-they only wanted to be straightened and to walk erect once more; others had deformed limbs which they thought I might be able to make perfect; but all were far beyond my limited skill. It is a mistake to physic a native stranger, 
as if he had any misfortune during the next month, it would be put down to the "Orang puteh's" medicine, and might cause you some trouble. As our house las no door we are visited by the people's fowls and cats, all coming, like their owners, to see what they can get; sometimes Dusun dogs prowl about outside, and once they carried off a Hornbill's skin which lad been put in the sun to dry.

The natives also bring me a few birds and animals. Once they brought me a fine Fish-Eagle (Polioaëtus ichthyaëtus): 'I also bought a beautiful little opossum-like animal, the Slow Loris (Nycticebus tardigradus), with large bright yellow eyes, which lived for some weeks tied up in our house; it was most active at night-time, and broke several articles I could ill afford to lose, but in the end it made its escape.

The larger Mammalia were fairly abundant on this river: wild cattle, semi-wild Buffaloes, Sambur and other species of deer, Malayan Honey-Bears, and wild pigs. The wild cattle used to frequent at nights a large open grassy plain some distance from our dwelling, the whole place being covered with their tracks; but though we often remained watching there until all hours of the night, only on one occasion did I get a glimpse of their white bellies as a small herd passed about one hundred yards distance between an open space of a few yards, when my native guide whispered to me not to shoot, as they were sure to come out in the open beyond; but we never saw them again: Nyhan, however, had several shots, which he missed. The wild buffaloes on this river are the offspring of those which have strayed away some generations back, and have become now quite wild and would prove more dangerous to the sportsman than most Bornean animals. One of the Orang SungeiOtto by name-formed a great attachment for myself and servants. He was a middle-aged man, well mannered, and never begged for anything, often bringing us small presents of coconuts and jungle-fruit. We often used to go out after big game with him up to all hours in the night.' In his company we several times visited a large stretch of thick jungle, and followed the tracks made by the buffaloes through it; but several times we heard them crashing their way through the dense undergrowth, and though only a fer yards off it was impossible to get a glimpse of them. It was perhaps just as well that we never met one of these huge brutes face to face in such a place, as if wounded the buffalo would have had decidedly the best of it, retreat being on our part impossible. We several times noticed the tracks of the Malayan Bear in the soft mud, which my men declared were the footprints of no less than the " old gentleman " himself. As bears' feet are very like short-fingered hands, and opinions are so divided as to what impression his Satanic Majesty's foot really would leave, I could not refute this point, though I had always been educated up to the goat's-hoof theory, and the Kadyans evidently to the bear's-foot; thus nothing could be gained by discussing this point further with them.

Sambur deer were numerous, and might be heard barking at nightfall before they left their forest-haunts to visit the native paddi-fields. We also shot several "Kîjangs," a small forest-loving species about the size of a goat. The little Mouse-deer (Tragulus javanicus), the smallest member of the family Cervida, known in Borneo as the "Plandok:" and about the size of a rabbit, was fairly common in the forests. Just before dark it bestirs itself in searcl of food, and by understanding its habits may be easily obtained. When trotting over the dry leaves which carpet these forests, the Plandok makes a sliglit rustling 
sound with its tiny hoofs, which is easily imitated by tapping gently the leaves with a light switch, and answering their peculiar low whistle. In this manner they can be attracted within a few yards and easily secured. I first saw a native doing this in Malacca; I tried it on some low hills at the back of our house with great success-not so much for sport, but to replenish my always-empty larder. As our shooting-grounds were some distance from home, and most of the journey had to be performed in the dug-out, often after nine o'clock at night, on a river plentifully stocked with crocodiles, I must say it was always with a feeling of relief that I left our canoe.

Crocorliles are always on the feed after dark, and there was one which had attempted to drag a woman into the water a short time previously, not far from our dwelling; also a man used to visit us with most of the flesh torn off his arm by one of these brutes, which had seized him in his canoe; and sometimes the larger ones will swamp a canoe and carry off one of the occupants : so you may guess that I was not very keen about these after-dark expeditions as perhaps the absence of crocodiles would otherwise have made me. A walk through a tropical forest in almost pitchy darkness is uncanny work at the best, as one always imagines every possible enemy to be ready to pounce out: every creeper transforms itself into a snake, every fallen $\log$ becomes a crocodile. In the Bornean forests after dark a curious fungus (like a toadstool) becomes quite luminous; added to this goblin-like effect, the extraordinary forms of the forest-growths, the cries and howls of many animals and night-birds, and a hundred other noises which must be heard to be understood, is enough to give a nervous person like myself "the creeps" or some other feeling. The only sport we had plenty of was pig-shooting in the maize-plantations, for which amusement the Orang Sungei would call us at all hours in the night. Wild pigs (Sus barbatus) and deer do great damage to the maize- and rice-plantations of these people, they not being a hunting or trapping race like the Muruts, who kill everything from a rhinoceros to a rat; so if they would save their crops they have to sit up all night in small shelters placed about in their fields, and keep a fire burning to scare both pigs and mosquitoes, which, as usual, are more than plentiful. In these shelters the people sit, yelling and calling out at the pigs, which may be heard carrying on their work of destruction some distance off. When we arrived on the river the maize-crop was nearly ripe, and in one night the pigs would destroy several acres; this they do by biting the stalks and laying them flat, when if the corn-pods are not quite to their liking they would proceed with their work, seldom eating more than one or two mouthfuls from a stalk of several pods. Often at night we used to stalk about in the maize-plantations listening to the pigs crunching and breaking down the stems; but my bootless servants got more shots than $I$ could, boots being horrible tell-tales anywhere. On some nights we got two huge brutes, to the delight of the plantation-owners and Dusuns. These pigs were larger. and of a different colour to any I met with elsewhere in Borneo, standing three feet nine inches at the shoulder, dirty white in colour, and almost hairless, except on the snout, where they were adorned with a huge tuft of coarse bristles. The Dusuns from a neighbouring village used to be on the spot the next morning whenever they heard us shooting after dark, and cut up the pigs in the most scientific manner, amidst a swarm of blow-flies, which were so numerous as to blacken the maize-leaves with their numbers. The way in which these men would carry huge lumps of meat on their heads, 
filling their hair and besmearing their bodies with gore, was a sight to see. The Orang Sungei being Mohammedans of course would not touch pig: whenever I aud my cook tried it we were ill, which Nyhan declared was the unclean animal; but in reality I believe some freshwater prawns caused the mischief.

Sometimes crocodiles would slowly float past our house, almost entirely immersed with the exception of their eyes and snout, when they afforded an excellent shot for my rifle. During the night these brutes will strike the ground close to the river tremendous blows with their tails as they try to knock their prey into the water. My friend Otto one day called to tell me that a native had killed a large crocodile, and if I wished he would guide me to see it: we started for the spot, and after traversing a swamp we perceived a dreadful smell that could only arise from some dead animal, which Otto declared was the crocodile. Shortly we arrived at a small pool, in which lay, half in and half out of the water, a large female crocodile. Close beside the dead reptile was a large heap of dead leaves and rubbish, in which her eggs had beell laid, but now covered with broken shells, the eggs being already hatched. While we were standing about, the young crocodiles, which were about fifteen inches long, kept coming to the surface of a small though deep pool to breathe, and I shot nine with a small collecting gun before I left. The mother, having her young with her, attacked a native, but was no match on land for this man, who soon dișabled her by cutting her tail nearly through with his knife: the whole place was on a buzz with blow-flies, which in these latitudes often lay live maggots instead of eggs, the quicker to perform the work Nature has allotted them. Crocodiles always seek out quiet spots in the swamps for their nidification; they collect a quantity of green and dead vegetable matter, making a huge heap in which numbers of eggs are deposited, where they are hatched by the heat of the fermenting leaves. The female, as a rule, remains in the vicinity, and is now savage and bold enough to attack anything.

On the 10th September our house was violently jolted, so, thinking that a buffalo might be rubbing himself against our frail structure, I told one of the boys to drive it away; but on going to do so he could see no animal near the house to cause this violent movement. When Otto called he asked us if we had felt a shock, as all the people on the river-bank had noticed it. This was the only earthquake-shock I felt during my sojourn in North Borneo : that island is generally believed to be free from such disturbances.

On the evening of the 16th September I had just commenced my evening meal, and was sitting at my table, a provision-box which served this purpose, admiring the first specimen I had ever seen of that finely-coloured Kingfisher Alcedo asiatica, when there arose what at first was a confused hubbub of voices, which drew nearer and nearer until a lot of excited women and children stampeded past our hut. Not knowing what could cause this unusual excitement, as a native campong is always hushed and still soon after dark, Nyhan went to the doorway and inquired of the fugitives the reason of this commotion, and gathered from these excited people that a man was running "amok" a short distance off and would probably work his way in our direction. Here was a pretty fix to be in! liable to be attacked at any moment by a bloodthirsty maniac, our house a flimsy leaf hut, and the night almost pitch dark: however, the only thing to be done was to load our guus and wait for the "amoker." We were not kept long in waiting; in a few minutes two men 
appeared at the bottom of our ladder with their krises in their hands, and entered our house- a most foolish thing to do on their part, as I covered the first with my gun, but did not fire on them as it flashed through my mind that they had come to warn us. Seeing that they had made a mistake, they dropped their swords and sat down. All this occurred in less time than it takes to read it. The men were two Orang Sungei, dressed in loose, dirty-white trousers and jackets, with red handkerchiefs on their heads: in a few minutes they explained that they had come to warn us of what had taken place at their house, and to advise us to be on the look-out; they said that the "amoker" had already killed several men and wounded many more, and asked me to lend them a gun to shoot this maniac with before he did any further harm. As they did not understand guns, they thought it would perhaps be better for me to go with them and shoot him. Their invitation I naturally declined, not caring to embroil myself in native quarrels, neither did I see the necessity of rumning the risk of being sliced up by this madman, whose whereabouts no one knew. So I lent them two guns on the understanding that they would first call upon the "amoker" to throw down his sword and surrender, or to shoot him. They left us at once, going in their canoes to the houses where the amoker was last seen. We were left to our own thoughts for a short space of time, when the distant and expected boom of a gun was borne to us on the still night air. We knew what that sound meant; it was the knell of Bandeira the amoker. It was now 9 o'clock; the moon, being in its early days, shed but little light on the scene. Not feeling secure in our fort of leaves, we decided, before retiring to rest, to make sure that the wretched man was beyond further mischief, so we started with two of our neighbours to visit, the scene of this tragedy. Our guide was armed with a spear, which he held close to the blade ready to plunge into any one who should attack us; Nyhan and myself carried guns. After cutting across a long bend of the river we arrived at the small lalang-grass plain where we had seen the attap-makers busy at work on our arrival. Here our guide suddenly halted, and at his feet lay stretched out, with his bones glistening in the pale moonlight, the body of Bandeira the "amoker." He had been shot from a canoe by the men who visited us, and then hacked all over by their swords. Whether he was asked to surrender or not I cannot say, though his executioners told me that they gave him the choice of throwing his "barong" or Sulu knife (see illustration, page 130) into the river or being shot, and the only answer received was a threat daring them to come and take it.

A few yards further we passed a hut in which a man was resting on his hands and knees, gazing apparently at us. Thinking this peculiar, I asked my guide what he was doing. "Matti tuhan!" was the answer ; and, sure enough, he was dead and stiff, with a fearful cut which had nearly severed his head from his body, death being so sudden that he remained as he fell. In another hut was the body of a native over which Bandeira had devoted more of his energies, carving the unfortunate man into ribbons; he had also hacked the attap roof in all directions. The custom of mutilating, or rather of hacking up, a fallen enemy prevails amongst all the Mohammedan sect in Borneo; the aborigines prefer to cut off the heads and limbs of their victims, which they keep as trophies.

Bandeira's executioners crossed the river and asked me to visit one of the wounded men, so I went with them to a house some short distance off, and found one of their friends looking very sick indeed from loss of blood. In trying to shield his head from Bandeiras 
knife he had lost part of his elbow, and received a gash laying open half his scalp to the skull. I did what I could; but the man was a bad patient, utterly refusing to have his wounds sewn up. Another wounded man had disappeared in the forest, and when he managed to reach a native's dwelling was nearly exhausted from loss of blood.

The way this tragedy was brought about was this:-Bandeira, a Sulu from the island of Palawan, had been working on one of the Banguey tobacco estates; when he was dismissed he came over to the Benkoker, where he remained for some months quartered on his friends. In this house there were a number of women and several good-looking girls; these no doubt had a good deal to do with the final scene. Bandeira had received notice that he was not wanted, so one night after the evening repast he suddenly jumped up and commenced laying about with his "barong." One of the women had the presence of mind to upset the light, and in the darkness all managed to make their escape through the frail sides of the house; the two men mentioned only receiving severe cuts. Having cleared the house Bandeira started for those of his neighbours, and, finding them quite unprepared, he killed two men. Having now cleared the small campong he tried to cross over to some houses on the opposite bank, but the fugitives had already taken to their canoes; so he sat down on the bank and dared the people he could not reach to come over and fight him-the negro Fareigh being among the number. Here, on the arrival of the canoe with the two men who visited me, he ended his career. Whether he was shot without the chance of surrender is a matter of no consequence, as probably another life would have been lost in attempting his capture, and then he must have been hanged later on by the Company's officials. The next morning when we visited the wounded they had already returned to the scene of their misfortunes, and were sitting looking deathly pale amongst a crowd of fully armed natives.

As amoking is often infectious, and in some places, I believe, becomes quite a common occurrence, my men remained ready for any emergency. Amongst the crowd I noticed a man strutting about in a pair of yellow socks, which he had probably received from some European. The women were busily employed collecting their goods, and were quite happy and unconcerned, apparently having recovered from the scare of the previous evening; others were digging graves for Bandeira and his victims. The amoker they did not take much trouble about, digging a shallow grave, over which they piled a great heap of stones and logs to keep his ghost from troubling them any more. All these people left this spot, being afraid to sleep where so many ghosts were at large, and weeks after when we passed these huts a few clickens, which the people had been unable to catch, were the only living representatives of a once busy household. It was not until'six days after this that $I$ could find a prahu and men willing to take me to Kudat. I left my boys in charge of the house and my belongings, and advised Situron, the man who shot Bandeira, to come over with me, so that he could give his evidence to the authorities; this he consented to do. The first act of the Government was to place this man under arrest, and later on to hold an inquiry into this affair. The officer in charge did not consider I was justified in supplying the men with guns to shoot Bandeira, and informed me that I ought to have sent over to Kudat for police and had the man properly arrested. This no doubt was the correct form to have gone through in a civilized country, but when the ruling powers and their agents are many hours distant, and a prahu with its crew takes six days to get together, the amoker 
in the meanwhile is doing his best to slice up the population; it seems to me that the only thing to be done is to ask the cause of so much trouble to surrender or to shoot him. If I had been able to leave the river at the time I should have told Bandeira to behave himself until the officer from Kudat arrived, when perhaps before such a commanding presence he would have put his head into a noose and quietly submitted to be strung up; but from what I know of "amoking" and the regard for natives' lives displayed by the officers of the British North Borneo Company in their police expeditions, I have no doubt Bandeira would have been shot down at first sight. Later on the authorities returned with Situron to the Benkoker. After holding an inquiry this man was freed from all blame; he afterwards informed me that the officer who held this court told him that he acted rightly, and if another amok took place he hoped he would do the same again. Situron agreed with me that he should do nothing of the sort, but rather paddle over to Kudat and let the officials know, so that they might be able to carry out the arrest a day or two later on.

I have perhaps gone more fully into this affair than I should have done, but as certain officials in the Company's service passed disparaging remarks regarding my conduct in this business, I feel it is only justice to myself to do so, and, at the same time, a warning to travellers not to interfere with native peculiarities, but rather to send for the police whatever distance they may be off.

Some two years later when in Palarvan, and Nyhan still in my employ, we met the relations of Bendeira, and no doubt had they known we had had any participation in his death they would have assassinated us; but we kept our own counsel during our sojourn in that island of lawlessness.

In our wanderings we found the nest of one of the Hornbills (Anorrhinus galeritus), and before being aware of its proximity we shot three of the birds which were visiting the tree. When I discovered the nest by the heap of guano at the foot of the tree I was sorry that we had done so, and sent one of my boys to see if he could climb to the imprisoned female and let her loose. On the following day he returned with the hen bird and a nearly full-fledged young one, and to my surprise he told me that there were two or three old birds busy attending on the imprisoned ones. Hornbills, as most ornithologists are well aware, have the peculiar habit of firmly fastening up the nesting female in a hole in a tree, leaving only an aperture large enough for her to get her beak out of and receive the food brought by some six or seven other birds. The hole is firmly fastened up with gutta, dirt, and various gums, and the same one is evidently frequently used, judging by the heap of excrement at the foot of the tree. The hen remains incarcerated until the young bird is able to fly, when I have seen four or five birds attending on one young one in the tops of the forest trees. It is perhaps fortunate that coupled with this peculiar nidificatory habit the birds do not pair, as any accident to the attendant male would mean death by slow starvation to the imprisoned hen, she being weak and useless for some time after her long incarceration; and, judging by the insatiable appetite of the youthful Hornbill, the old bird is to be pitied who has to keep the infant supplied with food. The object of firmly fastening in the hen bird is doubtless as a protection against the bands of monkeys which roam through the forests, and perhaps are the worst enemies to the increase of tropical birds. Huge tree-climbing Monitor Lizards also cause immense destruction amongst the feathered population of the forests. 

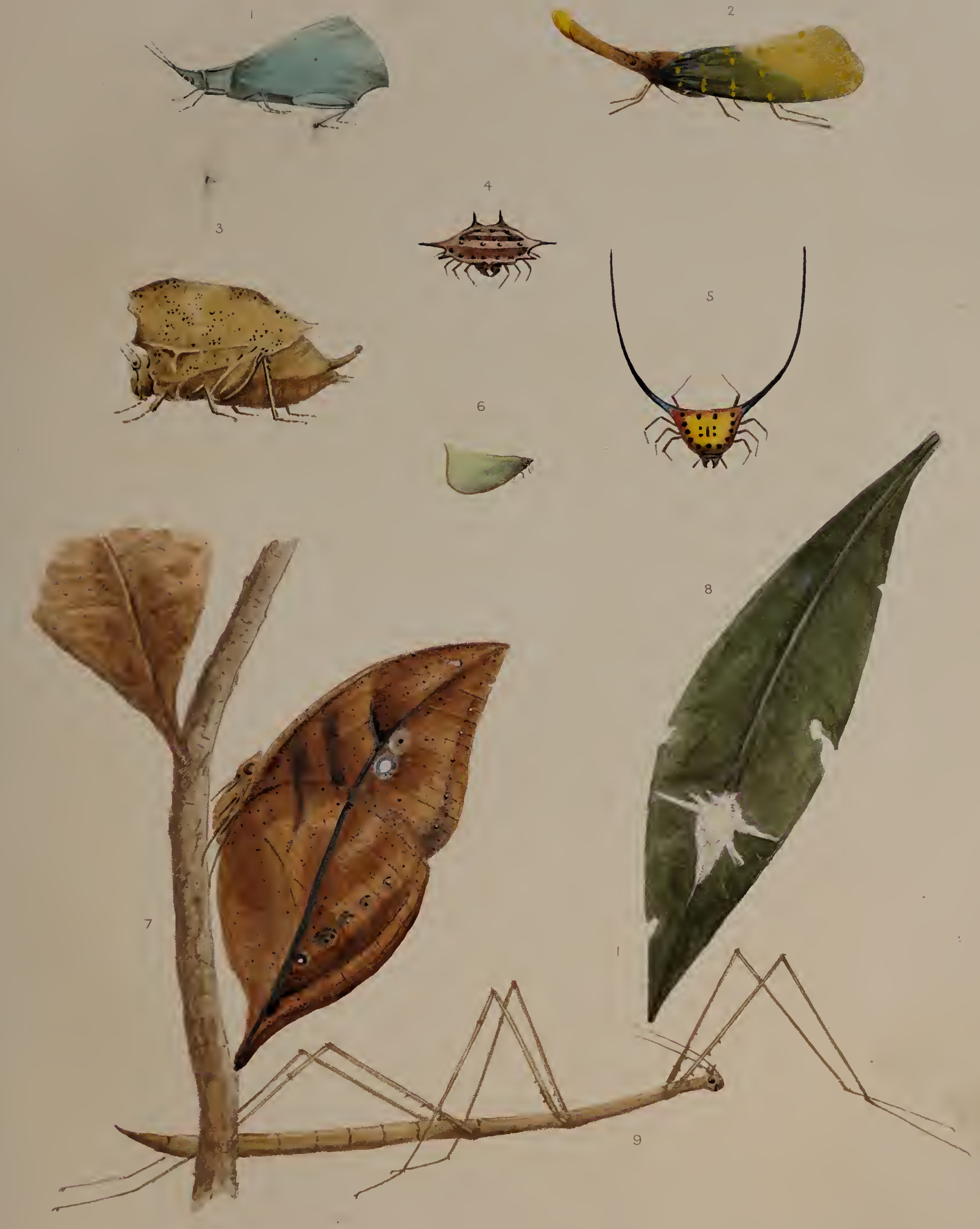

When my servant brought back the two birds, the mother was quite weak and totally unable to fly, so we gave her plenty of rice and fruit, and in about a week she took her departure; her infant from the first was quite friendly, the only thing it wanted was food, and then more food. It used to sit in a small hamper, where it kept up a continual noise which resembled the rubbing of a wet cork on a bottle, and shortly became such a source of annoyance that we used to put the baby too far off to trouble us with its music. This eventually caused its death, one of the boys putting it in the sun, which soon killed it. Hornbills soon become quite tame, and are sometimes to be found kept as pets in native villages.

Butterflies and insects were fairly plentiful, especially a small forest-frequenting bee. This little insect was at times quite a nuisance, swarming over one's hands and face, where they sought to obtain the saline exudations from our skin; in fact, for the time you are as attractive to these insects as the flowers. The nests of these bees are placed in a hole in a tree, the entrance being a long semitransparent pipe of resin, which doubtless protects the colony from rain running down the trunk of the tree.

Another species of bee builds a huge bag-like nest, which hangs from the boughs of the highest forest trees. As this nest is composed of valuable wax, the aborigines collect it by means of a frail ladder, which is formed by tapping bamboo spikes into the trunk and binding the other end of the round to a rattan cane, forming a ladder of often considerably over one hundred feet in height, of which the tree forms one of the side-pieces. 'This they ascend until the boughs are reached, when by means of a smoky torch they are able to secure the nests-a small profit for so much risk. Some of the forest spiders have most wonderfully shaped thoraces; one, the "Manga tandok," or Horned Spider, being most remarkable. The "Manga sisir," or Comb Spider, is also very curious (see illustration, page 50). These are native names for these insects, every Bornean being more or less a naturalist; most of the common insects even receive names.

The most beautiful of common butterflies, Symphodra dirtea, frequented the junglepaths, where they fed on rotting fruits. Another fine species, Prothoe uniformis, has the habit of always resting head downwards on the trunks. I was fortunate in capturing a perfect specimen of Papilio brama, a very handsome spoon-tailed species with wings of black spangled with bright metallic green, and with a broad band of the latter colour running right across both wings.

Though tropical forests teem with life, it must not be supposed for a moment that it is only necessary to take a stroll in order to collect as many birds or insects as you may think fit. After a few days in any one locality specimens come in very slowly indeed-that is, after you have collected the commoner species. The more gorgeous butterflies are seldom seen unless by good luck you find a flowering tree or some sandy stream which they frequent. The Papilio brama mentioned was the only example of this species I saw in Borneo; and many species are so rare that, though they were first discovered many years ago, only a few specimens as yet have found their way into collectors' cabinets. The same applies in perhaps a less degree to birds; many days during my travels neither my hunters nor myself have fired a shot. Numbers of well-known Bornean birds I never saw, and of many I only obtained one specimen ; and yet though the island of Borneo is by no means fully explored, every expedition of note adding a few new species to the list of its ornis, 
when compared with the now thoroughly explored European area it will be found to contain many more species. A list of Bornean birds compiled by Mr. A. H. Everett contains some 580 species, including a few later additions; while Mr. H. E. Dresser's list of the whole Western Palrarctic Region totals some 623 species. The Bornean list is less likely to be augmented by additions from the neighbouring islands, as it is surrounded, with the exception of Celebes on its east coast, by countries which contain an almost identical ornis. During the northern winter a great many migratory species are added to the list, the order of Limicolae alone adding 38 species. The great region selected by Mr. Dresser receives annual additions from all its boundaries, even including America; and it will be seen that many species are mere stragglers, and more than equalize the Bornean additions through migration. Thus, having shown that a tropical island contains in comparison to an equal area in temperate climes nearly double the number of species, the question to be answered is, Where does all this mighty host hide itself? Some travellers attribute the scarcity in numbers of birds in a tropical forest to the great height of the forest trees, and tell us that up in the roof of the primæval forest there is another world full of life, which man cannot reach; but I myself am inclined to think this greatly exaggerated, as I have attentively examined the tops of the forest trees for hours, and noticed neither bird, butterfly, nor flower. My experience of collecting in these regions has led me to believe that though species are more numerous than in colder climates, the individuals of each species are fewer in number, with the exception of a few specially protected genera; and after these have been collected the rest come in very slowly indeed; and yet the island of Borneo, by no means thoroughly explored, can boast of 580 species of birds and some 600 species of butterflies. The reason of this scarcity of individuals in most species is due, firstly, to their low rate of increase; secondly, to their numerous enemies; and, thirdly, to the fact that few tropical species are gregarious, and the domain over which they wander is so vast that many species are seldom met with.

Firstly, let us consider some of the reasons which tend to keep down the increase of most species of birds. One peculiar fact that at first I could not understand was that birds in the tropics seldom lay more than two eggs. At first when $I$ found a nest with two eggs I used to wait until the eggs were almost hatched for the other three which should complete the sitting; but it soon dawned upon me that two eggs were all I need expect to find in a nest in these latitudes. So, being of an inquiring turn of mind, I asked the natives about the fecundity of their domestic animals- $\operatorname{dogs}$, cats, and pigs, - and found that in every case the rate of reproduction was far below that of colder climates.

The families of natives are very small: in one or two instances I have known them to contain eight or more by one mother, but many women have only three or four, most one or two children; and it is by no means uncommon to find them childless. The cause of this low rate of increase has been ascribed by many writers to the hard work performed by the women of barbaric races; but to my mind this has nothing to do with it. I believe the reason is entirely to be attributed to the low degree of fecundity of such races, brought about by the climate, and aggravated by the difficulty of finding sufficiently nourishing food during certain periods. Besides this, infant mortality is decidedly above the average, there being no knowledge of medicine amongst such men. Few tribes increase much in number, an epidemic breaking out retards any increase for many years; and there 
is little doubt that, in any countries which are suitable to a white population, the native, even if he adapts himself to our civilization, is doomed to disappear, which, judging by our rate of increase, will be at no very distant date.

Now let us descend from man to the lower animals: amongst those domesticated by man the result of my inquiries tended in the same direction; the litters of dogs, cats, and pigs seldom exceed three in number in these countries, and are not more frequent than, if as frequent as, those of animals in colder latitudes.

Let us make the great zoological order of Aves our especial study for a few minutes, and we shall see that the low rate of increase is still the same. To prove this $I$ have compiled the annexed list (p. 54), giving the number of eggs found in each nest, and, when possible, the names of their allied European genera, with the number of eggs laid by them.

The entire list contains 53 species, and with the exception of two species marked with an asterisk, I either found the eggs or young in the nest: the two species marked, from frequently meeting the pair of birds with their fully fledged young, I conclude that they form no exception to the rule; and, as I have already remarked, I always waited before taking a nest to see how many eggs the bird would lay. Neither does my experience lead me to believe that birds in the tropics breed more frequently than those of temperate climates; many nest twice a year towards the end of the wet seasons, but in this country a great number do this, and some more frequently: so I conclude that the abundance of species coupled with the scarcity of individuals of any one species, in a tropical island, is more the result of the low degree of fecundity of the individuals than any other cause; and the only reason $I$ can assign for this fact is the high temperature and humidity of the climate.

I will now make a few remarks on the nesting-habits of tropical birds. The first object in those latitudes seems to be to secure immunity from the attacks of monkeys, and perhaps to a less degree from lizards and snakes; therefore birds never build visible nests in the tops of the forest trees. Woodpeckers, Barbets, and many other species nest in holes in the tree-trunks, which are secure from the attacks of monkeys; this, perhaps, in some way accounts for the unusual abundance of Woodpeckers in these countries. Hornbills, as we know, require a large hole to nest in, so. the female is securely built in by the others until her single young one is able to fly. Some species build long pendent bag nests at the end of slender boughs which would not support the weight of their enemies (see frontispiece); others seek safety for their young by stitching their nests to the underside of broad leaves, as, for instance, the Arachnothera: : most Flycatchers hide their nests in the festoons of moss and creepers which hang from the trees; the Timeline birds generally make rough domed nests of bamboo-leaves near the ground amongst the collections of forest-drift which are found in quantities in the bamboo and palm thickets. Many species, however, leave the forests during their nesting-period, finding safer quarters in the thick jungle which springs up to the height of twenty or thirty feet in a few years on the sites of old paddi-clearings, these places being seldom visited by mammals; most noticeable amongst these are such forest-loving species as Carpophaga badia. Two species of Doves (Macropygia) I found nesting amongst the dead bracken fern about the Dusun villages on Kina Balu; their nests were only two feet from the ground, but the colour of the birds' plumage assimilates so well with the dead fern that the protection is perfect. The struggle 


\begin{tabular}{|c|c|c|c|}
\hline Name. & $\begin{array}{l}\text { Number of } \\
\text { eggs laid. }\end{array}$ & $\begin{array}{l}\text { European } \\
\text { allied form. }\end{array}$ & $\begin{array}{l}\text { Number of } \\
\text { eggs laid. }\end{array}$ \\
\hline Accipiter rufotibialis & 2 & Sparrow-Hawk. & 4 or 5 \\
\hline Spizaëtus limnaëtus. . . . . . . . . . . . & 1 & Buzzard. & 2 or 3 \\
\hline Haliaëtus leucogaster . . . . . . . . & 2 & Fish-Eagle. & 2 \\
\hline Dendrocitta cincrasccns ......... & 2 & Magpic. & 5 to 7 \\
\hline Cissa minor $\ldots \ldots \ldots \ldots \ldots \ldots$ & 2 , very rarely 3 & Jay. & 6 \\
\hline Chibia borneensis $\quad \ldots \ldots \ldots \ldots \ldots$ & 2 & None. & \\
\hline Buchanga stigmatops ............ & 2 & & \\
\hline *Teplirodornis gularis . .......... & 2 & Shrike. & 5 or 6 \\
\hline Muscicapula hyperythra .......... & 2 & Flycatcher. & \\
\hline Siphia eritlacus $\ldots \ldots \ldots \ldots \ldots \ldots$ & 2 & , & \\
\hline Hypothymis occipitalis $\ldots \ldots \ldots \ldots$ & 2 & , & \\
\hline Rhipidura javanica ............ & 2 & $"$ & 5 \\
\hline Rhinomyias pectoralis............ & 2 & $"$ & \\
\hline ., gularis.$\ldots \ldots \ldots \ldots \ldots$ & 2 & $"$ & \\
\hline Culicicapa ceylonensis............ & 2 & & \\
\hline Pratincola caprata $\ldots \ldots \ldots \ldots \ldots \ldots$ & 3 & Chat. & 5 or 6 \\
\hline Copsychus amœnus ............. & 3 or: 4 & Thrush. & 5 \\
\hline 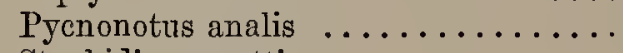 & 2 & Bulbul. & \\
\hline Staphidia everetti $\ldots \ldots \ldots \ldots \ldots \ldots$ & 3 & & \\
\hline Turdinus sepiarius ............. & 2 & & \\
\hline Macronus ptilosus $\ldots \ldots \ldots \ldots \ldots$ & 3 & Timeliidæ. & \\
\hline Pomatorhinus borneensis $\ldots \ldots \ldots$ & 2 & No allies & \\
\hline Stachyris borneensis $\ldots \ldots \ldots \ldots$ & 3 & in Europe. & \\
\hline Mixornis montana $\ldots \ldots \ldots \ldots \ldots$ & 3 & & \\
\hline " woodi $\ldots \ldots \ldots \ldots \ldots$ & 2 & & \\
\hline Athopyga siparaja $\ldots \ldots \ldots \ldots \ldots$ & 2 & & \\
\hline Chalcostetha insignis $\ldots \ldots \ldots \ldots \ldots$ & 2 & & \\
\hline Cinnyris pectoralis $\ldots \ldots \ldots \ldots \ldots$ & 2 & Sun-birds. & \\
\hline$\| \quad$ aurora $\ldots \ldots \ldots \ldots \ldots \ldots$ & 2 & None. & \\
\hline Anthothreptes malaccensis . . . . . . . . & $\begin{array}{l}2 \\
2\end{array}$ & & \\
\hline $\begin{array}{l}\text { Arachnothera modesta } \ldots \ldots \ldots \ldots \ldots \\
\text { Zosterops clara } \ldots \ldots \ldots \ldots \ldots \ldots \ldots\end{array}$ & $\begin{array}{l}2 \\
2\end{array}$ & None. & \\
\hline Dicæum nigrimentum $\ldots \ldots \ldots \ldots \ldots$ & 3 & 17vite. & \\
\hline Hirundo javanica $\ldots . \ldots \ldots \ldots .$. & 2 & Swallow. & 5 \\
\hline Artamus leucorbynchus $\ldots \ldots \ldots \ldots$. & 3 & None. & \\
\hline Munia fuscans................ & 5 & Finch. & 5 \\
\hline$", \quad$ brunneiceps $\ldots \ldots \ldots \ldots \ldots$ & 5 & & 5 \\
\hline Calyptomena whiteheadi......... & 2 & None. & \\
\hline Iyngipicus auritus $\ldots \ldots \ldots \ldots \ldots$ & 2 & Woodpecker. & 5 \\
\hline 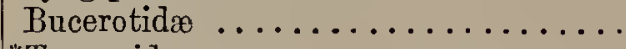 & 1 & None. & \\
\hline *Trogonidæ $\ldots \ldots \ldots \ldots \ldots \ldots$ & 1 or 2 & & \\
\hline Merops sumatranus............ & 4 or 5 & Bee-cater. & 6 or 7 \\
\hline Ceyx dillwynni $\ldots \ldots \ldots \ldots$ & 2 (hard set) & Kingfisher. & 6 to 8 \\
\hline Caprimulgus macrurus $\ldots \ldots \ldots \ldots$ & 2 & Goatsucker. & 2 \\
\hline Collocalia linchi $\ldots \ldots \ldots \ldots \ldots$ & 2 & Swift. & 3 or 4 \\
\hline Treron vernans & 2 & Pigeon. & 2 \\
\hline Macropygia cmiliana ..... & 1 ) in many & Dore. & 2 \\
\hline ruficeps & 1 hosts. & & 2 \\
\hline Excalfactoria chinensis .. & 5 or 6 & Quail. & 10 to 14 \\
\hline Turnix nigrescens $\ldots \ldots \ldots$. & 3 & Turnix. & 4 \\
\hline Agialitis peroni $\ldots \ldots \ldots \ldots$ & 3 & Plover. & mostly 4 \\
\hline Gorsachius melanolophus .... & 2 & Heron. & 4 or 5 \\
\hline Plotus melanogaster $\ldots \ldots \ldots$ & 4 or 5 & Cormorant. & 4 or 5 \\
\hline
\end{tabular}


for existence in these forests is so severe that unless birds nest in impregnable strongholds or hide amongst the masses of forest-drift, they must leave and seek positions in more open localities which are not frequented by their enemies.

Butterflies, with the exception of a few strong-smelling and distasteful species, more especially the Euploeas, are scarce-unless some attractive spot be found, such as a flowering tree, or the offal near native houses, when numbers of the stronger-flying species, such as the Papilios, congregate together. Many of the smaller species, such as the Narathura, seldom fly unless disturbed, passing most of the day amongst the leaves of the low trees which border the forest-paths; others, again, are crepuscular, such as many of the Morphino, remaining motionless with closed wings all day amongst the leaves on the ground or near it; so splendidly does the underside of their wings imitate the leaves they settle amongst, that on so doing they vanish, only to be seen again when your approach is sufficiently dangerous to cause them to take wing (see illustration, p. 50). The enemies of butterflies are very numerous-birds, reptiles, and more especially insects, which destroy their larvæ and pupæ; mason-wasps, ichneumon flies, ants, and spiders are continually carrying off or laying eggs in their defenceless grubs. Every living creature must have food, and that is obtained by the loss of life to organisms weaker than itself. Only consider, reader, the ever-waging war that is thus being carried on, and it will be easy to understand that unless a species has some special habit or peculiar form by which it escapes observation, or is armed with some weapon wherewith to fight the great battle of life, it must soon cease to exist. This we are told is the "Balance of Nature," or, by more enlightened thinkers, the "Survival of the Fittest," or that those species which cannot help themselves must soon disappear, be they fish, flesh, or fowl.

That most interesting subject of protection afforded by mimicry of colour and pattern of certain defenceless species to distasteful or dangerous species, known as "Protective Resemblance," we will discuss later on.

To return once more to our everyday life on the Benkoker River. On the 22nd October two of my servants were confined to the house with bad attacks of fever; the wet seasonhaving commenced-being probably the cause of this. My followers always suffered from fever on changing to a fresh locality, but soon recovered and were not afterwards troubled; I myself did not suffer from this disagreeable complaint until my return to Labuan. In November it poured with rain at intervals during the day, accompanied by terrific thunderstorms. When we used to be caught in the forest in one of these dormpours $I$ found it better to take my clothes off and put them in a waterproof bag until the rain was over. When walking through a forest in the costume of the aborigines, it was curious to me how seldom I got pricked or hurt by the many thorns which beset my path, for often my clothes have been torn to pieces in these paths by the rattan tendrils.

On the 13 th October I was called in by some Orang Sungei to visit a dying child; it was, as is customary in this country, in a crowded house of smoking and "sirih"-chewing natives, the last place in the world to aid recovery, and was so near death that it died a few hours afterwards : the little sufferer was bedaubed with chalk spots and crosses, and the gong-beating in the evening told us of its departure to the Orang Sungei spirit-world.

Our relations with the natives, both Dusun and Orang Sungei, were most friendly; often in the evenings my boys would be invited to attend some vocal entertainment; as gongs and tom-toms formed no part of these concerts the singing was rather pleasant. Sometimes 
a bevy of native ladies would pay us a visit in the evenings to inspect our collection of birds; they were most talkative and merry, knowing most of the birds by name: a little light refreshment of tea or chocolate and biscuits wound up the evening and sent all away rejoicing.

Collecting in the forests is really hard work; the continual stooping to avoid creeping plants and fallen trees, or often through the tunnels burrowed by natives in the thick undergrowth, the avoiding of hundreds of creepers from the thickness of fine string to that of a ship's hawser, which sprawl about everywhere ready to upset the unwary, added to this the heat and depression caused by want of proper food, used to bring on severe headaches in my case, which were probably the forerunners of malarial fever.

On the 16th of November I succeeded after much trouble in finding a prahu and crew willing to take us over to Kudat, and left my little home on the Benkoker for good. We started in the evening, and to my disgust our crew refused to leave the mouth of the river that night; so I passed an unpleasant time until morning with eight strong-smelling natives in the small prahu, anchored in the middle of the river; but mosquitoes were not long in attacking us, and thus added to my misery. On the 22nd of November we arrived once more in Labuan, with a fine collection of birds ; though many were rare, there was nothing new in this collection. I had secured a curious Gecko lizard, which turned out to be quite new, and has been named Hemidactylus craspedotus (see illustration opposite, fig. 3). The capture of this little reptile is an instance of what a chance the finding of many species is in a tropical forest. Whilst waiting one evening for the small "plandok," when it was nearly dark, I was standing near some small trees which formed the undergrowth, when something Hlew or rather parachuted from a tree and settled on one of my legs; I made a grab at the unknown thing in the semi-darkness and secured a new and interesting reptile: this little creature is very flat and provided along its entire length with loose folds of skin, which enable it to make short flights from tree to tree.

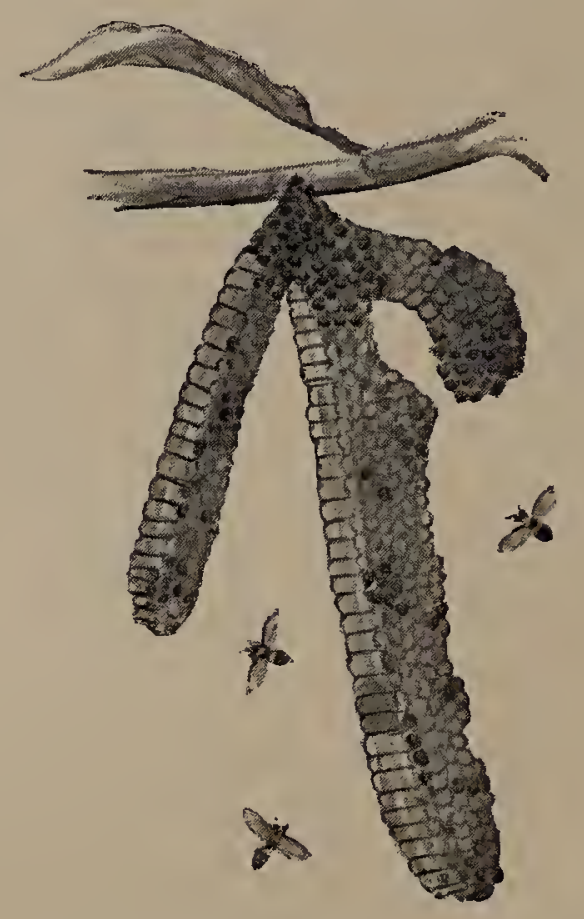

WASPS' NEST. (Icaria sp. ?) 


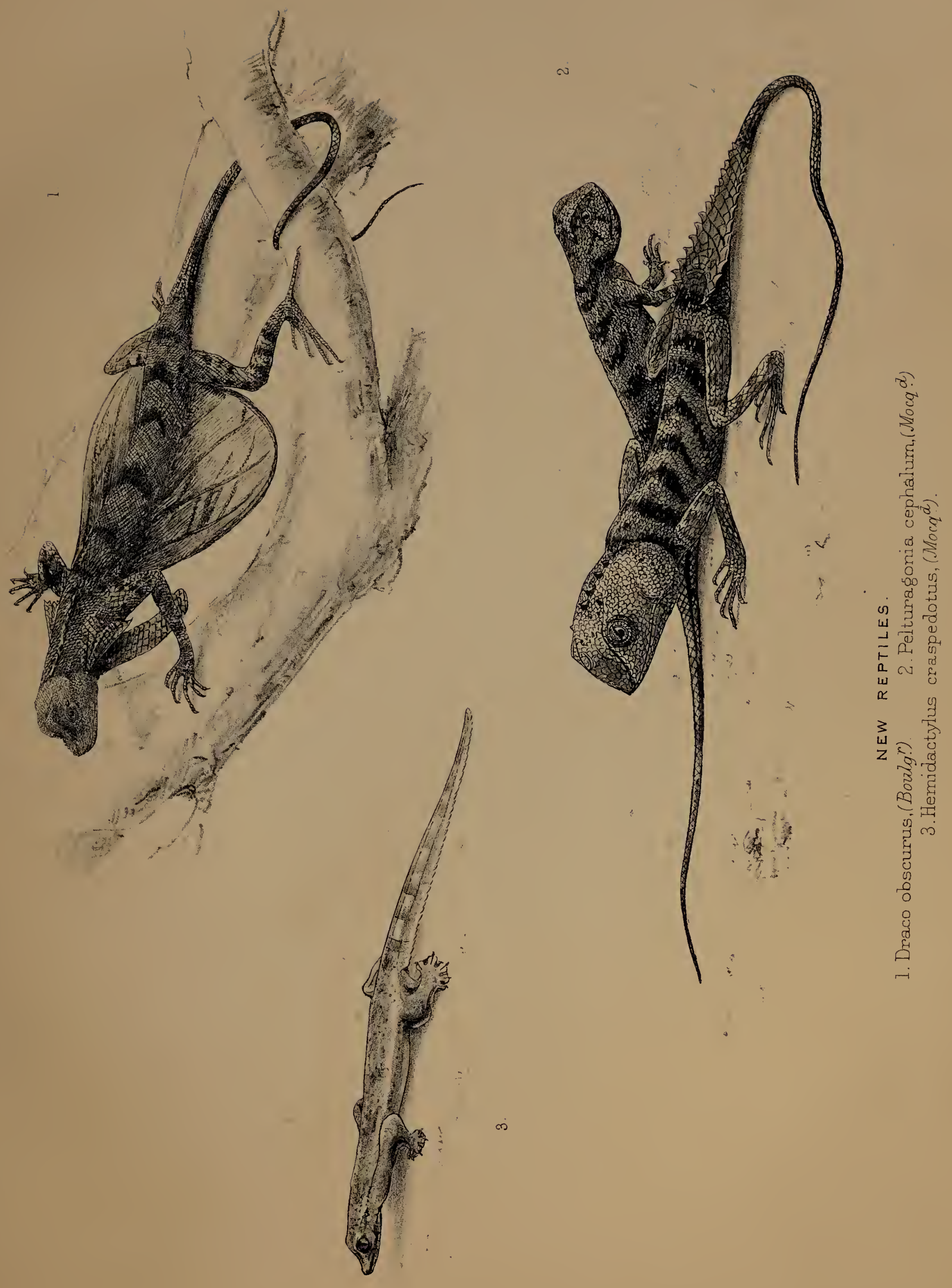





\section{CHAPTER IV.}

START FOR KINA BALU.-VIEW OF THE MOUNTAIN FROM ABAI.-DATU TUMANGGONG.-CATTLE-LIFTING.

—START FOR THETAMPASSUK.—BUFFALOES.-THE DATU'S HOUSE.-BAJOWS.—ILANUNS.—FAIL TO

FIND PORTERS.—THE TAMPASSUK PLAIN.-DISTURBED STATE OF THE DUSUNS INLAND.—RETURN

TO ABAI.—DYAKS.-SULUS.—ARRIVAL OF THE ' KIMANIS.'-RETURN TO LABUAN.—THE LAWAS RIVER.—BRUNEIS.—KADYANS.—MURUTS.—VISIT SI'LALANG'S VILLAGE.—HIS TROPHIES.—HEADHUNTING.-VISITED BY MURUTS.-BURIAL CUSTOMS.-TATTOOES.-CAVES.-BARK JACKETS.SUMPITANS.-LUKUTAN RIVER.-COAST TO BATU-BATU.-WANT OF FELLOW-FEELING AMONGST NATIVEs.-VOYAGE TO PULO TEGA.-NICOBAR PIGEONS.-RETURN TO LABUAN.-VISIT BRUNEI.

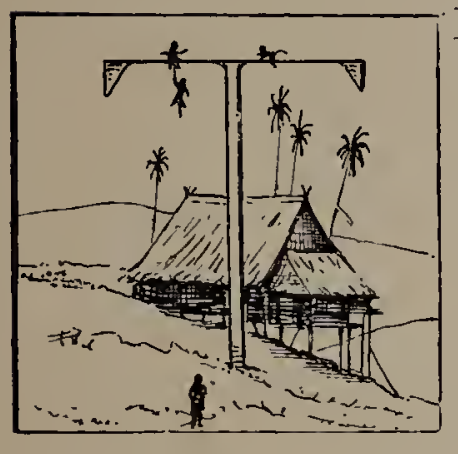

HE wet season was now advanced, so I remained in Labuan until the end of January, making during that period a trip to Singapore and back, in order to purchase many necessaries that could not be procured in Labuan, and to taste for a brief period the pleasures of civilization.

In the beginning of February I again attempted to reach the great mountain of Kina Balu. I had succeeded with the help of Nyhan in finding seven other Kadyans to accompany me; and having spent several months in Benkoker, coming in contact only with natives, I had succeeded in mastering sufficient of the Malay language to make myself understood, so was fortunately now able to dispense with the service of an interpreter.

On the 9th of the month we embarked with all our baggage on board the 'Bujang Barram,' a small steamer belonging to the Government of Sarawak, which was kindly lent me through my friend Mr. A. H. Everett for a moderate sum per diem. We steamed out of Labuan harbour at half-past three o'clock in the morning; but the monsoon, directly the sun rose, blew so strongly from the north-east that it was not until after 6 P.x. that we anchored under shelter of Pulo Gaya, not being able to reach the pier that night. 'The next morning we again started soon after daylight, and reached Abai at three o'clock in the afternoon; the wind was very high and the sea rough, but the small harbour is well sheltered by an island and a headland, which at no distant period was also an island, but has now been joined to the mainland by the mangroves and the alluvial deposits from the neighbouring hills. It being nearly high-water, the captain managed to get his vessel over the bar and landed my baggage without any trouble; the steamer at once started for Pulo Gaya, and I was left alone with my followers and baggage, to make ourselves as comfortable 
as possible in an old wooden house erected by the Company, which at one time had been occupied by the late Mr. Witti (who was murdered by some head-hunting tribes far inland some years previously), but was now occupied by a Bajow caretaker, this station having been abandoned.

As usual, the voyage had tried me severely, the sea being very rough, and I a victim to mal-de-mer, most of my followers I noticed suffering as well; but I find I had sufficient spirit left in me to make an entry in my journal that evening that large forvls cost 20 cents each, small ones a dollar for six, kids 60 cents each, and eggs 1 cent each: so provisions were apparently cheap in Abai.

Before going further it will be as well for me to introduce to my readers my native contingent. Nyhan, as I have previously stated, was my right-hand man during my sojourn in Borneo; the next was one called Lahir, a lanky, sharp-eyed, intelligent fellow, a good collector, but not very trustworthy, and afraid of hard work ; no. 3, Buckier, a good-natured big man, fat, very ugly, giggling all day like a school-girl, but willing to please; the next, Rhaman, good-looking but utterly useless; no. 5, Tungal, short, excessively ugly, hard-working and willing to do anything for me, remained in my service until within four days of my leaving for home, when, after all $m y$ kindness, he left me in the lurch (this is the usual way natives treat their benefactorsrather annoying to anyone who fancies he can gain the affection of these people!); no. 6 , a short man, good-looking, named Hadji Ahmet, was rather a swell, having made the pilgrimage to Mecca, well-mannered, and soon under my tuition became an excellent birdstuffer, he also became one of my permanent bird-collectors. The last individual was another Rhaman, who acted as my cook and valet; he, like his. namesake, was utterly useless, was ugly, dirty, dishonest, and was sacked on the first opportunity after I reached Labuan. Now my readers, I trust, have some idea of my escort.

Abai is a very pretty spot on the north-west coast; the harbour is sheltered from most winds except the N.W. by the headland and island already mentioned; the island at lowwater is also connected with the mainland by a sandbank. The water is too shallow for some distance out for anything but small craft, and even then, before reaching the deeper water of the river, the high tide has to be taken advantage of, the river, as usual in these parts, being rendered useless for navigation on account of a sandbank or bar which blocks the entrance. The river is in reality only a large salt-water creek which winds about among the low hills for many miles inland; it is, however, the outlet of several small streams, and has been formed by the gradual elevation of the sandstone hills around it, which at one time were islands in the sea, like those forming the harbour already mentioned, the supply of surface-drainage from the hills being just sufficient to prevent this creek from becoming a lake. A fine view of this picturesque swamp, bordered with mangroves and beautified with many graceful clumps of nebong and other palms, may be obtained from the neighbouring hills.

The country inland is much broken up by sandstone hills of low elevation, gencrally bare of trees, and in this month parched and brown, covered with one of the tropical curses, lalang grass. At the back of these lalang-covered hills are others topped with forest, sometimes sharp-peaked and rugged; at the back of all, towering above everything, is that 


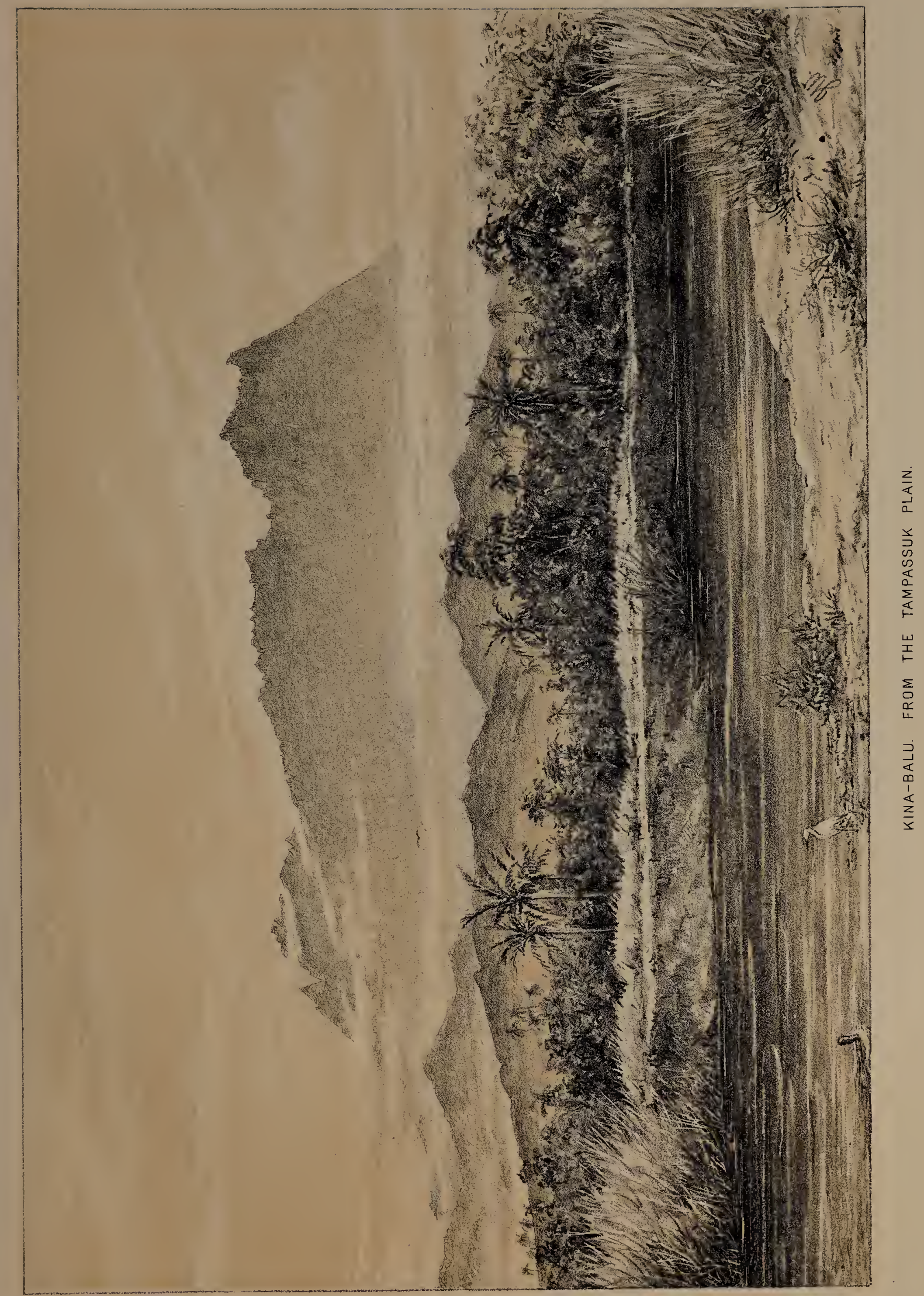



superbly grand mountain Kina Balu. This wonderful mountain looks more imposing than many mountains of a much greater altitude, from the fact that it is au almost isolated mass, at the highest end mounting up to the height of 13,698 feet (Belcher) and finishing off abruptly in sheer precipices of 10,000 feet; its proximity to the sea-const being less than forty miles in a direct line allows of it being viewed at once from the lowest level, none of its imposing grandeur being lost by a series of intervening plateaus which dwarf so many mountains. Kina Balu is nearly always visible until 9 A.м.; after that time clouds begin to creep over the hills at the less-elevated north-eastern end, and gradually increase in volume, first skirting along the foot of the mountain, then gradually rising and spreading until the whole of this mighty giant is swathed in mist; the mountain remains hidden until nearly sunset, when deluges of rain clear the atmosphere in time for Kina Balu to receive a rosy kiss from the setting sun. During the night this mountain is free from vapour, and forms a splendid sight when the moon is full. Before sunrise I think there is no more beautiful sight than to see Kina Balu, then of a dark blue shade, standing out in the clear morning air with all its rugged precipices backed up by the yellow tints of the rising sun. I used to rise before daylight every morning during my short stay in Abai to contemplate this lovely scene, and speculate in my mind as to whether I should be the first to explore this wonderland, picturing to myself the wonderful zoological treasures to be gleaned on its surface ; but, as you will see, it was many months after this that I first set foot on the "promised land."

Several years before I visited Abai the Company had a police-station with a European Resident stationed there; but for some reason this place was given up and a post on the Tampassuk River selected; this also was soon abandoned. 'The house at Abai was much out of shape from the violence of the winds, which blow along this exposed coast with great force during the monsoons; but I was very thankful to avail myself of this shelter on this and on several other occasions: so soon does man's nature become accustomed to certain modes of life that what at first he regards with the greatest dislike he leaves behind after a short period often with feelings akin to affection-at least, such were my feelings with regard to the tumble-down shanty, with its chairs and table, when I used to return from my long expeditions in later years from Kina Balu. The greatest drawback in Abai is the want of fresh water, the shallow wells containing only most disagreeably brackish water.

The following morning some of my men crossed the river and walked across the plains to the Tampassuk River to visit a Bajow Datu, or chief, in order to obtain sufficient buffaloes to carry my baggage to the Datu's, house, the valley of the Tampassuk being one of the highways to Kina Balu. In the evening, when the men returned, they told me that Datu 'Tumanggong had promised to send the buffaloes in two days' time, as he said it would tale some time to find a sufficient number. Datu Tumanggong called later on to tell us that he could only find two men willing to come for my baggage, but as a "tamel" or market would be held on the following Saturday on the opposite side of the river, I should then find no difficulty in procuring buffaloes enough to carry my baggage to his house.

The Datu was a shrivelied-up, toothless old Bajow, with a wonderful crafty look about him, and by nature a perfect diplomatist; he kept me waiting later on for days with promises of assistauce, but in reality he never stirred an inch to help me on my journey. He was 
clothed in a loose suit of thin blue cloth, a red handkerchief tied round his head, and above this a large round hat made of fine strips of bamboo was placed as a protection from the sun; in his girdle he wore a short kris, and a long thin-shafted spear conpleted his weapons ; from his shoulder was slung a small satchel in which he carried his sirih-chewing paraphernalia; being without teeth he pounded the betel-nut in a small metal cylinder before chewing : this is perhaps one of the filthiest customs indulged in by Malay races, the mouth becoming full of bright red saliva which is spat out, without regard to cleanliness, in all directions. 'The Datu is one of the Company's subsidized chiefs, receiving a small monthly payment for his services, which consist of collecting poll-tax and settling any paltry disputes among the people; but the Company have also subsidized another Datu living about two miles distant from Tumanggong, who was at one time in open warfare with him, when they fortified their houses and had long shots at each other's followers with "badils" when possible, but their enmity is now reduced to sullen hatred, consequiently there is little harmony or justice administered by these chiefs amongst the Bajows of this river ; added to this there are several other Ilanun chiefs who have always been enemies to, and independent of, the Bajows, and seem hardly inclined to recognize the selection of these rulers placed orer them. Consequently this district is equal in lawlessness to any part of Western Palawan, which is not surprising considering that the population only as far back as 1845 was famous all round the coasts of Borneo for their piratical pursuits. At that date their villages were distroyed by Sir Thomas Cochrane, and the supplanting of sailing-ships by steamers utterly ruined their occupation. This strong buccaneering instinct now bubbles to the surface of their characters in the shape of buffalo-lifting, which causes much ill-feeling and occasional murders amongst them.

As an instance of how subsidized chiefs are to be trusted in the administration of justice, the following tale will show :-I left Datu'Tumanggong's house, as I could see that we were unwelcome guests, so he lent me another small dwelling-used by the Bajows when watching their rice-fields—only a few yards distant from his more spacious residence. One night, shortly after dark, two Ilanuns came to our house with a buffalo which had been stolen from them in the morning, and which they had tracked to the house of Datu Tumanggong, the Company's subsidized chief! Here it was found tied up under the old gentleman's house, having been stolen a few hours previously by one of his retainers, and the next morning would have been miles away. The Ilanuns were highly indignant, and asked me what they were to do. I advised them to complain to the Datu; at which they laughed, knowing full well that the profits of such transactions are probably shared by him. Now, how it can be possible to trust such men and place them in authority over others I am unable to understand: as long as they have the control over those of their own religion (Mohammedan) matters are not so bad; but whenever they are placed over Muruts, Dusuns, and other heathen tribes the result is disastrous, and this, I believe, had as much as anything to do with the Company's unnecessary display of severity to the Padas Muruts in the early months of 1888 . I hope and trust that the Kina-Balu Dusuns-who have held their own for perhaps many centuries against the Mohammedan coast tribes-when they are brought under the Company's rule will not have to submit to this indignity. If this philanthropic company, the shares in which are held by rich Englishmen, cannot afford to place trustworthy European officers 
over these tribes, for God's sake leave them alone and avoid the stirring up of strife by placing such unprincipled blackguards, as I believe all native Mohammedan chiefs to be, in authority. For years there has been open war between the Tampassuk Bajows and the inland Dusuns, none of the men in Datu Tumanggong's campong daring to accompany me to Kina Balu. In days past, when these Bajows were more powerful, they used to attack the villages of the mountaineers and carry off their women and children to be sold into slavery. Even a month before my visit the Dusuns killed a Bajow in retaliation for an old bloodfeud. It is useless to think that these people will become friends, except by the lengthened residence of Europeans amongst them, and the impartial administration of justice to Bajow and Dusun, which would be impossible under Mohammedan chiefs. The Tampassuk, at the time of my visit, had not been visited for over a year by Europeans, and it was another year later, or in all over two years, before any officer in the Company's employ made a tour of inspection through this district.

On Saturday, the 13th February, the Tampassuk Bajows began to collect soon after daybreak in small numbers on the opposite side of the creek under a large Casuarina tree, for the purpose of holding their weekly "tamel." A "tamel" in Borneo is the same as a market day in this country; there are a number of localities fixed upon by the different tribes and villages at which to meet once a week or at longer intervals, where they barter produce of various sorts. At Abai the Tampassuk Bajows obtained salt and salted fish in exchange for rice, cooking-pots, and native cloth; the salt is exchanged by them at the next tamel held amongst the lowland Dusuns for jungle-produce, bamboo, sun-hats, baskets, tobacco, and many other necessaries, which have been bartered for previously by them with Kina-Balu tribes. Tamels are also the great centres for the distribution of news in these countries, and on Kina Balu in 1888 the Dusuns knew all about the Company's attack on the Padas Muruts, though nearly 100 miles distant. As enemies sometimes come into contact at these meetings a fight occasionally occurs in which one or more lives are lost. It was not until eleven o'clock that the Bajows were ready to start; after two hours' walk under the mid-day sun, our pace being regulated by that of the buffaloes, we reached the Datu's house. Our route for the most part traversed the level plain, skirting the foot of a low sandstone range of hills: this road, though longer than that which crosses these hills, is easier for the buffaloes; the other path is used by the Bajows during the wet season, the one we now followed being then impassable. On arriving at the river we crossed over and followed the opposite bank for some distance up stream to the Datu's campong, where the now weary buffaloes were relieved of their loads. Buffaloes make good beasts of burden on level ground and in cool weather, but if the sun is porverful the fatter animals if they are pressed will sometimes fall dead in their tracks from heat-apoplexy; their hoofs also soon become chipped and tender on rough ground, when the animal becomes useless. Amongst most Bornean people buffaloes are one of the chief forms of wealth; they are valued from ten dollars upwards, according to the way in which they have been trained for carrying purposes, as much as twenty dollars being paid for perfectly trained animals. The Bajows never seem to relish walking the shortest distances, always riding some animal, even a cow if nothing else is procurable; this habit has probably come about by their being formerly a sea-loving race, and the ease with which the plains may be traversed without the necessity 
of road-making. Buffaloes form part of the payment made by a Bajow to his bride's family, some young ladies being valued at several of these animals, with the addition of a few brass gongs. 'The harness of these animals is as simple as it is uncomfortable-a ring through the nose with a cord attached acts as bit and bridle, the small wooden saddle is sharp and uncomfortable, and a looped rope in which the rider places his big toe takes the place of stirrups. All the Bajows carry long-shafted spears, which assist them to mount and dismount.

'The Datu's house was prettily situated on the bank of the river (the distance from which is gradually lessening day by day), hidden amongst numerous mango-trees and coconutpalms; these trees, with a few others cultivated by the Bajows, border the Tampassuk River through its course in the plains, beyond this narrow margin the level lalang-grass plains stretch for miles to the foot of some distant hills. The house was spacious, and I at first thought clean, but on closer acquaintance it proved to be infested with bugs. Bugs are very numerous in most native houses, while Heas are almost entirely absent, except when the cooler and higher altitudes are reached. As usual in Borneo, the house was built on piles well off the ground. Inside it was, at first entry, gloomy and dark, but deliciously cool after our broiling walk from Abai. It took some little time to make out clearly the furniture of the place: straight from end to end on one side runs a passage floored with strips of bamboo a few inches apart, giving ventilation and saving the trouble of sweeping; running parallel with this is the main floor of flat bamboo, raised a few inches above the passage, on which are spread neatly made rattan mats. The rattan canes are split into three, then each strip is bored and threaded in several places, forming when finished a beautifully cool and pliant mat, but unfortunately in dirty houses a splendid harbour for insect pests; the Bajows purchase these mats from the inland Dusuns. Over these are placed plaited mats of palm-leaves, which are often worked in pretty colours : on these mats are numerous pillows like hard round sofa-cushions, generally made of red cloth and embroidered at each end with silk and gold crewel-wrork. A few mosquito-nets, made of blue or white cloth, are slung on wooden frames from the roof, but as most nets had seen several years' service, they looked somewhat filthy. The more valuable property consisted of earthenware jars and brass-ware, generally in the form of large platters, gongs, and highly ornamented "badils." At the sides of this house were piled up gaudily ornamented Chinese boxes, which contained, I presume, some of the Datu's Sunday-clothes and other valuables. A few glass wine-bottles hung in neatly-plaited grass covers; some common china plates and small bowls completed the crockery of this establishment. At the far end of the house was the small kitchen, built under a separate roof, thus keeping out some of the smoke, the fire being made on a mud hearth. The whole place was painted a dull brownish tinge. While making the sketch for my illustration (on the opposite page) the Datu's son-in-law had been looking on for some time, when he told me that the Datu objected to my making fun of his home by sketching it, as he knew I would take it to my people and laugh over it. The women in this house, as in most others we visited, were busy weaving sarongs and head-cloths, the prevailing colour being red, some for their own use, others for barter. The Bajow and Ilanun women are ugly in comparison to the Dusuns, having nasty sallow complexions; in their dress they are 


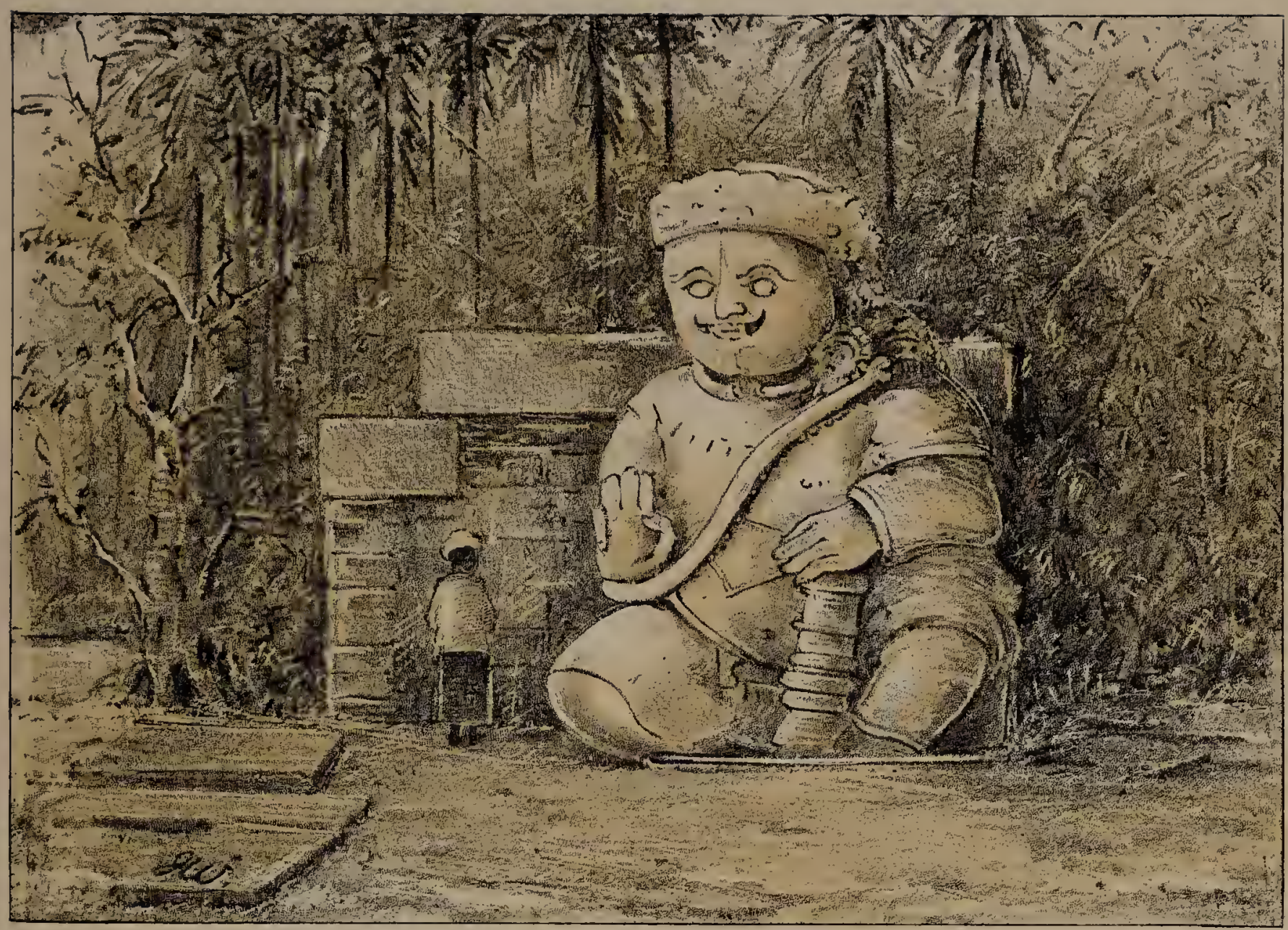

HINEOO IDOL. SINGOSARI. JAVA.

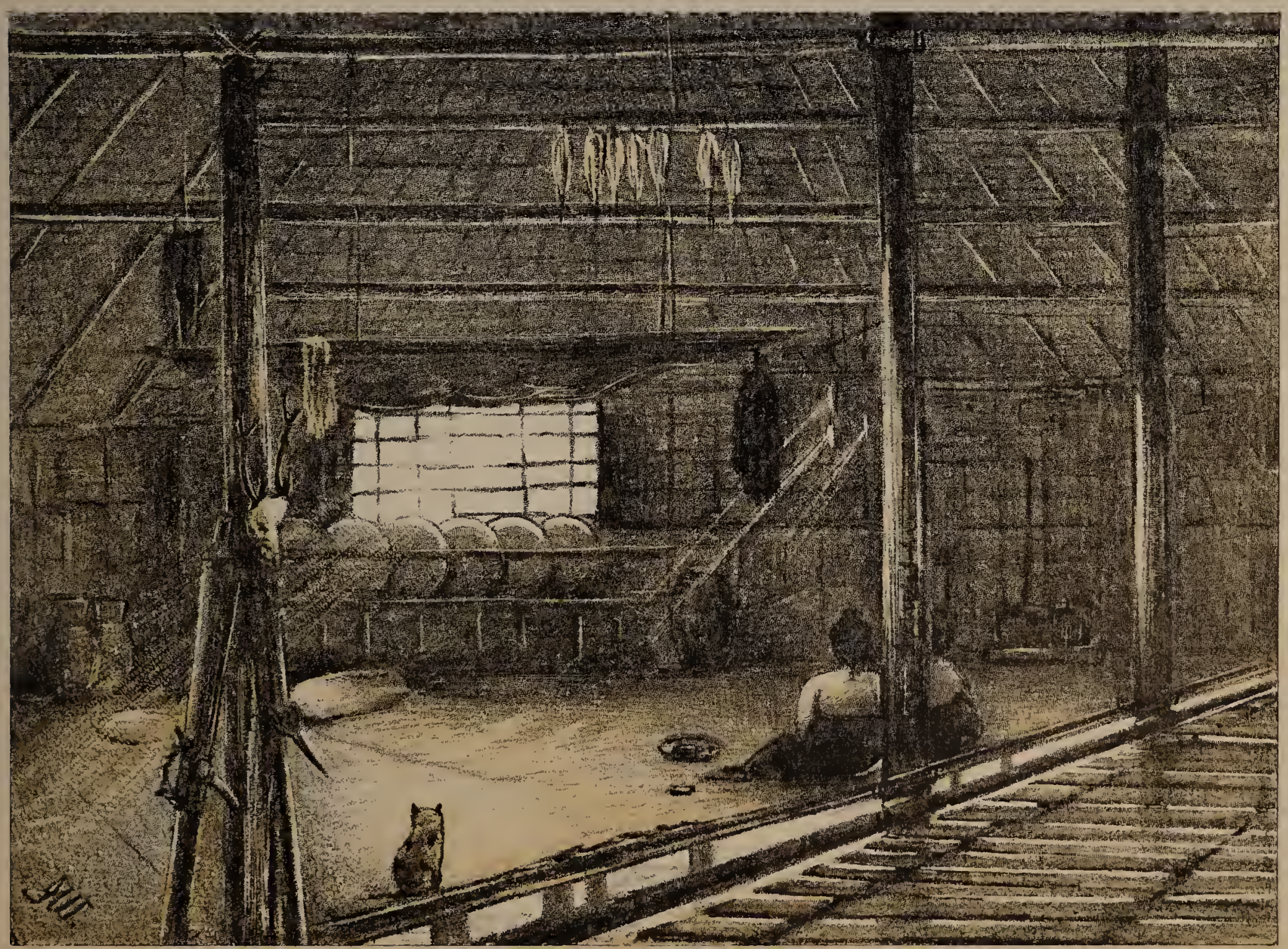

DATU TUMANGONG'S HOUSE. TAMPASSUK 

slovenly, wearing a pair of loose trousers and a long sarong generally of dark-blue material : as they are neither blessed with tapes nor buttons, they seem to be continually readjusting their garments, as if in fear of them dropping off. The attire of the male Bajow is similar to that of Datu Tumanggong already described, only the colours are often varied to white and red. On the whole the Tampassuk Bajows are ugly, often of a very swarthy complexion; few have pleasant expressions and many a forbidding scowl : they are probably the most lawless people in the Company's territory, and it will require an officer well backed up with police to whip them into shape; but, as I have already stated, they are so rarely visited by any magistrate, and then the subsidized chiefs swear against each other, so that it is almost impossible to administer justice.

For the next few days we were busy hunting up buffaloes in all directions, often walking from morning until night; but in the end I could only get four promised out of ten that I should require. During these rambles I made the acquaintance of a little fat Ilanun chief, who gloried in the title of Sultan Paitailan. High-sounding titles are very common in Borneo, mostly self-bestowed I imagine. There are dozens of Orang Kayas (i.e. manrich), Datus, Pangerans, Rajahas, Sultans, and Sherifs, the last being numerous in the Benkoker district and the descendants of Arab adventurers. Many of these titled personages are chiefs over their own household only-except my friend the Orang Kaya of the Padas, who was not even that-and have in reality no power at all, and very little influence.

The Sultan was a most obliging little man, troubled with a dry throat, which often brought on fits of coughing; he also had a grievance, as he was not a paid chief and thought he ought to be: by the assistance of this man I was able the following year to get my baggage carried to the Dusun village of Melangkap. In company with the Sultan I went to some dozens of houses, but all the Ilanuns, for some reason or other, were unable to go or lend us buffaloes.

The Ilanuns are more obliging than the Bajows, better featured, being more like Sulu Islanders, and more industrious. 'They occupy the territory near the mouth of the river, where they grow quantities of paddi and sugar-cane, which they make into dark-coloured sugar and barter with the Dusuns. They are also expert brass-founders, casting tastefully ornamented boxes for holding "sirih"-chewing necessaries, which they sell to their neighbours ; formerly they made their own "badils," but the suppression of piracy has extinguished this branch of industry. Formerly they also made curious coats of mail, formed by riveting together small oblong pieces of buffalo-horn: there are still a few of these fighting-coats to be seen in this district, where they are valued at one buffalo each; but even for this price it is difficult to get the Ilanuns to part with them. The Ilanun sword is a curious weapon, and is known as a "kompielan"; the blade is made of soft steel, very thin and broad; the hilt is of wood and provided with bells, carved, and ornamented with tufts of hair: these swords formerly constituted part of the payment for an Ilanun bride, they are also valued at the rate of one buffalo. These people are also great fishermen, catching and salting numbers of fish, venturing far out to sea in the smallest of canoes; but I am afraid with all their good qualities they equal their Bajow brethren in cattlelifting. 
Our buffalo-hunting excursions continued until the 17th, when the cause of the reluctance on the part of the Ilanuns to help us became known. The country only a day's journey from this was in such a disturbed state that none of these men would venture to assist us.

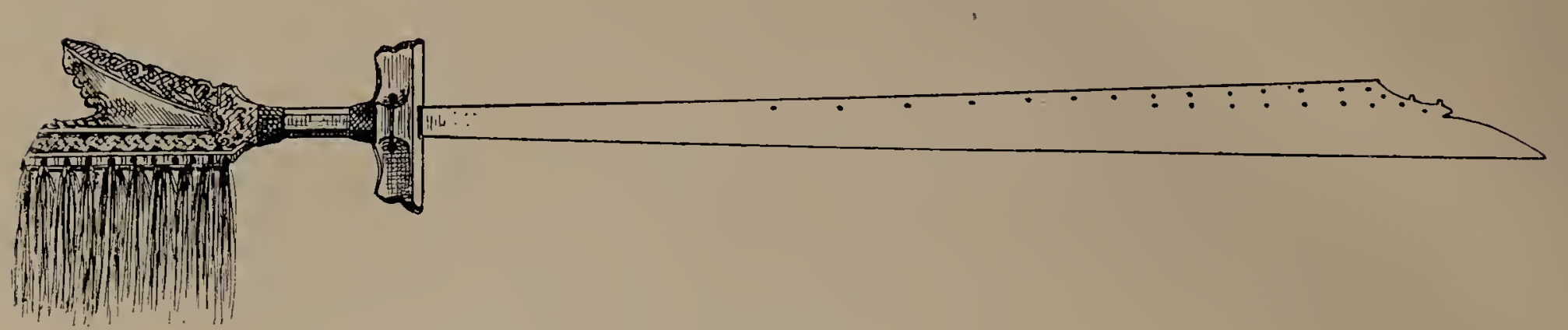

KOMPIELAN.

The Tampassuk plain is covered with "lalang" grass, and at this period of the year the Bajows were burning it in order to provide their herds of cattle with better pasturage. The whole country was often shrouded with the clouds of smoke from these fires, which are closely followed up by thousands of Wagtails and Pipits feeding on the singed grasshoppers and other insects: numerous hawks, chiefly Harriers (Circus spilonotus) fly about in the clouds of smoke hunting for dead mice and birds; at times a grim-looking Adjutant (Leptoptilus javanicus) may be noticed standing motionless on the charred ground.

The plain is intersected by numerous swampy creeks, which are probably the ancient bed of the Tampassuk, the river changing its course slightly every year, the soft alluvial deposit of which the plain is composed being easily washed away during the annual floods. In one of these flag-bordered creeks I disturbed a small flock of Wigeon, two of which I bagged, and though black as a coal before Rhaman served them up, I never enjoyed ducks more. Snipe swarm at times on these plains, especially at the end of December, when the plains are in places under water; then there would be but little difficulty in making a large bag, but when made the difficulty would be greater in knowing what to do with the birds : so, though fond of this sport, I soon gave up shooting them; the Bajows being Mohammedans will not eat flesh unless the animal has had its throat cut by one of their creed. The species of Snipe shot here was Scolopax megala, a Chinese migrant to Borneo, much larger than the Common Snipe, which also occurs.

These vast plains would, under more industrious people than the Bajows, grow enormous crops of rice, or might perhaps be placed under sugar-cultivation by Europeans; now they only serve as a pasturage for small herds of native cattle, which do remarkably well. The Bajows only cultivate sufficient rice for their personal wants ; this stock is apt to run short, when they have to fall back on the Patatan Dusuns to keep them alive until the next harvest.

After I had been in the Datu's house four days, the Bajows began to circulate rather alarming reports about the Dusun tribes. They told us that the Kong Dusuns had attacked those of Ghinambur and killed five, taking their heads, and that the Company's police had attacked a Dusun village near Ghinambur and had kilied eight men; this afterwards 
turned out to be true, though at the time, and until I received a letter from one of the officers of this expedition, I thought it merely a subterfuge on the part of the Bajows to make me abandon my designs. On the 17 th I received the letter mentioned, stating that as all the tribes were on the war-path it would be dangerous and foolish of me to attempt to proceed inland: as a matter of fact I could not have done so if I had wished, having no means of conveying my baggage; so it was now a certainty that $I$ should not reach the mountain this year. In later years, when I became intimate with the inland Dusuns, I found it was their annual custom for large parties of young men to go on the war-path about this period after the rice-harvest, when, if they are lucky, they may stalk and carry off the head of some unfortunate enemy. Two months before we arrived here, a few Kong and Kiau Dusuns made one such expedition right down to the Tampassuk plains, where they killed a Bajow and carried his head and limbs away with them; this was the continuation of an old bloodfeud, and when the Bajows have a chance they will retaliate. On the 16 th of this month a Tampassuk Bajow was shot dead by another from Pandasan; buffalo-stealing was the cause, but being a somewhat common occurrence this event caused little or no commotion amongst the inhabitants. The Datu went to view the body, and probably no steps will be taken to bring the murderer to justice, except by the relatives of the murdered man, who will carry on the vendetta on the first opportunity.

Having now occupied the Datu's house longer than he wished, partly in the hope that to get rid of us he would find the necessary buffaloes, and as it is now impossible, owing to the Company's police-expedition, to proceed inland, we resolved to relieve the Datu of our unwelcome presence, and asked him to lend us one of his small houses in a paddi-field close by. In this place I remained until 25th February, hoping that perhaps after all I might be able to start inland; on that date I gave it up as a bad job, and returned with all my belongings to Abai.

Food seems very abundant and cheap on the Tampassuk, but money is in small demand, trade-cloth and turkey-red, matches, knives, cottons, looking-glass, boxes, \&c., \&c. fetching in actual value more than trvice the amount that specie will when bartered for food amongst these people.

We remained in Abai until the 12th of March, when the Assistant-Resident left in the 'Kimanis' and we were able to return to Pulo Gaya. There is little or nothing to be done in Abai, the country round being parched up and almost destitute of birds. A few fine Sambur deer are to be met with in the evenings, but it is a great chance if one secures one. It used to blow heavy gales of wind every day, making it impossible to reach Gaya in any craft procurable on this river, so we had to sit down and wait patiently, wasting our time. The Hadji in my employ is becoming quite a nuisance; he commences his prayers at daybreak in a sing-song monotonous tone and continues them at intervals throughout the day, while the rest of his companions sit round laughing at some anecdote which is being related by one of their number, and, after the style of Malay tales, is far from proper: the Hadji, though studiously bowing his head to Allah, every now and then joins in with the lewd conversation of his companions, as a sort of slight relaxation. In Abai we met with a crew of shipwrecked Dyaks; they were returning from the island of Palawan, where they had been on a trading-expedition, and their prahu was driven ashore near this place. The 
Dyaks were busy repairing their vessel, in which later on they proceeded on their journey to Sarawak. Amongst the cargo were numbers of a large cone (Conus suratensis); the larger end of the shell is sawn off and fashioned into bracelets, which are much valued by the native women. Several Parrots (Tanygnathus luzoniensis) were perched about the boat looking rather miserable. From these natives I purchased an "Elang" or Dyak sword. The blade is slightly convex on one side and studded thickly with brass studs; the haft is of carved deer's horn, ornamented with tufts of human hair. The sheath is beautifully carved and ornamented with tufts of red, white, and black hair, and contains a loug-handled smallbladed knife. These Dyaks were a fine clean-skinned lot of natives, their chests being much tattooed.

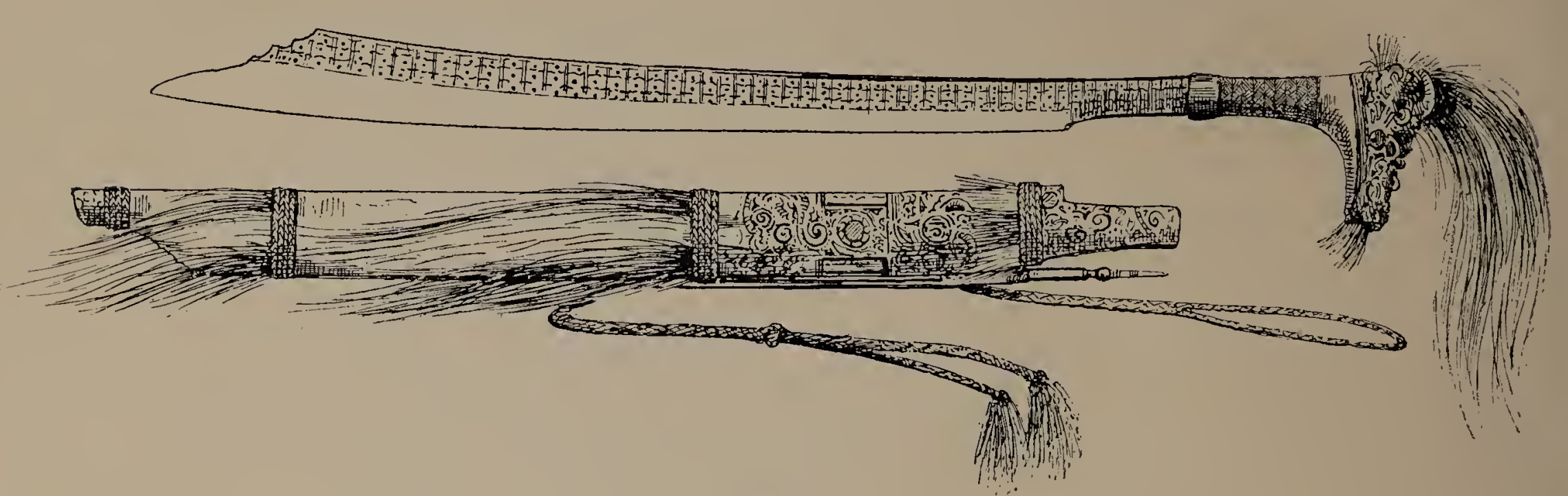

ELANG.

Whilst in Abai a small fleet of Sulu outriggers arrived, or "dapongs" as these boats are called; they came in for shelter from the fierce wind and remained some days. These boats are somewhat like the Ceylon catamarans, but have two outriggers; they carry a huge nearly square sail, which is attached to the top of a tripod mast, and are very fast, but, I should imagine, very wet, all the baggage being placed on light high-railed platforms astern; each boat carries two men only. The Sulus, some twenty in number, were a great nuisance; they used to come into the house and beg for everything they set eyes on, and no doubt would have stolen anything they fancied if we had not been continually on the look out; it was a great relief to us when one fine morning they sailed away. Sometimes the Panglima, or admiral, would sit for hours looking on while I was sketching; and one day I provided him with a sheet of paper on which he drew a very fair outline of one of his dapongs, under full sail. The Panglima told me that he came from Tawi Tawi (some islands of the Sulu group), and that his father was a famous pirate and was killed some years previously by the Spaniards. His father's skin was so hard that it was bullet-proof, and if a brass cannon was fired off close to his chest he would be blown away some yards unhurt. The present Panglima was driven away, and had settled in Mulliangin, and I should fancy is as big a pirate as his father was when opportunities offer, and a nasty gentleman to 
meet on the high seas, if he thought no one was looking on. The old Bajow caretaker is an amusing man. One day he told me that Captain Witti had always said, "Never steal, whenever you want anything ask the Company ; for if you steal you will go to prison." Then the old boy looked up and said, "Tuhan, I have no coat, give me some white cloth!" But I told him if he wanted white cloth he must go and catch me some fish; for although we are close to the sea and the Bajows go out fishing nearly every day, it is very seldom that we can buy any.

The few Bajows that live here work in the swamps, cutting up the roots of mangrove and nipa, which they pile into large heaps and set fire to, extracting salt from the residue after it has been boiled; this they mould into large flat cakes and barter at the weekly tamel. This salt is the only kind used in this district, the natives preferring it to the imported article. By barter it finds its way far inland beyond Kina Balu.

On the 9th the 'Kimanis' arrived with one of the Company's officers, the chief object of this visit being on my account, and partly to see about the building of a court-house on the Tampassuk. This officer told me that he had just returned from an attack on a recalcitrant Dusun chief some miles inland, where the expedition had burnt several villages and killed eight natives. The Dusuns of this tribe had several times raided down to the coast and cut off many heads : their chief was noted throughout the district for his bravery ; the Ghinambur Dusuns told me that he was invulnerable, so his and his tribe's chastisement at the hands of the Company was necessary and merited. The chief was not killed, and in the following year tendered his submission and became good friends with his former enemies. This expedition had a good effect among the mountaineers, being conducted against their most noted chief, and showed them that it would in future be useless to cope with Europeans.

Several coast Dusuns came one day, bringing brass-ware of various sorts, which was accepted by the Assistant-Resident as poll-tax. I must say it seemed rather hard on these people that they should be allowed to surrender up their goods and chattels to swell even indirectly the revenue of the Company. There can be no objection to the levying of this tax in the more civilized parts of the territory as payment for benefits conferred by the Company's rule, but in districts that are not even annually visited it seems to me to be an unprincipled exaction.

At midnight on the 12th we left for Pulo Gaya. The Assistant-Resident had been suffering daily from severe attacks of fever, which ultimately ended in his death in Labuan Hospital on the 19th of the following June. After waiting four days in hot uninteresting Gaya we left for Labuan in one of the coasting-steamers, and thus ended my second attempt to reach Kina Balu - the failure of this and the former expedition being due to no fault of my own, but to the disturbed state of the Company's territory.

After a few days in Labuan, which were occupied in finding a suitable prahu and in fitting her out for our next expedition, we started for the Lawas River. This stream debouches opposite Labuan, and is one of the last strongholds of the Murut head-hunters, being a sort of "no man's land" between the territories of the Company and those of Sarawak. It is, however, really a (nominal) dependency of the now rapidly decaying 
Brunei power, and sooner or later must fall under the rule of one of the neighbouring governments. Perhaps the sooner the better, as at the present moment it is a wedge of barbarism of the most brutal type between two improving States; but jealousy at present prevents either side from acquiring it. When speaking of a river in Borneo the large territory through which the river flows is included in the district bearing the name of the river.

After six hours' sail we reached the embouchure of the Lawas. The first inhabitant to meet us was a large wild boar, which was taking its evening stroll along the beach, but having no rifle handy he was passed unmolested. After rowing a short distance we reached a Brunei village where the nominal rulers of the district dwell. The Pangeran was not at home, but his sons and others in the evening did their best to dissuade us from continuing our journey, declaring that all the Muruts were out on the war-path, and that the district was too dangerous even for them to travel in; but as all Bruneis tell the same tale, being anxious to keep Europeans out of their districts, fearing, not without reason, that they will soon cease to be even nominal proprietors, we paid no attention to their warnings, and proceeded up stream the following morning to another Pangeran. This chief told the same tale about the Muruts, and advised us to return to the village of the first Pangeran and obtain his permission before we went further; this of course I refused to do, and we rowed up another branch of the river known as the Sungei Meropok, a confluent of the Lawas. The dark green foliage on the banks was greatly brightened up by numerous bright-red-sheathed Areca palms, which I did not notice elsewhere in Borneo.

After rowing some distance we reached a small settlement of Kadyans, who assured me that the Muruts were on good terms with them, and that the Bruneis fearing we had come on a trading-expedition to the Muruts, which might interfere with their gains, had painted them as black as possible to deter us from proceeding. As we had passed the houses of several Chinese traders, there was little doubt that the Muruts were comparatively peaceable.

The Kadyans lent us an old house, the occupants migrating with most of their property into that of one of their neighbours. We soon made ourselves fairly comfortable, and removed all our baggage from the prahu into our new quarters. This house is similar to others already described, but is built much higher off the ground on numerous thin piles of that excessively hard wood known as "biliong." There were two reasons for this: in the first place to be out of reach of the high river floods, and secondly the danger of attacks from inland tribes. It was no easy matter to reach the entrance, a climb up a 15 -foot notched pole being necessary; at night this pole is drawn up into the house. Soon after we were comfortably settled it began to rain; and I had the pleasure of being visited by the first real barbarian I had ever seen, for the Bajows, coast Dusuns, and Padas Muruts must be considered civilized in comparison with the Lawas Muruts. The object of my admiration was a tall handsome Murut, naked all but his loin-cloth or "chawat;" his hair was long, hanging below the shoulders, his forehead looked higher from the fact that the hair had been shaved off for about an inch; the eyebrows were also dispensed with. In the lobes of his ears were inserted looking-glasses, about the size of a florin piece, not 
suspended, but let in. These novel ear-ornaments were worn by all the Lawas Muruts, and are made by fixing a small round looking-glass in a bamboo frame. The nose of this individual was sharp, clean cut, and inclined to the aquiline; his face was longer than is usually met with in this tribe. One of his legs was much swollen with varicose veins, which caused him to halt slightly. This Murut was named Si'Lalang, and he was the only good-looking Murut I met with : the other members of his tribe I shall describe presently. Si'Lalang told me that his chief pastime was pig-shooting, varied by head-hunting expeditions. According to our neighbours the Kadyans, he was a well-known character, being the most famous head-hunter in the district. He told us that he had killed and taken the heads of some twenty of his enemies, which are the Pelluans at the head of the Padas River. After a short stay Si'Lalang left, to pass the night in the house of our neighbours the Kadyans, promising to call for me the next morning and to take me with him to his home to view this famous collection of crania.

In our house the Kadyans have left some children's toys; this was the only attempt towards making models to amuse children that I ever noticed in Borneo. The toys consisted of several well-made models of boats; but the chief object of interest was a peculiar wooden animal on four wheels, which looked more like a rabbit than anything else, but when told it was the model of a buffalo, it became more grotesque still in my sight.

Next morning Si'Lalang called, and we started with him to see his home and trophies. His louse was several miles distant, which we reached after a most tiring walk, the path for most of the distance traversing the last season's paddi-fields. There is nothing more trying than a walk through an old paddi-field, cultivated after the custom of the Bornean aborigines. Large trees are felled, falling in all directions ; this huge pile when dry is burnt, but only the smaller branches and foliage are entirely consumed. The great trunks for many years after lay about in all directions, often piled some height from the ground; amongst and over these slippery trunks is the native path: to their naked feet there is no difficulty in effecting such a journey; but to booted Europeans, broken shins, with a fall every now and again, is a certainty - in this case one fell into hot, stinking, muddy water. After some miles of this trying route we reached the outskirts of the Murut village; here Si'Lalang amused himself by pretending to catch the children, telling them that we were Bruneis and had come to purchase a few slaves; the children ran away howling, which caused much mirth to our guide. The house we had come to see was a brand new one, erected on a low hill, surrounded partly by a small stream which was bridged by a fallen tree, and, as is customary in head-hunting districts, was very long, containing some fifteen families. There were a number of Muruts at home when we entered, both men and women, and a more repulsive-looking lot I have never seen, especially the women. The men were dressed in the chawat or loin-cloth, of which little can be said except that it is a poor substitute for absolute nudity. The women, old and young, wore only one garment, a short petticoat, which has been aptly described as "commencing too late and ending too soon;" it is dyed blue and made of native cloth. The only other attempt made by a Murut woman towards adorning her person consists of a necklace of curious beads and agates. Their hair is cropped fairly short, making them, if possible, more 
ugly, and decorated with a few strings of the same beads. Their arms are tattooed from slightly below the shoulder to the knuckles in long, straight, blue lines, which give them the appearance of wearing long mittens. This completes the costume of a Murut woman, with the exception of a curious red jacket that is worn on special occasions only. She is often very dirty, and at times, like her male companions, covered with that horrible skin-disease known as "kürrup," to which few natives seem to object in the least.

The house was divided down the centre by a passage with a door at each end. On the one side was the public apartment, stretching from end to end, on which several mud hearths were constructed; on the other the whole length was boarded up to the height of about ten feet, and divided into a number of small cubicles, each with

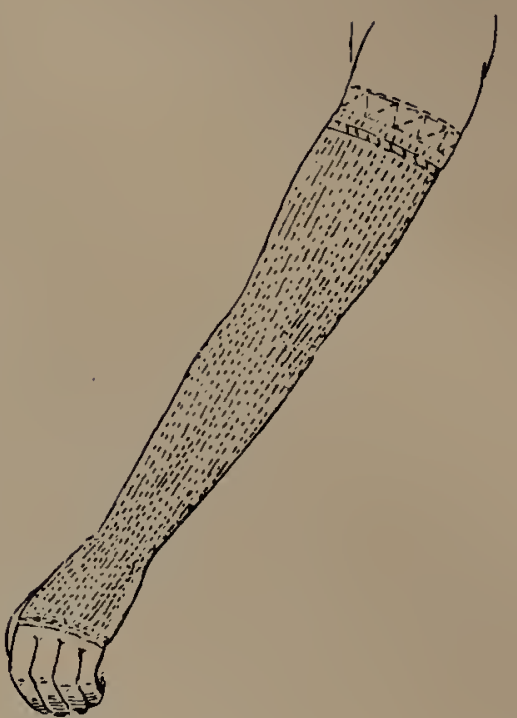
its own doorway, these spaces being the private apartments of the families. Along this partition, above the doorways, ran two parallel bamboo poles about a foot apart: between these were placed at intervals over fifty human skulls, the pride and glory of Si'Lalang. The skulls were for the most part old and black; a few were tied up with rattans to prevent them falling to pieces, so they were probably collected by Si'Lalang's forefathers : the newest addition had only occupied its place a few months, probably after the house was built, as it is the custom of most head-hunting tribes to celebrate the building of a house, or rather, I should say, to offer a peace-offering to their
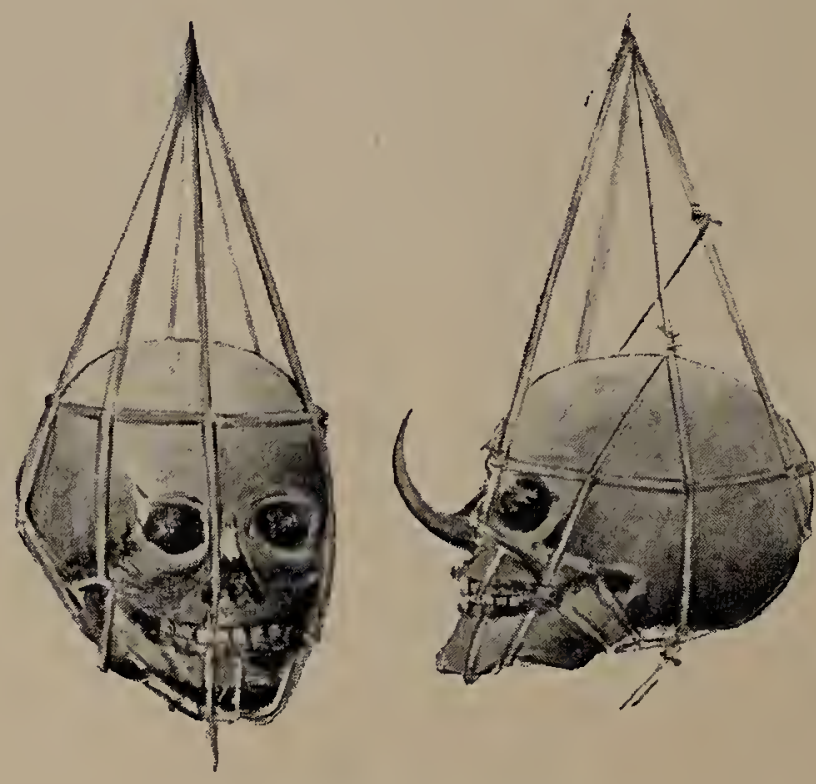

MURUT TROPHIES.

spirit-world to insure freedom from illness and good fortune whilst they dwell there, by the acquisition of a fresh head. Many of the heads were ornamented with a boar's tusk, which was stuck in the nose, the curve pointing upwards. At one end of this ghastly row was a 

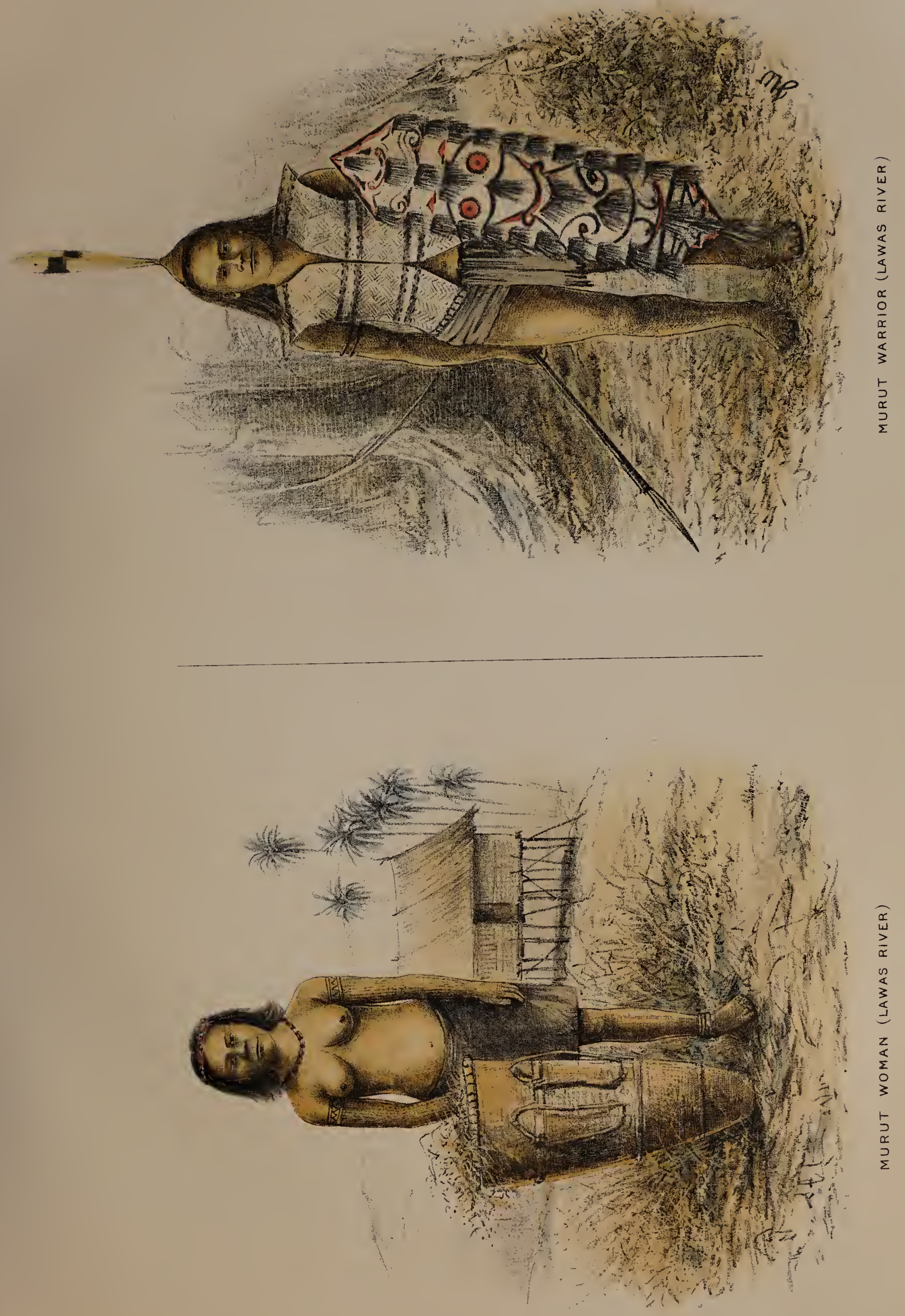

small wooden model resembling somewhat the shape of a man, which $I$ at first took to be a Murut household idol; but when I inquired of our hosts what this peculiar model really was, they answered that it was the model of a child which they had killed on one of their expeditions, but, as the skull would not keep, they carved out this as a memento of their bravery.

Head-hunting is one of the most cowardly of barbaric customs, and probably existed at one time in some form or other amongst the greater part of the inhabitants of the world. The North-American Indian kept the scalps of his victims; the South-American preserved the skin and hair in a marvellous manner, discarding the skull. Some Bornean tribes preserve the fleshy parts by drying and smoking the head over a fire; the nostrils are prevented from shrinking by small wooden plugs. In the Batavia Museum are many heads taken from the Sumatran and Bornean head-hunters, which are bedecked with gilt crowns and otherwise fantastically adorned; and so well is the facial expression retained by the means employed in drying, that I have heard that a man could recognize his relation's head years after by the features alone. The antiquity of this custom throughout the south-eastern portions of Asia probably dates from the early stages of man's development, when he first became acquainted with the use of weapons. Borneo has always been noted as the metropolis of this practice; in fact all the pagan population did and at the present moment most of the interior tribes still do indulge in this custom.

Head-hunting has become, as it were, a pagan religious rite, probably derived originally from a custom of "vendetta." I do not think many tribes in North Borneo embark light-heartedly on such expeditions, as they entail a lengthened absence from village comforts, in exchange for a very trying pilgrimage into the forests, from which the men return often in a very emaciated condition, at times even succumbing to the hardships they have to endure. This custom, as carried on by the Dusuns of North Borneo, does little harm, their victims being but very few; but when entered upon as formerly by the Dyaks and Kayans, and to a less extent by the Muruts of to-day, it has the effect of almost depopulating the surrounding districts.

The Muruts go on these expeditions for several reasons, but chiefly to propitiate their "Hantus" or spirits, as well as to gratify their love of bloodshed. Their enemies are the wild tribes inland, whom they speak of as "Orang Taggal," the Trusan Muruts to the south, and the Bruneis. They cannot, however, be on very bad terms with the latter, as I met Brunei traders in their houses. The chief reason for the addition of a head to the ghastly row is the death of a relation, when the departed spirit will not rest until this horrible custom has been complied with. After the harvest is another occasion, this time to insure a good crop for the following season; on the building of a new house, as a petition to the "hantu" to ward off illness and the attacks of enemies; and in some tribes by a bachelor to win the hand of his future bride. There always seem to be single individuals or parties of two or three on the war-path for reasous of their own; these scoundrels never openly attack, but hover about the outskirts of a distant village, and if possible cut off a woman or child and bolt with their trophy at once. Some expeditions are carried out, however, on a large scale when the cause is one that concerns the community, such as the rice-harvest or an epidemic: then the villages combine forces, and several hundred men go out on the 
war-path for months at a time; but so cowardly are these people that even so large a party would not dare openly to attack their enemies, if only half as numerous. Their omens are so numerous that when out in the forests most of the time is fooled away obeying them. The meeting of the omen bird would send back an expedition for days until a propitious omen declared the forward march advisable. As their omen birds and reptiles are generally common species, such as the small Kingfisher (Ceyx tridactyla), the delays caused by meeting them flying from the wrong direction must be almost of daily occurrence, and from the estimate I have formed of Murut bravery I should be much inclined to believe them more willing to retreat than to advance. Just now, at the time of my visit, there is a party of nearly two hundred Muruts on such an expedition: they have been away nearly two months, but their return is daily expected. The tactics of such an expedition is, if possible, to sneak up to a detached house in the early morning, just before daylight, and to set fire to it, killing the people as they rush out, or capturing the young women and children for slaves.

I never was witness to a head feast, so am unable to give an idea of such a festival; but I believe rice "arrack" flows freely down the throat of the Murut brave, and that the head is carried round on a cloth by the women. A Murut told me that they also cut off the first joints of the limbs, which they bring back with the head; these, he said, they amused themselves with by throwing at their women on such occasions: I should quite imagine Murut brutality equal even to this. In the house I noticed a few bark jackets, or "biangs" as they are called, one or two brass guns, many "sumpitans" or blow-pipes (Murut "oput"), a few long swords, Tower muskets, and forling-pieces. The Murut never cleans his fire-arms, learing them over the fire-places, where they become thickly coated with smoke. One Murut used the entire skin of a large red monkey as a satchel, the legs being tied round his waist and over his shoulders, the long tail hung down behind; and as this novel bag was stuffed with Murut property, it looked like a live animal clinging to the man's back.

Underneath the house were numbers of small black pigs, which greatly disgusted my Mohammedan followers. In front of the chief entrance was a peculiar structure erected of bamboo poles, festooned with bunches of dried palm-leaves. This had been erected, my Kadyans assured me, at the last head feast; so the latest addition to Si'Lalang's museum could only have been of recent date.

Next morning we were visited by twelve Muruts: they did not beg for any of my property, which was a blessing, some tribes, especially Sulus, being a great source of trouble, wanting everything. In comparison to the Kadyans and Bruneis the Muruts were taller and more powerfully built. After I had showed them most of my belongings they retired. The articles that took their fancy most were the walking-stick guns which I use for birdcollecting. These they thought would be splendid weapons for "tipu," i.e. treacherously killing a man; as they explained, you might sit opposite a man and shoot him without him knowing you had a gun. This is about the real idea of Murut bravery-"tipu." They were also interested in my fork, and seemed to think it almost impossible for anyone to put food into his mouth without hurting himself, as they explained it to each other by pretending to stab their cheeks and nose. 
One Murut remained after his comrades had left, so I amused myself for some time getting my questions interpreted to him by the local Kadyans.

The Murut burial customs are rather interesting. The corpse is for the first year potted: the dead body is doubled up, the knees to the chin, and placed in a large jar, the jar being carefully broken to admit it, and afterwards tied together with rattans and cemented, the top being secured by a plate also. cemented down. As this human jam-pot is kept in the roof of the house until the bones alone remain, it is necessary to drain off the liquid parts; this is done by inserting a long bamboo pipe through the bottom of the jar into the ground below. After the bones are dry they are placed in a smaller jar and buried. Whether this custom originated from the fear of the desecration of the graves by enemies I am unable to say; but as the Muruts have even journeyed to Labuan and stolen the skulls from the cemetery, it is not improbable that they are afraid of the same thing happening to their dead.

The price of a wife among these Muruts is 20 picul of brass guns (rather expensive), or 4 jars, or two gongs; and my informant told me that often several men subscribe to buy a wife for one. This tribe call themselves Mongallun Muruts; their chief is Orang Kaya Dowaha, his wife is named Selouar. At this point Seboya (my informant) got tired of being pumped, so got up and abruptly left. Muruts kept visiting us every day, and I noticed several of them were tattooed on their chests or thighs. Whilst busy drawing a peculiar tattoo, the Murut caught my eye and immediately covered the mark over. The tattoo was a peculiar one, resembling a threelegged dog with a crocodile's head, one leg being turned over the back as if the animal was going to scratch its ear. The reason the Murut gave for not allowing me to sketch this mark was that his wife was expecting a child, and he was afraid of my eye affecting her. I have always found Borneans most unwilling models, as they believe that when you have sketched them you have power over them however

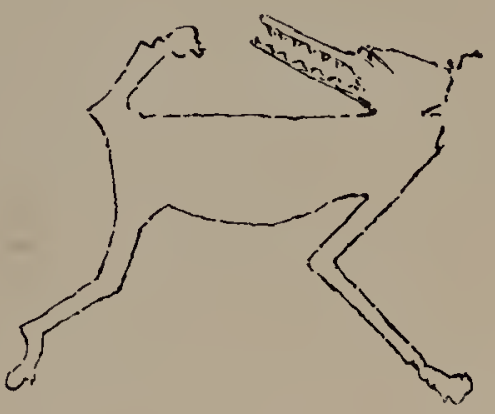
far you may be distant.

On the 28th, as we found but very few birds to collect about the campong, we carried our baggage up the mountain some little distance, and built a small shelter close to the edge of the virgin forest in an old paddi-clearing; here we remained until the 1st of April, collecting scarcely anything. This being a Murut country, birds and animals are very scarce-these people killing, either by trapping or shooting, everything they can possibly eat. I believe also my Kadyans are not anxious to go collecting any distance away from the hut, fearing that they might possibly be potted by some wandering Murut.

Seeing that there was but little to be done in this district, we used to make expeditions on the river, collecting a few interesting birds. One day we visited some limestone caves, where the Muruts informed us the Edible Sivallow nested. After rowing some distance down stream we struck off into the forest, and after a two hours' scramble reached the top of a hill, which was crowned with bare precipitous limestone cliffs. The top was rent in twain right through the centre of the hill, the gap thus formed being about fifty feet broad and sixty or seventy high; many other rents ran at right angles to the main fissure. At 
first the Kadyans were afraid to enter into the dark subterranean passage, which scemed the only way to reach the space beyond, being afraid of "hantus" and snakes, but on doing so we emerged into a most beautiful tropical garden. Beyond this, and for some considerable distance, this scenery continued, but was occasionally interrupted by masses of fallen rock, under which passages led, the crevices being so small that at times we could hardly squeeze through them. Here, at the end, a huge rent in the cliff ran at right angles to the main fissure; the end of this rent we were unable to see in the darkness, and a stone tossed in might be heard falling some distance into the bowels of the hill, disturbing in its course numbers of large horseshoe-nosed bats, which disappeared into the vaults beneath our feet and into the fissures beyond. Small Swifts (Collocalia linchii) flew about in this gloomy palace of theirs and into the vaults below the rocks on which we stood. Their nests might be seen in dozens adhering to the rocky sides of the cavern, each containing two shining white eggs, which were plainly visible some distance off in the gloom. Over our heads fine Papilios disported themselves in the bright sunlight, and a large Owl (Ketupa ketupa), disturbed by our visit, slowly flapped to the further end of the chasm. Orchids and fantastically twisted creepers, ferns, and palms added beauty to the scene; and I stood long in this fairyland enjoying this beautiful sight. We passed once more through the dark subterrranean passages and out as it were into the world beyond: at our feet lay stretched a sea of everlasting green, the roof of a tropical forest; beyond this the blue sea, with its distant horizon broken by the island of Labuan.

We collected several specimens of a handsome though well-known Swift (Dendrochelidon comata), with its plumage of bronze-brown and dark glossy blue. I also accidentally secured in my butterfly-net another of those extraordinary leaf-mimicking insects, Trigonopteryx obliqua (see illustration, page 50, fig. 1). This, unlike the grasshopper mentioned as obtained by me in Malacca, bore a close resemblance to a green leaf. Numbers of curiously formed spiders were plentiful on this river, and were known to the natives as the "Manga sisir," or Comb Spider, the body of this insect resembling slightly the comb worn by some native women.

I used often to make the Kadyans row the prahu to some pretty spot on the river, and while they were bird-collecting would amuse myself sketching the river scenery. On one of these occasions a small Kingfisher (Ceyx dillwynni) kept settling close to me; so thinking by its actions that its nest must be in the vicinity, I commenced to look for it, and after a short search discovered a small hole in a bank, which contained two white eggs nearly hatched. The hole was swarming with red ants; how the Kingfisher put up with these unwelcome visitors I am unable to imagine.

In the evenings we were visited by the local Kadyans, who came to chat with their Labuan friends. One or two of these men were formerly Muruts, but have been converted to Islam, and now call themselves Kadyans. They sometimes talk of the old times when they used to go head-hunting. One of their anecdutes will serve as a good example of how this custom is generally carried on. Some years ago one of these men was a member of a large expedition, amounting to quite a hundred Muruts. After they had been away from their villages some weeks, hovering on the outskirts of the enemy's country, sending spies 
to see if they could discover anything, they were one day told by their spies that there was a small house in a paddi-field not many miles off, the sole occupant being a decrepit old woman. Here was a chance not to be lost; in the night these hundred braves (!) surrounded the house, and suddenly rushed in on the poor woman, cut her head off, and decamped as soon as possible.

One afternoon we visited another Murut village: these people were more civilized than those of Si'Lalang's village. The men wore blue cotton coats and headcloths or "dastar" of the same material, but the skirts of the women were, if anything, shorter; they also greatly prized long agate beads, and some of old yellow porcelain, which they obtained many years ago from the Chinese; ordinary glass beads they would not look at. Most of the young men, they told us, were away with the expedition mentioned. They did not seem to set much value on their skull collection, as, instead of being hung up, these relics were packed away in baskets, in which there were several wooden dummy skulls.

In these houses I noticed some of the women busy making bark coats. The bark is peeled off a tree in broad strips and is very united and flexible; it is then hammered all over with a heavy wooden instrument, which has a flat surface on one side cut in deep cross lines like a file; this breaks up the harder tissues of the bark and reduces it to a very pliant though by no means united texture. The bark being full of rents and holes, this difficulty is overcome by transverse darning: one of these coats now before me has no fewer than 270 transverse strings on the back alone, each thread penetrating the outer surface only, and assists to work out a cross pattern for ornamentation. The size of a strip of bark for a "baju" is about 5 feet by 18 inches. This after being prepared is folded in half: the half for the front of the jacket is divided right down the centre; the sides are stitched up, leaving holes for the arms; from the back of the neck hang narrow strips of bark or long streamers of coloured wool. The bark is mostly reddish brown; but the best kind is white, the texture being more united and requiring little or no transverse stitching, but is occasionally ornamented with coloured patterns in wool. The sewing-thread is made from pine-apple leaves, which plant was growing in a semi-wild state on some hills near, the fruit being apparently valueless to the Muruts. These people, like those of the Padas, complain of the ravages committed by rats on their crops, and they have often to abandon their homes and migrate elsewhere on account of these pests. But they have this advantage over the Padas Mohammedans, that they can eat the rats.

On our return, when we had nearly reached our house, the Muruts suddenly commenced singing and firing off their guns, which one of my followers declared betokened the return of the expedition of head-hunters: but as we had been tramping all day I could not get up sufficient energy to return to the village again; this I afterwards much regretted. In the evening we heard that the Murut head-hunters had returned with a head; but as our informant also owned that one of their party-a slave-had died(!) in the forest, it is more than probable that they cut off his head, if they did not even murder him to obtain it.

The most interesting Murut weapon is the "sumpitan," the boring of which must require great skill, considering the primitive tool employed-a piece of trade iron sharpened 
like a chisel. The bore of these blow-pipes is as clean and bright as that of a gun-barrel, and is about six feet long, and drilled through a log of hard wood; the log is then pared down and rounded to less than an inch in diameter. At one end a spear-head is bound on with the sight. The ammunition is carried in a neatly made bamboo case, with a prong at the side for fixing in the chavat, and ornamented with rattan plaits (see illustration, fig. V.) : these darts are made from the stem of a palm-leaf-as hard as the tough nebong fibre-which is cut into slender strips, tapering into a needle-like point and nearly a foot in length. The resistance to the air is obtained by piercing a small piece of dried pith (from a species of mountain sago-palm) on a brass needle, which is fixed in the centre of a small length of rattan, previously pared to fit the barrel ; then by paring the pith towards the needle a neat little cone is formed, already pierced exactly in the centre, the base of which, being the same size as the rattan, exactly fits the barrel. In this cone the heavier end of the shaft is fixed, the point dipped into a deadly poison, and the arrow is complete. War-arrows differ from sporting-arrows by having a loose barbed point attached, either of tin or bamboo; this point is besmeared thickly with poison, and when shot home would remain in the wound with most of the poison.

The poison is a sticky mixture made from the juices of a poisonous creeper, and mixed with strong irritating ingredients, smelling strongly of camphor and pepper; the composition of the mixture is a secret, known only to the tribes of the interior. As a protection from these dangerous missiles, the Murut warrior covers his body with rudely formed jackets of deer or bear skin, which are sufficiently tough to protect his body. Their fighting chawats are very long, and wound round their bodies many times; their head-dresses on such occasions are made of rattan like wicker baskets, and covered with monkey-skin, ornamented with plumes from the tails and wings of Argus Pheasants, and over three feet long.

The Muruts have a great dislike to the Brunei Pangerans (i.e. nobles) and their followers. Their allegiance to the Sultan's government is but nominal, the Sultan claiming to be their suzerain; but now-a-days, owing to the rottenness of the Brunei Government, he would be unable to carry out his smallest desires. In former times, when the Brunei Government was powerful, it robbed these wretched aborigines of everything they were possessed of, even their women and children. If they resisted the exactions of the Brunei Pangerans, a horde of head-hunting Kyans would be turned loose on them. But times have changed: the Company on the one side, with Sarawak on the other, have gradually absorbed all the Sultan's territory except one or two rivers, on which the population have now discovered the weakness of the Brunei power and are in open rebellion against it. The wild tribes who were once willing, for the sake of the heads obtained, to carry out the wishes of the Bruneis are now lost to them, having been joined to the Government of Sarawak.

Though the Muruts were very interesting to me, their country was not, as animal life was very scarce, owing to their having destroyed for food everything they could possibly kill and eat, which in the menu of a Murut means a good deal.

On the 10th April we bid adieu to our Kadyan friends and left for the sea-coast, where 

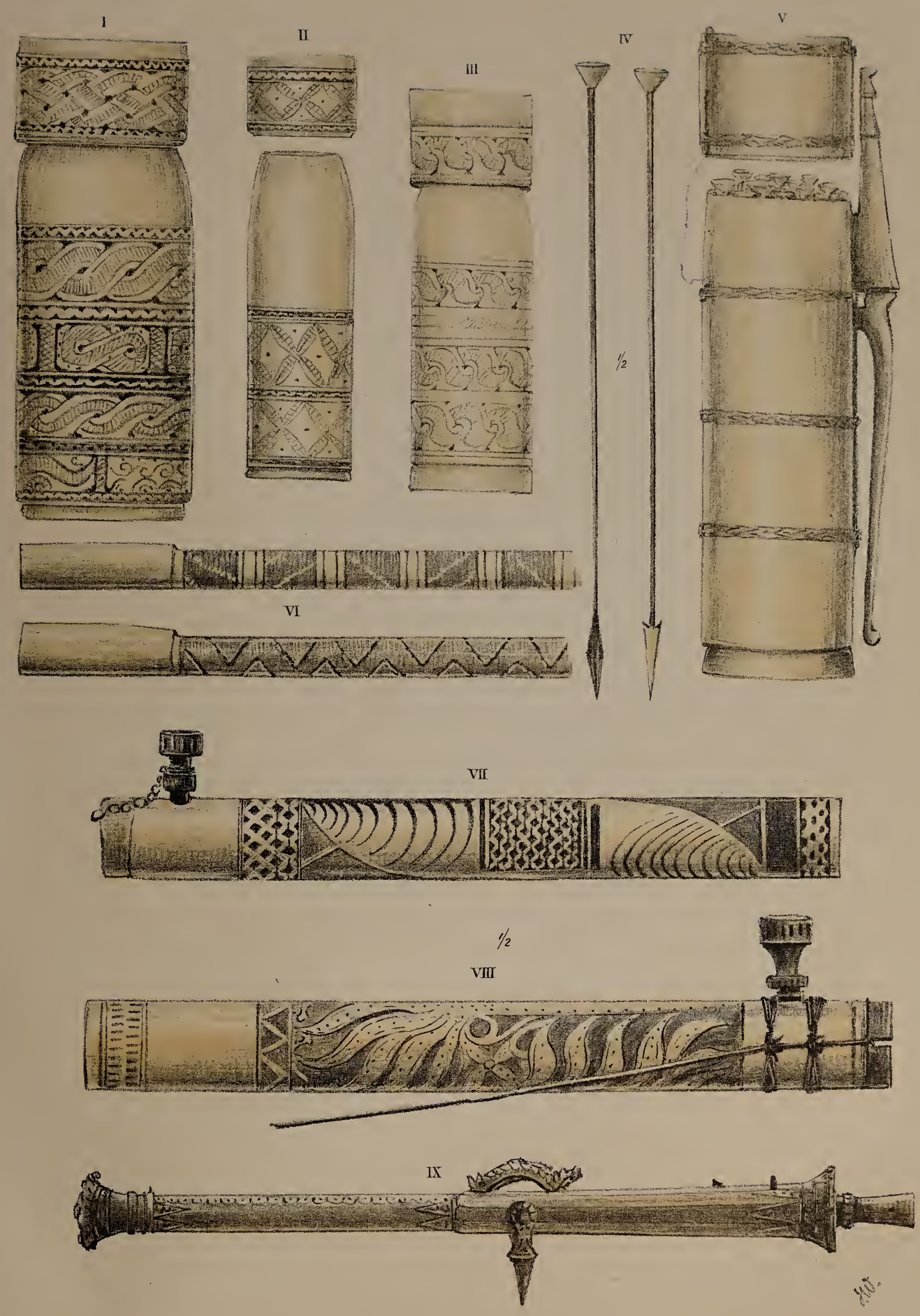

NATIVE DECORATIVE WORK

I. II.III. Palawan Dusun Tobacco Boxes.

IV. Sumpitan Darts
V Dart Case.

VI Ornamented Sumpitans
III. VIII Murut Tobacco Pipes

IX. Brunei (Cast) Brass Gun 

we coasted north, arriving on the following day at the mouth of another river, called by my followers the Lukutan. All along the sea-coast the forest had been burnt down, the blackened trunks of the larger trees alone remaining. This fire took place a few years previously during an extra dry seasoll, and devoured miles of primeval forest, as far as the sources of the Padas River. After rowing some distance up the river it began to rain, so we stopped at the first native house we came to. The owners, however, were away, so I hesitated as to whether we should occupy their house for the night, but a native called to us across the river that we were welcome to do so; on entering we found pillows, mats, fishing-tackle, and food left about just as if the owners were going to return shortly, but on the following morning we left without meeting our hosts.

After proceeding some distance we met with some Muruts who were busy cutting up a pig they had just killed, surrounded by their pack of small, sharp-looking, half-starved dogs, which were greedily snapping up the bits thrown to them. Our journey up stream was brought to an end by the fallen trees and snags which effectually blocked the way; so I ordered the men to build a shelter, which was roofed in by a large canvas sheet especially made for this purpose, and, with the sails from the prahu for the sides, was soon fairly comfortable. To-day on our journey here we have passed many abandoned native gardens, tenantless and half-rotten houses, showing that at one time this river supported a far larger population than it does to-day; but the inhabitants have either been killed or driven away by the Trusan Muruts, who, only a few months previously to our visit, murdered a man and woman as they were crossing the river, taking away both their heads.

It now rains every day in torrents, and as we are doing little or nothing, and our shelter is far from watertight, on the 16th we returned to the sea and coasted to the Company's station of Batu Batu (batu=stone). About the estuaries of the rivers are numerous Waders migrating north; they consist chiefly of Whimbrels, Turnstones, and Sand-Plovers of several species. On the 17 th we reached Batu Batu ; this station is built on the edge of a mangrove-swamp, and, as usual when such positions are chosen, is most unhealthy. 'The chief industry here is pearl-fishing: the pearls are found in a very transparent shelled oyster; so thin and clear are the shells that the pulsating movements of the fish can be seen through them. The oysters live in the shallow muddy sea in the estuaries of the rivers when sufficiently sheltered: the pearls are known as seed-pearls and are of little value as ornaments, but are bought by the Chinese, and I am told are ground down for medicinal purposes.

The next morning, after having spent a very pleasant evening with the officer in charge of the station, we started for Mempakol, and much to my crew's disgust they had to row the whole distance. Natives object very much to rowing, seeking every excuse to rest and waste time, so unless continually watched your progress is nil; if left to themselves they wait for the wind. I do not think a Bornean coolie is worth more than the smallest wage, as he is a perfect adept in the art of shirking his duties. The following day we started for Pulo 'Tega, on which islands I hoped to find that splendid Pigeon Caloenas nicobarica. So flat and swampy is the country round about Mempakol, that by rowing up the Kilias River the coast opposite Pulo Tega may be reached; thus many miles in the open sea are avoided. 
The Kilias and Padas districts are noted for the sago industry, which is carried on both by Chinese and natives. The sago-palm is indigenous in the Malay Archipelago, and grows freely with little or no care on the part of the native cultivators, the young palms springing from the roots of the old one: it does best in low swampy districts above the reach of salt water; but it also grew plentifully at an altitude of 1000 feet on Kina Balu in some swampy land, where I imagine it had been introduced.

The palms grow to a height of about thirty feet, and take between ten to fifteen years to reach maturity, when they are cut down and split in half, the reddish fibrous pith being chipped out with a bamboo hatchet fashioned for the purpose. The pith, now reduced to minute chips, is rubbed through a coarse cloth and water is poured over it during this operation; thus the starch becomes dissolved and is allowed to settle at the end of a trough, the water being gradually poured off. The sago of European commerce, however, goes through many processes, that eaten by the Bornean native being a thick clear glutinous paste, known as " boyat." To see natives feasting on "boyat" is not a pleasing sight, as the bowl containing the sago is placed on the floor, into which they dip sticks, winding the mess round until a ball accumulates, which with difficulty they manage to place in their mouths.

The Kilias is a fine stretch of salt water bordered on both sides with miles of nipaswamps; after rowing all day its breadth is no narrower than when we started early this morning (20th). My crew were afraid to sleep in the Kilias during the night, so they paddled slowly most of the time, fearing " hantus," which they say often draw prahus below the waters of this stream, never to be seen again. Many long-tailed monkeys howled on the edges of the swamps, and were the only hantus that troubled my slumbers. On the left bank we entered next morning a small stream which had been enlarged and channelled by the natives, and thus connected with the mangrove-swamps and creeks which run inland several miles from Qualla Penyu (qualla $=$ mouth of a river, penyu=turtle). So tortuous are some Bornean rivers when they flow through the alluvial plains, that by cutting a canal of forty or fifty yards through the bank the river is again met with, and several miles of paddling are thus saved to the natives.

The canal passed for several miles through flat uninteresting country: after this mosquito-swarming district has been passed a mangrove-swamp is reached; the mangroves here are no longer the dwarfed shrubs of the sea-coast, but fine trees, and at low water the quaint shapes of the roots form a most wonderful sight. Through this forest a passage has been cut, which leads to a large open lagoon; this is connected with the sea by a broad creek. 'The country is of such a low level that the whole of this journey is performed in salt water, and then only at high tide. This passage, though somewhat neglected and full of snags, is a great convenience to traders during the monsoon, when they can cut off many miles of rough sea and reach Labuan with little danger.

We stopped the night at Qualla Penyu, where the Company are building a spacious police-station for the purpose of levying duties on the produce carried by Chinese and other trading prahus which pass either in or out of the Qualla. Like all other stations on the coast, the water at Qualla Penyu is brackish and undrinkable. When travelling on the 
coast of Borneo, owing to the flatness of the country many miles inland, it is very difficult to find drinking-water even slightly brackish. At the station I met one of the Sikhs who had been wounded in the Kawang "amok"; he remembered me at once and was very grateful for the attentions I had shown him, insisting on making me the only present in his power-a chicken. I fancy the feeling of gratitude must be strongly inscribed in the mind of the Sikh ; but that feeling, or one akin to it, I have utterly failed to find in the Bornean Malay, who, though a pleasant and observant companion in forest wanderings, is as utteriy devoid of fellow-feeling as the soulless heathen Chinee. Several times I have had to remonstrate with my Kadyan followers for the utter indifference with which they treated each other's misfortunes; as an example I will relate a little episode which occurred on my Palawan expedition, during a lengthened march we made in that island from the sea-coast to a house which a native chief had lent me at the foot of the hills. On completing the journey, I noticed one of the Kadyans was missing, and on inquiring of his companions the reason, they told me that he had fallen down about two miles distant with an attack of fever, and was unable to walk any further, so they left him under a clump of bamboo. When I heard this I ordered two of them to return at once and assist the sick man, which they reluctantly did, with scowling faces and muttered curses at their companion's misfortune. This is only one example of the utter want of feeling natives have for each other ; but when travelling for months at a time with the same companions such episodes are of almost daily occurrence; and as apparently this trait exists in their characters when in their daily intercourse with one another, how can Europeans expect to find the least gratitude from such a phlegmatic race?

At daylight on the 21 st April we left Qualla Penyu for Pulo 'I'ega ( $p u l o=$ island, tega= three) or Three Islands, arriving there soon after mid-day, sailing nearly the whole distance. After landing, the first thing to be done was to search for fresh water; in aul hour or two one of my men discovered a small pool of foul, dirty-coloured water in some rocks, into which was slowly trickling what in the wet season would be a stream; with the assistance of my sponge rammed tightly into a joint of bamboo, we erected a filter, which slightly improved the liquid.

Leaving the men to erect the shelter, I started to explore the forest with which these islands are thickly covered. It was not long before the noise made by some heavy bird rising from the ground attracted my attention as it settled in the lower branches of a tree, when on firing I picked up a splendid specimen of the Nicobar Pigeon, the Burong jinjuni of the natives. 'This Pigeon is, perhaps, the most handsome of all its numerous genus, having the plumage of bright metallic green, which in certain lights shows bronze-red reflections; the neck is ornamented with long hackles of the same colour; the breast is almost black, with green reflections; the tail pure white; and when freshly shot the plumage of the neck, head, and breast is covered with a fine grey powder. This fine species frequents the ground, where it feeds on fallen fruit, is seldom met with, like several other species of its order, except on the small islands off the coasts of the large islands, where no doubt it is less molested by enemies. On being alarmed the Pigeon flies into the lower branches of the trees, where, seated perfectly still, it is protected by the assimilation of its 
colour to the surroundings. Though a heavy bird, this species migrates from island to island in search of food, traversing great distances; its flesh is tough and bitter, and was not relished by my followers, though I had "Burong jinjuni" every day for a week. Besides the Nicobar there is another Pigeon (Carpophaga bicolor) in hundreds on this island; this is perhaps as beautiful in its modest colouring as the other species is in its magniticence, being of a lovely creamy white with black wings and tail. These Pigeons swarmed in the tops of some fruit-bearing trees, where they were continually fighting and driving one another about. It is one of the wonders of Nature how her most conspicuously coloured offspring, when in their natural spheres, escape observation by their very conspicuousness. Thus it will be found on carefully examining the top of a forest tree which you know contains many dozens of these conspicuously coloured Pigeons, that you are unable to see one on looking up from below, unless they betray their whereabouts by action, the glare of the tropical sun, or the colours of the clouds, being all that is necessary to render them invisible. This Pigeon, the "Pergum rawa" of the natives, frequents small islands off the coast of Borneo, and may be met with out at sea during its migrations in search of food. The quantity of Pigeons on small islands is to be accounted for by the absence of monkeys. Another interesting though well-known bird, the Megapode, was also plentiful; but as I was able to study its habits when in Palawan, I will enter into fuller details about it in that part of my work. This island abounds in wild pigs, which have arrived by swimming from the main island, and several were shot by my natives during our stay.

Another beautiful bird is plentiful, Pitta cyanoptera; this species has a yellow breast, bright blue patches on the wings and tail, and a green back. They are here on one of their migratory movements, and when this island was subsequently visited by some collectors this species was absent, its place being taken by another species (P. muelleri), which was not on the island at the time of my visit.

Several times in the forest near the beach I have seen curious little models of houses; in the inside were coconut-shells and little grass trays containing tobacco: these little buildings have been erected by the fishermen, and contained offerings to the hantus, to ensure good luck in the fishing-season. In the Kilias, amongst the mangrove-swamps are many of these hantus' houses ; some have even models of cannons at their doors. My men would not touch anything belonging to them, declaring that the "hantus" would bring about ill-luck if they were to do so. Walking one day to the eastern extremity of the island, I discovered that we were not the only inhabitants of Pulo Tega, a number of natives from the opposite coast having built quite a little village, where they were busily employed salting and drying fish. On a pole was stuck the head of a Hammer-headed Shark. At nights we used to kill numbers of fish with the aid of a torch on the sandy banks; one night one of the men killed a small Saw-fish in this way. Natives are very fond of fishing at night with torches: at Labuan, during a low tide, the shore for miles is a perfect blaze with torches; there, however, a curious crab is the object of capture. After spending a pleasant week on Pulo Tega, we sailed again on the 28th for Qualla Penyu, and after visiting several spots on the banks of the Kilias for collecting, we reached Labuan 
again on the 3rd of May, when I busied myself packing up and drying my collections previous to shipping them home.

On the 26th May, the Resident of Kudat kindly invited me to make a trip to Brunei on board the 'Kimanis' with him; being delighted at the opportunity of visiting this Eastern Venice, I gladly accepted his invitation. Brunei is distant some forty miles from Labuan, and situated in a huge salt-water creek or lagoon, surrounded on all sides by bare hills of slight elevation. The river Limbang now debouches into this creek some distance below the town on the true left bank. The chief export of Brunei is sago-flour, the whole town reeking with the disagreeable sour smell of fermenting sago; the manufacture of this product is carried on by Chinese, who ship their flour to Singapore by the coasting-steamers which occasionally call at this port.

During my residence in Borneo the Court of the Sultan of Brunei was a hotbed of intrigue, owing to the rival interests of the Governments of Sarawak and the British North Borneo Company-the last remnants of the miserable old Sultan's territories being situated between these two States, which were bent on securing as much as possible for themselves; but as the discussion of Bornean politics is not within the sphere of my work, I shall leave them severely alone.

After entering the mouth of the creek it winds about for some distance amongst the hills, until the town of Brunei is visible, built over a large open stretch of water. The houses are of the usual type seen elsewhere on the coast, with attap roofs and walls of "kâjang" or pale yellow mats made from the nipa palm, which are fastened on the frail framework of the house by means of rattans; the houses have a rickety and often tumbledown landing-stage in front of the entrance, which is reached by means of a broad ladder from the canoes. On the landing-stage sprawl the children; and various sarongs, generally of red-coloured material, may be seen drying. The population of Brunei at the present day is about 14,000 , but in days gone by it was reckoned by early travellers to contain some 150,000 people.

The main street of this Eastern Venice is a fine, broad, deep water-way, admitting large steamers right into the centre of the town. This highway is fringed with native houses, which are laid out in a crescent-like form on either side; from the main water-way numerous by-streets lead off, and then any attempt at designing or laying out the town-plan ceases, the houses being built indiscriminately without regard to general effect. A few Chinese brick shops are to be seen on "terra firma"; but trade seems to be departing with the glories of the Sultan's court, and many of the Chinese are giving up business. My friend the Resident took me to see a collection of Brunei jewelry which had been pawned by the Pangerans to a Chinese pawnbroker. The Chinaman led us up a rickety staircase, and in a neglectedlooking room brought out several large boxes of women's gold ornaments, including bracelets, rings, hair-pins, brooches, ear-ornaments, gold-worked sarongs, and many other ornaments. What more evidence than this was necessary to prove the wretched state of the households of the Brunei nobles? they had pawned exerything of value they were possesser of. If the Chinese do quit Brunei it is very certain that they will leave nothing behind them, having already nearly cleared out everything of value. Some of the gold ornaments are very 
tastefully designed by the native goldsmiths; but as their art will soon be without support, it will die with the rest of the town.

We anchored in the main street a short distance above the Sultan's palace. The water-ivays were continually being crossed by canoes of the lowest free-board, in fact their occupants seem to be continually in danger of being swamped. 'The canoes were paddled for the most part by the ugliest of old women, hidden under the largest of hats. 'In Brunei the unattractive women alone have freedom, those that are cursed with good looks being secluded in the harems of the numerous Pangerans, where, should they live to be unattractive to their lords, they will become the slaves of reigning favourites, or, perhaps, paddle a canoe under the shelter of an enormous hat in the water-ways of Brunei. The ladies of title seem, however, to hold a certain position whatever their personal appearance may be, and are to be seen being paddled about seated under a kâjang placed $\boldsymbol{\Lambda}$-shape in the centre of the canoe, to hide them from the vulgar gaze; but one glimpse beneath that "kâjang" will satisfy the stranger, and banish all further curiosity-better, far better, that they should be covered.

The most extraordinary of Brunei fashions are the ear-ornaments worn by the women; they are about the size and shape of a champagne-cork, either of thin sheet gold fitted on a wooden foundation, or of gilt wood, often ornamented at the larger end with garnets and other precious stones; this ornament is inserted into the lobe of the ear, which requires to be slit open to fit these curious plugs. The hats worn by the women are the largest $I$ have ever seen, round, and about three feet in diameter, made from the useful nipa palm; at the market held towards sunset, when crowds of women in their canoes assemble for the purpose of buying and selling fish, the whole river seems as though covered with a moving mass of gigantic mushrooms.

The Chinese shopkeepers have adapted themselves to this life on the water, and display their merchandise in shop-boats, which are large roofed-in wherries open at one side. These boats are anchored in the market-place during the day and at night punted to the depot.

Brunei was known first to the Portuguese in the beginning of the sixteenth century, and was visited by the survivors of the first circumnavigation expedition after their famous leader Magellan's death in the Philippine Islands. In those days Brunei was indeed worthy of the name of the capital of Borneo, the wealth and pomp displayed by the Brunei Court being almost beyond belief to those who have contemplated its present state; but I must refer those who are anxious to learn of the glories of ancient Brunei to Crawford's 'Descriptive Dictionary of the Indian Islands,' where an account will be found, translated from the travels of an enterprising Italian who visited that Court in the year 1521.

We remained at anchor in the High Street of Brunei until the following morning, when we returned to Labuan, after a most enjoyable and interesting trip to the ancient capital of Borneo.

After packing off my collections, it was my intention to spend a few months in the western extremity of Palawan; but the Sulus who inhabit that portion of the island are 
renowned for their lawlessness, and had murdered several Chinese traders and looted their stores. This occurred only a few weeks ago; the year previous they killed an American trader: so the Governor of Labuan strongly advised me to defer my visit until things were a little more settled; therefore I decided to make a trip to the eastern highlands of Java, which would be an interesting as well as a beneficial change after the wretched experience of Bornean camp-life.

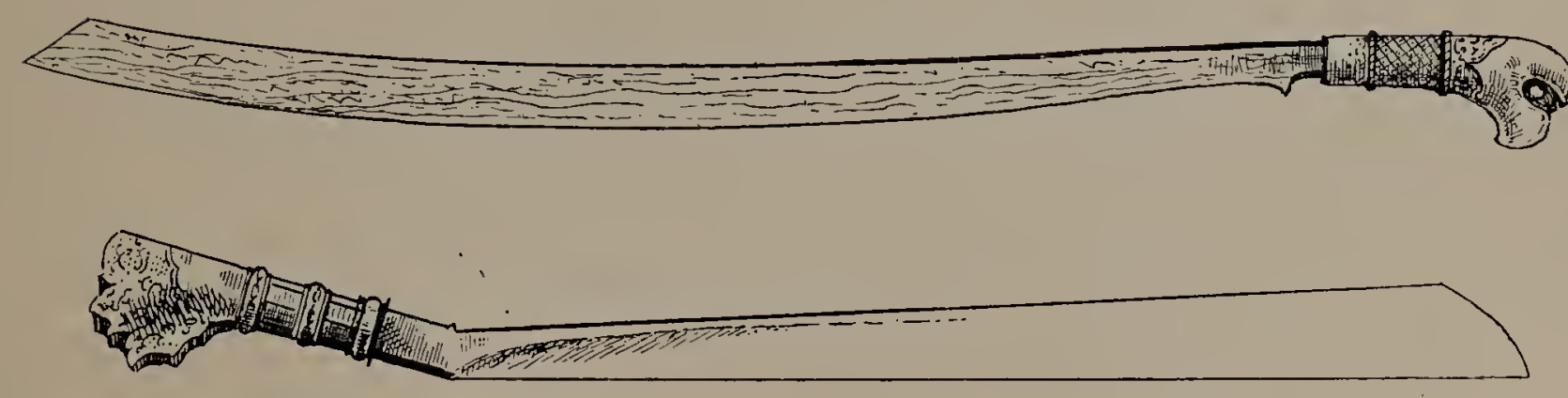

BRUNEI PARANG AND LATOK. 


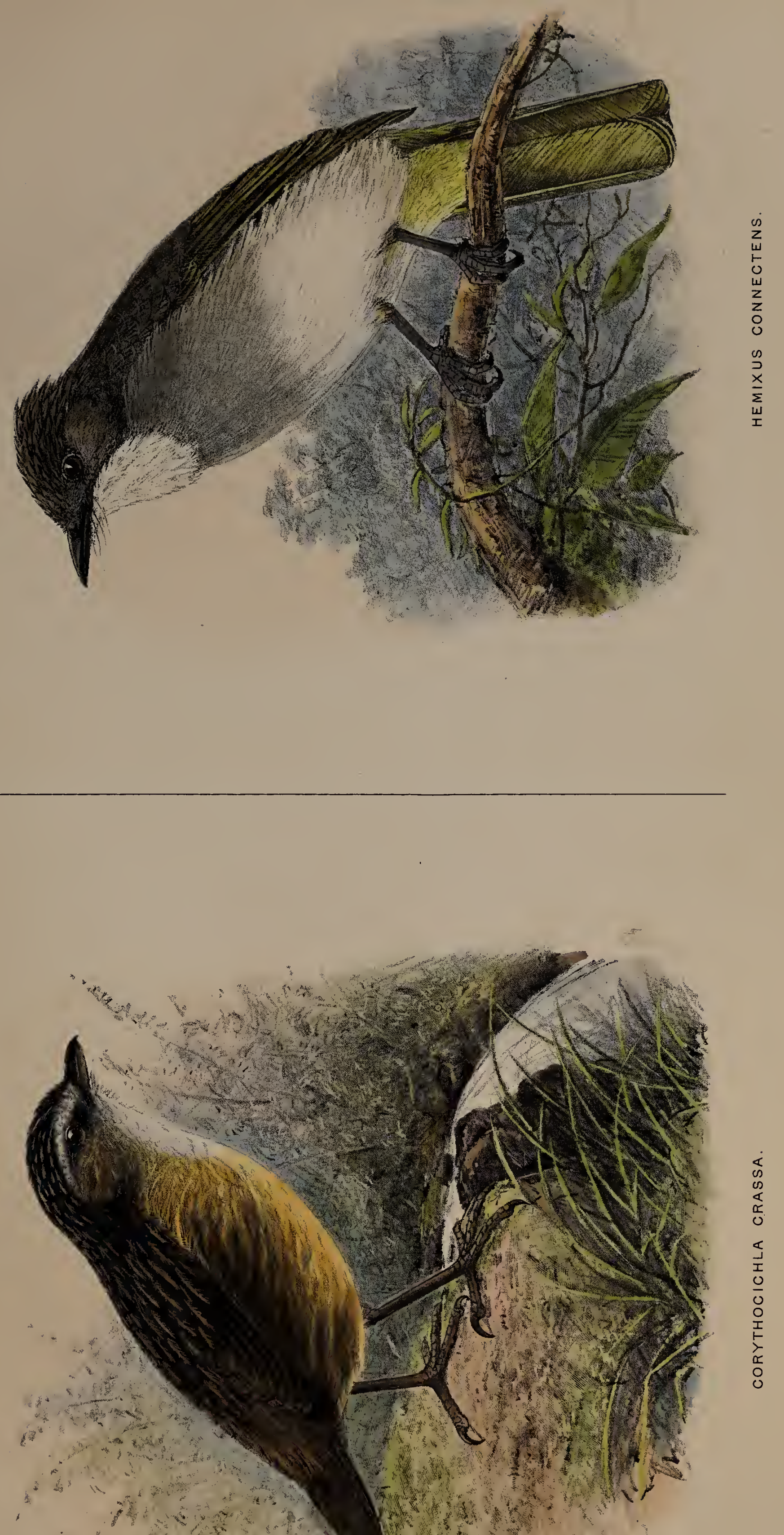



\section{CHAPIER V.}

VOYAGE TO JAVA.-BATAVIA.-CHINESE IN JAVA.-DUTCH CUSTOMS.-SOURABAYA.-PERMIT TO RESIDE IN JAVA.-JAVAN HIGHLANDS.-TOSARI.-EUROPEAN RESEMBLANCE.-CABBAGE-GARDENS. —THE BROMO VOLCANO.-BIRDS.-VISIT TO THE CRATER OF THE BROMO.-LEAVE FOR LAWANG. —PITTA CYANURA.-SINGOSARI.-THE TEMPLE OF BOROBUDDAH.-SEMARANG.—RETURN TO LABLAN.

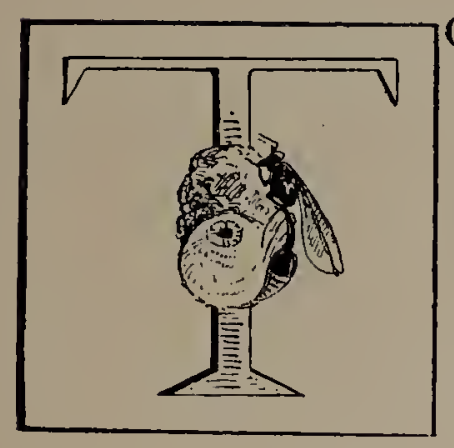

OWARDS the middle of July I arrived in Singapore, where I remained until the end of the month, embarking on the 1st August in the steam-ship 'Bantam,' a large Dutch mail-steamer, for Batavia. After passing amongst the numerous small islands which are clustered about at the extremity of the Malay Peninsula, we steamed along the low-lying swampy coast of Sumatra, where the country is so flat that the mangrove-swamps form the horizon. We passed close to the small island of Banka; the straits which take their name from that island are very shallow, and are apparently gradually silting up with mud. On the night of the 4th we anchored in Batavia harbour, but too late to land.

An account of all the wonders of Java would fill a large volume in itself; but as my stay in the island extended only over a few months, I shall be able to give only a brief sketch of those portions of Java actually visited by me.

For importance Java ranks first amongst the Dutch colonies. The island is opened up from end to end with railways, intersected by most perfectly kept roads, covered with plantations - chiefly coffee and sugar-and is as easy to travel over as any part of Europe. Very comfortable hotels are to be found in all the small towns, where the food is excellent and the charges moderate.

After landing, our baggage was examined at the custom-house. A railway connects the port with the town of Batavia, and traverses for some distance a low swampy country, which the Dutch have done well to avoid when choosing the site for their capital. At the railway-station a small light pony cart is hired, in which the traveller drives a distance of some miles to one of the numerous hotels, which are fine and comfortable buildings. The town of Batavia is well built, the principal buildings being of stone; then there are many of stuccoed brick, and in the native quarter houses of interlaced bamboo. The streets are clean and the principal thoroughfares laid with tramways, so but for the population one might be in any of the cities of Southern Europe. One peculiarity of the 
Dutch I noticed was the love of large costly mirrors, splendid marble floors, and baths: nearly every hotel contained several of these costly mirrors in every room.

Batavia, until the recent growth and competition of Singapore, was the chief trading centre of Eastern commerce; but now, owing to the more advantageous position of the latter place and also greatly to the lethargy of the Dutch themselves, it has lost most of its prosperity, and as a trading centre is second to its sister city Sourabaya, situated at the eastern extremity of the island.

I remained in Batavia four days, and visited, amongst other places, the Museum, where a most interesting collection of ethnological objects collected from the various islands belonging to the Dutch may be seen. It also contains a large collection of relics of the ancient Hindu régime, consisting of silver and gold ornaments, idols, weapons, and hundreds of curious monoliths from the ruins of the numerous temples which are scattered throughout the island.

The natives of this part of Java are known as Soendanese; they are a bright, cheery, willing race, dressed in Malay fashion, in neat bright-coloured cotton clothes.

All the hotel servants are Javanese, and are no longer known as "boys" but as "Spadah," which is probably a corruption of the Malay words Si-apa ada, i.e. "Who there ?" The calls for Spadah are frequent in all Javanese hotels, the luxurious Europeans requiring a great deal of waiting on. The Javanese "Spadah" is, when good, a decided improvement on the Chinese "boy," who in Dutch colonies is not allowed by law to compete in the native labour-market. So in Java we find the Chinaman in a very different position to that which he holds in our colonies. In Batavia he even departs from his conservative ideas of dress, and may be seen wearing European clothes, and is decidedly more courteous in his manner; so evidently John Chinaman knows that the Dutch do not consider his presence necessary to the welfare of their colonies. This is as it should be, Java having a large surplus population of its own, which the Government protect finm being swamped by hordes of Chinese, who by their superior cunning would gradually oust all native labour from a market which is its birthright. It is also better for the country that its wealth should circulate amongst its natural population and not be decamped with by the more knowing Celestial. A few laws against using Old England as the "dumping-ground" for the scum of European populations would be attended with equally gond results, and aid greatly the struggling poverty-stricken masses of the lower class.

The system of forced labour which is carried on in the Dutch colonies is not so objectionable as it may at first seem to our ideas of freedom. The large Government coffee-plantations are worked by this method, the villagers living in the neighbourhood of these plantations having to devote so many days per annum to keeping them up, for which they receive a small wage and a bonus on the crop. The roads in country districts are worked on the same principle, and are certainly as beneficial to the Javanese as to their masters. While in Tosari I was somewhat amused by the "Controlleur" of the district ordering the Tosari villagers to pull down numbers of their houses and build them further apart; the work of demolition and reconstruction continued for several weeks, the Government labour-days being engaged for this purpose. The reason of this edict was the frequent village fires; bit as there never had been a conflagration in Tosari, I should have thought it better to 
wait until after such an event before replanning the village. I am sure no one who has visited Java can doubt the sincere desire of the Dutch Government to benefit the native population under its rule, which of course at the same time must benefit those who govern by bringing about peace and prosperity. If any other proof were wanting, the naturai increase of the native population would be sufficient; but above all, I think, the rulers deserve all honour for the protection they afford to native labour.

The Dutch colonists have some curious customs which are, on the whole, more suited to the climate than to the neatness of their personal appearance. In the early mornings the gentlemen wander about their houses and occasionally in the public roads in their pyjama costume, which consists of a loose white linen jacket and a pair of most gaudily coloured and extravagantly patterned loose linen trousers; a pair of bath-slippers complete the costume. In this attire they remain until after the morning bath, when they dress for breakfast: the pyjama costume is donned again after the mid-day meal, when a siesta lasts until four o'clock; then tea is indulged in, after which another bath is taken before dressing for the six o'clock dinner. In the evenings short walks or drives are apparently the only outdoor recreation indulged in, the Dutch, unlike the English, never exerting themselves with violent exercise in this hot climate; consequently they become stout, but, after a long sojourn in the tropics, probably return to the Fatherland in a much better state of health than Englishmen, who often expose themselves too much during the heat of the day. The early morning attire of the Dutch ladies consists of a white frilled loose jacket, a bright-coloured sarong, white stockings, and a pair of high-heeled shoes, their hair hanging loosely down the back. In this costume the morning housework is done, and it is again donned for the afternoon siesta. After 8 P.M. it is once more dress as you please; and I must say this free-and-easy style is very suitable to the hot climate.

On the 10th I embarked for Sourabaya. The steamer was no longer a mail-steamer,
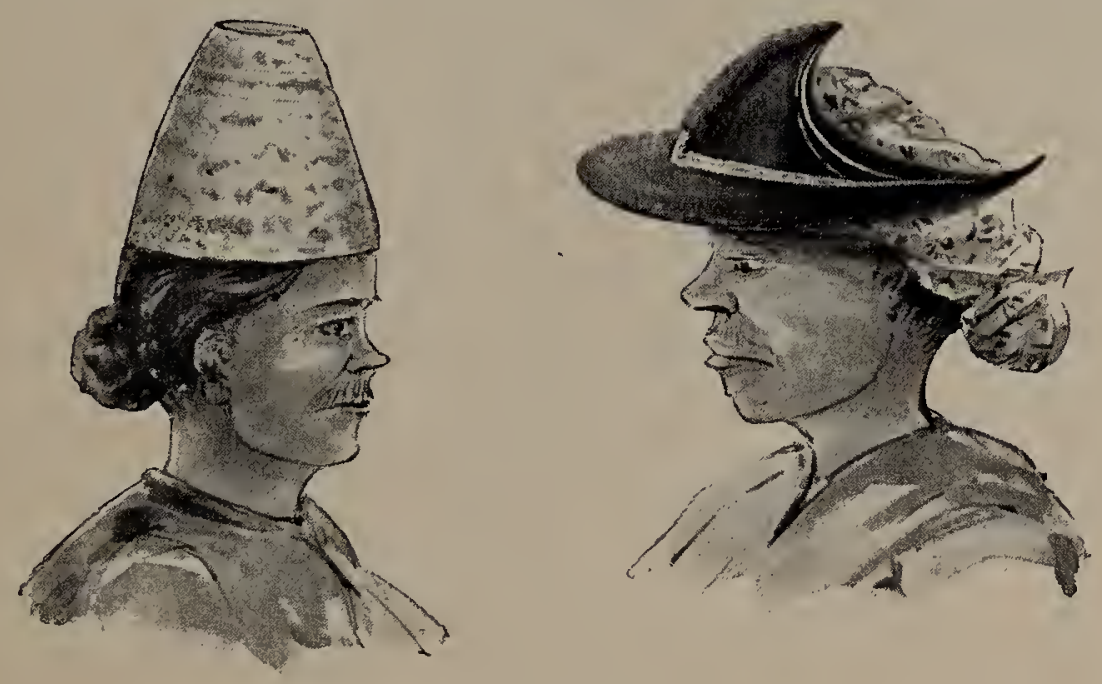

JAVANESE II.ITS.

but one of the large coasting-steamers which ply between the Dutch possessions in the Archipelago. These steamers, considering the exorbitant fares charged, are dirty and uncomfortable, their cabins scarcely habitable, and must be considered somewhat behind 
the day when compared to the state of civilization in Java. After steaming for four days along a most picturesque coast, calling at several of the principal ports, we anchored on the 14th in the perfect harbour of Sourabaya.

Sourabaya is similar to Batavia, but the native population no longer dress in the bright-coloured prints of the Soendanese, but wear indigo-blue dyed garments, which detracts from the liveliness of the scene. 'These people are known as Madurese, and come from the island of Madura, which is only a few miles distant, and forms one of the shelters to the harbour.

On landing, having a gun in my possession, I was forced to leave it at the customhouse, and drove about three miles to the hotel. After several expeditions to the Dutch Government offices, I obtained permission to land my weapon, and another drive to the custom-house was necessary to obtain it. Why the permit cannot be obtained on the spot, and thus save several journeys, I am unable to understand. But in some parts of Europe a gun licence takes one afternoon of hard work to obtain. In Corsica I had to go to some five bureaus situated in various parts of Ajaccio, paying small sums at each for stamps, forms, permits to obtain stamps and forms, and permits to obtain permit-forms, \&c., \&c.; in three days' time I received a placard giving a full description of myself and a copy of the game-laws.

On one of these expeditions to obtain permission to land my gun, my guide-one of the hotel Spadahs-led me to the wrong bureau, where I was ushered into the presence of Official Holland; there with due reverence I asked for the necessary permit, when the official replied that I had come to the wrong office, and asked in return if $I$ had permission to travel in Java. As this was the first time I had heard of any such permission being necessary, I replied I had not. "Then you will have to remain in Sourabaya until you have," was the answer. This was more than I bargained for. In the end the official telegraphed to Batavia. His telegram was made out regardless of expense-an emblem of verbosity; but I suppose I was the more struck with this fact, as the guilders to pay for it were to come out of my pocket. After a few days an answer was received from Batavia that "The Governor-General gives his permission for Mr. John Whitehead to travel in Java." The words "permit granted" would have cost me less.

The necessary document, I was informed, would be forwarded to Tosari in a ferv days, but, as a matter of fact, I did not receive it until two months later. When I asked the representative of the Government what was the use of this permission, "Oh! none," was his answer; "but it is the law, and you see we do not charge anything for doing all this work." My thoughts wandered to those telegrams and the little stamps at the corners of the various documents. In all it cost me twenty guilders and wasted four days of my time in Sourabaya. So if future travellers propose to visit Java they had better get their permits at once, or carefully avoid all Government bureaus. This permit lasts for a period of six months, and without it you are liable to a fine assessed at so much per diem during the time you neglect to obtain it.

It seemed to me a somewhat foolish and unnecessary system for the annoyance of travellers; but if the Dutch do not object to this custom, it is not for foreigners to complain. 
All European residents in Java, to whatever nationality they belong, have to join an armed force, with regular drills and parades; this force is for the suppression of any native rising should the troops be elsewhere employed.

After the receipt of the telegram from the Government at Batavia I was able, with the permission of the Sourabaya officials, to start for 'Tosari, the first stage of that journey being by train to Pasoeroean.

The following morning I left at 5 A.x. in a light pony-cart for Paserpan. The country through which we drove was flat and monotonous, being either under sugar or rice cultivation, with occasional clumps of trees and bamboos; here and there the everlasting green was broken by the white buildings and tall chimneys of the sugar-mills. The road was bordered on both sides with tall bamboos and tamarind-trees, which at this early hour were partly hidden in the morning mists ; before we reached the foot of the mountain on which 'Tosari is situated the population were astir, and I noticed all were dressed in indigo-blue dyed garments. As soon as the country became too hilly-that is, on our arrival at Paserpan - the cart was changed for two saddle-ponies, one for myself and the other for my baggage.

The mountain-road was wonderfully good; when the incline became too steep, this difficulty was overcome by making steps which were planked up, and these steps were easily negotiated by the plucky little ponies. After five hours' steady up-hill work, we reached the Tosari hotel, about 5600 feet above the sea. On the journey up we met numbers of natives with one or two ponies each, laden with maize-pods and cabbages, which they were taking to the towns on the plain.

The ride was most delightful: most of the route lay through coffee-plantations, until an altitude of 4000 feet was reached; then the country gradually transformed itself as it were into the highlands of Europe. The plants, birds, and butterflies were mostly of familiar European genera, a great number of common European weeds which grew on the roadside I believe are not indigenous, but have been either purposely or accidentally introduced. It is a curious sight to see homely cabbages growing amongst magnificent tree-ferns; and over this familiar European vegetation flitted butterflies closely resembling our European species, Painted-ladies (Vanessa cardui) and Fritillaries (Argynnis niphe), while the presence of Larks, Blackbirds, Titmice, and Chats were quite sufficient to complete this illusory transformation. The villages of the mountaineers so closely resembled those of the Swiss, when seen from a distance, that it was very difficult to believe one was still in the tropics. This strong resemblance to things European was not at all striking to me on the higher elevations of Kina Balu; there everything was still unmistak. ably tropical.

The hotel was comfortable, but unfortunately had been built in the style of those of the plains, as stone floors and airy passages are not at all times agreeable to travellers after a long sojourn in the hot plains.

In Tosari I remained more than two months, and made a small but interesting collection of birds and butterflies. The small village of Tosari is, like all other Javanese villages, built on the ground, the raised dwellings of the Malays not being adopted in this island. 'The houses are built entirely of wood, the walls being either made of roughly planed planks 
or of interlaced bamboo, and are close together, not scattered like those of the Malays. 'Iosari and several other villages are situated on the spurs of the Bromo, an active volcano, to view the crater of which is a most interesting and easy excursion from the hotel, and it is annually visited by numbers of tourists. The chief industry of the Tosari villagers is vegetable growing: the spurs of the Bromo, mounting up to 7000 feet, are cleared and planted to the top with cabbage-gardens, these vegetables finding a ready market in the coast towns, and even being exported to Singapore. The mountaineers are fair-skinned, and some have quite rosy complexions; they are a strong and active race; some I noticed had slightly developed goitre: their religion and ceremonies are Hindu.

The soil is a very loose, sandy, volcanic ash, and is most disagreeable and tiring to wander over, if once the excellently kept bridle-paths are quitted: at times, when toiling up the slopes of this mountain, one sinks in over the ankles in this loose ash, but it has the great advantage of becoming dry at once after the heaviest rains. The foliage of the trees and shrubs is covered with a fine coating of volcanic dust, which is apparently continually falling. The Smeroe, a magnificent and ever active volcano, is continually shooting up clouds of steam and dust, which mount high in the heavens and are blown in all directions by the wind, the minute sandy ash falling in fine powder over the country for many miles round. The Bromo is a mountain covered to a depth of several feet with fine dust, and after a ramble in search of birds one's body and clothes become thickly covered with a fine black powder. The hills in places are very steep, owing to the water-courses which, during the heavy rains, have cut deep ravines through the soft soil ; in such places-which are too steep for cultivation-the mountain is clothed with most luxuriant clumps of tree-ferns, which must be seen to be appreciated. On the tops of the spurs and other uncultivated places a species of mountain pine or Casuarina forms small forests, which, as usual, are covered with dust.

Every day, when possible, I used to wander up the steep dust-covered mountain-slopes in search of birds or butterflies; the latter were very scarce, with the exception of three or four species, the only species of importance being the fine green-spangled Papilio paris, nearly allied to $P$. brama, which I have already described from the Benkoka. This fine insect frequented an extremely rocky stream, which formed deep cañons and waterfalls in its passage down the mountain.

My bird collection was, however, of great interest to me, and consisted of many interesting European genera, such as a (new) Blackbird (Merulc whiteheadi), Horsfield's Thrush (Geocichla horsfieldi), a Chat (Pratincola caprata), a Lark (Mirafra javanica), and a Titmouse (Parus cinereus). 'The Blackbirds I frequently flushed in the cabbage-fields, and in note and manner of flight they might have been mistaken for our old familiar garden friend. Horsfield's Thrush is a very rare species in collections, and is somewhat like our Missel-Thrush. The Titmouse mentioned seems common throughout Java, and I afterwards met with it in the lowlands; in the distribution of its coloration it is similar to the common British Ox-eye Tit, but is without any yellow in the plumage, the breast being nearly white and the rest of the plumage pale blue-grey.

The handsomest tropical species I obtained here was a beautiful Sun-bird (Ethopyga eximia); this species was occasionally met with amongst the fuchsias in the hotel garden. 
The male is green on the breast and back, the tail and head metallic green, while the throat is deep claret with a necklace of metallic purple, but its most beautiful ornaments are the tufts of fluffy white feathers on the flanks. A splendid Golden Oriole (Oriolus maculatus) was fairly common; and another interesting species was a long-tailed Shrike (Lanius bentet) which has the peculiar habit of skimming through the air for long distances down the mountain sides with motionless wings, steering itself by its long tail. One of the commoner birds was a new species of Zosterops, which has been described by Mr. Seebohm under the name of $Z$. neglecta. Two pretty Flycatchers, which I afterwards met with for the first time on Kina Balu, and which are well-known Himalayan species, were also common (Muscicapula maculata and M. hyperythra). Another species of tropical Flycatcher, a bright rosy Minivet (Pericrocotus miniatus), was occasionally met with in small flocks; this species frequented the maize-plantations, in which there were numbers of trees in blossom during this month, their flowers being bright red like the Minivets, and amongst these flowers they invariably settled when disturbed. Sometimes in the cabbage-fields a small covey of wild fowls (Gallus varius) would be met with, but those I shot were unfortunately immature.

Thus in the distant highlands of Java we find the botanical and zoological inhabitants in many cases only slightly different from our old familiar European species. This to the inquiring mind unfolds the marvellous history of the past, showing us how these distant mountain tops have in remote ages probably been directly connected with, or at any rate received their living organisms from, the great Asiatic continent, which the long isolation together with climatic and other influences have now rendered specifically distinct from their ancestral types. When the highlands of the Malay Archipelago are explored, those countries which contain mountains of any altitude over 7000 feet, unless of comparatively modern volcanic origin, will in all probability contain old Asiatic continental species.

The weather for the most part of my visit was perfect; towards mid-day mists would often envelop the mountain, ending in a slight shower, which left the atmosphere clear again before sunset. The coldest night registered in August was $50^{\circ}$ Fahr., the warmest $54^{\circ}$; this temperature is, however, really very cold after the heat of the lowlands. The day temperature ranged between $66^{\circ}$ and $75^{\circ}$, a most pleasant and invigorating atmosphere to live in.

Early in September I made an excursion, accompanied by a young Dutchman, to the crater of the Bromo. After reaching the top of the spur on which Tosari is situated, the bridle-path runs for some distance along the ridge, then gradually slopes into a valley covered with a forest of Casuarina pines, rising again until the rim of the crater is reached, when by a steep zigzag path the sandy desert is gained. We started from the hotel at 5.30 A.M., mounted on ponies, and slowly ascended the Tosari spur; when the top of this is reached a wonderful panorama of distant hills and valleys unfolds itself to the view, but towering above all is one of the finest sights in Java, the cone of the Smeroe, an active volcano of 12,000 feet, which in the clear morning air looks but a short distance off.

The summit of this volcano is bare some distance down, before the forest belt begins, forming a black ring round the pinkish-coloured conical top. After standing expectant some time-waiting for the next eruption-slowly a small ball issues from the point of the 
cone, which gradually becomes a rolling pillar of pinkish smoke; the pillar slowly rises and unrolls itself, gradually growing, and wonderfully spreads itself out until clear of the craterrising and still spreading until it has become a simple cloud, to be dispersed by the winds in the higher air, and to fall in fine powder over the surrounding country; but slowly as this little pillar seems to ascend in the distance, it is leaving the brink of that mighty crater with a velocity and roar greater than mere words can express, accompanied by huge masses of rock and ash, which fall again into the crater's mouth, securely blocking it up, to be blown skywards again when sufficient steam-power has been accumulated. This explosion takes place at intervals of a quarter of an hour. After standing for some while struck with the beauty of this scene, we rode on towards the crater of the Bromo, which lay to our left. On the path were tracks of Peafowl, one of which we flushed, but it disappeared too quickly for me to obtain a shot. After a few miles we arrived at the edge of the ancient crater of the Bromo, and from this point of vantage one of the most wonderful sights in the world may be contemplated. A thousand feet below you is a great level sandy desert, surrounded on all sides by barren mountains of volcanic ash, scarred and deeply furrowed in all directions; here and there numerous small craters have burst up, piling up huge fantastically formed mounds of ash: one of these mounds, several hundred feet high, resembles a gigantic cooking-mould, fluted all round with deep gullies equidistant from each other; this crater is called the Batok. The curious colouring of the landscape adds much to the wonder of the scene, the walls of the crater being of various shades of grey, the numberless deep scars on its surface casting shadows from blue to deep purple in the early morning sunlight, the atmosphere being so wonderfully clear at this time that the smallest irregularities of outline are distinctly visible. After descending the steep side of the crater we traversed the sandy desert, covered sparsely with patches of rank grass, the only animal life I noticed being a Pipit (Anthus rufulus). After a ride of some considerable distance across the desert, the base of a long hill composed entirely of soft ash is reached; this desert was at one time the active crater of the Bromo, but is now as it were roofed over by an even plain of lava, which is hollow beneath, the ground echoing with every footfall. At the base of the hill mentioned the ponies were left; the ascent of this hill is greatly facilitated by steps and hand-rails. On the way up steaming fissures in which sulphur has bubbled out may be noticed. This low hill of ash is now the only active crater of the Bromo, which in remote ages must have had an active crater of perliaps some twenty or twenty-five miles in circumference.

On reaching the rim of the crater, a narrow path leads almost round it, from which you can look down into the depths of a pit, the bottom of which is obscured by the everrising steam, which rolls over and over, seldom rising to the summit of the crater, accompanied by a dull roar like the boiling of a huge caldron; but to-day is a quiet day with the Bromo, for goodly-sized blocks of larva, strewed for hundreds of yards around on the sandy plain, testify to the fearful force at times exerted by this apparently harmless giant. It is only by seeing such sights that one is able to form an idea of the wonders of volcanic force, which at times have altered this world's surface over areas many miles in extent. A few months before I visited Tosari, the landlady of the hotel lost one of her sons, who was 


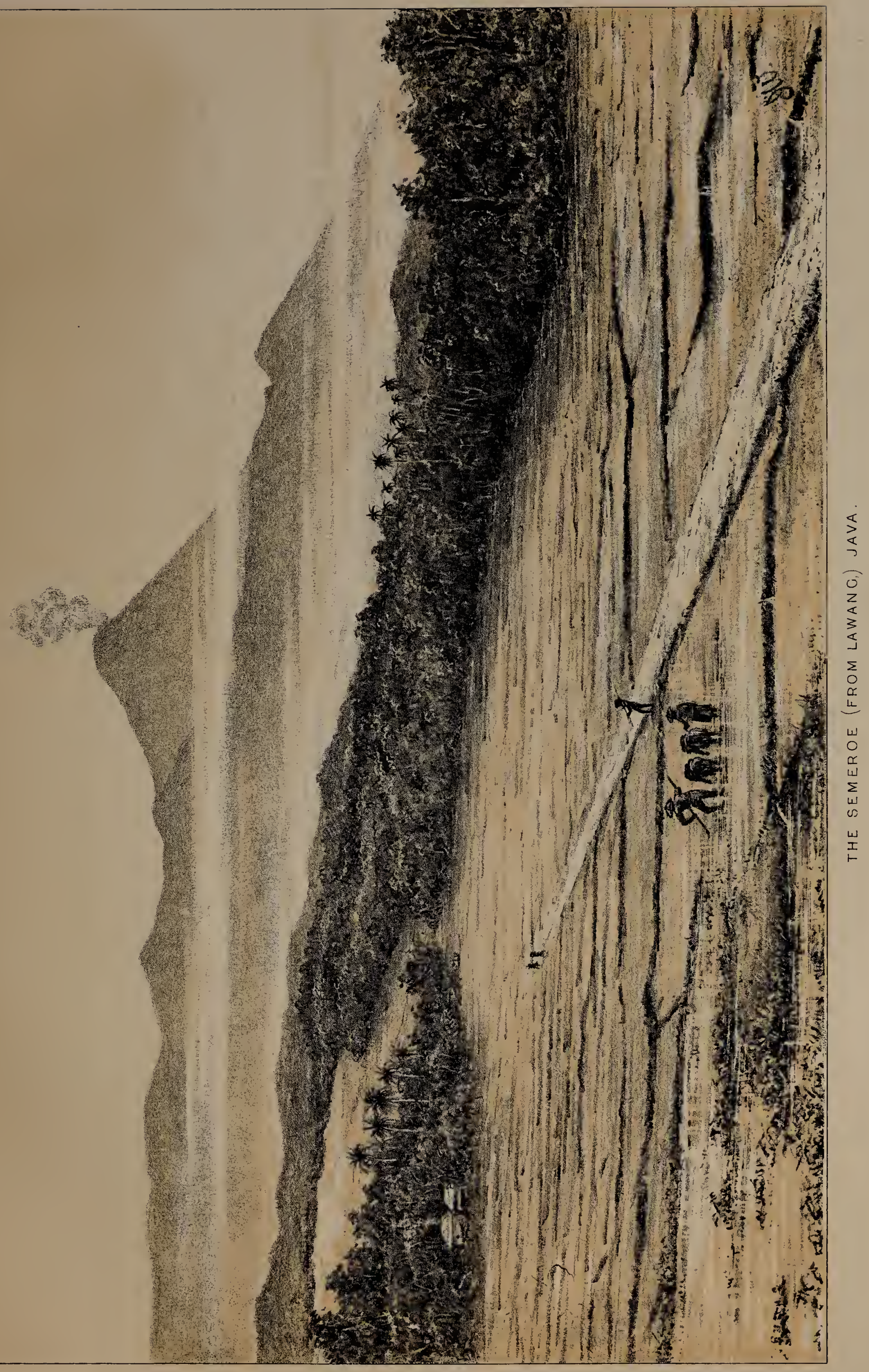



buried, together with an entire coffee-plantation, houses, occupants, and all, by a copious fall of boiling mud, which had been shot out of the Smeroe from a distance of several miles. This plantation was not situated on the slopes of the volcano, the coffee-estates on the Smeroe itself escaping all injury. On our return journey, just before ascending the steep path of the ancient crater-wall, my friend somehow parted company with his pony, so being totally unable to walk the distance back to the hotel, he sat down and resolved to wait until we should reach Tosari and send another pony for him; so I rode on and left him, but repenting I sent the guide back with my pony and walked the rest of the way home. During my walk I found the nest of the Chat (Pratincola caprata), which was in the side of a steep bank, a site often chosen by the Whinchat in this country. Thus ended an expedition to one of the most magnificent sights I have ever beheld-the early hours of the morning giving an effect to the panorama seen from the top of the Bromo's old crater-wall which it would be impossible to portray.

On the 4th October Wagtails (Motacilla flava) began to arrive from the northern regions in large flocks, and with them the first signs of the coming wet season.

During my stay in Tosari, I witnessed two native (Hindu) processions. The central figures in these ceremonies were two youths who had attained the age when the rite of circumcision is performed. The lads were stripped to the waist and powdered all over with yellow dust, bedecked with white flowers and brass ornaments; they were mounted on ambling ponies (which are the pride of the Javanese) and over them were held large coloured umbrellas. The procession was headed by musicians and priests playing horns, gongs, and drums, and marched for some considerable distance round the villages.

On the morning of 25th October I bid adieu to Tosari; there I had spent many happy days roaming about on the mountains, and in the good company of several Dutch gentlemen who were visiting this health-resort; but all good times will come to an end, so on that morning I rode over the Tosari spur to Lawang, accompanied for some distance by my Dutch friends.

The bridle-path gradually descends through most lovely scenery, until the plains are

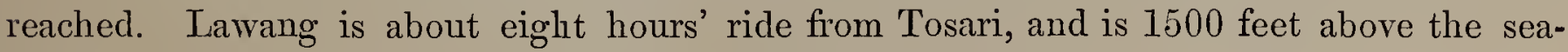
level; the town has quite a suburban appearance, and, being connected by rail with Sourabaya, is a Saturday to Monday resort of the Dutch; the hotel is most comfortable and the food excellent. The country round about is undulating and mostly under rice-cultivation, carried on by terrace-irrigation, but coffee is also extensively grown in this district. The great volcano of the Smeroe is distinctly visible from Lawang, but the sharpness of its outline is now softened in the hazy atmosphere; the rolling pillar of smolse can be clearly seen as it slowly rises to the skies (see illustration, facing p. 92).

In Lawang I engaged a Javanese hunter to guide me to the best localities for birdcollecting. The coffee-plantations formed my best liunting-grounds, and there I collected numbers of a beautiful Pitta (Eucichla cyanura), the breast of this species being golden yellow, finely banded with blue stripes; of other gaudily-coloured Javanese birds, I will merely mention Bee-eaters, Barbets, and Kingfishers, of which I collected several varieties of each, all birds of most brilliant plumage. 
I made a short journey by train to Singosari, at which place there are some ruined Buddhist temples. The temples for the most part have been thrown down by earthquakes, only one being left standing, which owes its stability to the beautiful squaring and fitting of the hard volcanic rock (trachyte) of which it is built; although this temple is split in all directions, it is still very stable, the inside chamber, containing a curious stone font, being still almost perfect. The images have been taken from their niches or fallen down, and are placed in a row on the grass opposite. In the "temple" districts of Java, Buddhist images are to be met with everywhere, in private gardens, hotels, \&c., and might be had for the asking; this, perhaps, is a pity, but the value of such things has deteriorated to $\mathrm{nil}$ on account of their very abundance. A few yards from this temple are two gigantic stone figures, one of which has sunk into the ground up to the knees. I made a sketch of the other, showing its relative size when compared with a man (see illustration, facing p. 62). These temples and all graveyards in Java and throughout the Malay East are surrounded by plantations of Frangipani trees.

In all Javanese towns of importance there is a system of night-watchmen, which is formed of natives, who have to perform this service by turns; they each carry a lantern, and are armed with pronged sticks often covered with spikes, or "thief-catchers." In all the numerous watch-houses in Java, numbers of "thief-catchers" may be noticed, useful weapons in case of an "amok." After dark all pedestrians have to carry lanterns, to prove they have no evil intentions.

On the 19th I left Sourabaya for Djokjakarta, viâ Madioen and Solo. A long drive from Djokjakarta is the famous temple of Boeroboedoer or Borobuddha, a description of which I copy from 'Chambers's Encyclopredia,' which will be better than the scanty notes I was able to take down. This temple is not far from Magelang, and would be easiest visited from that town.

This temple "is a pyramid of a square form, each side at the base measuring 600 feet, and consists of seven walls, which are built like the steps of a stair up a hill. Between the walls are narrow terraces running round the building. The walls are richly ornamented with statuary. Outside are niches, each of which is occupied by a statue of Buddha, larger than life, seated in the usual attitude, with his legs crossed under the body. The number of these figures is about 400 . Between each of these are bas-reliefs, representing the god in the same attitude, besides architectural ornaments and carvings of all sorts. Below the niches, on the lower story, is an immense bas-relief running round the whole building, representing scenes from the life of Buddha and religious subjects. The inner faces of the building are also profusely ornamented with bas-reliefs, seated figures, and architectural ornaments, carved to an extent unrivalled by any other building in the world. Above and within the upper square terrace are three circular ones, the outer ornamented with 32 , the next with 24, and the upper with 16 small domes, each containing a seated statue of Buddha, which can be seen through the open work of their roofs. The whole is surmounted by what must be considered as the Pagoda $(q . v$.) itself, which is now empty, its centre being occupied only by a sunken chamber, 10 feet deep, meant originally, no doubt, to contain the relic for which this splendid temple was erected." 
The general colouring of the whole structure is dark grey, which in the distance looks black.

Judging from the general form of perfect Buddhist temples in British India, one would be much inclined to regard the Borobuddha as the upper part of a temple buried by the hill; this I am much inclined to think is correct, for at the time of my visit slight excavations had revealed another, or part of another, terrace as beautifully sculptured as the upper ones, and in all probability others will be discovered deeper still. In a country like Java, subject to great showers of mud and ashes thrown up by volcanoes, numbers of such temples must have been thrown down and buried from time to time. Many interesting Hindu relics are occasionally dug up in the fields round about this temple, and a thorough search would in all probability reveal much of interest. Before I started for Magelang it began to rain and continued to do so for the rest of the drive; near the Borobuddha there is a small square temple like those of Singosari, in which a great tree has grown up and divided the walls. The Gurong Merapi, an active volcano, is in sight the whole of the drive, and jets of steam may be seen issuing from near the summit. It takes six hours from Djokjakarta to the temple, and two hours from there to Magelang. I remained in Magelang a few days, during which time it was very wet; from there I drove to Salatiga, and thence to the port of Semarang. Semarang is an important business centre, and an extensive and wellbuilt town. On the 16th December, I left in one of the coasting-steamers, by name the 'Maha Vajirunhis'; not being able to afford the first-class fare, I travelled second, and even then the fare was most exorbitant. From Semarang to Singapore it takes four full days' steaming; the first-class fare is $£ 157 s .6 d$., the second $£ 713 s .9 d$. The first-class accommodation is, I believe, good ; the second is only fit for pigs. 'The second-class cabin, of course, one did not expect to find even habitable, nor was it. Our meals were served in a filthy shed: the table-cloth might have been clean once; bread is not provided, and when I asked for some I was told that the captain did not provide any such luxuries in the second class. The captain of this ship was too important a personage to be even decently civil to second-class passengers; but before I left I had an encounter with him which lowered his colours a bit. The smell of the bedding in the cabin being too rotten to be supportable in so confined a space, I had it taken on deck at nights. One night it began to pour in torrents, and I took refuge under the lee of the captain's cabin; he seeing the mattress in the wet came out like a mad bull and began to storm. This was the last straw, so I opened on him and gave him in carefully selected language my idea of his ship, and the fraud it was to pretend to have second-class accommodation. The captains of these ships find the passengers in food, receiving so much per head from their employers, so consequently they take care that you do not over-eat yourself. As I have before stated, I consider the Dutch coasting-steamers are a disgrace to these beautiful colonies, and think that a fair tariff should be forced on them by the Government.

After waiting a few days in Singapore, I sailed for Labuan, arriving there on the 10th January, 1887, after one of the roughest passages I have ever experienced. 
<smiles>CC=C=C(C)C</smiles> 


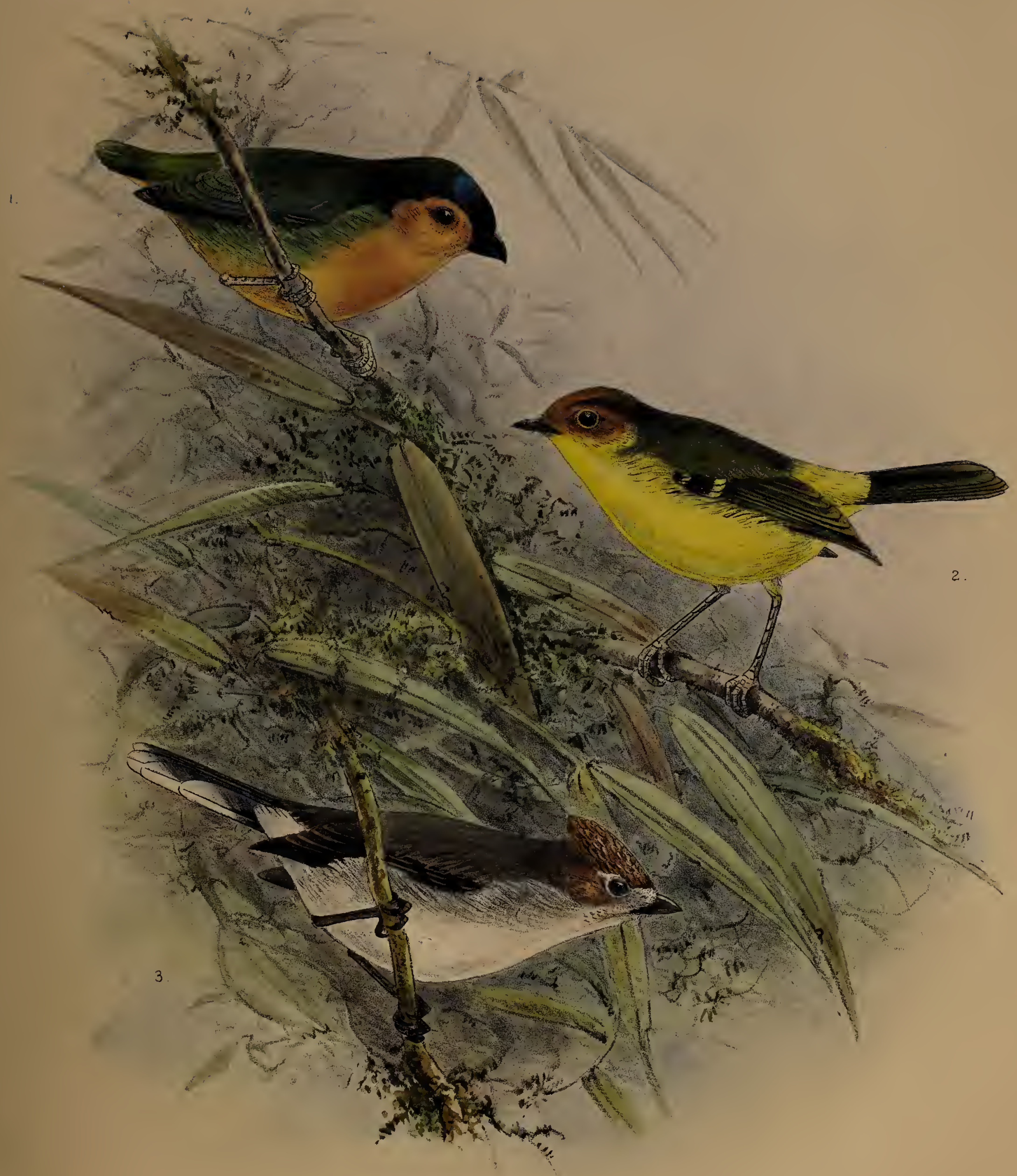

1. CHLORURA BORNEENSIS. O

2. CRYPTOLOPHA XANTHOPYGIA. 3. STAPIHDIA EVERETTI. 



\section{CHAP'TER VI.}

MY THIRD START FOR KINA BALU.-DATU TUMANGGONG AGAIN ASSISTS TO THE TAMPASSUK ONLY. —SULTAN PAITAILAN.—OUR INTERPRETER.-GHINAMBCR.-DUSUNS.-FORDING THE RIVER.BUFFALOES BECOME USELESS.-ANOTHER SULTAN.-SINOROB.-MELANGKAP.-MOUNTAINOUS SURROUNDINGS.-DUSUN HONES.—CUSTOMS.-COSTUME.-CROPS. - MARKETS.—TRAPS.—HOUSEHOLD UTENSILS.--MUSICAL INSTRUMENTS.-WEAPONS.-HOSPITALITY.-HEALTH.-RELIGION.IIEAD-HUNTING.-MARRIAGE.-BURIAL.—DOMESTIC ANIMALS.-LAND.-PAYING PORTERS.-THE SULTAN GUIDES US TO KINA BALU(?).-OUR CAMP.-RAMBLES ON THE MOUNTAIN.—BIRDS.BUTTERFLIES. - FROG-HUNTERS.-RETURN TO MELANGKAP.—THE POLL (TAX) COW.-WANT OF RICE.--RETURN TO THE COAST.-PURCHASE A BOAT TO RETURN TO LABUAN.-ZOOLOGICAL RESULTS OF THE EXPEDITION.

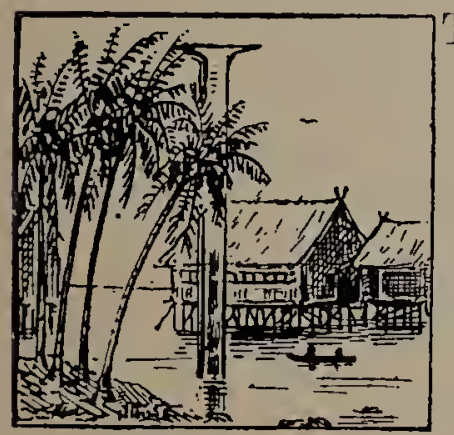

${ }^{\mathrm{T}}$ was not until the 25 th January that $\mathrm{I}$ was again able to leave Labuan for Kina Balu. My followers consisted of six Kadyans, one Chinaman, and a large black Chinese dog called Jack. We started at midnight, arriving at Pulo Gaya soon after mid-day, and steamed into Abai harbour about 12 o'clock the following morning. The sea was rough, and had the usual effect on myself. We had, however, the good fortune to get over the bar, and landed all the baggage in safety, close to the old house, which is in a slightly more tumble-down condition than it was last year.

I had letters from the Government officials to their paid chiefs, Datu Tumanggong and others, which I despatched to Tampassuk the next morning by some of my men. The following morning the Datu arrived with some of his retainers and carried my baggage to the Tampassuk, where I put up in a tumble-down shed belonging to the Company. However, with the help of a large waterproof sheet we were able to keep out the rain which poured in upon us through sundry large holes, made by falling coconuts from the palms overhead.

The next morning I called upon the Datu, but after wasting three hours of weary palaver I left the old man's house without the least chance of obtaining the desired buffaloes through his assistance. Though quite willing to carry baggage between the Tampassuk and Abai, it was now quite evident to me that I should never be able to leave for the mountain through this man's aid. I think he is really unable by his influence to 
do anything for me, as he has only a nominal power over those actually dependent on him, - his lazy loafing retainers and slaves. So the letter kindly given me by the AssistantResident of Gaya was evidently useless, the Company's paid chiefs being totally unable by their influence to help me-the reason of their incapability being that for years their followers have robbed and murdered the Dusuns, and now most of the Bajows have blood-feuds with these people, and consequently they dare not show their faces inland. So in my hour of need I turned to my little fat friend the Ilanun, Sultan Paitailan.

As none of my followers could speak a word of the Dusun dialect,' it was necessary to procure the services of an interpreter. After some inquiries, an old Bajow offered his services. He was married to a woman who had belonged to one of the Dusun villages; he said he could speak the language perfectly, and was well known to the mountaineers; but he stipulated that he was not to accompany me to Kiau, as he had a feud with those people. I engaged this man to accompany us, bringing up our party to nine. This Bajow was one of the most cunning and amusing rogues I have ever met, always seeking to benefit himself by every transaction. His name being a lewd one, we rechristened him "Billio" - $i$. $e$. the "old man"; and by this name he always went while in my service. He proved most useful, having a perfect knowledge of the Dusun tongue, was good at making bargains with the people, and worked hard to please me.

"Jack," the Chinese dog, found the nights rather too hot for him and the mosquitoes too numerous, so he sought a cooler sleeping-place on the damp sand a few yards distant from the water. One night, soon after dark, when sleeping there he had a narrow escape from a crocodile. The reptile had swum close up to him, and in trying to knock the dog into the water it struck the ground a tremendous blow with its tail. Jack uttered one terrified howl and disappeared into the coarse canes which bordered the river, and did not appear until late the following morning.

On the evening of the 4th February, Sultan Paitailan succeeded in collecting sufficient of his followers with their buffaloes to carry my baggage, and with twelve Ilanuns came to the hut to choose their wages and rope up the baggage they would have to carry. I paid these men for four days, some in cloth, others in silver dollars, which they wanted to pay their poll-tax, so was able to settle with all without parting with too much cloth. They were willing to carry my baggage-the heaviest part consisting. of rice-for two days inland, after which they told me buffaloes could not travel, the country being too rough. This would land us some distance inland, and I expected then to obtain Dusun porters.

The next morning all the buffaloes were under weigh by 7 o'clock, each Ilanun having carefully weighed his load the night before and tied it up in two parcels of equal weight, which were slung across the buffalo's back-those which carried the rice having the heaviest, though the easiest portions to manage. It seems curious, but it is really necessary, if you have more than one or two followers, to carry large quantities of rice into a rice-growing country with you, but I have always found great difficulty in procuring rice from the aborigines of Borneo. Of course, if you merely travel through villages you can generally procure enough for one or two meals, but often then at exorbitant prices, and for a lengthened stay this would be impossible.

Our party was to pick up Billio at his village en route, where he was to receive part of 
his wages in advance and a blanket, which he said was necessary as the nights in the mountain villages were very cold. My spirits began to revive when I saw all the buffaloes really started on this the second part of our journey. Kina Balu, our "promised land," stood out clear in the morning sky, and during our walk the Kadyans speculated on the well-known wonders of the mountain: the lake at the top, in which a solitary tree grows - the Lagundi tree-which, if they could reach and eat of its fruit, would make them everlastingly youthful; then of the golden plates and the dragon: all these myths to them formed a pleasant topic of discussion. In the following year, when two of these men did reach the summit with me, they saw neither lake, Lagundi tree, gold plates, nor anything else, but a field of stone; so I am afraid Kina Balu dropped many points in their estimation.

The first few miles of our journey traversed the 'Tampassuk plain. The level country at this time of the day was slightly veiled in the morning's mists, different to the quivering atmosphere over it during the heat of the day, caused by the radiation of heat from the plain, which makes the landscape dance before one's eyes.

Shortly before reaching Billio's village, the fat little Sultan fell off his buffalo into the mud and, according to his own account, was nearly killed. At his village Billio met us, and bid farewell to his family. He presented the blanket I had given him, "as it would be so cold in the hills," to his wife ; this, of course, I could not allow, as he would have demanded another when we arrived inland. He was dressed in his walking-costume, which consisted of a light cotton coat and a pair of trousers, or rather bathing-drawers, of the same material. On his back he carried all his belongings in a small bamboo basket, on which was tied cooking-pots and coconut-shell drinking-cups; in his hand he carried a long spear. Thus attired, Billio led us on the march, taking short cuts over parts of the country which the buffaloes could not traverse.

After passing several Bajow villages, which are situated on the river's banks amongst mango- and coconut-trees, we forded the Tampassuk for the first time, where the river broadened out and the bottom was level and gravelly, the water being up to our waists; on the other side the same flat land continues until some low hills, composed of reddish soil, were reached. After crossing these hills the track again leads to the plains, where the first Dusun villages are to be seen. The houses are long ones, divided into half a dozen partitions, each with its own door, the presence of pigs being sufficient to advertise the fact that the traveller is no longer in the land of the Mohammedan Bajow. These Dusuns are known as the Piasau Dusuns (piasau = coconut); they cultivate rice largely, and are apparently more industrious than the Bajows.

We crossed the river once again before mid-day, the path following the old courses of the Tampassuk, which was fairly easy travelling, though the sun before we halted had heated the stones sufficiently to make the barefooted Kadyans find walking unpleasant. The Tampassuk seems to change its course pretty frequently, a wide stretch of country between the low hills on either side being at one time or other part of the river-bed.

At mid-day, after a tiring and hot march since 7 o'clock, we halted for the Sultan and his followers: they began to arrive in about half an hour in straggling parties of two or three, each man on arriving relieving his mount of the baggage and leading the animal to 
the river, where it received a refreshing batll. After our mid-day meal we again started, hoping to reach Ghinambur before dark. The river here was very broad but shallow, and had to be forded to the path which traversed a lalang-grass covered plain for some distance on the opposite side. The day had now clouded over and it shortly began to drizzle, which during the afternoon developed into a steady downpour. The paths were much cut up by the buffalo traffic, and in places deep holes had been worn into the soft and slippery earth, making progress extremely slow. As each buffalo puts its feet into the holes made by those before it, by degrees large holes, often over a foot deep, with a space of about one foot between, are formed; on these intervening spaces the foot passenger has to walk, and as the path was either partly or entirely under water from the heavy rains, a plunge into the stinking mud is frequent. The most trying part of the day's march was at a distance of about five or six miles from Ghinambur, where the path is much grown over and cut up in the manner described. This distance after the fatigues of the day seems extra severe on the traveller; and it was not until 5 o'clock that we arrived at our haltingplace, appearing like drowned rats, the buffaloes and their riders not turning up until over an hour afterwards.

Ghinambur reached, an old native made us welcome to pass the night in his house. The first thing to be done was to change our soaking garments and put on others, which we carried for such eventualities. Before the last buffaloes arrived it was nearly 7 o'clock; but the evening had cleared up, so the Ilanuns were able to graze their animals during the night. Some of these men watched their buffaloes all night, fearing, rightly, that they would be stolen by the Dusuns if they did not do so.

Ghinambur is a small Dusun village built on the banks of the Tampassuk, half hidden amongst coconut-palms and fruit-trees, fine clumps of bamboo also add beauty to the scene. The houses for the most part are tumble-down and dirty, the spaces below being fenced round, and into these the live stock of the household-buffaloes and pigs-are driven for security during the night. Our host was very hospitable and showed us every kindness, turning out of his apartments to make room for us. The men wore garments of the usual thin blue trade-cotton, while the women make their own petticoats of native cloth. The village was fenced round with sharp bamboo-stakes, which had been put up to protect the people against the Koung and Kiau Dusuns, who live about a day's journey up stream. The Koung Dusuns and those of other villages formed a party and raided down on the Ghinambur people after the rice-harvest last year, killing seven and taking their heads. This fight, together with the Company's expedition, was the clief cause of Datu 'Tumanggong's reluctance to assist me last year. The old Dusun chief explained that it would be impossible for him to look upon the Koung and Kiau Dusuns, so great was his slame (which remark he suited by covering his eyes with his hands), until his people had had their revenge. At the present moment, he told us, his enemies were five heads to the good, and until this account was squared, either by heads or by payment of a fine, his tribe would not be free from disgrace. This feeling is identical with the Corsican vendetta, where the nearest relation of a murdered man is taunted and worried by his companions until he redeems the family name by another murder. The old chief wanted to call on the Company to protect him; but as no one had been near Ghinambur for many years, I advised him to 
try and protect himself. After this conversation we retired to rest, as we should have to make the most of our day on the morrow.

The next morning, after a light repast, and presenting our host with a few small trifles, we started once more inland. The Tampassuk is here a fine stream of broad clear water, and has to be forded directly on leaving the village, and seems icy cold to those who have been long in the plains; once wet through means wet all day, the river being frequently forded, the water occasionally up to one's armpits. Jack, the dog, at first did not like these long swims in the rushing water, so had to be assisted halfway across, when he would be carried down stream nearly a hundred yards before landing; but before this dog got back to Labuan he used to enter the stream high up and be gradually carried to the right landingplace. The track to-day hardly diverged from the river's bed, which is now becoming more difficult for the buffaloes, the stones being larger and hurting their feet. Before the evening we had forded the Tampassuk seven times, the rush of water on several occasions being strong enough to carry us off our feet; but by crossing in parties of three or four, and allowing one's self to be carried slightly down stream, all these fords were crossed without any casualties: one or two of the buffaloes missed their footing and almost disappeared, baggage and all, beneath the rushing waters; but as all my property was in waterproof bags nothing was spoilt.

At about four in the afternoon we arrived at a spot where another river joins the Tampassuk; this is an affluent on the true left bank, and called by the Dusuns the Panataran. Here we encountered a large party of Dusuns from the village of Tambatuan, who were going to a "tamel" held on a small plain which we had passed at mid-day. Billio had a palaver with these people as to the state of the track, and was told that it would be impossible for coast buffaloes to travel any further. This to most of us was quite evident, the course leading up the river's bed was now full of huge granite boulders and occasional blocks of serpentine which had come down from the sources of the Panataran.

Here we waited until nearly 5 o'clock for the Ilanuns; most of their buffaloes had chipped their hoofs, and were consequently quite lame. Many of the Ilanuns were walking, a most unusual thing for an Ilanun to do, so further progress with buffaloes was out of the question. A short distance off was a small Dusun village called Sinorob, situated on the slope of a hill, and for this village we made, resolving to stop there the night and see if the Sultan and his followers could get any further on the morrow. To-day our progress has been extremely slow, the buffaloes being quite done up by the rough ground, accustomed as they are only to the plains; but as the slowest member of a traveller's party regulates the daily distances, we have to walk as slowly, in order to keep the party together.

The Ilanuns have carried some slightly salted fish attached to their saddles from the coast, which after frequent immersions in the Tampassuk has become quite rotten, and is followed closely by a swarm of large blowflies, but at a respectful distance by myself: the Ilanuns dined off this putrid fish with apparent relish.

7th February.-The Sultan and his party left for the coast to-day, many of the men leading their buffaloes, which seem quite done up; but without this little man's assistance there is no doubt we should never have succeeded in getting thus far on our journey.

Our next job was to find sufficient Dusun porters to carry our baggage further inland. 
It required thirteen buffaloes to carry our baggage thus far, and therefore will take about double the number of Dusun porters; this number of men will, I expect, take a considerable time to find. Billio asked the Dusuns met yesterday if they would like to carry our baggage to their village, which they said they would do when they returned from the "tamel." To-day they arrived, but their ideas of the value of their services are beyond our means: their village is only a few miles distant, and they would not come to terms for less than six fathoms of trade-cloth per man, so they left.

On our way here yesterday we met an old Dusun fishing in the river; to-day he called and offered to show us a shorter way to the mountain without going to Kiau. As the exorbitant demands of the Dusuns had quite blocked my way in that direction, I was glad to avail myself of the old man's offer. When I asked Billio the old Dusun's name, he told me he called himself Sultan. "Sultan what?" I asked. "Only Sultan," was Billio's reply. This man had been thus named by Mr. Wittie. It is no uncommon thing for the Dusuns in the interior to ask Europeans to rename them; several times I have been asked by the Kina Balu people to visit their campongs in order to give their head man a new title: They perhaps get this peculiar idea from the coast people, who are Mohammedans, and after they return from the pilgrimage to Mecca, add the title of Hadji, changing at the same time their name into an Arabic one.

Sultan's advice that we should not go to Kiau is of course easily understood; he knows that we must have a quantity of trade goods judging by the amount of baggage we have brought, so of course he is anxious that his own tribe shall share the spoils, knowing that if we go on to Kiau they will lose all chance of securing anything. The old chap is fond of gin and seems quite happy, and was, I fancy, not much inclined to move.

The country round about this village is very mountainous, and no view of Kina Balu can be obtained from the village. The hills have all been cleared at one time or another up to the summits, so there is on them no collecting-ground for a naturalist. During a short walk to-day, however, the presence of several large red-coloured Doves (Macropygia emiliana), which flew about in patches of thick undergrowth, was sufficient to show me that I had already reached a new ornithological region, these birds not frequenting the coast. Sultan sent word to one of the campongs, called Melangkap, for porters to-day, and thinks that we shall get off to-morrow.

8th.-A number of Dusuns came from Melangkap this morning to arrange for their wages. They agreed to carry our baggage to their village, which they say is a few hours distant from here and close to Kina Balu. After haggling for over three hours I left Billio to conclude the bargain, and took a walk. In the end the Dusuns agreed to carry double loads for three fathoms of cloth: one piece of trade-cloth did not cut up into three pieces of the required length, so the men who were to receive it refused to go; but after a prolonged haggle one box of matches per man, total value about one halfpenny, settled the bargain. Three women belonging to the house where we were staying also carried loads which I should not have cared to carry many hundred yards. In all my dealings with the Dusuns I seldom found them trouble much about the weight of their loads, but over the amount of their wages they would argue for several days, three or four needles often being sufficient to decide them. These people never agree to anything you may offer, always 
wanting more; whether the value of goods divided amongst six of them is worth a halfpenny or not, as long as they think they have bested you they are quite satisfied. This they think clever, and in each village there are one or two men who are the chief spokesmen and do all the bargaining: these men are always called in, and if at the time of your visit they should happen to be elsewhere, the traveller will have to wait until their return, the rest of the villagers refusing to talk over matters in their absence.

As there were not sufficient porters to-day, I could only send part of my baggage to Melangkap, with three of the Kadyans. These Dusuns are wonderful baggage-carriers: one of them carried a buffalo's load, and twenty-one Dusuns have carried the loads of thirteen buffaloes. They tie up their loads with broad bands of cloth or bark, leaving loops to go over the shoulders and one round the forehead; the head band is used when going up-hill, when the head is bent forward, thus taking a good deal of the strain. The women always carry baggage in their paddi baskets, which are cone-shaped, made of the broad bases of sago leaf stems, neatly fastened with rattan to wooden hoops.

9th.-This morning I was able to start with the rest of my men and baggage, but it was not until late in the day that we left Sinorob. Our guides led us down to the Panataran River, and continued for some distance along its course under a broiling sun. Both sides of the river were bordered with forest, and from one tree I noticed a most perfect natural flower-basket suspended on a long creeper, being a large collection of parasitic plants, including ferns and flowering orchids, which were dangling in mid-air. After leaving the river the course led over some steep hills which had been cleared from time to time for rice-growing; the heat was so great that several times I was forced to seek the shelter of the bamboo clumps. In about four hours we reached Melangkap, where the Kadyans sent on yesterday had found quarters in the house of one of our porters named Ganiboie. They had not wasted their day, and had already commenced bird collecting, and I was delighted to find they had several specimens of birds belonging to this region which I recognized from their printed descriptions (among them being Ianthocincla treacheri and Buchanga stigmatops).

The first thing to be done was to agree with our host about our rent, as I intended to make a long stay in this neighbourhood. I resolved to make Melangkap my headquarters, and leave all my stores there during my expeditious to the mountain. Gamboie is a widower, and is the father of a girl about four years old; part of the house belongs to him, and the rest to another Dusun who at present is living in his paddi-fields. So in the end I made both these men small presents, and occupied their house during my stay in Melangkap.

The village of Melangkap is situated on a grassy slope facing the mountain, and consists of nine or ten houses, each house containing two or three families: the houses are built in the usual style, but have plank sides instead of attap or kâjangs like those of the Bajows.

When we arrived at the village, Kina Balu was completely hidden by the clouds, so I was unable to form an idea of its proximity, and it was not until the evening that $I$ was gratified by a view of the mountain. It looked wonderfully near, the rocks, and water falling over the summit down the main buttress, being perfectly distinct; but at a glance one 
could see that the mountain on this side was a sheer precipice and quite inaccessible, the water falling thousands of feet without touching the rock; and I found out later that it was a very tough job to reach it.

The prominent points seen from the coast looked now very different, the peculiar sharp point at the more northern end becoming a round-topped peak, separated from the main ridge ; the long jagged main ridge is broken in one place by a peak which towers up in front of it. Between the main buttress and the long jagged ridge is a huge gorge surrounded on three sides by sheer precipices of bare rock, the entrance to this gorge being from the western side, facing Melangkap. At the most southern extremity the mountain suddenly terminates at its greatest altitude by precipices of rock. The top along the whole distance is bare of vegetation and very rough; here and there great scars formed by rockslips may be noticed. Though Kina Balu is only a few miles distant, the intervening country is a mass of high forest-clad ridges, which look from here very steep, and through which the Panataran and other streams have cut, in the course of ages, deep channels. The Panataran flows half round the hill on which Melangkap is situated, but is several hundred feet below the village, the mountain-sides being very steep. In the foreground of the picture are native clearings and a few coconut-plantations, the fruit and forest trees growing in patches mingled together. The hill-sides are covered with a species of bracken fern, and in some places with lalang grass, or last year's and the present year's rice-clearings, in which may be noticed the small watch-houses of the Dusuns.

The village of Melangkap is situated at the end of a huge spur, which runs round in a slight curve almost to the base of the great buttress of Kina Balu. At the Melangkap end the altitude is over 1000 feet, but this spur gradually rises on nearing the mountain to over 5000 feet. It is covered with a dense forest-growth and branches off in several directions, the Panataran flowing along its base, the head waters of this river falling from the top of the buttress itself. On looking to your left, when facing the mountain (from the village of Melangkap), another lofty spur sweeps round from the other end of the mountain. This spur is more broken up and about 4000 feet in altitude; on it, facing Melangkap, are the villages of Kapar and 'T'eung, and over it a path leads to the village of Siap. Directly in front of Melangkap, and between the two mentioned ridges, the country is a mass of huge spurs, mounting up, as Kina Balu is neared, to 5000 or 6000 feet ; one sharp peak, as I have already stated, is very much higher, and when seen from Melangkap breaks the outline of the main ridge of Kina Balu itself. Another stream drains this district and flows past the spur on which Kapar is situated, joining the Panataran shortly below that village. The Tampassuk plain, the sea beyond, and the islands of Mantinani, are distinctly visible from the top of the Melangkap ridge. I find that the late Mr. Frank Hatton mentions this village, then composed of six houses ('North Borneo,' p. 247).

- The afternoon we arrived I made my first attempt at foraging, but found food of all sorts excessively scarce. A Dusun brought me a small chicken, and on asking him the price, he looked round the house for a second or two, and pitched on a blanket, which he evidently considered would be about the ralue of his chicken. He refused to take anything else, so I went without my dinner. The Dusun values all material by length, not by quality; cloth of all sorts is measured by the fathom. 


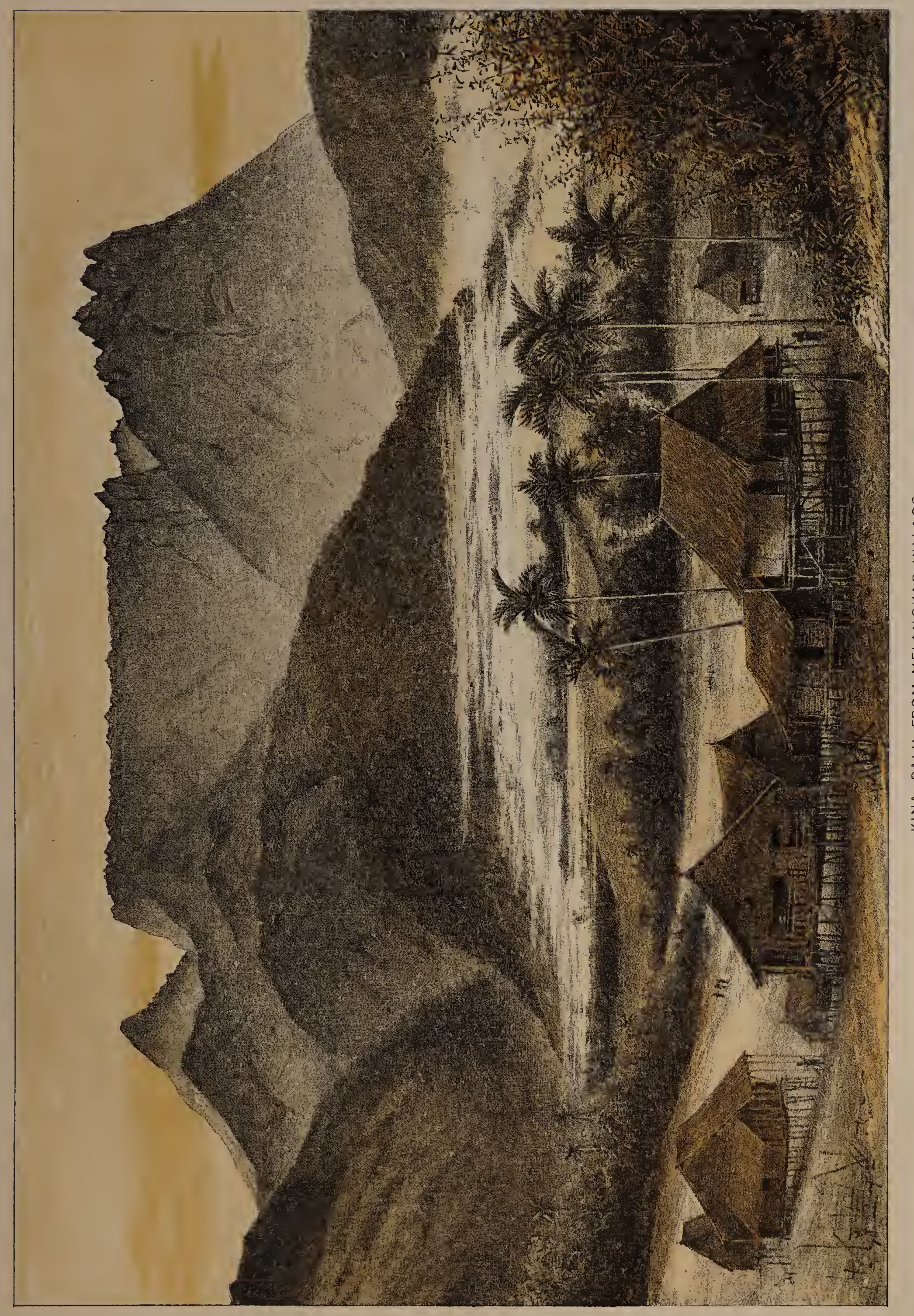



Gamboie's house is a small one, and divided in half by a planked partition, the houses of these people being arranged like those of the Lawas Muruts. One of the small divisions or cubicles the Chinaman uses for my kitchen and also as his sleeping-apartment. I prefer the large open public apartment, being better ventilated and free from smoke; by slinging my mosquito-net I have a very small but private bed-chamber of my own. Billio, with his usual cuteness, has secured two rice-mortars and a plank, which he has placed across them, which forms a plank-bed about a foot from the floor. 'The other cubicle belongs to another Dusun, who is at present living in his paddi-fields; and the door of this part is fastened up. In these small dark private apartments the Dusuns sleep and do their cooking; the fire is made on a mud heartl, and has a light bamboo framework built over it for drying rice and placing a few earthen cooking-pots. In the public apartment the Dusuns do their daily work, such as pounding rice, making fishing-nets, ropes for their buffaloes, baskets and hats to be sold at the tamels.

Dusuns are decidedly of a sociable turn of mind, assembling in small working-parties, after the day's toil is done, at each other's houses. Light is admitted by windows and small doorways in the plank sides; the shutters have rattan hinges. In some houses the whole of one side of the public apartment is open. As there is no special outlet for the smoke, the roof and nearly everything inside is black and dirty. A house lasts from five to seven years, when it falls or is pulled down, the plank sides being used again for the new one. Some of these planks are of great age, and it is wonderful how smooth they are considering the tools at command. 'The floors are made of bamboo: the bamboo is split from end to end when green, then each joint is cut through in many places; after this operation the bamboo is forced open and laid flat on the ground, heavy stones being placed on it to keep it so until dry, when it remains perfectly flat and soon becomes beautifully polished, but, I am sorry to say, affords a splendid covert between the tiny cracks for numerous specimens of most disgusting insects. The bugs which infest these floors at times become sufficiently troublesome for the Dusunš even to take an interest in their everincreasing numbers. It is no uncommon sight to see a Dusun who is patiently working at a rope or fishing-net suddenly jump up and commence scratching himself; then he walks to the fireplace, on which he proceeds to boil some water in his small earthenware cooking-pot; this, when ready, he pours over these bug-infested planks, and once more proceeds with his occupation. As most Dusuns at home wear the chawat, their interest in these pests may be well understood.

The Dusuns are at first sight fairly clean, especially the younger men and women; but it is only after living for months with these people that the traveller discovers how filthy they really are. A mother seldom washes herself or her children, some of the latter being besmeared from head to foot with mud and filth, in which state they remain for montlis. A child of Kuro's had a mark on the centre of its chest as though some lump of mud had been thrown at it; the pattern of this dirt was there during the whole time we remained in Kiau-nearly three months. The heads of the children are shaved for the first fer years, after which the hair is allowed to grow. The young men do not shave their heads or cut their hair until they become fathers; consequently many youths have fine heads of long black locks, which they generally tie up beneath their head-clotlis or "cigare," as the 
Dusuns call this article. Hair is seldom allowed to grow on the face, most men being provided with a small pair of tweezers, with which they jerk out all stray specimens, the importation of small looking-glasses by ourselves giving a fresh impetus to these hairjerkers. One old man here had a long grey beard, and was the only bearded Dusun I ever

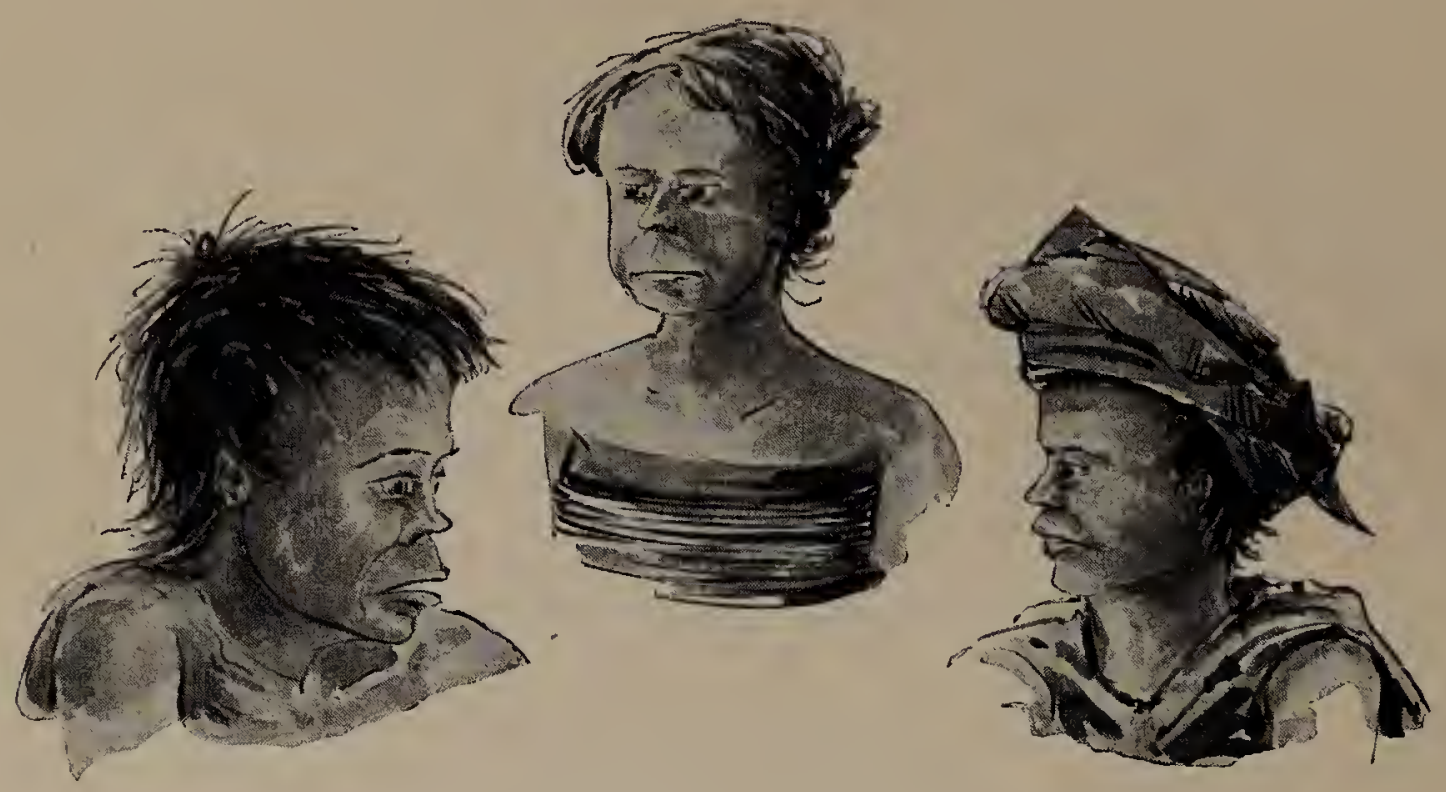

MELANGKAP DUSUNS.

saw. Teeth are filed down short and blackened; this does much in a European's idea to spoil the good looks of these people, but they equally object to the long white teeth of Europeans. Some of the men are slightly tattooed with a few parallel short lines on the forearm: The costume of the male Dusun consists of a pair of loose Chinese-cut trousers of blue trade-cloth, fastened round his waist by a long piece of turkey-red; their jackets are often tight, especially in the sleeves, and are adorned down the front with many rows of white china buttons, eight in a row; round the head is tied a red or blue headcloth. A short useful chopper is always carried and occasionally a light spear. When on excursions many wear the chawat and occasionally a bark coat; but these coats are poorly made when compared with those of the Muruts.

The Dusun women have perhaps one of the most picturesque dresses of all Bornean tribes. They wear a fairly long petticoat of home-made cloth dyed indigo-blue; above this skirt and over it for a few inches are coils of black and red rattan; below these hang rows of red beads closely threaded to a depth of six inches or so; sometimes numerous brass chains hang above the beads. The bright metal cylinders worn by the Patatan women were seldom worn by the Dusuns round Kina Balu. Until they are mothers a strip of blue trade-cloth is worn over the breasts, which is kept in its place by numerous coils of red rattan; these coils, like those round the waist, are tied together in quantities of six or eight. The women file their teeth like the men; their eyebrows are shaved into narrow arched lines; as a rule, the right ear only is pierced. Their coiffure is simple, the hair being tied in a knot on the top of the head, through which a bone hair-pin attached to a string of beads is stuck, the beads being wound round the base of the knob. Some of 


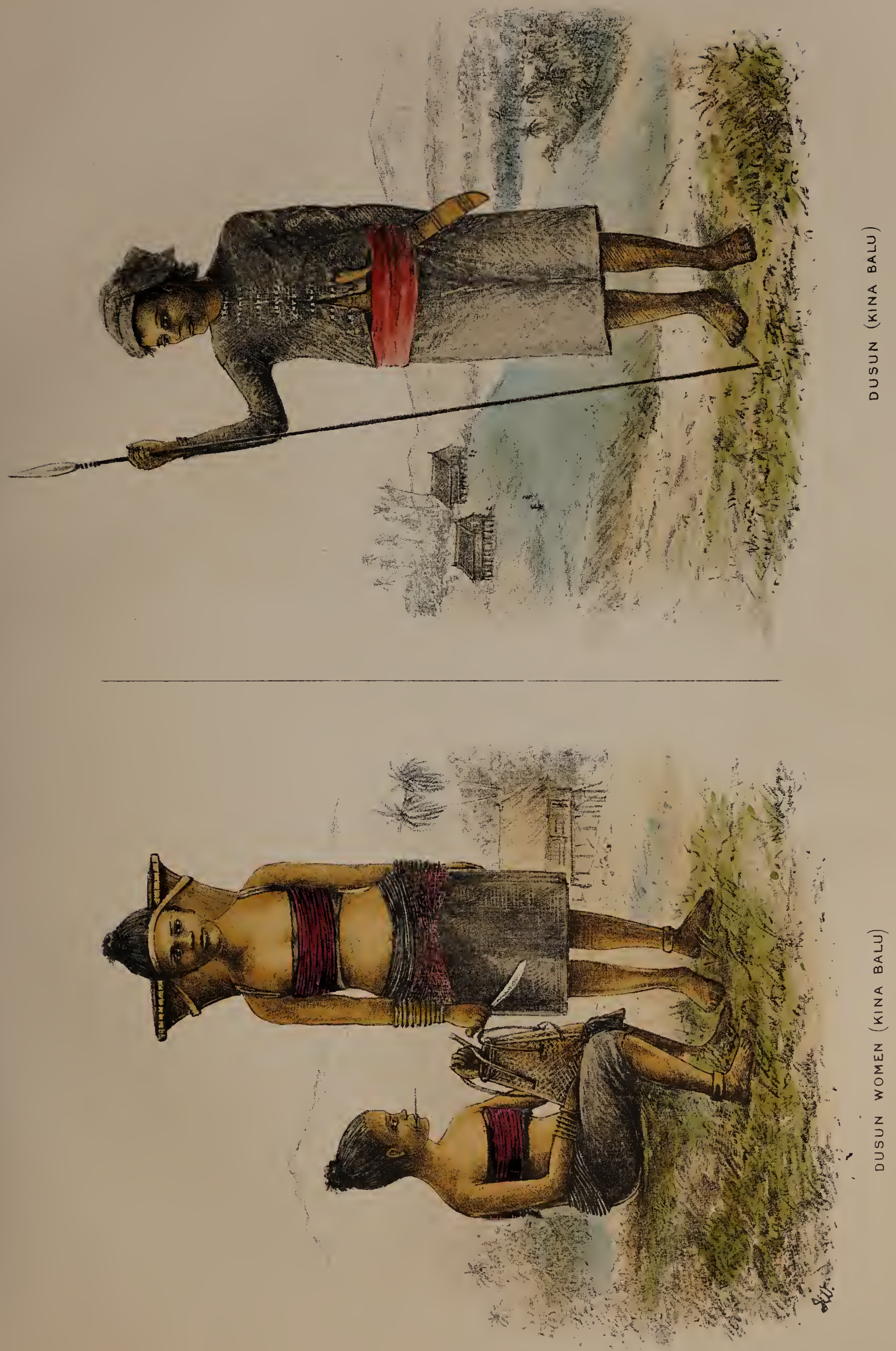



the women wear coils of thick brass wire round their wrists and ankles, one old dame having a pair of solid brass anklets, several pounds in weight, which she always wore. A cowl is worn during field-work as a protection from the sun. I purchased in Melangkap a suit of clothes worn on festive occasions; they are tastefully embroidered with a pattern worked in red and white. Children run naked until about four years of age. Both men and women are fairer-skinned than the coast people; some of the youths are really handsome, with well-cut features, but the Mongolian type of feature predominates. Few men are as tall as 5 feet 10 inches, the average height being about 5 feet 4 or 6 inches; but they are marvellously strong and active considering their rather frail limbs, and they can carry loads all day over the most mountainous country that few Europeans would care to carry for many hundreds of yards.

The everyday life of a Dusun is much the same from year's end to year's end, varied only by the seasons. He plants his rice, and after that has been harvested "kaladi" (Caladium esculentum) is put in on the same ground. During the season that the crops are ripe most of the Dusuns spend their time in the fields, a small bamboo house being built for the family, whose work is to scare away the flocks of rice-eating finches, the chief offender being a small brightly coloured finch (Erythrura prasina). This bird is called "Tuhan" by the Dusuns; it is very brightly coloured, red, blue, green, and buff being amongst the colours of its plumage. The principal fruits are jack-fruit, tarripe, and pisangs; of vegetables, cucumbers, gourds, sweet-potatoes, and kaladi. Of palms, the coconut supplies a strong-smelling intoxicating drink, which is obtained by tapping the fruit-stem and suspending a bamboo-joint to catch the sap; the nuts consequently are not of much account, and are seldom eaten by the Dusuns. Areca palms supply the usual chewing-nuts; and I also noticed several clumps of sago-palms in some swampy land near the village, the leaves of which were used for attaps. After the harvest the men are busy felling the growth which has sprung up during some seven years since the last crop was planted; after the trees are dry enough they are burnt and the new crop is planted. Many Dusuns go three or four times a month to the tamels, which are generally held in dried-up river-beds. To the tamel they will often make a two days' journey, with a few articles of their own manufacture-such as bamboo baskets and hats, bark ropes, and, where they grow it, tobacco-over a country which is in itself a pilgrimage to traverse, a good many of the heaviest loads on these occasions being carried by the women. The tamel is the Dusun's market-day, and, like the European, he often gets drunk and does a deal of gossip on these occasions. Now and then enemies meet, and there is a free fight, especially if the men are liquor-brave. During the slack season, after the rice is planted or again after the harvest, the men do a little hunting or fishing,

The Melangkaps, however, are not such great trappers as the Kiaus. They set numerous pig-traps in the vicinity of the village. The trap is made by fixing a long sharp bamboo spear to a tough sapling, which is bent back and fixed, so that by touching a fine string the unwary porker lets loose the sapling, the force of which is sufficient to drive the spear clear through a pig, or occasionally through a Dusun's leg. One of the Kadyans narrowly escaped an accident with one of these traps, the spear going through his trousers and grazing his leg. The forests they search for rattan canes and damar: with the first 
mentioned they make good mats known as "lampits"; the second is sold to the Bajows or used in bamboo cylinders for illuminating purposes after dark.

Occasionally the Dusun indulges in pig-hunts, assisted by packs of small curs; but pigs, like everything edible in this neighbourhood, are scarce and wary.

Fishing is carried on either with a rod and line, or by poisoning the pools with "tuba," the milky sap from a creeper. 'The commonest fish is like a dace, but I failed to catch them with any bait offered. Some of the Dusuns have circular cast-nets, and the women occasionally fish with small hand-nets; but Dusun fishing always seemed to me a failure.

Their home life is apparently happy: disputes, considering that often several families occupy the same house, are rare. The Dusun is an early riser, the want of warm bedclothes turning him out before sunrise. His bed is a broad plank, his pillow a small block of wood the size of a brick, which, as with the Chinese, is placed under the neck. Those that have them wear sarongs at night, but many have nothing but their thin cotton clothes to sleep in, so a bed sluggard is an impossibility. They sleep in the private apartment, the family huddling together for warmth; a fire is kept up until nearly daylight, when their puffing attempts amongst the dead embers may often be heard. Before daylight has fairly established itself, and when the country is veiled in bone-chilling mists, the Dusun girls rise and have an hour's warming exercise, pounding the rice-to separate it from the husk -for the family's daily wants. After a slight repast most of the household leave their homes for their outdoor avocations, until 4 o'clock in the afternoon, when they return loaded with provisions-from their gardens-and firewood. The men then busy themselves with their various manufactures, already mentioned. About dusk the evening meal is partaken of, which consists chiefly of rice, and any delicacies the Dusun has collected during his daily wanderings-such as rats, mice, fish, frogs, tadpoles, beetles, grubs, and chrysalides, all of which are stewed down and eaten as a relish with the rice. Rice is stored away in small houses, built for this purpose, in large round enclosures made of bark, circular wooden disks, about 12 inches in diameter, being placed on the piles to keep the rats out: a good deal of rice is stored in large long lengths of bamboo, which stand upright against the wooden partition in the house. Household goods are few, jars are rare, but gongs may be found in nearly every house. A few large earthenware cooking-pots and rather well made wooden spoons complete the cooking-utensils. The women use bamboo or wooden hair-combs made by their lovers or husbands, and this is their only toilet article. Their musical instruments are of several sorts, and rather ingenious. Gongs and tom-toms of course take part in all festivities. A boy gave me a very cleverly made jew's-harp of bamboo. Then there is a species of panpipes fixed in a gourd, and, lastly, an extraordinary long guitar with two strings ; the performance on all these instruments is, however, feeble. Their arms, besides the chopper and spear above mentioned, sometimes consist of Brunei swords and krises; these weapons, however, are seldom worn, but hang up in the houses. Sumpitans are scarce, and never used except for shooting birds; a few old shields, either of plaited rattan or of light wood, are to be seen in most houses, but the Dusuns, being neither brave nor warlike, do not take the pride in their weapons that the coast people do. In disposition the Dusun is hospitable and kind, a visitor from another tribe nearly always meeting with hospitality; but I have known the Melangkaps receive a cold 


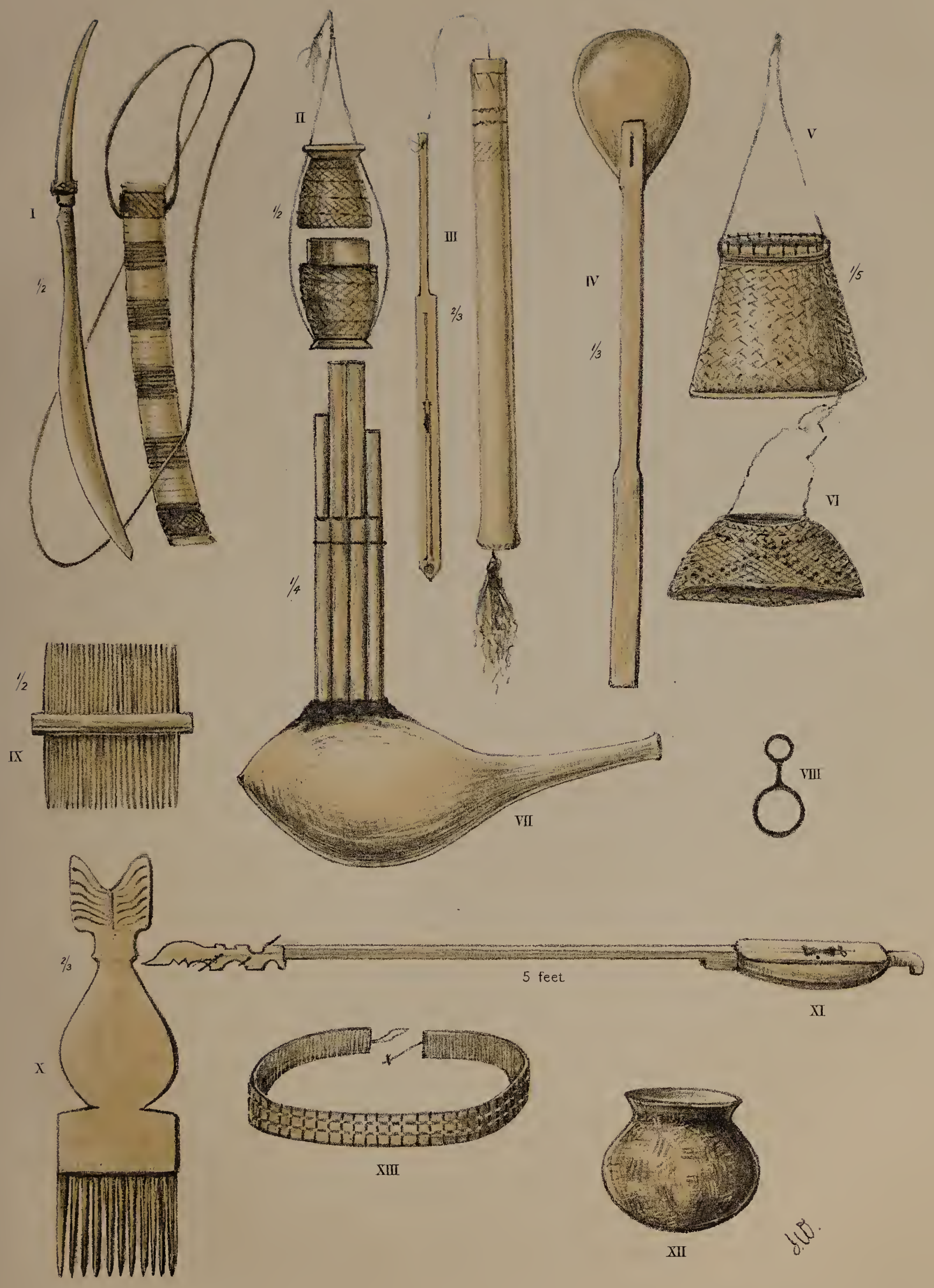

DUSUN HANDICRAFT
I. Knife
IV Spoon.
VIII. Finger Ring for
XI. Guitar
II. Tobacco Box. V.VI. Small Baskets
holding Cigarette XII. Cooking Pot.
III. Jews Harp. VII Pan-pipes.
IX. X. Combs.
IIII. Necklace. 

reception in Kiau, and they would have gone without rice if we had not supplied them ; these villagers, however, seldom visit each other. To a European they are very hospitablelighting fires and doing their best to make him comfortable. There is, however, in all their dealings with one another a certain callousness and a desire to ridicule the sufferings of the less fortunate. 'This feeling I especially noticed:' on the march when mere boys got into difficulties with their heavy loads, instead of being assisted by their stronger comrades they were more often chaffed. The women mix freely with the men, and some of the old liags carry great weight in the village discussions. They are good-tempered and easily managed with firmness and kindness, though of course, as amongst ourselves, there are men with whom it is impossible to deal.

The people are generally healthy; as medicine is unknown, so the weedy ones die. Many, however, suffer from bad sores on their shins, brought about by weakness and want of good food, as there are seasons of scarcity, when the Dusuns are reduced to the verge of starvation. Small-pox from time to time commits terrible havoc amongst them; numbers of Dusuns in Melangkap were deeply pitted by this disease. Kūrrup, that most filthy skindisease, is occasionally noticed, when the presence of the "kürruped" is not in the least objected to. One or two men died of swellings or tumours on the face and neck while I was in Melangkap. Their most amusing anecdotes are generally more or less lewd, the more so the greater the merriment; they often chatter and laugh long past midnight, especially when there is a good supply of "tuak" or arrak in the house, when the men get quarrelsome at times in their cups. Of their religion I was unable to gain much information. The old hags of the villages are the priestesses. The belief is, that all the dead go to the top of Kina Balu, which is the abode of all spirits. In every house is to be seen a curious bunch of charms to keep away evil spirits. This bunch consists of all sorts of rubbish, or rather anything curious to the Dusun. Never visiting the coast, he knows not of the abundance there of bits of coral and nipa-seeds, so when he has such an article given him he carefully ties it up in the household bunch, together with teeth of animals, curiously twisted roots, eagles' feet, and anything that to him is out of the common. This miscellaneous collection is tied with a bunch of grass to a short bamboo, and used to exorcise evil spirits or "hantus." I could never succeed in purchasing such a bunch, as they said it kept away evil spirits, and they dare not sell them. So great is their belief in these curious-shaped roots and bits of rubbish, that occasionally they would ask us to shoot at these charms, thinking we could not blow them to pieces. Head-hunting is carried on in an indifferent sort of way, heads being seldom seen in the houses, and often enough the broken remains of skulls may be found hanging outside the windows in rattan baskets. The vendetta feeling is strong amongst these tribes, and they generally go on the war-path after the rice-harvest, for the purpose of paying off old scores. The villagers of Kiau, Koung, and surrounding districts are, however, decided head-hunters, and, I believe, make annual expeditions. The old head-collecting instinct, however, is still existent, and shows itself in the form of a collection of animals' skulls, including those of monkeys, deer, pigs, rats, \&c., \&c., which are carefully preserved and hung up in strings, or tied to the attaps in nearly every house.

They believe all diseases are caused by evil spirits, and anxiously inquired if I lived 
near the country where the small-pox devil came from, which they explained by bringing forward those that were marked, so that I might see this devil's work.

On building a new house, to insure the inmates from devils and bad luck, a long ceremony is held over a pig. This animal is tied down and a rice tray is placed over it to keep off the sun; the priestesses and the female occupants of the new house stand in front of the pig with the household bunches of charms and coconut-shells filled with water, with which the pig is sprinkled: after nearly an hour's incantation, accompanied by the klicking of small flat pieces of metal held by the women in their hands, the pig is taken by the men into the new house and there killed, and afterwards forms part of the evening's feast.

Children are betrothed when very young and of about the same age; their parents seem to arrange all for them. The marriage ceremony is somewhat complicated to European ideas. When the young people have arrived at a marriageable age, the parents of the bridegroom visit the bride's family dressed in their best, bringing with them a buffalo and a brass gong-but I have known only a gong given. This is the "berrihan," or payment for the wife; the parents then return to their own home. The following day the bride pays a visit to her future husband's house, but the young people do not converse; the next day she returns to her home: in a few days she again pays a visit, this time attended by two of her girl friends, dressed in their holiday clothes; in the evening there is a feast of buffalo-meat and "arrak." The night and, in some tribes, the next two days and nights are spent in dancing; but the Melangkap brides return home the next morning, where they remain for five days, after which the ceremony is over, and the happy pair considered man and wife.

A man marries into his wife's household, she not leaving her father's house; thus, by this arrangement, the man's labour goes to enrich his wife's family: this is the old patriarchal system. In Melangkap some of the women were married to men who belonged to villages a few miles distant, in which case, when the men owned paddi-fields in their own districts, they worked there during the busy season separated from their wives. Thus a father of several daughters always has sufficient labourers for his household, while sons, if they are not possessors of land, leave their own family and join that of their wife. The father-in-law has great power over his son-in-law, as the following anecdote will show. A Melangkap youth, who was married to a girl living just below the house we occupied, got intoxicated-a not unusual occurrence amongst Dusun youth. He came out of his wife's house armed with a spear and the usual small chopper carried by all Dusuns, and challenged all the world to come out and fight. As no one seemed anxious to accept the challenge, he vented his drunken rage on the neighbouring coconut-trees, one of which he spoilt; after this he was disarmed and taken home and kept there until sober. The next morning his father-in-law called a meeting of some of the elders of the tribe; this meeting decided that unless the youth paid a fine of a calf and a pig to his father-in-law, he should not be received again into that house. The boy was unable to pay the fine, so the girl's father divorced liim, and he never entered his father-in-law's house again. Shortly after this the boy left Melangkap, though his young wife had already one child by him. The lady herself was decidedly the "belle" of Melangkap, and named Kratas. She, I must 
say, bore her bereavement without shedding a tear, as she had always showed a positive dislike to her boy husband, who was a diminutive and disagreeable young man. Before we left Melangkap, Gamboie, the widower, had asked and been accepted as Kratas's second husband.

As the father-in-law has great power over his son-in-law, so the father loses all influence over his own son. In the house where I stopped during my second expedition, a young man was living, as is the custom, with his wife's family; his father used to visit the house frequently, often staying for a few days at a time, his home being a few hours distant at Ghinambur. One day his son had high words with him, and told the old man to leave the house, as he did.not intend to feed him any longer.

There are a few female orphans in the village; they, when married, either join their husband's household, or the young people set up for themselves.

The Dusuns bury their dead at no great distance from the campong-in Melangkap at one end of the village green. The graves are at first hung round with the personal property of the departed-the clothes, small chopper, and the bamboo basket every Dusun carries at his back; the garments are left till they rot away. I have seen jars half sunken in the earth over some graves, but after a time these are removed, and there is nothing left to show the Dusun's last resting-place. Small children are occasionally buried under the houses.

The domestic animals of the Dusun are ferw-cattle, buffaloes, pigs, dogs, and chickens. First, and perhaps most important, is the Dusun pig, or "Waguk." The "Waguk" is an interesting animal ; he is very narrow-a Rail among mammals; his colour is black; he has an evil but inquiring eye, and generally cruises below the house, where he pounces on anything that may accidentally fall through the floor. The "Waguk" is the pet of the Dusun household, and is christened with a single name, like the Dusuns themselves. 'The pig belonging to our house-the following year-rejoiced in the name of "Empallong." The Dusuns feed their pigs twice a day, but they subsist chiefly on the filth they can find in the neighbourhood of the campong. At sunset you may hear half a dozen women calling their pigs home; the cry is "Ke-Ke-Ke, Empallong, Empallong!" of the women in our house. When Empallong is big enough he forms part of a religious ceremony, and is afterwards stabbed to the heart. Under the houses may be often noticed small pens, composed of stout sticks stuck in the ground a few inches apart; in this enclosure the young "waguks" are fed, to the discomfiture of their parents. Buffaloes are used for riding, but more often allowed to run in a semi-wild state like the cattle, and killed for feasts.

The next animal in importance is the dog, or "Tasso." They are small foxy-looking little animals, generally as thin as a rake, and ready to devour anything, from a traveller's boots to his mosquito-net; as most houses have several dogs belonging to them and these animals are seldom fed by their master's, they are a great nuisance. In our house there was more food about than in those of the natives, so at night the clatter of falling cooking-utensils would give the alarm, and one or two native dogs would make a rush for the door, in which there is often a hole cut for their convenience. The Melangkap dogs ate several of my bird-skins and the top off one of my boots. They became such a nuisance at night, that at last the Kadyans set nooses for them and soundly belaboured all captured. 
Cats, or "Tungow," are very scarce; there was not one in Melangkap, and I only saw one in Kiau. Cats are common in the houses of the coast people; but as a Dusun can both catch and eat his own rats and mice, the presence of this animal would be superfluous.

Chickens are fairly plentiful, but hawks commit great depredations amongst them. At night they are packed away in long baskets under the houses; over these baskets it has been my misfortune to sleep, when the rooster wakes one before daylight with one or two powerful crows, let off as it were in one's ear.

Bees are kept in hollow logs about two feet long, blocked at the ends, with a small hole at the side. The logs are generally fastened outside the windorvs; but honey is apparently scarce.

All the land that it is possible to cultivate belongs to families; some own considerably more than others. An orphan-a little girl in this village-was quite an heiress, owning a good deal of rice-land that had returned to forest, and therefore the more valuable. 'The Dusuns advised one of the Kadyans, whom they had taken a fancy to, as his ideas of the Mohammedan faith were not too strict, to marry this girl, as they told him that she had plenty of land, and the rattans had not been cut there for years. So landed property has its rights, which are handed down to the children. Some of the larger land-orvners who are short-handed employ their less fortunate brethren at the harvest-time, the payment of wages being made in rolls of tobacco. The same land is used once in about seven years for rice-planting, when from three to six acres are planted. Kina Balu itself and the uncultivated spurs are portioned off to the various tribes which surround it, each village owning the collecting and sporting rights over the country opposite their village. I do not think this etiquette is ever transgressed; whenever I visited these forests, the people of the village where I was living always took me to their part of Kina Balu. The Kiau Dusuns have the rights over the only pass to the summit, which perhaps is also shared with the villagers of Teung Tuhan, and it would probably cause a disturbance if a traveller tried to follow this path with baggage-carriers other than Kiaus. In their partitions of the mountain they set dozens of rat-traps. I remember asking a Kiau Dusun what lie would do if he found another man taking game, i.e. rats, from his traps; his answer was that he would kill him; though perhaps this was merely swagger, the etiquette regarding traps is very strict. In Melangkap there was only one bad character, a stout idle young fellow named "Saggi." This man used to rob his fellows by digging up their kaladi and sweetpotatoes at night. An old man, who had been robbed, on one occasion challenged Saggi on the village-green to come out and fight him; the old fellow made a good deal of noise and flourished the household sword about for some time. Saggi, if he does not mend his ways, will either have to leave Melangkap or will come to a violent end.

The Dusuns are a very honest people; during the whole of my lengthened intercourse with the Melangkaps I never had the smallest article stolen by them, though opportunities were many. The only thieves I met with amongst these tribes were the Kuro family at Kiau; and when I informed the villagers of this fact, they were most anxious that I should not give their village a bad name.

I will now proceed to give an account of our daily doings, and of the natural 
history collections and expeditions amongst the spurs of Kina Balu; and as it was not until the following year that I was able really to ascend to the summit of the mountain, I prefer to recount that part of my travels separately.

10th February.-I began to inquire for porters to carry my baggage to the mountain. Billio did all the talking, which lasted nearly a day, the Dusuns wrangling over their wages until I was heartily sick of them, and, as usial on these occasions, I took a long walk. When I returned to the house the Dusuns had settled to accept 2 fathoms of trade-cloth, either red, blue, or white, 5 needles, 1 reel of cotton, 1 looking-glass box, 2 boxes of matches, 10 buttons, or, in all, about 1s. per diem to carry our baggage for two days up the Panataran, by which route they said we could reach Kina Balu.

The next day it took seven hours to pay off these fifteen Dusun porters; they, always expecting you are trying to cheat them, examine every article most minutely, and measure and remeasure the lengths of cloth with one another. If all is not of exactly the same length and quality, the man who has an inch less than his fellow porter has to be propitiated with an extra needle or a few buttons, otherwise he will most certainly refuse to go.

The measuring of cloth is rather an amusing occupation. All cloth is measured by the fathom or "dapah," which is seldom more than 5 feet 10 inches, often less, being the length that a Dusun can stretch while holding the cloth between the tips of his fingers across his chest. The villagers invariably hunt up their longest "dapah" stretcher, and he measures the first length, which is cut off-all eyes during this operation being bent on the cloth to see that it is just slack and not stretched in the least. After the first length has been cut, it is best to mark an equal measure on the floor and work from that. The head men generally look on while this is being done, to see that there is no cheating by stretching the cloth, and to secure for themselves any lengths that may have an inch or two over; it is policy on the part of the traveller to let them have these extra lengths. It is a great mistalse to have more than one quality of cloth of the same colour, as this only leads to disputes, all naturally wanting to have the best and refusing the inferior quality.

There are several species of interesting birds in the vicinity of this village, besides the two species mentioned. A very handsome greenish-yellow Jay with claret-coloured wings (Cissa minor) frequents the growth on the old rice-clearings; this bird is called "Tonkakis" by the Dusuns, "Tonkakis" being the note of the bird. Another species, a bronzy-blue Drongo Shrike, may be seen frequently close to the village; this bird belongs also to the true highland fauna of Borneo, and is called the "Limbas" by the Dusuns, and Chitice borneensis by ornithologists. The most numerous species about the village is Ianthocincla treacheri, the "Lahoie" of the Dusuns. This bird is quite one of the ornithological features of the mountain; it may be heard every day whistling in the bamboo-clumps and old paddi-plantations.

12th.-As the Dusuns weighed, selected, and bound up their packages last night, we are able to leave this morning at daylight; our destination is hardly known. Sultan is to accompany us and is to act as guide; he knows the way to the summit of Kina Balu (?). Billio goes as interpreter. I am leaving two Kadyans at the village to look after my baggage and collect what birds they can: oue is a Hadji; but his fingers are all thumbs, 
and no amount of teaching in the art of making up a bird-skin will do him any good. Jack also goes with us as camp watch-dog.

We started with all our porters but one, Kratas's husband; we, however, met him, and abused him for not keeping up to time. As all porters in Borneo receive their wages in advance, they are expected to keep to their part of the contract, and I must say always do, for though I have paid dozens of natives in advance, I have never once been swindled; if a man cannot go he pays over his wages to a substitute.

Our path led through a few rice-fields, then suddenly down a steep slope to the bed of the Panataran. The river was to be our highway, and a more trying, break-neck journey I have never made. The Panataran was fairly low, clear as crystal, and to us as cold as ice. The way was blocked by huge granite boulders, serpentine, and other rocky débris, some of the granite boulders being solid masses 15 feet high by 20 feet in length and breadth-as the Kadyans remarked, "as big as houses." Up this stream we struggled all day, at times through pools of clear cold water up to our necks; we were more often in the water than out of it.

The sides of the mountain were very steep and inaccessible in many places, making it impossible to avoid the course of the river. In places huge landslips had filled the river, almost blocking its course. I also noticed a good deal of shale. We had our mid-day meal on a small level space, when it commenced to rain; at this time all the Dusuns had kept well together. At 5 P.M., after traversing, if anything worse could be possible, a more trying country, I found myself drenched to the skin, with the Kadyans, the Chinaman, Billio, Sultan, and four Dusuns all in the same state, shivering and livid with cold, beside a large rock which afforded us no shelter from the steady downpour; the rest of the Dusuns far behind and Jack anywhere. By degrees the Dusuns began to arrive, but it was after dark before the last came in; Jack did not turn up that night. After opening a large waterproof sheet (used as a roof for our forest houses), which we propped up on sticks, we were able to put all the baggage out of the rain and change our dripping clothes. It was impossible to find wood for a fire, but we lighted our lamp and passed the night trying to sleep amongst the granite boulders in the course of the Panataran. Rain continued to fall steadily all night, and at times we were afraid the river would rise and swamp us out of our position. The next morning, after a meal of cold rice, the Dusuns again started up stream: about mid-day we arrived at a deep pool, flanked on both sides by precipitous rocks; this stopped all further progress, so we returned to a small level spot-out of the reach of floods - about a hundred yards down stream. Here, with the assistance of the Dusuns, we soon made a clearing in the forest on which to erect our house. After informing Sultan through my interpreter that he was a fraud, as he had promised to lead us to the summit of Kina Balu, which by this route anyone could see was an impossibility, the Dusuns returned with Billio to Melangkap and promised to call for us in a month.

During the journey here I had noticed a good many species of birds that were new to me, so I was not so much troubled as I might otherwise have been by this failure to ascend Kina Balu. When I state that at this camp were collected some fifteen new species of birds, besides many new insects, I have now reason to congratulate myself at our then 
apparent misfortune. Yesterday it commenced to rain at 11 A.M. and continued until 10 P.M. ; to-day it has commenced at mid-day, and rained incessantly until 8 P.M.

The Kadyans, and the Chinaman especially, do not like the idea of stopping here a month, as they are afraid of a spate, which might occur just about the time we want to return; but as we have plenty of rice and other provisions I do not mind. Jack turned up about mid-day very hungry, and without a claw that was not bleeding.

Owing to the height of the mountains around us, this camp receives no warmth from the sun until nearly 10 A.M., although we have selected the best place for catching the sun's rays. Usually at 11 A.M. the sky began to cloud over and a gentle drizzle set in, which developed into a steady downpour by $20^{\prime}$ clock in the afternoon, at times accompanied by terrific thunderstorms.

Sometimes the sky would clear again by 6 P.M., but more often the rain continued until 8 or 10 o'clock at night. The river, which flowed within ten yards of our house, was often in high flood, coming down with a sudden rush about 4 o'clock in the afternoon; but luckily we were out of harm's way, though the roar of the water at night, as it carried away the trees we had felled, made one feel rather nervous at times. In such an incessant downpour, with so little sunlight, the humidity was so great that we had to dry our clothes and collections by fires. All my insect-boxes, and anything fastened with glue, became unfastened, though kept in waterproof bags. My bedding I always had placed in the sunlight when possible, and rolled up, after the sun was clouded over, in a ground-sheet.

14th.-The Kadyans are busy finishing the house. Nyhan cut a path to the top of the hill behind, from which we have a splendid view of the huge buttress of Kina Balu and the jagged ridged range beyond. We are quite close to the buttress; the spur on which we stand is an offshoot from the main spur which runs close up to the foot of the precipices. Our collection to-day consists of Leucocerca albicollis, discovered to-day for the first time in Borneo, and two new birds, Hemixus connectens* and Staphidia everetti $\uparrow$; also a new squirrel, Sciurus jentinki. The spur which we explored to-day is for some distance on one side a sheer precipice, and then continues as a narrow rocky ridge, when an easier travelling ground is reached. This formation makes it almost impossible at times to retrieve the birds shot, as they often fall hundreds of feet down the mountain sides, the tops of some high trees being on a level with the ridge and only a few yards distant from us.

15th.-To-day some of the Kadyans started cutting a path up the mountain, on the opposite side of the stream, as yesterday, from the top of the spur visited, we were able to form some idea of the surrounding country, and in that direction it was decidedly less precipitous. Our greatest trouble in cutting paths is a small creeping bamboo, the stems of which are like wire and about the thickness of a lead-pencil. This bamboo is hard to cut, as it gives with every stroke of the "parang." I find that in path-cutting it is best to take three men and let them work two at a time for about fifteen minutes, then shift one by turns. To-day we reached an altitude of 3700 feet, and while slowly following the pathcutters, I shot a new Dicceum (D. monticola) with a bright rosy-scarlet breast. I also destroyed the only specimen I obtained on this expedition of a new Tailor-bird (Phyllergates cinereicollis), and procured two scarlet-breasted Nectarinias (Athopyga temmincki).

\footnotetext{
* Figured on plate facing p. 84 .

$\uparrow$ Figured on plate facing p. 96.
} 
The country over which we have cleared a path to-day is at first on leaving the river very steep and a mass of clean-cut sharp-edged granite boulders. Whenever the ground became more level and the soil was not washed away, the disagreeable creeping bamboogrowth smothered everything, reaching to a height of ten or fifteen feet above the ground. The trees on these slopes were often high, the most numerous and finest being a species of pine-the casuarina-from which the Dusuns collect quantities of damar. It rained yesterday and to-day as usual.

16th.- Sent the Kadyans to work again on the path on the opposite side of the river. I wandered up the steep path and shot three birds, two of which are new to BorneoPericrocotus montanus and Hemipus picatus. Kina Balu is, in a direct line, perhaps less than two miles distant and is a magnificent sight; but from what knowledge we liave of the obstacles to be overcome in the intervening country, I fear we shall never reach even the base of the mountain. The country on all sides is a mass of high forest-clad mountains, in places scarred by landslips, which have brought down avalanches of rock, cutting broad lanes through the forest-growth. These landslips generally take place where the casuarinas grow, the subsoil in those places being too poor for other trees. Round about our camp, where the ground is fairly level, the forest-growth is still tropical, nebong and other palms growing luxuriantly. The rain commenced to-day at 11 A.M. and continued until night.

17th.-The river is to-day a roaring torrent, so we are unable to cross to our path on the other side. It has never ceased raining since yesterday, and continued without intermission all day to-day, so we have spent a miserable time in camp.

18th.-The river went down considerably during the night, so we are able to continue with the path. I shot several birds on the hill behind the camp, two of which were new. This morning we have had enough sunshine to dry all our clothes and bird-skins. This sort of weather, however, could not last for long, so at mid-day we were treated to the usual downpour, and later in the afternoon the temperature became very cold. The Kadyans who had been working at the path on the opposite side only arrived in camp a fer minutes before the Panataran came down in full spate, owing to a deluge of rain on the upper part of the mountain. If they had not crossed in time they would have had a sorry night on the opposite side of the river.

19th.-As we have now two long paths over the hills, the Kadyans go out independently on hunting expeditions. To-day Nyhan returned with a fine new Flower-pecker, which has been christened Arachnothera julioe. The rump and crissum of this bird are golden yellow, the rest of the plumage striped with white and dark brown. As all other species of this genus are dull green-coloured birds, the new species is a very interesting departure from the colouring of the group. Small red leeches infest these mountain forests, and levy their blood-tax from the legs of the Kadyans. Several species of Nepenthes grow freely on the more open spaces near the tops of the ridges, and a very fine Cypripedium I found growing amongst the piles of loose rock on the tops of the hills. This species, of which I made a sketch, I am told is C. rothschildianum, the same species as is found in New Gunea; this to me seems too improbable. I saw also several other species of orchids; in one walk I noticed some five distinct terrestrial species in flower, and nerer before in the tropics have I noticed so many. Rain held off until 2.30 P.II. 
20th.-The only event to-day has been the capture of a new Flycatcher (Hyloterpe hypoxantha). The Chinaman is very unhappy: he sits, when the weather permits, on a rock gazing into the river, and has quite made up his mind that he will never see Labuan again.

21st.-To-day it did not rain a drop, being the first really fine day since we left the Tampassuk. I made a long expedition with one of the men, following our path on the opposite side of the river: we reached an altitude of 4800 feet, but saw no birds; orchids, however, were plentiful, several species being in flower. I also saw several nepenthes and a rich orange-flowered rhododendron.

2.2nd.-We had a long scramble down stream amongst the rocks in search of a Kingfisher, which was new to me; but we did not succeed in shooting one. To-day, while.after the Kingfisher, I saw a flock of small grey Hornbills, which flew very close together and settled side by side in the casuarina-trees : they flew over my head once, but I had no gun, or I might have added another new bird to the Bornean list. Though I saw this bird in small flocks on several occasions and heard them often, I was never able to procure a specimen, the nature of the country being such that the birds had only to fly across the Panataran and it would have taken a day to reach them. This Hornbill is probably a new species, allied to some of the small grey species already known. Rain in torrents after 2 P.M.

23rd.-Only four birds collected to-day; rain from 1 P.M. till dark. The Panataran in full flood.

24th.- TVent for a long ramble up stream. The Panataran a short distance above our camp flows past a steep cliff, which at its base is composed of green serpentine; the deep pool below it blocked the way for our Dusun carriers. With the assistance of some felled trees we were able to ford to the opposite side and climb over a high rock; beyond this the Panataran is fairly easy for some miles, though at times the rocks are so steep that it is necessary to traverse the forest on the hill sides. During the day I collected three specimens of a Green Bulbul, which I have often seen during the time I have been here, but did not shoot it, thinking it was a common species. On picking up the first specimen I saw at a glance that it was new to me, so I collected others. This bird turned out a very interesting new species, and has been named Phyllornis kinabaluensis.

The Chinaman in our absence shot a beautiful pigmy squirrel (Sciurus whitelieadi). This is an extraordinary little animal, being about the size of a large mouse, with a head too large for its body; the ears are ornamented with long tufts of grey fur, the rest of the animal being brownish yellow. I several times noticed this squirrel in the trees close to the camp ; it is somewhat inclined to be crepuscular, but is also active during the day. At erening time it utters many shrill squeaks, and bobs about on the trees like a cork on a string. (Figured on plate opposite page 196.)

25th.-To-day has been the grandest day for me since I took an interest in ornithology, and has brought to light the first specimens of the large green Cock-of-the-Rock (Calyptomence whiteheadi) *-the plumage of this superb bird being bright emerald-green, which shines like glass, picked out with jet-black markings; but of this species I shall have more to relate during my next expedition. We have also another fine bird for the first time,

\footnotetext{
* Figured in Frontispiece.
} 
Oriolus vulneratus ${ }^{*}$, with dark black plumage and a large patch of deep crimson in the middle of the breast, also marked on the wings with the same colour. This, though a very interesting bird, was of course eclipsed by the Calyptomena.

Five Dusuns came to-day from Melangkap to see how we were getting on. They say that they have been cutting a path for us to return to the village by, for if the river is high we shall not be able to return by that route. They brought us some coconuts and coarse cucumbers, which were very acceptable, for which they took in exchange my empty soupand other tins.

26th.-Last night was bitterly cold. The Dusuns left early to finish cutting the path. One of them before leaving made a small enclosure of sticks, in which we are to put all our empty meat-tins. The Dusuns were much taken with my kerchiefs, having never seen such fine linen; they were also much interested with my watch, and listened to the compass, which they found was " not alive."

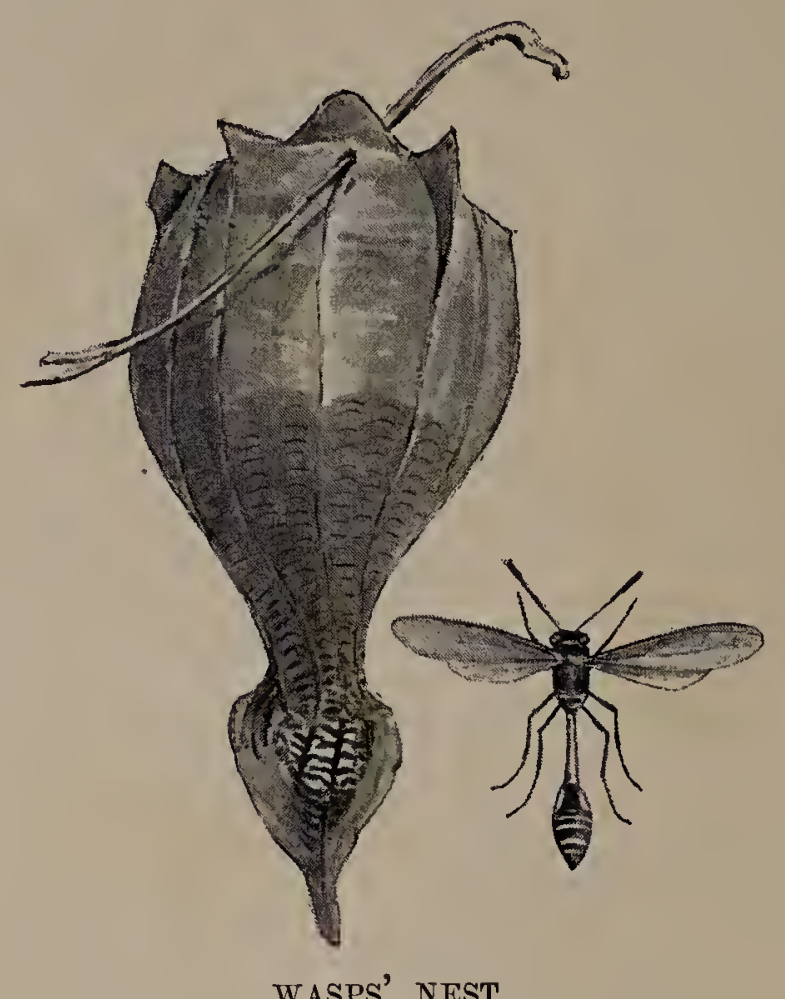

During the few hours of sunshine I was able to secure a few butterflies. Amongst them were four new species of Papilios, one very handsome species-P. stratiotes-being creamy white, and marked with two bright crimson spots just above the base of the tail. (opposite page, figs. 1 \& 2). But by far the most interesting species was a white-and-black butterfly, Appias whiteheadi (opposite page, figs. $5 \& 6$ ). This insect has the wings bordered with a broad margin of black. Its habits are, however, most peculiar: it flies up and down stream in small parties of from six to as many as twelve or fourteen individuals, each butterfly keeping exactly the same distance apart-about two feet. 'The procession plays a perfect game of "follow my leader." The first butterfly's flight follows closely the rocks, and it rises and falls to each obstacle met with; these movements are exactly imitated by the butterflies in the rear. The train is augmented by any stragglers,

* Figured on plate facing p. 146. 

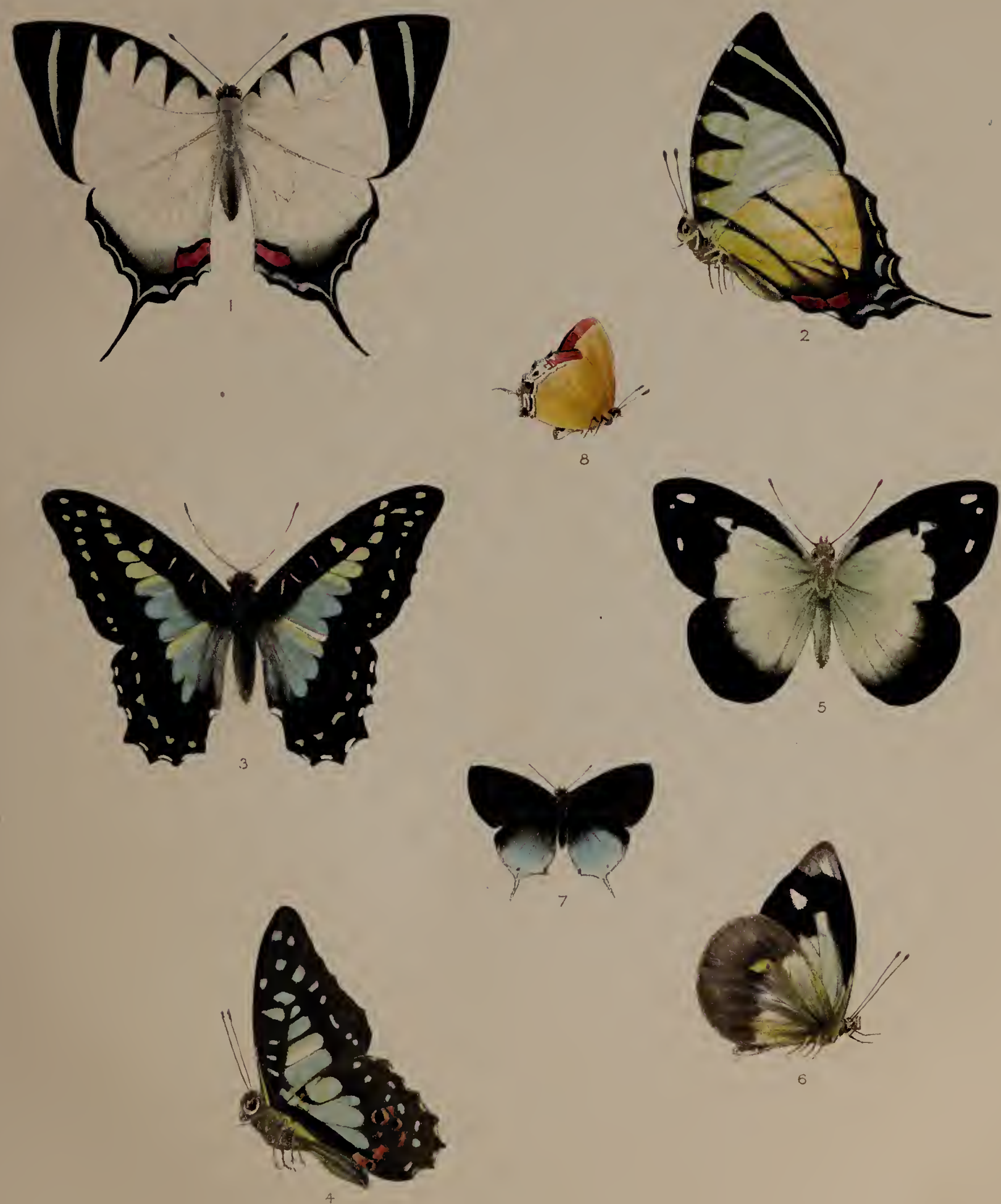

NEW BUTTERFLIES FROM KINA-BALU 

which take up their place behind the last insect. If the party flying down stream meet another coming from the opposite direction there is a collision, and both parties mount straiglit up in the air, swirling round and round, presently to break up into numerous small parties of three or four individuals, which proceed as before.

On this river I saw for the first time that beautiful, and at one time highly prized, insect Ornithoptera brookiana. Its flight is swift and flickering, the wings being worked very fast. This butterfly used to pass up and down stream, low over the rocks, nearly every day, and occasioually with other species would visit the neighbourhood of our camp, where the refuse was very attractive. If the weather had only been fairly fine, I could have made a large collection; as it was, I only captured about a hundred specimens, six of which were new. Hidden suspended amongst the roots of some large trees, the soil having been washed away by the river-floods, causing a large dry roofed-in chamber, I discovered several most beautifully designed wasp's nests. 'The nest, of which I give an illustration (p. 118), is composed of chewed wood; the comb, which contains about a dozen cells, is in the upper part of the nest, and, as far as my observations go, is attended by one wasp. The genus, Mr. Waterhouse tells me, is Ischnogaster, sp. ?

27 th, 28 th. - The event of the day was a visit from Billio, who brought with him six Dusuns. The object of this visit was to deliver a letter from the Assistant-Resident of Gaya, who was visiting for the first time for many years some of the Dusun tribes round about the mountain. Billio brought news of a fight that had taken place at a tamel just below Melangkap in the dry bed of the Panataran, in which a Kapar Dusun had been lilled by a Bungal man. The Dusuns of the two villages near Melangkap were in an excited state, and had collected together at Melangkap with the intention of attacking the villagers of Bungal ; but discretion overcame valour, and they disbanded without striking a blow. The following year, however, when I returned from Melangkap from Kiau, a small party, composed of the youth of three villages--Kapar, Teung, and Melangkap-were out on the war-path. After hovering round about the outskirts of the Bungal village for nearly three weeks, they returned to their homes without the desired head, and doubtless they will make expeditions. to that district once or twice a year until they are able to pounce upon some unfortunate individual of that tribe. I should think that head-hunting amongst the Dusuns could be easily stamped out; but to do this it would be necessary for the Company to locate a European contrôlleur somewhere within easy distance of these tribes, when their disputes could be settled before they led to bloodshed.

The native custom of fining those who have the balance of heads in their favour, and handing over the said fines to their enemies could, I believe, be carried out without the loss of a life and with very little trouble. The officer in charge formerly living in Abai has beeu removed, and an attempt is being made to govern the whole of this large district from Pulo Gaya, which is an impossibility, as the officer placed there has not sufficient time at his disposal to travel so far. Thus the Bajows of the coast have full scope for their cattle-lifting propensities, which canses frequent murders amongst themselves and bloodshed between them and the Dusuns inland. $U_{p}$ to the present the Kina Balu Dusuus have never had their affairs settled; a police expedition is merely a raid into the district, and as no officer is stationed in the country afterwards, little good accrues from such expeditions. 
At the present moment the Assistant-Resident of this district is making the first expedition to settle the quarrels of these tribes. In the 'British North Borneo Herald ' (July 1887) he gives an interesting description of his journey amongst these tribes and how the "Coast and Hill Dusuns laid their hands on the stone, swearing eternal friendship,"-the people mentioned being the villagers of Kiau, Koung, and Labong Labong, and, I presume, the Tawaran Dusuns. This officer was only in the district a few days, his primary object being to ascend Kina Balu, swear in the tribes, and settle how much poll-tax they were to pay the Government. After thus settling the tribal disputes, some Moharnmedan coast chief will be sent round perhaps once a year to settle all disputes and collect the poll-tax; as I have already given my opinion as to the placing of these gentry over Pagan tribes, I need not write further. I know, as a fact, that the very tribes which this officer visited, and settled their tribal disputes, made a head-hunting raid the following spring. 'Thus it is my opinion that Officials' visits once in five or six years are worse than useless, as they disturb the people for the time being; and it is impossible to expect semibarbaric tribes to wait for years to have their disputes settled, so the result is that they take the law into their own hands and frequent blood-feuds ensue. As the path is cut over the hills, Billio is able to return to Melangkap to-day, avoiding the break-neck journey in the course of the Panataran.

1st March.-To-day I have succeeded in shooting two birds which up to this have by their vigilance escaped. One is the Kingfisher already mentioned, which occasionally flies swiftly past our camp; the other is a curious fork-tailed bird, white and black, and turned out to be a new species, named Henicurus borneensis. The Kingfisher is a well-known species, Alcedo euryzona. 'This bird has been the cause of great excitement, as I thought it would be a nerv species. A pair used to pass our camp nearly every morning before it wis fairly light, so, to intercept them, I used to wait on a rock in the river, where the Chinaman used to bring me my early cup of chocolate, waiting for my little friends to pass; but I never could get a shot, as the bird altered its course into the forest on seeing me. One morning, however, I was eating my breakfast as usual with my gun ready, when a whistle warned me just in time to get a snap shot, when the cheers of the Chinaman told me that the bird was at last mine.

To-day the Kadyans brought in a handsome new Flycatcher (Stoparola cerviniventris), which I have figured opposite page 40 .

3rd.-The birds collected to-day are pair of fine Bamboo Partridges, Bambusicola erythrophrys, and a Cuckoo Skrike, Artamides normani, both new species. The Partridge is a handsome bird, and in the distribution of markings is somewhat like the wellknown French Red-legged Partridge,一the feathers on the flanks are beautifully marked with black and white, the general colouring is of a deep reddish fawn on the breast, the back being black and brown. This Partridge was rare and very difficult to obtain, frequenting as it does the impenetrable bamboo-jungle which clothes the slopes of these steep hills. It is useless to set traps, as the country over which it rambles is so vast. The three specimens collected by me were shot by the same Kadyan, and were the only ones obtained.

4th, 5th.-I have been busy making a sketch of the huge buttress-shaped end of Kina Balu from the top of the spur above the camp. During my sketching the formation of 


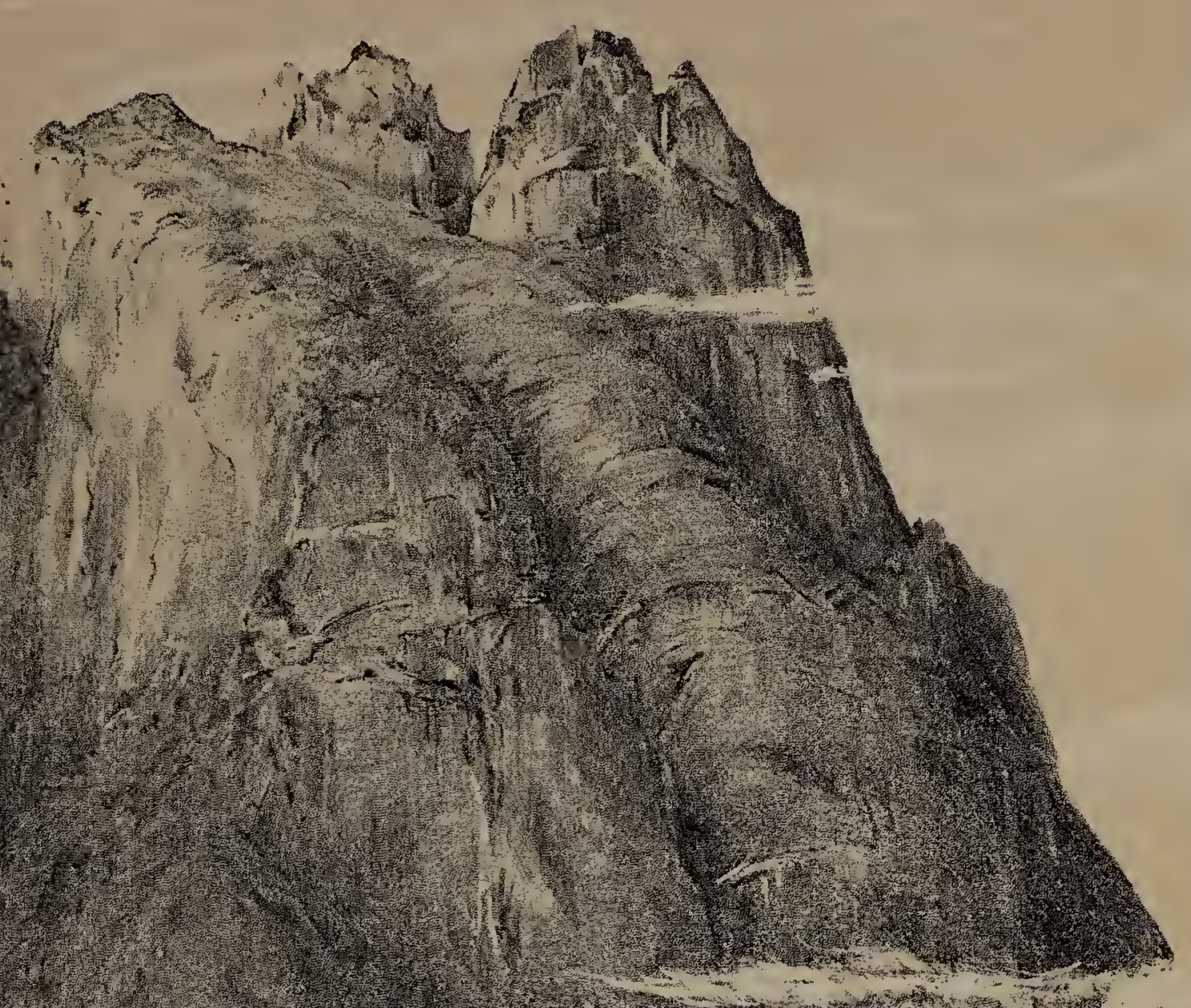

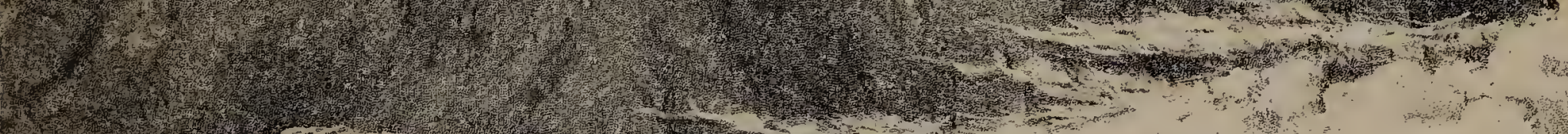

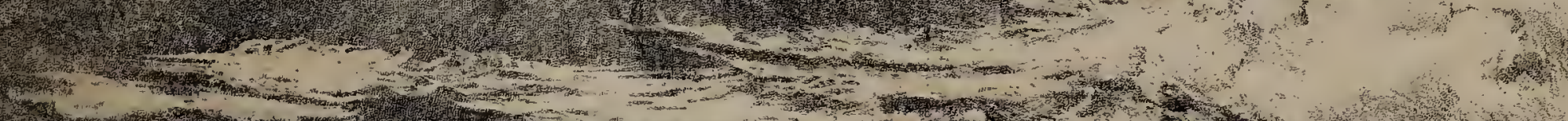

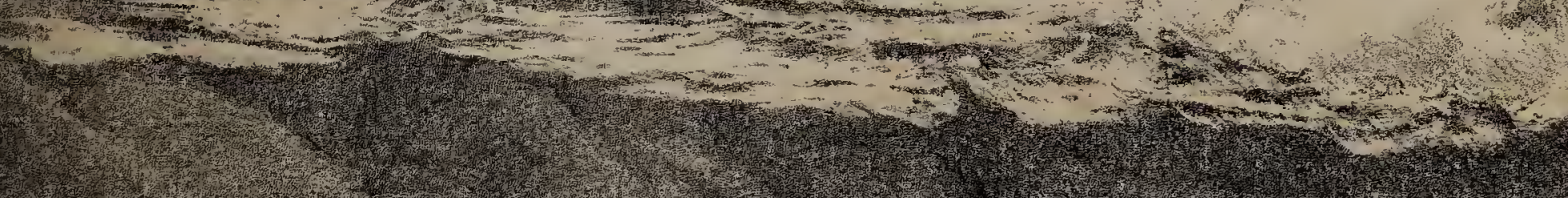

H.

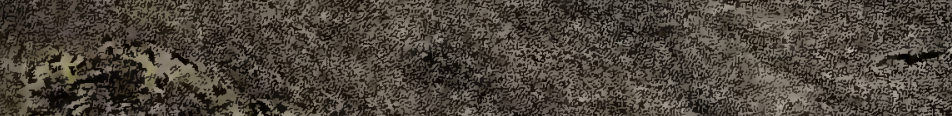

H.

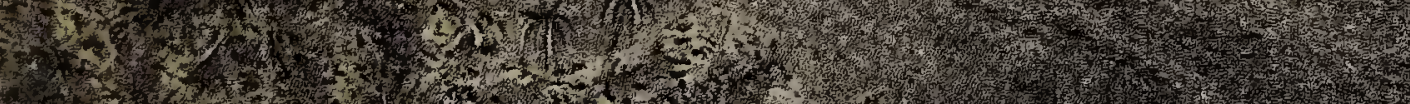

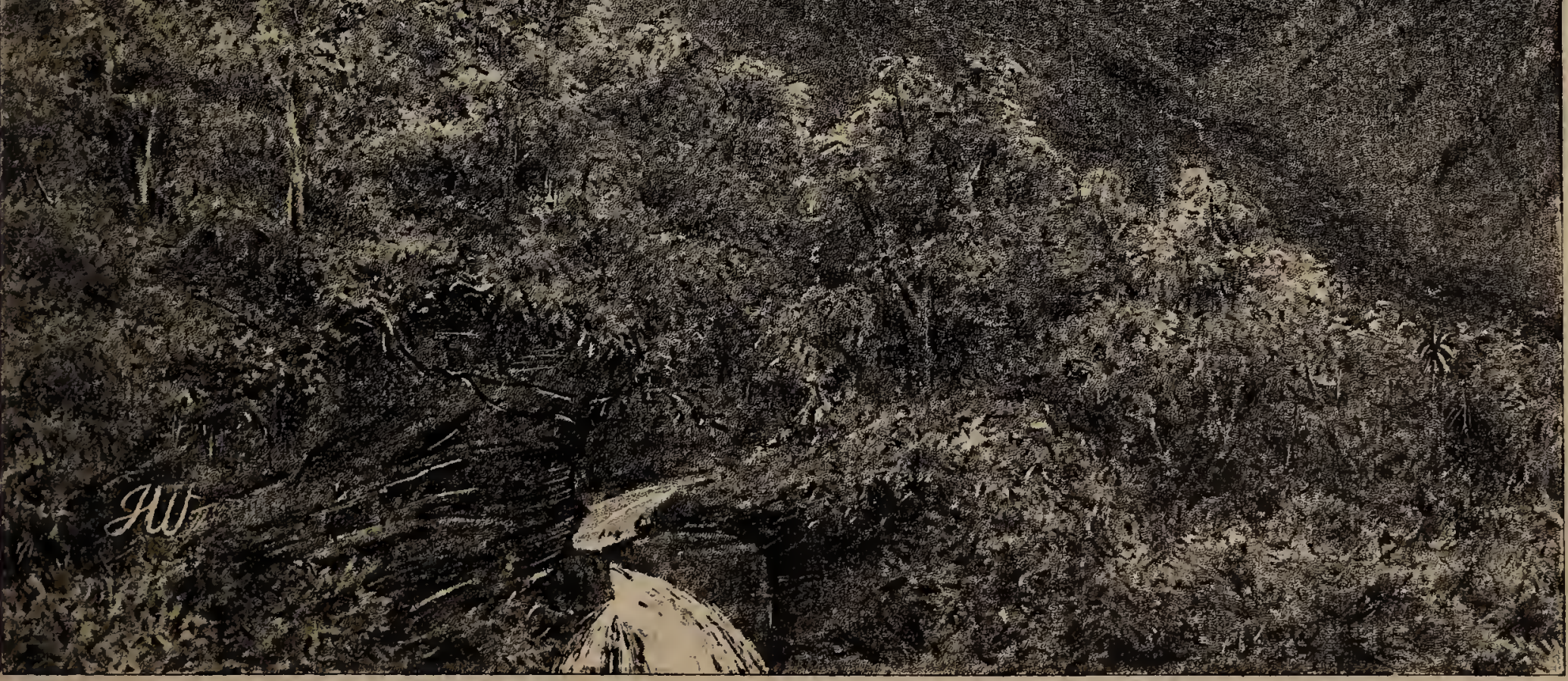

KINA-BALU. FROM NEAR MELANKUP. 

nebulous matter was beautifully illustrated by the clouds at the base of Kina Balu. " A hazy point barely perceptible-a little wreath of mist, increasing in volume and becoming darker and denser, until it obscures a bare portion of the heavens. It throws itself into fantastic shapes, gathers glory from the sun, is borne onward by the wind; and perhaps as it gradually came, it gradually disappears." Thus were the clouds being formed on the sides and amongst the ravines of Kina Balu, where, before mid-day, they had grown, spread, and enveloped the whole of this mighty mountain.

6th.-I have four specimens of a beautiful green-coloured bird to-day, Psarisomus psittacinus; though not new, it is the first time the bird has been recorded from Borneo. The plumage of this Boatbill is bright emerald-green on the back and breast, the chin is yellow, head black and separated from the back by a white collar of silky feathers, the tail being long and bright blue. The bill in this family (the Eurylomidce) is nearly always a wonderful piece of colouring; in some species of a delicate turquoise-blue, in Psarisomus it is all shades of bright green and yellow, but becomes black shortly after death, when the beauty of the bird is thus somewhat spoilt.

Five Dusuns arrived just before dark in the usual downpour, for though I have not troubled the reader with daily accounts of the rainfall, the weather has been no better. The Dusuns brought with them a quantity of damar, some bamboo-joints, a few strips of rattan, and some dried palm-leaves. They were busy until dark making torches, which they did by pounding the resin and filling up the bamboo-joints with the powder, first inserting a wick of dried palm-leaves ; after satisfying themselves that these torches would burn freelysome making two each-they proceeded to split the rattans and cut them into lengths of four feet. After all their preparations were complete they sat down and waited patiently until it was pitch dark-some searching for the empty meat-tins about the camp, for which they gave us a few vegetables. About half-past seven they lit up their torches and commenced a frog-hunt in the river: being interested in their movements, I followed these men some distance dowr stream. The frogs, or "Bunong" as these reptiles are called by the Dusuns, were to be found sitting on the rocks in the river, and remained perfectly still in the bright torchlight, when the Dusuns were able to secure them easily with their free hand. As each "Bunong" was secured he was threaded through the middle on the strip of rattan, until the length was filled; then another was ready. These men would arrive in Melangkap at daylight on the morrow, and with luck they would have several yards of threaded "Bunongs" all alive and kicking. The wretched frogs, after this most unpleasant treatment, are cleaned and boiled, and much relished by the Dusuns. What a scarcity of food! 'To think that these men would travel the whole night down the break-neck course of the Panataran in search of a few meals off frogs! I made several Bunong-hunts after this with the aid of candles, and secured several species of these reptiles: one species, Ixalus latopalmatus, sp. nov., is especially interesting; the feet being provided with large discs, with which it adheres firmly to the rocks. This frog frequents the rocks in the rushing waters of the river; the foot being highly developed, it is able to fix itself firmly to the rocks without danger of being washed away. Another new species thus collected was a very long-legged frog (Rana whiteheadi): some small reddish-coloured toads, Bufo leptopus; these the Dusuns avoided, saying that they were poisonous. The Dusun, I 
always notice, turns up his nose and makes grimaces when discussing any animal that he cannot eat.

7th.-To-day one of the Kadyans brought in three curious birds; they have been placed by Dr. Sharpe in a new genus, Chlamydochara (sp. jefferyi). The plumage of the male is light pearly grey, with a broad black band on the upper part of the breast; throat and forehead ochreous yellow; wings black. The female is marked the same, but the general colouring is brownish ochre. This genus is an interesting addition to the family of Carpophagidce.

Sth.-The only event of the day has been the collecting for the first time in Borneo of a Shrike-Tit, Pteruthius xralatus.

9th, 10th.-The Panataran has been in high flood all day, and is the colour of coffee. Our food is getting short, which is rather alarming, as the Dusuns and Billio will find great difficulty in reaching us.

11th.-River still in high flood; rice stock getting very low. To-morrow I have resolved if possible to send three of the Kadyans back to Melangkap. Three Dusuns came in before dark; they want to go to the head of the stream to visit a cave for birds' nests, but as the river is too high they cannot go any further. I have to-day a very interesting bird, Tarsiger hodgsoni, hitherto known only from the Himalayas.

12th.- Sent off three Kadyans with a Dusun and a load of birds' skins to Melangkap. The river fell a foot in the night, but during the day it rained heavily and drizzled during the intervals, so we were unable to leave the camp, the two Dusuns spending the day with us. There are several small caves in the neighbourhood of our camp, formed, not by the agency of water, but by huge rocks which have been displaced and fallen from the slopes above, thus forming caverns. I have read several accounts of the caves found on Kina Balu, but in the true sense of the word there are none, those mentioned being merely huge rocks that have become displaced and remain tilted in such a position as to form a shelter. The well-known cave near the summit is merely a collection of rocks that have tumbled together, forming a good-sized apartment. The caves in this neighbourhood are frequentèd by dozens of small black Swiftlets, Collocalia linchi. Though I see numbers of Cypselus infumatus flying about in the evening, they do not nest in these holes.

13th.-The Dusun porters arrived soon after mid-day; the river, though still unpleasantly high, will, they think, allow of our return to-morrow, as we are to follow its course for a short distance only, and then strike the path which they have cut for us.

14th.-We left the camp at 7 A.M., after having risen early and packed up the waterproof roofing, cooking-utensils, \&c., \&c.; it always takes quite an hour packing up the camp necessaries that you are unable to put up the night before. When we succeeded in reaching the path, after many plunges into the cold waters of the Panataran, we found this much-talked-of path was hardly worthy of the name: most native paths over these hills are little better than those which the wild pigs make for themselves. Where the bamboo-growth is thick, the Dusuns burrow a tunnel through it, which is most trying to the traveller, who has to walk doubled up, the tough bamboo twining round his legs and neck. This path led up and down the spurs, and it was not until nearly 3 o'clock that we reached Melangkap, 
utterly exhausted. Thus to-day we have accomplished in a few hours the same distance, over a slightly less trying country, which under the Sultan's guidance took us a day and a half.

The Thumb-Hadji left in charge of my baggage has collected a number of birds, but all are badly skinned. There are, however, two specimens, the only ones as yet obtained, of a new Sparrow-Hawk (Accipiter rufotibialis).

15th.- The whole day has been passed by us bartering with the Dusuns for rice, and in the end we only secured sufficient for seren days, and this at an exorbitant price, so after this is finished we must return to the coast.

16th.-The Melangkaps are anxious to make brothers of our party, and are going to sacrifice a cow to celebrate this occasion. Their object in doing this is to make us, by accepting their gifts of food and returning other like presents, vow always to be friendly with the tribe, and in our absence never to do them any harm. Strange as it may seem, the aborigines of Borneo believe that people have power over each other though separated by many miles. This of course was at one time, and is even now, the belief of the ignorant even in enlightened England.

17th.-The Dusuns killed the cow to-day, and presented us with one of the legs: they have also given me a quantity of rice, every household in the village presenting us with a small quantity. When the evening meal came, I ate my beef and rice surrounded by all the chief men of the village; I also had to drink some of their disagreeable "tuak." In return I did my best with the small stock of provisions at my disposal, but I had still two bottles of "Three Star Brandy," which could not have been more appreciated. Before the feast was over, several of the Dusun nobility were intoxicated; when they shortly afterwards started for their homes, they returned, only to start for their homes again. Later in the evening we were visited by the young men and women of the tribe, when several youths performed their monotonous dance. The success of the evening was Billio's performance, which delighted everyone, and it was not until nearly midnight that the festivities came to an end.

The only unpleasantness caused by these festivities was that $I$ received on the $22 \mathrm{nd}$ March a letter from the Assistant-Resident, on the day he left Tambatuan for the coast, in which he said that he had heard that we had eaten the Company's poll-tax cow, and he thought that my men had been imposing on our Melangkap friends by pretending that we were North Borneo Company's officials. This gentleman also advised me to cut their wages, as the value of the cow would go to our debit when we returned to Gaya-and civilization. As the Melangkaps had never once received a visit from any North Borneo Company's official, I failed to understand how the defunct and devoured cow belonged to the Company. I am sure when travelling in North Borneo I have always been most careful to let the aborigines know that I had no connection with the Company whatever, as I imagined by doing this I should meet with a better reception than if I posed as one of the Company's officials. However, on receipt of this letter I called a meeting of the head menthe knights of the three-stars-brandy brand,-and through Billio the interpreter I asked them whether they gave us that cow's leg believing that we had any connection with the Company; to this they replied they sacrificed the said cow to bind us as their friends, and that we were "Orang Labuan." After all, a cow's leg is not a very serious loss. I should have refused to pay the Assistant-Resident for any other portions, as the Dusuns ate the rest. 
I remained in Melangkap until the 7 th of April, not being able to make any more expeditions to the mountain, as I had barely sufficient cloth to pay my way to the coast. So I sent Nyhan and two other Kadyans to the village of Teung, where they remained a few days, collecting specimens of Dendrocitta cinerascens, and one specimen of a Timeliine bird, the only one obtained in Borneo (Stachyris poliocephala). They also procured a pair of Pitta arcuata, one of the handsomest species in this genus, and that is saying a good deal.

Our relations with the Melangkaps were most friendly; they visited us nearly every day, generally towards evening, after the day's work was over. The young women, Kratas especially, took a great interest in my Chinese servant, who, I may mention, is a very handsome Chinaman. Kratas flirts so openly with him that her little boy of a husband is getting quite nasty, and one evening insisted on sitting in our private apartment, from which at last he was forcibly ejected by the Chinaman, who is very powerful. This so upset the youth, that in future he always came armed, with two or three of his friends, and I believe with little provocation these youths would have attacked the Chinaman.

We made daily expeditions to the forest near Melangkap and collected many good birds, including Rubigula montis, Harpactes orescius, and the female of a new Trogon, since named Harpactes vidua; the male of this species up to the present has not been discovered. On the evening before we left, Nyhan secured a pair of a beautiful little green Finch, Chlorura borneensis (see illustration facing p. 96).

I now exchanged most of the things I did not want to take back with me with the Dusuns for food. Meat-tins still fetch a good price in exchange for vegetables, but tins that have good lids are much valued : a few small medicine-bottles being highly prized, so much so that the following year I brought a few dozens with me. ,

It was with great difficulty that I was able to find enough goods to pay the Dusuns to carry our baggage to the coast; but with old clothes, tins, bottles, and other rubbish I was able to satisfy the porters. On the evening of the 6 th of April the porters were paid off and their packs tied up, which now consist of light bulky parcels of bird-skins. I left a few pounds of shot with a Dusun, which he faithfully took care of and returned to me the following year.

The next morning the whole village remained at home to see us start, and many were the salutations of "Passi passi!" ("Good-bye!") we received on starting; and we promised to return the following year.

The Dusuns carried my collection to Billio's village on four buffaloes : one of the men, being evidently a new hand on buffalo-back, fell off four times, and arrived at our restingplace for the night a mass of mud; his buffalo sat down in the river at each crossing, so the old man in his rage drove his spear through the animal's ear. We took a short cut across the hills after fording the Panataran some distance below Melangkap, and in the evening were far on the other side of Ghinambur. The river was much higher than when we came, and at two fords the Chinaman got into difficulties. The dog Jack became quite clever at crossing the river, and would go well above the ford before attempting to cross. With a little more water the Tampassuk would have been unfordable. I often thought when travelling along this river what an excellent trout- or salmon-river it would make, some of the pools being perfect for casting. 
On the evening of the 9 th we arrived once more at the Bajow campongs, where $I$ had my birds carefully dried, as some were wet from the frequent immersions in the Tampassuk, though carefully packed in waterproof bags. Here I purchased a large canoe-shaped boat, or, as it is called by the Bajows, a "pakarangan," in which we paddled down the Tampassuk and sailed round to Abai, where I had left a few provisions and some boxes, in which we repacked our precious birds.

The next morning we sailed for Pulo Gaya. Billio accompanied us, as he wished to invest his wages in trade-goods and also to visit Patatan; he had a sharp attack of junglefever during the night, so had to be looked after. The next morning, before daylight, the sea became rough, so we had to paddle hard for the mouth of the Menkabong river, and steered safely into the somewhat dangerous entrance. The wind blew half a gale during the day, so we had to pass our time in idleness on the sea-shore. Towards evening the wind moderated and the off-shore breeze sprang up, so we set sail, and before morning had rounded the dangerous headland into Gaya Bay, where dozens of Frigate-birds were busy fishing round about the islands there. The view of Kina Balu in the bright silvery moonlight, as seen from the sea, is superb; and these nights, calmly sailing down the coast, are perhaps the most enjoyable part of a naturalists travels. After resting during the heat of the day in Gaya, we proceeded on our journey to Labuan by the Kilias and Mempakol. We reached Labuan in a week from the Tampassuk, having frequently to take refuge in the estuaries of the rivers during the, at times, violent winds. My Chinese ser rant was seized with a violent attack of fever two days after reaching Labuan, and could hardly stir for three days. I rather benefited by the change to the cooler mountain climate.

The results of this expedition were most interesting to naturalists, as this was the first collection of importance from the highlands of Borneo, and was sufficient to prove the close affinity that exists between the fauna of highland Borneo and the great Himalayan chain, leaving little doubt that Kina Balu has received its ornis from that great region. But though the results of this expedition were beyond my anticipation, I was by no means satisfied, for though we had collected amongst the highlands of Kina Balu, we had utterly failed to reach the higher altitudes of that great mountain.

For information concerning the collections made, the reader is referred to the papers, by eminent specialists in zoology, at the end of the volume; but I hope I shall be excused for giving a short summary of the results of this, my first expedition to Kina Balu.

We were away from Labuan from the 25th January until the 16th April, of which time eight weeks were spent in bird-collecting in the neighbourhood of Melangkap and amongst the mountain spurs. During this period we collected some 300 birds, eighteen of which were new to science, and many others added to the ornis of Borneo for the first time. 'The Calyptomena and the Arachnothera would have been a sufficient reward in themselves. Besides birds, I had several new mammals, including two new squirrels and several rats. There were also four new reptiles-a Draco, a snake, and two new frogs; and six new butterflies, four of which were Papilios. During the month spent by us amongst the defiles of Kina Balu we were greatly hampered by the almost incessant rain, not liaving more than three really fine days and many entirely wet ones. The time during which rain fell-roughly speaking-averaged seven hours per diem. With fine weather our collections, especially of 
insects, would have been larger; but I do not believe that fine weather ever occurs for any lengthened period in the vicinity of this mountain, Kina Balu's great height being sufficient to attract all the rain in its district. With good food one would be able to do more, but half-starved, living on tinned provisions entirely, in this miserably damp climate, hemmed in on all sides by the steepest and roughest of mountains for our collecting-grounds, it took no little persuading and bribing, by the gathering of some of Nature's prizes, to keep my energy and spirits up to the mark. I am sure the Kadyans, who were not buoyed up with the keen interest in the collections being formed, had a most miserable time of it. Several of these men had been with me a considerable time; by treating them with kindness and consideration I always found them willing to do their best to please me, though towards each other they are excessively selfish. On arriving at a village I have seen two men drink the contents of a large coconut, while a third, equally thirsty, would not be offered a drop, though these men had been travelling companions for months: this is the sort of good fellowship that exists amongst natives!

By this expedition I was able to gain a great deal of information as to the necessary goods required for barter; I also assured myself that to be successful it would be indispensable to carry a large stock of rice from the coast, as it was impossible to provide more than one or two mouths with rice obtainable in the villages. Having once succeeded in getting the coast people to carry my baggage, I was also the better able to arrange with them the following December. In concluding this chapter I beg to commend the small Grey Hornbill to the attention of future travellers, for, although I made another expedition up the Panataran the following year, I never once saw or heard this bird again. The male of IIarpactes vidua is also to be found in this same district, and would be an interesting discovery. 


\title{
CHAPTER VII.
}

\author{
THE GEOGRAPHY OF PALAWAN. — SULUS. - TIIEIR CUSTOHIS. — DUSUNS. — ORANG-UTAN. - THE \\ 'ROTALIST.'-BALABAC.-TAGUSO.-THE STORE.-CHINESE.— SULU THIEVES.— TRADE.—TR.DE \\ RELATIONS BETWEEN SULU AND DUSUN.-THE RANEE.-BIRDS.-A TROPICAL FOREST.-INLAND \\ DUSUNS.-THEIR CHIEF.-BLEGI.-EXPEDITION INLAND.—SLAVES.—TWOSSONG'S VENDETTA.- \\ RETURN TO BLEGI.-MEGAPODES.-HEREDITARY RESEMBLANCE OF BUTTERFLIES.-MIMICS AND \\ THEIR SURROUNDINGS.-CUCKOOS.-RETURN OF THE 'ROYALIST.'-VISIT THE NORTHERN COAST.
}

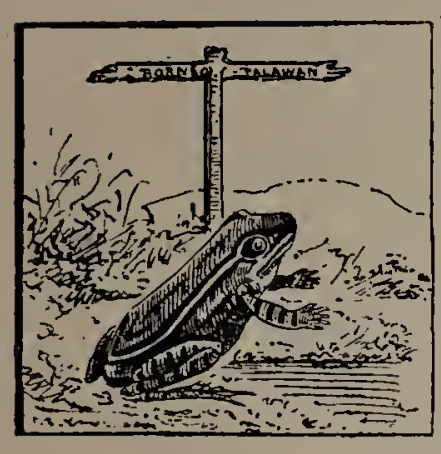

HE Island of Palawan, Palaúan, or Paragua is situated some 90 miles to the north of Borneo. Geographically speaking, Palawan belongs to the Philippine group, being, like those islands, of later volcanic origin. Its fauna, however, has been received from both Borneo and the Philippines, and the greater proportion of its zoological productions have undoubtedly been received from the first-named island. This has been carefully demonstrated by Mr. A. H. Everett, in a paper read before the Zoological Society (April, 1889). Thus we may conclude with a fair degree of certainty that Palawan has been, at some time or other: during the world's history, joined to Borneo and perhaps also to the Philippines, and for a considerably longer period formed part of the great island of Borneo.

Palawan is about 275 miles long, the breadth varying from 6 to 26 miles. To the north it is connected with the Philippines by a collection of islands-the Calamianes. To the south the islands of Balabac, Ballimbangan, and Banguey may be mentioned as the connecting-links with Borneo. The depth of the sea at the southern end is only 100 fathoms, while at the northern extremity a deep channel of 722 fathoms divides Palawan from the Philippines.

The coasts are dangerous to navigators, being a network of coral reefs, over which the sea often breaks. These reefs rise like walls from the bottom of the sea, deep channels often running in close to the shore.

Through the centre of Palawan run ranges of volcanic mountains, none of which, however, are active. The alluvial washings from these mountains have formed extensive plains on the southern coast; but the plains are not so great on the opposite side, where the mountains at times rise from the sea-coast: this is to be accounted for by the violence of the China Sea, which breaks with full force on this coast.

The plains that extend in some places on the southern coast to a distance of four or 
five miles before the base of the mountains are reached have been formed chiefly by the agency of coral reefs. The country directly behind Taguso is level for about two miles inland, where a sudden rise of about twenty feet takes place, when another extensive plain stretches to the foot of the mountains.

Land-making in Palawan is carried on to a small extent by the mangrove-swamps, which are unable to stretch out to sea, chiefly owing to the coral formation around the coasts-these great land-makers being unable to do much, except in protected bays or straits, where the mud collected is not washed away by storms. The great makers of these plains are the small rivers, which do not build up land so much by their fluviatile deposits, but chiefly through the opposing action of the sea itself. To explain my meaning the better I have drawn the accompanying diagram.

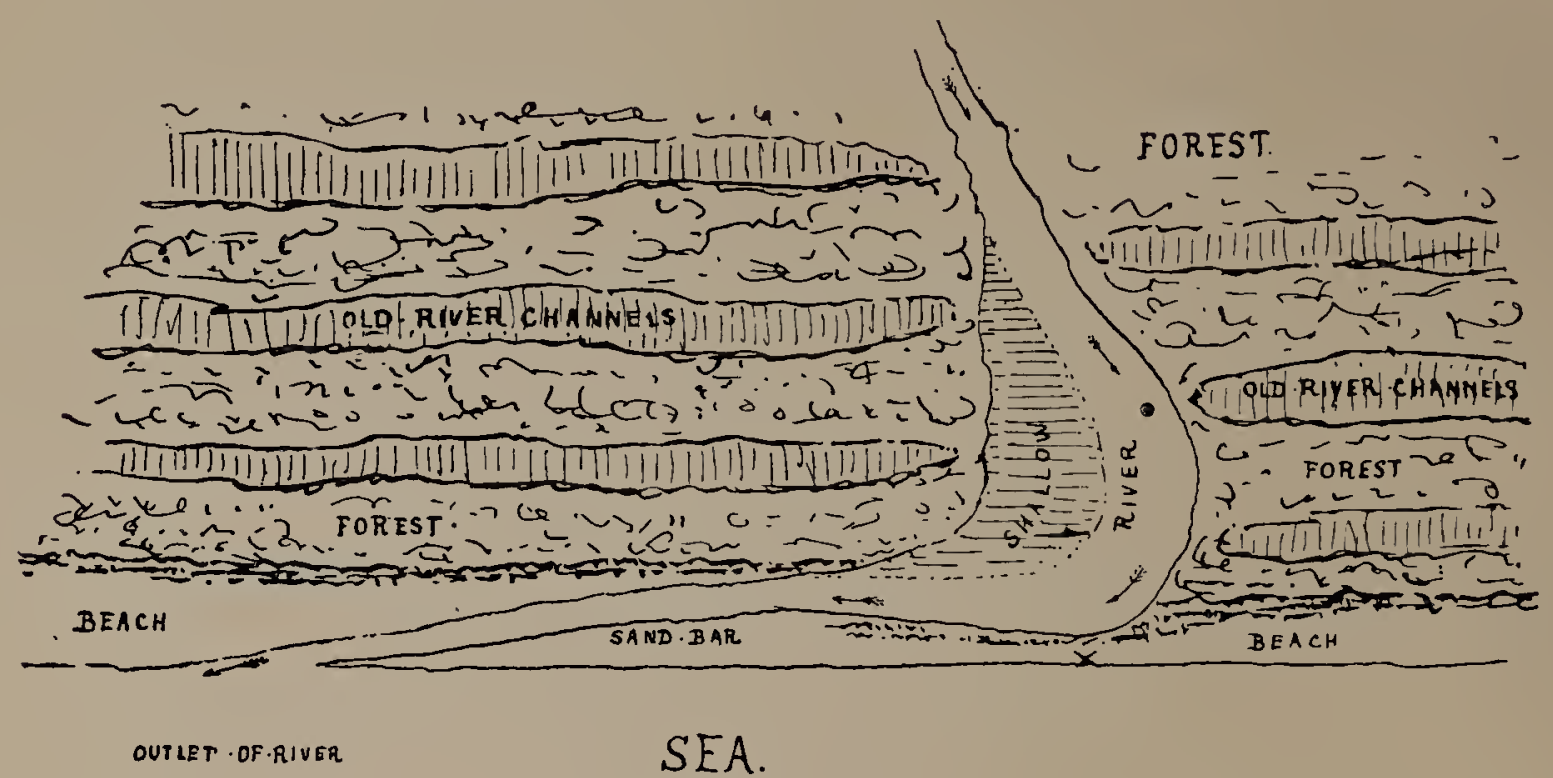

The river flowing in a direct line into the sea meets with the opposing waters, and by this action a sand-bar is formed directly across the mouth. The course of these rivers being short, for the greater part of the year the force of their flow is small, so that the bar is formed close to the shore, unlike the great Bornean rivers, where the bar may extend several miles out to sea. This bar once formed, the river's force is insufficient to disperse it, so it gradually increases, by sand and coral débris thrown up by the sea and by an occasional tree-trunk. Soon the river's course flows to the right or left and runs parallel with the bar; the force being insufficient to keep open two mouths, the unused channel gradually becomes blocked. The river gradually increases its length, running parallel with the bar, easily cutting away the sandy shore against which its course is now directed. Meanwhile the further extremity of the bar has become joined to the mainland, and shortly supports a vigorous vegetable growth of plants and shrubs especially adapted to the shore. Amongst these plants I must especially mention a long rope-like stemmed convolvulus with pretty pink flowers-the runners of this plant attaining a length of 30 yards or more, rooted here and there along their length in the sand. When once such a growth becomes established, our sand-bar is substantially strengthened. In the meanwhile the bank, at the point where the river formerly debouched, has been gradually weakened by the 


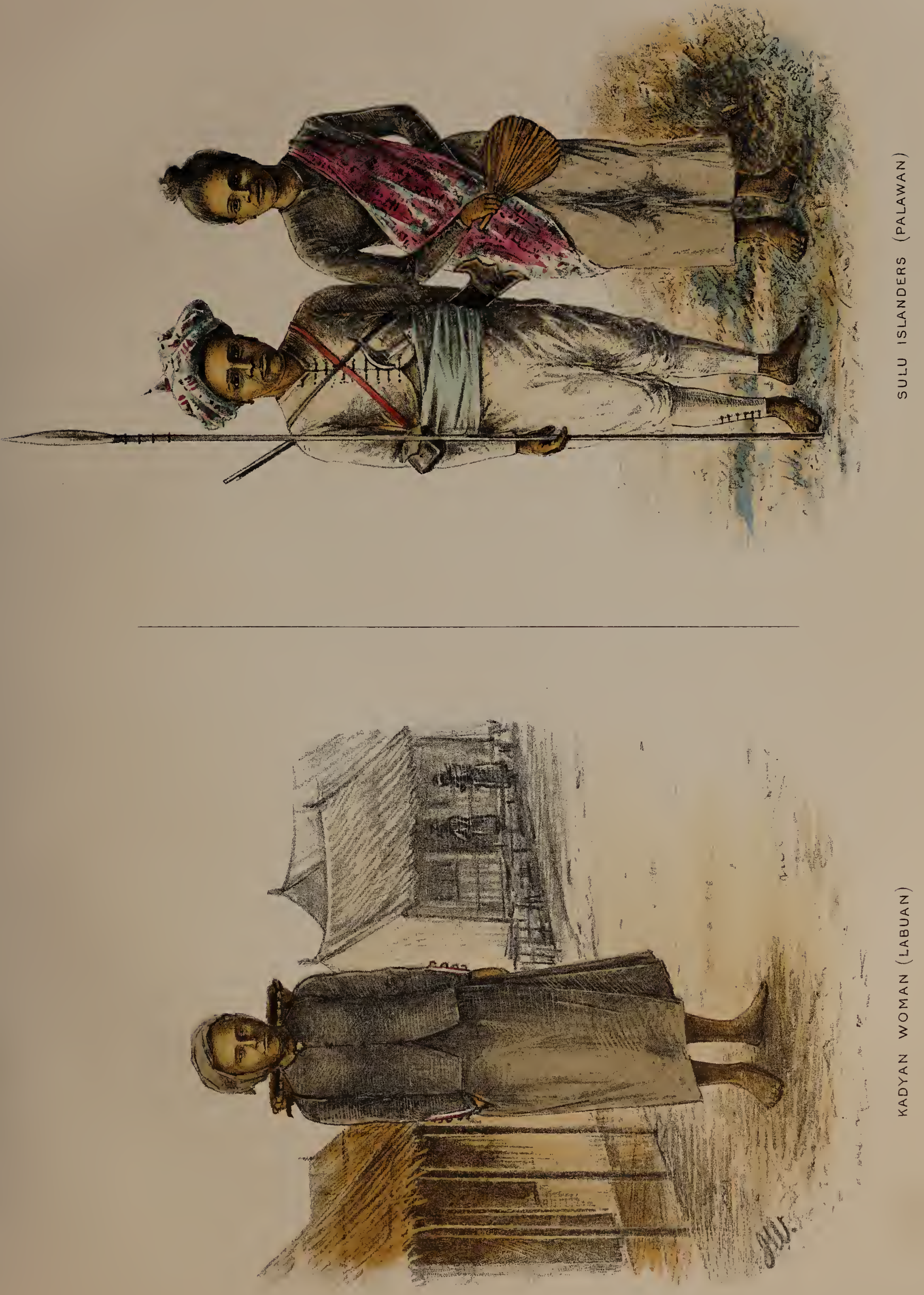



swirl of the waters past it, and a large pond has been formed by this action; the opposite side has become shallow and silted up by disuse. When the first flood comes down with a rush, it breaks through at the weakest point (marked $x$ ), which is the worn-away bank directly in front, and once more the river runs straight out to sea. The old course along the sand-bar is now strengthened by the vegetable growth, numerous trunks of trees, and other drift washed up by the sea, and, being no longer used, is gradually blocked up by vegetable débris and reclaimed by the forest. These operations are continued as long as the coral banks make the sea sufficiently shallow. Series of shallow depressions may now be counted hundreds of yards inland; those still further arway from the sea have long since been blocked by alluvial deposits washed down from the mountains, and now support a tropical forest growth. Large ponds of salt water may occasionally be seen divided from the sea by a few yards of sandy beach: these have been formed by the rivers, and are probably the result of a longer period elapsing before the river burst through the sand-bank; thus the pond is greatly enlarged.

Coral rock may be found below the subsoil some distance inland at the depth of a few inches. The highest mountain in Palawan is near the southern extremity of the island, and is known as Kalamutan by the Sulus; the altitude is given in the charts as 6500 feet; a sketch of this mountain I have given, showing its undoubted volcanic formation. The sea-coast is bordered by a fringe of forest, which has been left by the Sulus to break the force of the wind; belind this fringe are clearings for rice-cultivation or lalang-grass covered plains ; beyond are the mountains, mostly covered with forest at the summits, but cleared by the Dusuns where the slopes are easy.

The southern end of Palawan is inhabited by two races-the Sulus and the Dusunsa subclass of the Sulu (the Orang Sungei) and of the Dusun (a wandering forest race which is unnamed, equivalent to the Jakuns of the Malay States or the Peluans of Borneo). First let us discuss the Sulus. This race of people inhabit the coast, and are mostly emigrants from the Sulu Islands, from whence they have flocked to the south-western part of Palawan, being one of the few places left where they can live-as I shall presently show -without exertion, and where murderers and thieves can brave the sun's light. At the time of my visit (1887) the Spaniards had no forts or "Contrôlleurs" for some sixty miles east of 'Taguso, and Sidanow on the opposite coast was their most western point, so that beyond these limits the Sulu dwelt undisturbed by law and order. The Sulu is well built and wiry, though short; his complexion is much lighter than other races in the Archipelago. His character is treacherous, making one always doubtful of his intentions, whether friendly or otherwise; but he is, as a rule, polite, and a pleasant fellow to meet. Several Sulus in Palawan did their best to assist me, one man especially doing a great deal for me; but these are the better class of Sulu, often the sons of the old nobility. The most objectionable class of Sulu are the slaves and retainers of these men : they are often the offspring of the Orang Sungei, and are of a swarthy complexion, some being, like the Bajows, nearly black. 'These men are nothing more or less than a swaggering lot of cut-throats, whose hands are on their "barongs" the greater part of the day; they are rank thieves, and are quite willing to back up their thefts with murder. The Sulu costume is decidedly original: their garments are generally made of good yellowish-coloured cloth, and often of gaudy silks or satins. 
The jacket is short, with very tight sleeves, and ornamented down the front with cross braids and buttons, which are often of gold. Their trousers are either of the loose Chinese pattern or of the Sulu cut, which is decidedly peculiar. The seat is enormously bagged and contains enough material for another pair; below the knee they are as tight as they are loose elsewhere, buttoned halfivay up the outside of the leg, and barred with black stitching. Round the waist is wound in many folds bands of gaudy-coloured cloth, the object of this being as a protection from each other's "barongs," which weapon is nothing more or less than a butcher's cleaver. A turban completes the dress of the Sulu, which is

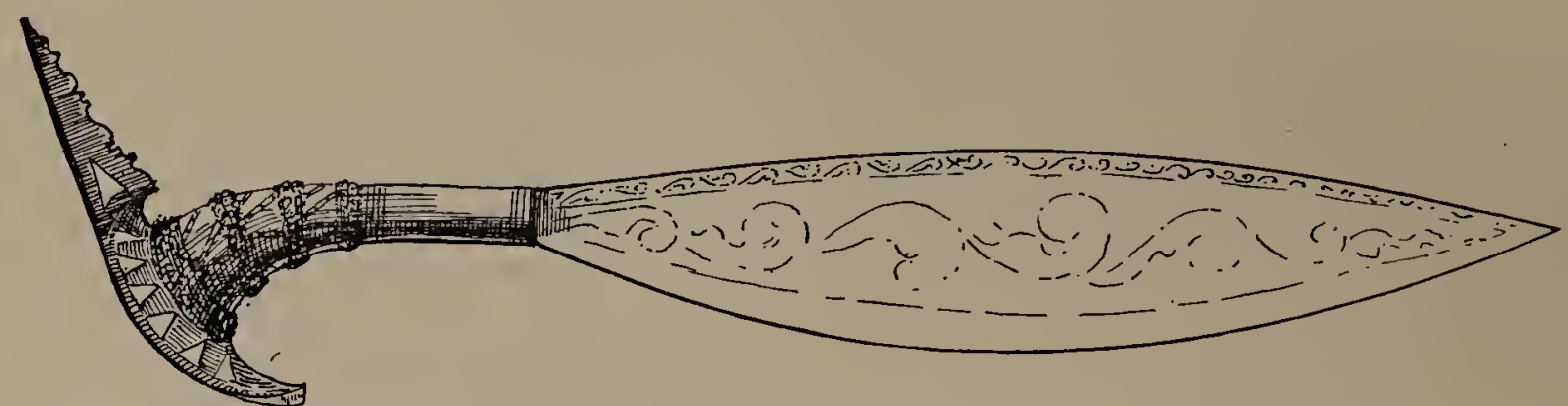

SULU BARONG.

often a Battak head-cloth, worked by the women in silks. The Sulu is such a treacherous scoundrel himself, and has generally a vendetta hanging over him, that he imagines everyone he meets to be the same, and consequently is never seen without his weapons, which consist of an enormously long heavy spear, a barong, or kris, and often a Snider rifle or a revolver. In Taguso I never met a Sulu unarmed, and in their own houses they either wear or murse their " barong." Such was the state of Sulu society in 1887.

'The dress of the women consists of a tight-fitting short jacket and a pair of loose trousers; a sarong is generally worn over one shoulder. All these garments are made of the brightest of colours; and as many of the young Sulu women are very pretty, when dressed in their best they are by no means to be despised.

'The Sulus generally congregate in small villages; these villages are compact, as the inhabitants live in a perpetual state of vendetta with others often living but a few miles distant. Slaves are kept by all the better class, are generally seized for debt, and are often Dusuns.

The Sulu is a Mohammedan, and buries his dead in small cemeteries some distance from the village. The accompanying sketch is of a Sulu grave-yard in Palawan. The graves are raised about a foot from the ground, the sides being built up with rough timber. The curious round bottle-like head-pieces are made of wood and are used for men only, and are probably a modification of the Turkish Turban Head-stakes-the head-pieces for the women's graves being flat. In the centre of my sketch is a rather better class of grave, this belongs to a Sulu noblewoman. The mosquito-net in the distance is hung over a fresh grave, the custom of the Sulus being to hang the departed's "Colombo" over his last resting-place.

'The Orang Sungei, as the Kadyans called the half-cast Sulu Dusuns, are settled on 


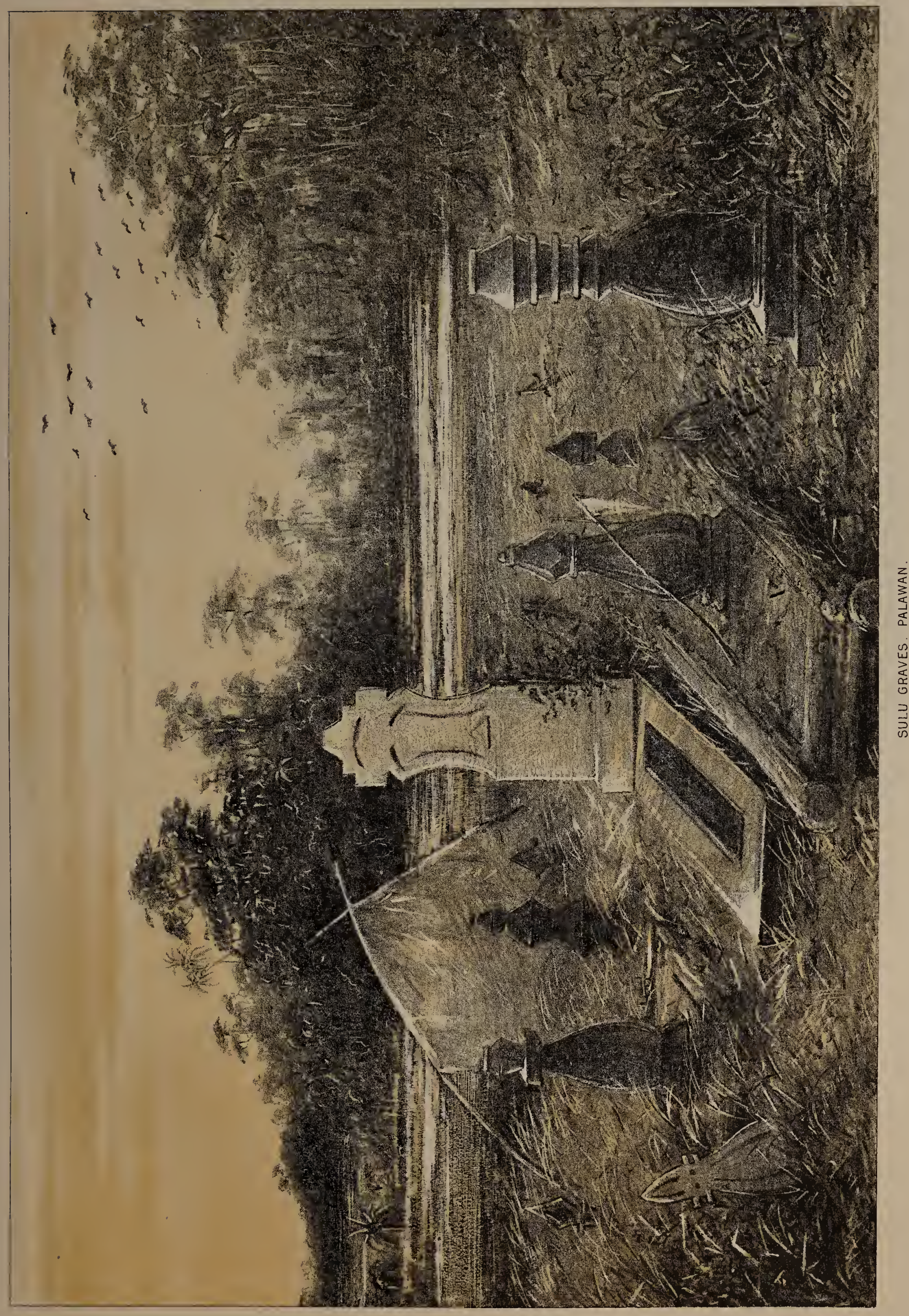



the various rivers, and are, like the Sulus, Molrammedans. They work larder than the Sulu, not having the trade monopoly, are dark-sliinned, usually ugly, and badly dressed in Sulu fashion, being poor.

The Palawan Dusuns differ in many respects from those of Borneo, being greater barbarians, having experienced but little if any of the ancient Chinese civilization. I never saw a Palawan Dusun wearing anything but the chawat. This garment is generally composed of two colours, red and white; sometimes a short jacket of flimsy blue cloth worked with rows of china buttons, and a head-cloth of the same material, is worn, like his Kina-Balu relations. Physically he is a finer man than the Bornean, taller, but longer in the leg, often lanky; his hair is straight, and some have clean-cut features. His weapon is the Sumpitan, which differs from the wooden tubes of the Borneans, being made of bamboo. The outer tube is seven feet long, in which are inserted two tubes of smaller bore, very carefully fastened together; the ends are fastened with wax, a large lump of the same material fixing on the sight. These blow-pipes are often tastefully ornamented with patterns burnt in. The dart-cases and darts are slightly different to those seen in Borneo. The Palawan Dusun also carries a small basket in which he keeps his sirih-chewing and smoking necessaries, the small bamboo boxes in which these articles are kept being tastefully deccrated in cut patterns. I never saw much attempt at ornamentation in Nortlı Borneo, the handles of swords and some paddles being the only articles thus beautified. The women, both young and old, wear nothing but a short petticoat, generally made of cheap white trade-cloth.

The Dusuns are the agriculturists, their numerous clearings may be noticed on the mountain-slopes from tlie sea. Their houses are small and apparently contain one family only. I saw no signs of heads in their campongs, and, as far as I could ascertain, headhunting is unknown. Their treasures, curiously enough, consist of common earthenware plates and bowls, which are utterly useless to them, and hang in racks round the house. These plates form part of the "burnihan" for a Dusun bride, and at one time, before they becaune too common, one plate was cnnsidered sufficient; but now plates, bowls, rice, and brass ware are required to satisfy the bride's family: such is the march of civilization even in distant Palawan!

The houses of these people are constructed of bamboo planks and poles, the roofs of lalang-grass attaps, the grass being fastened between two laths, like the sago-leaves in Borneo. I never saw the Nipa palm growing in these parts of Palawan, but sago attaps are used by the Sulus.

Of the wild interior tribes, or "Orang-Utan," of Palawan I only encountered two individuals accidentally in the mountains. We were resting quietly on the top of a slope when two of these wild men came up the mountain path, and were within a few yards of our party before they noticed us--too late to turn back; so they put on a bold face and passed us, halting for a few minutes when we tried to speak to them. Their heads were covered with big mops of towzled hair, tied back with a piece of dirty rag; they had welldeveloped moustaches, wore an apology for a charvat, and were covered from head to foot with that disgusting skin-disease "kürrup." These men are the inhabitants of the mountains, orer which they wander, subsisting, the Sulus say, on roots and what they can 
shoot with their sumpitans, having no houses, living under rocks. The Sulus told me that bargains with these people are made in the following curious manner. When a native wishes to purchase rattans or damar from these people, he has to place his exchange value of goods in the forest at some recognized spot, and the following day he returns and finds what the Orang-Utan consider the equivalent value in produce. This seems rather too curious to be true, but as there is always some foundation of fact in native tales, I give it for what it is worth. A Sulu told me that the best way to frighten these barbarians was to pretend to have a cold, which he suited by the action of placing his finger and thumb to his nose; then, said he, "they run away like fools." I can believe this, as catarrh is as dangerous as any disease to these people: their constitutions being unaccustomed to colds, therefore when attacked they often die.

Having now given some account of this part of Palawan, its physical geography, and inhabitants, I will give a detailed account of my lengthened residence in this island.

The communication betwecn Palawan and Labuan is carried on by the steamship 'Royalist'*, a small but clean and comfortable steamer, owned by a company of Chinese traders who trade between that island and Singapore, making trips about once in two months.

On the 1Eth of June, 1887, I left Labuan for Palawan with seven Kadyans, all trusted followers. I had been advised by the Governor of Labuan not to visit this island, as he considered the Sulus unsafe, as they had a short time previously murdered an American trader located there, and had only a few months since murdered several Chinamen and sacked their stores. 'The Sulus are nothing else but a lot of pirates who have lost their occupation through the invention of steamships. But, even now, whenever a steamer gets stranded they secure a good deal of loot before they are driven off. Though Palawan belongs to Spain, no attempt has yet been made to keep in check the lawless Sulus who inhabit the southern end of the island, but before I left there were rumours of forts being erected a short distance from Taguso. The advent of the Spanish, and more especially their priests, will cause an exodus of the Sulus, who will retire elsewhere. The Sulu being Mohammedan hates the Spaniard, and does his best to poison the minds of the igmorant Dusuns, by telling them that the Spanish will make slaves of them all. In reality the Dusun will be much better off when his Sulu masters have disappeared.

19th.-We anchored at mid-day in the small harbour on which the Spanish colony is situated in the island of Balabac. This island is the most western possession of the Spanish in the archipelago; it is small and mountainous, and covered with dense forest. The small town from the decks of the 'Royalist' looks well-to-do, the houses being. zinc-roofed; but on a closer inspection the zinc roofs only serve to show up the neglected woodwork of the buildings. The hills at the back of the town have been cleared for some distance for health's sake, but a full cemetery testifies to the unhealthiness of this place. 'The trade is carried on by the ubiquitous Chinese. A circular building in which the Sunday cock-fights take place was one of the sights visited by us. Near the shore were stacks of horse-shoes which had been salvaged from a steamer wrecked a few montls 
previously on the other side of the island. This extraordinary cargo was bound for China, the shoes being required in the manufacture of cutlery. We left soon after midnight, and the following morning were steaming in a calm sea along the coast of Palawan. I had settled to stop in Taguso, as I heard that the Sulus were of a better class there, but in reality they are probably the worst in the island.

20th.-About mid-day we dropped anchor opposite a few attap dwellings on the coast; this is Taguso, where we are to disembark, and one of the buildings is the store belonging to an enterprising Labuan trader. On landing I was disgusted with the state of the store. Built on the ground, as is usual in Chinese buildings, it was not only without flooring, but the sandy ground was distant only a few feet fiom a fetid mud-swamp. At high water the ground in the store became wet and soft. The store was not finished, wanting two sides. I thought twice whether I should re-embark or not before it was too late; in the end my desire for exploration overcame all others, and I'stopped. 'The 'Royalist,' after loading up with the produce collected since her last call, left for Puerto Princesa, promising to return in less than two months, when I should have changed my locality to the other coast.

The store consists of a large attap-roofed shed, built perhaps in the most unhealthy spot the Chinese could have selected, but suitable for loading the steamer. The sides are only partly covered in with kâjangs. I am told that it is intended to build a raised floor about a foot from the ground; it would be unsafe to build it higher owing to the predatory habits of the Sulus, who would then be able to steal at night what they had sold to the Chinese during the day. The inside of the store is in the greatest confusion, goods and rubbish of all sorts being piled up in a confused heap in the centre, round which are located the sleeping-places of the four Chinese guardians. Their beds are formed of planks piled on oil-cases and boxes, over which is suspended a mosquito-net. Tro of the Chinamen are opium-smoking skeletons and yellow with fever; the other two look fairly well. The store is generally occupied by some idle loafing Sulus, who live a short distance off. When I left this horrible place in October the building was still unfinished, with the exception of a small part which had been covered by a nebong floor.

After landing our multifarious baggage, we stacked it in a heap in one corner of the store. On it and amongst it the Kadyans slept-for two reasons, because there was no other place, and secondly to protect it from the night attacks of the thieving Sulus. The Chinese in this store live in a perpetual state of alarm after dark, and though we augmented their party by eight, several attempts were made by the Sulus to rob the store by cutting holes in the flimsy kâjang walls at night.

During the day robbery is carried on in a more open and simple manner. A number of Sulus used to surround the head Chinaman and pretend to bargain with him for the rattans and damar they had brought to the store, whilst two of their companions, stooping low behind these men, were busy passing the trade-goods through the window or flooring to friends outside. This actually occurred several times under our eyes, more especially after the small part of the store was finished, the window in the store-keeper's private apartment being most useful to the Sulus. Though the rest of the Chinese were also aware of this, they said nothing, as any interference on their part would probably have ended in a fight. It was no affair of mine, and I must say I did not care whether the Chinese were 
robbed or not, though I was their guest, for of the two sets of rascals the Chinese "win in a canter," the luge profits made by them in their trading-operations being sufficient evidence.

The profits made by the Chinese are very large, or would be if they were honest amongst each other. Goods brought from Singapore, such as crockery (plates and bowls), cloth, silks, sardines, biscuits, rice, and lamp-oil, \&c., \&c., are exchanged with the Sulus for jungleproduce at from 100 to 200 per cent. of their real value, the produce being valued again very low. But not contented with this enormous profit, the store-keepers swindle the Sulus by manipulating their weighing-poles, so that they gain four piculs in every ten. One day I saw a Chinaman weigh sixteen piculs of damar as six piculs (a picul $=133 \mathrm{lb}$.) under the very nose of the Sulu from whom he was buying it. The Sulu at first looked perplexed, but in the end the Chinaman proved to his satisfaction that his sixteen piculs of damar weighed six. This may seem impossible, but I would back a Chinaman to swindle any Sulu. Now supposing the Chinaman had been detected, a few high words and the "barong" would have settled the dispute, and probably the rest of the Chinamen as well. "Then in the course of time we should have heard of another massacre of Chinese in Palawan. In an island like Palawan every man is his own lawyer and settles his own disputes; so if Chinese traders care to run the risk of making large profits by swindling, they must take the consequences.

The Sulus in their relations with the Dusun aborigines are interesting. The Dusuns are farmed by them, no Dusun being allowed to deal with the Chinese at all. All jungleproduce must first be brought to the Sulu, who gives in exchange about half what he receives from the Chinese in trade-goods. As an example of this bullying trade custom: I have seen a Dusun bring a basket of damar to the entrance of the store, when an idle Sulu would get up and go to lim and inquire what he wanted in exchange. After a few words the Sulu would go to the shelves in the store and get a plate or bowl, which lee handed to the Dusun, taking the damar into his own possession. Duriug this business transaction our Chinese store-keeper has been looking on, witliout daring to purchase direct. In a day or two the Sulu sold the damar to the Chinaman at about .100 per cent. profit to himself. Wishing to get the Sulu idea of "Free Trade," I one day had a conversation with a Sulu on this subject, and asked him why the Dusuns did not sell to the Chinese direct. "Well, if they did," was his answer, "how should I be able to sell it?" or, in other words, how could I make a living? This answer was convincing enough for anyone. Thus it will be seen that the Sulu is a forced middle-man and one might suppose of no benefit to the community; his right he enforces by might, $i$. $e$. with his Snider and his barong. He never collects produce himself and would not be permitted to do so by the Dusums. The point I cannot understand is why the Dusuns are so submissive to the Sulus, whom they vastly outnumber. At the same time, the absence of the Sulu element would not benefit the Chinese much, if at all, - as the wants of the aborigines are almost nil, and if they were able to procure their small necessaries more easily they would only collect less produce; while our Sulu is a lazy, extravagant, gambling scoundrel, fond of opium-smoking, and, when he can afford it, dressing in silks and satins. Thus by doing away with this apparently useless nou-producing Sulu drone we do away with demand, and bring the Chinese in direct contact 
with a non-luxurious barbarian, whom he might cheat more, but with whom he would do less. The Chinese willingly permit the Sulus to get into their debt; this spurs the Sulu to work the Dusun, or leads to disputes, when the account is balanced with a stroke or two of the "barong" and by setting fire to (after looting) the store. Such was the state of trade in Palawan in the year 1887 A.D.

For the occasional murders of Chinamen I have given sufficient reasons. The murder of the American trader was because he was being continually robbed by the Sulus, and getting no satisfaction from the nominal Sulu chiefs, he lost his temper one day and shot a Sulu: he was then set upon by some others and literally hacked into pieces. No man in his senses should have resorted to such severe measures, surrounded as this trader was by a tribe of cut-throats.

Not far from the store is the house of an old woman who calls herself the Rajah-really, I suppose, the Ranee. 'This evening I called on her with the Chinaman, and asked her to assist me in visiting the mountains. The old lady is white-haired, and is, I hear, the mother of the Sultan of Sulu, which is perhaps true; she pretends to have a good deal of power, but I afterwards discovered that the only power she possesses is over her own household, the rest of the Sulus not troubling themselves about her. I often used to call on this old lady at her request, when she either wanted to beg for something or used to ask advice as to her various ailments. After a long conversation, in which she described how the people were afraid of her-dear old thing! for it existed in her imagination only,-I found that she could do nothing to help me. Being of a religious turn of mind she held prayers twice daily ; and this being the month of the Mohammedan fast, or Rhamadan, the "Bulan puossa" of the Malays, chants and prayers go on all day, which are occasionally attended by my two Kadyan Madjis, with whom I have agreed that they shall do no work until after the fast is over, that is on the 23rd. So the seven Kadyans have been sitting about doing nothing all day. This trying state of things became too much for Tungal, so the day before the fast was completed he went fishing with a cast-net and secured a fine fish, off which he dined; after this he went bird-collecting as usual, to the intense amusement of the rest.

21st, 22nd.-I went with the Chinaman to-day to be introduced to the various Dusuns who are living round about Taguso-the object of this visit being to let them know that we were going to collect birds in the forests, so that they need not be alarmed at our guns. The people visited to-day have very small houses with interlaced bamboo sides; they are a miserable-looking lot, but some have fine features. One of the first birds I saw to-day was the Palawan Titmouse (Parus amabilis). This little bird is of a bright sulphur-yellow with a black head and tail, the back being whitish grey; it is peculiar to this island and perhaps Balabac. The large Fruit-Pigeon (Carpophaga cenea) is very common, and I saw for the first time in my life two wild Cockatoos.

During the night the horrible swamp-crabs have covered the ground in the store with a number of small mounds of filthy black mud, which they have forced up from the swamp beneath. Occasionally, too, a large boiled-looking lobster-like crustacean used to come out of its burrows in the evenings and throw out a quantity of filth, at times close to one's bed; it was incomprehensible to me how the Chinese could live in such a place. My bed 
consists of some planks laid across the old kerosene-oil cases, over which I have slung my mosquito-net.

23rd.-To-day I shot a beautiful little new Dicæum (Prionochilus johannce); this bird is closely allied to the Malay species, but differs in having a yellow rump. Another species was a splendid Irena, with a light silvery-blne head and back and a jet-black breast and tail; this, like the preceding species, is peculiar to this island (Irena tweeddalii). Another species I shot in the virgin forest belt near the sea was a reddish-brown and white Flycatcher, also a new species (Siplia erithacus).

The Sulus are a great trouble in the store; directly I open any of my boxes they crowd round and want to handle everything they see, so I am forced to rise early in the mornings in order to arrange my baggage for our projected excursions inland.

24th.-To-day Tungal brought in a green Pitta, P. sordida: this species is allied to P. muelleri of Borneo, but differs in having a large black patch in the centre of the stomach above the crimson; this very striking difference has been quite overlooked by the various naturalists who have written on this group-owing, perhaps, to the badly skinned specimens at their dispcsal. I collected two more Palawan species to-day, Criniger frater and Mixornis woodi.

Up to this I have not given my readers a description of a tropical forest, but will now do my best to paint for them this picture. A tropical, primæval forest, when it has not been interfered with by man, and where the soil is suitable, commences just above highwater mark; in places, as in Palawan, the branches hang right over the sea and are often covered with several species of orchids, which get sprinkled with salty spray, most noticeable amongst them being a handsome yellow, brown-spotted species. As seen from the sea the forest looks like a high green wall, sharply ruled off above and below by the blue sky and silvery sand, lightened here and there by a pale-coloured tree-trunk. On entering, the edge for a short distance is covered with a dense low growth; but this disappears entirely, from want of light and air, as soon as the trunks of the first high trees are reached. The first thing that strikes the visitor to this vegetable domain is the gloom, the absence of undergrowth, and a peculiar smell of decaying vegetation. The trees, on looking up, it will be observed are free from branches until near their tops; the trunks are straight and many comparatively slender. Their combined crowns form a dense canopy, through which the sun scarcely penetrates. The bark on these trees is generally smooth and tight-fitting, unlike our oaks and elms. No colour but the various shades of green is visible, flowers of any sort being seldom seen in this verdant roof.

Most striking of all to visitors from temperate climes are the extraordinary forms of the numerous creepers and the trunks of the larger trees.

The main effort of these creepers is to reach the top of this forest-roof, and this accounts for their wonderful length, and the same reason is the cause of the slender branchless trunks of the forest giants. The forest-roof is often over 200 feet above the ground, and if it were twice this height the creepers, to exist, would have to reach the top for light, air, and sustenance. These creepers, as Mr. Bates has remarked, "are really climbing trees of most divergent genera," their climbing habits being necessary for their very existence. These climbing trees fight "tooth and nail," clinging like serpents to the topmost branches of the 
forest giants, from which they occasionally fall and rise again, leaving lengthy festoons hanging in mid-air; they climb up the trunks and stretch across the ground-all for daylight. Their growth is apparently very rapid, these jungle-ropes being often mere water-pipes: the natives, when thirsty, will cut off a length of three feet or so, and by holding it end down over their mouth, a sufficient quantity of pure water will gush out to satisfy their thirst. The curious way iu which the rattan (a climbing palm) has adapted itself to climbing habits, and the way in which it attains its object, have been fully described by me in my Malacca journal. These forest-ropes vary in size from the thickness of a man's thigh to that of fine string, are always pliant, and near the ground leafless and branchless; often rough-barked, and occasionally armed with spikes or hooks.

The bases of the trees themselves are often remarkable, some species throwing up for thirty feet a buttress, above which the trunk commences in the usual manner. The object of this buttress is doubtless to give stability to the tree and counterbalance the enormous crown. One such tree I remember in Palawan, which was known by the name of the "devil's tree" by the Sulus, had the most marvellously developed base I have ever seen. The wooden partitions close to the trunk were eight or nine feet high, and ran out from the tree to a distance of fifteen yards; the spaces between these partitions were large enough to form a comfortable dwelling for several men. The floor of the forest is sometimes sparsely covered with a sickly, almost leafless, undergrowth; several species of palms, however, often flourish. But the fall of a forest giant leaves an open space which is soon covered by a luxuriant vegetable growth. The ground for the most part is bare, and carpeted with dead leaves and falien fruits and their often brightly coloured cases. The boughs of the high trees are covered with a parasitic growth of orchids and ferns, some of the latter being enormous; but it is rarely that any blossoms are noticed. Mammals are very seldom seen, except monkeys and squirrels; birds are individually scarce, though, when compared with Europe, specifically numerous; butterflies, with the exception of two or three species, are seldom seen, except when an open sunny spot be found.

25th.-The Kadyans captured a beautiful wild cat in their snares; and we obtained a specimen of Cittocincla nigra, a species peculiar to this island.

26th, 27th.- The messenger sent by the old lady has returned to-day from the mountain Dusuns, with the news that they do not wish us to come inland, and will not carry our baggage.

27 th to 30th.-Have collected many interesting birds, amongst them a handsome Philippine Pitta ( $P$. erythrogastra) : this species has a bright scarlet breast; the back pale green mixed with slate-blue, which colour extends over the upper part of the breast; the head is brown.

July 1st to 4th.-The Kadyans have snared to-day a small Peacock-Pheasant, one of the birds I especially wanted to meet with. The breast of this Pheasant is black; its back bright metallic blue; the lower part and tail brown, mottled with dark brown; the entire tail beautifully studded with green and blue peacock eyes: this Pheasant (Polyplectron napoleonis) is truly a magnificent species; the legs, as is usual in this genus, are armed each with a pair of powerful spurs; the female is brown, with dull peacock eyes on its tail: this species we caught in snares; we never saw it running about in the forest. Our 
enemies were wild cats, monkeys, and monitor lizards (" biawaks"), which would sometimes succeed in destroying our captures.

While wandering about in the forest one day, two otters came in a direct line for me, and did not discover my presence until at my feet. On another occasion a wild boar was taking an afternoon stroll, and stood at a distance of ten yards surveying me for a few seconds.

The Dusuns are reported by the Sulus as being unfriendly; this is true, but the reason of their unfriendliness is that the Sulus are influencing them against us, not wishing us to go inland-their reason being that they believe we either wish to trade or search for precious stones, of which they have most remarkable and exaggerated ideas.

5th.- To-day I went to the foot of the hills with some Sulus to visit a Dusun chief, in hopes of being able to persuade him to assist me; but after at first refusing to meet me, I. sent another messenger, and in three hours the Dusun and a companion came to have a palaver. During this time we had been waiting about half a mile from the Dusun campong. When the chief approached near enough, from force of habit I held out my hand to him; he, being unaccustomed to such a mode of salutation, jumped back, fearing no doubt I was going to seize him by his chawat. After a long conversation through the Sulus as interpreters, he said that his men would not assist or molest me, but he would not be answerable for the hill Dusuns or the pig-traps set in the forests. As I have now been in Palawan two weeks without any signs of assistance from the Dusuns, I am beginning to despair. 'The rain since we arrived has been almost incessant, and my collections will not keep without being dried over a fire.

Tth to 14th.-The weather is very wet; the Dusuns near Taguso will do nothing for us, and the Sulus do worse-they influence these ignorant people against us. I have two wild Jungle-fowl (Gallus bankiva), caught only a few days ago ; they are already wonderfully tame, feeding freely off the rice given them, and being especially fond of small red chilies.

On the 17th I left in the Chinaman's boat for Blegi, where I was told that the Dusuns would help us to reach the big mountain Kalamutan. We carried in this rotten little boat provisions for a month, and with the Kadyans, the Chinaman, and myself the boat was loaded within a few inches of the water; as the sea was calm this did not matter much. Blegi is only two hours paddle from Taguso. We sent for the Dusun chief, who came at once to talk over matters, but as everything was not settled he said he would call again on the following morning. The mountains are only a few miles distant from the coast, but the nearest hills are cleared for paddi, so they are not good hunting-grounds.

We waited patiently on the coast for three days, sleeping on the beach, but as the Jusuns could only muster eight men instead of the twenty required, I set sail once more for Taguso ; they, however, promised to have more porters after their rice-harvest, which is just now commencing, so I shall return later in the month. The sea, on our journey back, was rather rough, and before we had crossed the large bay between Blegi and Taguso our heavily-laden rotten little boat shipped several slight seas and was in danger of founderingshe would have gone down like a stone ; but the Kadyans, two of whom were capital sailors, got us across the bay in safety, where we jumped out and pulled the boat out of the breakers high on to the shore. I walked back to Taguso, not wishing to be drowned just yet.

23rd.-I left Taguso with five Kadyans and the Chinaman, who accompanied me out of 
kindness, fearing we should get into trouble with the Dusuns. We marched, each carrying a few provisions, direct for the mountains. On passing through a Dusun village the women and children ran away screaming and the men would not direct us to the right paths; they requested us to return by a different path, as they objected to us traversing their campongs. At night we camped in the forest, at about 1000 feet: here I remained three nights under a small shelter; we saw no aborigines but the two wild men already mentioned. The hills were very steep and composed of disintegrated rock, but from want of camping necessaries I was unable to do much, and owing to the hostility of the Dusuns it was not safe to venture too far in small parties. I ascended the mountain to the top of the ridge, and saw another high peak opposite us apparently covered with casuarinas, these trees producing, I expect, most of the damar brought into 'Taguso. I saw very few birds, and those all belonging to species collected on the coast. So on the afternoon of the third day we walked back to Taguso, avoiding when possible the Dusun villages. In a few days a party of fifty Dusuns came down to the store and threatened to attack us if we went inland again in their direction: having a very small party and no carricrs it was useless to further incur their hostility, so we left their mountains alone after this.

There is a good deal of property belonging to the steamer wrecked on Balabac amongst the Sulus here, who successfully looted her before being driven away. I see fish and other knives and forks, chairs, candlesticks, and other articles. The candlesticks have had both ends knocked off, and are now used as ferrules for spears. One morning I noticed one of the Chinamen mixing gunpowder with his dog's food; on asking the reason of administering such powerful doses to the animal, he told me "that gunpowder would make the dog wow-wow" if any thieves came, evidently imagining that it will be as useful in the dog's stomach as in a gun-barrel.

A Sulu trader brought two slaves to the store for sale; they were Dusun children and had been seized for debt. 'The Sultan's mother bought them for goods valued at ten pounds sterling, but in reality worth about a third of that price. The first night the boy ran away, but no doubt they would be able to find him again at his home; the girl, however, remained with the old lady and looked very content, and doubtless was better clothed and fed than she had ever been before. Slavery in this part of the world is only of a very mild form-a slave, being on almost equal terms with his master, is free to go where he likes. Masters never ill-treat their slaves-barbarians seldom ill-treating anything; the slaves generally perform the hard work, such as carrying jungle-produce.

The Sulus have many blood-feuds amongst each other. One good-looking young Sulu I remember, named Twossong, who was always most polite and friendly with me, lived about a mile from Taguso in a house away from the village. One morning, as I was seated busily sketching on the sandspit opposite the store, Twossong came towards me looking extra pleased with himself; the first words he said to me were-“"Tuhan, I shot a man last night!" He then told me, in a few words, how his wife's brother had been murdered a few months ago by a Sulu from a village about ten miles distant, and that last night he received intimation that this man was spending the evening in a house a few miles off. So about eight o'clock in the evening he got under this house, and saw his brother-in-law's murderer sitting there; in a few scconds a bullet from 'Trossong's Snider had ended this 
man's career. As Twossong was living some distance from the village, perhaps for the express purpose of carrying out this murder, he left his house with his wife in the night, and took refuge with the rest of his family in the Sulu campong. The same day we were advised not to go bird-collecting in the direction of Twossong's house, as the Sulus from the murdered man's campong had taken possession of it; but curiously enough, though full of damar, these men did not take any, nor did they do any harm to Twossong's property which had been left after his hurried flight. In a few days the relations of the murdered man called at the store to barter some produce; they were, as usual, all "armed to the teeth." The brother of Twossong's victim showed me the "barong" worn by his late relation; it had been hit by the bullet and had nearly saved the man's life. Twossong used to visit the store almost daily; he was thickly padded all over the upper part of his body, but never seemed to be in the least afraid of the death which, in all probability, he will shortly meet.

The Sulus, as a rule, do not cultivate enough rice for their wants, and consequently have to buy large quantities from the Chinese. Towards the rice-harvest many become nearly starved; and I have been offered ten dollars for a large sack of rice that cost me less than four in Labuan.

On the 2nd of August we again sailed for Blegi, and the Dusuns carried our baggage a few miles (to the foot of the curious-shaped hill to the right of my illustration) inland. They are poor baggage-carriers, resting often and not using shoulder-straps, but only a head-band, for their packs. We reached a house belonging to the chief, which he allowed us to occupy, he and his family living in their paddi watch-house higher up the hill. After remaining here eight days-during which we made several excursions to the top of the hill, getting a good view of the country beyond and of Kalamutan-we returned to Taguso. The only bird obtained belonging to the mountain region was a Flycatcher, which Dr. Sharpe thought identical with Cryptolopha montis, first discovered by me on Kina Balu; but on closer examination the Palawan species is sufficiently distinct to warrant its separation, so I have named it Cryptolopha xanthopygia*. So perhaps these mountains when explored will yield further species allied to those inhabiting Kina-Balu.

Our relations with the Dusuns were most friendly. They used frequently to visit us; and of all my possessions nothing interested them so much as part of a ham which was hanging up in the house. This ham became so renowned that perfect strangers on entering our house would at once walk straight up to it and stand discussing its merits, they having been told about it by their friends previously. Before I left I presented the remainder and the bone to the Dusun chief.

These Dusuns are a clear-skinned people, some of them, the chief especially, being fine-made men. They wear a few beads round their necks, and do not file or blacken their teeth. All the Kadyans and myself were laid low in this house for two or three days with slight attacks of fever.

This was my last attempt to reach the highlands of Palawan, being unable to do anything with the Dusuns; perhaps but for the doubt occasioned by the expected return of the 'Royalist,' I should have made another attempt with the Dusuns near Blegi.

* Figured p. 96. 


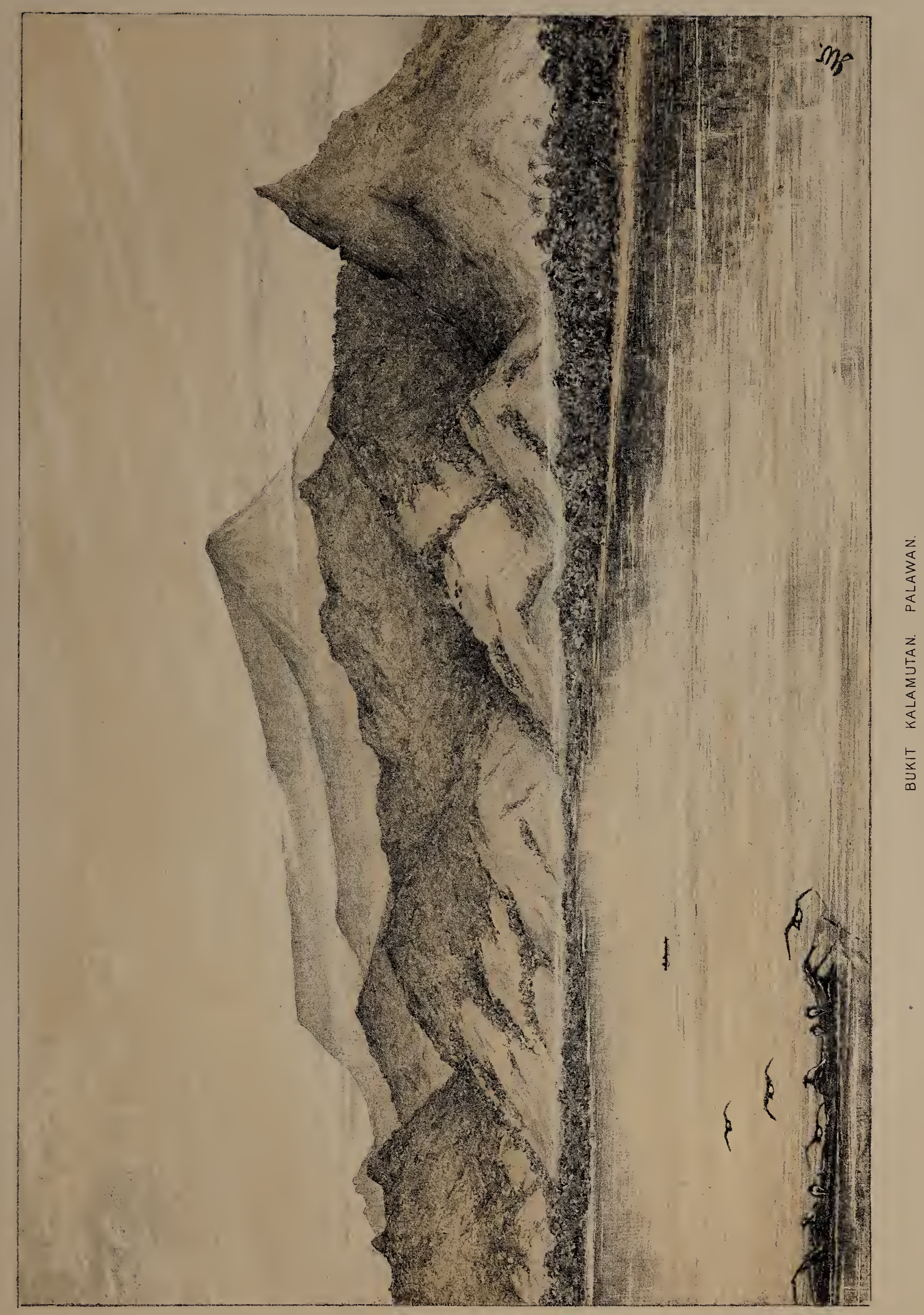



On the 10th August we again left for Taguso in the small boat in which one of the Kadyans (left in charge at the store) sailed over to meet us. After getting a few more stores from Taguso we camped on the shore, some five miles from that place, chiefly to be away from that horrible crab-eruptive store and also to avoid the pestering Sulus. One of the commonest birds in Palawan is the Megapode ( $M$. cumingi). This bird inhabits the narrow strip of brushwood round the coast, where it makes those extraordinary large mounds in which its eggs are laid and hatched. In our present camp we see numbers of these birds, and constantly hear their peculiar cat-like "mew." The nest is a wonderful structure, and is doubtless the labour of several pairs of birds. The largest nest I have seen was 34 paces round and $5 \frac{1}{2}$ feet high; this heap must have contained many cartloads of earth, sticks, and stones, and yet the ground round about was apparently untouched. How such a heap is brought together is a mystery; but it is no doubt the gradual work of many birds during several years. The eggs are buried very deep in this mound, and often placed amongst the roots of a tree, on a bed of green leaves; the leaves ferment and hatch the egg, when the young bird quits the mound-its foster-mother-in perfect plumage, being much more willing to fly than the old birds. But for a fuller account of this extraordinary mode of nidification, I must refer the reader to my notes on this species in the Appendix — "Notes on the Birds of North Borneo" (species 286).

In making our excursions into the forests we often had to cross shallow streams, which, near the coast, contained hundreds of a small prickly shell. My attention was first attracted by the Kadyans picking the shells off the soles of their feet after wading the stream. This shell is known to conchologists as Neritina diadema, and, like many other allied forms, has a peculiarly shaped hard operculum and frequents brackish water. Crocodiles often swim out to sea, where they may be seen basking on the surface in company with numerous sharks, in the deep depressions amongst the coral-reefs. Sharks seem unusually plentiful around Palawan, and are occasionally caught by the Sulu fishermen. In the forests I had often heard a loud owl-like hoot, which the Kadyans declared was a devil ; but one day Nyhan returned with a fine large Wood-Owl, in which I recognized the Kadyan's devil. This Owl was somewhat scarce, is a new species, and has been named after me, Symium whiteheadi.

On the shore, close to the water's edge, are hundreds of a handsome orange-coloured butterfly (Appias nero); this species belongs to the Pierino, to the same subfamily as our common white butterflies. Now the peculiar part of these butterfly assemblies is that they are composed entirely of males, which may be seen in rows along the damp sand, sipping the salty moisture. The female of this bright orange male is a very differently coloured insect, and, comparatively speaking, very rare : there would be no difficulty in securing a few hundred males, but a dozen females would take some time to find, they being hidden about the foliage at the edge of the forest; though they differ most decidedly from the males, I do not think they can be said to resemble any distasteful species. Now in the same neighbourhood, the males often mingling together on the coast, is another species (Nepheronia lutescens), the male of which is a lovely pale blue; he is not so very distantly related to the orange male, belonging to the same great family, the Papilionida, subfam. Pierince ( $o$ and $o$, see page 142, figs. 5,6). The female of the blue male is rarely seen, 
never in company with her males, on the sea-shore, but may be found also on the borders of the forest; she, like the female of the orange male, differs entirely from her mate (the blue one), but closely imitates a species obnoxious to birds and other enemies by means of its disagreeable odour: this distasteful butterfly is Radena vulgaris (fam. Nymphalida, fig. 1). Thus we have in one locality apparently a protected and an unprotected species living together, the species most protected through its female being most decidedly the rarest. I am much inclined to think that the "Protective Resemblance" theory of late has been made too much of, as I have never yet found in the tropics a protected species abundant. Some of our supposed highly-protected Papilios are excessively rare, when the crowds of Euploeas which they resemble are taken into account, and the hundreds of Papilios daily seen, such as P. sarpecton, P. helenus, P. demolion, and P. evemon. Birds, the supposed enemies of butterflies, seldom try to catch them: though these many hundreds of male Appias nero were under my observation for many days, and are an unprotected and conspicuous insect, I never once saw a bird of any sort make the least attempt to capture one. Now the greatest mortality in butterfly life will take place amongst the larva and pupæ, which must be and are attacked by many enemies, especially by other insects: it is here protection is wanted and must be obtained, either by the close resemblance of the larvæ and pupæ to their surroundings, or by some special armament, either by actual weapons, such as bristles or spikes, or by an offensive smell; the pupæ also must be protected, either by hiding-places or strong cocoons. The most highly-protected first stages of the butterfly's life must necessarily mean the most numerous perfect insects. My own opinion as to the marvellous resemblance of certain butterflies of now widelydistinct genera is that they only bear a resemblance to their ancestral type, and that it would be infinitely more important for the first forms of butterfly existence to receive protection than for the perfect insect; this is evident by the comparative rarity of "mimics," which should not seek to hide, but rather to flaunt themselves in the face of their enemies.

In the accompanying plate will be seen a coloured figure, No. 1, of a well-known distasteful species of butterfly, and others which resemble it in colouring and pattern. The Danaina, the distasteful forms, it will be seen, are mimicked by members of some three or four families only, three of which I have figured, viz.: 1. Prpilionince; 2. Pierince; and 3. Satyrina. The first two groups are closely related to one another, while the third, Satyrince, is not very distant from Danaince itself, both belonging to the same family, the Nymphatide.

Fig. 1, Radena vulgaris, belongs to the Danaina, a group of butterflies distasteful to their enemies by reason of their strong odour and the juices of their bodies. The tlree genera Hestia, Euploca, and Danais are very tenacious of life: when tightly squeezed and placed apparently dead in collecting-papers; on opening these papers hours after the butterfly will be found strong enough to fly away again. The male of Euploea midanus, when on the wing, often displays two bright yellow silky tufts on either side of the sexual organ; these tufts are withdrawn and may be noticed on dissecting cabinet specimens. The whole group are slow-flying, forest-frequenting, and gregarious. Mestia, horrever, which has also a slow flapping flight, is generally, seen singly, flying some distance from the ground. Ilestia 

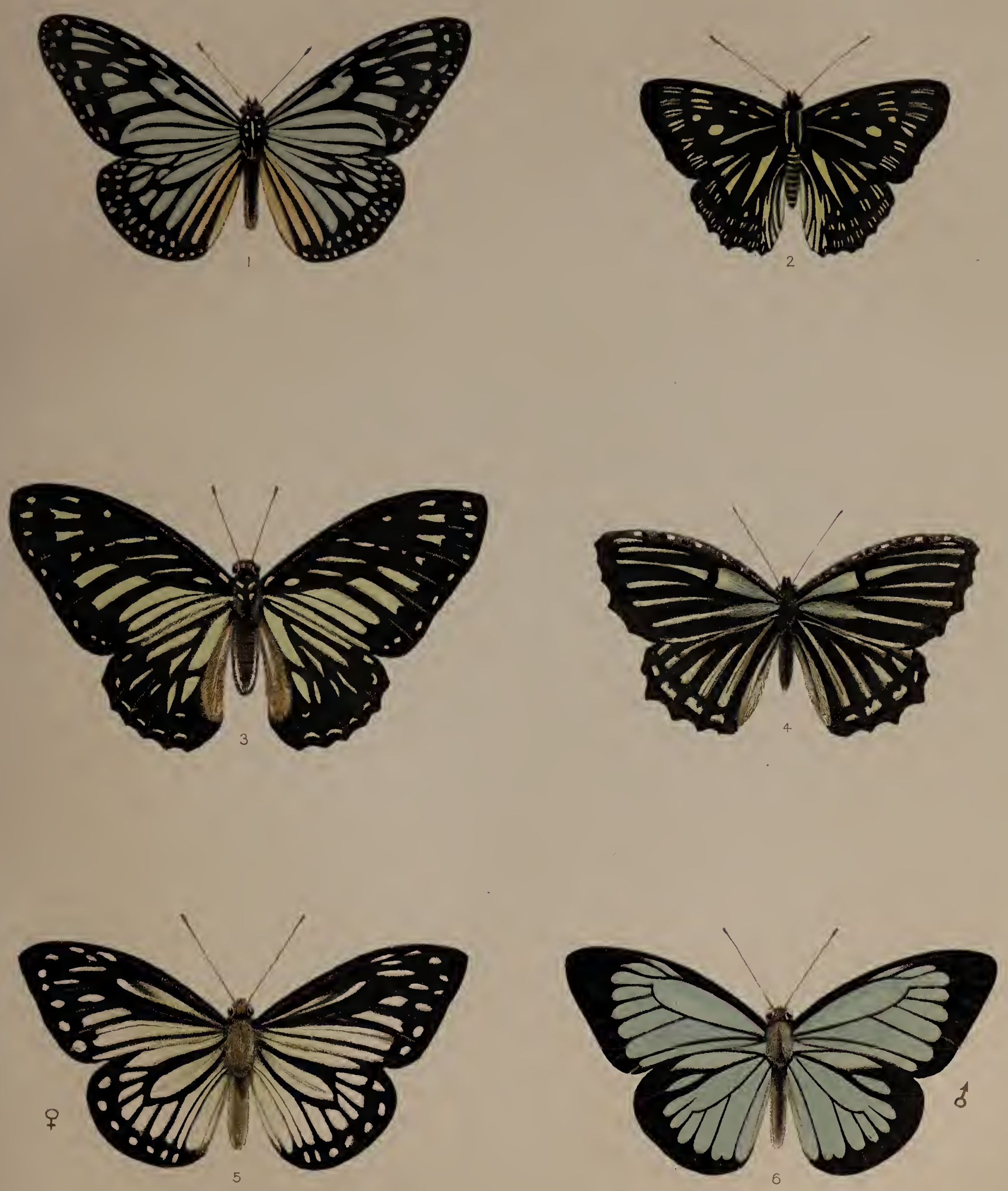

leuconoë is closely imitated by Papilio idceoides, and the isolated spots on the wings of $P$. delesserti show an approach to Hestia daos.

This group of Asiatic butterflies extends into Africa, and in Equatorial America is replaced by the Heliconida, the distasteful qualities and habits of all being similar. Now, Hestia, Danais, and Euploca are said to be mimicked by the Papilios, an apparently widelydifferent family; they are also mimicked by Elymnias, a somewhat nearly-allied genus, by the female of Nepheronia lutescens (fig. 5), by Euripus euplooides (fig. 2), more especially by the female of this species; but by Papilio they are mimicked both in Africa and in America. So closely do some Papilios resemble the Danainoe that by the uninitiated they would be placed in the same drawer of a cabinet.

The Danainæe may be divided into two groups: 1. Danais, and 2. Euplea. Group No. 1 is composed of dull-coloured semitransparent-winged insects marked as in fig. 1: No. 2 of handsome dark-purple butterflies. Papilios imitate both Danais and Euploca in a wonderful manner. P. macaristus, sp. nov. (fig. 3), mimics Radena vulgaris (fig. 1); in the same way $P$. zanoa resembles Euploea midamus.

Elymnias lais (No. 4) resembles somewhat the distasteful Danais, but another species of the same genus, $E$. discrepans (a purple-coloured butterfly) resembles Euploca ledereri.

Euripus euploooides (fig. 2), as its specific name implies, more especially its female, which I have not figured, resembles Group No. 1, Danais; while Euripus halitherses is a purple-coloured insect resembling Group 2, Euploca.

Nepheronia lutescens (figs. 5,6) resembles Danais (Group 1) in its female only, and I do not think any species of Pierine can be said to bear any resemblance to Group 2, Euplea, though some individuals of the genera Detias and Appias are very black.

Thus we have Danais mimicked by Papilio, Elymnias, Euripus, and Nepheronia (Pierince), and a dark purple Euplaca mimicked by the first three mentioned genera also.

The divergence of markings and colouring of the two sexes of Nepheronia lutescens (figs. 5,6) is most interesting. The female closely resembles the distasteful Danais, and is supposed to receive protection by this mimicry: her mate is not in the least protected by this resemblance, and may be even considered a conspicuously coloured butterfly; but he is decidedly the most willing to display his unprotected self, and is for this reason apparently, if not actually, more numerous. Therefore I fail to see how the female benefits by her "Protective Resemblance," as she is afraid of showing herself.

Ornithologists are well aware that many birds belonging to the same orders are perfectly distinct in markings and coloration and at times in their structure; but the young in their early stages, or the eggs, often reveal what the adult bird does not, viz. to which order it rightly belongs. The many circumstances in the struggle for existence that have left the marks of divergence from the ancestral type do not affect the eggs and young. Thus the nidification and the early stages of the young of the gorgeous Humming-bird are similar to those of the dull-coloured Swift, and next to that order these apparently very different Humming-birds have been placed by many writers.

The Swift is the Euploea or Danais, the dull-coloured Humming-birds the mimicking Papilios, and the highly ornamented gorgeous Humming-birds, which have departed further from the ancestral type, are like the spoon-and swallow-tailed Papilios: that is to say, 
that all these mimicking genera are not mimics at all, but are the least divergent members of their orders from the ancestral type, a Danais-like form, from which the present Euplocas have also to some degree diverged.

Again, once more applying ornithology with regard to our Nepheronia (figs. 5, 6). In many groups of birds the colouring and markings of the sexes are at times very different, a familiar example of which is our common Blackbird or Wild Duck. 'The male Blackbird is black, the female brown; the young of both sexes alike resembling the female, but more spotted on the breast. The young of other species of Thrushes are nearly always spotted, though the adult birds of both sexes are not thus marked. Thus the resemblance to the ancestral type is still kept up by the young, and we can only conclude that the first forms of this genus were spotted Thrush-like birds.

Now let us once more return to our butterflies, Nephieronia lutescens and its Danaislike female. The female butterfly has, like the female Blackbird, departed less from her early type, while her mate, like the cock Blackbird, has become highly developed in colouring.

As Danaince is an almost cosmopolitan group, being found on all the great continents and on most of the Pacific islands, and, as shown by Mr. Wallace, "the most widely distributed species are probably the most ancient," we can only conclude that the several genera under discussion branched off from the ancestral tree after the appearance of Euploea.

That the local varieties of Danais and Euploca should be mimicked by local varieties of Papilio is only what might be expected when we take into consideration that both insects have been reared under the same climatal and other circumstances (that is, if they are descendants from the same type), as the causes that altered the Euplcea would also act on its ally the Papilio.

The extraordinary resemblance of certain insects to their surroundings-such as leaves, twigs, and bark-both in form and coloration is more remarkable than the occasional resemblance of species of apparently widely different orders to one another.

Those insects which receive protection by the wonderful resemblance which they bear to the objects on which they rest will, as a rule, allow of closer approach than those which do not, and we are thus led to conclude that they are aware of the fact that by remaining perfectly still they will escape observation. Writing of Kallima paralekta, Mr. Wallace tells us: "at length I was fortunate enough to see the exact spot where the butterfly settled, and though I lost sight of it for some time, I at length discovered that it was close before my eyes, but that in its position of repose it so closely resembled a dead leaf attached to a twig as almost certainly to deceive the eye even when gazing full upon it" "The Malay Archipelago'). The insect figured by me is Kallima buxtoni, a fairly common Bornean insect; but there are a great many other butterflies which frequent the ground in or about the Bornean forests, and when settled amongst the fallen leaves become as it were leaves themselves-for example, Melanitis ismene and Thaumantis noureddin; and I might mention a dozen other species.

Besides the two curious leaf-mimicking grasshoppers figured by me opposite page 50 (figs. 1 \& 3) -of the capture of which I have already given an account--a fairly common though rarely noticed insect is the Stick-insect, which is a splendid mimic of the twigs 
amongst which it climbs. On several occasions I noticed that on my approach this peculiar insect would lower its head and thrust forward its legs and antennæ in a straight line, thus making its appearance more stick-like. Many species have their antennæ much longer than that figured (fig. 9), and some insects grow to a length of fourteen inches.

The small spider which spins its web in imitation of a bird's excreta, upon which it rests, and even by its presence perfecting this resemblance, is able by this clever device to secure its insect-prey, and is another example of what is termed mimicry. That the spider purposely imitates a bird's excreta one does not for a moment suppose, but rather that certain species of spiders spin their webs in this wonderful manner because it is beneficial to their existence, and the more perfect the resemblance of this trap, the greater the foodsupply and protection afforded to the spider itself; therefore past generations of spiders have gone on perfecting this peculiar web until it is now presented to us a perfect imitation of a bird's excreta. For this most interesting discovery we are indebted to Mr. H. O. Forbes ('A Naturalist's Wanderings in the Eastern Archipelago,' pp. 63-65). The leaf drawn by me (fig. 8 on plate facing page 50) I found on Kina Balu (above 8000 feet); the spider was very small and black, and different to that described by Mr. Forbes.

Doubtless the same instinct which causes a gaudy powerful winged insect to take flight on the approach of an enemy causes another which resembles its surroundings to remain motionless--the instinct being in each case self-preservation. That these remarkable imitations are certain to improve and increase has been shown by Mr. Darwin in his great work 'The Origin of Species.'

One of the most interesting birds in Palawan is a large glossy blue-black Cuckoo, Eudynamis mindanensis-speaking of the male bird only, as the female is ochreous brown, beautifully barred with dark glossy green. When we first arrived in this island these cuckoos were very noisy, especially just before sunset, when the males would leave the forest and perch on the low trees in the vicinity, where they would utter their loud call"Phow"-many times in succession. When shooting in the forests, the report of a gun or any sudden noise, such as the falling of a dead branch, also caused these birds to utter the same cry.

In August most of these cuckoos had left the island, probably migrating elsewhere. In that month I shot a young male which was being fostered by a Yellow-wattled Mynah (Eulabes palawanensis). The plumage of this young bird was similar to the adult male cuckoo, only less glossed with blue.

A few days later we obtained three more young Phows-" Phow" being this cuckoo's Sulu name-all of them black like the adult male, and, at first sight, all young males; but an anatomical examination revealed the remarkable fact that two of these birds were young females. On closer comparison the two females showed slight plumage differences from the two males, in being of a greenish brown instead of bluish black, in having the entire underside of the wing mottled and barred with brown, and on one specimen there were several ochreous feathers on the back. Here was a puzzle which required some explanation; for it is a known fact that when the plumage of the sexes differs, the young either resemble the female, or the different sexes follow the plumage of the adult sexes or have a plumage peculiar to immaturity. 
In the case of the Phow the plumage law is reversed, and both sexes resemble their male parent. The Mynah is the key to this riddle: the Phow lays her eggs in the Mynah's nest; the young Cuckoos being black do not differ from the young Mynahs. The Wattled Mynah is a glossy purple-and-black bird about the size of a Jackdaw; it nests in holes in old rotten trees, often in those made by Woodpeckers-consequently the first few days of the young Mynah's existence are spent in the dark, and when the young Mynah appears for the first time in broad daylight, a glossy black beauty, a joy to her proud parents, they feed and assist her until she is able to look after herself. But let us suppose that, instead of a glossy black beauty, the Mynahs were greeted by a brown mottled arrangement; they would say, "This has surely nothing to do with us!" and fly away, abandoning the wretched brown Cuckoo to die of starvation; therefore we can now understand that the young female Cuckoo benefits, is protected, and probably exists by its resemblance to its male parent. This is a very interesting deviation from the plumage law for the benefit of a species, and may be caused either by the gradual survival of the darker forms of the young females, or, more likely perhaps, the adult female has become more divergent from the ancestral type than the adult male, the progenitors of Eudynamis being dark brown or blackish plumaged birds.

Of course it may be argued that it is unnecessary to perpetrate such a fraud on the Mynah, seeing that other birds rear parasitic Cuckoos when they cannot but be aware of the fact that they are not their own young; the Mynah is, however, a knowing bird, and perhaps requires more hoodwinking. To me the plumage deviation of the female seems the true explanation.

When bathing on the coast I was occasionally severely stung by a large jelly-fish. Several times I noticed what looked like a small yellow ball in their inside, which on closer examination proved to be a small bright yellow crab, evidently living inside the jelly-fish as a parasite.

After some weeks on the beach we returned to Taguso, expecting daily to see the 'Royalist.' We had now collected all the lowland species of birds, but those of the highlands we could not reach. In the store we were continually bothered by the Sulus, who wanted everything they saw. One of the Ranee's retainers-a big ugly bearded Sulu-was a great nuisance; his friendliness might be gauged by what he daily received. Through this man I obtained many Dusun curios, sumpitans and carved boxes, in exchange for beads. One day I refused him a small tin box he much wanted, so thinking he had seen all my belongings he kept away several days, until one of his friends saw some more beads in one of my boxes: in a few moments the big ugly Sulu was hovering round again, as friendly (?) as ever. The store-keeper, I notice, keeps an open tobacco-pouch for the Sulus, thus gaining a little of the goodwill of these ruffians.

It was now getting ou in the month of September; our daily doings were so uneventful that I find a blank in my journal during the greater part of this month. During September the weather was very tempestuous, heavy clouds accompanied by rain and gales of wind set in from the south-west, and but for the large arrivals of northern migrants I should have been miserable indeed-landed here in Taguso, our food becoming daily less, most of my small tinned luxuries finished, little to do, and still no 'Royalist.' My chief, if not only, 

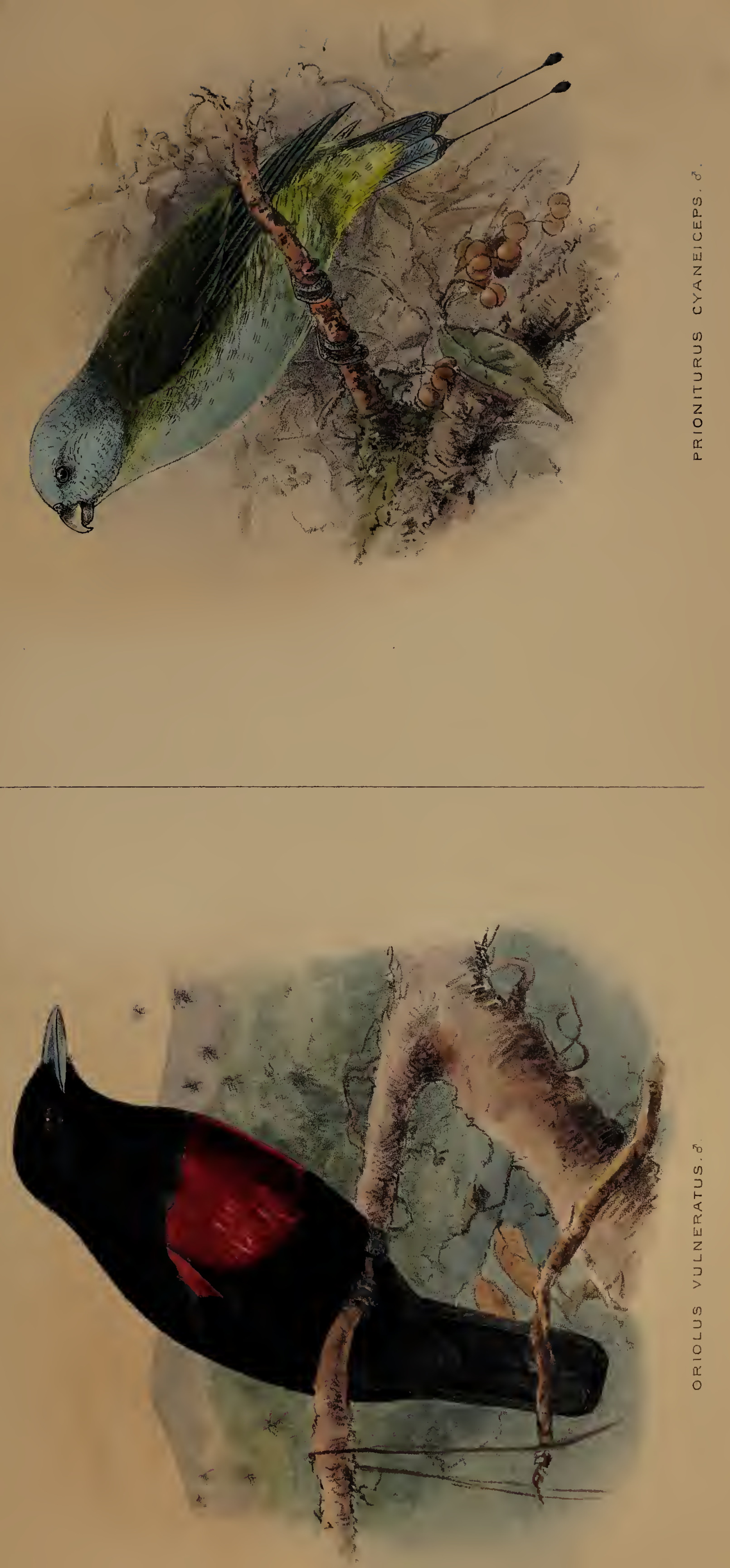

amusement was to walk to the estuary of a small river some distance from Taguso, where I used to collect the many species of Waders which were now steadily flying south. Golden Plovers, Redshanks, Whimbrels, Stints, and Sandpipers were very common, and some had hardly changed their summer dress ; all these Waders were flying full against the gale, and the harder it blew the more plentiful the birds became. Frigate-birds (Fregata minor) were plentiful, remaining poised high in the air, scarcely moving for several hours. The natives believe these birds feed on the wind, and say they live on nothing else. Towards the end of our stay we procured many examples of a beautiful blue-and-green racket-tailed Parrot (Prioniturus cyaneiceps, sp. nov.), of which species I give a figure.

By the end of September I became anxious about the 'Royalist,' she being now two months overdue, and began to fear that she had been wrecked. However, on the 1st of October we were delighted by the sight of our long-expected steamer which was to carry us away from this miserable place. My men, who were some distance away, on hearing her whistle came running back to the store, and could hardly restrain their feelings of delight. The wind was blowing a south-west gale and the sea running high: after landing the Chinese from the ship, the coolies commenced to try and load the steamer with produce; but the gale increased, and by mid-day blew with such violence that the 'Royalist' had to flee before it, taking shelter behind a headland up coast. 'The next day she was still unable to approach; but having the Chinese traders as hostages I felt safe, and on the 3rd a terrific gale made the 'Royalist' weigh her anchors and flee for shelter once more. It was not until the 5 th that we again saw our steamer, when the sea was calm with a long rolling swell. I felt relieved when we were all safely on board, and we bid adieu to Taguso-I hope for ever: the miserable days spent there have left no pleasant impressions in my mind.

The 'Royalist' before returning to Labuan was going to visit the opposite coast, so I had an opportunity of seeing that part of Palawan. We soon passed Rocky Bay, where the mountain of Kalamutan is much nearer the sea; but I have heard that this spot is inhabited by some desperately bad Sulu characters. 'The southern extremity of Palawan ends up with numbers of small islands between it and Balabac. On arriving at Kalusian, one of the trading centres, I left some of the Kadyans to collect a few birds, and proceeded to the north to Sidano in the 'Royalist.' Sidano is a small island off the coast, where the Chinese have another store. A comfortable plank-built house, now in possession of some Sulus, formerly belonged to the American trader who was murdered here. It is rather annoying to see the Sulus occupying this house, thus benefiting by their own misdeeds. On our return journey we were boarded here by two Spanish officials, but, as they could neither speak French nor Malay, our conversation with them was limited. I, however, gathered from their conversation that they had lately been posted here to open up the country on the mainland opposite, where they had erected a fort. The colony had suffered dreadfully from fever, some thirty Manilla soldiers and one Spaniard having succumbed. The Doctor who visited us said that he was entirely without quinine, and they had not been visited by a gunboat with fresh stores for several months. I should by no means envy the life of a Spanish official in Palawan.

We steamed for half a day further up the coast to a spot where a few Chinese had 
opened stores on their own account. These men had been dealing direct with the Dusuns, there being no Sulus much above Sidano. Here we anchored for two days, the 'Royalist' taking in a cargo of damar collected by one of these Chinamen. The few Chinese settled here had not seen a steamer for nearly two years; in the meanwhile they had been busy trading with the Dusuns. They valued the cargo we took on board at 15,000 dollars. It is wonderful how the Chinese will settle for a few years on the coast of some of these islands, and after that time they are able to retire with a fortune, unless cut up by the Sulus. I made several expeditions on shore, and followed the course of a small river some distance inland. Besides Dusuns, there are numbers of Manilla men here, a somewhat stunted and ugly lot; various signs of the Cross cut on the trees indicate that they have at one time or other received their religious instruction from the priests. The mountains here come right down to the sea-coast and are covered with high forest. I thought this would be a suitable place from which I could explore the mountains, but the explorer might have to remain for a long period without seeing a steamer; the coast here being open to the full force of the China Sea, and a mass of coral-reefs often uncovered at low water, it would be dangerous to coast along in small boats, to say nothing of the numerous piratical Sulu "dapongs."

We returned to Kalusian, where my men had been left. I landed here also for some hours while the steamer loaded up with rattans. The Sulus here seem more peaceable than those of Taguso, and go about unarmed, even without their "barongs." Kalusian is no great distance from Kalamutan; but the Dusuns would not be more inclined to assist the explorer, if they did not evince open hostility, as the Sulus would do their best to keep the interior closed against white men. In a few days we once more reached Labuan, where most of the Kadyans were more or less ill with fever.

After packing up my collections and shipping them home, I prepared for my second and final expedition to Kina Balu, the success of which surpassed all my expectations.

A full account of the birds found and discovered by me in this island will be found in the Appendix at the end of the volume.

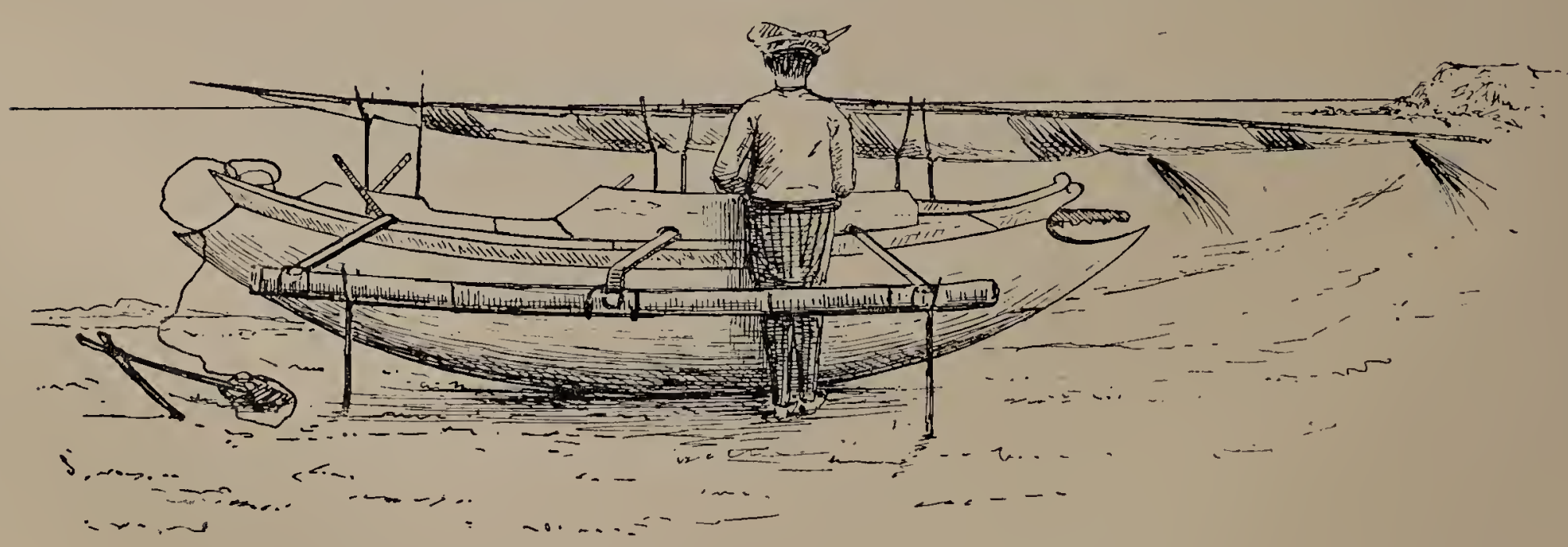

SULU DAPONG. 


\section{CHAP'IER VIII.}

SULTAN PAITAILAN ASSISTS ME AGAIN.-GHINAMBUR.-AN UNPLEASANT NIGHT.-BILLIO LOSES THE WAY.-ILANUNS RETURN.-TEUNG VILLAGERS.-REACH MELANGKAP.-REFCSAL TO HELP VS TO KIAU.-NATIVE GIFTS.-START FOR KIAU.-REACH KOUNG.-UNPLEASANTNESS WITH THE KOUNGS AND MELANGKAPS.-MIEET KURO AND KABONG.-KaBONG'S HOUSE.-BUSINESS-LIKE KIAUS.-START FOR SUMMIT.-FOREST CAMP-LIFE IN SUNLESS HOLE.-VISIT IHIGHER ALTITUDES. -NEW BIRDS.-CHANGE CAMP.-BOTANY.-TRAPPING-PATHS.-NEW BIRDS.-VIEW FROM OUR CAMP.-THE MISERIES OF CAMP LIFE.-RATS.-THE CAVE.-A VISIT TO THE UPPER GRANITE SLOPES.—KURO'S PRAYER.—LOW'S GULLY.—THE SUMMIT.-MORE PRAYERS FROM KURO.-RETURN TO THE CAMP.—ILLNESS.—RETURN TO KIAU.-KURO AND THE CHIEF OF LOWER KIAU.METEOROLOGICAL REPORT FOR FEBRUARY.

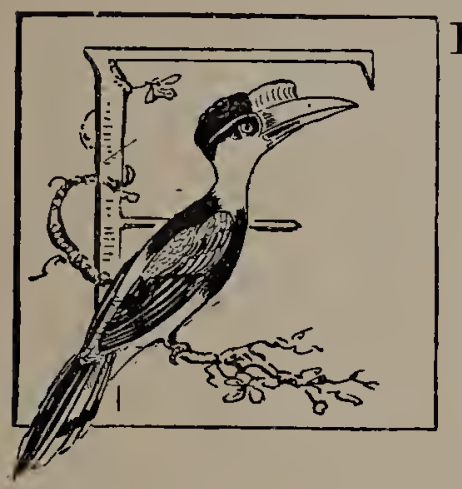

ROM inquiries made during my first expedition, I came to the conclusion that it would be best to leave Labuan for Kina Balu by the middle. of December, as by the time I should arrive at Tampassuk the river would then be as low as at any time during the sear. My party on this occasion consisted of six Kadyans, one of them, "Buntar" (a most useful and plucky little man), acting as my servant. By cutting down the numbers of my party I was the better able to make the rice last; this was my chief object in taking such a small number of followers-the providing of one's followers with rice being one of the chief difficulties in Borneo. My friend Mr. A. H. Everett accompanied me to Abai, afterwards he proceeded to the Islands of Mantinani.

The north-east monsoon, as usual at this time of the year, blew hard in our teeth, and several times I feared that my pakarangan, which we towed astern, would come to harm.

16th December.-We steamed into Abai at 10 A.M., but as it was low water the steamlaunch could not cross the bar, so we had to land all the baggage by means of the ship's boat and my own on the small island opposite Abai, the 'Bujang Barram' leaving for Mantinani directly all was safely landed. Before dark we had succeeded in housing all our belongings in the old Rest House, where $I$ had a sharp attack of fever, brought on, no doubt, by the rough voyage.

17th.-We were busy arranging our baggage into suitable packs, for the buffaloes to carry to the Tampassuk. In the evening Nyhan shot a fine stag, or "Rusa"; these animals 
seem fairly common in this part. The next morning I sent three men over to the Tampassuk to ask my friend Sultan Paitailan to bring over twenty-two buffaloes to carry all our impedimenta. The Sultan came the next morning, and we discussed the possibility of sending the boat round to the Tampassuk River full of baggage ; but in the end gave up this idea, as the Tampassuk bar is a bad one and the sea rough, and a wreck would be fatal to our success.

20th.-I am attacked every day with a low fever, which is far from pleasant. The country round about Kina Balu is always hidden in cloud, so the wet season must still be continuing: the Tampassuk Bajows report the river very full.

It was not until the 30th that the Sultan was able to collect the desired number of buffaloes, and on that day we reached the Tampassuk River. The next day I walked back to Abai with the men and arranged the rest of the baggage left there, consisting of a small stock of rice and other provisions; we pulled the pakarangan out of the sun into a mangrove-swamp, and put a quantity of water into it, covering it over with kâjang mats, leaving word with some Bajow salt-makers to look after it until we returned. The plain is now swampy, and in places the mud is waist deep; Snipe and Golden Plover are now plentiful.

1st January, 1888.-The Sultan thinks we shall be able to start inland on the day after to-morrow, but is afraid of another flood on the Tampassuk before the dry season really sets in. A Bajow and his wife have been having high words in a house on the opposite side of the river this morning, and the lady nagged at her spouse for so long that it ended by the man drawing his kris and waving it about in a threatening manner in her vicinity: this quieted the woman at once.

2nd.-The Ilanuns called early and tied up their packs, but only for sixteen buffaloes, though I could have had thirty if I had required them; but I prefer to divide the risk and take only part of my things, leaving two Kadyans here with the rest, who are to come on in a few days. 'The Sultan requested me not to employ Bajows, as he could find sufficient men amongst the Ilanuns ; this, of course, I was willing to do, as the Bajows had refused to help me before. Billio is still alive, and again joined the ranks as interpreter, and again stipulated that he was not to go to Kiau with us. The famous blanket of last year has been divided amongst the Billio family, Billio himself wearing a lung strip as a cummerbund; he has not sufficient cheek, however, to ask for another. I amused myself in the afternoon shooting Snipe, and unfortunately lost a Snipe which I have little doubt was a Great Snjpe (Scolopax major). The plain is in a fearful state, a mass of slushy black mud, and it will, I expect, be most unpleasant walking to-morrow. The river is sufficiently low, so if all goes well we shall reach Ghinambur to-morrow evening.

srd.-We were all on the road by 7 A.Mr.; but for the state of the plain our journey would have been most enjoyable: the Tampassuk is decidedly lower than it was when we returned last year. We arrived at Ghinambur soon after 4 P.M., without a drop of rain falling during the day. The old Dusun who entertained us last year did so again, but owing to the fact that our host kept his buffaloes and pigs fenced in below the house, where they wallowed in several feet of their own filth, the stench arising from such a cesspool prevented my sleeping. Every now and then a buffalo would change the position 
of its huge carcass, and with this movement the filth would be stirred up afresh, and I was forced to take refuge under my blankets to avoid being choked. How any human beings could sleep nightly over such a place I am still at a loss to understand.

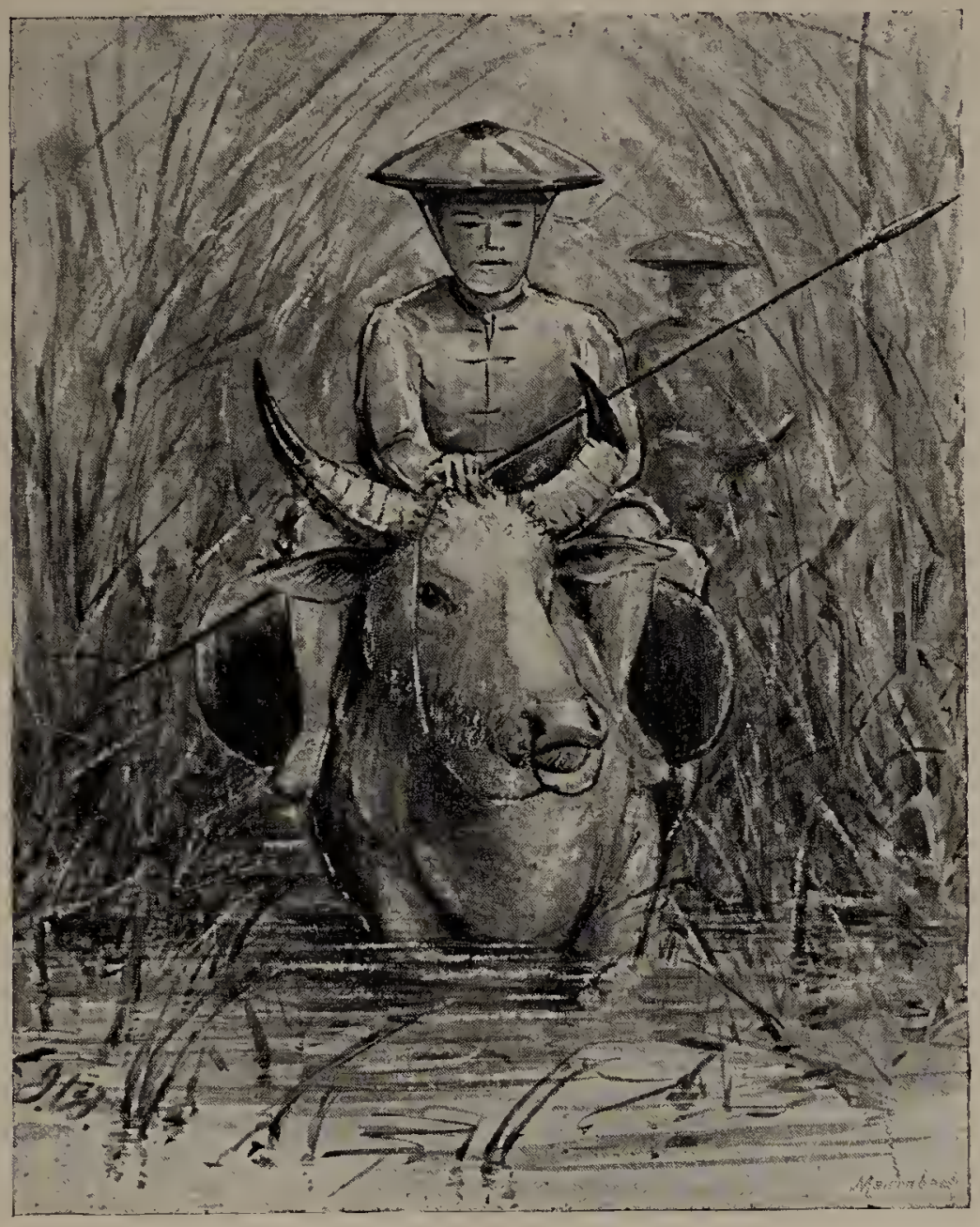

BAJOW AND BUFFALO.

4th.- -Rose long before daylight, and left our host's abode for a breath of fresh air. Buntar made my chocolate beside the river, where I breakfasted. After giving a few small presents to the Dusuns we waded across the Tampassuk and resumed our journey. We forded the river three times after this, and followed a path on the left bank which Billio said he knew would take us to Melangkap; this was a mistake, and landed us in a sea of troubles. After ascending several steep hills, the buffaloes, unaccustomed as they are to anything but the level plains, began to give in, and our party became greatly divided. On reaching a comfortable-looking Dusun village, the name of which I do not know, the Ilanun drivers did their best to persuade me to stop; but rather than do this I made them come to a stream a little further on, where we could get water for cooking. No sooner, however, had the Ilanuns relieved their beasts of the loads, than down came the rain, wetting us through to the skin, and made all so uncomfortable that they were anxious to move on, hoping no doubt shortly to reach Melangkap.

Shortly after starting we met a Melangkap Dusun; he at once opened his basket and gave me some pisangs: though this old fellow had been the most disagreeable man to us 
in Melangkap last year, on meeting us again he was at once quite friendly. We trudged up hill through mud and slush until nearly 4 o'clock, when Billio discovered that he had struck a "terra incognita," so when the buffaloes arrived there was nothing for it but to make the best shelter we could for the night. The rain steadily continued, and the whole of the surrounding country was hidden in mist. A short distance off we found the framework of a Dusun field-house, minus roof and sides; this we soon covered with the large waterproof sheet, and stowed the baggage away below. In this small space-some ten square feet-twenty-one men sat huddled together until the following morning. It rained hard all night; sleep was made impossible by the presence of thousands of midges, which were first attracted by the buffaloes and then attacked ourselves. It was a pleasure to me when the sun rose, even after having walked hard for two days and spent two sleepless nights. Billio went on last night, still believing that he knew the way, and shortly arrived at the village of Teung, from which place he brought porters this morning. With the daylight we find ourselves on a low range of hills on the opposite side of the Panataran, facing Melangkap : the well remembered notes of the Tonkakis and Lăhoie were the first sounds heard at sunrise, announcing that once more we had succeeded in reaching the kingdom of Kina Balu. My agreement with the Ilanuns being for two days only, they refused to go on to Melangkap, stating that their buffaloes' feet were broken up, so they started on their return journey at daybreak; but later on I heard that they were unable to cross the Tampassuk at the first ford, owing to the flood, and were delayed a day. I was indeed lucky to have missed this by a few hours.

5th.-Billio returned with some Teung villagers; they say that the Panataran is too high to ford, so we shall have to wait until to-morrow, passing another day and night in our miserable lodgings. We, however, settled with the Teungs and paid for seventeen buffaloes from this to Melangkap. I was glad that I had not brought the whole of my baggage, or this mistake would have cost me dearer still. Billio is much upset over his mistake. The Dusun tracks over these hills during wet weather are almost impassable, no Dusun ever taking the trouble to repair the paths. Rain after mid-day.

6th.-We left the bamboo framework at 8 o'clock, and reached Melangkap in two hours. The Teungs were a great trouble to settle with, their chief spokesman being a disagreeably harsh-voiced man, who would not at first come to terms; but in the end I let him imagine that he had bested me by giving each Dusun five common needles extra, which one could buy in Singapore at about twenty or thirty for a penny. This I have always found the only plan when dealing with these people, viz. to offer a certain amount, and at the last moment, when negotiations are apparently broken off, to add a trifle.

'The Melangkaps, after their fashion, seem pleased to see us. Our first trouble is to find a house, the one we occupied last year having fallen down. Most of the Dusuns at this time of the day are in their fields. After visiting one or two houses which were unsuitable, the old priestess-with the brass anklets-arrived, and at once offered us a share of her house, which is the best in the village. I am glad for other reasons to accept of her hospitality: the old lady, being a tremendous talker, carries a great deal of influence in the village, so her friendship is desirable. 
I divided a piece of grey shirting, value $\$ 1$, between the joint owners of the house, being my rent for any length of time, which in the end was nearly six months. The Dusuns we knew last year have given us small presents of fruit, though to judge by their faces we might have been perfect strangers to them. Gamboie and the old lady were undoubtedly pleased to see us again. Rain after mid-day.

Tth.-Busy all day arranging and drying the baggage, which is slightly damp.

This house is a great improvement on the one we occupied last year. I have taken possession of one of the private apartments, which Buntar has made quite comfortable. Rain after mid-day.

Sth.-My anerroid gives the height of Melangkap at 1300 feet. To-day it has kept fine up to 5 P.M. Just now a small richly-coloured Finch is in swarms in the paddi-fields, and is a great trouble to the Dusuns; this bird was not seen by us last year, the riceharvest being over. Of the Chlorura I am unable to find further specimens amongsi the flocks of this Finch (Erythrura prasina).

9th.-The Dusuns are good reptile collectors ; a man brouglit me a beautiful little snake to-day, bright coral-red on the underparts, and spotted with the same colour above. Rain after 2 P.M.

10th.- We shall have to wait here until the two Kadyans bring up the rest of our baggage, consisting chiefly of rice ; they should arrive-the river permitting-in Melangkap on the 15th. The Dusuns do not seem anxious to carry our baggage to Kiau, the harvest being their excuse. Rain after 2 P...

11th.-I was busy making a sketch of the mountain from Melangkap to-day. The men are steadily collecting the birds in the vicinity, and besides those mentioned last year they have obtained further specimens of a new 'Timeliine (Mixornis montana) and a brown Bulbul (Criniger ruficrissus). Flocks of a northern Siberian Thrush (Turdus obscurus), and dozens of Wagtails (Motacilla melanope), are about the village, these two species being on migration: of course many of the common lowland species are also present. The new Mixornis has a peculiar note (like its near relation M. borneensis), which may be heard any morning in the vicinity of the village ; it is a bell-like "Chou chou buckier buchier." The nest we have also found; it is a small ball of dried grass-stems, placed near the ground. Rain after 2 P.M.

12th.--Remarkable as being a fine day, a sharp shower falling at 2 P.M.

13th, 14th.-Quite fine. This weather is very propitious for my men, who should leave Tampassuk to-day. I am doing a daily trade with the Dusuns, old and young, in frogs, snakes, lizards, and beetles, giving them in exchange needles, matches, and cottons; I brought quite a cargo of such articles with me for this purpose. One youth, whom we named Maharajah Malus (malus=lazy) last year, is my best customer. 'This boy is a sort of do-nothing; he comes daily with some fine specimens of insects or reptiles, which he finds onl his way to the rice-fields. He is rather vain, and wears round his neck two neatly-made necklaces of red and white grass. The village is in a filthy state of slush just now, the hill-sides being very slippery.

15th.- The two men from the Tampassuk arrived in the campong soon after mid-day, haring found the river easily fordable. 'T'hey came beyond Ghinambur last night, and early 
this morning followed the short cut which Billio made such a mess of: this is the first time we have succeeded in reaching Melangkap with Tampassuk buffaloes in two days.

16th, 17th.- The Dusuns have promised to carry my baggage in two days to Kiau. Rain half the day. The sun shines upon Melangkap at 7.30 A.M., or one hour and a half after it rises-Kina Balu lying north and south. Thus this side of the mountain loses at this distance $547 \frac{1}{2}$ hours of sunlight in the year; this, considering that the sun is generally obscured by clouds about 10 A.M., is a great loss of heat. The situation is not benefiter much in June, when the sun attains its most northern limit, as then the high range on which Kapar is situated blocks the way. Therefore the best collecting-grounds must be on the eastern side, which $I$ am most anxious to reach.

18th.-We are engaged in a squabble with the villagers; they refuse to carry our packs to Kiau, for most reasonable wages--their chief object being to keep all the spoils in Melangkap ; but we have soundly blackguarded them, reminding them of their promises to help us to Kiau last year: we have threatened also to go elsewhere for porters. 'The whole day has been wasted in useless palaver. Day fine.

19th.--These Dusuns still refuse to go, which is very annoying. A Kapar Dusun brought with him about half a dozen sweet-potatoes, which he presented to me, and then waited patiently to see what I was going to give him in return; but as he did not receive quite as much as he expected, he took back his potatoes. The following morning, at 6 A.m., before I was out of my blankets, there sat the Dusun with his beastly potatoes at my bedside. I could not help saying, "___ you and your potatoes!" when he again offered them to me, and I absolutely refused to deal; so the Kapar Dusun had to carry them back to lis village, some miles distant. The habit of giving presents is most objectionable; these people only do so hoping to receive more than the value they would receive in actual exchange. One old man always used to be giving Buntar presents of pisangs for me, and invariably turned up in a few days - when he expected they were beyond return-demanding something in exchange. Shortly, however, we became too knowing, and always kept presents to be returned to the donors when they should call. An old man with a long beard, when we were returning from the Panataran last year, was sitting in the doorway of his house and offered us a fine bunch of pisangs, for which we were truly grateful; but before we had gone many yards, he called out that he must have a pair of trousers in return -his present was returned. Another fine day.

20th.-The Melangkaps have given in, and are going to carry my baggage to Kiau tomorrow for the wages already offered. These people are very trying to deal with, never being satisfied. The only way is to wait patiently and pretend you do not care-pretence only, as it wastes precious time and still more precious food. In all villages - as with ourselves-there are men of superior minds to their fellows, so that whenever the Dusuns refused to do what I wanted, I used to wait until they had finished their discussions-my usual resource being a long walk, as these nagging-parties were especially trying. When I returned to the village I would send for the better class of Dusun and talk the matter quietly over with them, and so I generally succeeded in getting my own way.

21 st.-Left soon after daylight with eighteen Dusuns and five of my own men for Kiau, leaving the honest but useless Hadji with Billio to take care of the rest of my property. Billio, we had agreed, should not go, as one of his friends had been killed by a 
Koung Dusun only seven months before; and as our route lay through that village, the old man was afraid to accompany us. Thus we were left without our interpreter; but Gamboie and the Kadyans managed to understand each other pretty well, and after full instructions from Billio as to what we wanted to do when we reached Kiau, this Dusun was able to do all the palavering necessary. Our path led up and down the steepest of hills, across a good-sized stream which drains the other side of the Melangkap spur. We passed through two or three Dusun villages. At Tambatuan the Dusuns were anxious for us to stop the night in their village, promising to kill "another cow" and make a feast: this offer was most tempting to the Melangkaps, but not to myself, as I did not wish for another cow's leg to my debit; and besides this we passed a cow shortly before we came to the village-this cow had died a natural death; so for these reasons I did not look upon this invitation so graciously as I might otherwise have done, knowing that Dusuns are not particular, and, curiously enough, it was in this very campong that the Assistant-Resident wrote me the letter about the poll-tax cow last year. After leaving Tambatuan the route descends to the Tampassuk, which has to be forded several times before Koung is reached. Some of the granite bouiders in the bed of the Tampassuk are of immense size. The Dusun paddi and kaladi are to be seen wherever the ground is suitable for cultivation. We reached the village of Koung at 3.30 P.Mr.; but our Iusun porters were far behind, so we walked through the village and waited beside the river until they arrived. The village of Koung is very prettily situated on a level green sward round which the Tampassuk flows in a graceful curve. On the left hand is the curious mountain of Saduc Saduc, the "Anak Kina Balu" (child of Kina Balu) of the Dusuns; this mountain is pointed, and the side visible from Melangkap is very precipitous. On the opposite side of the river the mountains rise abruptly; the green is planted with coconut-palms, which seem to thrive here.

Our porters arrived before dark. My men and myself shared a large paddi-house, as the Koungs appeared by no means friendly and did not invite us to their houses. The paddi-house was more like a large bird-cage, but, though in cold and airy quarters, we passed a comfortable night. Our carriers mingled with the Koungs, sleeping in their houses, which on the next morning had the following result.

22nd.-As soon as we were ready to resume our journey to Kiau, the Melangkaps refused to move, saying that they had no more rice, and unless I provided them with some they would not go any further. This of course I refused to do, as it is always part of a traveller's agreement that local porters carry their own rations; after a deal of threatening several of them produced their own rice and ate it. This was the work of the Koungs, who persuaded the Melangkaps to refuse to go further, hoping no doubt to benefit themselves by this manœuvre by earning wages from their village to Kiau. The Melangkaps having been paid beforehand willingly acquiesced in playing their part. But as we proceeded to cross the river the Nelangkaps soon followed. The Koungs are apparently a well-to-do lot of people, and are physically finer and better-looking than the Melangkaps, especially the young women, who were handsomer than any Dusuns I saw round about Kina Balu.

The headman of this village ( $I$ do not know his name) is a handsome man with a some. what sharp and disagreeable look; when I offered him a present on the morning before we started, more than equal to the hospitality he had shown us, he refused to accept it, so I gave him nothiug else and left his village: he was no doubt angry because we had gained the 
Melangkaps over to continue to Kiau, not liking to do without a share of the white man's goods. I passed through this village on several occasions after this; always avoiding the inhabitants, camping a short distance on either side of it. A short distance from Koung is the village of Labong Labong; one of the villagers being in Koung at the time of our visit, this man did his best to persuade us to follow the route through his village to Kiau, but we followed the Tampassuk.

The ford at the end of Koung village is rather a nasty one, being deep and rapid; the rest of the way leads up the valley of the Tampassuk, occasionally in the river-bed or in the native fields. The river has to be forded several times before the foot of Kiau hill is reached. On the banks of shingle in the dried-up bed of the river that curious plant Coix lachryma grows abundantly; the hard white bead-like seeds are occasionally threaded by the Dusun women and worn instead of beads. Near the foot of Kiau hill we were hailed by a big, dirty, ugly, chawated Dusun, who was sitting in his small field watch-house: this is a well-known character to those who have read 'The Gardens of the Sun'-Mr. Kuro, of Kiau. We sat down to rest at the foot of the hill, tired and hungry ; it was nearly mid-day, and our light breakfast, a cup of chocolate and some biscuits, was not sufficiently sustaining. While waiting here, Kuro was joined by another Dusun, whom he introduced to us as his friend Kabong, also of Kiau. Kabong carried a large bamboo of "tuak," and his flushed face showed that he carried other bamboos full of this intoxicant. Gamboie and the two chiefs of Kiau retired to the paddi-house, and finished the "tuak" with a breakfast of cucumbers. After breakfast these gentlemen were much intoxicated, and Gamboie, who had been carrying my gun, had to be relieved of it. As all the porters had not arrived we started up the long steep Kiau hill and arrived at Kabong's village quite exhausted, the sun being very hot and we very hungry: Kiau hill under such conditions is most trying.

After reaching Kabong's house I had to wait until 4 o'clock for the Dusun porters who carried my provisions. It was as much as some of the Melangkaps could do to reach the village; when they came in thoroughly done up they were received with jeers and laughter by those who had arrived some hours before. However, after a meal of rice, these men, relieved of their burdens, started on their return journey at once, excepting some who wished to trade for tobacco, and who stayed until the following day.

Kabong invited us to stay in his house, which was a brand-new one and the finest I have ever seen in Borneo. Kaboug and Kuro are the headmen of Middle Kiau (I say Middle Kiau, because there are two other villages, one above, and the other below the Kiau we stopped in). The upper village is called Kiau Nuloh, and its inhabitants are on decidedly unfriendly terms with those of Middle Kiau. Kabong always told us these people were a bad lot and not to be trusted; they showed signs of hostility to us by yelling out threats at the Kadyaus, and occasionally small parties of youths threw stones in our direction; but as these demonstrations were quite harmless, being generally carried on at a distance of several hundreds of yards, we did not take any notice of them. This feeling of hostility towards ourselves was probably brought about by jealousy, these people knowing that Kabong's village would gain all our trade-goods.

23rd.-My ancroid gives the altitude of Kiau as nearly 2800 feet. Kiau is built near the top of a spur which runs round in a curve from the S.E. extremity of Kina Balu; this spur is actually part of Kina Balu, and runs up to the base of the granite precipices seen 
in illustration facing page 166, where it attains a height of nearly 9000 feet. The ground in the ricinity of the village is covered with turf and planted with a few coconut-palms, but these palms do not look healthy, the continued tapping of the "tuak"-loving Dusuns being the chief cause of their deterioration. A wild raspberry (Rubus rosafolius) which was in fruit at this season was for some reason not eaten by the Dusuns; these people, I often noticed, have no taste for sweets - a child would rather receive a piece of salt fish than the best sweets made. Kabong and his household seem very well-to-do for Dusuns. The Kiaus are generally taller, broader, and healthier-looking than the Melangkaps : the reason of this physical change in the condition of these people is not far to seek. The Kiaus are great tobacco-cultivators, and they exchange this product freely amongst the other villages; they are thus able to keep themselves more abundantly supplied with the necessaries of life than their neighbours. 'The land in this district suitable for rice-cultivation is also extensive. Being more robust, they are more industrious: this is evident at a glauce to the traveller by the occupations of the men, who during their leisure make numbers of neat round sun-hats, baskets, rattan mats, bark ropes, and other articles, which they sell at the tamels. The bamboo sun-hats I never saw being made in Melangkap: Kiau is apparently the chief factory for these hats; as nearly every Ilanun and Bajow of the coast has one or two, the Kiaus must derive a good deal of wealth from this article of commerce. The Bajows, as I have before stated, do not trade direct with any Dusuns much above Ghinambur, as they have blood-feuds with the Koungs and campongs above that village. The Koungs and Kiaus have also a feud with the villages near Ghinambur, so do not meet at the "tamels." The middlemen for this river must be the Tambatuan and other villagers in that neighbourhood; a good deal of trade is also done with the Tawaran Dusuns, several of whom I met at Koung.

When watching a native of Borneo at work it is interesting to notice how much use . he is able to make of his feet, the grasping-power of the big toe being considerably developed. A native generally holds his work between the two greater toes; he is also able to pick up anything by this extra hand without stooping; on climbing a rope or creeper, the rope is always grasped between the two toes. He uses a knife differently to Europeans. The small-bladed long-handled knives are made in this somewhat peculiar form for a purpose : the long handle fits the arm, and rests on it as far as the elbow, the handie being grasped close up to the blade; then, instead of cutting as we do, these people pull the substance to be cut against the blade.

Kabong's house is slightly different in its internal architecture to other Dusun houses, the private apartments being especially well arranged: they contain a large private room, and beyond this are the sleeping-apartments of the family. 'The plank sides of the house and the dividing partition are quite new, the panels being neatly let in between supports about three feet apart; some of these panels were even slightly carved and ornamentedthis I have never before noticed in a Dusun house. Our host Kabong, his wife and two children, his sister, and another family complete the household. Kabong, though well-todo, is one of the laziest of men; he nurses the baby while his wife, a frail little woman, is wearing herself out carrying heavy loads of fire-wood, water, and other household necessaries ; she also visits the tamels several times a month with heavy loads, orer this most mountainous country. 
Gamboie, who is staying with us as interpreter, returns to Melangkap to-morrow. Several of the Kadyans are becoming fairly efficient in Dusun, and have managed to make Kabong understand that we wish not only to visit Kina Balu, but to spend at least a month near the summit.

24th.-The Kiaus are a most agreeable disappointment. I expected to find them even more difficult to manage and more greedy than the Melangkaps: instead, I find them most business-like, and we soon settled the price in cloth that I am to pay them for their services. All Kabong's household were somn enlisted, and the rest of the porters were easily obtained in the village. Kabong and IKuro are going as guides; this is, of course, unnecessary, but being the headmen, it is best to submit to Dusun customs, though I gave them to understand they would have to carry packs like the rest of the party. Kuro is tall for a Dusun, also dirty for a Dusun, which implies a great deal. His family is very large, consisting of eight. Some of the infantile Kuros are covered to such a depth in filth, that it is at first somewhat difficult to make out what they really are. Most of the Dusuns bathed frequently when on the march; the Kuros never-in fact, they despise cold water. One day, for a joke, Kuro called out to one of his younger sons that we intended to wash liim; at the word "manjo" (wash) the urchin bolted, howling, into his home. Kuro still talks of 'Tuhan Helow (Mr. Low) and Tuhan Hingin (Mr. St. John), but he cannot remember them well, as it was exactly thirty years ago since those gentlemen visited Kiau. He speaks of these two gentlemen as the only two white men he ever took a fancy to.

The Kiaus build their houses very quickly, the whole village assisting. Just now some forty Dusuns are busy pulling down Kuro's house, and, judging by the rapidity with which they work, his new house will soon be finished. Nyhan brought in my first specimen of a fine reddish-brown Pigeon, Carpophaga badia, the Hadji a small black-and-white Flycatcher, Muscicapula maculato; both these birds are well-known Himalayan species, but obtained to-day for the first time in Borneo.

While taking a short walk early this morning, I saw a pair of the new Sparrow-Hawk, Accipiter rufotibialis, but they were too high to shoot as they circled above us. The Kiaus have tied up their packs and are going to start to-morrow: they are better hands with packs than the Melangkaps, making the baggage up in a most suitable style for carrying on their backs. 'Jo-day Kabong has made me a blood-brother, which consists of my holding a chicken by the legs while he cuts its throat, collecting the blood in a bowl, which he afterwards drinks or mixes with his food. Later on I had to go through this ceremony with Kuro, he also gives me another chicken; these chickens are most acceptable, and I should have no objection to perform the same ceremony daily with any number of Dusuns. The Kiaus say they would have started to-day for the mountain, but they have no rice ready for the journey. We cannot see much of Kina Balu without walking to the top of the hill, when we are, it seems, quite close to the precipices of the highest part of the mountain; the valley below, through which the Kinokok River flows, divides the Kiau spur from Kina Balu itself. As it rained half the day, the precipitous crags of Kina Balu were not often visible, the mists beating down on the village making it much colder than Melangkap. Kabong, besides being nurse, is more of a "general," I find, also acting as cook to this establishment. Fresh hill rice has a nice flavour, being, when boiled, brownish 
in colour and sticky, being also more nourishing than the Siamese prepared rice, in which, I may mention, the Chinese sometimes mix quantities of small white stones which they collect on the sea-shore; this is worse than the sand-and-sugar combinations of civilized grocers, as the stones break one's teetl.

25th.-This morning we were ready early, but were kept waiting some time by the Dusuns, not leaving Kiau before 8.30. Kuro started with us, bringing with him his son, a precocious boy of ten years old, with a loud voice and a huge mouth. Kabong started some time after, but caught us up before mid-day. I left some provisions and cloth in his house, which he faithfully took care of.

After descending to the river, which is now no longer known as the Tampassuk but as the Kadamyan, we followed the bed of this stream over the usual break-neck course. Kuro was anxious to halt soon after mid-day at the foot of a huge rock, which slightly overhangs the river and affords shelter from the rain; he told us that former travellers had always stopped here. By the time we had boiled our rice for our mid-day meal, the rest of the porters had all anived; so, after a light repast, I determined to move on, though it had already commenced to rain. The Kadamyan now flows through a grand gorge, the sides of which are very precipitous. After struggling up the rocky boulder-filled bed for some time under a steady downpour, the Dusuns who were on ahead with us discovered that they had passed the right spot for ascending to the top of the gorge, so we had to wait until the rest of our party arrived. The supposed guides came to the conclusion that the right place for ascending the mountain had been passed some distance down stream on our right hand, so there was nothing for it but to climb up the precipitous sides of the gorge. This was the only difficult climb we encountered during our ascent of Kina Balu. How the Dusuns succeeded in bringing their heavy loads to the top I do not know, as but for the kindly assistance of roots and creepers I could not have reached the top myself. About 4 o'clock we reached a huge rock which was slanting slightly forward, like the one where we rested at mid-day, so that the rain did not fall within several yards of its base. Since we gained the top of the gorge the travelling has been fairly easy, though we failed to find the Dusun path until the rock was nearly reached. I do not think many of the Dusuns knew much about this part of their mountain. The mountain at this altitude (4800 feet) is covered with a dense tropical forest, the ground being hidden under a carpet of ferns and mosses. When we reached the rock we discovered that five of the porters were missing, amongst them being the man who carried my cooking-utensils, and another who carried the ground sheets; this was a great nuisance: so I had to dine off boiled rice and salt fish, which was, however, most acceptable. We made arrangements for passing the night here. This rock, judging by the remains of old fires, is often used by the mountaineers as a camping-ground.

26th.-After a cold damp night the day broke shrouded in a mountain mist, which is accompanied by gusts of cold wind; the mist soon dereloped into a steady dormpour, and the five lost Dusuns have not yet arrived. Thus it is impossible to proceed further up the mountain, as without cooking-utensils and ground sheets a stay in the colder altitudes would be quite impossible.

The five lost porters arrived at 2 P.M., after having passed a most miserable night, as 
they said, in the forest in the drenching rain without fire, food, or clothes. One told us that the situation made him feel inclined to "amok." When they arrived at the rock, half dead with the heavy loads, they were saluted with jeers and laughter by their more fortunate companions. This is the usual sympathy showed by the aborigines of Borneo to one another. It has never stopped raining all day, so we are unable to proceed, as I am told that the next shelter will take half a day to reach.

27th.-The Dusuns returned to Kiau, leaving us and our belongings under the rock. They have no more food: our stock of rice is far too valuable, so sooner than waste it by feeding fourteen hungry men, I have let them go. During the night the Dusuns stole some of the Kadyans' salt fish; with this I debit the Kuros. In front of the rock is a slender orange-tree, which Kuro says has grown from a seed planted by Tuhan Helow; this tree has never been damaged by the Dusuns, who seem to look upon it with a sort of veneration.

When the Dusuns left we commenced making a clearing in the forest, where we erected a small house, which was roofed in with one of the waterproof sheets. The spot for this clearing was selected a short distance from the rock on a slope where we hoped to receive a little sunlight, as up to this we have been unable to dry our soaking-wet garments. The sun does not reach the place we have chosen before 9 o'clock, and the rock never. As the clouds shortly obscure the sun, and heavy rain generally falls soon after mid-day, our baggage is wet and is sadly in need of drying; but we are in such a sunless hole that this is impossible. We were unable to finish the house to-day, so had to pass another night under the rock. Buntar has been trying to dry some of our garments by wood fires; the result has been very little drying, but changing them into a dirty-yellow colour, besides half blinding and choking us with smoke.

We are all in miserable spirits to-day, the humid surroundings making us both downcast and damp. I have come to the conclusion that fifty new species of birds would hardly repay me for the miseries endured during the last few days. The Kadyans do not take even a real interest in birds, as now they are audibly repenting that they ever came, and no doubt quietly wishing that something serious would happen and cause our return to the more comfortable campong life; but my determination if possible to reach the higher altitudes is not for a moment shaken, it is only this miserable camp that depresses me. I often think how big the comfortably situated people in English homes sometimes talkespecially after a good dinner, when seated at peace with all the world before a comfortable fire, puffing away at a cigar--" how they would like nothing better than to explore wild countries." But, my friends, a few weeks on tinned food-perhaps hardly enough of that at times-cold and wet, want of society, and a hundred little annoyances would soon make you wish that you had never left your comfortable home. To be a traveller a man must be keenly interested in some pursuit, and that pursuit alone buoys him up. This is a kind of traveller's lament written in my journal, below the rock, on a wet day in a gloomy forest.

In front of the rock the forest is still tropical, the trees ligh and of vigorous growth, covered with creepers, parasitic ferns, and orchids. I am also interested in the birds, of which $I$ have seen a good many. Kiau from this is W.N.W. $60^{\circ}$. The temperature is $67^{\circ}$ at 3 I.M. Raiu as usual. 
28th.-Nyhan and I left the camp to be finished by the others, and made an expedition up to about 8000 feet. We carried our collecting-guns, and my spirits revived, as I well knew that the birds of highland Borneo were still unknown; so I picture to myself all sorts of new species.

We followed the Dusun path, which crosses a small strean that flows past the base of the camping-rock, and proceeded up a steep slope on the side of the mountain, which was only slightly difficult in one or two places. When we reached a height of 5000 feet we met with a small flock of greenish-yellow-coloured birds, about the size of a sparrow. We secured three specimens; the species turned out to be a new genus, and has been named Chlorocharis emilice. This is evidently the bird mentioned by Mr. St. John in 'Life in the Forests of the Far East,' vol. i. p. 269 :- "The Ida'an (Dusuns) during the day amused themselves in trying to secure some small twittering birds, which looked like canaries with a green tint on the edges of their wings, but were unsuccessful. They shot innumerable pellets from their blowpipes, but did not secure one; in fact, they did not appear to use this instrument with any skill." This was written thirty years ago; and it was not until the beginning of 1888 that the first of these "twittering birds" arrived in this country. The other birds noticed to-day were the ubiquitous Ianthocincla treacheri, Pericrocotus montanus, and Pteruthius aralatus, and several other new species. Pitcherplants were numerous and beautiful. My glance was a hasty one at this, "the promised land;" but I saw sufficient to convince me that it was absolutely necessary to change our camp to a small cleared patch of slightly sloping ground on the top of the ridge which we had traversed on our way up. It began to rain at 10 o'clock, so we were forced to return to the camp. We had no view of the surrounding country, a pall of mist enveloping everything. Rain continued until dark.

29th.-Opened the packs, which are wet, but there is no sun to dry anything; by exposing our clothes to the air they become, if anything, damper. This morning the sunlight reached within a few yards of our camp at 10 A.xr.; and as I sat anxiously watching the light and heat that was to do so much for us, the clouds obscured the sun-so we had none; this part of the mountain must get but little smulight during the year.

The birds collected to-day are a splendid new Flycatcher (Rhinomyias qularis), a beautiful new Barbet-as its name implies (Megaloma pulcherrima) - the head and throat of a light blue, separated from the back (which is green) by a golden-yellow collar. In mists all day; rain after 4 P.м.

30th.- Sent off four Kadyans, with as much food as they can carry, to the campingsite seen on the 2Sth, with orders to erect a shelter for me and to do their best with a grass-roofed Dusun shelter which we saw there; they are to hide the provisions and return again to-day, and to-morrow we will carry as much as possible to that place. It has rained off and on all day.

31st.-We started soon after daylight, leaving one of the men, who has a swollen leg; he will have to remain in this miserable sunless spot, with another man whom I am sending back to keep him company, in charge of our camp until the Dusuns arrive, when I will make other arrangements. I must say I was heartily glad to leave that miserable spot, where the sun never once shone to dry and warm us. At times, when the mists 
cleared, we had a fine view of a small waterfall which tumbled down into the depths below at the head of the gorge. After heavy rain the water fell over, as it were, in masses; this stream is the source of the Tampassuk River, flowing from the very summit of Kina Balu.

When we arrived, greatly fatigued-carrying as much as we were able-at the canip, I found that the Kadyans had made a small shelter just large enough for me to lie down in; it was raised a few feet off the ground: this erection we roofed in and surrounded on two sides with waterproof sheets. The three Kadyans for themselves have rebuilt the low grass-thatched Dusun shelter and covered part of the leaky roof with a waterproof sheet; but it is still far from watertight. The flooring they have made of poles a few inches above the ground, above which they have tied a light platform of sticks, fastened to crossbars, for their sleeping accommodation. The fireplace we built up with mud and stones, to be out of the reach of the water. The Kadyans were quite done up with carrying their loads up to this camp-which my aneroid gives as 7350 feet-being unaccustomed to such altitudes, and during our frequent rests on the mountain side they declared that this was the last time they would go mountaineering. I have resolved when the Dusuns call to see us, which they have promised to do, to send the two men in the lower camp back to Kiau and have everything we want brought up here. The two men will do little or no good below and will consume our rice, which is too valuable, while at Kiau they may collect something, and they will be able to buy rice from the villagers. Rice near the summit of Kina Balu is worth a fortune to the explorer, not even taking into consideration the actual cost of bringing it up from the coast. Just now, at 3 P.M., the sun is shining through a steady shower of rain; this is the first time it has shone upon us for a month. How all-important is our great luminary to our comfort, and what miserable beings we are without his all-powerful rays! in a few months after the close of those millions of years which scientific men tell us will see him consumed and dead as the moon, Kina Balu may still be here, but not an organic form, such as we now know, will exist.

Our camp is situated in a good position: it is on the top of a spur, and receives, after we have cut down a few of the low trees, all the sunshine. This small open spot is perhaps 25 yards square, is marshy, and contains quite a number of plants. When I was too ill to get far from the camp, I amused myself by making a small collection of dried plants, chiefly from this spot. 'The most abundant species here, and of which the hut's roof was composed, was also the most interesting plant: it is, I am told, a Patersonia, closely allied to P. glabrata; this plant is an Australian species, and even in that country is extratropical; it has never been recorded from any other islands in the Archipelago. This geographically interesting plant, though common on this small marshy patch, I did not notice elsewhere on the mountain. Just now it is in flower; the flower, however, is insignificaut, being threeand rarely four-petaled, white with a purple centre; it belongs to a genus somewhat allied to Iris. As I have introduced the subject, I may as well complete the account of the botany of this small marshy spot. Round the edge are numerous Nepenthes, the commonest, or perhaps the most conspicuous, being $N$. lowii; more hidden, but equally common, is N. villosa, with its beautiful rose-coloured pitchers. A fern allied to Polypodium dipteris (Blume), together with Lycopodium cernuum (Linn.), a species of bracken, and a variety of mosses reach to the upper edge of the marsh. Amongst the flowers collected by me on 
this spot I may mention a small gentian, Gentiana pedicellata, a Utricularia, sp.?, Trachymene saniculafolia (Hk.). Of sedges, Gahnea javanica (Steud.) was one of the commonest; and Xyris schnenoides (Mart.), a Panicum, sp.?, Alectris, n. sp.?, Ericaulon, n. sp.,-the last four species being insignificant-looking weeds.

Not far below the camp I noticed a small white Begonia, sp. ?, flowering freely. The trees in the vicinity are about fifteen feet high, stunted, twisted, and weather-beaten: on the top of the ridge they are exposed to every blast, are clothed inches deep about the trunks with dripping mosses; their branches are festooned with long beard-like growths of silvery lichen, a proof, if proof be wanting, of the humidity. The commonest tree is a species of mountain Casuarina: of other pine-like species, Dacrydium elatum (Wall.) is common; I also collected a species of Juniperus, sp.? In the forest above the camp I found a Medinilla, sp. nov., which had a pretty pink flower. In the marshy patch we have dug shallow wells, which I hope will keep us supplied with water, even if the weather should turn fine. The soil in most places is only a few inches deep, and is mixed with a good deal of white limy-looking earth; this want of subsoil accounts for the absence of trees and has saved the Patersonia from extinction. Most of the plants mentioned are found in Australia, and the Patersonia, I am told, is peculiar to that region: this is curious, as the ornis of this mountain is almost entirely Himalayan.

After a short rest I was most anxious to explore the forest in our neighbourhood, so I went for a stroll with Nyhan, leaving the other two men to finish the camp. Unlike the Melangkaps, the Kiaus have a path right up to the higher altitudes of Kina Balu; this is a great blessing to us, as we are able to get about at once without spending days in cutting paths: the path leads straight along the top of the spur, and later on, as we discovered, right up to the granite slopes, or to about 11,000 feet. As long as the path is followed it is pretty easy travelling, so we were able to traverse the mountain with comparatively little trouble. These paths are made by the Kiaus for the express purpose of setting their bamboo rat-traps: the traps are placed a few yards apart, the intervening spaces being generally difficult, or made so by the Dusuns, along the sides of the paths to nearly 9000 feet. The frequented runs of the small mammalia, such as rats, squirrels, mice, \&c. \&c., are easily discernible on the soft moss-covered ground. After leaving the camp we proceeded for some distance through the low weather-beaten trees, no view being obtainable on account of the mist. Feeling fatigued I sent Nyhan on, and sat down to meditate on the situation: my thoughts were, however, shortly disturbed by a Blackbird, which perched within five yards and calmly examined me, wondering no doubt in his unsophisticater mind what an extraordinary new species of monkey had turned up in his domain. 'The eye of this Blackbird was bright, his bill and legs of a golden yellow, his breast black with the lower half reddish brown; I knew at a glance that he must be unbaptized. He kept so near that I could not secure him, so I was forced to do what birds in this country try to do-to get away from him, thus reversing the order of things; shortly he settled on the ground, but too near, so when he was slightly hidden behind a stump I fired, hoping to secure the bird with a few pellets only; but he was untouched, most of the shot lodging in the stump. This attempt upon his life was nothing to my Blackbird-lie merely flew up into a low tree and examined me with more interest than before, as much as to say, "W' hat 
an extraordinary noise!" I walked further away, and this time he fell dead; but on reaching the place I found that the bird had fallen amongst a mass of moss-covered boulders, where, with the assistance of Nyhan, I searched for it for nearly an hour before we found the first specimen of Merula seebohmi. This beautiful species is somewhat allied to Merula javanica, and may be considered the representative Bornean form of that species. My fatigue at once left me and we proceeded up the mountain, shortly reaching a more protected spot where the trees formed a goodly-sized forest, the undergrowth of which, as usual, was chiefly composed of the horrible creeping bamboo, which here grew most luxuriantly. Whilst standing still in this forest we noticed a small rusty-brown breasted, blue-backed bird, at first sight something like a Robin; I give its colours as it was within two yards of me. At first we tried to catch it, then we endeavoured to get away from it, but the bird closely followed us: at last Nyhan went in one direction and I in another, and before long he shot it. 'This was another new and interesting species, being an exception to the plumage rule of the sexes-the male being entirely blue, with a narrow streak of silvery white over the eye. In most other countries the sexes of this species are alike. My species has been named Brachypteryx erythrogyna (the red female). Before Nyhan had picked up the dead bird, I saw creeping about-almost at my feet-a small creature which I at first thought was a mouse, but I soon discovered that in reality the new comer was a small Timeliine bird. This little brown bird was if anything tamer than the species just shot, and was only secured after ten minutes in trying to get away from it; and when shot it was too much hit. This bird was of general dull brown, the throat being dusky white and speckled, the tail-feathers being exceptionally weak and loosely webbed; this, our third new bird within an hour, was not only a new species but a new genus: it has been named Androphilus accentor (i.e. the man-loving Accentor). What mistaken confidence, poor bird! The few specimens of these two species obtained by me invariably sought us out in the forest, appearing within a few yards or often under our very toes. I have been closely followed by an Androphilus for fifteen yards or so, as I walked slowly purposely to see how far the little friendly bird would follow. The Kadyans used to laugh at and call these little innocents "bodo," i. e. fools; at times they used to try and catch them with their head-cloths. Thus ended my first stroll, when in three shots we had collected three new species. During this walk it drizzled or rained without ceasing.

1st February.-I have set my maximum and minimum thermometers, and my meteorological return for the month will be found at the end of this Chapter.

During our first ascent from the lower camp to this altitude I heard a feeble attempt at "Tonkakis." 'This note was so decidedly different to the "Tonkakis" of Cissa minor, the Green Jay found near the campongs, that I knew that the bird which uttered this note must be different, nearly allied to, or perhaps a new species of, Cissa. This morning, after Nyhan and Tungal had started, I had just finished my breakfast of porridge, when I heard again that same note uttered amongst the gnarled moss-covered trees close to the camp. After a careful stalk I caught sight of a bird moving about amongst the branches; taking a most deliberate pot-shot, on reaching this spot I picked up a perfect specimen of a Cissa, which at a glance I saw was entirely different from Cissa minor-the eye alone of the new bird being white, while that of the other is lake. This bird was new, and has been named 
Cissa jefferyi. My next viction was a small Flycatcher, obtained for the first time in Borneo, but a bird whose acquaintance I had already made in the highlands of Java, Cryptolopha trivirgata.

After the usual mid-day downpour I took another stroll, and in the open path near the edge of a precipice I secured a specimen of a new genus of Bulbul; this bird has been named Oreoctistes leucops, and is somewhat allied to a Ceylonese form of the group. Nyhan and Tungal have brought in two specimens of the new Barbet and the small Fantail Flycatcher (Lencocerca albicollis). Our accommodation is of course miserable; besides just room enough to lie down in, I have no shelter except the low, thatched Dusun hovel. The nights are cold, and the mist drives continually over this ridge; luckily, I brought my mosquito-net, which helps me to keep fairly dry and warm. No traveller should ever be without this most necessary article in the tropics, as it is most useful where mosquitoes do not exist, keeping off the damp vapours at night; at this camp my net used to remain slung all day, protecting my bedding from the driving mists. Badly off as $I$ am, the Kadyans are worse, though I have provided them with suits of old winter tweeds and warm underclothing, which they wear at nights; but for these clothes they certainly would have succumbed to the cold, as they are men that soon give in under hardships or illness. The Patersonia-roofed shelter under which the Kadyans sleep is very uncomfortable, the roof at the centre being only four feet from the ground; here, however, we sit round a smoky fire during the greater part of the day, the continual rain preventing us getting about much. Over the fire Buntar has slung some racks for drying wood, clothes, and our precious bird-skins. Under this miserable shelter dozens of most valuable birds were skinned, and are now to be found in most of the museums in Europe. This camp, though over 2000 feet higher than the one below, is much more preferable, as we do sometimes get the early morning sunlight. Owing to the tameness of the birds we have reloaded most of our cartridges with half charges, in this way obtaining most perfect specimens; for easy as it is to kill a bird, it is difficult to collect good cabinet-specimens. Tungal always shot geod birds, being a greater rambler than the others, but his fault was giving them too much lead: of this habit I never succeeded in breaking him; when told of it he would get sulky, and say he would not shoot at all.

2nd.-Nyhan brought in another specimen of Cryptolopha montis, a birl obtained for the first time last year on the Panataran; this, however, is its home, as it was fairly common. Close to the camp I came across a little brown bird, puffed out and evidently enjoying the morning's sun, sitting with half-closed eyes; every now and then it uttered a few musical notes. I approached it quite close, but it did not move. When I secured it I found that it closely resembled a small bird I had collected in Tosari, Java. The KinaBalu bird is a new species, and has been named Cettia oreophila. 'Tungal brought in an enormous leech; when it reared itself up it was quite a foot long and of a pale creamcolour. He found this horrible creature in the pathway close to the camp; it is now in thes Paris Museum, but I have been unable to obtain its name.

Respecting the country round about us, I may now say a few words. Our position is now nearly directly behind the main buttress, of which I have given a sketch as seen from Melangkap (facing p. 120). The accompanying sketch is a view of the mountain as seen 
from a short distance above our camp, and shows the bare granite slopes and precipices; the tops of the highest are just visible. To the left of the picture is the commencement of a spur which runs parallel to the one we are on, and on which the village of Kiau is built. The Kadamyan-or head waters of the Tampassuk-runs through the deep gorge between these two spurs. In the centre of the sketch is a deep forest-clad depression : to the right, in the distance, are two peculiar rocks, and above them a point just visible; the latter is the top of one of two high crags, a short distance apart, known as Low's Gully. The spur sweeps round to the right, and in the depression at the base of the granite slope the Kadamyan flows past the well-known cave where Messrs. Low and St. John stopped. The stream flows below the steep herbage-covered rocks in the foreground, and forms a splendid fall a short distance below this camp. In the foreground may be seell one of the commonest ferns at this altitude, Polypodium dipteris (Blume). The colouring of the granite is various shades of grey, with a pinkish tinge on the more precipitous parts. The vegetation which straggles up to near the summit is of a brownish green. Our camp is S.W. of this part of the summit.

The next view is of the interior looking S.E. from the camp, and is a bird's-eye view, when the clouds permit, of an unexplored country. The distant mountains are, as far as I know, unnamed, travellers who have seen them having made guesses as to their names and positions. The most distant mountain in the centre of the sketch was only visible twice during the thirty-three days spent by me at this camp. It is apparently about 70 miles distant, judging by the paleness of its distant colouring, and must be of very considerable altitude, perhaps not much lower than Kina Balu. 'The steep spur on the left-hand side is the end of the main buttress of Kina Balu in this direction. To the right may be seen, on the sides of the hills far below, the clearings of the Teung Tuhan Dusuns, whose gongs we can occasionally hear. Being well above the clouds, we see the tops of them; the country below us was generally completely covered as with a billowy sea of vapour. The trees in the foreground, a species of pine, are hung with beard-like tufts of lichen. Looking to the S.W. a view of the coast is obtained, including Pulo Tega, Pulo Gaya, Mengkabong, and Suliman, the hazy atmosphere hiding Labuan. With my telescope I have seen a steamer, perhaps the dirty little 'Spaniel.' The trees on the top of the ridge are stunted and twisted, the trunks in places stretching low across the paths. The whole country is clothed in moss, which is like a wet sponge ; occasionally, when diving under these treetrunks, one gets soaked by accidently squeezing against this saturated parasitic growth. Amongst the trees climb the botanical glories of Kina Balu-Nepenthes lowii and, to a less extent, $N$. villosa. $N$. lowii is most at home when creeping amongst the trees, where it grows luxuriantly; the pitchers may be counted by the dozen. The colour of the pitchers at first is a light green, blotched inside the lip with rusty brown; after a time they become quite tough and leathery-looking, and rattle when the plant is shaken. This plant has also another very different-looking pitcher, which at first puzzled me a good deal; growing near the root of the plant some of the stems bore a pitcher something like $N$. villosa, the lip being striped with lake like $N$. rafflesiana (Jack); these are the radical pitchers. I mention this, as Mr. Burbidge, on page 99 of 'Gardens of the Sun,' writes-" All the pitchers hitherto seen are cauline ones, and as the plant has never yet been seen in a young 


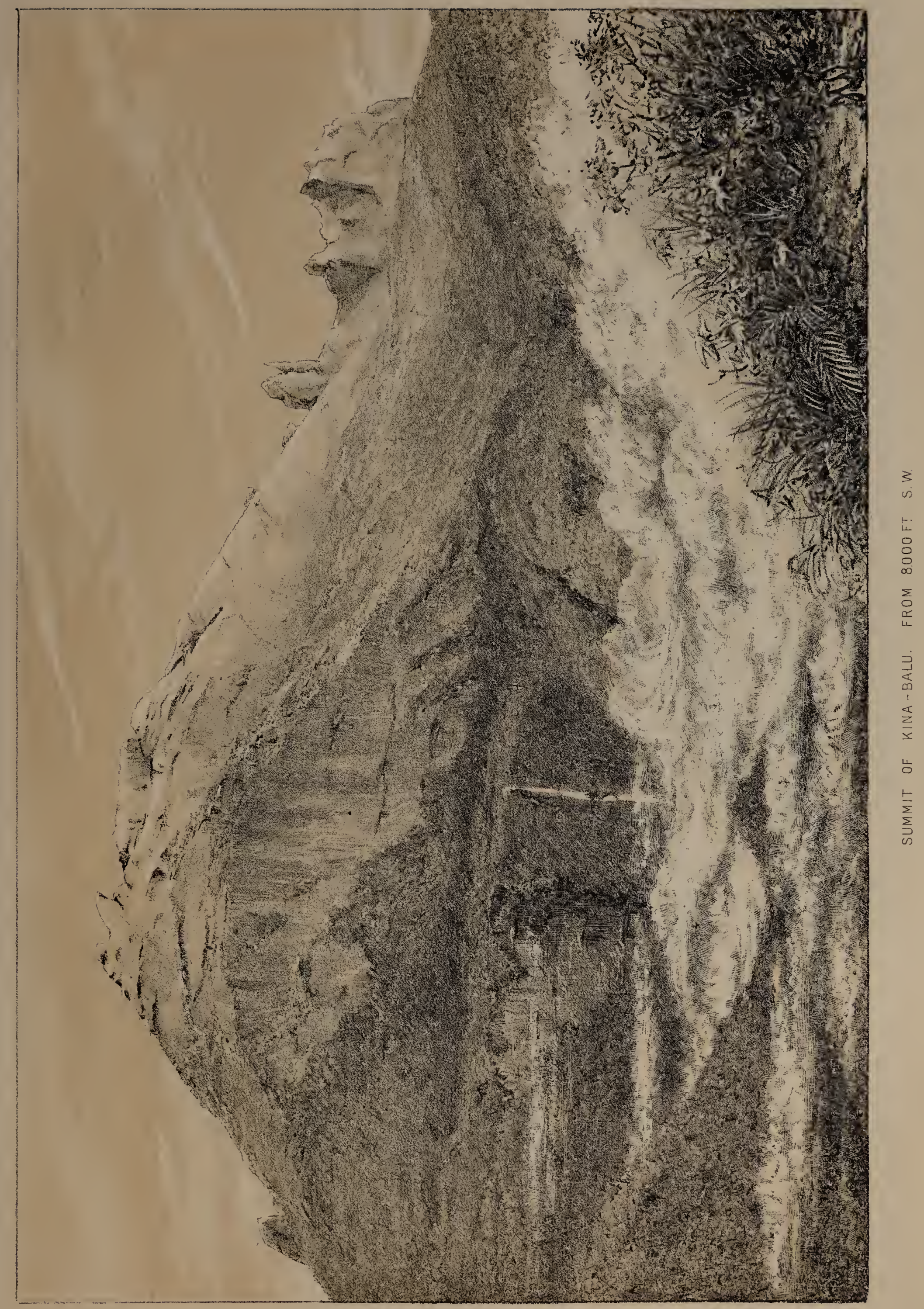





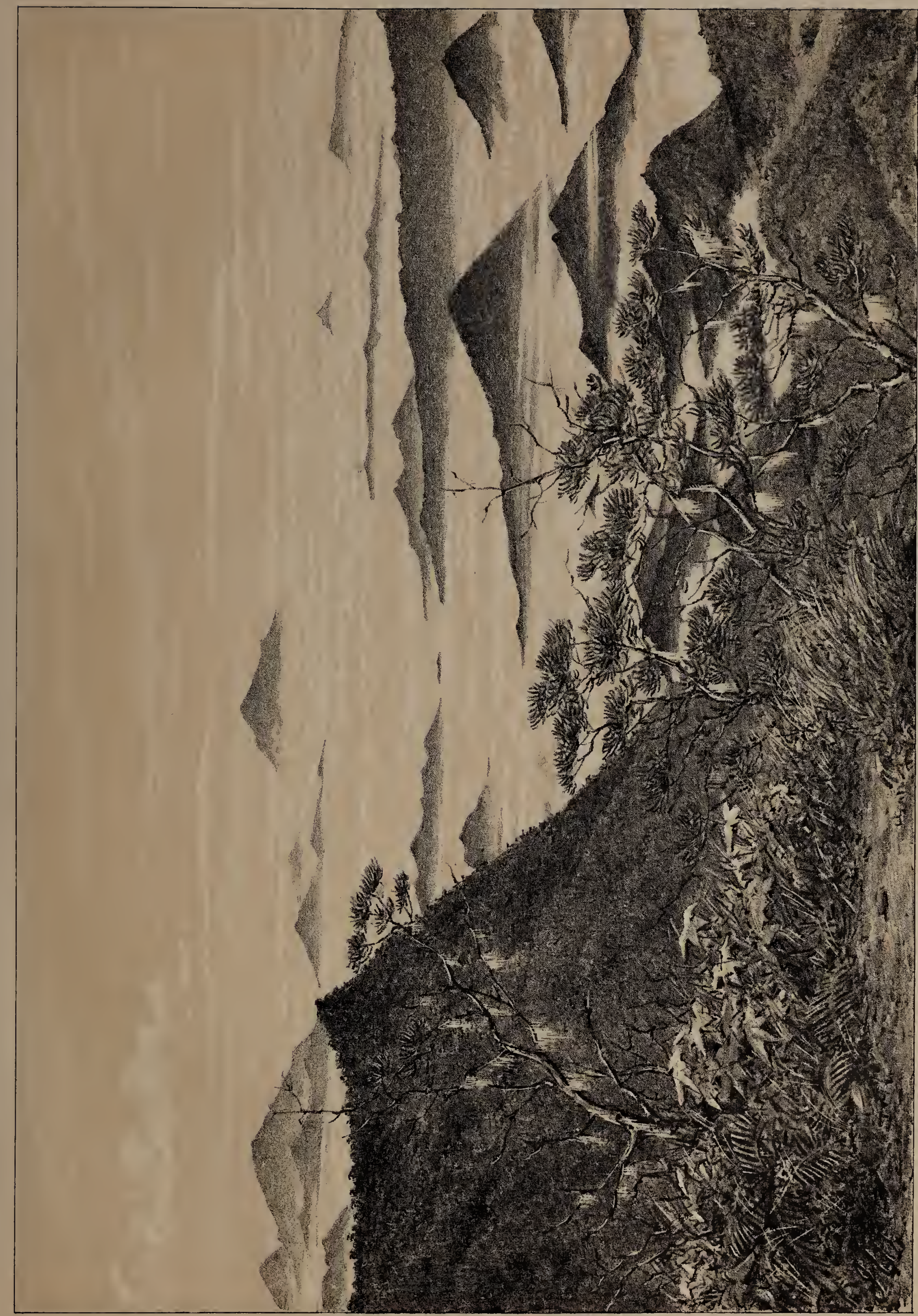



state, it is an open question as to whether the radical pitchers differ in shape or size, as is the case with most other species." Nepenthes villosa has most beautifully rose-coloured pitchers, which seen to attain the largest size, nearly a foot long, when half-buried in moss and leaves, on the more sheltered parts of the mountain, where the trees are stunted. It is to be found growing plentifully up to 10,000 feet. There was besides these two beauties a small species somewhat like $N$. phyllamphora (Willd.); but, unfortunately, I am no botanist, or I might perhaps have discovered other botanical wonders on Kina Balu.

3rd.-To-day I discovered my lost green Finch, of which Nyhan shot a pair the night before we left Melangkap last year. I have seen three of these birds to-day, one of which I shot, but failed to find. Yesterday I collected all the old Dusun rat-traps and got the

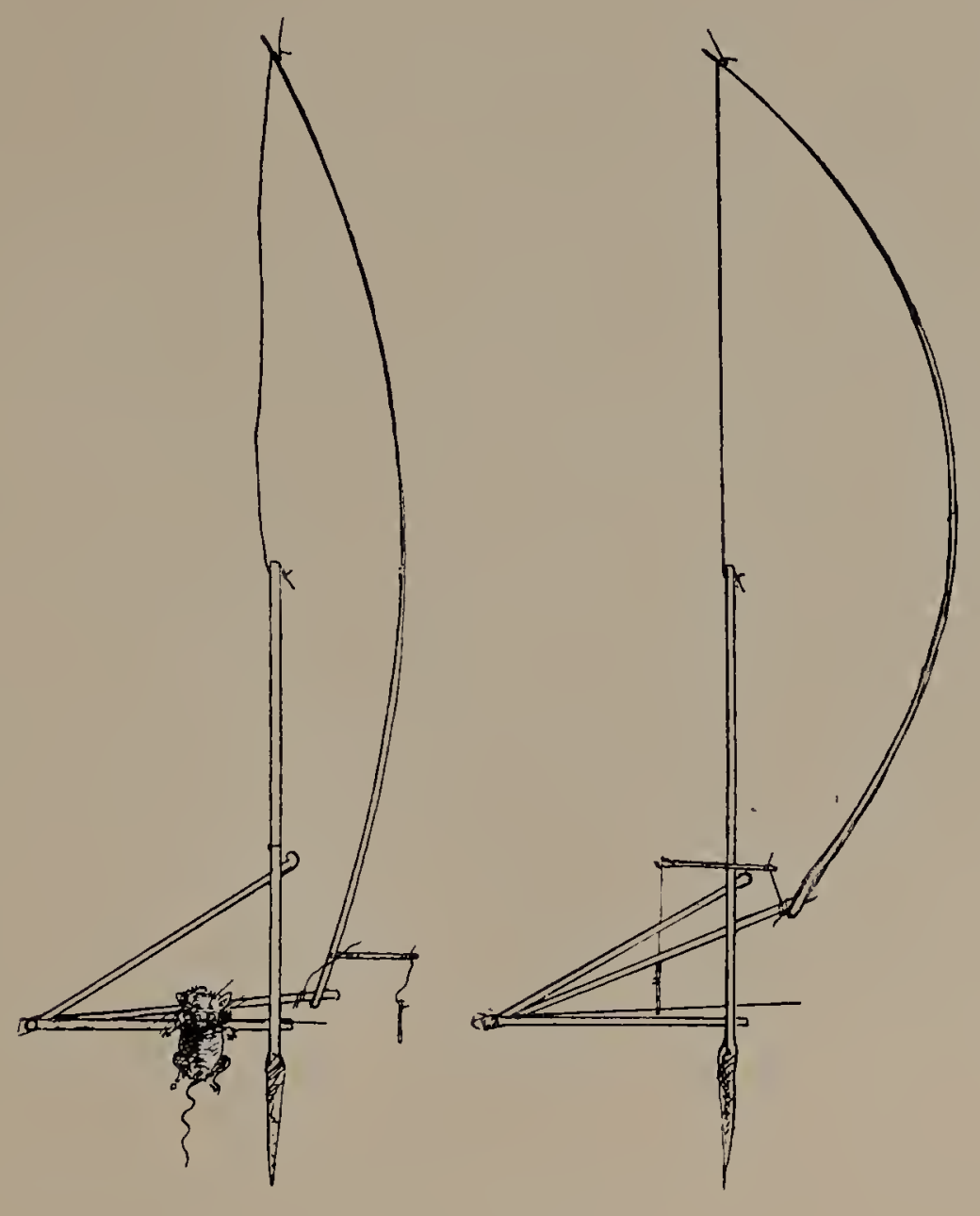

DUSUN RAT-TRAP.

Kadyans to mend them. I set them last night in some likely-looking runs; the result this morning is one rat and a "Topia Tanah"-a new species of insectivore resembling a squirrel, and named Topia montana (Thos.).

4th.-Yesterday it rained steadily from 10 A.M. until night, accompanied by a severe thunderstorm. This morning the world, as far as we know, is enveloped in a saturating mist: this soon, after the sun rose, became a steady downpour, which continued without intermission during the day. So we passed a most miserable day, sitting huddled round 
our smoky fires under the low-roofed shelter; the yellow smoke is blinding, and covers one's face and hands with sticky dirt. The mist drives right through the open ends of the shelter, the continued rain runs down the slope under the floor of the shelter in small rivers, rising at times sufficiently high to put out the smoky fires; besides this I am far from well, having a severe cold in the head and aching bones-such are the vicissitudes of tropical exploration!

5th.-I am very seedy, so have passed most of the day under the mosquito-net in my most limited shelter. Nyhan brought in the green Finch, which, as I expected, was the bird collected last year. I afterwards found this little bird fairly common, feeding chiefly on the seeds of the creeping bamboo; but it is difficult to see, seldom moving, and flying away at once when alarmed: this is a new species, Chlorura borneensis (fig. opposite p. 96). I noticed to-day the first butterfly I have seen at this altitude, a species of Danais; but as the members of this genus are so numerous and hard to separate into species, this butterfly is at present unnamed. The only other species of butterfly I saw at or above this camp was a blue Comma (Vanessa perakana) and a Skipper (Ismenaria, gen. \& sp. ?), which was very dark, almost black; this insect I failed to obtain. Kabong and Kuro arrived about 4 P.M. ; they were surprised to find we had changed our camp. They want me to go to the summit to-morrow, as they think the weather is going to be fine for a few days ; unfortunately I am too seedy. Buntar, my servant, has completely collapsed, and remains without eating or speaking all day, rolled up in his blanket; he has a bad cold in his head, but, Eastern like, has given up entirely. Kuro stole some of our food during the night; this is very annoying, as we are unable to replace our losses. At the rock below the Dusuns stole fourteen dried fish, or enough food for my men for several days; Dusuns cannot resist the charm of salt fish.

6th.-I have arranged with Kabong and Kuro that they shall return to Kiau and bring back sufficient Dusuns to carry up the rest of our baggage from the camp below, after which I will go with them to the summit; the two Kadyans in the camp below can return to Kiau with the rest of the Dusuns, carrying with them our collections and any spare baggage. In order to make the necessary arrangements I had to descend to the lower camp. My head is still bad; the journey to me was a pilgrimage. When I arrived at the camp I found the Hadji still unwell and very depressed: these men had never once feit the sun's warmth, and nearly the whole time the rain had continued to fall steadily; their collections were very small, and contained nothing worth mentioning. I tied up everything I wanted to be carried to our upper camp, and told them to accompany the Dusuns to Kiau, where they are to remain until my return. Kabong has promised to supply them with rice, which will help me a good deal. The last two days have been fairly fine, so our shallow wells, which are merely filled by the drainings of the swamp, are dried up. I have one new bird to-day, a Timeliine, Corythocichla crassa (fig. opposite p. 84).

7th.-We secured another specimen of the new Cissa to-day. This bird is difficult to procure from its habit of keeping near the sides of the precipices, and when shot it falls into the depths below. Our wells are now quite dry; Tungal, however, has discorered a stream some distance off, where we now have to go, using the bamboos left by the Dusuns for carrying the water in. Buntar is still ill and has not made the least attempt to move 
or help himself, so, added to other miseries, I have now to do all my own cooking, of which I make a sorry job.

9th.-The Dusuns arrived with the rest of our things from the lower camp. The want of water is a great nuisance, as I cannot now get enough to wash with, so am obliged to remain well smoked; our clothes of course cannot be washed, and Tungal's stream looks like drying up. Last night was the coldest we experienced at this camp, the mercury falling to $42^{\circ}$ Fahr. Nyhan shot a peculiar small Scops Owl, which was a new genus having no ear-tufts, and has been called Heteroscops lucice. Yesterday I saw a hawk fly over our camp, which I believe was a Peregrine. These Dusuns are easier to deal with than the Melangkaps: having no more cloth they agree to wait for their wages until I go back to Melangkap, showing that they trust us. To-day I obtained a curious insectivorea species of Shrew-in the bamboo traps. I have several times seen this little animal running about in the daytime, but up till now have failed to secure it. Its scientific name is Hylomys suillus. This animal looks more like a tiny pig than anything; its caudal appendage is the merest apology for a tail. It searches for its food amongst the roots and rocks. The Dusuns, besides eating this animal, are very amused at its want of tail, always laughing at the "Nampungher" and making the same remark, "Esok tikiu!" i.e. without a tail. The commonest mammal on this mountain is undoubtedly the rat, which Mr. Oldfield Thomas, of the Natural History Museum, says is nothing more than a variety of our common Brown Rat (Mus rattus), the skull of the two species being identical, though the fur of the Kina-Balu rat is softer and longer. 'This rat was quite tame, running about our shelter and over the men's bodies at night; we caught numbers in the Dusun traps round about the camp. In the forest amongst the larger trees we trapped two specimens of a new rat, Mus alticola (Thos.), the fur of which was slightly spinous. Besides the rats there are two species of Squirrels, the new ones collected by me last year, and a Shrew, sp.? Tungal came back to the camp in a great fright one day-he had seen a devil looking at lim out of a thick tree in the forest; for some time he sat quiet, but at last began to tell us about this "hantu" (this " hantu" was doubtless a large Orang-Utan or Mias). He had met with it close to the camp, but when I went in pursuit the devil had disappeared. Another large long-tailed red monkey comes up occasionally to the forest near the camp; this animal is called by the Dusuns "Kurra," their name for the Mias being "Kāgeau."

I saw traces of a stag near the camp, which might turn out a new species: but large animals are a great trouble to preserve in such a damp atmosphere, our principal enemy being a large blowfly (Dipteris, ? sp.); this insect generally succeeded in laying its beastly maggots in the animals trapped before we found them; if left a day an animal would be unfit for preservation, but not for Dusun dinners. Kuro, Kabong, and two other Dusuns are stopping here to take me up to the summit to-morrow; the rest of the porters returned to Kiau. On the way up with my baggage, Kuro and his big-mouthed son opened their packages and carefully hid some of the tinned meats under the rocks; but, unfortunately for them, one of the Kadyans, following at a distance, on passing the spot noticed some of the tow in which I roll up the tins (making them better to carry), and afterwards use for bird-stuffing, sticking on the bushes at the side of the path. So, with the natural acuteness of a native, he tracked the bits of tow till he found the stolen tins. Of course I could do 
nothing, dependent as I am entirely on these people; so I waited until I returned to Kiau, when I informed the Dusuns that Kuro was a thief. He was the only thief I met among the Dissuns.

10th, - I left Buntar in charge of the camp, as he is now a great deal better; he much wanted to accompany us to the summit, but I could not leave the camp unguarded, so he had to stop. I have since heard that his wish to see the summit of Kina Balu has been gratified. We started on ' a fine clear morning-not a cloud being visible-to ascend, if possible, to the top of this great mountain. The path was easy but for the continual stooping to avoid the twisted moss-covered tree-trunks : on the way up I noticed hundreds of Nepenthes villosa. The cave where Messrs. Low and St. John stopped was reached at 10.30 , or in two hours and a half after starting. This cave, as I have before stated, is not a true cave, being merely formed by a few huge granite boulders falling together. Directly past its mouth flows a small stream, the Tampassuk, in which the temperature is $4 \delta^{\circ}$ Fahr. My aneroid gives the height of the cave at 10,300 feet. The cave mentioned by Burbidge in his expedition to the mountain could not have been this one, as he mentions the difficulty of finding water, having to use that found in the Nepenthes. Directly in front of the cave a path leads along the mountain-the Dusuns tell me to Kiau. After having partaken of some rice, Nyhan and I proceeded to explore, the Dusuns and Tungal to make ready for the night. We ascended the mountain for some distance above the cave, which is covered with a straggling growth of rhododendrons, one white- and the other pink-flowered; the flowers are by no means striking, being small, the shrubs themselves too straggling, having a tuft of foliage here and there, and by no means equal to a rich yellow-flowered species seen below. The sky, for a wonder, was cloudless, and the sun shone bright and warm upon us. I felt happier than I have done for weeks. The slopes are nearly bare of shrubs for some distance, after the growth mentioned is passed: here I saw a small white-flowered alpine in bloom, and a heath with waxy pink bells; in the cracks of the granite rocks a small orchid was in flower (Eria, sp.?). The granite slopes over which we walked are covered with sharp crystals, sticking up like pins, the softer particles having been worn away by the weather. This kind of rock soon wore down the horny soles of Nyhan's feet, making them very tender.

The only birds noticed were the Blackbird, the Chlorocharis, and the small Cettia. The last few days have been most propitious for the appearance of insects, but I never saw a single butterfly, though I was out all day; the only insects noticed were a beetle (a species of weevil) and a few blue-bottle flies. We reached a height of 11,300 feet and then sat down-Nyhan to sleep, I to contemplate the wonderful scene around. The rocks near the top seem quite inaccessible, but to-morrow I hope to see more of the upper regions. Around us was a desolate region of granite slopes, the general effect of which is curious, giving one the idea that ererything is much further off than it really is. This effect is produced by the stunted but perfectly formed shrubs and trees, which in the bright sunlight looked as though they were covered with dust of a light grey colour, which gave the apparent prospective distance; but this was an optical illusion, as not a particle of dust exists here, and was caused by the reflection of bright sunlight on these greycoloured slopes. When we returned to the rave, soon after 5 P.M., the Dusuns had a 
bonfire ready for the night. I shot a Blackbird opposite the cave as a memento of my visit. We had plenty of warm clothes, but no blankets, being unable to carry them, so could hardly manage to keep ourselves warm. I heated a stone in the fire to keep my feet warm during the night. Kuro has brought a chicken with him from Kiau; the bird seems half dead with cold: as yet I do not understand his reasons for doing this. 'To-night he has had a religious fit, and has remained in a kneeling position muttering Dusun prayers to the spirits and dragons of the mountain. I hear my name mentioned occasionally, and my men, who understand a little Dusun, say that he is telling these mythical worthies that we have only come to see their home, and do not intend doing any harm. I am in bed, or ratler lying at the further end of the cave on a bed of green boughs: presently a few drops of cold water fall on my face; I imagine that it is dripping from the roof of rock above, but after another, and yet another dose, I discover that the water comes from the direction of the prayer-muttering Kuro, who is baptizing us indiscriminately, as a preparation for our intended intrusion into the Dusun spirit-world to-morrow.

11th.-I could not sleep for the cold, though I wore several pairs of trousers and coats ; the smoke from the bonfire was suffocating, so I was forced to change my position before morning to the mouth of the cave. After partaking of some food we started for the summit soon after $T$ A.M. When we arrived at the spot reached by Nyhan and myself yesterday, the four Dusuns stopped and held a consultation as to the right route; they were so undecided, and were wasting valuable time, that I soon lost patience, knowing that the summit might be clouded over within a few minutes. So I started off on my own account with the two Kadyans. The slope was at a fairly easy grade, but I soon had to abandon my boots, which I left amongst the rocks. The Dusuns soon passed us, and on reaching the two high crags known as Low's Gully I found them waiting there; they called to us to come up to them, Kuro stating that this was the top of Kina Balu, and was the place where Tuhan Helow had left the bottle containing a record of his visit. But as the mountain was free from clouds to our left, I at once started for some high crags visible in that direction. The Dusuns called out that there was no path and that we could not go any further, so we left them, and shortly afterwards they descended from the gully and followed us. The formation of the mountain now became most interesting, one part being shaped like part of a huge amphitheatre, the seats, as it were, being tilted up high at the back. This peculiar appearance is produced by the formation of the granite, which has beel worn by the elements into huge shield-like slabs; these slabs get loosened and split by atmospheric influences and gradually slide down the slope: they are as neatly cut as if from a quarry. These slabs start their downward journey goodly sized rocks, perhaps nine inches in thickness by six or eight feet long and five or six broad; before reaching the bottom of the slope, which must take years, they are reduced to pieces of less than a foot square, and often into small particles. This is the only way in which I could account for the curious sizes and shapes of the pieces of granite débris picked up by me, and preserver as mementoes to be placed in the bunch of household charms by the Dusuns. The slabs were always thicker on the highest or most up-hill edge: thus the weight and form would tend to assist their slow downward progress. Much of the summit of this mountain is very loose; perhaps there are occasional frosts-the most powerful of Nature's 
rock-splitting agents. After travelling along this gradually rising slope for a distance which must have been close upon two miles, we reached the tooth-like rock to be seen in illustration facing page 180. 'This point has been christened St. John's Peak. A quotation from Mr. St John's work will be interesting:- "I was now anxious to reach one of those peaks which are visible from the sea ; so we descended Low's Gully through a thicket of rhododendrons, bearing a beantiful blood-coloured flower, and made our way to the westward. It was rough walking at first, while we continued to skirt the rocky ridge that rose to our right ; but gradually leaving this we advanced up an incline composed entirely of immense slabs of granite, and reaching the top, found a noble terrace half a mile in length, whose sides sloped at an angle of thirty degrees on either side. The ends were the Southern Peak and a huge cyclopean wall. I followed the guides to the former, and after a slippery ascent reached the summit. I have mentioned that this peak has a rounded aspect when viewed from the eastward, but from the northward it appears to rise sharply to a point; and when with great circumspection I crawled up, I found myself on a granite point, not three feet in width, with but a water-worn way a few inches broad to rest on."

I will now continue my own observations. From this point, however, we could see that a huge pile of loose rocks to our right, on the opposite side of the granite slope, was decidedly higher; this we reached, and after climbing amongst the loose rocks sat on the top, where I opened my aneroid case-it read 13,525 feet. The mountain in front of us is walled off by the "huge cyclopean wall," a perpendicular rock of perhaps 60 or 70 feet

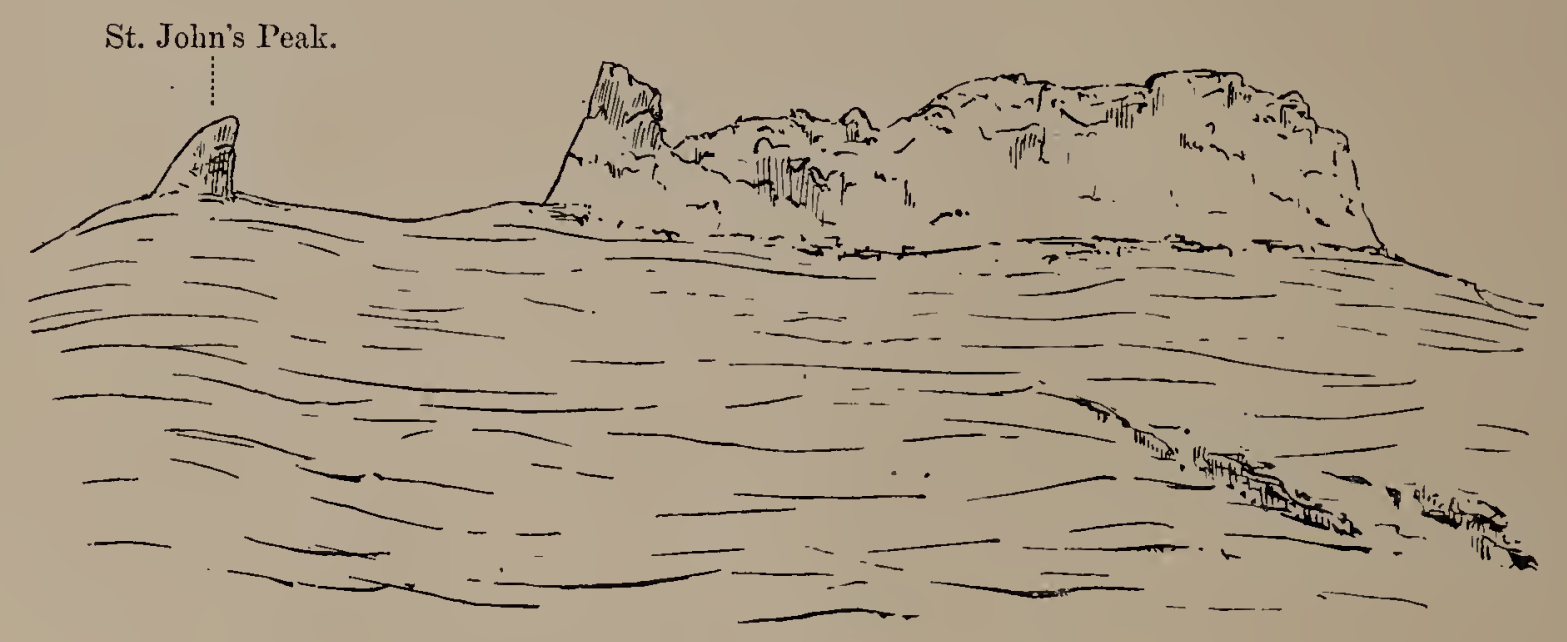

VIEW OF SUMMIT.

in height; so the estimation of the height taken by Sir Edward Belcher's trigonometrical observations, 13,698 feet, may be considered as nearly correct as possible. Mr. Spencer St. John is the only other European who has reached the base of this wall, which bars all further progress, and he writes:- "I tried to reach the summit of this peak by a narrow edge of rock abutting from its southern front, but after following it till it narrowed to about eight inches, I thought it prudent to return; but at a spot where I had secure footing I pitched a stone on the summit, which was about forty feet above the highest point I reached." The barometer carried by these gentlemen (Mr. Low also) proved useless unfortunately at this point, or I might verify my own measurements.

The only birds I have seen to-day are the Chlorocharis and the Cettia, which were 
flying about amongst some rhododendrons at the foot of Low's Gully; I also saw a solitary Swift flying between the two crags. In all the crevices where plants have formed a small quantity of vegetable mould are to be found growing scrubby heaths (Leucopogon, ?sp.) (representative Australian form), a long slender grass (Scirpus, sp. ?), and a handsome white hairy-leaved Potentilla with yellow flowers; the latter, I am told, is a Himalayan species$P$. peduncularis (Hook. fil., var.).

When I had taken my observations, I devoted my attention to the world around below. The scene in front of me was a view of the barren granite slopes, over which naked-legged Kabong was stalking, looking the more grotesque as he wore an old black office coat which I had given him-truly a most laughable-looking object! Kuro, who still carried the chicken, wore an old coat of mine, and was wandering about with the two other Dusuns in search of the small crystals, which they chipped off the lumps of rock. In a small crevice below me they were very busy, having found quite a mine; Kuro had one or two fine pieces, the best of which-white-man like-I confiscated or bagged for myself; these I still preserve as a memento of this expedition. The view of the country was fairly good. I thought I recognized Molu at the head of the Baram River, also the range of mountains on the Lawas; more to the south a range of lofty mountains was visible; to the west the Islands of Mantinani and the Tampassuk plains. "The far interior of Borneo was hidden under a sea of clouds, which reminded me more of a huge ice-field than anything else; to the south-east some of the highest mountains kept their summits above the clouds, like islands in a sea. Directly behind me, to the N.W., Marudu Bay was visible, and in this direction Kina Balu had its chief interest for me. Directly below us was a sheer precipice of some thousands of feet, a stone tossed from our position fell to the bottom : directly in front was another wall of rock similar to the one on which we sat; these two walls form a huge gully, which continues to and beyond the two peculiar rocks at Low's Gully, where it is walled off by a similar precipice. The other end below us is open, and it will be seen, on examining the drawing of the mountain taken from Melangkap, that the distant end beyond Low's Gully is visible from that position. 'The long rough-backed ridge, which cannot be much less than 11,000 feet high along its entire length, and runs in a northern and slightly eastern direction, was quite free from clouds; it seems very rugged and covered with curious piles of granite rock; the whole length of this ridge is probably more than three miles. Melangkap was visible from this airy seat, and also the country traversed by us when collecting birds on the Panataran last year; and from Melangkap this point reached by us is visible, at the base of the most northerly of the three high crags. Now came a ceremony of which Mr. Low must be considered the originator, the leaving of a bottle with a paper inside giving the names of the visitors to the mountain. The Dusuns look upon this as a ceremony not to be omitted, evidently believing that it is a religious rite on the part of the "Orang puteh," so I tore a leaf out of my journal and on it wrote :-

"11th Feb., 1888.

Kina Balu.

"This is the highest point reached by John Whitehead, with Tungal and Nyhan of Labuan, Kabong, Kuro, and two others, Dusuns of Kiau.

"Height 13,5ะ5 feet, compensated Barometer (Negretti \& Zambra, no. 10,465, London).

"10 4.Ir., 11th Feb., 18\&8.

"Thermometer 59 .

JoIIN W IIITEHEAD." 
This page I neatly rolled up and placed in an A 1 sauce bottle, which has a glass stopper; this I put in a sheltered position under the rocks, upon which we built a small cairn.

The rocky sides of the precipices in front of us are curiously coloured with rose and purple-grey tints, and to me there is something solemn and dreadfully wonderful about this place. The Kadyans are imbued with the same feeling, and devoutly knelt and offered up a prayer to Allah, baptizing themselves in the pools of water which had collected amongst the granite slabs. I thought as I sat and wrote my journal how I could have spent days here with pencil and paints; but ny reverie is soon cut short by the clouds which are rolling up the granite slopes to the southward and have already hidden St. John's Peak opposite, so at 10.15 we were forced to leave this most interesting spot. The Dusuns and iny men complained of shortness of breath and headache; I myself was likewise troubled. At 11.30 we again reached the base of Low's Gully. As this distance took over one hour to accomplish, and there are no difficulties to prevent a fair rate of progress en route, I conclude that it must be at least two miles; some idea of it may be obtained from my sketch opposite page 180, which was taken from the Kinokok valley. My socks (of which I wore two pairs) were by this time worn through and in rags, my feet bleeding; the horny-footed natives were also crippled by the sharp granite crystals, which at the same time prevent slipping. When we reached Low's Gully, we ascended between two high crags to the end, where a wall of rock bars the way. On the other side of the wall is the chasm already mentioned, and at the bottom, just below the place where we are standing, is a huge hole, the depth of which is lost in obscurity. In this hole, Kuro tells us, the Dragon lives. Here we rested for some time after our exertions, most of us suffering from the rarity of the atmosphere. Kuro, who is quite an authority on the legends of the mountain, has been holding forth. The Dragon, he says, has been heard to roar once to-day by himself and Kabong-Mr. Low, he says, also heard it; but unfortunately one of my men fired off a gun, which the Dragon objected to, so he did not roar again. Now came a most important ceremony; we descended out of the wind, which blew in cold gusts through the gully, to the foot near a clump of rhododendrons. Here we sat down, Kuro aloue standing upright, with the miserable cockerel under his left arm, the bird's tail to the front. He now commenced another prayer to the spirits of the Dusun valhalla: part of his prayer is about myself, "Tuhan Burong" (my Malay name) and "tembilug" (the Dusun word for bird) being frequently heard; he is also telling these invisible ghosts by which we are surrounded that we do not wish to do any harm; at intervals of perhaps half a minute he jerks out a long feather from the chicken's tail, and by the time he las finished his incautations the bird's tail-feathers are planted upright in a row in a small crevice in the rock at his feet. After this ceremony we started for the cave below, the whole mountain being now enveloped in mist. The cave was reached with little difficulty, the rock in one or two places only being slippery from the water which ran over the slopes. On reaching the cave we made a hasty meal, the Dusuns kindly offering me the chickell, but, having neither the time nor the means to prepare it, I refused it; so they killed, half-roasted, and devoured the sacred bird themselves. After this we started for the camp, which we reached in two hours under a steady downpour. I do not think further exploration of these barren granite slopes would ricld 
much zoologically speaking, but the plants would be well worth a visit from some botanist. The ascent of Kina Balu, and the walk along the granite terraces of the summit, is by no means a difficult task. The peaks which bar the way might be ascended by ropes, and the view of the formation of the mountain on the other side would, in my opinion, well repay this ; but the shortness of unclouded daylight would in all probability destroy the explorer's chances of success. The most trying parts of this climb are the forest-paths between our camp and Kiau, where the ridge is often narrow, the ground wet and slippery. Kiau with luck might be reached in three days from the coast via Tampassuk, which writers who have travelled also by the Tawaran route tell us is the easiest journey from the coast; from Kiau to the rock in "Sunless Hole" would take another day, to the cave another, and one day might be spent in the exploration and ascent of the summit. But the traveller will have to deal with Eastern aborigines whose ways are curious and aggravating to the white man; he may see a good deal, but his policy is only to notice their transgressions when they become too unbearable. We reached the camp at 4.30 p s.., and found Buntar all right, though he must have felt lonely during our absence. I do not think the Kadyans were disappointed with their visit, though they saw nothing of the "Lagundi Tree" and other mythical wonders which they expected to find on the summit.

12th.- Having now the large waterproof sheet, we started building a new and spacious dwelling. The Dusuns caught and ate two rats during the night; they left early this morning. I see by my journal I have come to the conclusion that "Kuro is a nasty man to deal with," never being satisfied.

13th, 14th.- These days have been very wet. Nyhan shot an interesting new 'Timeliine; this bird is very small and somewhat Wren-like; its breast is white, the mpper parts of a dark brown, with a broad bright. golden-brown streak over the eye. It has been named Orthnocichla whiteheadi, and its nearest ally comes from 'Timor. This was the last new bird we discovered at this camp.

15th, 16th, 17th.-I busy myself making sketches of the surrounding scenery. The Kadyans, as usual, go out bird-collecting. The weather is now fine and bright, with a high N.E. wind blowing. My constitution is beginning to suffer from the effects of this lengthened sojourn in "the promised land,"-tinned provisions being the chief cause of my troubles.

18th, 19th, 20th, 21st, 22nd.-The men continue collecting. I seldom go far from the camp, being too uinwell. Some onions Buntar has planted are doing well. The Dusuns came to-day, the 22nd, to see how we were; but more especially to collect my empty provision-tins, for which they gave me some cucumbers.

23rd.- The Dusuns started early for Kiau; I tried to get them to carry some of my baggage back with them, but could not come to terms with the grasping Kuro.

24th, 25th.-To-day we have collected twelve birds ; this means a busy time preparing them. Birds, I notice, in the tropics mix a good deal together, several species forming a small flock. In some flocks to-day I saw two Leucocerce, several Chlorocharites, and two other species of Flycatchers; again, in another small party I noticed a Pericrocotus, a Cryptolopha, and two other species of Flycatchers. These miscellaneous hunting-parties are thus made up owing to the scarcity of the individuals of a species, locally speaking; thus a 
number of birds club together the better for their mutual protection. Amongst the forestgrowtl it is often bitterly cold-so cold, that when I found an open sunny spot I used to bask in the sun awhile for warmth.

26th, 27th, 28th, 29th.- These days have been very wet and cold. I am quite done up for want of proper food, and shall be glad when the Dusuns come to carry our baggage back to Kiau.

March 1st, 2nd.-This morning we had a rery clear view of the high mountain to the S.E., which forms the centre of my sketch facing page 167 .

3rd.- Seven Kiaus arrived at 10 A.M., and in two hours we were ready to start, and bid adieu to the spot which has done so much for my ornithological reputation. By 4.30 P.M. we had reached the slanting rock in the bed of the Kadamyan, under the usual steady downpour of rain during the whole of this journey; here we are going to sleep the night, starting for Kiau to-morrow morning. To-night, as I lie amongst the rocks watching the Dusuns, who are visible in the firelight, they are sitting round a fire in a circle and handing round for inspection and general admiration of the company-as the winner of some prize cup would do with his friends in this country-the empty meat-tins they have found at the camp; it is truly a picture of barbaric simplicity. The temperature is here to us, after our long sojourn in the highlands, quite warm.

4th.-We started for Kiau soon after daylight, reaching that village about 11 A.M. While walking up the Kiau spur we had to pass through the fields belonging to the inhabitants of the lower village, who turned out and had high words with Kuro and the other porters. As this quarrel did not concern me I plodded steadily on up that wearily long hill-side, leaving the Dusuns to settle their own disputes. Later on, in the afternoon, the headman of the lower village, accompanied by three of his followers dressed in their best, arrived at Kabong's house, and here held a long palaver. This Dusun chief demands a quantity of cloth, equal in amount to that paid by me to the Kiau porters, as he sars Kina Balu belongs to him. Kuro is the chief spokesman for this village, and is sitting with a nonchalant air, leaning his back against the side of the house; the only word that this great man deigns to utter, to every statement made by the infuriated old chief sitting opposite to him, is "udut," which is the Dusun equivalent to our word "liar." Kiau was visited last year by one of the Company's officers, who, during his short stay, settled the affairs of the Kiaus, swore them in to the Company, and settled the annual payment of polltax. The old chief says that he has been made headman, and on this he bases his foolish demands; but as we have only his word for it, we are not inclined to respect him, and certainly less inclined to pay him for other peoples' work. 'The account of this officer's visit will be found in the 'British North Borneo Herald' for July 1887. I do not think these hurried scampers through the country do any good, as it would take months for any European to understand the tribal problems of these people; and the only way to do this would be by a lengthened residence in the district. As a proof of this, I hear that the Company's relations have since become strained with these villagers, and that only lately it has been found necessary to send a police expedition into the neighbourhood.

I shall now make a few concluding remarks on this part of my second expedition. During my sojourn on the mountain we spent some of the most miserable days imaginable 
reduced to a state of extreme bodily weakness by a continued diet of tinned food and the almost perpetual rain and cold; the Kians even remarker? how thin we had become-thin, indeed! I could feel every bone in my body.

The mammals collected were mostly rats, one of which was a new species, Mus alticola; the IIylomys which was common above our camp also descends to about 3000 feet. The group of the animal kingdom to which most of my attention was directed was that comprising the birds, and the collection of these was naturally the most important. At above 7000 feet I collected ten new species, no less than four of which belonged to new genera. The species inhabiting the region above 8000 feet, and which do not descend much below that altitude are Cryptolopha trivirgata, Oreoctistes leucops, Androphilus accentor, Corythocichla crassa, and Cuculus poliocephalus. I only noticed three species above 10,000 feetMerula seebohmi, Cettia oreophila, and Chlorocharis emilice. Most of the other species collected at our camp are met with also at a much lower altitude. Butterflies and other insects were very scarce. I made a small collection of moths, but up to the present time these remain undescribed. I collected a number of small frogs and toads, amongst them a new one, Nectophryne misera. Of the small botanical collection made I have already given a short account.

The following is a Table of the daily temperature for the month of February at 7850 feet, with a few short remarks on the weather:-

\begin{tabular}{|c|c|c|c|c|}
\hline & Date. & Minimum. & Maximum. & General Remarks. \\
\hline 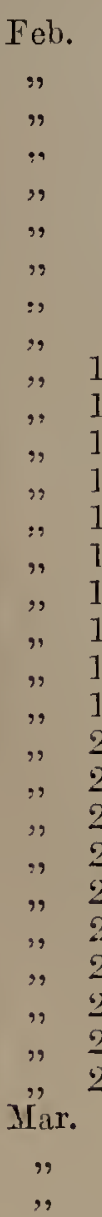 & 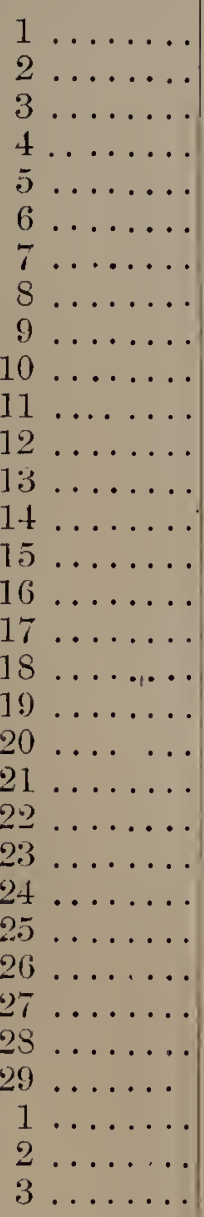 & $\begin{array}{l}47 \\
49 \\
52 \\
52 \\
48 \\
45 \\
45 \\
43 \\
42 \\
45 \\
49 \\
47 \\
47 \\
50 \\
46 \\
50 \\
51 \\
47 \\
47 \\
46 \\
44 \\
44 \\
48 \\
45 \\
43 \\
43 \\
49 \\
49 \\
50 \\
48 \\
46 \\
47\end{array}$ & $\begin{array}{l}67 \\
65 \\
60 \\
60 \\
60 \\
62 \\
64 \\
60 \\
66 \\
64 \\
60 \\
64 \\
67 \\
68 \\
66 \\
66 \\
70 \\
68 \\
65 \\
64 \\
67 \\
69 \\
64 \\
64 \\
63 \\
69 \\
60 \\
62 \\
61 \\
69 \\
70 \\
\ldots\end{array}$ & 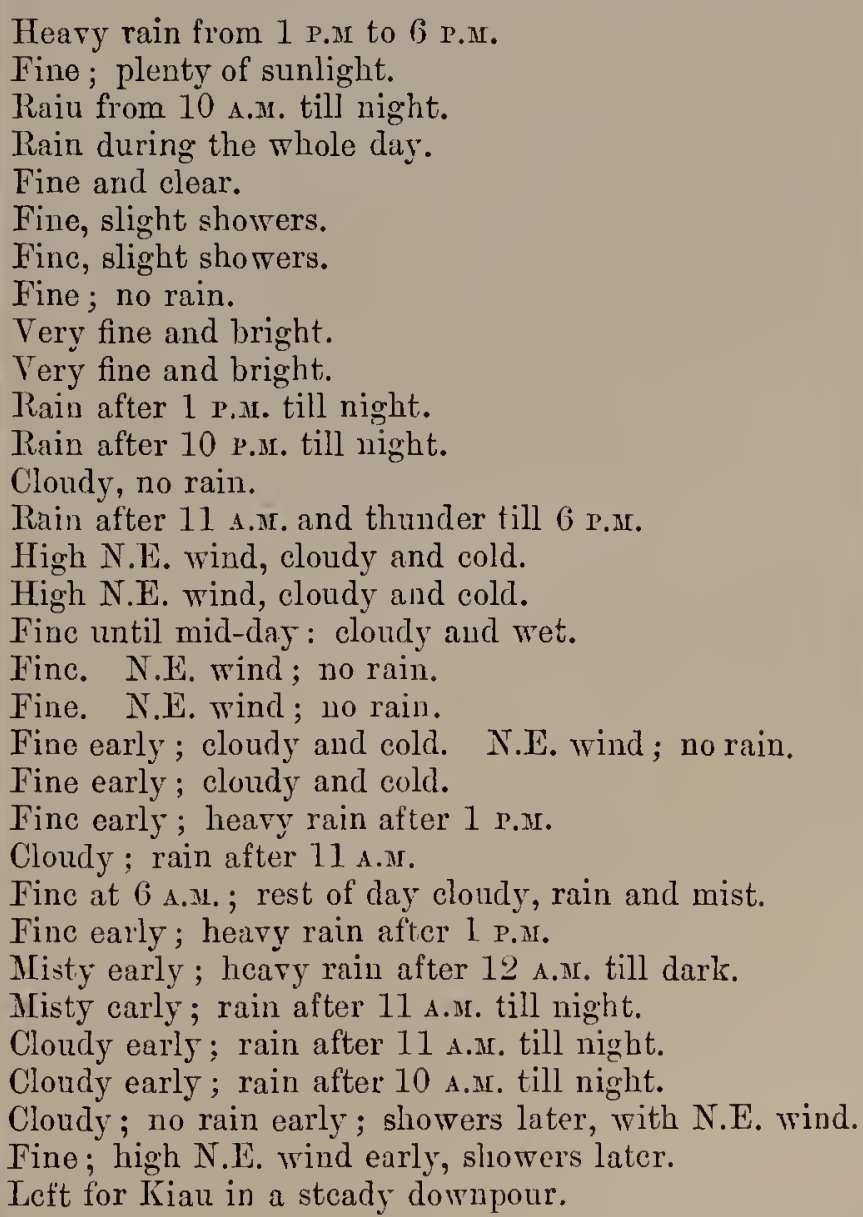 \\
\hline
\end{tabular}


The temperature, as will be seen by the above Table, was very even: the nights varying between $42^{\circ} \mathrm{Fahr}$. and $52^{\circ} \mathrm{Fahr}$., the days between $60^{\circ}$ Fahr. and $70^{\circ} \mathrm{Fahr}$., - a difference of exactly $10^{\circ}$ between the warmest and coldest night, and also the same between the warmest and coldest day. One of the coldest days (the 8 th) was fine, no rain falling; this was followed by the coldest night, the thermometer falling to $42^{\circ}$. The wind blew steadily from the N.E., as might be expected during this month. February has always had the credit of being the driest month in this region, which is probably correct. The country below us was never clear of vapour, and only on the 2 nd of March did I get a good view of the high mountain to the S.E. Thunderstorms accompanied by deluges of rain often occurred in the deep valleys below us, while we were basking in the sunshine. The nights were generally fine and perfectly clear. 


\section{CHAPTER IX.}

RETURN TO AIELANGKAP FOR RJCE.-POTTED MEAT.-KINOKOK VALLEY.—NEW TROGON.-NEST OF MY CALYPTOMENA.—KABONG ON RATS.-NEW BEETLES.-KURO ANONG THE MONEEIS.-RESULTS OF TRAPPING.-KABONG'S NEWS.-DUSUN OMENS.-RETURN TO MELANGKAP.-ATTEMPT AT BLACKMAILING.-FEVER.-GAMBOIE VISITS GAYA.-HEAD-HUNTING RAID BY THE KIAU DUSUNS. - VISIT KAPAR VILLAGE. - A KAPAR DESLN WOULD IMPOSE A FINE.-RETURN TO THE COAST AND LABUAN.-HOME AGAIN.

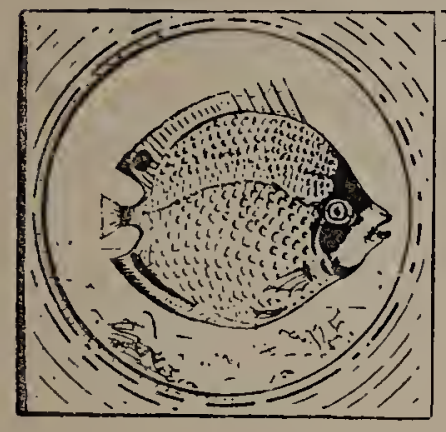

$\mathrm{N}$ the 5th of March I left with Buntar and three Kiaus, carrying my bird collection, for Melangkap. The object of this journey is to bring a further supply of rice and provisions to Kiau, as I intend to make another expedition from here into the Kinokok valley and to remain there for a month.

The Hadji and his companion, who have been living in Kiau since the 11th February, are on excellent terms with the Dusuns, and my friend Kabong has behaved well to them. The Hadji has collected some sixty birds, including specimens of the Tailor-bird spoilt by me last year: this is a new species-Pliyllergates cinereicollis; he has also a new Zosterops, Z. clara. The other man has been busy collecting butterflies and beetles-the native children bringing numbers of the latter-some of which are very fine, belonging both to new genera and species.

We left Kiau at 11 A.M. and accomplished the tiring journey to Melangkap by 5 P.M.,the reason of this good record being the splendid carrying qualities of the Kiau Dusuns: en route we met numbers of the Kiau villagers returning from a tamel, all more or less intoxicated. The two men left in Melangkap have done absolutely nothing as far as collections go, a few beetles and a dozen badly-skinned birds being the total of their work; but as they have taken good care of the things left in their charge, I must not grumble. Before I started for Kiau, now more than six weeks ago, Damaring, the son-in-law of the lady with the brass anklets, slaughtered a buffalo : after the feast a considerable portion of the animal remained; this Damaring potted à la Dusun, which consists in putting the meat into a jar with a small quantity of salt. The smell of this now semi-decayed meat cannot be imagined; the whole house is now pervaded with this most disgusting odour. Damaring and the family occasionally eat this filthy carrion, and the Kiaus who arrived with me to-night have also been treated to a feast off it. 
A Bajow has been murdered by some Dusuns not far from Ghinambur since I was last in Kian, which has created a little excitement.

6th.-Busy drying my bird collection. I also planted a number of Nepenthes and other plants that I brought from our camp on Kina Balu, but all died before I left for the Tampassuk, except the Nepenthes and a handsome Kaladium.

7th.- The Kiau Dusuns returned to their village loaded with rice, but I am too busy to accompany them.

Sth, 9th.-Yesterday I arranged with the porters, and this morning was able to start at 6.30 A.M. with seven Melangkaps: We should have reached Kiau the same evening, but one of the Melangkaps gave his load to a young woman after I had started, and she delayed our progress. At 6 P.M., when we reached the foot of Kiau hill, the woman was quite exhausted and could not proceed: four of the Dusuns reached Kabong's house before dark. I, Buntar, and the others passed the night in the small watch-houses. It is a great nuisance the way in which the Dusuns transfer their loads to one another without your being aware of it till several hours after, as the day's journey is always regulated by the slowest porter.

10th.- Started at daybreak and reached Kabong's house at 7 A.M. The Dusuns in this house are very noisy, and now that the girls begin to know the Kadyans they are too talkative. At night they work hard before my lamp spinning cotton, which they mix when weaving with their cloth. This cloth is made from the fibre of a long-leaved Curculigo, sp. ?, and is called by the Dusuns "Lamba ;" the lengths of fibre which run in parallel lines along the underside of the leaf are separated and tied together. This occupation is generally carried on of an evening. The fibre is wound round a stick, and when sufficient has been obtained is woven into a hard cloth on the small Dusun looms: one of these interesting looms I brought home, together with several pieces of native cloth. When woven the cloth is dyed with indigo-blue, and mostly used by the women for petticoats. After my tiring journey I was unable to sleep, owing to the noise in and under the house. I find the following note in my journal :- "This house is quite a Zoo: below a herd of pigs grunt and squeak, dogs fight and snarl, cocks crow, hens cackle; above babies squealing, men and women laughing and talking: combine all these sounds and you get an idea of the babel in a Dusun house."

11th.-Arranged our baggage for a fresh start to-morrow for the Kinokok valley, which country lies over the spur at the back of the village and up to the base of the main buttress ridge, or below the summit of Kina Balu traversed by us. The Kiaus told me that there were Pittas in that district, but I afterwards discovered by "Tembongeau " they meant a bird which we afterwards discovered to be a new Harpactes. Nyhan delighted me this morning by bringing in an extraordinary bird ; it was of a general dark brown plumage, with the entire head and a patch on the sides of the neck bare of feathers, the skin being bright yellow and the bill coral-red. 'The Dusuns call this bird the "Rigo Rigo;" it belongs to a new genus, and has been named Allocotops calvus.

12th.-Left Kiau soon after daybreak, and in two hours over hilly country reached the River Kinokok, a confluent of the Kadamyan, joining that river a few miles above the rillage of Koung. 'The forest round about us is virgin, and should form a splendid 


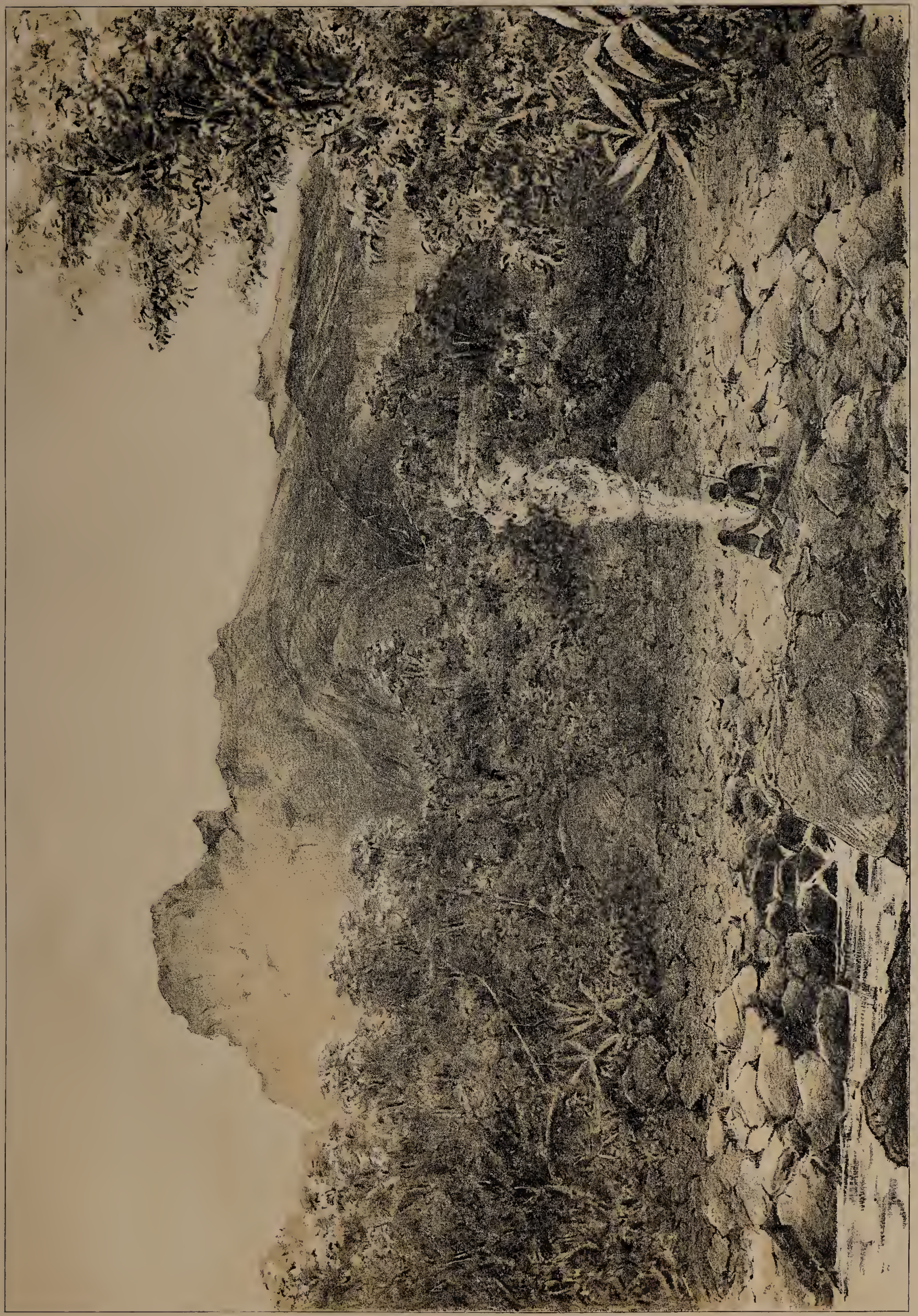



hunting-ground. The river is a broad rocky torrent full of boulders : at this season it is low, so we pitched our camp on a high bank of shingle, as being the most healthy spot, a camp in virgin forest being almost to a certainty a place to catch fever. The situation of our camp is spleudid, the bed of the river being here almost east and west, so we get all the sunlight possible after the sun has mounted above Kina Balu. The accompanying illustration is taken from the S.W. of the summit, which lies to the N.N.E. $20^{\circ}$ of us; my aneroid gives the altitude of this camp as 3650 feet. The great precipices of Kina Balu are a grand sight from a little above our camp on the opposite side of the river, being perpendicular walls of thousands of feet of granite. As there were plenty of fine bamboos growing in the vicinity, the Dusuns, as part of their agreement, assisted us in building a house; this was finished and most comfortable before night, with a split bamboo plank floor. Before starting home the Dusuns turned the course of the river by damming it with rocks: when they had accomplished this they made a collection, in the small pools left, of fish, tadpoles, frogs, caddis-grubs, \&c., \&c.,-such a collection as an English boy brings home from his visit to a horse-pond; this zoological mixture they boiled in bamboos and devoured with their rice.

13th.-To-day we have explored the forest about the camp; this is easy work, as the Dusuns have rat-trapping paths in all directions. I see most of the species of birds we collected last year on the Panataran, and several of the highland species in the vicinity of the camp. I sent one of the Kadyans to Kiau to fetch some bird-skins we had left there: when he returned he told me that the Dusuns were celebrating their rice-harvest festival, and that all the men and women in Kabong's house were "as drunk as lords." During this month most birds are nesting. To-day was fine, with slight showers.

14th.-The men started shortly before me this morning, and when following their path I found a Trogon tied by its legs to a branch, which had just been shot by the Hadji. This was a splendid new species, of which I am able to give a coloured illustration. 'This was the bird spoken of by the Dusuns as "Tembongean." You may imagine my great joy at the first sight of this beautiful bird.

The pigmy squirrel with the long ear-tufts is common here, and I am often able to approach within a few yards of it. It travels over the trunks of the larger forest-trees somewhat after the manner of a Woodpecker, the tail being pressed against the tree and the hind legs sprawled out on either side of the stomach on the bark, while the front legs and fore part of the body are kept well off the tree; in this way the little animal proceeds in short jerks over the large trunks, feeding on the bark, which is sometimes much gnawn away; the ears are generally held erect: the squirrel every now and again utters a shrill whistle. I shot a Serpent-Eagle new to the Bornean avifauna (Spilomis bacha); this Eagle frequents the river-bed, pouncing on the various lizards and snakes which are found there.

15th.-We collected to-day fifteen birds, which gives us plenty of work; amongst them is a young Rigo Rigo, which has a feathered head. This species is gregarious, has a loud booming note, and might be mistaken, but for its dark wings, for the more common Ianthocincla treacheri when seen in the forest. In the evening we had rain.

16th.-Rain nearly all day. The Kiaus come to see us almost daily, bringing with 
them fresh vegetables-for which we are truly thankful--in exchange for empty provisiontins! We have now several of the new Harpactes; like all Trogons it is hard to obtain, being a living puff-ball of soft feathers. When shot, if it strikes a branch, the back or breast is shaved clean of feathers.

17th.-The great event of the day has been the discovery of the nest of Calyptomena whiteheadi. Whilst resting in a dense part of the forest, I sent on Nyhan to try and shoot some large Fruit-Pigeons (Carpoplaga badia) which were "booming" in the high trees near. In a few minutes a bird settled near me, making a peculiar "Kurr-r"-like sound; on my moving slightly it flew away, but shortly returned to another tree, which I carefully approached. I soon espied the bird, a Calyptomena, holding on to a large tuft of moss ; it remained in the same position for some seconds watching me, when it dawned upon me that that dangling lump of moss was a great prize-the nest of my finest novelty. A shot from my collecting-gun brought down the bird, and when Nyhan returned I sent him up the tree; but the nest, alas! contained two dull yellow featherless youngsters, both killed by the same shot that destroyed their mother. The nest was hanging from the end of a slender bough about fifty feet from the ground. The outside was composed of fresh green moss bound over the bough and worked into the sides, ending in a long streamer, which assists in assimilating the nest to the long dripping streamers of moss and lichens which hang from every bough in this continual rainy region (see frontispiece). The inside of the nest is very solid, lined with dry bamboo-leaves above and below, forming a well sheltered pocket. Having thus obtained a clue to the nesting-habits of this species, I visited all likely places for their nests, and shortly after found a nest containing two eggs. This nest was similar to the one first found, and was placed at the extremity of a long slender bough over an open space; this position is chosen doubtless as a protection from the attacks of monkeys. The eggs are glossy, creamy white. Rain late in the day.

18th.-Kabong called and has set over one hundred bamboo rat-traps in the forest. As we are living here, he says we can collect the rats, skin them, and save the flesh for him to take away when he calls, which is about every other day. I have been having, with the assistance of Buntar, who can now converse with the Dusuns, quite a long conversation on rats with Kabong. He has given me nineteen Dusun names of nineteen species of rats and squirrels with which he is acquainted on these mountains. There are three species he says I have not got-namely, the Hintabŭn, the Rapit, and the "Parad Parad." The pigmy squirrel he calls "Mantok," the common rat "Ticus-tahiti," the housemouse "Ticus-walli," and a shrew "Gansouri." At the mention of this little animal's name Kabong's face bears an expression of disgust, and he turns up his nose (for Kabong, I must tell you, is rather a handsome Dusun and has a nose with which he can express displeasure); he shakes his head and says "No good!" That is to say, that shrews are too strong for even Dusun stomachs, and in this country they are avoided by cats. A Dusun has no admiration for an animal if he cannot eat it; at the mention of "Kurra," the large red monkey, his face is wreathed in smiles. Rats are very numerous in Borneo, quite a plague at times; the Dusuns, however, eat rats, so the rodents do not have it quite all their own way. Two very large species which I discovered, Mus sabanus, the "Barud" of the 


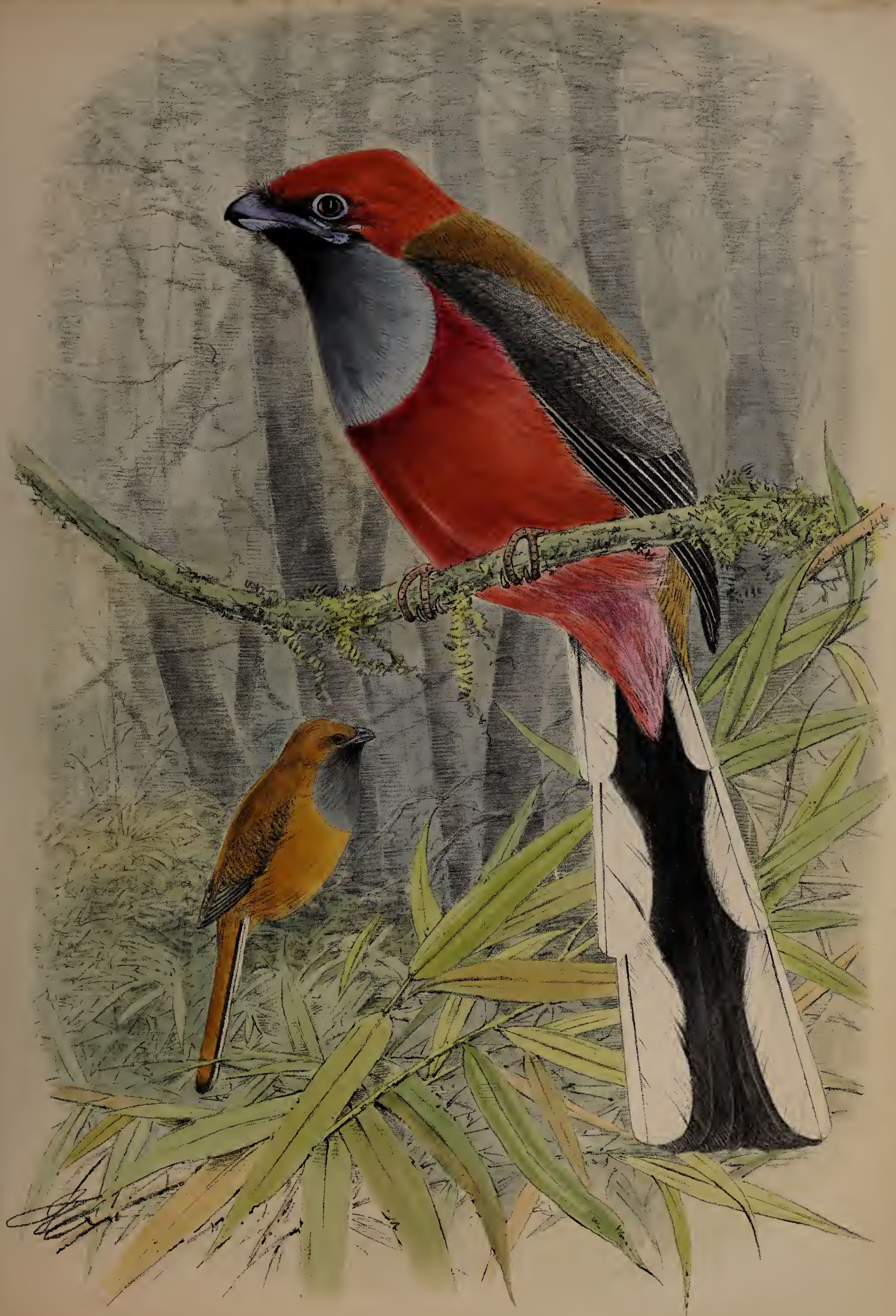



Dusuns, and Mus infraluteus, the "Mankulum," are occasionally caught, and afford these people quite a meal. Rats are often split and fixed on bamboo frames, then smoked and stuck over the fireplaces in the houses until required. 'To-day the weather was splendid, without a drop of rain.

19th.- This camp, being in a broad open place in the full sunlight, is a wonderful place for beetles and butterflies. I collected about the camp some magnificent new Cetonias (see illustrations facing p. 184). This group of beetles was described by the late Mr. H. W. Bates; another portion of this collection has been described by the Rev. H. S. Gorham: copies of the papers by these gentlemen will be found at the end of this work. To-day Buntar shot three large grey-backed, white-chested monkeys, which we gave to the Dusuns on condition that they skinned them for us. The skins, unfortunately, soon became destroyed by the blowflies, so I got another skin; this also soon became spoilt, and on our way to Melangkap I threw it away. This monkey was a new species and has been re-discovered since on the Baram River and named, after its discoverer, Semnopithecus hosci. Another fine day without rain.

20th.- Kuro came early, like a vulture which scents its prey from afar: Kuro hâs smelt the monkeys, or has heard of them from the other Dusuns. Kuro had a day with the three large monkeys shot yesterday; he prepared one for me, and was such an adept with the skull that it struck me that he had prepared a few human ones in his day. He tells us that in Kiau there are over fifty heads, which have been taken from the various tribes around. Just now, he says, four Kiau men, with a band made up of others from Koung, Labang Labang, and Teung-Tuhan, are out head-hunting, and have gone to attack a village at the head of the Tawaran River. In Kabong's new house there are two headmarks of rather recent date, probably since the building of the house. Kuro made a hearty meal off monkey soup, and before he had finished his day's work his face was splashed with soup and gore. There is something too human about a monkey; I must say I object to shoot them, and seldom did, except when they attacked the native maize-fields. These Dusuns are very keen after monkeys, and would eat an Orang-Utan.

21st.-I am again ill with a bad cold, so do not go far from the camp, being in a weakly state from want of good food. 'The Dusun rat-traps are so numerous that all the ground-birds are long since extinct in this forest. Kabong after visiting his traps one morning brought me two extraordinary lizards: they have large swollen heads and a flat patch of broad sharp-edged scales above the tail of a greenish-blue colour, the callosities on the head being of a pale blue, almost white. This species, of which I give a drawing copied from Dr. M. F. Mocquard's splendid account of my collection, was named by that gentleman Pelturagonic cephalum (see illustration facing page 56, fig. 2). The female is very much smaller and of a dull brown. These traps often catch, besides lizards, the large earthworms, so beautifully are they adjusted. To-day the weather was fine but cloudy.

22nd.-To-day a Dusun brought in a gigantic rat, but in a very decomposed state and full of maggots; but the cold in my head is so bad that my sense of smell has completely gone, and to that science may be grateful for the addition of the "Mankulum" to the genus Mus.

23rd, 24th.-Busy sketching, the weather being splendid. 
25th, 26th, 2ith.-Though steadily increasing the bird collections, I have nothing new. The Dusuns come all the way from Kiau with regetables and insects, which they exchange for tin pots, buttons, needles, and cottons. A woman one day brought me a Cetonia which was not perfect, and on my refusing it she nipped off the beetle's head, and tied the body up in a piece of cloth for the children, who will eat it as they eat chrysalides and grubs.

29th to 31st.-Working as usual : the last two days have been very wet.

1st April.-A few fine butterflies are common about the camp, several of which are new species. A small tailed blue Sithon kiana is figured opposite page 118, and several of my other new species have been figured in Mr. Henley Grose Smith's ' Rhopalocera Exotica '; a full description of the new species will be found anongst the papers at the end.

2nd.-Kabong called to-day ; he brings us some rather alarming news : he says that all the available male population of Kiau are going head-hunting with the Teung-Tuhan Dusuns, and that they are going inland to attack a village four days distant. He came to see us, he says, because we shall not be able to get carriers amongst the Kiaus to Melangkap, but he thinks perhaps the women will go instead; he does not seem quite sure whether he is going or not. As Mr. Kabong is decidedly in "tuak" and intoxicated, we are not much alarmed by his big talk.

3rd.-We have a peculiar porcupine-rat which is covered with spines; this animal the Dusuns call "Licis." It was first described as a tailless species under the name of Trichys lipura; the animal, however, has a long tail with a tuft of stiff bristles at the end. The skin of this rat is most tender, almost dropping to pieces in one's hands while skinning it. The peculiar delicate skin is the same on all spinous rats, their hides being more tender than a Goatsucker's skin. 'The flesh was white and looked palatable. This animal was also caught in the bamboo traps. We had heavy rain after mid-day; the river Kinokok is now in flood, which makes us somewhat nervous about our return to Melangkap.

4th.-I took a nest with a young Calyptomena to-day, for which I have been watching some time, waiting until the youngster was full-feathered. The little fellow, when looked at, puffed out his feathers and backed his body up to the roof of the nest; so much so did he rear his tail-end, that losing his equilibrium he fell heels over head, and required my kind assistance to put him comfortable again. Later on, when I took it out of the nest, it immediately wanted food, and devoured squashed pisangs and rice. I put the bird to rest for the night with a young Cissa some Dusun boys had brought, but in the morning both were dead with the cold. One of the Crow-Shrikes, Buchanga stigmatops, has a nest at the end of a branch which stretches over from the top of the high bank on the opposite side of the river. The birds are always mobbing any hawks which come near their nest. I was unable to reach this undescribed egg. Kabong came this evening: his news is that the party of head-hunters were unable to go on the expedition, as soon after starting they met a mouse coming from the wrong direction; this was a bad omen, so the expedition returned to start again down the Tampassuk shortly after we reached Melangkap. Kabong is drunk, I may say extra drunk, and has evidently been having a high old time in Kiau before he came on here after meeting the mouse. He is going to sleep at this place, and there are also six other Dusun lads stopping here; they seem fond of coming to see us, often staying a 

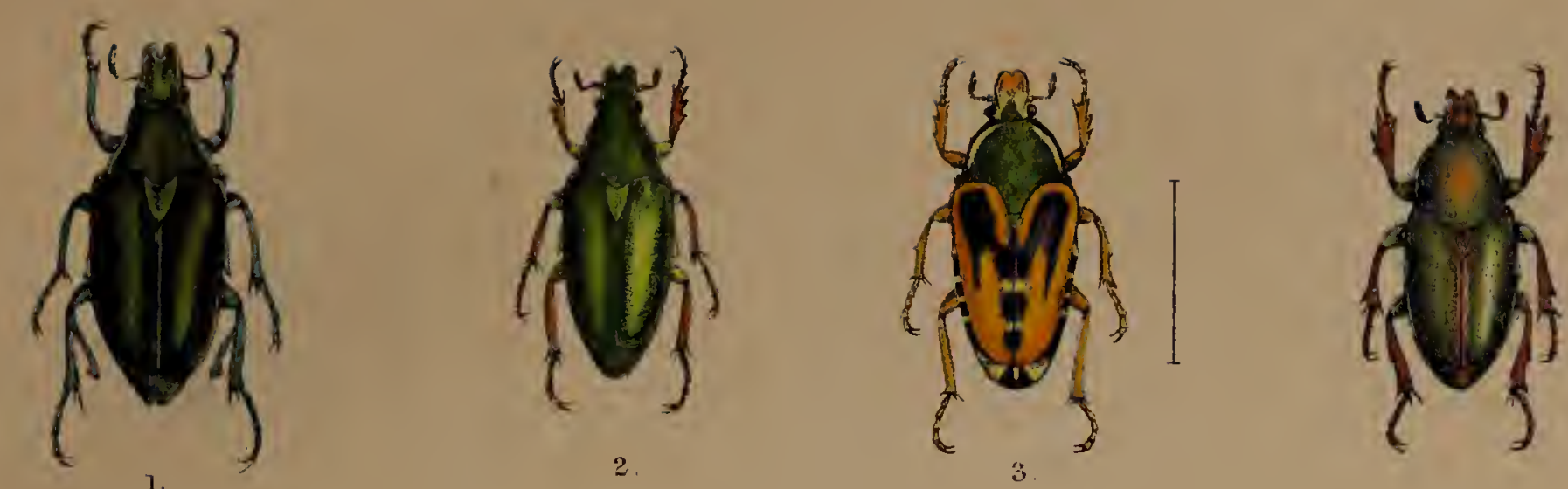

4
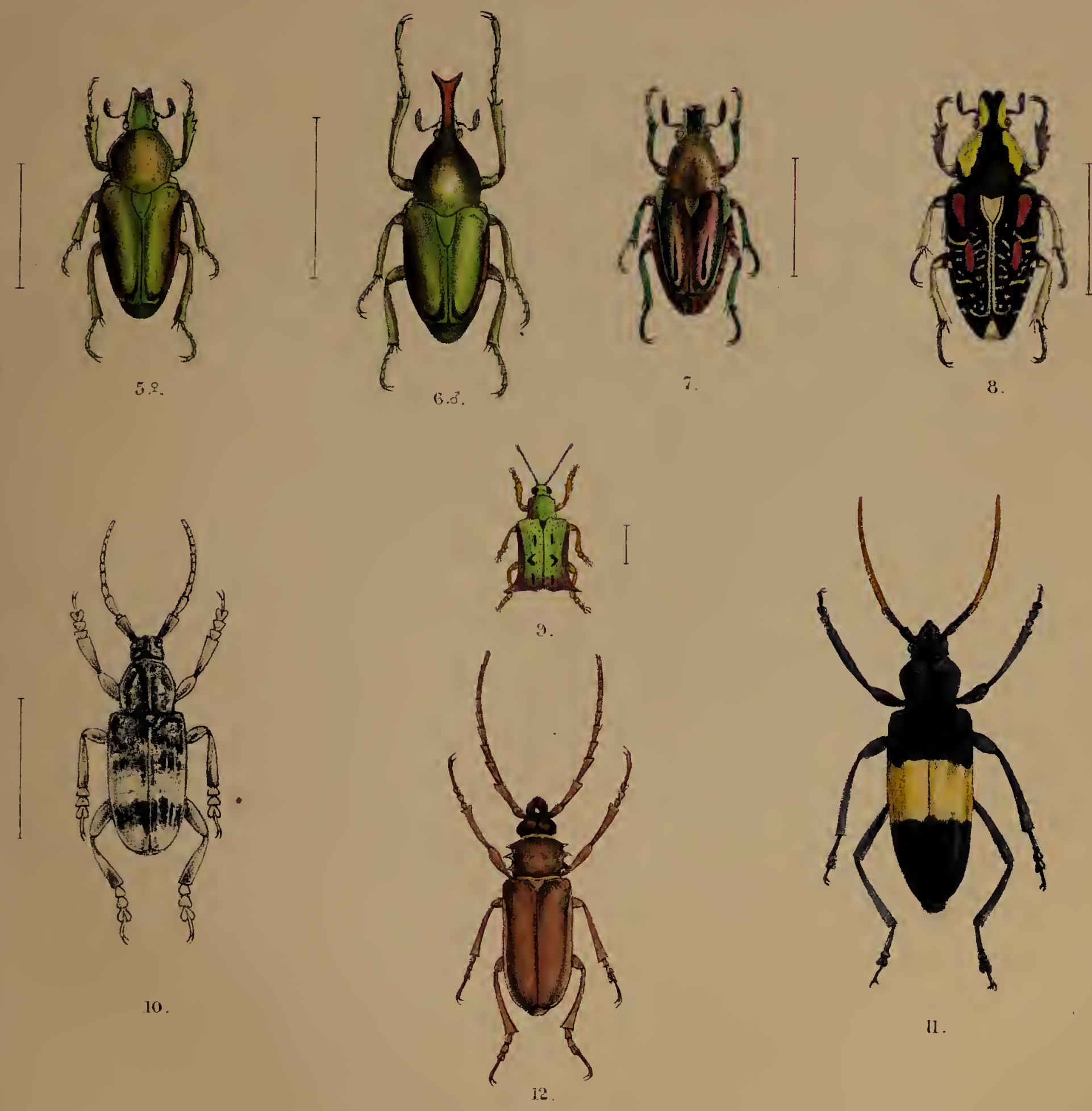

10

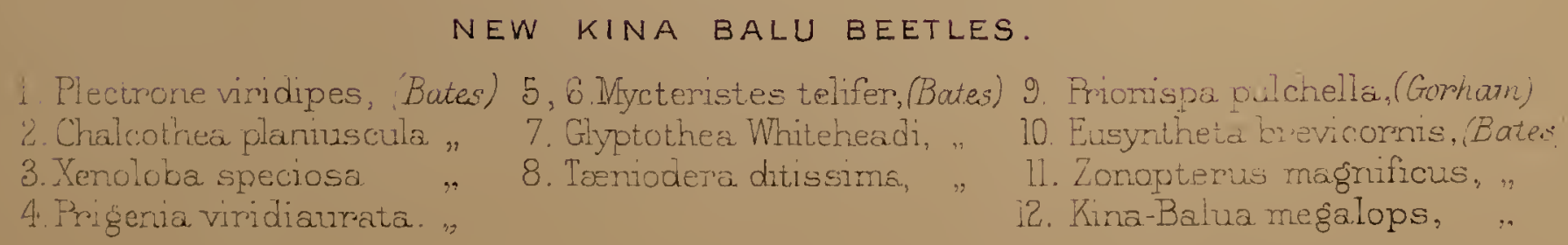



long time. Dusun omens are apparently very numerous: snakes, centipedes, kingfishers, and other animals coming from a wrong direction turn back an expedition. I knew a girl in Melangkap who set out for her paddi-fields, and on the way there she encountered a snake, which she killed and sold to me; she, however, did not attempt to do any work that day, but loitered about the house doing nothing.

Kabong pretends to be very sorry that he could not go ; but it is ali put on, as he is a lazy drunken fellow, and would, I know, rather sit at home and nurse the baby than go headhunting; but to us he has always behaved with great kindness, and is fond of coming to see us, spending most of the day about the camp.

5th, 6th, 7th.- Several Melangkaps came to-day: they are anxious to earn wages from Kiau to their village by carrying our baggage; the Kiaus will not like this, but they must settle their own disputes. Heary rain half the day.

Sth.-Packed up our baggage, as we hope to start for Kiau to-morrow. Several Dusuns came from that village to-night in order that they might secure a pack.

9th.- Started for Kiau at 7 A.M. On reaching Kabong's house he gave me all the baggage I had left in his charge untouched; this man is greatly superior to Kuro, though the latter is not a drunkard, but is, on the other hand, very dishonest.

10th.-Wo-day we bid adieu to Kiau, after having been amongst these people for eleven weeks. We had great difficulty in starting the Dusuns, owing to the numerous parting cups of tuak. The day was hot, and where the track led through paddi-fields and jungle the air was suffocating. We reached Melangkap at dark, after a most trying journey, the river at some of the fords being rather too deep for my liking.

11th.-I am going to send four Kadyans up the Panataran beyond last year's camp; there are two birds I wish to secure there-the unknown male of the Trogon I discovered last year, which has been named Harpactes vidua (B. M. Cat. xvii. p. 501), and the small grey Hornbill. I shall remain in Melangkap, sending the Hadji and Billio to the coast to bring up some of my stores left in Abai, and more especially a tin box in which I intend to send off some of my new birds to England. These men returned on the 17th. In the meanwhile I busied myself drying and examining my now extensive collections. When I received the box I packed in it a pair of most birds that I thought would be new; and this collection formed a second paper in the 'Ibis'-by Dr. R. B. Sharpe (1888). 'The Hadji has now to go with this box to Pulo Gaya; Billio is going with him and is leaving us, as he wishes to fast during the "bulan puossa," or the Rahamadan of the Mohammedans. I have no objection to this, as the old man is now useless to us, Buntar being able to converse freely in Dusun by this time. The other Hadji, who was taken ill in the camp at Sunless Hole, also wants to return to Labuan to fast; this does not matter much, as Nyhan will be able to do all the bird-skinning.

20th.-Before starting with Buntar to-day, I gave the Hadji final instructions about sending this precious box off by the first steamer from Gaya and the bringing back of my mails. Gamboie is anxious to go to the coast for the first time in his life, and will be company on the return journey. The Melangkaps made a serious attempt at blackmailing us this morning. I suppose, seeing that our party was separated, four of our men being up the Panatarnn, they thought to frighten us. They claim payment for our using the path to 
the Panataran, which was cut especially for me and paid for last year ; they declare that they will not allow us or the two Dusuns who are carrying my baggage to go over this path until we have paid them so much cloth. This course I will not submit to. Buntar is in a great state of excitement and is talking very warlike; he has filled the Winchester repeater with bullets, and evidently means fighting, and has ended by daring the Dusuns to defend the path against us. Knowing the character of these people, their threats are in no way alarming. When we reached the path in question the Melangkap braves were not there to defend the position, so we marched triumphantly to the camp, which is about a mile higher up the Panataran than the one last year. This was merely an attempt on the part of some of the Dusuns who had not received their fair share of baggage-carrying to frighten us; the men belonging to the house in which we are staying getting, of course, as much work as I can give them, this makes the others nasty.

21st.-I sent two of the Kadyans back to Melangkap with the Dusuns-the Hadji is returning to Labuan, and the other is to remain in the village and guard my property during the absence of the others in Gaya.

22nd to 28th.-I see I have made a mistake in again visiting this locality, as we are doing very little. I am low-spirited and far from well, so to-day sent Tungal to Melangkap to fetch some porters to carry our baggage back again; as I brought a very small supply of food, I shall not require more than five. The clearing made at last year's camp is now covered with high coarse grass. I have collected further specimens of a flying lizard, Draco obscurus, a new species obtained last year. It is rather rare, frequenting the trunks of high dead trees; where it seems to remain, changing position from time to time by short flights.

29th, 30th.-The Dusuns arrived, so we started for Melangkap, as I am now very seedy and feverish, my legs hardly supporting my body: at the bottom of Melangkap hill I gave in and lay for some hours in high fever, with a splitting headache, amongst the boulders of the Panataran-such is the fate of all explorers in the tropics!

1st, 2nd May.-Have been quite prostrated with fever. The Hadji returned from Gaya and brought with him my mails and a copy of my last year's collections in 'The Ibis,' but I was so ill that my eyes refused to look over them. My old friend the priestess has been doing her best to hasteu my recovery, and has several times said long Dusum prayers over me.

3rd.- I am decidedly better. The Kadyans I have sent to a Dusun paddi watch-house, in a field at the top of this hill, on the edge of the forest. Gamboie, who accompanied the Hadji to Pulo Gaya-at his special desire-returned with an umbrella, two sarongs, and a box of biscuits; these are his purchases with the pocket-money I allowed him, and for uselessness to a Dusun could hardly be equalled. This was the first time he had ever visited the sea-coast, and consequently the first time he had ever seen the works of more civilized man. He went on board one of the coasting steamers; he could not describe this, as the Dusuns have no ideas of boats, much less of steamboats : the only articles that made an impression on this man's mind and that could be compared with things Dusun were the ship's liawsers; these he described as buffalo ropes as thick as a man's arm; the steamer, its engines, and the other triumphs of the white man's brain were as nothing to Gamboie, as he 
was totally unable to compare these wonders with anything known to his Dusun mind, and they were therefore quite beyond his intelligence. I think this is one of the reasons why Eastern races are so undemonstrative when shown the wonderful works of our civilization, they are unable to compare them with anything else. It was not until some days after that the reason of Gamboie's eagerness to visit the coast transpired-lie was anxious to steal a Bajow's buffalo to give to his future father-in-law, the father of the lovely Kratas, who has been divorced some weeks from her disagreeable boy of a husband; so I suppose he thought that this would be a grand opportunity.

4 th, 5th, 6th.-Dusuns commence cutting down the jungle for their next season's ricecrop. I am still far from well.

7th, Sth.-Kabong's big talk about head-hunting has at last taken a serious turn. Last night a Melangkap Dusun arrived in the campong saying that he had seen a large head-hunting party of nearly two hundred men. Later on in the night we heard the alarmgongs beating in the villages around. I heard, the following day, that this party was composed of men from Kiau, 'Teung-'Tuhan, Koung, and Labang Labang-that they marched down to the outskirts of a village between this and Ghinambur, where some of their number sneaked up close to the village and attacked a woman, who was pursued by these wretches close up to the village, screaming; this brought other villagers on the scene, and the Kiau braves, having no stomach for a real fight, bolted. This is the account that Sultan, who is the chief of the village, gave us. The woman was severely wounded in three places and nearly provided a head for the harvest thanksgiving in Kiau.

9th.-Last night I was awakened by loud screams and cries: the old priestess said, "Soand-so's baby is dead!" This morning they are making preparations for burying it, and will soon forget their sorrows.

10th.-I am now better, so now fetched my collectors from the top of the hill; they have a few good birds, amongst them a third specimen of the new Partridge. To-morrow we are going to the hills behind Kapar, and after this expedition I shall return to Labuan. Amongst the coast people who brought up my baggage last time were some Bajows; these cattle-lifters could not help robbing the Dusuns even on this occasion. 'This they did by "obtaining goods under false pretences :" they told Damaring that they had paid his wife for some tobacco and that he was to give them the tobacco; this the youth did, being in his paddi-house some distance from the village. When Damaring returned home he discovered how he liad been duped, and loudly did he curse these Bajows. The present hostility between Bajow and Dusun is not surprising.

11th.-Started for Kapar, the Dusuns of that village carrying our baggage. They took some considerable time to reach their village, which is perhaps two hours' walk distantcontinually sitting down to rest and smoke and bathing in several of the small mountain torrents. Many of the Melangkap Dusuns have already finished their rice, so they will have to get on as best they can with kaladi and sweet-potatoes until the next harvest: this occurs with some families year after year, and before the next harvest they are nearly starved out, living on roots and anything they can find in the forests.

12th. - Most of the Kapar women and many of the men wear brass necklaces; this fashion I have not noticed in the other villages. Kapar village is similar to all the mountain 
villages, built on a smooth grassy spot and containing about a dozen houses of various sizes. We left Kapar early and encamped in the forest high on the mountain side behind the village: as I do not intend remaining here long I did not bring much baggage. In the trees over the camp there are several shelters made by the Orang-Utans, which consist of platforms of boughs. In the afternoon, while the Kadyans were building the house, I shot a species of Thrush, Geocichla aurata; this was a new species. The forest here is virgin, being above the zone of Dusun cultivation. 'The absence of a thick undergrowth caused by the shade of the high forest trees makes the hillside easy to traverse. The Kapars do not seem to be rat-trappers like the Kiaus-in fact, I did not notice a trap in this forest. There is a fairly clear path over the mountain, which the Dusuns tell me leads to the village of Siap. The forest is dark and damp, many of the trees being as large as those in the coast forests. Rain in torrents half the day.

14th.-Tungal brought me three specimens of a Whistling Thrush closely allied to one of the Himalayan species; this was new and has been named Garrulax schistochlamys. Our camp is pitched in a miserable sunless spot, and to-day, to add to my miseries, it has poured with rain from 11 A.M. until dark.

15th.-I am again beginning to suffer from fever, this damp forest camp being the chief cause. Heavy rain and thunderstorms half the day.

16th.-Had a bad attack of fever to-day, so resolved to depart for Melangkap, leaving the three Kadyans here to collect until 1 have packed up for the return journey.

17th, 18th.-Left with Buntar for Melangkap with part of my baggage.

19 th to 21st.-We are busy packing up the collections and shall leave as soon as possible for the coast. The Kadyans returned from Kapar with our last new bird, an interesting little Timeliine closely allied to a Himalayan species; this bird has been named Turdinulus exsul. 'The men also delighted me with a pair of a Bornean Pitta, P. schwaneri, which till within a few hours of my giving up bird-collecting in Borneo I had been unable to procure. This lovely bird is closely allied to a Javan species, P. cyanura, but differs chiefly from that species-already mentioned by me-in having a dark indigo-blue patch on the centre of the belly.

During the time the Kadyans were living on the hillside above Melangkap, some Kapar Dusuns entered their dwelling and pulled the men's clothes out of their "sabuts " or baskets; whether they would have robbed them or not I am unable to say, but on seeing my men returning the Dusuns ran away. The Kadyans told some of the Melangkaps that these men intended to rob them, and this report soon travelled to the Kapar men themselves. This morning the house is empty, and I am busy with Buntar packing up my collections in the small private apartment, the door of which we barred. On looking up we observed a big Kapar Dusun looking over the door at us: he at once let us know his business; he said he was one of the men who had turned the Kadyans' clothes out of their sabuts, and that he had heard that they had called him a thief. So as compensation he demanded that we should pay him a fine of several lengths of cloth, or, he said, he would return to Kapar and kill the Kadyan who was his accuser. As the Kadyans were still in the forest there, this might have been alarming with others than Dusuns. Buntar, however, began to bounce the Dusun, and threatened to burn down the village of Kapar if he dared do this, 
telling this man at the same time to go and kill the Kadyan. The burly Dusun found that he had met his match for brag, so in the end was willing to reduce this fine to a box of matches; but as we refused to be fined he did not even get this. On the following day this man accepted of wages and carried the rest of the baggage from Kapar to this village without slaying the Kadyan. This is a fair example of the Dusun attempts at blackmailing us; but we always returned threat for threat, showing them that we were in 110 way frightened of them.

On the evening of the 2 2nd everything was ready for an early start on the morrow. The Dusuns had even settled to carry our baggage. Some I paid in shot, of which I had a good deal to spare: this they use for weights for their casting-nets, melting the lead in small wooden moulds. Old clothes that had seen months of hard wear, bottles, tin boxes, and our spare stock of rice were accepted by these people as wages; I had also a small stock of trade-goods, and with this miscellaneous collection paid my way to Billio's village. There was, however, a serious hitch in our arrangements, caused by the entrance of a drunken Dusun, who talked very big and declared that all the packs were too heavy and that he would not accept of the wages offered; others who were disappointed at not receiving baggage immediately sided with this drunken man, and swore that we should not traverse the paths which led through their fields, as they would put up cross bamboos (I suppose the sign of Dusun "Tabu"); and so for some hours our chance of reaching the coast did not look very great. Through Buntar as interpreter I thanked them for treating us so kindly after our long stay in their village, and wound up by telling them that two of my men would start at daylight for the coast and bring back sufficient Bajows to carry everything. Seeing that they would lose everything by this manœurre, by 10 P.M. Dusun after Dusun had sneaked into the house and agreed to go for the wages offered.

I was much amused with one of my Dusun friends. One evening he came and sat down beside me, and said he was very sorry that I was really going to leave Melangkap and not going to return. I was just beginning to congratulate myself that $I$ had found some affection at last in the Dusun mind, when my friend told me the cause of his sorrow, wlich immediately dispelled this illusion; his reason was that when I was gone he would have no more trousers: since $I$ have been in this district most of these chawated Dusuns are able to wear trousers of trade-cloth.

23rd May.-This morning all the village turned out to see us off and to secure the many articles we left behind, the people of the house being delighted with their plunder of old sacks, bottles, biscuit-boxes, and other rubbish. I presented the old priestess with a towel a few days ago; this she folded in half, sewed up the sides, leaving holes for her arms, cutting a slit in the middle for her head, and in a few minutes was wearing this novel garment. She has prophesied that something serious will happen to the tribe on account of our visit, which is, to these ignorant aborigines, an event caused by the supernatural, so they conclude that they will be visited by some calamity.

24th.-Yesterday we succeeded in travelling far beyond Ghinambur, and camped under the starry heavens, beside a great tree-trunk that has been stranded on a shingicbank in the middle of the river. After sunset we were visited by some Dusuns, who came to beg for needles, whom we sent home rejoicing with five each. The river is high 
and rather difficult at the many fords. An incident occurred to-day which might have had serious consequences. Gamboie had assisted me over a dangerous rapid where some Bajows were crossing with a quantity of rattans that they were bringing from a tamel. On reaching the opposite side Gamboie turned round to recross the river to assist the others. For some few moments he stood glaring at two Dusuns who were standing with the Bajows on the opposite side, and whom he had not noticed before; these two men at once turned sharply round and hurriedly made for the jungle. Gamboie, who was busy untying his kris from the top of his load, where he had placed it to keep it dry, became very excited and called out "Languk!" two or three times, and proceeded to recross the river; but after following the two Dusuns to the jungle he waited there for the rest of the Melangkaps, who were far behind. In the meanwhile I gathered from the Kadyans that one of the two men who had bolted was Languk, the Bungal Dusun, who had murdered the Kapar man last year near Melangkap, and for whom an expedition had been organized in the spring. It was a very lucky thing for Languk and ourselves that Gamboie did not notice him before crossing the ford, or Languk's head would in all probability have been in Melangkap that same evening, my baggage would have been thrown down, and the Melangkaps would liave hurried home, fearing a Bungal attack.

25th.-We started at daylight and reached Billio's house by 11 A.M. ; here I bid adieu to Gamboic and our Dusun friends, with whom we have had many disputes, but on the whole must consider a decent lot of people, and on whom we have had to depend more or less for the successful carrying out of these two expeditions. Billio in an hour or two collected sufficient Bajows with their buffaloes to carry my collections to Abai, which we reached shortly before sunset.

26th.-The Kadyans are busy getting the "pakarangan" ready for sea; it had not been spoilt by the sun, after having remained in the mangrove-swamp since the beginning of January.

27th.-We started at mid-day for Pulo Gaya, and had a splendid view of Tĩna Balu in the evening.

2Sth.-Reached Pulo Gaya and started that same evening for Labuan; the wind being fair we touched Pulo Tega the following morning, where we rested during the heat of the day, setting sail once more about midnight, when the wind again favoured us.

29th, 30th.-We reached Labuan at 8.30 P.M., sailing along the coast, occasionally towing the pakarangan with a long rope. The sea was slightly rough, but preferable to the mosquito-swarming Kalias passage. In Labuan I remained a few days drying, before finally packing, my collections, when I returned to Singapore, reaching England once more in safety on the 8th August, 1888.

A complete account of my collections, as far as they are yet worked out, will be found in the Appendix.

I will now make a few remarks upon the altitudes estimated by me, which will be found to tally with those calculated by Mr. St. John and Mr. Little. 'The cave visited by 
Mr. Burbidge, the altitude of which he gives as 9000 feet, cannot be the one visited by the two other travellers and myself, as shown by the following quotation:- "'The next difficulty was to obtain water, since the men we had sent to search for it returned empty-handed" ('The Gardens of the Sun,' p. 101). 'The well-known cave has a stream flowing past it, and the same altitude, 9000 feet, is given by St. John. On his second expedition (page 275), Burbidge writes :- "We reached our former camping-ground, the cave, about 3.30." That Burbidge must have reached about this altitude, 9000 feet, is evident from the following note:- "Another occasional visitor is a Blackbird having a golden bill and a reddish-brown breast." This bird is Merula seebohmi. The little bird he mentions possessing a note of "ravishing sweetness" is Cryptolopha schwaneri. As far as I can see there is no altitude that I can use for comparison in 'The Gardens of the Sun,' so I have only the estimates of three travellers at my disposal, which I give below :-

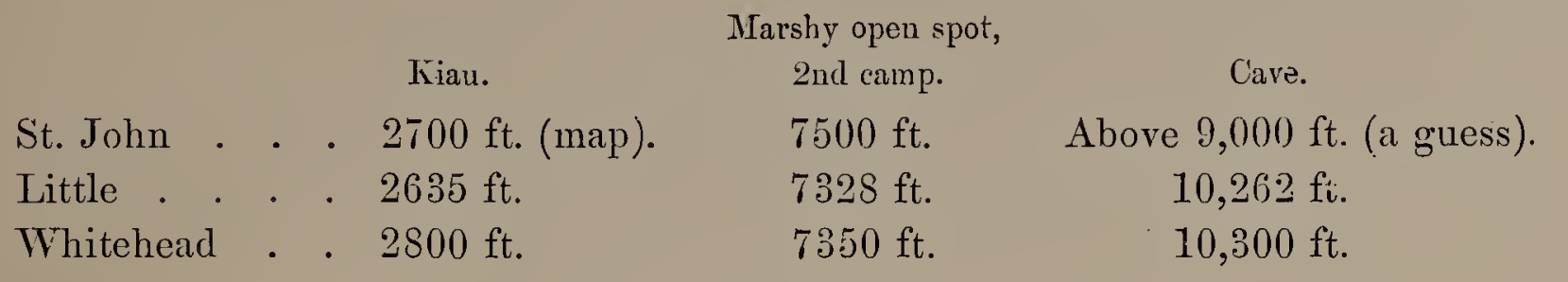

Little gives "Low's Gully" as 11,312 feet; this point he evidently considered the summit, but the true top of the mountain is perhaps a mile and a half further to the west. The height, 13,69S feet, estimated by Belcher, is in all probability within a few feet of the true altitude.

Speaking of the summit, Mr. St. John tells us that it "consists of syenite granite, which is in many places so jointed as to give it the appearance of being stratified. It is gradually giving way before atmospheric influences, its northern base being covered witl huge angular stones that have fallen."

Granite is an igneous rock which, we are told by geologists, "is always a compact rock. The absence of cellular cavities which are produced in other volcanic roclis by gas expansion has led to the belief that granite has been formed at a considerable depth below the earth and has been crystallized slowly under great pressure, either from superimposed strata or deep seas." Thus has the great granite mass of Kina Balu been formed and reared to its imposing height from the bottom of the sea, perlaps from a depth of many thousands of feet. The surrounding hills and spurs of this mountain are composed of sandstone and are not much higher than four thousand feet.

The derivation of the great mountain's name is still doubtful.

Mr. Treacher, in an interesting article on "British Borneo" in the "Journal of the Straits Branch of the Royal Asiatic Society' (1889, p. 66), gives a quotation from the 'Telselah Besar' (i.e. the native history of Brunei):- "At that time also the Emperor of China ordered two of his ministers to obtain possession of the precious stone of the dragon of the mountain of Kinabalu. Numbers of Chinese were devoured by the dragon, and still possession was not obtained of the stone. For this reason they gave the mountain the name of Kinabalu (Kina=Chinese, balu= widow)." 
A writer in the 'North Borneo Herald' for September 1892 seems rather inclined to lay down the law, and thinks his "the true derivatiou, which once known will we are sure put further discussion to an end. It is well known," he says, "that the name Kinabalu . . is spurious. The prefix Ki- was attached to the word Nabalo by the Brunei Malay." His derivation is Mangalo, meaning the "act of flight of the soul after death." " "Na balo' or 'Pangaloan' are both titles of this mountain, meaning the place of the soul's flight."

The third theory, also published in the 'Herald' (November 1892), is: "The Chinaman, if not locally born, turns his r's into l's. . . . I would simply suggest that Kina Balu is nothing but Kinabaharu, or New China (Kina=China, bahar $\iota=$ new)."

Mr. Frank Hatton mentions a part of this mountain as called "Nabalu" by the Dusuns.

I am inclined to accept the second explanation of the derivation, viz., that " $\mathrm{Ki}$ " is a prefix (either Malay or Chinese) to the Dusun word Nabalo="the place of the soul's Hight." The "Kinabaharu" theory has not enough antiquity about it, and little meaning, for surely this mountain must have had some name before the advent of the Chinese. "Nabalo" is a Dusun name for the mountain, and Kina Balu is undoubtedly looked upon by the Dusuns as their last resting-place; and therefore I think that this derivation is the most acceptable. 


\section{A P P E N D I X.}

The Appendix consists of an aluost complete description of the zoological collections formed by the Author. These papers are printed through the kind pcrmission of the sevcral Societies to which they were communicated; they comprise :-

No. 1. The Mammals of Mount Kina Balu. By Mr. Oldfield Thomas. From the 'Proceedings of the Zoological Society of London,' April 16,1889. The only alteration being the addition of Tupia montana, sp. nov., with remarks as to my claim as the discovercr of this species.

No. 2. On the Birds collected by me in North Borneo, comprising the descriptions of 43 new species by Dr. R. B. Sharpe, from 'The Ibis,' and one by Mr. Ogilvie Grant, from the 'Catalogue of Birds,' rol. xvii. p. 501, which is an addition to the "Ibis' paper; also my "field-notes" on the species met with.

No. 3. On the Birds of Palawan. By John Whitehead, witl descriptions of two new species, and of seven new species described by Dr. R. B. Sharpe. Also from 'The Ibis.'

No. 4. On a small Collection of Birds from the Highlands of Eastern Java. By John Whitehead. With descriptions of two new Species by Mr. H. Seebohn. From 'The Ibis.'

No. 5. On a Collection of Reptiles collceted by John Whitehead on Mount Kina Balu, with a complete list of Bornean Reptiles by Dr. F. Mocquard, entitled "Recherches sur la Faune Herpétologique des Iles de Bornéo et de Palawan," par Dr. M. F. Mocquard.

No. 6. Two papers on collections of Reptiles and Freshwater Fish obtained by John Whitehead on Kina Balu, by Dr. F. Mocquard and Professor M. Lćon Vaillant.

No. 7. On some new Land-Shells from Borneo and Palawan. By Mr. Edgar Smith aud Lieut.-Col. Godwin-Austen.

No. 8. Two papers on a portion of the collection of Coleoptera obtained by John Whitehead in North Borneo, by the late H. W. Bates, F.R.S., and Rev. H. S. Gorham, F.Z.S.

No. 9. Descriptions of Sixteen new Butterflies from Kina Balu. By H. Grose Smith.

No. 10. Descriptions of ncw Species of Rhynchota from Borneo. By W. L. Distant.

\section{ON THE MAMMAIS OF MOUNT KINA BALU. BY OLDFIELD THOMAS.}

[From the 'Proccedings of the Zoological Society of London,' April 16, 1889.]

THe Mammals described in the present paper formed part of the large zoological collections made during 1887 and 1888 on the great mountain Kina Balu in North Borneo by Mr. John Whitehcad, a gentleman who, although primarily an ornithologist, yct wisely collected whaterer Mammals he was able to obtain in that most interesting and as yet unknown part of the island. 
The species of whieh specimens were obtained number 21. Of these 6 were new to science, and 5 more were new to Borneo, thus incrcasing the known Mammal fauna of the island by no less than 11 The large number of new species is a most, remarkable fact, and one that shows how far we still are from anything like a complete knowledge of the smaller Mammalia and their distribution; and this is espeeially the case with the Rodents, to which, as usual in such cases, the majority of the new forms belong.

Until more is known of the Mammals inhabiting the other mountains of Borneo, it is not possible to draw any general geographical deductions from the present collection; but it may be noted that, of the additions to the Bornean fauna, one species was previously only known from the Himalayan region, where also is found the nearest ally of one of the new species, two are Sumatran, one is Javan, and onc occurs in Celebes.

1. SeMropithecus hoset, Thos. P.Z.S. 1889, p. 159, pl. xvi.

a. Șkull, 4000 feet.

The only other locality known for this speeies is Baram, on the coast at the junction of Brunei and Sarawak, where the type specimen was obtained by Mr. Charles Hose. The present skull is that mentioned in the original description.

2. Cynopterus encaudatus, Temm.

a. 3000 feet. $29 / 3 / 88$.

Previously only known from Sumatra. This species may be readily distinguished from the somewhat similar C. lucasi, Dobs., by its rather smaller size, by not possessing any trace of a tail, and by the attachment of its wing-membrane to the distal third of the first phalanx of the hallux instead of to its base.

- 3. Tupaia montana (Thos.), sp. n.

$a-b .3000$ feet. $3 / 87$.

c. 8000 feet. $5 / 2 / 88$.

Rather smaller than T. ferruginea. Dark grizzled rufous above, with an indistinct black dorsal line from the withers to the rump, broadening out and almost indistinguishable over the loins. Tail rather short, above dull grizzled rufous, below more olivaceous yellow, the lateral hairs ringed terminally with black.

Dimensions :-Head and body of type ( $\left.\sigma^{\star}\right)$ (c.) 200 millim.; tail (c.) 140 ; hind foot 41 ; front

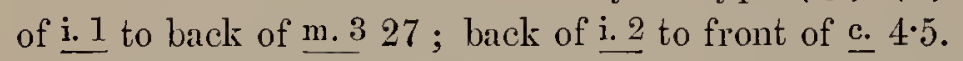

[This speeies has been deseribed in the 'Annals and Magazine of Natural History', March 189̀2, by Mr. Oldfield Thomas, as collected on Dulit by Mr. Charles Hose. This Tupia, however, was really diseovered in 1887 by myself on Kina Balu, and was again met with by me in 1888 . The three specimens collected by me have been in Mr. Thomas's possession since 1889, and, for reasons known only to himself, he preferred to give Mr. Hose the credit of this diseovery, my name not being mentioned in his paper in the 'Annals,' though the latter gentleman's specimens were reccived by him several years afterwards.-J. WV.]

4. Hylomys sulllus dorsalis, Thos. Ann. Mag. N. H. (6) ii. p. 407 (1888). (Figured on plate faeing p. 196.)

a. o. $^{2} 8000$ feet. $2 / 88$. Type of var.

b. $\delta$. 8000 feet. $9 / 2 / 88$.

c. 3000 feet. $21 / 3 / 88$.

Essential characters as in the typical variety, but with a more or less distinct black line running from between the eyes down the neck to the middle of the back.

Dimensions:-Head and body (c.) 116 millim. : tail 16 ; hind foot 25.

Since all the five or six specimens of Hylomys obtained on Kina Balu show a black dorsal line, sometimes, it is true, faint and indistinct, but always present, I believe this to be a valid geographical 
race, charaeteristie at least of Mount Kina Balu, if not of the whole of Borneo, whenee, up to the present, no other specimens hare been obtained. It should be stated, horrever, that Dr. F. A. Jentink, of the Leyden Museum, where the type of $H$. suillus is preserved, believes it to be not wortly of separation from that animal ; but as he is inclined to give, in certain other allied groups, rather less importance to the presence or absence of a dorsal streak than appears to me eorrect, I do not as yet feel disposed definitely to withdraw the merely varietal name already given to the Kina Balu Hylomys.

The true Hylomys suillus has been recorded from Burma, the Malay Peninsula, Sumatra, and Java.

5. Chimarrogale himalayica, Gray.

a. Ad. sk.

The occurrence of this fine Water-Shrew on Mount Kina Balu is a most interesting fact, and affords a remarkable instance of the relation that the fauna of the mountainous regions of the Malay islands bears to that of the Himalayas. The species has previously only been recorded from Sikhim, Assam, and the Katchin Hills in the North of Burma. The Bornean specimen is rather sniller than the type, its lind foot measuring only 20 millim. in length as against $22 \cdot 5$, but is otherwise identical ; this difference in size is very probably only sexual.

6. Crocidura (Crocidura), sp. inc.

a-c. 1000 feet. 1887 and 1888 .

In the present state of our knowledge I am unable to name these Shrews with eertainty. They are allied to, but markedly larger than, C. fuliginosa, Blyth.

7. Ptrromys nitidus, Desm.

a. Very young. 3000 feet. 4/88.

8. Sciurus bicolor ephippium, Temm.

a. ㅇ. 3000 feet. $14 / 3 / 88$.

9. Sciurus prevostit, Desm.

a, b. 1000 feet. March 1887.

$c$, d. 1000 feet. 1888 .

$a, b$, and $c$ are of the grey-backed form of the species, and $d$ of the black form, "S. pluto, Gray."

10. Sciurus Jentinki, sp. n., Thos. Ann. Mag. N. H. (5) xx. p. 129 (1887).

a. ㅇ․ 3000 feet. $14 / 2 / 87$. Type.

l. 3000 feet. $14 / 2 / 87$.

Native name "Tigae."

Size about equal to that of $S$. tenuis, Horsf. General eolour of upper surfaee yellowish grey, strongly suffused with ornge on the head and along the centre of the back. Hairs dark slaty grey for four-fifths of their length; their tips yellow or orange. Face grey, but with a white rim round ench eye. Ears extremely short, rounded, their edges white or pale yellow, and standing out in marked eontrast against a patch of wholly black hairs situated just behind them on the sides of the neck. Hairs of chin, chest, and belly slaty grey basally, dull yellowish white distally; line of demarcation on sides quite gradual. Limbs coloured as in S. tenuis ; hind soles hairy for their proximal 8 millim. Tail slender, the hairs being eomparatively short, only about 10 or 12 millim. in length; these hairs are broadly ringed with orange basally, and have a black subterminal and a white terminal band.

Incisors dark yellow above and below; premolars $\frac{2}{1}$; molars ratler smaller and lighter than those of S. tenuis.

Dimensions of specimen a, a female, preserved in skin :-

Head and body 140 millim.; tail, without hairs 103 , with hairs 136 ; hind foot 32.5 ; ear, above erown $4 \cdot 0$.

Skull : tip of nasals to bregma 25 ; greatest breadth 20 ; length of nasals $9 \cdot 5$; interorbital breadth 11.8 ; palate, length $16 \cdot 6$; length of upper tooth sories 6.4 . 
This speeies is most nearly allied to S. tenuis, Horsf., which ranges from the Malay Peninsula to Borneo, and of which there are a large number of examples in the Natural History Museum. It differs, however, in its much paler orange-washed baek, shorter and more prominently white-rimmed ears, the dark patehes behind the latter, and in its less bushy tail. It is also worthy of note that although $S$. tenuis, throughout its rangc, is singularly uniform in coloration, yet, if anything, the Bornean specimens of it are darker in eolour, and are thercfore still less like S. jentinki than are those from the Malay Peninsula, a fact which shows that the two speeies have no tendeney to grade into one another.

I have named this species in honour of my friend Dr. F. A. Jentink, Director of the Leyden Museum, to whose labours we arc indebted for mueh of our knowledge of the mammals inhabiting the East-Indian Arehipelago.

Mr. Whitehead informs me that S. jentinki ranges on Mount Kina Balu from about 3000 to 8000 feet altitude.

11. Sciurus notatus, Bodd. Elene. Anim. p. 119 (1785).

S. badjing, Kerr, Linn. An. K. p. 262 (1792).

S. plantani, Ljung. K. Vet.-Ak. Handl. xxii. p. 99 (1801).

$a, b$. Ad. $q$ and imm. 3000 feet. 28/3/88.

This eommon species, the Plantain Squirrcl of Pemnant, is represented by two specimens of the blue-bellied type, without any trace of red or yellow on their undersides.

At the cost of another change of name, I am glad to be able now to supersede the barbarous term "S. badjing," which I was guilty of resuscitating on account of its priority over the eommonly used "S. plantani." An examination of Boddaert's rare work proves, however, that the Plantain Squirrel had already reeeived a Latin name there, and one also that is fortunately both classical and appropriate.

12. Sciurus whiteheadi, sp. n., Thos. Ann. Mag. N. H. (5) xx. p. 127 (1887).

a. 3000 feet. 24/2/87. Type.

b. 3000 feet. $28 / 2 / 87$.

c. $\delta$, in spirit.

Native name "Mantok."

Sizc very small, only slightly larger than that of S. exilis, Müll. Ears narrow, pointed, their tips provided with beautiful black and white pencils of hair, so long as to reach, when laid backwards, almost to the withers; the ears themselves cdged with black, and with a markerl white spot on the head behind them. Colour otherwise uniformly fincly grizzled olive-grey all over, cxactly as in S. exilis and S. concinnus. Claws both before and behind long, very sharp and much curved, so as to enable the animal to hang on to almost, or quite, vertical surfaces. Palms with five large pads. Solcs with four subcqual digital pads, and a small eireular posterior pad ; back of sole hairy for about 9 or 10 millim.

Skull very peculiarly shaped, with a short and broad eranial, and a disproportionally long and powerful faeial portion, the distance from the tip of the nasals to a point betwcen the anterior edges of the orbits 12.8 millim., as compared to 11.3 in $S$. exilis, and 11 millim. in S. melanotis, the latter an animal with the eranial part of the skull as large as, if not larger than, that of S. whiteheadi.

Teeth :-incisors narrow, strongly eonvex in front, orange above, nearly white below ; prcmolars $\frac{2}{1}$, the anterior upper minute, circular in section.

Dimensions of specimen $c$, an adult male in spirit:- Head and body 84 millim.; tail, without hairs 67, with hairs 98 ; hind foot $25 \cdot 7$; ear, without hairs $10 \cdot 0$, with hairs 26 ; head $29 \cdot 3$; tip of muzzle to eye 18 , to ear 24 ; forcarm and hand 36.5 ; heel to front of last foot-pad $12 \cdot 3$; lairy part of sole in centre line $9 \cdot 4$.

This very beautiful little Squirrel is perhaps the most attractive of all the new Kina Balu mammals. It belongs to a group of pigmy squirrcls, consisting of S. exilis, S. melanotis, and a species only recently deseribed by myself, namely $S$. concinnus; the latter species comes from the Philippines, but the other 


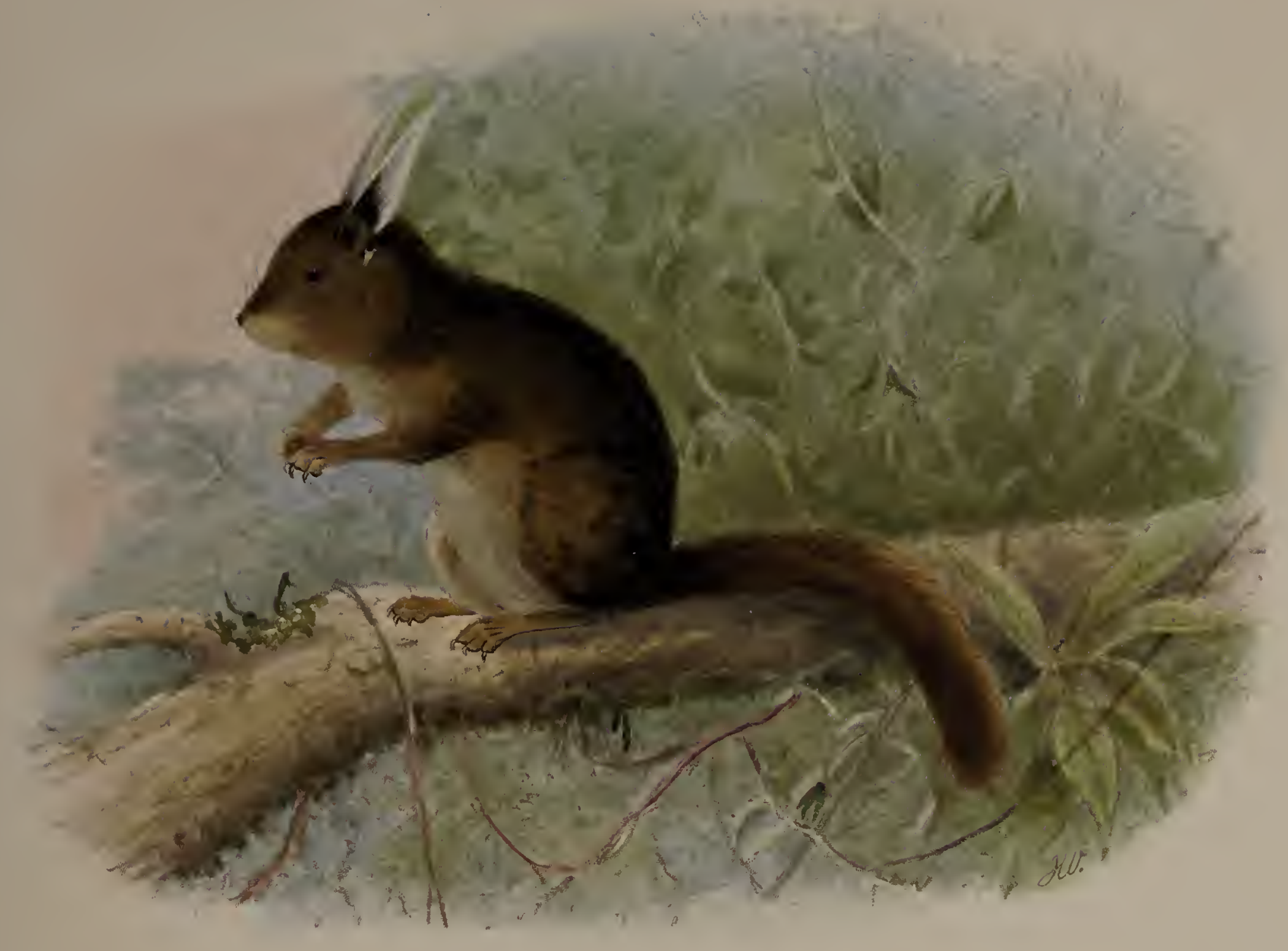

THE "MANTOK"

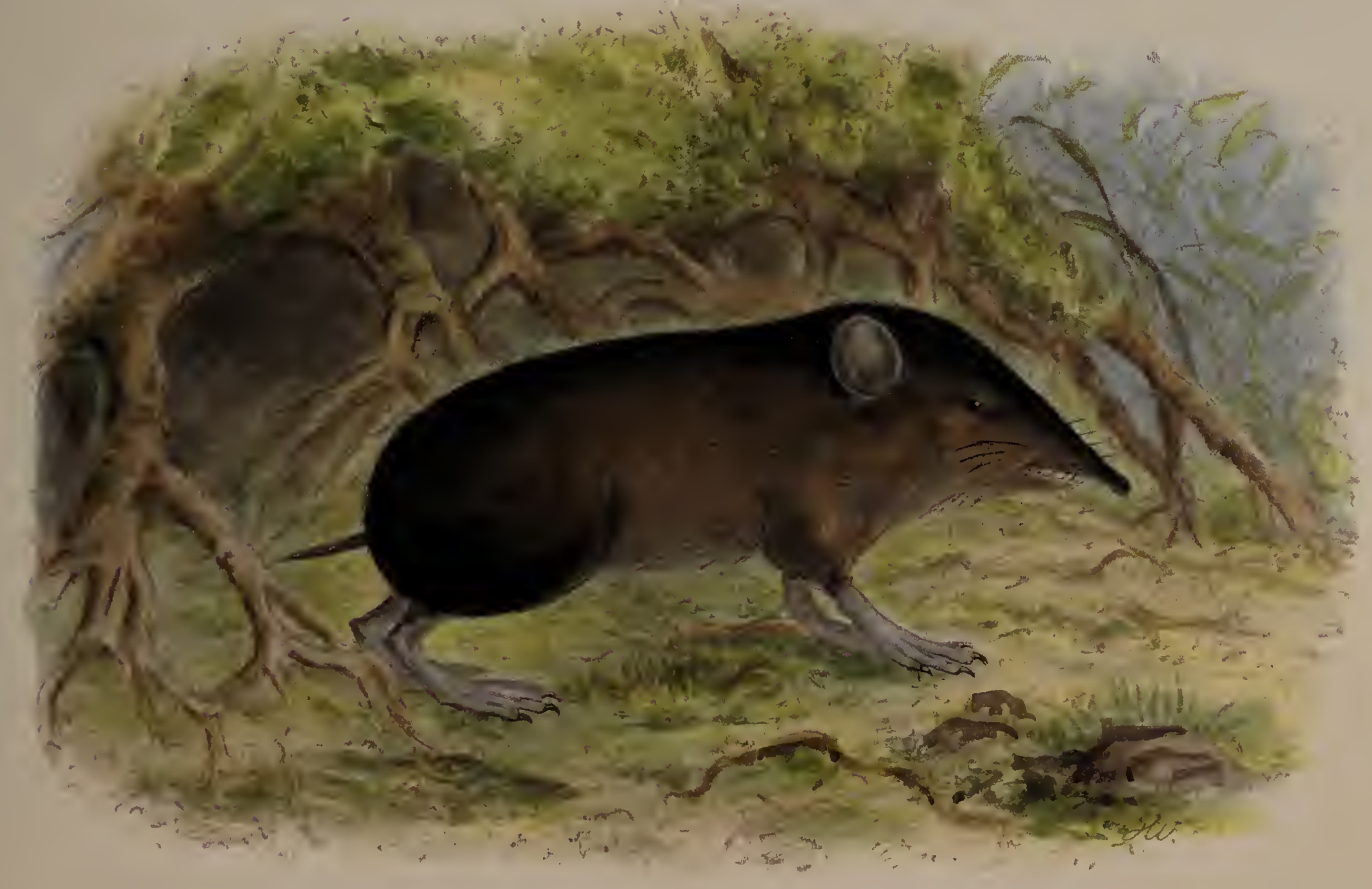



two, like S. whiteheadi, both oecur in Borneo, which possesses therefore three of the four members of the group. Of these species, S. vriteheadi is evidently most nearly allied to $S$. exilis, but it is readily distinguishable from that, as from all the others, by its benutiful elongated ear-tufts, which, in proportion to its size, are probably longer than those of any other known Squirrel, not even excepting Rhcithrosciurus macrotis.

Mr. Whitehead informs me that this little Squirrel may often be seen on the upper slopes of Kina Balu rumning up and down the trunks of the trees, and apparently gnawing at their bark. (Figured on the opposite page.)

13. Mus infraluteus, sp. n., Thos. Amn. Mag. N. H. (6) ii. p. 409 (1888).

a. 3000 feet. $22 / 3 / 88$. Type.

Size large. Fur coarse and harsh, but not spinous. General eolour dark greyish brown, the tips of the shorter hairs with a silvery lustre. The longer straighter hairs numerous, not markedly lengthened on the rump, uniformly black. Under surface a dirty yellowish brown, the tips of the straighter hairs dull orange, their base and the whole of the under-fur slaty grey. Ears small and rounded, naked. Hands and feet brown; last hind foot-pad elongate. Tail rather shorter than the head and body, thinly haired, dark brown above and below; rings of seales averaging about $S$ or 9 to the centimetre. Skull stout and heavily built. Supraorbital edges strongly ridged. Anterior edge of outer wall of infraorbital foramen evenly convex forwards. Palatine foramen about equal in length to the two anterior molars together, not reaehing backwards to the front of $\mathrm{m}^{1}$.

Teeth powerful ; incisors broad, dark yellow in front above and below.

Dimensions :-Head and body (e.) 285 millim. ; tail (extreme tip wanting) 235 ; hind foot 51; heel to front of last foot-pad 26 ; length of the same pad $9 \cdot 3$.

Skull : tip of nasals to lambda 51 ; nasals, length $21 \cdot 8$, breadth 6.5 ; interorbital breadth $8 \cdot 8$; infraorbital foramen, length of outer wall 7 ; palate, length 32 ; diastema 16.7 ; anterior palatine foramen $8 \cdot 4$; combined breadth of upper incisors $4 \cdot 6$; length of upper molar series $10 \cdot 7$.

This fine Rat has a eertain similarity to the Indian Bandieoot Rats (Nesokia), resembling them botl in general external appearance and in the stout and heavy build of the skull and teeth. No species hitherto described can be mistaken for it, as all the Oriental Rats whieh have external or cranial proportions at all similar are distinguished either by having elongated rump-bristles or parti-coloured whitetipped tails.

The single specimen obtained was found lying dead in the forest.

14. Mus rattus, L.

$a, b .8000$ feet. 4 and $5 / 2 / 88$.

c, d. 3000 feet. $1 / 4 / 88$.

The two specimens from an altitude of 8000 feet have their fur long and soft, while in those from 3000 feet it is short and harsh, so that it seems difficult to believe that both the forms can be referable to the same species.

15. Mus sabanus *, sp. n., Thos. Ann. Mag. N. H. (5) xx. p. 269 (1887).

a. 1000 feet. 3/87. Type.

b. (?) juv. 3000 feet. $21 / 3 / 88$.

Fur short and fine, mixed with slender spines along the centre of the baek. General colour rufous, mixed with brown' along the top of the lead and back, brighter and clearer on the cheeks and sides, the general tone very similar to that of $M$.jerdoni. Thole of underside pure creamy white, sharply defined trom the rufous of the sides. Outsides of limbs like sides, but rather greyer, inner sides white; lower leg and ankles greyish brown all round. Hands and feet brown along the middle of their upper surfaees,

* From Saba, the district of North Borneo in which Mount Kina Balu is situated. 
their cdgcs white, the contrast espccially strongly marked on the fcet, where a broad band of deep blackish brown passes along the centre, cdged on each side with pure white. Sole-pads large, smooth, and prominent, the last one about three times as long as broad. Fifth hind toe, without claw, rcaching to the cnd of the first phalanx of the fourth. Ears rounded, rather short, laid forward they barely reach to the posterior canthus of the eyes. Tail cnormously long, evenly finely haired, the scalcs, which are large, averaging from seven to nine to the centimetre, uniformly dark brown above and below throughout, but the hairs black for the proximal two thirds above only, elsewhere pure white. Nammæ 2-2=8.

Dimensions of the type, an adult male, prescrved as a skin :-

Head and body 280 millim.; tail 340 ; hind foot 43.5 ; ear, abore head 18 ; breadth 18 ; heel to frout of last foot-pad 23; length of last foot-pad $7 \cdot 0$.

Skull : tip of nasals to centre of fronto-parietal suture ("bregma") 36 millim.; nasals, length 21 , greatest brcadth $6 \cdot 0$; interorbital breadth $7 \cdot 7$; outer wall of infraorbital foramen, length $4 \cdot 7$; palate length 26.5 ; length of palatal forancn $7 \cdot 9$; diastema $13 \cdot 6$; lcngth of upper molar series $9 \cdot 4$.

Dimensions of a fine female in spirit, preserved in the Museo Civico, Genoa:- - Head and body 230 ; tail 393 ; hind foot 49 ; ear 20 ; hecl to front of last foot-pad 25 ; length of last foot-pad $8 \cdot 8$.

This spirit-specimen was obtaincd by Signor Beccari at Sungei Bulu, W. Sumatra, thus affording another instance of the relationship between the mountain-faunas of Sumatra and Borneo. Its examination, which I owe to the kindness of my friend the Marquis of Doria, has enabled me to add certain particulars, only observable in spirit-specimens, to the original description of this species.

Mus sabanus belongs to a wcll-marked group of Rats which oontains MLus jerdoni, Bly., Mr. niveiventer, Hodgs., M. coxingi, Swinh., M. edwardsi, Thos., M. hellwaldi, Jent., M. alticola, Thos., and others. These species are, however, all vcry much smaller than it is, with onc exception, M. edwardsi, which is as much larger, and not one of them has a tail of anything like the extraordinary length of that of Mus sabanus.

One species, indeed, also a native of Borneo, has a certain superficial resemblance to the present one, although bclonging to quite a different group of Rats. This is $M I$. muellevi, Jcnt., of about the same size, and with a nearly equally long tail; but it may be readily distinguished by its coarse Mus decumanus-like fur, Jellowish instead of rufous coloration, the less sharply defined whitc underside, and by the quite uniformly brown-haired feet and tail.

16. Mus Lepturus, Jent.

a. Ad.

b. Imm. 3000 fect. $24 / 3 / 88$.

Described by Dr. Jentink from Javan examples now in the Leyden Museum.

17. Mus alticola, sp. n., Thos. Ann. Mus. N. H. (6) ii. p. 408 (1888).

a,b. $\delta$ q. 8600 feet. 24/2/88. q. Type.

Fur mixed with flcxible spines both above and bclow. General colour above a peculiar bluish grcy, not speckled or grizzled, darker along the median line. Dorsal hairs and spines creamy white basally, gradually darkcning to grey terminally. Underside pale yellowish white, the hairs and spines uniformly of this colour to their bases; the linc of demarcation on the sides not very sharply defined. Hands and feet white, the hairs short and fine; fifth hind toc (without claw) renching nearly to the end of the first phalanx of the fourth. Tail fincly ringed, the rings averaging about 10 or 11 to the centimetre; shorthaired, sharply bicolor from base to tip, brown abore, yellowish white below.

Dimensions, o :- Head and body (probably stretched), 177 millim.; tail 162; hind foot 32 ; heel to front of last foot-pad 16 .

Slull : tip of nasals to lambda (junction of sagittal and lambdoid sutures) 34 ; nasals. length 15 ; interorbital breadth $7 \cdot 4$; palatc, length 19 ; length of anterior palatine foramina 6 ; upper molar series $5 \cdot 8$. 
This species is most nearly allied to the Nepalese M. niceiverter, Hodgs., but may be distinguished by its unspeckled back, by the more gradual passage of the upper into the lower colour, and by its larger size.

So fur as its collector has observed, Mus alticolor is confined to the higher parts of Mount Kina Balu.

18. Mus musschenbroecki, Jent.

a, b. 1000 feet. $3 / 87$.

c, d. $\delta$ ㅇ. 3000 feet. 18 and $20 / 3 / 88$.

It is of considcrable interest to find this species, previously only known from Celebes, in Borneo, on a different side of the line separating the Oriental from the Australian regions. Its occurrence here suggests that other membcrs of the Orieutal clement in the peculiar Celebean fauna may also prove to have survived on the tops of the Bornean mountains.

19. Mus ePHippiun, Jent.

$a, b$. Ad. and juv. 1000 feet. 3/87.

It appears rather doubtful whether this species is really distinct from M Ius concolor, Bly., found in Burma and the Malay Peninsula ; but for the present I do not feel justified in definitely uniting the two forms, and the Kina Balu individual clcarly belongs rather to the Sumatran 'ephippium' than to its northern ally.

20. Chiropodomys glirondes, Bly.

a. 1000 feet. $1 / 88$.

This specimen is immature, but would not apparently have ever reached the dimensions of the two individuals obtained by Mr. Wallace at Sadong, and now in the British Museum. However, it cxactly matches some of those collected by Signor L. Fea in Burmah and ''enasserim, and is evidently specifically identical with them. In the general account now in course of publication of the collection made by that gentleman some further details as to the character and synonymy of this beautiful little species will be found.

21. Trichys GUENTHerI, nom. nov.

Tirichys lipura, Günth. P. Z. S. 1876, p. 739.

a. Juv. 3000 feet. $3 / 4 / 88$.

This specimen is the fourth example of the interesting genus Trichys that has come to England, although therc have been examples of it for many years in the Leyden Museum. The first one, a tailless individual, was described by Dr. Günther as "Trichys lipura," under the circunstances detailed in his paper of the present year (Proc. Zool. Soc. 1889, p. 75). Since, howcver, I differ from him as to the admissibility of the namc 'lipurc' for a species which normally has a long tail, I propose now to rename the species accordingly.

No better name can be found for it than of its original describer, whose judgment in forming a new genus for it is fully confirmed by an independent examination of its cranial characters, even after the downfall of the peculiarity supposed, and not unnaturally, to belong to it of not possessing any trace of a tail.

As to the alleged applicability of Shaw's name "Iystrix fasciculata." to this Porcupine, I can only express my entire agreement with Dr. Günther's opinion (l.c.) that that name should stand as a synonyul of Atherura macrura, L.

The Kina Balu specimen, although only half-grown, shows all the characteristies of the genus, and is distinguishable at the first glance from Atherura by its short spines and narrow parallel-sided caudal bristles. 


\section{ON THE BIRDS OF NORTH BORNEO. \\ BY Dr. R. B. SHARPE AND Mr. JOHN WHITEHEAD.}

THE following account and descriptions of the birds collected by me in the North of Borneo appeared in 'The Ibis' during the years 1887 to 1890 inclusive. I have arranged the several papers in a connected form, cutting out all matter that I considered would be of little interest to my readers.

All the new species were described by Dr. R. B. Sharpe, with the exception of one by Mr. Ogilvie Grant, my notes being given in brackets.

[From 'The Ibis.']

Order ACCIPITRES.

Suborder FALCONES.

1. Crrous spilonotus (Kaup).

Family FALCONID出.

The series of this Harrier collected by Mr. Whitehead seems to prove conclusively that the sexes are similar when they are fully adult.

Iris bright yellow ; feet dull straw-yellow.

2. Astur trivirgatus (T.).

[I met with this Hawk on Kina Balu at a height of 1000 feet in the middle of March 1887. Both specimens procured on that occasion were adult females; and on my second expedition I met with a male bird in February 1888 at a precisely similar altitude. All had well-developed crests.

In Palawan I only obtained a single specimen, a young male, on the 14th of September. The cere and feet were pale yellow, and the iris light straw-yellow. This specimen was shot at Taguso, on the coast, so that, so far as my observations go, this Goshawk is not found at any great elevation.]

3. Astur soloensis (Lath.).

o juv. Kina Balu, Feb. 26, 1887.

[On Kina Balu I only found this Goshawk at a height of 1000 feet, when I shot a young female. Iris king's-yellow ; feet and cere similar.]

4. Acciptter virgatus (T.).

ơ ad. Kina Balu, Feb. 1887.

[This bird is evidently a migrant to Kina Balu, and was obtained under the same circumstances as Astur soloensis.]

5. Accritter RUfotibialis, sp. 11., Sharpe.

Adult male. General colour above dark slaty grey, the feathers blackish on the edges, the head and mantle blacker than the back; quills blackish brown, crossed with bars of black, from five to six in number ; rump, upper tail-coverts, and tail slaty grey, lighter than the back, the tail crossed by four black bands, five in number on the outer feather; lores, sides of face, and ear-coverts sooty black, the cheeks blackish washed with rufous ; the under surface of the body rich chestnut, the throat buff, with a central line of blackish streaks ; abdomen chestnut, with a few white bars on the upper part, the lower abdomen white with a few broad reddish bars; under tail-coverts white; thighs uniform chestnut; under wing-coverts reddish buff, spotted with black; axillaries whitish, washed with rufous and barred across with dull blackish. Total length $9 \cdot 3$ inches, culmen $0 \cdot 4$, wing $5 \cdot 95$, tail $4 \cdot 2$, tarsus $1 \cdot 8$.

Young male in moult. The first plumage has evidently been brown, with broad ferruginous edges to all the feathers ; tail ashy brown, with four black bands, five on the outer feather. The under surface is 
rufous, like the adult, with remains of the broad blaek streaks on the chest belonging to the first plumage. Thighs nearly nniform rufous, with slight remains of brown mottling. Total length 9 inclies, culmen $0 \cdot 4$, wing $5 \cdot 7$, tail 4 , tarsus $1 \cdot 75$.

Since describing this species I have been able to compare it with specimens of $A$. manillensis in the Twceddale collection, and I find that it is quite distinct and easily recognizable by its rufous thighs.

[This species seems to be confined to the more open country of Kina Balu, $i$. e. the Dusun clearings. I saw it from 1000 feet to 4000 feet, but it appears to be extremely rare. In fact I only managed to procure two speeimens on my first expedition, and in 1888, during my second visit, I only saw three birds, none of which I was able to procurc. I was witness to a plucky fight between one of these SparrowHawks and a Spilornis, when the former attacked the Eagle with fury and drove him out of a tree.

On the 30th of March, 1888, a native brought me two eggs, evidently of this Hawk, which had been seen by me about the locality where the nest was found. One egg is of the typical Sparrow-Hawk type. Length $1 \cdot 15$, diam. $1 \cdot 16$ in. Colour greenish white, with the usual reddish blotches towards the larger end. The seeond egg is nearly spotless. Length 1.5 diam. $1 \cdot 2$ in.]

6. Spizaetus limnaetus (Horsf.).

[In Labuan this species is resident and breeds on the island. A female with the under surface white, and striped with brown, was shot from the nest on the 15 th of December. She was paired with a black male, and the nest contained one large white egg, which has since been unfortunately broken. Another pair, from Tampassuk, with a nest and eggs, the male of which is nearly uniform clocolate-brown, while the female is light brown below, streaked with black.]

7. LoPHOTRIORCHIS KIENERI (Geoffr.).

\& ad. Kina Balu, March 20, 1887.

[This is a beautiful adult bird, and was the only one I saw in Borneo. Mr. Wallace had previously proeured a specimen in Sarawak, but no one else seems to have met with it. I eonsider it to be probably only a visitor to Borneo during the N.E. monsoon, as, had it been a resident, I think I must have noticed it on other occasions. My single specimen was procured on my first expedition to Kina Balu at a leight of about 1000 feet. Iris dark brown; feet and cere pale chrome-yellow.]

8. Neopus malayensis (T.).

a. đo ad. Padas River, June 14, 1885.

b. ठ imm. Tampassuk, Feb. 15, 1886.

[The male from the Padas had the iris hazel and the feet and cere ling's-yellow. The younger male las the soft parts exactly as in the old bird. Not seen on Kina Balu, but frequently observed on the large plains on the sea-coast, where I have seen it beating low over the hill-sides.]

9. Spilornis bacha (Daud.).

우 ad. Kina Balu, March 11 .

This is apparently the first real instance of the oecurrence of the speeies in Borneo ; I have compared it with Javan specimens and find that they cannot be separated.

[This Serpent-Eagle replaces the small Spilornis pallidus in the higher regions of Kina Baln. I did not meet with it below 3000 feet, and even at this altitude it was scarce. The crop of the specimen shot was full of lizards and snakes, and I notieed it frequently beating along the dried-up beds of rivers, where it could easily obtain the various rock-lizards on which it preys.]

10. Spilornis pallidus, Walden.

a. đ ad. Benkoka, Maruda Bay, Oct. 2, 1885.

b. $\delta$ ad. Tampassuk, Feb. 26, 1886.

[This species is more frequently met with in the jungle than in the open country. I do not remember observing it above 1000 feet on Kina Balu, but my specimens were destroyed by insects.] 
11. Butastur indicus (Gm.).

a. Juv. Labuan, Nov. 1885.

b. ठa ad. Labuan, Dee. 9, 1885.

c. Juv. Benkoka, Oet. 22, 1885.

[I have observed this speeies in various parts of Northern Borneo between the end of Oetober and the end of Mareh, and it is evidently only a migrant of the N.E. monsoon. During my aseent of Kina Balu I found it as high as 1000 feet. It is generally met with in open places. A young male had the iris yellowish olive, the feet and eere dull yellow.]

12. Haltaetus leucogaster (Gm.).

[Iris hazel ; feet dirty white ; skin on face Freneh-blue. Plentiful all round the eoast of Borneo, but rarer in Palawan. I found a nest on the 12 th of April with nearly-fledged young. The nest was on a dead tree in a forest which had been recently burnt. The nestlings were beautifully speekled, much more so than in the full-grown young birds whieh were afterwards proeured. The nest was full of the remains of sea-snakes, on which this Eagle frequently feeds. One of my specimens is stained on the breast with the ink of the euttle-fish, whieh, aeeording to the natives, is also a favourite food of this speeies.]

13. Polionetus тchthyaetus (Horsf.).

ơ ad. Benkoka, Sept. 6, 1885.

[Iris light hazel; feet greyish blue; bill blaek. Brought to me alive by a native.]

14. Haliastur intermedus, Gurney.

[A young male from Tampassuk had the bill and feet dull greenish yellow. Although I did not bring a specimen from Kina Balu, the bird is found there up to 1000 feet. It is a great robber of ehickens, and is mueh detested by the natives.]

15. Pernis ptilonorhynchus (T.).

[Iris light straw-yellow; feet yellow. All the Bornean and Palawan birds are old, with grey faces, and two of them have large erests. They are inhabitants of the forest, but do not extend above 1000 feet on Kina Balu.]

16. Mrcrohmerax latifrons, Sharpe.

ㅇ ad. Benkoka, Sept. 30, 1885.

17. Falco communis (Gm.).

[Only found during the N.E. inonsoon.]

18. Cerchneis tinnunculus (L.).

An immature male, apparently of the dark Chinese form.

[This species is evidently very searce, and I only noticed it on the large plains of Tampassuk.]

19. Pandion haliaetus (L.).

Suborder PANDIONES.

These birds belong to the large form of Osprey and not to the small Australian race.

[The first female had the iris yellow; bill black, slaty blue at base of lower mandible; cere slaty blue ; feet white, with a pale bluish tinge ; elaws blaek. I think that the Osprey is a migrant in Nortleru Borneo.]

20. Ketupa ketupa (Horsf.).

\section{Suborder STRIGES.}

Family Bubontide.

$q$ ad. Benkoka, Nov. 12, 1885.

[Shot in the forest in open places near the paddy-fields in Northern Borneo. I never met with it in my Kina Balu expeditions. Iris pale greenish yellow; bill and feet brownish yellow.] 
21. Bubo orientalis (Horsf.).

a. $\delta$ ad. Kina Balu, March 2, 1887.

b. $q$ ad. Kina Balu, April 3, 1887.

[The male had the iris blaek; bill light straw-yellow ; feet darker straw-ycllow. I met with it at about 3000 feet in the serubby jungle on the lower spurs of Kina Balu. The female bird was obtained at about the same elevation and in precisely similar situations. I do not think it goes higher up the mountain. The first bird was obtained under curious circumstances. One of my hunters having found a flock of Staphidia everetti and other small birds in the jungle, singled out one of them and brought it down with a walking-stick gun. To his astonishment this large Owl came tumbling down along with the little Staphidia. The man had not seen the Owl in the thick jungle, and there is no doubt that the small birds had been mobbing it.]

\section{Suborder STRIGES.}

\section{HeTERoscops, gen. $n$.}

Genus simile generi 'Scops' dieto, sed fasciis auricularibus absentibus, et facie crinibus tenuibus ornata distinguendum. Typus sit

22. Heteroscops luciж, sp. n., Sharpe.

Adult female. General colour above tawny rufous, mottled with coarse black vermieulations, giving here and there a spotted appearance; on the linder mantle some large ovate fulvous marks, not sufficiontly indicated to form a "wig" ; scapulars externally yellowish white, forming a broad streak, with a black spot near the end of the shaft; upper tail-coverts rather more regularly barred with black; wing-coverts like the back, but the black vermiculations on the median series more sparsely distributed; bastard-wing blackish internally, with a chequered patter'l of broad black and tawny-buff bars on the outer webs; primary-eoverts rufous, with small black vermiculations and feebly indicated bars of black on the outer web; primaries ehequered with black and tawny-buff bars on the outer web, the black more or less mixed with tawny buff; inner webs blackish; seeondarics rufous, vermienlated with black, scarcely forming any bars; tail-feathers black, with a few more or less distinct rufous bars towards the ends; crown of head like the back, but rather more strongly mottled with black bars ; forehead tawny rufous, the frontal plumes tipped with black; base of bill beset with long plumes, barred with rufous and black; above the eye a dusky blackish spot; sides of face, ear-coverts, and cheeks rufous, barred with black spots, the auricular plumes produced into hair-like tufts: under surface of body rufous, like the upper surface, with large black spots on the recurved plumes of the upper throat; the black vermiculations much more scanty than on the upper parts, with a few broad interspaces of tawny buff on some of the feathers, giving an appearance of light spots here and there; abdomen whitish; sides of body and flanks like the breast, but with scarcely any trace of black vermiculations; thighs tawny rufous, whitish behind; under tail-eoverts white, with a slight rufous tinge; under wing-coverts tawny, with paler buff edges; the edge of the wing mottled with blackish; outer coverts uniform blackish; quills below blackish, barred with tawny on the outer web and with pale tawny buff along the inner webs. Total length $7 \cdot 8$ inches, wing $5 \cdot 3$; tail $2 \cdot 75$, tarsus $1 \cdot 0$.

One male bird is almost of the same tawny rufous as the female described, but is a trifle darker. It differs in no importint particulars beyond such as is usual in Seops Owls, viz. rather more or less strongly indicated black spots and vermiculations. The second male is mucl darker and browner, and has a good many clear indications of tawny-buff spots on the hind neck. In both males a tawny eyebrow is well marked. In the darker male the black markings on the throat are strongly developed, and behind the ear-coverts there are some whitish bars, giving a slight appenrance of a ruff. The wings measure $5 \cdot 2-5 \cdot 3$ inclies, which is about the same as in the female, but the size of the male bird is decidedly smaller.

This little Owl, by reason of its yellow bill, comes nearest to the section of the genus Scops which 
embraces S. balli and S. rufescens, but on comparison it shows but little similitude to either of those speeies. The tarsus is bare for half its length behind, but the feathers come down on the front almost to the junetion of the toes. It is not quite so thickly feathered as in S. rufescens, but is more so than in S. balli. Neither of the last-naned species has the whitish abdomen of Scops lucio, and the rufous coloration and rufous eyebrow also distinguish it from them, as well as the curious bristly elongations of the shafts of the faeial plumage, which have induced me to separate the bird as a distinet genus from Scops.

[I first met with this small Owl in the dark and gloomy forests whieh oeeur in large patches at about 9000 feet on Kina Balu. The male had the iris greenish yellow, the green showing espeeially round the pupil; skin round eye pinkish brown; bill pale yellow, almost white; feet dull white and bare. I never heard the note of any sinall Owl during my residenee of a month at my eamp at 8000 feet, and I only got three specimens during my eight months' residence on the mountain. I only met with it during my seeond expedition, and fancy that it must be rare.

The eirenmstanees under which this little Owl was proeured were quite different from those under which I found Scops lempiji. The latter bird is always to be seen in the neighbourhood of villages up to about 1000 feet, and its call ('Pwok,' whenee the native name) is quite a feature of the localities whieh it frequents. On the other hand, I never heard H. luciee utter a sound.]

23. SCOPS LEMPIJI (Horsf.).

a. $C^{\text {A }}$ ad. Kina Balu, Feb. 1888.

b. ㅇ ad. Kina Balu, Mareh 20, 1887.

c. $\delta$ ad. Kina Balu, March 20, 1887.

d. of ad. Abai, N. Borneo, Feb. 11, 1886.

[See nuy note on II. lucia for this Owl, which is a bird of the lower lands. An egg (white; length 1.45 inch, diam. 1.2 inch) was procured with the old bird on the 20th of Mareh, 1888; but as the bird had been eaptured with gutta-percha, its plumage was too mueh spoiled for it to be preserved. The natives often eateh birds by means of "gutta," which they smear on to a little piece of bamboo. This little stiek they fix loosely into a long bamboo, and when they see an Owl or any bird which they can approach silently they lay the "gutta" stiek aeross the baek and withdraw the long bamboo. The bird opening its wings with a start attaches them at onee to the stieky bamboo-twig and is eaught. Unfortunately the specimens thus obtained are seldom worth preserving.]

24. Scops Rufescens (Horsf.).

a. ㅇ ad. Benkoka, Sept. 25, 1885 .

b. 3 ad. Benkoka, Scpt. 25, 1885.

25. Ninox Japonicus (Bp.).

a. $\delta$ ad. Lawas River, April 9, 1886. Wing 9.3 inehes.

26. Ninox Borneexsis $\left(\mathrm{B}_{\mathrm{p}}\right.$.).

a. $\delta$ ad. Benkoka, Oet. 10, 1885.

b. ơ ad. Benkokra, Oet. 30, 1885.

c. + ad. Benkoka, Oct. $30,1885$.

d. \& ad. Labuan, March 20, 1886.

[These small Owls are often seen flying about in the early part of the evening, hawking for dragonflies. I have shot them with the dragon-flies in their claws.]

27. Syrnium Leptogramicum (T.).

[An old male had the iris black and the feet slate-blue. These birds were obtained by my hunters at a time when I was ill, so that I know nothing of the habits of the speeies. It is probably a resident, as the young male has still a good deal of the nestling-plumage adhering to the neck, so that it was evidently bred in the neighbourhood. I nerer met with the speeies on Kina Balu, or, in faet, on any of the high lands.] 


\section{Order PASSERIFORMES.}

\section{Fanily CoRvidæ.}

28. Corone texuirostris (Moore).

$\delta$ ad. Benlikoka, Sept. 17, 1885.

\& ad. Kina Balu, April 2, 1887 .

[Rathcr a scarce species, and never met with in flocks, but generally seen in pairs. I have noticed it on Kina Balu about the Dusun villages up to 1000 feet.]

29. Dendrocitta cinerascens (Sharpe).

a. ô ad. Kina Balu, April 3, 1888.

b. $\delta$ ad. Kina Balu, March 17, 1888.

c. $\delta$ ad. Kina Balu, March 20, 1888 .

「This bird is fairly common on Kina Balu from about 1000 feet up to quite 9000 feet. It frequents the thick junglc-growth which springs up after the rice-crops, and in four or five years reaches a height of from 12 to 20 feet. It is also met with at 9000 feet among the big trees in the thick forest, but it is not so common. It has a loud bell-like note, also a cackling cry like that of our Common Magpie. Sometimcs four or five may be seen together. It builds in the low jungle, constructing a shallow nest of finc twigs. I found one on the 13th of March, 1888, on a low tree in the scrub. It contained two eggs, very Magpie-like in appearance. Length $1.2 \mathrm{in.}$, diam. $0.9 \mathrm{in.}$ The ground-colour is greenish white, dotted all over with brown markings, which increase in size towards the larger end, where there is a blotch of brown, forming a nearly complete ring. Iris light bazel; bill and feet black. Dusun name "Mantihak."]

30. Cissa minor, Cab.

[Feet and bill vermilion ; iris lake. Cissa minor is fairly common in the same kind of scrub-country as is frequented by the Dendrocitta, but, unlike that species, it does not ascend Kina Balu, being confined to a level between 1000 and 3000 feet; it is, indeed, very rare at the latter elevation, though deeidedly common lower down. In the early morning and towards evening the Cissas become very garrulous, one bird whistling to anotler. The notes are many, the most pceuliar being a three-syllabled whistle, from which it gets its Dusun name of "Ton-ka-kis." I often shot specimens in the evcning by watching the birds as they called to each other from a long distance. As one bird finished whistling it would fly off and its place would be occupied by another bird, whieh would again commence calling to its more distant companions. The natives often brouglit me nestlings in March, but all attempts to rear them failed, as they perished at night-time, apparently from the cold. The nests were found in the thick undergrowth, and contained two young birds, in one instance threc. The two long centre tail-feathcrs are often much worn, making it difficult to obtain good specimens.].

31. Cissa Jefreris sp. n., Sharpe.

Adult male. General colour above bright emerald-green ; scapulars like the back, with greenishwhite edges, as well as the upper tail-covertz; lesser wing-coverts green externally, rcddish on inner wcb; remainder of coverts deep claret-red or maroon; the bastard-wing and primary-coverts reddish brown; quills claret-red, the primaries reddish brown, the inner secondarics greenish white, exccpt on the outer web, whieh is for the most part claret-red; tail-fcathers grecn, with a slight bluish tinge, tipped with greenish white, all but the centre feathers witl a black subterminal bar; crown of head bright emerald-grecn; a narrow line at base of nostrils; lores, eyebrow, feathers round eye, sides of face, and ear-coverts black, forming a broad band, which encircles the nape; cheeks and under surface of body light emerald-green; under wing-coverts and axillaries ashy brown, washed with green; quills below eoppery brown. Total length 11 inches, culmen $1 \cdot 25$, wing $5 \cdot 3$, tail $4 \cdot 1$, tarsus $1 \cdot 7$.

Adult female. Similar to the male, but a trifle more bluish. Total length 11 inches, culnicn 111 , wing $5 \cdot 2$, tail $4 \cdot 8$, tarsus $1 \cdot 6$. 
Mr. Whitehcad writes:- "I cxpect this is a new speeies, as it is quite distinet from Cissa minor, and I should like it named after my father, Cissa jefferyi. The note of this bird is quite distinct from that of $C$. nninor. I first met with it in pairs, at 8000 feet; but I afterwards found it at 4000 feet, where it closely approaehes the range of $C$. minor. I fancy the alpine bird las a more grcenish tinge than the lattcr speeies, whieh is met with at a lower altitude. While $C$. minor frequents the thiek growth whieh springs up in a eouple of years after the riee-erops, Cissa jefferyi never leaves the virgin forest."

When a series of this spceies is laid out side by side with a similar series of $C$. minor, a great diffcrence is noticeable at once in the green colour of the bird, which is very decided, and no yellow of any kind appears on the erown. Sometimes a little bright blue ean be seen in the plumage of the baek, but never appears on the underparts. Independently of the strong differenees in the wings and tailfeathers, pointed out by me in my original deseription, C.jefferyi, as seen in a row of speeimens, can at once be distinguished from $C$. minor by the mueh narrower tips to the tail-feathers, and these pale cnds are distinetly greenish whitc.

The males of $C$. jeffery $i$ have the wing $5 \cdot 25-5 \cdot 5$ inches, and the females $5 \cdot 2-5 \cdot 4$. A young bird has a blaekish bill, the eolour is more dingy, and there is no subterminal black band on the tail at all.

[Bill and feet deep lake-red, much darker than in C. minor. Iris white, with a faint pink tinge round the pupil. In the young birds the bill is duller in colour, blaekish towards the base.

I first met with this beautiful bird at 8000 feet, and I could tell at once, from its note, that it was a different specics from C.minor, and eoneluded that it must be a highland representative of the latter; but when eamping at 3000 feet this spesies was met with again, so that it is evidently the thiek forest whieh divides the two speeics. While C. minor inlabits the morc open and cultivated distriets, C.jefferyi, even at its lowest altitude, never quits the true forest, and the ranges of the two specics never secm to overlap. In April the old birds had their families with them, consisting of two young ones. On the higher slopes of Kina Balu this speeies was deeidedly rarer, and I found it frequenting the twisted and moss-eovered trunks near the ground, feeding on snails and probably the small frogs whieh were numerous. The note is not nearly so elear as that of C. minor, but is still a feeble attcmpt at "Ton-ka-lis."]

32. Platysunuds aterrimus (T.).

[Bill and feet black; iris erimson-lake. Not at all Crow-like in its habits, frequenting the middle growth in the junglc. Sometimes two or three are seen in eompany. One speeimen was procured on Kina Balu at nearly 1000 feet.]

33. Oriolus xanthonotus, Horsf.

\section{Family OrIOLID 瓜.}

[Iris dark lake; bill dull pinkish red; feet blackish brown. Fairly eommon, frequenting the higher trees in the jungle. It does not extend up Kina Balu beyond 1000 fcet. Native name "Burong Sarawak."]

34. Oriolus vulineratus, sp. n., Sharpe.

Adult mule. General colour above glossy blue-blaek; the lower baek somewhat mottled with aslyy bases to the feathers; lesser wing-coverts like the baek; median and greater eoverts, bastard-wing, and primary-eoverts blaek, with a narrow edging of glossy blue-blaek, the piimary-coverts margined with erimson near the ends; quills blaek, edged with glossy blaek, the primaries with hoary brown ; upper tail-coverts like the back; tail-feathers glossy blaek; crown of head, sides of face, ear-eorerts, cheeks, throat, and fore neck glossy blaek, with an ashy shade on the fore neek; eentre of breast glossy erimson, forming a large pateh; abdomen, sides of body, and flanks blaek, slightly varied with greyish bascs to the feathers ; thighs and under tail-corerts, under wing-coverts, and axillaries blaek; quills below blackish, rather more ashy along the inner web. Total length 9 inches, eulmen 1 , wing $5 \cdot 1$, tail $3 \cdot 6$, tarsus $0 \cdot 9$.

This is a very interesting representative of $O$. sanguinolentus of Java and $O$. consanguineus of Sumnatra. The reflexion of the upper plumage has more of a green gloss than in either of the allied 
speeies, and it differs in the amount of red on the primary-coverts, the three species being easily distinguishable as follows:-

a. Primary-coverts entirely erimson . . . . . . . . . . . . . . . consanguineus.

b. Primary-coverts only partially orimson.

$a^{1}$. Outer primary-coverts entirely black; inner ones broadly edged with orimson . sanguinolentus.

6. Outer primary-coverts uarrowly fringed with dull crimson; inner ones eutirely

black . . . . . . . . . . . . . . . . . . . . vulneratus.

The young bird merely differs from the adult in being altogether duller black, with mueh less gloss. The breast-patch is very small, and the primary-eoverts have ouly a slight reddish tinge at the end.

[This Oriole was only met with on Kina Balu, and first made its appearance at an altitude of about 3000 feet. It frequents only the higher trees and never leaves the forest. The nesting-season is apparently in February, as the females, shot during that mouth had well-developed eggs in the ovaries, and a full-grown fledgling was proourod early in Maroh. Adults had tho bill whitish eobalt, darker blue at the base ; foet darker blue, the soles yellowish.]

35. Chibia borntimasis, Sharpe.

\section{Family Dicrurid}

$a, b, c . f$ ad. Kina Baln, Jan. 1888.

d. $\delta$ ad. Kina Balu, March 20, 1887.

$e, f \cdot \delta$ ad. Kina Balu, April 1888.

$g, h$. + juv. Kina Balu, April 1888 .

[The iris is lake, bill and feet black. Like its relation Buchanga stigmatops, this Drongo prefers the neighbourhood of clearings made by man, where no doubt the food-supply is greater than in the thick forest. It frequents, however, the more open places in the latter up to about 5000 feet. I found several nests near the Dusun " campongs" containing two eggs, which were of a vory pale salmon-pink, dotted all over with reddish spots and underlying grey spots and mottlings, chiefly eollected near the larger cnd. Length 1.1-1.15 in., diam. 0.8-0.85. One nest was taken on the 20th of March, 1888, and another on the 20th of May. After the mauner of Drongos the nest is plaeed at the end of a long bough at no great height from the ground; it is a shallow structure, consisting of roots neatly twisted rounded the fork of a slender bough. Dusun name "Limbas."]

36. BuChaNGa stigmatops, Sharpe.

[Dusun name "Mansaluium." Iris lake ; bill and feet black. This bird is apparently eoufined to Kina Balu, but is not found much above 3000 feet. Like Ianthocincla treacheri it is one of the ornithological features of the lower slopes of the mountain, being mueh more plentiful about the Dusun villages and riee-fields than in the thick forest. Like the other speoies of this genus which have come under my notice iu other countries, it is pugnaeious in the extreme, attacking even big birds of prey like Spilomis bacha, if they approaeh too near the Drongo's quarters. It has a wonderful power of ehanging its notes in imitatiou of those of other speeics, and I have often heard them ealling out at night. At one of my eamps a pair had a nest at the end of a very long bough in a high tree, whioh, again, overhung a steep river-bank. The nest contained two eggs on the 4th of April, which, as far as I could see, were white, but all our attempts to reach them were in vain. This Drougo takes up its position on the edget of a small wood, and thenee makes short flights after inseets, often returning to the same spot.]

37. Disseyurus brachiphorus (Bp.).

[Frequents the lower boughs of the high jungle-trees. It has a wonderful bell-like note. Does not aseend Kina Balu.]

38. Tephrodoryis gularis (Raffl.). Family Prionopid e.

[6 ad.: iris brownish yellow; feet sealy browu; bili blaek. $q$ ad.: iris yellowish green. The young have the eye dark hazel. 
I first mct with this bird on Kina Balu, at about 3000 feet, where it was somewhat scarce, but I never saw it higher up the mountain. It is fond of sitting about in open places, hawking for insects, but it is also sometimes observed hopping about in the high trees. The young seem to be two in number:]

39. Hemipus obscurus (Horsf.).

[This is evidently a bird of the low country, but it ascends Kina Balu to a height of 1000 feet. Above that altitude its place is almost immediately taken by the next species. I found it in Malacca and again in Java, but in neither locality at any great height. Iris brown ; feet brownish black; bill black.]

40. Hemipus picatus, Sykes.

This species is new to Borneo, and on comparison with Tenasserim and Himalayan specimens, $I$ an unable to find the slightest variation.

[Iris, bill, and feet black. Found on Kina Balu from 3000 to 4000 feet, frequenting the lower growth in search of food. This is a difficult bird to preserve, the skin being so tender. It is not a Flycatcher in its habits, but is a thorough Wood-Shrike, like Tephrodornis. I noticed them in small familics of four or five together; they were not met with above 4000 feet altitude. 7

41. Platylophes coronatus (Raff.).

[I have met with this bird only in the low growth of the forests, as high as 3000 feet on Kina Balu. I also procured it at Benkoka.]

\section{Suborder TURDIFORMES.}

\section{Family Campophagide. .}

42. Graucalus rormani, sp. m., Sharpe.

Adult male. General colour above dark slate-grey; wing-corerts like the back, the greater coverts lighter and more ashy; bastard-wing black; primary-covcrts and quills black, edged externally with slate-grey; the inner secondaries externally cntirely pale ash-grey, like the greater coverts; upper tail-coverts like the back; tail-feathcrs black, edged with slate-grey, the two centre feathers dull grey for two-thirds of their length, the outer ones tipped with ashy; crown of head dark slatc-grey, a little dceper in shade than the back ; forehead, eyebrow, sides of crown, ear-coverts, cheeks, and throat glossy blue-black, shading off into slate-colour on the fore neck ; remainder of under surface of body dark slategrcy, likc the back ; thighs, under tail-coverts, under wing-coverts, and axillaries like the breast; quills below dusky, light ashy along the inner web. Total length $10 \cdot 4$ inches, culmen 1 , wing $5 \cdot 9$, tail $4 \cdot 1$, tarsus 1.

Adult female. Similar to the male, but without any black on the forehead or throat; the lores, feathers round the cyc, sides of face, and car-coverts glossy black. Total length 10 inches, culmen 0.95 , wing $5 \cdot 55$, tail 4 , tarsus 0.9 .

The young bird is like the female, but with remains of ashy whitish edges to the feathers of the abdomen, whilc the under tail-coverts and under wing-coverts are barred with white. The female is rery closely allicd to Artamides concretus of Java, but the latter has an evident white quill-lining. Its nearest ally is doubtless A. melanocephalus (Salvadori), from Mount Singalan in Sumatra.

[Apparently the only species found on Kina Balu, as A. sumatrensis was not met with. It is found between 3000 and 5000 feet, frequenting the old forest, but it is by no means a common bird anywhere. Bill, feet, and iris black.]

\section{Artamides sumatrensis (S. Müll.).}

[Iris straw-ycllow; bill and feet black, the soles of the latter yellow. The only place that I met with this species in Borneo was in Benkoka, where I found a few individuals, always flying very highl ; indeed it was some time beforc I succeeded in getting specimens, all of which were shot from very high trees.] 


\section{CHLAMYdoch खRA, gen. $n$.}

Chlamydochara, generi "Edoliisoma" dicto maxime affinis, sed primario primo abbreviato et pieturâ insignissimâ et insolitâ faeile distinguenda.

44. Chlamydoch жra Jefferyi, sp. n., Sharpe.

Adult male. General colour above dark French grey; wing-coverts like the back, the greater series rather paler externally, with eoneealed black bases; bastard-wing blaek, externally grey near the base; primary-coverts and quills blaek, with a eoneealed grey speeulum near the base of the outer webs of the primaries; inner seeondaries Freneh grey, like the baek, with a conspienous blaek pateh on the inner web; upper tail-coverts like the baek; eentre tail-feathers Freneh grey, witl a narrow white tip, before which is a subterminal band of blaek; remainder of feathers black tipped with white, inereasing in extent towards the outer one, all more or less grey towards the base; crown of head paler Freneh grey, the forehead ochreous buff, a wash of whieh colour pervades the crown; lores and a broad eyebrow blaek, eontinued along the sides of the erown and joining on the nape; eyelid blaek in front, white on the lower edge; ear-eoverts and sides of faee ochreous buff, as well as the cheeks and throat, paler on the hinder part of the ear-eoverts, and on the sides of the neek inelining to buffy grey; fore neek and ehest blaek, forming a large plastron; the feathers of the lower throat white tipped with black, the white forming an indistinct eollar ; remainder of under surfaee of body light Freneh grey, washed with oehreous buff, espeeially towards the lower abdomen and vent; thighs dark grey; under tril-eoverts pale oehreous buff, with grey bases; under wing-eoverts grey, washed with ochre ; axillaries dark slate-grey, the long ones tipped with white; quills below black, with large white spots near the base of the imner web. Total length 9 inches, eulmen $0 \cdot 75$, wing $4 \cdot 5$, tail $3 \cdot 7$; tarsus $1 \cdot 05$.

The adult female differs in being brown above, washed with ashy grey, the inner seeondaries and the centre tail-feathers reddish brown, instead of grey, the marking being the same. There is less grey on the head, which is nearly all ochreous buff, with a grey tinge towards the nape; the reddish oehre-eolour on the sides of the face and throat is rieher than in the male. The under surface of the body is deep oehreous brown where the male is grey. Total length 8.7 inehes, culmen 0.75 , wing $4 \cdot 2$, tail 3.35 , tarsus 1.

I have named this speeies after Mr. Jeffery Whitehead, the traveller's father, by whose aid and eneouragement Mr. John Whitehead has been enabled to earry out his ornithologieal expeditions.

The males scarcely vary at all in tint, but some are rather greyer towards the nape than others, and the throat is a little deeper buff in some individuals. In my description of the female I have not noticed the grey at the base of the primaries, whieh forms a very distinet small speeulum. There is a slight differenee in the richness of the buff of the throat, and the back is browner in some specimens.

Young males have the seeondaries edged with white at the ends, and the blaek spots are very small. The wing-coverts are also tipped with oehreous-buff spots.

[Found on my first expedition at about 3000 feet, and they were, so far as we observed, always feeding on berries. On my seeond aseent I found the speeies as high as 8000 feet; it is strietly a forest bird, and deeidedly loeal. Iris light reddish brown; bill blaek ; feet darkish brown.]

45. Pericrocotus igneds, Blyth.

[This speeies is more plentiful where the Casuarina trees, whieh generally skirt the shores, are found. Iris, bill, and feet black.]

46. Pericrocotus xanthogaster (Raff.).

[Noticed only between 3000 and 4000 feet on Kina Balu, in eompany with $P$. cinereigula. Both these birds were seen together, hopping about among the higher branches of a speeies of pine, often making flights to the other side of the deep gorges.]

47. Pericrocotus cinereigula, sp. n., Sharpe.

When Mr. Whitchead first sent an example of this species home, I determined it as $P$. montanus of 
Salvadori. One young male is in the adult female plumage, and agrees so well with the description of Count Salvadori's P. montanus, that I did not hesitate to call it by that name. I must confess that I now describe the species as new with great diffidence, but I see no alternative. I propose to restrict the name montanus, so far as Borneo is concerned, to the bird of the higher portion of Kina Balu, as it is more likely to be the same as the species from high Sumatra than is the bird of the lower level. It will, however, be impossible to determine the question until the male of the true $P$. montanus is known.

The diagnosis of $P$. cinereigula is as follows :-

Similis $P$. montano, sed gutture et regione parotica cineraceis nec nigris distinguendus. Long. tot. $6 \cdot 8$, culmin. $0 \cdot 5$, alo $3 \cdot 1$, caudx $3 \cdot 5$, tarsi 0.55 .

It will thus be seen that the only difference between $P$. cinereigula and $P$. montanus lies in the ashy-grey throat and ear-coverts of the former, and it might be thought that $P$. cinereigula was only a male of $P$. montanus in an intermediate stage of plumage. Luckily, however, we know that, in the genus Pericrocotus, when the young males moult from the first female-like dress they pass at once to the full plumage of the male, and assume the black throat straight off. As in every respect the type of $P$. cinereigula is fully adult, and perfectly black and red in other parts of the plumage, there is no reason to suppose that the bird is otherwise than in full dress. It will be seen, also, that the elevations inhabited by the two species are quite different.

[Iris dark hazel; bill and feet black. I shot this bird along with specimens of $P$. xanthogaster. The two species were mingled togetber in flocks, and it was only on picking up the birds that I discovered that there were two kinds. It was not seen above 3000 feet.]

48. Pericrocotus montanus, Salvad.

[Iris, bill, and fect black. All the males are exactly alike, with black throats, and this is the only Pericrocotus on the higher parts of the mountain. I only met with it at about 8000 feet.]

49. Lalage culminata (Hay).

[Iris dark brown ; bill black; feet black in the males, greyish in the females. Met with on Kina Balu at 3000 feet, but not seen at a greater altitude. I have also noticed the species in the lowlands of Northern Borneo.]

50. Lalage terat (Bodd.).

[Collects together in large flocks towards evening in Labuan, roosting in the mango-trees. The note is a kind of chipping sound, like that of a Ficldfare.]

\section{Family Muscicapid 玉.}

51. HeMithelidon Cinereiceps, sp. n., Sharpe.

Adult male. General colour above reddish brown, inclining to clear chestnut on the lower baek, rump, and upper tail-coverts ; lesser wing-coverts dusky black, edged with the same colour as the back; median and grcater coverts blackish, edged with pale chestnut; bastard-wing, primary-coverts, and quills blackish, the first primary and inner secondarics edged with pale chestnut ; tail-feathers dusky brown, with a good deal of chestnut on the inner wchs of all but the two centre ones, increasing towards the outer featlers, which arc all but entirely chestnut, with a little dusky brown at the ends; orown of head and lind neck dark ashy grey ; lores whitish with a tarny tinge ; eyelid conspieuously white ; ear-coverts, sides of face, and cheeks dark ashy brown, with a rufous tinge, the ear-coverts streaked with fulvous shaftlines; throat entirely white; sides of neck ashy grey; fore neck and under surfice of body clear tawny rufous, more dingy on the fore neck and breast, the sides of the latter rufous brown; lower abdomen pure white ; sides of body and flanks, thighs, and under tail-coverts clear kright tawny rufous; under wingcoverts and axillaries dark rufous brown, the lower ones and the edge of the wing clear tawny; quills below dusky, rufous along the inncr edge. Total length 5 inches, culmen $0 \cdot 45$, wing $2 \cdot 7$, tail $1 \cdot 9$, tarsus $0 \cdot 5$.

This new species differs from $I I$. ferruginea in having the crown and sides of face diurk ashy grey.

[Iris black; bill black; feet dark brown. This species was decidedly rare on Kina Balu, and on 
my first ascent I only got one speeimen, while on my seeond expedition I could only obtain a pair. I did not see it above 3000 feet.]

52. Alseonax latirostris (Raffl.).

[Found at 3000 feet on Kina Balu. I also met with it in Malacca in December and again in Labuan in the same month. It is probably only a visitor in the N.W. monsoon.]

53. Poliomyias lutella (Pall.).

[Evidently only a visitant in Northern Borneo. I first saw it on Kina Balu on the 20th of March, on nyy first expedition, and on my second ascent I met with the species almost on the same day of the month. On loth occasions it was seen at about 3000 feet altitude, and was not observed higher up the mountain.]

54. Muscicapula hyperythra (Blyth).

Apparently identical with Himalayan specimens. New to Borneo.

[Bill blaek; iris black; legs dirty white. This small Flycatcher is fairly plentiful between 4000 and 8000 fcet on Kina Balu, though I did not meet with it on my first expedition. The nest is a neat little moss-lined eup ; it is generally placed, with considerable talent for conccalment, right in the loose moss which grows along the trees in profusion. In structure the nestitself is so exactly similar to the mass of moss in which it is placed as almost to escape observation, the entrance being merely a small hole in the side of the overhauging moss. On the 22nd of March I found a nest with two white eggs, the latter so hard-set as to be ineapable of preservation. I met with the species in Java at about 5000 feet.]

55. Muscicapula macllata (nce Tiek.).

New to Borneo.

[Bill, feet, and iris black. One of my hunters discovered a pair engaged in building a nest, and on the 25th of March he again visited the nesting-place. The nest was placed in a creeper in the big forest, at about 40 feet from the ground; it was quite a small pile of moss, deep, and lined with fine white roots, a very pretty bit of work, and eontained one small fawn-coloured egg. The bird would probably have laid two eggs, after the manner of most species in these latitudcs. This species ranges from 4000 to $\Omega 000$ feet.

I cannot agree with Dr. Sharpe in ealling this species M. westermanni, so I lave altered the name in the 'Ibis' paper to M. maculata. The females of this species are mueh greyer in the Malay Peninsula. Manipur speeimens seem intermediate, being greyer than those from Sikkim, but not so dark as those from Borneo. A Javanese bird in my collection is much browner than those from Kina Balu, more like Sikkim specimens. In my opinion it would be impossible to determine the geographical linit of M. vestermanni, the males of both species being identical.]

56. Xanthopygia narcissina (Temm.).

New to Borneo. A young male has the orange throat of the adult, but is brown on the back and wings, the latter just showing the white wing-patch. The head and feet are black, and the yellow eyebrow is well developed.

[I first, met with this bird on the Lawas River, but the skin was too much dannaged for preservation. The two which I got on Kina Balu were also extremely fat and difficult to preserve. They were proeured at about 1000 feet on the mountain, and were evidently bent on migrating northwards.]

57. Xanthopygia cyanomelana (Temm.).

A young inale, procured in March, has nearly completed his moult, but still retains a few feathers of the old brown plumage. The blue is less bright than in the adults, and has a greenish tinge. A female shot in January is mueh browner than the bird of the sane sex killed in March, the latter being decidedly greyish.

[On my first expedition I only proeured a single immature male at about 1000 feet on Kina Balu, but on my second journey this bird was fairly plentiful throughout February and March, at about the 
same elevation. The males procured on the 24th and 26th of March were in most beantiful plumage, and had cvidently assumed their full nuptial dress before flying northwards. They are only winter visitants to Northern Borneo. Iris, bill, and feet black.]

\section{TARSiger hodGsoni (Moore).}

I cannot sec the slightest difference ietween the pair scnt by Mr. Whitehead and a pair collected in Sikkim by Mandelli; and this is the more curious as no one had previously found the species out of the Himalayas, where its range is also very limited, extending merely from Nepal to Sikkim. It has not as yet been met with in Tenasserim, the Malayan Peninsula, or Sumatra, and the reappearance of the species in Borneo is rather surprising.

[I ouly cane across this beautiful species on my first expedition to Kina Balu, when I procured a pair at about 4000 feet elevation. Both sexes had the iris and bill black, and the legs greyish blue.]

59. Нуротнуміs оссірітALis (Vig.).

[I first met with this Flycatcher in Malacca, and in Borneo on the Lawas River, and at Benkoka on the north coast of the island. I found it nesting both on the Padas River on the 12th of June, and in Palawan, and caught the hen bird on both occasions. The nest, however, and the eggs of the Palawan bird are strikingly different from the Bornean ones. On the Padas the nest was situated about five feet from the ground. It is a firmly made little cup, constructed of twigs and lined with fine roots, and was placed in a large plant in the undergrowth. The eggs have the appearance of those of the Garden Warbler of Europe; they are creamy white, blotched and spotted with brown, and have some large underlying spots of grey, chiefly at the larger end.

The nest which I found in Palawan forms a great contrast to the neat little structure of the Padas. It is not only smaller, but is inartistically constructed, in the loosest manner, of fine roots and spiders' webs \&c., but the whole structure was so frail as almost to fall to pieces. The eggs, though somewhat sinilar in type of marking to those of the Padas bird, are different in colour, being of a light salmon-pink, broadly blotched with red, and showing smaller spots of red and grey. The markings are chiefly collected round the larger end, and the eggs more resemble those of the Common Flycatcher of Europe.

I procured this species on Kina Balu, up to a height of 1000 feet.]

60. Rhipidura albicollis (Vieill.).

Apparently quite the same as specimens from Tenasserim. The female is only a little greyer than the male, and is not quite so dcep a black, but there is really very little difference in the sexes.

[Iris, bill, and feet black. Met with on the first expedition at 4000 feet, and again on the second ascent at the same elevation. It ascends Kina Balu to quite 9000 feet; this species, unlike $R$. javanica, frequents thick forest, and does not approach the haunts of man.]

61. Rhipidura perlata (S. Müll.).

[Apparently rare. I only net with it on one occasion.]

62. Rhipidura javanica (Sparmm.).

[This Fantail is common in Labuan, appearing in all the native clearings and often entering the verandahs of the houses in search of insects. It loves to frequent the lower boughs of trees, often settling on the ground, where it expands its fan-like tail and droops its wings. It is altogether a very graceful little bird. Its note is a four-syllabled squeaking cry of 'Kip-kip-pě-wheeek,' with the accent on the last syllable.

Whilst going up the Lawas River in a boat, I often got the men to row close to the 'Nipa ' palms, which line both sides of the tide-ways of these tropical rivers, and I found several nests of this Flycatcher perched on the sunmit of the broken stems of the dead palms. Eggs taken on the Lawas on the 8th of April, 1886, agrce with the description given by Mr. Sharpe (P. Z. S. 1879, p. 337) ; but the grey spots are more collected round the middle of the egg.] 
63. Terpsirhone affinis (Blyth).

[Mct with in the low country, not seen on Kina Balu.]

64. Philentoma pyrrhopterum (T.).

[Shot in the old jungle near the ground.]

65. Rhinomyias RUficrissa, sp. n., Sharpe.

Adult male. General colour above ruddy brown, more clearly rufescent towards the lower back and rump; lesser and median coverts like the back; greater coverts, bastard-wing, primary-coverts, and quills dusky brown, edged with ruddy brown like the back; the secondaries externally reddish brown, the innermost with indistinct dusky cross bars ; upper tail-coverts and tail-feathers rufous, more distinetly chestnut on the margins ; crown of head rather more olive-browu than the back; lores dull whitish, with an asliy shade above them ; feathers round eye and ear-coverts brown, rather more ashy near the cheeks, which are dull ashy; throat white; sides of neck brown; fore neck, breast, sides of body, and flanks ashy grey, the latter washed with brown ; abdomen white ; thighs browu ; under tail-coverts pale rufous; under wing-coverts and axillaries pale brown, with ashy bases ; quills below dusky, pale tawuy along the inner edge. Total length 6 inches, culmen $0 \cdot 65$, wing $3 \cdot 05$, tail $2 \cdot 2$, tarsus $0 \cdot 65$.

Adult female. Not different from the male. Total length $5 \cdot 6$ inches, culmen $0 \cdot 65$, wing $2 \cdot 8$, tail $2 \cdot 1$, tarsus $0 \cdot 6$.

Differs from $R$. ruficauda in having olive-browu ear-coverts, brown axillaries and under wingcoverts, and espccially iu its rufesceut (not white) under tail-coverts.

The specimens brought back by Mr. Whitehead on his second journey agrec with the types. The species is very close to $R$. muficauda of Basilan.

[Iris dark browu; bill black; feet whitish cobalt. This species seems to be very local, and I only uet with it in one spot. It was first procured on my asceut of Kina Balu, at a height of about 3000 feet, and on my second jouruey I came across it in the sanc locality. It is a Flycatcher in its habits, frequeuting the lower branches of the high trees.]

66. Rhiтomyias Pectoralis (Salvad.).

[A bird of the low country, but I found it on Kina Balu up to 1000 feet. Here it was nesting, and I obtained a female with the nest and eggs. The nest is a neat cup-shaped strueture of moss and small sticks. The eggs are like small specimens of those of the European Robiu. Wheu fresh they had a bluish tinge which has now faded, and the ground-colour is brownish white thickly clouded all over with faint spots of reddish brown. Length $0.7 \mathrm{in}$, diam. 0.55 . Iris aud bill black; feet flesh-colour.]

67. Rhinomyias gularis, sp. u., Sharpe.

Adult male. Geueral colour above dark ochraceous browu of a russet tint; upper tail-coverts more rufous brown; wing-coverts like the back, the median and greater coverts dusky, edged with the same colour as the back; bastard-wing, primary-coverts, and quills dusky brown, edged with rufous browu, the inuer secondaries with dusky cross-bars under certain lights; tail-feathers blackish, exterually rufous brown, the centre ones with dusky cross-bars under certain lights; crown of head like the back, but a little more dingy towards the forehead; lores dusky, surmounted by a white streak passing into an eyebrow of dull ashy gey; feathers round eye, sides of face, ear-coverts, and cheeks reddish brown; the chin and sides of tlroat a little more dusky; throat ereauny white ; sides of neck like the mautle ; fore neck aud chest ashy olive, slightly washed with ochreous browu; breast light ashy grey, paler towards the abdomen, which is white; sides of body, flanks, and thighs dull ashy, washed with ochreous brown ; under tail-coverts pale fawn-buff; under wing-coverts aud axillaries dull ashy, with whitish edges; quills below dusky, ashy fulvous along tho inner edge. Total length $5 \cdot 9$ inches, culmen $0 \cdot 7$, wing $3 \cdot 4$, tail $2 \cdot 3$, tarsus $0 \cdot 95$.

Female (immature). Like the male, but with tawny-rufous tips to the greater wing-coverts and 
upper tail-coverts; the throat purer white, and the abdomen with a few dusky tips to some of the white feathers. Total length $5 \cdot 8$ inches, culmen $0 \cdot 7$, wing 3 , tail $2 \cdot 2$, tarsus $0 \cdot 9$.

The large size of this species, its ashy-grey flanks and breast, distinct ashy eyebrow and rufous earcoverts, all easily distinguish it from its nearest ally, $R \cdot$. pectoralis.

An adult female procured by Mr. Whitehead on 29 th of January has the lower abdomen, vent, and under tail-corcrts rufescent. It is also rather more rufous brown above than the adult male, and has the head above rufous brown; the chin is likewise more rufescent. Wing 3.35 inches.

The young bird has the appearance of a young Robin, being mottled all over with orange-rufous spots on the upper surface, taking the character of longitudinal streaks on the head and mantle. The wing-coverts have also orange-rufous spots at the ends. The throat and abdomen are white, and the rest of the under surface from the fore neck downwards is thickly mottled with pale orange rufous and black, the feathers being of the former colour in the centre and edged with black.

[Bill black; legs whitish blue; iris hazel. Found on Kina Balu from 3000 to 7000 feet, but more plentiful at higher clevations. I procured a nest and eggs on the 11 th of March at about 3000 feet on the mountain. The nest was cntirely composed of moss, with a few small sticks outside, and a few dead leaves; inside it was lined with roots and red fibres.

The eggs are pale olive greenish, clouded with reddish spots all orcr, collected somewhat at the larger end, where they form a distinct zone. Length $0.95 \mathrm{in}$., diam. $0 \cdot 65$.]

68. Culicicapa ceylonensis (Siw.).

[On Kina Balu this species is found up to 3000 feet, but does not ascend the mountain to a higher elevation. Close to one of my camps a pair had a nest in a long dangling piece of moss. It was a simple pocket in the moss itself.

The eggs are very pretty, somewhat like those of our English Lesser Whitethroat, being glossy white, plentifully spotted with brown and blotched with underlying grey mottling, principally towards the larger end. Lengtlı 0.6 in., diam. 0.5. The nest also contained an egg of Hierococcyx fugur, which will be described later on.]

69. Cryptolopha trivirgata (Strickl.).

A very curious fature is noticed in the series of this bird, the majority of specinncns bcing dark greyish green, with a grecnish-grey stripe along the hcad, and the sides of the face of a pale greenish grey; the under surface of the body is white, with a wash of yellow, the sides greener. This is the prevailing tint of the wholc set of specimens, and at first sight they would seem to be quite distinct from the true C.trivirgata of Java; but mixed with these greyish birds are one or two yellow birds of the Javan type; thesc occur at the same place and along with the ordinary grey birds, so that no definitc character can be drawn from these variations in plumage. The yellower hirds may be the young ones.

This species is recorded from Borneo for the first time.

[Iris hlack; bill dark brown ; feet slaty grey; soles yellow. Only met with on Kina Balu mountain betwecn 5000 and 9000 feet. Its habits are very much like those of a Regulus.]

70. Cryptolopha schwaneri (Blyth).

I give a detailed description of a pair of this rare Flycatchcr, the male of which was previously unknown.

Adult male. General colour above dull olive-yellow, a litile brightcr towards the rump; lesscr wingcoverts like the back; median and greater coverts light lrown, edged with pale olive-yellow; bastardwing and primary-coverts light brown, fringed with olive-yellow ; quills brown, the primaries edged with vellow, the sccondaries cxternally yellow, lighter than the back; upper tail-coverts brighter yellow than the back; tail-featliers brown, edged with dull olive-yellow, the inner webs conspicuously pale tawny buff along the margins of all but the centre feathers; crown of head dull ashy, washed with olive towards the nape ; lores dull ashy, surmounted by a narrow white eyebrow, running from the base of the nostrils 
to the sides of the occiput ; feathers round eye whitish; ear-coverts light ashy grey, with a slight wash of olive-yellow; cheeks also ashy, white on the fore part; throat also white, tinged with yellow towards the fore neck; remainder of under surface of body bright yellow; a little more olive on the sides of the upper breast; thighs and under tail-coverts also bright yellow; under wing-coverts and axillaries yellow, with white hases; quills below dusky, light tawny along the inner edge. Total length $4 \cdot 1$ inches, culmen $0 \cdot 45$, wing $2 \cdot 15$, tail $1 \cdot 75$, tarsus $0 \cdot 7$.

Adult female. Similar to the male in plumage. Total lengtl 4 inches, culmen $0 \cdot 45$, wing $1 \cdot 9$, tail $1 \cdot 5$, tarsus $0 \cdot 65$.

All Mr. Whitehead's specimens are similar.

[Inhabits the tangled bamboo-jungle on the steep sides of Kina Balu, at an elevation of from 3000 to 5000 feet. It has a very pleasing song, and creeps about with very much the habits of a Willow Warbler. Iris black; bill black ; feet dull greenish brown.]

71. Cryptolopha moxtis, sp. n., Sharpe.

Adult male. General colour above dull olive-green, a little more yellow on the lower wings and upper tail-coverts, the latter being olive-green with yellow tips; lesser wing-coverts blackish, with dull olive-yellow ends; median and greater coverts blackish, edged with olive-green and tipped with yellow, forming a double wing-bar, the second one rather yellowish white; bastard-wing, primary-coverts, and quills blackish, edged with olive-green, rather more yellow on the margins of the primaries; tail-feathers dusky asly brown, edged with olive-green, with a narrow whitish tip to the outer ones; crown of head, occiput, and nape chestnut, extending on to the hind neck; sides of crown also chestnut, with a broad band of black running down the crown from above the eye to the sides of the neck; lores yellowish; eyelid white ; ear-coverts and sides of face chestnut; cheeks bright yellow, becoming rufous posteriorly ; throat and under surface of body bright yellow, with a wash of rufous on the sides of the upper breast; thighs and under tail-coverts, under wing-coverts, and axillaries bright yellow, the greater series of under wing-coverts with white bases; quills below dusky, ycllowish white along the inner edge. Total length $3 \cdot 6$ inches, culmen $0 \cdot 4$, wing 2 , tail $1 \cdot 5$, tarsus $0 \cdot 65$.

The nearest ally of this species is Cryplolopha custaneiceps; but it is easily recognized by its chestnut ear-coverts and entirely yellow under surface.

The female is exactly like the male in colour, and measures :-Total length $3 \cdot 6$ inches, culmen $0 \cdot 35$, wing $1 \cdot 8$, tail $1 \cdot 45$, tarsus $0 \cdot 65$.

[I first met with this little Flycatcher at 4000 feet, on my first expedition to Kina Balu, when I procured a single specimen. At 8000 feet, where I fell in with it again during my second ascent of the nountain, it was much more plentiful. It has a peculiar habit of hovering below the leaves of the big trees and suddenly flying up and snatching an insect. It is most often met with in the thick bamboo undergrowth.]

72. Stoparola cerviniventris, sp. n., Sharpe.

Adult male. General colour above blue as far as the upper tail-coverts; lesser wing-coverts brighter blue, inclining to cobalt; median and greater coverts blackish, edged with dull cobalt; bastard-wing black, witlı a slight blue edging; primary-coverts and quills black, edged with bright blue, clearer and paler on the outer webs of the immer secondaries; upper tail-coverts black; tail-feathers black, edged witl blue, all but the two centre feathers with broal white bases; crown of head like the back, with a black band across the forehead, this succeeded by a band of silvery cobalt, extending backwards above the eye ; eyelid, and feathers above and round the eye, black; ear-coverts and cheeks deep blue, the latter black anteriorly, as well as the chin ; throat and under surface of body blue, the lower breast washed with hoary whitish edges; abdomen and under tail-coverts light fawn-buff, increasing in deptli of colour on the litter, sides of body and flanks ashy blue, the lower flanks pale fawn-colour ; thighs blue, with whitish margins; under wing-coverts and axillaries pale farm-buff, the edge of the wing blue; quills below dusky, ashy whitish on the imner edge. 
Of the same group as Stoparola indigo of Java and S. muficrissa of Sumatra, but distinguished from both by the rufescent abdomen.

The female is not distinguishable from the male in colour. Total length 5.4 inches, culmen 0.5 , wing $3 \cdot 05$, tail $2 \cdot 15$, tarsus $0 \cdot 65$. This species is extremely close to S. ruficrissa, but is lighter and more verditer-blue, and the under tail-coverts are paler fawn-colour.

Compared with $S$. indigo, the male of $S$. cerviniventris is distinguished by its much darker blue colour, both above and below, especially on the throat, and by the buff colour of the abdonen, which is perfectly constant throughout the series. The females differ even more than the males, that of $S$. indigo being of a very much lighter blue, inclining to greyish cobalt, while the difference in the colour of the abdomen between the two species is maintained quite as strongly as in the males.

The dimensions of the type specimen are as follows:-Total length $5^{\circ} 7$ inches, culmen 0.5 , wing 3 , tail $2 \cdot 15$, tarsus $0 \cdot 65$.

[Only one specimen was collected during the first expedition at about 3000 feet, and the species is decidedly rare at this elevation. On ascending the mountain a second time 1 found it more plentiful at a higher elevation, between 5000 and 8000 feet. It frequents the real forest, and does not come into the open. Iris, bill, and feet black.]

73. Stoparola thalassinoides (Cab.).

[Apparently very rare everywhere, as I only found it on the lower parts of Kina Balu, nowhere above 1000 feet.]

74. Siphia Elegans ('T.).

[A female was procured on Kina Baln at 3000 feet. It was decidedly an uncommon bird at Benkoka.]

75. Siphia banyumas (Horsf.).

[Common cnough all over the lowlands, but I never met with it on Kina Balu.]

76. Locustella ochotensis (Midd.).

\section{Family Turdid e.}

[This bird was obtained for me by one of my collectors close to my camp at 1000 feet elevation. It was probably on its way north at the time.]

77. Phylloscopus xanthodryas, Swinh.

a. 우 ad. Kina Balu, March 15, 1887.

[Obtained at about 1000 feet.]

78. Acrocephalus orientalis ('T. \& S.).

[Evidently a migrant. Inside of mouth bright orange ; legs slaty blue.]

79. Cettia oreophila, sp. n., Sharpe.

Adult male. General colour above dark olive-brown, the wing-coverts like the back, the greater coverts and quills a trifle more russet-brown; tail-feathers brown, externally lighter brown, like the back; crown of head like the back; lores dusky, surmounted by a narrow eyebrow of yellowish buff; eyelid yellowish buff; sides of face and ear-coverts dark olive-brown, washed with ashy; cheeks and under surface of body pale ashy grey, the fore neck and sides of chest washed with brown; abdomen a little whiter ; sides of body and flanks ochreous olive-brown, with silky-white bases to somc of the flankfeathers; thighs more reddish brown; under tail-coverts like the flanks; under wing-coverts and axillaries white, with a tinge of olive-yellow along the bend of the wing; quills below dusky, ashy whitish along the inner edge: "upper mandible dark brown, the lower one yellow at base; legs pale brown ; iris dark brown" (J.W.). Total length $4 \cdot 8$ inches, culmen $0 \cdot 5$, wing $2 \cdot 05$, tail $2 \cdot 2$, tarsus $0 \cdot 95$.

Adult female. Similar to the male, with the grey of the throat very strongly mottled and overspreading the entire breast. Total length 4.8 inches, culmen 0.55 , wing 1.9 , tail 2 , tarsus 0.9 . 
This species resembles Cettia fortipes of the Himalayas, but is easily distinguisherl by its ashy-grey throat and breast. These birds are placed in the genus Cettia by Mr. Seebohm, but they seem to me to belong to at least a distinct subgenus, and, but for the weight of his authority, I should have preferred to call this new species Horornis oreophila.

[It was only when I reached the higher slopes of Kina Balu that I met with this Warbler, which occurs between 7000 and 12,000 feet. It is always found frequenting the thick undergrowth, and it has a fceble song.]

80. Geocichla aurata, sp. n., Sharpe.

$G$. similis $G$. citrince, sed saturatiùs aurantiaca et abdomine subcaudalibusque albis distinctè flavido lavatis clistinguenda. Long. tot. $8 \cdot 3$ poll., culmin. $0 \cdot 85$, ales $4 \cdot 45$, caudø $2 \cdot 9$, tarsi $1 \cdot 4$.

The adult female is exactly like the male. Total length 8 inclies, culmen $0 \cdot 8$, wing $4 \cdot 4$, tail $2 \cdot 75$, tarsus $1 \cdot 35$.

The young hird is duller blue-grey, the bead aud mantle mottled with orange-yellow centres to the feathers, and the wing-coverts with large yellowish-buff spots at their ends; the lores and sides of the face are orange-buff, with a black line from the eye dowu to the hiuder cheeks, and a black patch on the hinder ear-coverts; under surface of body bright orange, the throat whitc, encircled by a black line on fore neck, the breast-feathers mottled with blackish ends; abdomen and under tail-coverts white, with scarcely any yellow tinge. The bill entirely black, without the pale base of $G$. citrinc.

In the depth of the orange-colour on the head and sides of face this species almost equals G. rubecula of Java, but is not so intensely colonred on the body. It is more richly coloured than the ordinary $G$. citrina, but has the abdomen and under tail-coverts white washed with yellow.

[Bill black; legs dirty pinkish white; iris black. It was only when I was on the point of leaving the mountain on my second expedition that I fell in with this Thrush, which I obtained at about 3000 feet elevation. The young were fully fledged by the beginning of May.]

81. Merula seebohmi, sp. n., Sharpe.

Adult male. General colour above, including the wings and tail, black; head, entire sides of face, ear-coverts, checks, throat, and chest black, the latter rather more sooty black; abdomen, breast, and sides of body rich chestuut, the lower abdomen white; flanks, thiglis, and under tail-coverts black, the latter with white centres to the feathers, tiuged with tawny buff; under wing-coverts and axillaries blackish, the latter fringed with whitish at the ends; quills below blackish, a little more ashy along the inner edge. Total length $9 \cdot 6$ inches, culmen $0 \cdot 95$, wing $5 \cdot 2$, tail $4 \cdot 2$, tarsus $1 \cdot 45$.

Female (uot quite adult). Browner than the male, and having the chestuut underparts rather duller. Some pale centres to the wing-coverts make it appear that the specimen is not quite full-plumaged, and the primaries have ashy uargins. Total leugth $9 \cdot 5$ inches, culmen 0.95 , wing $4 \cdot 7$, tail 4 , tarsus 1.35 .

The typical female had a few remains of buff.centres to the wing-coverts, and was described by me as "immature," but it is practically adult. The fully adult female is scarcely to be distinguished from the male and is only a trifle browner. Wing 4 inches. More than one specimen has the abdomen mottled with black feathers edged with buff; but these markings are unaccompanied by other signs of nonage.

The young bird has a dusky bill and is more dingy black than the adults, with deep buff streaks down the back and on the wing-coverts, taking the form of small spots at the end of the greater series ; sides of face and ear-coverts dusky blackish, mottled on the cheeks with rufous; a broad blackish malar streak; throat uniforin rufous buff; rest of under surface deep rufous, whiter on the abdomen, the fore neck nottled with black-spottcd feathers, the sides of the neck uniform black; the black spots less distinct on the breast; under tail-coverts as in the adult female.

[Iris black; bill and feet and riug round the eye king's yellow. This Blacklird was at once recognized by ne as new directly I saw it, for I had already met with 1 . javanica in tho highlauds of 
Java. It was the very first bird to greet me when I reached the height of 8000 feet, and while I was preparing my camp onc came and settled close to ne. In my anxiety to shoot it I got away to a little distance and fired somewhat orer it, so as not to injurc the speeimen too much. I missed it, however, altogether, but instead of flying away it perched in a tree above me, whon I easily secured it. It fell into the mossy and tangled undergrowth, and gave me a long lunt before I picked it up. I was delighted to see how different it was in appearance from its Javan representative, and I afterwards gave great attention to the procuring of further specinens. Altogcther I met with several pairs, and obtained a full-fledged nestling on the 18th of February. I nerer observed this Blackbird below 8000 fect; but it was seen as high as 12,000 feet, and was most plentiful at about 9000 feet. I never heard it sing or utter any particular cry ; but the Jaran Blackbird has very much the habits of its English consin, evcn to the chattering note with which it takes flight.]

82. Merrula obscura (Gim.).

[This bird was plentiful round Kina Balu up to 8000 feet, going in flocks, like Redwings. The note is also somewhat like that of the latter bird. It passes through Labuan every year in considerable numbers during the north-west monsoon.]

83. Erithacus cyaneus (Pall.).

[Shot on the lower hills of Kina Balu at about 1000 feet during my first aseent. It was collected near one of the Dusun villages, but I know nothing of its habits.]

84. Monticola solitaria (P. L. S. Mï̈ll.).

[Apparently a regular winter migrant through Labuan.]

85. Mriophoneus bonneensis, Sclater.

[Frequenting the borders of rocky streams, where it may be noticed most oftcn in the early morning, hopping about on the large rocks, but disappearing at the least alarm into the thick forest. Met witl sparingly from 2000 to 9000 feet on Kina Balu. This bird has a pleasant whistling note, which it utters when perched on the lower boughs of high trces. I saw a nest of this species which was placed in a crevice in some high and precipitous rocks orer a small river, but it was impossible to reach the spot. The nest, I believe, contained young, judging by the frequent visits of the old bird; this was on the 23rd A 1 ril, 1888.

Iris dark brown ; fcet and bill black.]

86. Trichixus pyrrhopygus, Less.

[Bill black; iris black; feet flesh-colour in the adult male.

Only met with in this locality, where it frequented the lower growth in the true forest.]

87. Copsichus amenus (Horsf.).

[This is one of those species that frequent the haunts of man. I have never scen this bird far from the native campongs ; in the early mornings it may often be seen sitting on the tops of houses singing and being answerch by some rival near at hand; the note is pleasing, and the bird is honoured by the name of the "Straits Nightingale." During the heat of the day it frequents the thick fruit-trees and more shady spots; it often settles on the ground, when it raises the tail perpendicularly, in fact orer the back.

Native name "Kaliageau."

Is met with on Kina Balu up to 1000 fect. In the beginning of May I found the eggs. They are threc or four in number, of a pale blue, thickly blotched all over with reddish brown, especially at the larger end, where the blue under surface is entirely covcred. Axis 0.95 inch, diam. 0.65 .

The nest is composed entirely of fine roots, and hidden away amongst the ovcrhanging roots of some tree, or in the branches. I once saw a nest within a few yards of a native's house.] 
88. Cittociscla stricklandi (Motley \& Dillw.).

[One of the commonest forest-species, where it may be met with frequenting the lower growth anl] branches of the high trees. Bill and eye black, feet brown.

Native name "Pleata sungei," i. e. "River Lamp," no doubt from the yellow breast of the birl.]

89. \#atrhina virinissima (Bp.).

\section{Family Prononotide.} bird.]

[This was recorded for the first time from Labuan by Governor Ussher. It is everywhere a scarce

90. ÆGithina viridis (Bp.).

[Very plentiful in Labuan, where it breeds. The egg procured by me differs slightly from that described by Mr. Sharpe. The ground-colour is creamy white, and the spots are nearly absent on the body of the egg, but collect in a zone round the larger end.]

91. Chloropsis zosterops, Vig.

[A common bird in Northern Borneo.]

92. Chloropsis cyanopogon (T.).

93. Chloropsis kivabaluensis, sp. n., Sharpe.

Adult male. General colour above bright grass-green ; lesser wing-coverts bright cobalt-bluc, forming a shoulder-patch; median and greater corerts externally green like the back, blue in the centre of tho feather ; bastard-wing and primary-coverts bright blue, dusky blackish on the inner web; quills black, externally bright blue, the secondaries duller blue on the outer web, which is green like the back, the inner secondaries entirely green; upper tail-coverts like the baek; tail-feathers dull blue, more or less distinctly edged with green; crown of head more yellow than the back, becoming slightly greener towards the nape, which is like the baek; base of forehead bright yellow, extending backwards in a short streak above the eye; lores and feathers below the eye black, extending downwards in a well-defined line, and embracing the anterior half of the ear-eoverts and cheeks; throat also black, this large patch being succeeded by yellow, which skirts the black from the eye across the sides of the face and joins on the fore neck; hinder ear-coverts and hinder cheeks washed with green ; on the fore part of the cheeks a small streak of purplish blue; under surface of the body from the chest downwards lighter and more emerald-green, washed with yellow ; the sides of body, flanks, thighs, and under tail-coverts greener ; under wing-coverts and axillaries pale bluish green, the edge of the wing brightcr blue; quills below blackish, ashy along the imner edge. Total length 7 inches, culmen 0.75 , wing $3 \cdot 65$, tail $2 \cdot 65$, tarsus $0 \cdot 75$.

Compared with five specimens of $C$. viridinucha, this new specics is distinguished at a glance by its yellow instead of emerald-green under surface. The blue on the bastard-wing and primary-coverts is of a different shade, being light cobalt instead of purplish blue.

Adult female. General colour above green ; lesser wing-coverts glossy cobalt-blue, forming a shonlderpatch; median coverts green; greater coverts also green, with lighter olive-green edges: bastardwing and primary-coverts blue; quills black, cxternally cobalt-blue, the secondaries green on their onter edges, the inner ones entirely green like the back; upper tail-coverts like the back ; tail-feathers dull blue, with a greenish margin to most of them ; crown of head emerald-green, a little duller towards the nape ; forehead rather brighter emerald-green ; lores, eyelid, feathers below the eye, fore part of cheeks, and throat black; ear-coverts and hinder cheeks bright emerald-green, skirting the black throat and forming a green collar on the lower throat; remainder of under surface from the forc ncek downwards light greenish yellow; the sides of body and flanks more of a grass-green; thighs and under tail-coverts light grass-green; under wing-coverts and axillaries light bluish green, the edge of the wing blue; quills below dusky blackish, the inner edge ashy grey. Total length 7 inches, culmen 0.7 , wing $3 \cdot 45$, tail $2 \cdot 6$, tarsus $0 \cdot 75$. 
The extent of the bluc monstache of the male varies grcatly, being in some large and broad and in others absent altogether ; it is sometimes quite light blue.

A young male is very like the old.female, but is paler green, and with the emerald-green collar round the black throat less distinct. The lores and a patch near the base of the cheeks are black, but the malar line and the rest of the cheeks are emerald-green, like the sides of the face. This bird was slot on the 10th of May. Another immature male, procured on the 24th of February; has the face black, like the old male, a good deal of yellow on the forehead, and the emerald-green collar has a good many yellow feathcrs intermixed, showing an approach to the mature plumage of the male.

The young female is like the old female, but has the black on the throat more restricted, and has no bright shoulder-patch. The black is confined to the lores and feathers below the eye, and does not extend across the fore part of the cheeks, which are green, like the ear-coverts.

[Iris dark brown ; bill black ; feet scaly green. Met with on my first expedition, froquenting the higher branches of the jungle-trees at altitudes of from 3000 to 4000 feet. My efforts to find this bird in $18 \div 8$ were for months unsuccessful, and I began to fear that I should have to descend the mountain without procuring any more specimens. I was most anxious to obtain some, as I wished to prove conclusively that the birds to which Dr. Slarpe had given separate names were but sexes of one and the same species. I therefore organized a special excursion for the purpose of obtaining a series of specimens, and at about 1800 feet I found the species fairly plentiful, and procured the young birds which Dr. Sharpe admits to have convinced him of the correctness of my original determinations.]

94. Hemixus connectens, sp. n., Sharpe.

Adult male. Gencral colour above earthy brown, slightly washed with olive on the lower back and rump, which are very full-feathered; lesser wing-coverts brown, like the back; median and greatel coverts olive-yellow; bastard-wing and primary-coverts darker brown, slightly washed with olive; quills dark brown, externally washed with olive-yellow, more broadly on the secondaries, the inner ones being entirely of the latter colour ; upper tail-corerts olive-yellow ; tail-feathcrs olive-yellow, browner on the inner web; crown of head crested, brown like the back, the feathers lanceolate and with ashy tips; lores, sides of face, ear-coverts, and cheeks brown; throat whitc; lower throat and fore neck ashy brown, extending over the upper breast; lower breast and abdomen whitc ; sides of body and flanks ashy brown, the latter slightly- washed with olive-yellow ; thighs ashy brown; under tail-coverts clear yellow ; under wing-coverts and axillaries white, with a tinge of yellow; quills below dusky blackish, ashy white along the inner edge, with a tinge of yellow. Total length $7 \cdot 5$ inches, culmcn $0 \cdot 85$, wing $3 \cdot 75$, tail $3 \cdot 1$, tarsus $0 \cdot 65$.

A very distinct species, recalling the general appearance of $H$. cinereus, but having the olive-yellow tail and wings of the $I I$. flarala section of the genus. It is in fact intermediate between the two sections noticed in the 'Catalogue of Birds' (vol. vi. pp. 48, 49).

The female is like the male. Total length 7 inches, culmen $0 \cdot 8$, wing $3 \cdot 5$, tail $2 \cdot 85$, tarsus $0 \cdot 6$. The plumage of the upper surface gets worn to a very pale brown, and some of the specimens procured in February are changing to a dark ashy brown.

[Iris brown; feet and bill black. Found during the first expedition from 3000 to 5000 feet. In 1888 it was met with again at the same level as the Chloropsis. These birds were in small companies, apparently family parties, after the nesting-season, and many of them seemed to be in immature plumagc. Like Criniger ruficrissus, this Bolbul has a peculiar appearance at a distance. It sits with its fluffy throatfeathers puffed out, so much so that my men often thought the bird had a piece of wool in its bill for nesting-purposes, and spared the bird in the hopes of finding its nest.]

95. Hemixus malaccensis (Blyth).

[Legs and bill dark brown ; iris dark reddish brown.]

96. Micropus milanoliucus (Eyton).

[Iris, bill, and fect black.] 
97. Micropus melanocephalus (Gm.).

98. Criniger pheocephalus (Hartl.).

99. Criniger ruficrissus, Sharpe.

[Bill black, lower mandible bluish white; feet pinkish brown; iris light brown. On Kina Balu, to which mountain this spccies appears to be eonfined, it is only found in the lower valleys at about 3000 feet, among the tropical forest-growth. It is generally seen searching about high up in the trecs, and las a loud disagreeable note, but at times whistles prettily.]

100. Tricholestes Criviger (Blyth).

101. Trachycomus ochrocephalus (Gm.).

[This bird ascends Kina Balu to about 1000 feet.]

102. Picnonotus analis (Horsf.).

[One of the commoner birds of the Malayan region. It ascends Kina Balu only to about 1000 feet. These Bulbuls are seen in Labuan towards evening in swarms going through the mango-trees, where they roost in large flocks; at this time they are very noisy. They are eommon enough also on Kina Balu at a low elevation, and I have known a Dusun boy to go out of an evening and eateh three or four with his "gutta" stick. It nests on the mountain.

The eggs are of the usual Bulbul type, with the ground-colour pinkish white, thickly mottled with red spots and underlying grey markings. The shape varies a good deal. Axis $0 \cdot 83-1 \cdot 0$ inch, diam. $0 \cdot 65-0 \cdot 7$.]

103. Pychonotus simplex, Less.

[Ascends Kina Balu up to about 1000 or 1500 feet. I also shot one in Malaeea, which had a white iris, like the specimen figurcd by Dr. Sharpe in the 'Catalogue of Birds.']

104. Rubigula Montis, Sharpe.

[Iris dark brown; bill and feet blaek. Only met with on Kina Balu at 3000 feet, frequenting the rough growth which springs up on the old rice-fields. It is deeidedly scarce.]

\section{Oreoctistes * gen. $n$.}

Genus simile generi "Kelaartia" dicto, sed rostro breviore et crassiore, caudâ magis roundatâ, et fasciis auricularibus absentibus disting uendum.

The type is

105. OREOCTISTES LeUCOPS, sp. n., Sharpe.

Adult male. General colour above dull olive-greenish, the feathers dusky in the centre, with olive margins; wing-coverts like the back; bastard-wing, primary-coverts, and quills dusky brown, edged with rather lighter olive-yellow, particularly the primaries, the inner secondaries resembling the wingcoverts ; tail-feathers blackish, extcrnally olive-yellowish, the ends narrowly fringed with wbity brown; crown of head dusky, the fcathers edged with dark ashy, produeing a scaled appearance, many of then, on the nape especially, washed with olive-yellowish; eentre of forehcad like the head ; lores, eyebrow, feather's round eye, sides of face, cheeks, and throat white, the hinder ear-coverts and hinder part of eyebrow light carthy brown ; lower throat, forc ncck, and chest light ashy brown, some of the feathers edged with pale olive-yellow, the sides darker brown; breast and abdomen white, with a slight tinge of yellow ; sides of body, flanks, and thighs dark brown, with an olive tinge; vent and under tail-eoverts bright yellow; under wing-coverts and axillaries white tinged with yellow; edge of wing bright ycllow ; quills below dusky, ashy fulvous along the inner edge : "bill, feet, and iris black" (J.W.). Total length $7 \cdot 3$ inches, eulmen $0 \cdot 55$, wing $3 \cdot 45$, tail $3 \cdot 45$, tarsus $0 \cdot 85$.

Adult female. Exactly like the male, but the ashy colour on the chest not quite so sharply emphasized. Total length $7 \cdot 5$ incles, culmen $0 \cdot 6$, wing $3 \cdot 3$, tail $3 \cdot 4$, tarsus $0 \cdot 75$.

\footnotetext{
* öos, mons; кrírīs, colonus.
} 
The genus is close to Kelaartia of Ceylon, but has no aurieular tufts, a more rounded tail, and a very peculiar short bill.

[Iris, bill, and feet blaek. It was only met with at a great altitude on Kina Balu, and is apparently rery loeal. I found it between 7000 and 8000 feet, and it was mostly seen near the latter elevation. It frequented the scrub in parties of two and three.]

106. Irena crintgera, Sharpe.

[Eound on Kina Balu up to 1000 feet.]

\section{Family Hexicuride.}

107. Henicurus borneensis, sp. n., Sharpe.

ơ. Similis $H$. sinensi; plagâ frontali albâ, rotundatâ; rectricibus apiealiter maculatis, sicut in H. leschenaulti notatis; supracaudalibus et subcaudalibus cervino lavatis. Long. tot. 9.5 poll. Angl., culm. 0.9, alæe $4 \cdot 0$, caudæ $4 \cdot 95$, tars. $1 \cdot 2$.

o mari similis. Long. tot. $8 \cdot 8$ poll. Angl., culm. $0 \cdot 9$, alæ $4 \cdot 0$, eaudæ $4 \cdot 5$, tars. $1 \cdot 1$.

[Frequents the rocky beds of the mountain-torrents, seeming to prefer the deep gorges, where little or no sunlight enters. This species is rather difficult to obtain, being very shy, and flying out of shot, or more often out of sight, into the forests which border the streams. The note is a pleasant whistle, which is always uttered when the bird is alarmed, before taking flight. I have seen three or four flying after each other up these dark gorges, and the tail seems more like a streamer, waving up and down with every motion of the bird. It is fairly plentiful on some of the many streams which come down from Kina Balu, from 1000 to 3000 or 4000 feet; but on others, which were apparently too broad and open, I did not notice the bird.

Eye and bill black ; legs and claws white.]

108. Hydrocichla Frontalis, Blyth.

[This species is apparently a lowland representative of the last, agreeing in habits; but those I shot frequented a deep muddy ditch in the tideway of a river not far from the eoast, and were very wary, requiring a great deal of work to bring them to bag.

Eye and bill black; legs and elaws white.]

\section{Family Timelitd 2.}

109. Burnesia superciliaris (Salvad.).

[Iris light hazel; bill black; feet light yellow in adult male. In the young the bill and fcet are light yellow and the iris light brown.

Met with in the lalang plains and other open places. This little bird makes a very andible snipping noise with its wings when making its short flights from onc bush to another. The nest is a round structure, placed well off the ground amongst the stems of enarse grass or fcrns; it is composed of grasses, lined witl the same matcrial, and entered from a hole in the side. Eggs three, of bright terracotta red, slightly deeper at the larger end ; laid about the middle of May. Axis $0 \cdot 6$ inch, diam. 0.45.$]$

110. Олтнотомus RUficeps (Less.).

[One of the omen-birds (or angī) of the Teutongs. Only proeured on my first ascent of the mountain at a height of 1000 feet.]

111. Orthotonus cineraceus, Blyth.

[These two species of Tailor-birds are similar in their habits, affecting the same localities, and often found in company. They frequent the more open places near the edges of the forest, where they hunt the low growth for their insect food. I met with both speeies up to 1000 feet on Kina Balu.

Native name "Chuk bodo."] 
112. Phyllergates cinereicoldis, sp. n., Sharpe.

$P$. similis $P$. cucullato, sed collo postico et colli lateribus clarè cinereis distinguendus. Long. tot. $4 \cdot 4$, culnin. $0 \cdot 65$, alæ $1 \cdot 85$, cauda $1 \cdot 85$, tarsi $0 \cdot 8$.

Adult male. General colour above olive-green from the mantle to the upper tail-coverts ; lesser wingcoverts like the back; median and greatcr coverts, bastard-wing, primary-coverts, quills, and tail-feathers dusky brown, with olive-green margins ; crown of head orange-rufous to the occiput; the nape washed witl olive-grcen ; hind neck clear ashy grey, like the sides of the neck, and forming a broad collar ; lores blackish, surrounded by a narrow superciliary line, which becomes bright yellow abore the eye and white again above the ear-coverts; sides of face and car-coverts dark ashy grey; cheeks and throat, fore neck, and chest ashy white, becoming purer white on the breast; sides of throat and breast ashy grey; abdomen, entire sides of body, flanks, and under tail-coverts bright yellow; thighs yellow, with dusky bases: under wing-coverts and axillaries yellow; quills beneath dusky, white along the inner edge. Total length $4 \cdot 4$ inches, culmen $0 \cdot 65$, wing $1 \cdot 85$, tail $1 \cdot 85$, tarsus $0 \cdot 8$.

Adult female. Similar to the male. Total length 4 inches, culmen $0 \cdot 6$, wing $1 \cdot 7$, tail $1 \cdot 6$, tarsus $0 \cdot 7$.

[I met with one specimen of this species during $\mathrm{my}^{r}$ first expedition in 1887 in a bamboo-jungle at 4000 feet on Kina Balu, but it was so much destroyed by shot as to be useless for identification. During the next expedition it was found more plentifully in the stretch of old forest close to the foot of the mountain, where it frequented the low growth and large jungle-plants near the ground.

Bill and eye black; legs light brown, paler at the back.]

113. Cranoderisa bicolor (Blyth).

[Fairly common in the low growth in swampy jungle and in old forcst.]

114. Staphidia everetti, sp. n., Sharpe.

Adult male. General colour dull ashy grey, with white shaft-streaks to the feathers of the mantle; lcsser and median coverts brown; greater coverts dusky, externally brown; bastard-wing, primarycoverts, and quills dusky blackish, edged with brown, the inner secondaries entirely brown, with whitish shaft-lines; upper tail-coverts brown, with ashy margins; tail-feathers blackish, edged with brown, the four outer feathers tipped with white, increasing greatly towards the outer one; crown of head and hind neck dull rufous ; lores and eyelid whitc ; ear-corcrts rufous, like the crown ; cheeks, throat, and under surface of body white; sides of neck ashy grey, like the back; a few brown streaks on the cheeks and on the malar line; thighs ashy grey; under tail-coverts, under wing-coverts, and axillaries white; quills below blackish, whitish along the inner cdge. Total length $5 \cdot 2$ inches, culmen $0 \cdot 45$, wing $2 \cdot 5$, tail $2 \cdot 3$, tarsus $0 \cdot 65$.

Adult female. Similar in plumage to the male. Total length 5 inches, culmen $0 \cdot 4$, wing 5 , tail $2 \cdot 2$, tarsus $0 \cdot 65$.

Resembles Staplidia castaneiceps, but differs in its entirely rufous crown and nape, the ashy margins to the frontal feathers of $S$. castaneiceps not being visible in S. everetii.

[Fairly common in the old forest between 3000 and 4000 f'cet on Kina Balu, where they pass from one tree to another in small twittering flocks of frorn six to nearly a dozen individuals. The crest is often raised and the throat puffed out. This Staphidia builds its nest in small holes in the river-banks and in other suitable spots in the forest; it is composed of moss and lined witl fine roots, and contains three eggs, which are white and spotted all over, especially at the larger end, with durk reddish-brown, and may be found about the 13 th March. Axis 0.7 inch, diam. 0.45.

Eye dark brown; bill black; legs brown.]

115. Herporyis Brunnescexs, Sharpe.

[Legs flesh-colour ; bill black, lower mandible flesh-colour ; iris dark brown.

I shot my first sprecimen in a bit of old forest near Sandakan, and did not again meet with this species until years after, when I found it in small companies at an altitude of 5000 feet on Kina Balu.] 


\section{Chlorocharis, gen. $n$.}

Genus simile gencri "Cyanoderma" dicto, sed candâ magis quadratâ nec rotundatâ.

The type is

116. Chlorocharis emiliz, sp. n., Sharpe.

Adult male. General colour above light olive-green, the lesser and median coverts like the back; greater coverts, bastard-wing, primary-coverts, quills, and tail-feather's dusky blackish, edged with the same colour as the back, a little brighter and more olive-yellow on the primary-coverts and quills; crown of head dusky brown, washed with olive-green ; the occiput and nape like the back; base of forehead washed with olive-yellow; lores and feathers above and below the eye black; a distinct eyebrow of oliveyellow ; eyclid black ; sides of face, ear-coverts, and cheeks olive-yellow, rather greener posteriorly, like the sides of the neck ; throat and under surfice of body pale olive-grecn, vellower on the centre of the breast, abdomen, and under tail-coverts ; sides of body, flanks, and thighs light olive-green ; under wingcoverts and axillaries whitish, edged with olive-yellow, the edge of the wing green; quills below dusky, ashy white along the inner edge. Total length $5 \cdot 5$ inches, culmen $0 \cdot 7$, wing $2 \cdot 75$, tail $2 \cdot 1$, tarsus $0 \cdot 85$.

Adult female. Similar to the male. Total length 5 inches, culmen $0 \cdot 7$, wing $2 \cdot 6$, tail $1 \cdot 9$, tarsus 0.9 .

[The first notice I find of this species is in Mr. St. John's book, 'Life in the Forests of the Far East,' where he mentions, during his first expedition to this mountain, that "the Ida'an (Dusuns), during the day, amused themselves in trying to secure some small twittering birds, which looked like Canaries, with a green tint on the edges of their wings, but were unsuccessful. They shot innumerable pellets from their blowpipes, but did not secure one. In fact, they did not appear to use this instrument with any skill." This note was made nearly thirty years ago, and it was only in the beginning of 1888 that the first of these "twittering birds" was sent to this country. I met with this species at from 6000 to 12,000 feet on Kina Balu; it frequents the low trees in small flocks, and is, perhaps, the commonest bird after 7000 feet. I shot a young bird on the 12 th of February which had not long left the nest; it is coloured much the same as the adult, but is less vivid.

Eye hazel; upper mandible brown, nostrils black, lower mandible pale yellowish orange ; feet brown, toes more yellowish, claws brown.]

117. Macronus ptillosus, J. \& S.

[This, though common, is a really beautiful bird. It frequents the low growth in old forest, in the thickest and most cntangled places. Is found only a few hundred feet up on the spurs of Kina Balu. It makcs a large nest, which is hidden away in the thick rank undergrowth. The nest is a loosely constructed ball of dead leaves, lined inwardly with fine roots, and the entrance is often somewhat hidden with fresh green moss stuck in the nest. The eggs are three, and glossy white. The nest was taken on the 17th January. Axis 0.8 inch, diam. 6.6.

The native name is "Konkut Landak" (porcupine). Konkut is the native name of all Timeliine birds ; the name "landak" is applicable to the long white-stemmed feathers which stream from the sides and back.

Bill and feet black; skin round the eye and bare space on the sides of the neck dark French blue. These bare spaces arc also found on the neck of Stachyris maculata, which has also long feathers on the back; so perhaps these gencra are only slightly removed.]

118. Alcippe cinerea, Blyth.

[Found on Kina Balu up to 2000 feet.]

119. Brachypteryx erythrogyna, sp. n. * Sharpe.

Adult male. Entircly dark indigo-blue ; wings black, externally dark indigo; tail-feathers black;

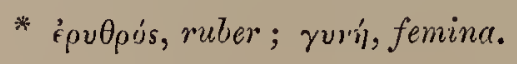


from the base of the forehead to above the eye a lialf-concealed strcak of silky white. Total length $5 \cdot 7$ inches, culmen $0 \cdot 65$, wing $2 \cdot 45$, tail 2 , tarsus $1 \cdot 15$.

Adult female. General colour above indigo or slaty blue, the scapulars like the back; lower back mixed with reddish brown; rump of the latter colour, deepening towards the upper tail-coverts, which arc decp chestnut; lesser wing-coverts like the back, with dull rufous margins; median and greater coverts, bastard-wing, primary-coverts, and quills dusky blackish, edged with deep chestnut, especially distinct on the latter, which appear chestnut; tail-feathers deep chestnut-brown ; crown of head chestnutbrown, more dingy on the hind neck, which is slightly mixed with the blue of the back; forehead, lores, evebrow, sides of face, ear-coverts, cheeks, and under surface of body rich chestnut; sides of body, flanks, thighs, and under tail-coverts rather deeper in colour and more chestnut-brown; under wing-coverts and axillaries deep chestnut; quills below dusky, more ashy along the inner edge. Total lengtl $5 \cdot 3$ inches, culmen $0 \cdot 6$, wing $2 \cdot 4$, tail $1 \cdot 9$, tarsus $1 \cdot 15$.

This species has a certain resemblance to the male of $B$. cruralis, but instead of having a distinct white eyebrow, it has only a half-concealed white mark on the sides of the crown. The female is of course quite different from the hen of any other species of the genus.

A young male in Mr. Whitehead's collection is of a duller blue than the adult male, and not only has the abdomen washed with rufous, but has some rufous feathers on the breast, evidently the remains of the first plumage, which must therefore resemble that of the adult female.

[Frequents the true forest from 4000 to 8000 feet, though very scarce at the lower elevation, owing to the Dusun rat-traps, which have almost exterminated all the small mammals and ground-loving birds. This species, like the little Androphilus, was most difficult to shoot from its extreme tameness, as it often came within a few feet of us, and followed us for several yards through the forest, making it extremely hard to obtain specimens without blowing them to bits. Eye dark brown; feet and bill black.]

120. Orthrocichla whiteheadi, sp. n., Sharpe.

Adult male. General colour above warm chocolate-brown; wing-coverts like the back; bastard-wing and primary-coverts blackish, cxternally edged with chocolate-brown; quills blackish, the primaries externally lighter brown than the back, the secondaries like the latter; tail-feathers blackish, narrowly margined with brown; crown of head blackish brown, as far as the nape; hind neck like the back; a broad eyebrow of tawny buff running from the base of the nostrils to the sides of the hind neck ; sides of face tawny buff below the eye ; lores, feathers round eye, and ear-coverts blackish brown; cheeks and under surface of body pure white; the fore neck and breast mottled with a few ashy margins to the feathers; sides of body, flanks, and thighs ashy brown, more dccidedly dark ashy on the sides of the breast; under tail-coverts lighter brown; under wing-coverts and axillaries blackish, edged with white; quills below blackish, more ashy along the inner edge. Total length 3.3 inches, culnen 0.65 , wing 1.95 , tail $0 \cdot 8$, tarsus $0 \cdot 8$.

Adult female. Similar in colour to the male. Total length 3.3 inches, culmen 0.5 , wing 1.85 , tail $1 \cdot 85$, tarsus $0 \cdot 75$.

This peculiar little bird seems to be strictly congeneric with my Orthnocichla subulata from Timor, and though so strikingly different in colour, there are several points of characteristic resemblance, viz. che white under surface, the pale yellowish-white legs, and the broad eyebrow.

[Very Wren-like in habits, frequenting the undergrowth close to the ground, through which it crceps more after the manner of a mouse than of a bird. This little bird is apparently rare, and in my expeditions I only procured three specimens, which were met with in the true forest at elevations of from four to seven thousand feet. Eye black; feet and claws white; bill brown.]

121. Pomatorhinus borneensis, Cab.

[I only met with this species in the old Dusun rice-clearings, at about 1500 feet, where it frequented the low growth ncar the ground, especially where broad coarse grasses were abundant. In these spots it 
makes a large nest like a ball, eomposed of eoarse grasses and lined with finer leaves, in whieh it lays two glossy white eggs, about the middle of January, those found having been taken on the 20th of that month; axis 0.95 ineh, diam. 0.7. Eye pale yellow; bill dirty white, exeept at the base of the upper mandible, where it is blaek; legs pale slaty blue.]

122. Garrulax schistochlamis, sp. n., Sharpe.

Adult male. Slaty grey on the head, mantle, and baek; lower baek, rump, and upper tail-eoverts as well as the seapulars and wings ehestnut-brown, the primaries externally paler and more fulvous brown; centre tail-feathers deep ehestnut-brown, the remainder blaekish, externally deep ehestnut ; lores and base of forehead blaekish, extending below the eye; ear-eoverts, eheeks, sides of neek, and under surfaee of body light slaty grey, with blaekish shaft-streaks to the feathers of the throat; sides of body and flanks, thighs, vent, and under tail-eoverts light ehestnut-brown; nnder wing-eoverts dusky, washed with rufous ; quills dusky brown below, ashy rufous aloug the inner web. Total length $9 \cdot 5$ inehes, eulmen $1 \cdot 1$, wing $4 \cdot 7$, tail $4 \cdot 15$, tarsus $1 \cdot 6$.

Adult female. Similar to the male, but rather lighter in eolour. Total length 10 inehes, eulmen $1 \cdot 05$, wing $5 \cdot 0$, tail $4 \cdot 15$, tarsus $1 \cdot 65$.

[ 1 only met with this speeies at my last eamp, where it frequented the true forest, at an altitude of 4000 feet, feeding amongst the higher branehes of large trees. Small bands of five individuals were observed, being probably the old and young birds of the year. Iris lake-red, with a fairly large subocular pateh of bare skin of a pale blue eolour, almost white ; bill blaek ; fect dark brown.]

\section{Rhinocichla treacheri, Sharpe.}

[This speeies is one of the ornithologieal features of the lower slopes of Kina Balu, where it frequents the low growth whieh springs up in the old rice-fields. It is found more sparingly at high elevations up to 9000 feet in the true forest, so that perhaps it has a wider range on. Kina Baln than any other bird. Its real head-quarters are, however, the low growth from 700 to 1000 feet, from whieh point it beeomes seareer as one enters the forest or reaehes higher elevations. The "Lăhoie," as the Dusuns eall this bird, ereeps and hops about within a few feet of the ground, or may sometimes be seen amongst the highest branehes of old forest trees, in parties of four or five, probably an entire family.

It utters a loud whistling note, whieh may be heard more frequently in the early morning. This is one of the first sounds whieh attraets the traveller's attention on entering the Kina Baln region.

I saw a nest which was built in a long tangled mass of ereepers some 30 feet fiom the ground; it was composed of dead leaves and roots, and eontained one bright greenish-blue egg : this was on the 17th of Mareh. Iris dark lake-red; bill pale orange-yellow; skin round eye bright king's yellow; feet paler yellow.]

\section{Allocotops *, gen. n.}

Genus simile generi "Melanocichla" dieto, sed pileo et genis nudis faeile distinguendum.

The type is

124. Allocotops calyus, sp. n., Sharpe.

Adult male. General eolour above dull choeolate-brown ; bastard-wing and primary-eoverts blaekish; quills and tail-feathers blaekish brown, externally dull ehoeolate-brown; erown of head, lores, spaee round the eye, eheeks, and sides of throat bare and yellow; ear-eoverts ehoeolate-brown, like the head ; eentre of the throat and under surfaee of body sooty brown, inelining to ashy: "bare part of head yellow ; feet brownish yellow, more brown than yellow" (J. W.). Total length $10 \cdot 2$ inehes, eulmen $1 \cdot 1$, wing 5 , tail $4 \cdot 7$, tarsus $1 \cdot 15$.

Adult female. Similar to the male, and with an equally bald head. Total length 10 inehes, eulnen 1 , wing 4 , tail $4 \cdot 4$, tarsus $1 \cdot 35$.

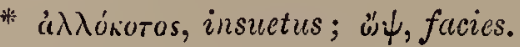


Young male. Of the same eolour as the adults, but with the crown feathered; the under surface slightly more ashy.

[Native name "Rigo-rigo." Loeal.

Met with on my second expedition in the old forest at 4000 feet. It has a loud booming call-note, and ereeps about in the trees much like Rhinocichla treacheri, from which it would be difficult to distinguish it but for the white marks on the wings of that species. This bird is by no means common and seens to be local. The young bird, euriously enough, has the crown of the head feathered to the base of the bill, but has a largc space of bare skin behind the eye, as well as bare spaces on the neck. The feathers are softer, and the wings of a lighter brown than in the adult.

The adults had the iris dark brown, the bill vermilion, the head quite bald, and the skin of a brownisin greenish-yellow, more yellow at the base of the bill; bare skin on neck dull bluish green ; feet brownish yellow.]

125. Stachyris Borneensis, sp. n., Sharpe.

Adult male. General colour above dark olive-brown, a little more rufescent on the upper tail-coverts ; lesser wing-coverts like the back; median and greater eoverts dusky brown, edged with the same colour as the back, a little more fulvescent on the outer ones; bastard-wing and prinary-coverts blue, like the rest of the wing-coverts ; quills dusky brown, edged with reddish brown, inelining to olive-brown towards the base of the outer webs; upper tail-coverts more rufous brown than the back; tail-feathers dusky brown, rufous brown on the edges, with dusky cross-markings under eertain lights ; crown of head dusky olive-brown, streaked with hoary-grey edges to the featbers, producing a striped appearance towards the forehead; along the sides of the crown a broad streak of black, followed by a greyish eyebrow, which becomes paler posteriorly, the hinder part of the black band being skirted by hoary streaks ; lores dull ashy; feathers in front of and round the eye blackish; ear-coverts dusky brown, the fore part hlackish, as well as a streak below the eye; throat and cheeks blackish, washed with ashy, with a broad white streak on the fore part of the cheeks; sides of neck and under surface of body ochreous buff, with paler shaft-streaks; abdomen light ashy ; sides of body and flanks, thighs, and under tail-coverts brown, with an ochreous tinge ; under wing-coverts and axillaries ochreous brown, the edge of the wing ashy; quill below dusky, edged with ochreous bruwn on the inner edge. Total length $5 \cdot 3$ inches, culmen $0 \cdot 7$, wing $2 \cdot 5$, tail $2 \cdot 25$, tarsus $0 \cdot 85$.

Differs from $S$. nigriceps in having a black bill, grey (not white) eyelid, and in having the head more uniform brown, less streaked with hoary grey.

[Frequents the old rice-plantations and the true forest from 1000 to 5000 feet. It hunts through the low growth in small parties or families of five or six individuals. The nest is a large ball of broadleaved grasses and other leaves, hidden away anongst the stems of palm-trees or in other dark places. The eggs are three, glossy white; axis 0.8 inch, diam. 0.55. Eye brownish yellow; bill black; feet horny grcen.]

126. Stachyris maculata (T.).

[Frequents the true forest near the ground. Iris whitish yellow; feet and lower bill cobalt-blue; upper mandible black; the sides of the neck are bare of feathers, and the skin is of a pale blue.]

127. Stachyris poliocephala, Temm.

[Only one specimen met with on Kina Balu, at an altitude of 4000 feet.]

128. Turdinus atrigularis (Bp.).

[Only one specimen met with, which I shot one evening at a small stream in the forest. Iris dark brown ; the bare skin behind the eye of a pale blue; feet dull pinkish brown.]

129. Turdinus canicapillus, sp. n., Sharpe.

Adult female. General colour above dull tawny brown, the mantle and upper back with distinet paler shaft-lines; lesser and median eorerts like the back; greater corerts dusky brown, externally chestnut; 
bastard-wing and primary-coverts tawny brown, internally dusky; quills blackish, externally chestnut lighter and more tawny on the primaries; upper tail-coverts like the back; tail-featlers reddish brown, more decidedly rufous on the margins; crown of head dark ashy, with a narrow whitish shaft-line to each feather, the shaft-stripes on the forehead more fulvescent; lores and an indistinct eyebrow of ashy white, the feathers of the latter with narrow white shaft-lines; ear-coverts light tawny rufous, with paler shaftlines; cheeks and throat white, with a few dusky streaks on the fore neck, which is pale tawny; breast and abdomen white; sides of body and flanks conspicuously tawny rufous; thighs also tawny rufous; under tail-coverts tawny rufous, white at the base; under wing-coverts and axillaries light rufous; quills below dusky, palc fulvous along the inner edge. Total length $5 \cdot 2$ inches, culmen $0 \cdot 65$, wing $2 \cdot 3$, tail $2 \cdot 05$, tarsus 1 .

The male exactly resembles the female.

This species is closely allied to T. sepiarius, but differs in having a distinct eyebrow streaked witl white, and more especially in the colour of the breast and sides of the body, which are bright tawny rufous.

[Fairly common on the lower slopes of Kina Balu from 3000 to 4000 feet, frequenting the undergrowth.]

130. Turdinus Magntrostris (Moore).

The single specimen is rather smaller and greyer than Malaccan examples. This seems to be the first recorded occurrence of the species in Borneo.

[Legs dark cobalt ; bill black, lower mandible whitish cobalt.]

131. Erythrocichla bicolor (Less.).

[Frequents old forest, but apparently not very common. Those shot were hunting in the lower branches of the undergrowth near the forest-paths. Iris light hazel ; upper mandible dark brown, lower one yellow at the hasc; feet flesh-colour.]

132. Drimocataphus capistratoides (T.).

[Found in the thick jungle on the ground. This species walls on the ground, never hopping or climbing about amongst the low growth. The Kina Balu specimen was killed at an elevation of 1000 feet.]

133. Trtchostoma rostratum, Blyth.

134. Malacopterum cinereum, Eyton.

[Bill black, lower mandible flesh-colour ; feet flesh-colour.]

135. Malacopterum affine (Bl.).

136. Kenopia striata (Bl.).

[I only met with one specimen, which came to drink at a small stream which I was watching. Iris black; feet white ; upper mandible black, lower one white.]

137. Mixornis borneeysis, Bp.

[Frequents the lower growth of tangled masses of jungle, especially in the neighbourhood of wet places. The note is "Buckier, buckier, buckier," which is uttered sharply. Iris whitish yellow ; bill and feet dark brown.]

138. Mrxornts Mon'tana, sp. n., Sharpe.

Adult female. General colour above reddish brown, with a strong shade of asliy olive, especially on the mantle and hind ncek, the latter having sundry dusky streaks; the feathers of the lower back and rump very long and fluffy; lesser wing coverts like the back ; median and greater coverts dull chestnut; bastarl-wing, primary-coverts, and quills dusky brown, externally dull chestnut, more conspicuous on the secondaries; upper tail-coverts reddish brown; tail-feathers blackish, externally washed with rufous brown; crown of liead reddish brown, streakcd with obscure blackish shaft-strcaks, the base of 
the forehead and lores ashy blackisl ; feathers round eye and ear-coverts dull ashy; washed with rufous and having obscurc dusky streaks; cheeks blackish, streaked with white, with which the feathers are edged; throat and fore neck white, washed with ycllow and strongly marked with triangular spots of black, more longitudinal on the lattcr; breast pale sulphur-yellow, streaked with dusky blackish ; abdomen rather whiter; sides of body and flanks uniform ashy olive-brown; thighs brown, with hoary whitish edges ; under tail-coverts dull sulphur-yellow ; under wing-coverts and axillaries elear sulphurycllow; quills below dusky, ashy along the inner edge. Total length $5 \cdot 6$ inches, culmen $0 \cdot 65$, wing $2 \cdot 45$, tail 2 , tarsus 0.85 .

[Fairly common at an altitude of 1000 feet on Kina Balu, frequenting the old clearings, where it creeps about amongst the coarse grasses and dense masses of undergrowtl within a few feet of the ground. In the early mornings this little bird may be heard uttering a loud bell-like note, which it ends up with "Chou chou buckier buckier," uttered as sharply as with its relation $M$. borneensis.

The nest is a small loosely-constructed ball of broad grass-stems cntered by a hole in the side ; it is generally placed within a foot of the ground amongst dead ferns or coarse grasses. The eggs are three in number, white spotted all over with pale pink spots, and may be found from the middle of January to March. Axis 0.75 inch, diam. 0.55. Iris light yellow.]

ANDrophilus *, gen. $\mathrm{n}$.

Genus simile generi "Elaphrornis", dicto, sed plumulis nuchalibus absentibus distinguendum.

The type is

139. ANdrophilus accentor, sp. 11., Sharpe.

Adult male. General colour above uniform rufous brown or dark chestnut, the feathers of the lower back and rump extremely lax; upper tail-coverts like the rump; wing-coverts, quills, and tail-feathers dusky brown, edged with the same colour as the back; crown of liead a little more dingy than the back; lores dusky, surmounted by a line of dusky grey, scarccly forming an eyebrow ; sides of face and ear-coverts reddish brown, washed with grey, with ashy shaft-lines; checks and sides of throat dark slaty grey, spotted with black, especially along the malar line; throat ashy white, spotted with black; sides of neck rufous brown, washed with grey; fore neck and brcast light slaty grey, the former with black spots; abdomen ashy whitish, washed with rufous brown; sides of body and flanks dark rufous brown, as also the thighs and under tail-coverts; under wing-coverts and axillaries dusky brown, with rufous edges; quills below dusky brown, ashy along the inner edge. Total length $5 \cdot 8$ inches, culmen $0 \cdot 6$, wing $2 \cdot 3$, tail $2 \cdot 35$, tarsus $0 \cdot 95$.

Adult female. Similar to the male, but with less grey on the face and chest, which are more rufous brown. Total length 6 inches, culmen $0 \cdot 6$, wing $2 \cdot 2$, tail $2 \cdot 4$, tarsus $0 \cdot 9$.

"A peculiar little bird, with a throat like an Alpine Accentor."

I have chosen the gencric name from the extraordinary tameness of this bird and the Brachypteryx, both of which, Mr. Whitehead says, were difficult to shoot from thcir persistence in closcly following the observer.

[This spccies invariably sought us out, and would appear almost under one's toes, following for several yards, along the forest-paths. My men often tried to knock them down with their head-cloths. If this bird ever frequented the lower altitudes of Kina Balu it has long since been exterminated by the Dusun rat-traps, which no doubt account for its scarcity at the altitudes which it now frequents. Iris dark brown; upper mandible black, the lower one greyish brown at base ; legs dark brown.

I only met this species at from 7000 to 9000 feet, where it frequented the dark and damp patches of forest, amongst the wet moss-covered fillen trunks of large trees, where this peculiar bird was found singly. The first individual of this species I took for a mouse, as it crept about within a few yards of nily feet; it was quite ten mintes before I could get a shot, the bird following me for several yards.]

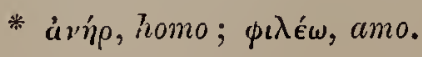


140. Corythocichla crassa, sp. n., Sharpe.

Adult male. Gcneral colour above streaked, the feathers being light brown in the centre, with palcr shaft-streaks and broad black edges; scapulars like the back; lower back and rump uniform brown; upper tail-coverts slightly more reddish brown, with whitish shaft-streaks; wing-coverts dusky, externally light reddish brown, with pale shaft-lines; the bastard-wing similarly marked; primarycoverts and quills dusky brown, externally pale brown, slightly more olive on the primaries; tail-feathers dusky brown, extcrnally dull earthy brown ; crown of head, nape, and hind neck blacker than the back, but similarly pale-centred and showing white shaft-streaks; forehead and lores white, as also a narrow eyebrow, the latter somewhat tinged with ashy; feathers round eye and a streak above the ear-coverts black; sides of facc, ear-covcrts, and hinder cheeks pale tawny buff, with ashy-whitish shaft-lines, the upper ear-coverts edged with black; fore part of cheeks and throat white, shading off into delicate ashy on the fore neck; sides of neck like the back, but with broader pale centres; chest and reinainder of under surface bright tawny buff, with slightly indicated dusky margins and shaft-lines of tawny whitish; sides of body and flanks browner, but with pale shaft-lines; thighs dingy brown; under tailcoverts like the flanks and similarly streaked; under wing-coverts and axillarics dusky brown, with tawny-buff shaft-lines; quills below dark sepia-brown, slightly more ashy along the inner edge. Total length $5 \cdot 3$ inches, culmen $0 \cdot 7$, wing $2 \cdot 7$, tail $1 \cdot 9$, tarsus $1 \cdot 1$.

Adult female. Similar to the male. Total length 5 inches, culmen $0 \cdot 6$, wing $2 \cdot 65$, tail $1 \cdot 7$, tarsus $1 \cdot 15$.

To judge by descriptions this new species must approach C. epilepidota of Sumatra, but the KinaBalu bird is much larger and stouter than C. epilepidota, and is distinguished by its ochre or tawny-buff under surface, tawny-buff ear-coverts, \&c., and many other points, which can be secn at a glance by comparing the descriptions of the two species.

[Met with at 7000 feet on Kina Balu, where it frequents the low bamboo-growth, hunting in small families of four or five individuals, often at some hcight above the ground. Iris dark brown; legs also dark brown; bill black, the lower mandible greyish at the base.]

141. Turdinulus exsul, sp. n., Sharpe.

đ. T. similis T. roberti, sed regione paroticâ cinerascente nec rufescente distinguendus. Long. tot. $4 \cdot 6$ poll., culmin. $0 \cdot 65$, alæ $2 \cdot 2$, caudæ $1 \cdot 15$, tarsi $0 \cdot 85$.

The female is like the male in colour. Total length $4 \cdot 3$ inches, culmen $0 \cdot 6$, wing $2 \cdot 2$, tail $1 \cdot 1$, tarsus 0.85 .

[I obtained only two specimens of this species at about 5000 feet on Kina Balu, where it is apparently rare.]

142. Anuropsis malaccensis (Hartl.).

143. Lanius luctonensis, Sharpe.

Family Lanidoe.

[Met with on Kina Balu up to 1000 fect. Native name "Burong Cassip."]

144. Hyloterpe hyPoxantha, sp. n., Sharpe.

Adult male. General colour above dull olive-yellow, with a little tinge of brighter yellow on the rump: lesser wing-coverts dusky, with greenish margins; median and greater coverts dusky, with greenish edges, some of the outer ones rusty brown on the outer webs; bastard-wing dusky ; primarycoverts dusky, margined with greenish; quills dusky, with yellowish-green cdges, the primaries ashy towards the cnds, the secondarics rusty towards the ends of the outer webs, the innermost almost entirely rusty brown; upper tail-coverts yellowish green ; tail-feathers blackish, edged with olive-green ; crown of head likc the back, a little brighter olive-yellow towards the foreliead and orer the eye; lores dark aslyy ; eyelid, sides of face, and ear-coverts olive-yellow, with a reddish tinge on the linder margin of the latter; cheeks and under surface of body bright yellow, duller and more olive on the lower throat and 
fore neck, as well as on the sides of body and flanks; thighs and under tail-eoverts yellow; under wingeoverts and axillaries white, edged with bright yellow ; edge of wing bright yellow ; quills below dusky, ashy whitish on the inner edgc. Total length $5 \cdot 8$ inches, culmcil $0 \cdot 65$, wing $3 \cdot 25$, tail $2 \cdot 25$, tarsus $0 \cdot 75$.

This species belongs to the section of the genus containing II. sulfuriventer and II. plitippinensis, but differs in its entirely yellow under surface.

The sexes are alike in colour, and a pair measure :-

\begin{tabular}{|c|c|c|c|c|c|}
\hline Adult male & $\begin{array}{c}\text { Total length. } \\
\text { in. } \\
5.8\end{array}$ & $\begin{array}{c}\text { Culmen. } \\
\text { in. } \\
0 \cdot 6\end{array}$ & $\begin{array}{c}\text { Wing. } \\
\text { in. } \\
3 \cdot 3\end{array}$ & $\begin{array}{l}\text { Tril. } \\
\text { in. } \\
2 \cdot 3\end{array}$ & $\begin{array}{l}\text { Tarsus. } \\
\text { in. } \\
0.75\end{array}$ \\
\hline Adult female & $6 \cdot 0$ & $0 \cdot 65$ & $3 \cdot 4$ & $2 \cdot 35$ & 0.75 \\
\hline
\end{tabular}

The young bird is like the adults, but rather duller in colour, and has several rufous-edged feathers on the baek, wings, and breast.

[Met with on Kina Balu from 3000 to 8000 feet, but more plentiful at the higher elevation, where it frequents the lower branches of high trees. Iris and bill black; feet bluish grey; the lower mandible of the young bird is yellowish at the base.]

145. HyLoterpe Grisola (Bl.).

[Feet cobalt-blue.]

146. Pteruthius eralatus, Tick.

New to Borneo.

[Met with from 4000 to 9000 feet; fairly common at the latter elevation, where it haunts the low weather-beaten trees in small parties; they sit on the lowcr boughs, hopping sideways when moving, every now and then leaving their perch to pick an insect off the leaves ; and have a very hawk-like look, sitting with the head sunk low on the shoulders, are quarrelsome with other birds, always driving them off. Iris pale bottle-green; legs light pink. Upper half of upper bill black, rest and lower mandible palc blue.]

\section{Family Certhinds.}

147. Dendrophila corallipes, sp. n., Sharpe.

D. similis D. frontali, sed pedibus corallinis nec fuscescenti-nigris distinguenda. Long. tot. 5‘2 poll., culmin. $0 \cdot 6$, alæ $2 \cdot 9$, caudæ $1 \cdot 15$, tarsi $0 \cdot 65$.

It is rather curious that no one has noticed the difference in the eolour of the feet in the Bornean bird. Mr. Whitehead was the first to point it out to me.

[Mrore plentiful on the sea-eoast, where it frequents the Casuarina trees and miangrove-swamps on the edges of rivers. Also found on Kina Balu up to 3000 feet. In habits this bird is like a true Nuthatcl. It was only on shooting a Dendrophila in Palawan that I discovered the difference of the two species. The Borncan bird has turned out to be the undescribed form, the Palawan and Java species being the true $D$. frontalis with black legs. The Bornean bird is also more vivid in colouring.

Native name "Tempakcris." (What this neans I do not know.) Iris straw-ycllow ; bill and legs vermilion, the former tipped with black. The bill in the true $D$. frontalis is not "bright cobalt-blue" as is stated in vol. viii. of the Museum 'Catalogue' (p. 359), but of an orange-vermilion.]

\section{Family Nectarinidd}

148. Etrhopyga teminiscisi (S. Müll.).

Description of the female :-Adult female. General colour above olive-yellow, with a golden shade on the back; lesser and median coverts like the baek; greater coverts, bastard-wing, and primarycoverts dusky browu, externally olive, with a tinge of orangc-red; quills dusky. brown, edged with yellow, whieh is more or less tinged with orange-rcd; the innermost seeondaries olive-brown; tail- 
feathers dusky brown, edged with orange-red, olive towards the ends of the outer webs ; crown of head ashy grey, the occiput and nape washed with olive-yellow; lores ashy; eyelids whitish; sides of face, ear-coverts, and cheeks ashy grey, the latter washed with olive; chin, throat, and under surfaee of body pale greenish, the throat rather more ashy; on the sides of body a silky-white patch; long feathers on the flanks ashy white; lower abdomen, thighs, rent, and under tail-coverts pale greenish yellow; under wing coverts and axillaries white; quills below dusky, white along the inner edge. Total length $3 \cdot 3$ inches, culmen $0 \cdot 55$, wing $1 \cdot 75$, tail $1 \cdot 05$, tarsus $0 \cdot 5$.

[Fonnd on Kina Balu at from 2000 to 6000 feet, but most plentiful about 4000 feet, where it frequents the high forcst trees and feeds among the parasitical plants whieh cover their boughs with many beautiful flowers. Iris and bill blaek; feet dark brown.]

149. Ætethopyga siparaja (Raffl.).

[Fairly common in the lowland forests, and found on Kina Balu up to 2000 feet, above which elevation its place is immediately taken by $E$. temmincki, neither species seeming to overlap the range of the other.

In the end of April I found a nest of this species which was placed under an overhanging bank amongst loose roots of trees. The nest was a long pocket madc outwardly of dead grass and lined with fine roots. The eggs were two in number, of a pale salmon-pink, blotched with darker tints at the larger end, then spotted and marked with dark lake-red. Axis 0.55 inch, diam. 0.4.

Native name "Suit merah" (red). "Suit" is the native name of all species of Nectarinia, called so from their note, which is "suit suit."]

150. Chalcostetha insignis (Jard.).

[This species is met with more frequently in the mangrove-swamps than elsewhere, and I do not think that it is ever found very far from swamps. I saw a nest in Palawan which was a suspended pocket made of grass-stems, and contained two young birds.

Native name "Suit Tungeon" (i. e. the "Swamp Suit.")

151. Cinnyris hasselti (T.):

152. Cinnyris pectoralis (Horsf.).

[Common in Labuan, and in open places generally. It prefers to frequent fruit-gardens to most other localities. I have seen many nests of this bird, which are generally suspended about 3 or 4 feet from the ground on an outside brinch of some bush or small tree. The nest is often a benutiful structure, composed of dead leaves; over the sniall entrance-hole is a roof which projects so as to keep out the wet. At the bottom is generally a long streamer which assists in making the nest look much like a lump of leaf-refuse that has become fixed in the branches. Inside the nest is lined with "Lalang"grass down, from the seeds of that plant.

The eggs are always two in number, of a pale greenish-blie under surface, sometimes thickly clouded with light brown, and slightly speckled with small black spots, or of the same underlying colour, only slightly marked with greyish blotches and small black spots. Axis 0.55 inch, diam. $0 \cdot 45$.]

153. Arachnothera Julie, sp. n., Sharpe.

Adult male. General colour above brown, longitudinally streaked with white, morc broadly on the mantle, where the white expands slightly towards the end of the feathers; scapulars like the back ; wingcoverts uniform dark brown, as also the bastard-wing, primary-coverts, and quills, the latter blackish; lower rump and upper tail-coverts bright yellow; tail-feathers uniform blackish brown; crown of head like the back; lores and feathers round eye uniform brown; ear-coverts and siles of neck brown, narrowly streaked with white; cheeks hoary white, streaked with brown edges to the feathers; throat and under surface of body streaked like the upper surface, the white centres to the feathers much broader; thighs white, streaked with brown; vent and under tail-coverts bright yellow; under wing-coverts and 
axillaries brown, with longitudinal whitish centres; quills below dark brown, ashy brownish along the inner edge. Total length 7 inches, culmen 2 , wing $3 \cdot 4$, tail 2 , tarsus $0 \cdot 7$.

[This Spider-hunter, one of the finest of my discoveries, was scarce on Kina Balu. During my first cxpedition I only obtained one specimen, and altogether, by carefully watching some high trees in a large forcst for a month, we collected six specimens. These birds seldom left the orchids and other plants which flower on the tops of the highest trees. In the month of March a young bird was obtained which was like the adults, but less distinctly marked on the breast and back, the white stripe in the centre of the feathers in the young bird having a decided yellowish tinge, while the yellow of the rump and vent is not so bright as in the old birds. The food of this species is not entirely insects, as one specimen had several small berries in the throat. Bill, feet, and iris black.]

154. Aлthothreptes maLaCCensis (Scop.).

[One of the commonest Sun-birds, especially in the ncighbourhood of coco -nut plantations, where it finds abundant food anongst the flowers of the young nuts.

The nest is a pocket, suspended from a branch in some tangled bush, and is much more open at the mouth in proportion than that of Cinnyris pectoralis; it is made of grass-stens, and lined with the down off thc "lalang" grass, and bound together by spiders" web. Eggs two, dull pink, thickly scribbled over with grey, spotted and sprinkled over with black, after the manner of some Buntings'. Axis 0.7 inch, diam. 0.55. Iris hazel; feet greenish brown; bill black.]

155. ANтhothreptes PHønicotis (T.).

[Met with at 1000 feet on Kina Balu. Iris reddish brown; feet yellowish green ; bill black.]

156. ArachNothera AFFinis, var. nov.

[This is the Bornean representative form of $A$. affinis of Java, differing from that species in being of a more golden green on the back, the Javan bird being brownish green. This species was overlooked by Dr. Sharpe, and entered as A. modesta in 'The Ibis'; he is shortly to describc it under a new specific name. This bird was obtained by me for the first time in Borneo.

Fairly common in old forest. Met with on Kina Balu up to 4000 feet. This species makes a beautiful cup-like nest, which it suspends from the underside of some large leaf. The nest is fastened to the leaf by spiders' web, which is sewn through. It is composed of a bright brown silky substancc, which is found on the young fronds of ferns; a good deal of white down from seeds is also used. The outside is covered with small flower- and plant-stcms, stuck together with spiders' web.

The eggs are two in number, of a deep olive-brown, mottled and clouded all over with grey specks, sometimes with a well-marked zone of black spots and blotches. I took several nests about the middle of March on the spurs of Kina Balu. Axis 0.95 inch, diam. 0.7.

Native name "Sussut busar." "Sussut" in Kadyan means "lost," "bnisar" "big," that is in comparison with $A$. longirostris. As both species have a peculiar babit of flying low and fast through the jungle, uttering their peculiar call-note at short intervals, the natives may have imagined that the bird is "lost." This species is one of the bird-omens of some tribes. Iris and upper mandiblc black, lower one brown; feet dull flesh-colour.]

157. Arachnothera longirostris (Lath.).

[Fairly common in old forest. It reaches an altitude of nearly 3000 feet on Kina Balu.

The nest is different from that of $A$. affinis, the entire structure being sewn on to the underside of some large leaf, which forms one side of a pocket. The building-inaterials are dead leaves. The nest I have is unfortunately unfinished.

Native name "Sussut."]

158. Arachnothera chrysogenys, Temm.

[Iris black; bill black, yellowish at base ; feet dull pink.] 


\section{Family Meliphagide.}

159. Zosterors auriventer, Hume.

The specimens from Kina Balu cannot be separated from Tenasserim examples.

[Fairly common on. the lower spurs of Kina Balu, frequenting the more open spaces, flying in twittering flocks amongst the tops of small trees.]

160. Zosterors Clara, sp. n., Sharpe.

Adult male. General colour above clear greenish yellow, the rump and upper tail-coverts scarcely lighter than the back; wing-coverts like the back; bastard-wing black; primary-coverts and quills blackish, externally greenish yellow, a little lighter on the primaries, the innermost secondaries like the back; tail-feathers blackish, narrowly margined with greenish yellow ; crown of head like the back ; the forehead and lores as well as the feathers at the base of the bill blackish, extending on the forehead across the centre of each eye ; feathers round eye silky white, except in front, where they are blackish ; earcoverts and cheeks greenish yellow ; throat clearer yellow ; sides of neck like the back ; fore neck, chest, sides of body, and flanks pure bluish grey ; centre of brcast, abdomen, thighs, and under tail-coverts clear yellow; under wing-coverts and axillaries silky white; quills below dusky, white along the inner edgc. Total length 4 inches, culmen $0 \cdot 55$, wing $2 \cdot 05$, tail $1 \cdot 4$, tarsus $0 \cdot 6$.

Adult female. Similar to the male. Total length 4 inches, culmen 0.5 , wing $2 \cdot 05$, tail 1.35 , tarsus $0 \cdot 6$.

[Met with only in one locality on Kina Balu, at about 5000 feet. I found a nest of this speciez, which was built of fine roots on the underside of a moss-covered bough, in the dark damp forests on the slopes of the mountain. The old birds were feeding their young on grubs.]

\section{Family DiceID e.}

161. Dic正Uм monticolum, sp. n., Sharpe.

Adult male. General colour above glossy purplish blue; lesser wing-coverts like the back; median and greatcr covcrts, bastard-wing, and primary-coverts black, edged with purplish blue ; quills black, the secondaries edged with purplish blue ; upper tail-coverts like the back; tail-feathers blue-black; crown of head glossy purplish blue, like the back; lores, sides of face, ear-coverts, and cheeks blackish, slightly glossed with purplish blue; chin whitish ; throat, fore neck, and breast bright scarlet, followed by a large. patch of dark ashy on the lower breast and abdomen ; sides of upper breast dark slaty grey; abdomen ashy, slightly washed with olive, yellowish white towards the vent; sides of body and flanks dull oliveyellow; thighs dark ashy; under tail-coverts pale saffron-yellow; under wing-coverts and axillaries white; quills below blackish, ashy along the inner edge. Total length 3.7 inches, culmen 0.4 , wing 1.95 , tail $1 \cdot 15$, tarsus 0.5 .

The affinity of this species with Dicceum sulaense instend of with $D$. celelicum is most interesting. The steel-blue colour of the back separates the Kina Balu bird from botl, but it has olive-yellow flanks like $D$. sulaense. Of the latter species the female is at present undescribed, but between the hens of $D$. celebicum and $D$. monticola there is a great difference, the female of the Celebean bird being dull purplish, while the female of $D$. monticola is olive-yellowish on the back, clearer olive-yellow on the rumy and upper tail-coverts; the head dusky steel-green washed with olive; wing-coverts blackish, with a steel-green gloss, and edged with olive-yellow; quills blackish, with narrow olive edges; tail-feathers blue-black; sides of faee dull ashy shaded with olive, as also the cheeks, with a grey shade over the sides of the fore neck and chest; throat white, gradually turning to palc ochreous yellow on the breast and abdomen and under tail-coverts; sides of body olive; axillaries, under wing-coverts, and quill-lining white, with a yellow tinge. Total length $3 \cdot 2$ inches, culmen 0.4 , wing 1.85 , tail 0.95 , tarsus 0.5 .

The young bird resembles the adult female, but has the base of the bill yellowish white and the colours duller; the head olive like the back; the throat pale ashy grey, this colour extending over the breast. 
[I first met with this beautiful little bird at an altitude of 4000 feet, where it frequented the I $^{\text {arasitic }}$ plants and flowers on high trees. In some trees wcrc large clusters of parasites, which were eovered with small fruits; these trees were regularly visited by this Dicaum. Iris, feet, and bill black.]

162. Dic

[Common, especially in the neighbourhood of gardens and other open spaces. I have a beautiful nest of this bird, which is a small rounded pocket suspended from the underside of a small twig, well sheltered from above by the broad leaves of the tree. The nest is composed of white (seed) down, and woven on the outside with small red leaves and fine grass-stems. The eggs were three in number and pure white.]

163. DiCAuM CHRysorrhæuM, T.

[lris red ; feet and bill black.]

164. Diceum trigonostigma (Scop.).

[Iris dark brown ; bill black ; fcet greyish black.]

165. Prionochilus xanthopygius, Salvad.

166. Prionochilus thoracicus (T.).

[Iris, feet, and bill blaek.]

167. Hirundo Javanica, Sparm.

Family Hirundinid 2.

[Native name for all Swallows and Swifts " Liang-liang."

Iris, feet, and bill black.]

168. Motacilla melanope, Pall.

Family Motacillides.

[This species prefers the beds of rocky torrents, where it is generally met with singly. On Kina Balu it frequented streams up to 3000 feet. Native name "Bras bras." "Bras " is " rice" in Malay, and as Wagtails visit Borneo in swarms during the rice-planting season and frequent the fields when the grain first springs up, the native name is derived from this eircumstanee.]

169. Motacilla Flava, L.

170. Anthus richardi, Vieill.

Reeorded from Borneo for the first time.

171. Anthus gustavi Swinh.

172. Sturnia violacea (Bodd.).

\section{Fanily STURNid}

173. Calornis chalybea (Horsf.).

[Very common in Labuan, wherc they frequent the fruit-gardens and other open spots. They retire to rest in large flocks in the coeon-nut trees, wherc they take some time before settling down, making a good deal of noise.

This Starling nests in holes in dead trees in eolonies, and I have seen them frequenting a doveeot in numbers for ncsting-purposes.

Native name "Salangkir."

Iris bright vermilion, feet and bill blaek.]

174. Gracula Javanensis (Osbeek).

[Common, frequenting the more open distriets, where it nests in holes in the old dead trees. This hird is, in Borneo, as elsewhere, a great favourite with the natives, who teach it to talk. Native name "Teung."] 


\section{Family Artamide.}

175. Artanus leucorhynchus (L.).

[Iris dark hazel; bill light blue; feet dull brown.

This is a common species, frequenting open spaces, more especially where dead trees remain standing after forest fires.

The nest is composed of light grey stalks and small roots, which assimilate wcll with the bleached trees on which they are built; it is lined with finer roots and grasses.

Eggs three, laid in June, creamy white in colour, slightly spotted with grey and light brown, especially at the larger end, wherc a zone is formed with blotches of the same colour. Axis 1.05 incin, diam. 0.7.]

\section{Family Ploceidx.}

176. Padda ortzivora (L.).

[This species is, I believe, an importation of Sir Hugh Low, the late Governor of Labuan. It is now too plentiful to please the natives, doing great danage to their rice-fields. I have never seen it on the mainland of Borneo, though Labuan is only a few miles distant. The Sarawak Dyaks, I believc, are fond of these birds, and purchase them in Labuan, so no doubt before many years are past it will be common throughout Borneo.

Native Bornean name "Pipit Java."]

177. Munta fuscans (Cass.).

[This little Munia was at one time more common in Labuan than it now is, having been driven away by its larger ally, which, again, in no distant future will be driven before the ever-increasing hordes of Pald a oryzivora.

It is now by no means common in Labuan, where it frequents the rice-fields and gardens, nesting in the fruit-trees. The nest is a large ball of various grasses with a small hole at the side, around which project the sced-ends of many grasses, almost hiding the entrance.

The eggs are five, pure white, and may be found in January and other months : axis 0.6 inch, diam. 0*45. I met with this specics on Kina Balu up to 1500 feet.

Native name "Pipit itham."]

178. Munia Brunneiceps, Walden.

[One of the commonest species, found in open districts, where it is ever ready to pounce on the ripening rice of the natives. In some places these little pests (unless the fields are carefully guarded) get more rice than the native himself. They nest in numbers in gardens; the structure is similar to that of M. fuscans, the eggs being also white. Axis 0.65 inch, diam. 0.45 . I have often turned out seven or eight birds from one of their old nests in the evening, and am at a loss to know how they could possibly pack together into such a small place.

Native name "Pipit," which is evidently given them from their note "Pipē-pipē," which they frequently utter.]

179. Chlorura borneensis, sp. n., Sharpe.

Adult male. General colour above bright grass-green ; lesser wing-coverts like the back; median and greater coverts black, externally green, like the back; bastard-wing and primary-coverts black, fringed with green; quills black, edged with somewhat lighter green fringes on the primaries, the secondaries cxternally like the back; upper tail-coverts likc the back; centre tail-feathers olive-green, with black bases, the remainder black edged with green, the outermost witl an ashy greenish spot at the end ; forehead black, succeeded by a blue crown, the hinder part of the crown like the back ; lores, eyebrow, feathers round the eye, ear-coverts, cheeks, throat, fore neck, and breast pale tawny, deeper on the fore neck and breast; abdomen light ochreous buff, washed with grcen; sides of body and flanks light 
grass-green ; thighs and under tail-coverts deeper ochreous buff; under wing-eoverts and axillaries light tawly buff, like the brcast; quills below blackish, ashy rufous along the inner cdge. Total length 4 inches, culmen $0 \cdot 45$, wing $2 \cdot 3$, tail $1 \cdot 0$, middle tail-feathers $1 \cdot 15$, tarsus $0 \cdot 65$.

The adult female is very similar to the malc, but is everywhere duller in colour, with less blue on the crown, and the black on the forehead less pronounced. Total length $4 \cdot 1$ inches, culnen $0 \cdot 45$, wing $2 \cdot 35$, tail $1 \cdot 2$, tarsus $0 \cdot 65$.

[The young bird is similar in eolouring to the adults, but wants the black forehead and blue crown, which is green like the baek. The cheek, throat, fore neck, and breast are not so vivid in eolour as in the adults.

The flight is very quick, and when on the wing the bird continually utters its call-note, which is a hissing sound like "Tzit-tzit," but when settled it is silent. Iris and bill black; feet flesh-colour.]

180. Erythrura Prasina (Sparrm.).

[Though their plumage is composed of the brightest of colours, these birds are difficult to see when settled in the jungle, into which they fly on being alarmed. Iris and bill black ; fect flesh-colour.

After January there was not a bird to be met with in the neighbourhood of Kina Balu.

Dusun name "Tuhan." Kadyan "Pipit trepas."

"Trepas" is the name given to the small Parrot (Loriculus galgulus), which this bird resembles somewhat in colour.

Some of the natives have a peculiar belief that this species makes a glutinous nest in caves like a Collocalia, which of coursc is extremely improbable.]

\section{Family EurYLÆMID丑.}

181. Calyptomena whiteheadi, sp. n., Sharpe.

Adult male. Bright shining grcen ; large blotch on front of the neck and a spot on each side behind the ear-eoverts black; feathers of back and breast black, with lanceolate green tips; tail velvety black, green at the base ; secondaries slightly edged with blue. Whole length 11 inches, wing $6 \cdot 35$, tail $3 \cdot 2$.

Female. Similar, but not so bright, the frontal crcst less developed.

Bill (horny) green, the upper mandible darker ; feet (horny) green ; iris black.

An immature female is of a much duller green than the old birds, and is much less mottled with the black bases to the feathers, which give the latter sneh a distinguished appearanee. The head is very little crested, and the black patch on the throat is duller and much smaller. The green of the nnderparts is also much duller than in the adults, and, as in the case of the back, the black bases to the feathers are not secn.

[I met with this beautiful species on my first cxpedition at an elevation of 3000 feet. On my second expedition, after reaching altitudes above 5000 feet, it was not observed, so the exact range is apparently from 3000 to 5000 feet. This Calyptomena frequents the dark damp ravines of Kina Balu, where the forest is tropical, but wherever the ground is poor and the trees become alpine in character it is absent.

The bird frequents the lower boughs of big trecs and feeds ehiefly on jungle fruits. I diseovered a nest with eggs and also one nest containing young birds.

Dusun name "Ralo."

Eggs two, glossy creamy white. Axis 1.45 ineh, diam. $1 \cdot 0$.

A young bird just out of the nest was of a much duller colour on the breast than the adult, the feathers being mingled with greyish down. The black patch on the throat is scareely perceptible. The back, wings, and tail are as bright as in the adult female.]

182. Calyptomena viridis, Raffl.

[Fairly common in old forests, where it frequents the lower branches of high trees in shady places. This speeies reaches an altitude of 4000 feet on Kina Balu, but is scarce at that elevation. 
The Kadyans eall it "Bintarrang."

Iris black ; bill and feet dull yellowish hrown.]

183. Psarisomus psittacinus (pt.), Sel.

New to Borneo.

184. Eurylamus javanicus, Horsf.

[Fairly eommon everywhere, reaching an altitude of 1000 feet on Kina Balu.

Iris greyish blue; hill turquoise-blue green, cobalt at base ; feet dirty pink.]

185. Eurylamus ochromelas, Raff.

[Distribntion the same as in the last speeies. Met witl on Kina Balu at about 1000 fcet. Native name "Tapau." Iris hright yellow, hill turquoise-blue.]

181i. Cymbirhynchus macrorhynchus (Gm.).

[A common forest species. Iris bottle-green; upper mandible turquoise-hlue; under one blue, running into light blue and king's yellow at hase ; feet liglit blue.]

187. Corydon sumatranus (Raff.).

[Rather a searce speeies in Borneo, frequenting old forest. Met' with on Kina Balu up to 2000 feet. Iris dnll white; skin round eyes pink ; bill dull pinkish brown ; feet brown.]

188. Pitta arcunata, Gould.

There is no differenee in the colouring of the sexes; hut the female has searccly such a finely developed neeklace.

[I met with this heautiful Pitta on Kina Balu at from 2000 to 4000 feet in true forest, where it frequented the thiek bamboo-jungle. Iris hlack; bill dark brown, greyish at base of lower mandible; legs slate-grey.]

189. Рitta baudi, Müll. et Schleg.

[Apparently rarc. I only saw three hirds of this species during my stay in Borneo. Iris and bill black; legs slaty blue.]

190 Pitta schwaneri, T.

[Only two specimens met with, which were procured on Kina Balu, at 5000 feet, hy one of my men after I had left to pack up for my return journey to the eoast.]

191. Pitta ussueri, Sharpe.

[A local species, being fairly eommon in parts of Northern Borneo. Though extremely hright in plumage, this Pitta is diffieult to see, the bright scarlet brenst, when turned towards one, is not so easily distinguished froin the scarlet fruits and bright red dead leaves whieh carpet these forests. Then the bird when alarmed generally keeps its dark back towards one, whieh is still more difficult to see in the dusky shades of the forest. The note is peculiar, heing a prolonged whistle, gradually rising in power, and suddenly ceasing when it reaches its highest pitch. These birds are good ventriloquists. I have often been looking for a Pitta in the opposite direetion to which he was, and at last discovered the hird hopping about in the thick jungle within a fow yards of my hack. Iris and hill blaek; legs slaty blue.]

192. Pitta cyanoptera, T.

[Met with on Pulo Tega in numhers during April 1886, but in the following year Mr. A. H. Everett sent a collector to that island, wherc lie procured numbers of Pitta muelleri but no P. cyanoptera. When I visited the island there were no $P$. muelleri to be seen. This species must therefore he migratory. It is fairly plentiful in Labuan in some seasons ; at other times it is not to he mot with.

It frequents the ground and lower hranches of trees in old forest, and is not so casy to shoot as might be inagined from its colouring, as it takes good care to keep its grcen back to the bird-collector. This species takes flight more often when alarmed than $P$. ussheri or any other species of this genus 
that I have met with. The note is a short whistle uttered sharply three times, the first note being the shrillest. Iris black; bill dark brown; legs pale pink.]

193. Pitta muelderi (Bp.).

[Fairly common in Labuan in certain montls, and no doubt migrates at certain seasons to this island. Iris and bill black; feet slaty grey.

Native name of all species of Pitta "Teung tana."]

\section{Order PSI'TTACI.}

191. Paldeornis longicauda (Bodd.).

[Common in the lower reaches of rivers, cspecially near the higher swampy growtl.

Native name "Bian."]

194a. LoRICULUS GALGULUS (L.).

[Cominon in Labuan, frequenting fruit-gardens.

Native name "Trepas."]

\section{Order PICARIE.}

Family Trogonide.

195. Harl'actes whiteheadi, sp. n., Sharpe.

Adult male. General colour above bright cinnamon ; scapulars like the back ; wing-coverts black, finely barred with white cross lines; bastard-wing similarly marked; primary-coverts black; quills black, with a distinct white margin ; secondaries black, externally lined with white, likc the wing-coverts ; upper tail-coverts like the back; two centre tail-feathers deep cinnamon, with a broad black tip; the next pair black, with a chestnut shaft, the remainder black, with black shafts and some white near the end of the outer web, the outer feathers white for nearly the terminal half and for a good distance along the outcr web ; crown of head brilliant scarlet; lores black; ear-coverts scarlet, like the head; throat black, shading off into slaty grey on the fore neck; the chest pearly grey, extending in a kind of crescent up the sides of the throat, the lateral feathers tipped with scarlet; remainder of under surface of body brilliant scarlet, deeper below the grey chest; abdomen slightly paler and more rose-coloured; thighs blackish, with cinnamon ends ; under tail-coverts like the back ; under wing-coverts black; quills below black, with a white patch at the back: "bill and bare cheeks blue, as well as the bare patch round the eye; feet dull brownish pink; iris reddish brown" $(J . W$.$) . 'Total length 12$ inches, culmen 0.9 , wing $5 \cdot 2$, tail $6 \cdot 5$, tarsus $0 \cdot 55$.

Adult female. Differs from the male in having the head ciunamon, as well as the lower parts from the chest downwards, which are scarlet in the male; the wing-coverts and secondaries barred with ochreous brown instcad of white. Total length 12 inches, wing $5 \cdot 5$, tail 7 .

The beautiful red head and grey chest of this species distinguish it at a glance from $H$. kasumba, H. hodgsoni, and, in fact, from cvery known spccics-of the genus. It is quite a Trogon apart.

[This beautiful Trogon was met with on my second expedition, at 4000 feet, where it frequented the dark and wet patches of old forest. These birds generally sit in the higher branches of the lower forest trees, and seldom move, cxcept to take short flights from perch to perch. They generally keep their dullcoloured backs to the hunter, thus rcndering themselves more like a bunch of dead leaves, for which they may often be mistaken.

On the 4th of April, whilst I was taking shelter from the rain under some palm-leaves, one of these Trogons settled on a tree quitc close to me; it uttered every now and then a pcculiar growling note, swaying its tail backwards and forwards, spreading out the feathers with each movement, and every now and then making a short flight to capture some insect, and scttling on another perch.

The young birds in nestling-plunnge are similar to the female, but there is little or no distinction in colour bctween the throat, breast, and the rest of the lower parts. The pencilling of the wing-coverts is not nearly so fine, the yellow and black stripes being broader. The colour of the back is not so bright, 
being mixed with greyish down. I have a young male, in which the crimson feathers of the back and breast are mixed with the brown nestling-plumage.

Native name for all Trogons "Burong angi," or the "Omen bird."]

196. Harpactes Kasumba (Raffl.).

Benkoka, Oct. 1885 .

197. Harpactes Diardi (T.).

Benkoka, Oct. 1885.

198. Hatrpactes Duvauceli (T.).

Benkoka, Nov. 1885.

199. Harpactis orescius (T.).

A specimen in the British Museum was the sole authority for the occurrence of this species in Borneo before Mr. Whitehead's ascent of Kina Balu. The specimen in question was purchased at the sale of Baron Laugier's collection in 1837, and it is doubtful whether the locality is authentic ; but Mr. Whitehcad has now placed the Bornean habitat of the species bcyond doubt.

[Met with on Kina Balu, from 1000 to 3000 feet, but nowhere common, frequenting shady spots in old forest. I have noticed that all Trogons are more active in the early morning and evening; during: the rest of the day they are seldom seen. Iris black; gape cobalt-bluc, darker at base of bill and on lower mandible ; skin round eye whitish blue; feet slaty blue.]

199 a. Harpactes vidua, sp. n., Ogilvie-Grant.

[Since I sent home a skin of this species in 1887 , another specimen, also a female, was sent by Mr. Hose from Mount Dulit (Borneo) in 1892. Mr. Ogilvie-Grant would not describe and make a ncw type of my spccimen, but waited for further material; on receiving Mr. Hose's specimen he named it Harpactes vidua.]

"Adult female. Resembles the adult female of orrhophceus, from which, however, it differs in the following particulars:-The top of the head is olive-brown instead of blackish brown; the back olivebrown in place of rufous-brown; the rump and upper tail-coverts olive-buff instead of dull rust-colour; the wing-coverts and secondaries are more widely barred with rufous-buff; and lastly, but most important of all, the chin and throat are uniform rust-red, whereas in H. orrhophous the feathers on the sides of these parts are mostly black. Total length 9.5 inches, wing $4 \cdot 4$, tail $4 \cdot 9$, tarsus $0.55 . "$ (Cat. of Birds Brit. Mus. vol. xvii. p. 501.)

Hab. Mounts Kina Balu and Dulit.

\section{Family Capitonide.}

200. Megalmima chrysopsis (Goffin).

Benkoka, Sept. 1885.

201. Megalema verstcolor (Raffl.).

[Iris and bill black; feet dull greenish blue.]

202. Megal mima uystacophanes (T.).

[Has a peculiar note, which it utters when perched high up in the tree, "Pooh pooh lentogok lentogok."

Native name "Lentogok." Found on Kina Balu up to 3000 feet.]

203. Cyanops pulcherrima, sp. n., Sharpe.

Adult male. General colour above grass-green, all the feathers erged with lighter green ; wingcoverts like the back; bastard-wing and primary-coverts green ; quills blackish, externally green, yellowish along the edge of the primaries towards their tips, the innermost secondaries entirely green ; tail-feathers grcen, bluish below ; crown of head beautiful cobalt-blue as far as the nape ; siles of crown golden green from above the eye ; hind neck ornamented with a distinct collar of golden yellow ; lores black, washed with cobalt-blue, a line of which colour skirts their lower edge to the eye ; above the latter a small streak 
of cobalt-blue ; sides of face, ear-coverts, and chceks golden green, the fore part of the latter cobalt-blue, like the throat; remainder of under surface of body emerald-grecn, with a wash of golden green on the fore ncck and breast; on cach side of the lower throat a spot of bright golden yellow, like the collar on the ncek; sides of body and flanks more grass-green, the latter with paler green edges; thighs green, yellowish on their inncr aspect; under tail-coverts light emerald-green ; under wing-coverts and axillaries pale yellow, slightly washed witl grcen ; quills bclow dusky, ycllow along the inner edge: "bill black; fcet scaly green ; iris black" $(J . W$.$) Total length 7 \cdot 8$ inches, culmen $0 \cdot 8$, wing $3 \cdot 7$, tail $2 \cdot 35$, tarsus 0.95 .

Adult female. Similar to the male, but with an enormously large bill (!), the colour of the sides of the crown and the sides of the face golden ycllow, not so bright as the collar on the neck, but not so green as in the male. Total length $8 \cdot 3$ inclies, culmen $0 \cdot 95$, wing $3 \cdot 6$, tail $2 \cdot 3$, tarsus 1 .

[I discovered this fine Barbet at 5000 feet in high forest, but it is, perhaps, more at home on the mountain at about 8000 fect. It has a hooting-note rather like that of the last species. An immature bird is of a much less vivid grcen, and has the blue on the throat and head duller and greener than in the adults, and the golden collar is absent.]

204. Cyanóps monticola, sp. n., Sharpe.

o ad. Prasino-viridis, alis et cauda saturatioribus; fronte et loris smaragdinis, sincipite et pilei lateribus late cyaneis; plaga magna verticali scarlatina usque ad nucham producta ; facie laterali et regione parotica pallide cyaneis, fascia supraparotica smaragdina ; genis gulaque pallide flavis, hac infra cyanescente et macula scarlatina ad latera juguli posita ornata; præpectore ct corpore reliquo subtus pallide smaragdinis.

Long. tot. $9 \cdot 0$, culm. 1.15, alæ 3.9, caudæ 2.5, tarsi 1.05 poll. Angl.

The nearest ally of this specics is Cyanops incognita, Hume, from Tenasserim. It differs, however, from that species in its larger sizc, in the absence of the black facial stripes and rod loral spot, as well as in the colour of the throat, which is bright bluish green in $C$. incognita.

I at first thought it might represent one of the many phases of plumagc through which Megaloma mystacophanes passes before it becomes fully adult. A close examination, however, convinces me that it is a distinct species, different from any eastern Barbet yet known.

[Met with on my first expedition at about 3000 feet, and again during my second at the same altitude. This bird at first sight bears a strong rescmblance to the young of $M$. mystacophanes, so much so that it has remained nearly two years undescribed, though I had little doubt that it was a good species, the bill being quite distinct from that of $M$. mystacophanes, to say nothing of the colour. I was glad to find that Dr. Sharpe, at last, took my view as to its distinctness.]

205. Xanthol mia duvauceli (Less.).

[Iris and bill black; feet slaty green.]

206. Calorhamphus fuliginosus (T.).

207. Irngipicus aurantilventris, Salvad.

208. Iyngipicus auritus (Eyton).

209. Xylolepes validus (Reinw.).

210. Hemicercus sordidus (Eyton).

[Iris claret-colour; bill and feet slaty black.]

211. Lepocestes porphyromelas (Boie).

212. Gecinus puniceus (Horsf.).

213. Chrysophlegia humi, Hargitt.

214. Chrysophlegma malaccexse (Lath.).

[Iris dark lake.]

\section{Family Prcid无.}

215. Alophonerpes pulverulentus (T.).

216. Thriponax Javensis (Horsf.).

217. 'Tiga Javanensis. (Ljung.).

218. Gauropicoides rafflesil (Vig.).

219. Miglyptes gramaithorax (Horsf.).

220. Miglyptes tukki (Less.).

221. Micropternus badiosus ( $\mathrm{T}$.).

222. SASIA ABNormis (T.). 


\section{Family INDICATORID \&.}

223. INdicator aRchipelagicus, 'T.

Benkoka, Sept. 1885.

\section{Family Cuculid}

224. Chrysococcrx xanthorhynchus (Horsf.).

[Not common in Northern Borneo, where it frequents the tops of the highest trees, making it diffieult to obtain specimens. Its note is "Kievik, kievik," by which name the natives eall it. Iris lake ; bare skin round eye and bill vermilion ; feet dull green; bill in the female dark brown, more reddish at base.]

225. Surniculus lugubris (Horsf.).

[Iris hazel ; feet and bill black.]

226. Penthoceryx pravatus (Horsf.).

227. Cacomantis merulinus (Seop.).

228. Hierococcyx fugax (Horsf.).

[Met with on Kina Balu, about 3000 feet. I found this speeies laying in the nest of Culicicapa ceylonensis, on the 29 th April. The egg was creamy white, slightly spotted with pale yellowish brown and grey, forming a complete zone at the larger end : axis 0.9 inch, diam. 0.65 . Iris and bill light brown; feet and skin round eye bright yellow ; base of bill yellowish green.]

229. Hierococcyx nana, Hume.

The first reeorded oeeurrenee of this species in Borneo.

230. Hierococctx bocki, Wardlaw Ramsay.

New to Borneo. The oeeurrenee of this species on Kina Balu is interesting, as showing a very distinct relation between the avifauna of the mountain and that of High Sumatra.

231. Hierococcyx sparverioides, Vigors.

232. Cuculus micropterus, Gould.

[Apparently new to Borneo.]

233. Cuculus poliocephalus, Lath.

New to Borneo.

[This Cuckoo frequented the high ranges of Kina Balu up to 9000 feet, and I saw one specimen much higher. The note is exactly like that of Cyanops pulcherrima, and I have often stalked the supposed Barbct and shot a Cuekoo. Iris brown; legs, gape, and skin round eye king's yellow.]

234. Coccrstes coromandus (L.).

235. Eudynamis malayana, Cab. \& Heine.

236. Rhopodytes erythrognathus, Sharpe.

[Native name "Nampak."]

240. Centrococcyx eurycercus (Hay).

[This large and powerful Cuckoo frequents the small tangled patches of forest, being rarely met with in the larger stretches of old forest. The natives say that it often feeds upon flesh, killing and eating birds that have been snared, if left long in the traps. I have no doubt that it would take the young from nests, and have watched two little Flycatchers (Rlipidura javanica) very busy attacking and trying to drive this Cuckoo from a tree where they probably had a nest.

The note is loud, "būh būh," uttered many times, as the bird sits, generally towards the erening, in some prominent position.

Native name "Bubut," probably from the note.]
237. Rhinortha chlorophas (Raff.).

238. Poliococcyx sumatrayus (Raffl.).

239. Zanclostomus javanicus (Horsf.). 
241. Centrococcyx Javanensis (Dumont). clearings.

[This specics, unlike the last, is seldom secn except in the "lalang"-grass plains near the edges of

This Cuckoo may often be turned up in the coarse grass plains within a few yards, when it rises with a slow flapping flight, often soaring long distances, seldom more than a few feet above the grass, and then dropping suddenly out of sight.

Native name "Bubut."]

242. Buceros rhixoceros, L.

\section{Family Bucerotid无.}

[Iris dark lake; bill red and yellow ; fcet dull yellow.

This large Hornbill is fairly common, frequenting the high fruit-bearing forest trees. I have seen eleven flying in one flock, when they could bc heard a great distance off, the noise they make with their wings being very loud.

Native name "Sungung."]

243. RHiNoplax vigit (Forst.).

[Fairly common in most old forests, frequenting the tops of high trees. It utters a lond deep cry, "Lentodoon" (from which it gets its native name), and then goes off' into a fit of laughter, which may be heard at a great distance.

The native idea is that the heavy knob on the bill is used for hammering the gutta and gum round the hole when it closes up the female in the nest.]

244. Anthracoceros convexus (T.).

[Native name "Lēliup."]

245. Axthracoceros malayaxus (Raffl.).

246. Anorrhinus comatus (Raffl.).

Recorded from Borneo for the first time.

247. Axorrhinus galeritus (T.).

Adult. Iris lake ; bill black, sometimes white-striped ; feet black; skin on face pale blue.

$J$ r. Iris blue; bill dull red at tip, pea-green at base; skin on face bright king's yellow.

248. Merops sudiatranus, Raff.

$$
\text { Family MERopid } \approx \text {. }
$$

[Native name "Tampa-Kuro."]

249. Nyctionnis amicta (T.).

[Fairly common, frequenting high forest, where it sits solitary on the lower boughs of trees, making short flights after insects. It has a peculiar loud cry which I have often mistaken for the cackling of geese, wondering where the latter could be, and quite expecting to see some in one of the native campongs. Native name "Darah leihier," i. e. "blood-neck." Iris straw-yellow.]

250. Alcedo Bengalensis, Gm. [Native name "Mantis."]

251. Alcedo meninting, Holsf.

254. Ceyx dillwynni, Sharpe.

[Iris black; feet and bill coral-red.

Common. Often will the traveller see a small bright yellow bird pass him in the forest like a little express train, whistling as though it were important to let every one know it was coming. Then suddenly
252. Alcedo eURyzona, $T$.

253. Pelargopsis leucocephala (Gm.).

[Iris black; bill and feet coral-red.]

\section{Family ALCEDINID}


the whistling ceases and the bird has perehed, often at some distance away, where it sits motionless until again disturbed. It often frequents small forest-streams, but I should doubt if it ever fceds on fish. This is one of the Bornean "Burong angi," or "omen birds."]

255. Halcyon Coromanda (Lath.).

256. Halcyon pileata (Bodd.).

257. Halcyon Chloris (Bodd.).

[Common along the sea-coast perching on some elevated spot, from which it makes short darting flights on its prey, whieh is exposed at low tide. This bird has a peeuliar harsh ery, whieh is "Kang kang." The head is thrust forward and the tail cocked at right angles to the baek. They nest in holes in trees, and are generally met with in pairs. Native name "Kang kang."]

258. Halcyon CONCRETA (T.).

259. Carcineutes Melanops (T.).

260. Eurystomus orientalis (Li.).

Family Coracinde.

[Common, frequenting open places, espeeially dead trees that have been left standing after forest fires. It perehes on some high braneh, from whieh it makes short flights at inseets, returning often to the same pereh.

The note is "Kiek kiek," sounding somewhat like the noise made by eoachmen to horses.

Native name "Lahi."]

\section{Family Caprinulgidæ.}

261. Caprimulgus macrurus, Horsf.

[Common in open plaees and on the edges of forest. In the evenings it may be seen on Labuan plain in numbers sitting on the ground, making short flights from plaee to plaee. The name of "Ieebird" mentioned in Jerdon, and derived from its peeuliar note, whieh sounds exaetly like a stone thrown on thiek ice, is the best description of the sound it utters. It is met with on Kina Balu up to 2000 feet. It generally nests in open places, and I have seen a nest on the sea-shore under the shelter of a tree just above high-water mark. The eggs are two in number, laid in April and other mouths, of a pale ereamy yellow, with a slight pinkish tinge, blotehed all over with pale grey, and less so with pale brown. None of these spots and blotehes are distinet. Axis 1.25 inel, diam. 0.9. Native name "TampaKampa."

There is another spceies of Caprimulgus in Borneo, whieh I failed to obtain, but whieh is, I believe, Lyncornis temmincki, a species eommon in Malaeea, but only observed by myself about the foot of Kina Balu.]

262. Cypseius infumatus, Scl. [Fairly eommon.]

263. Collocalia fuciphaga.

Lawas River, July 1885.

264. Collocalia linchi, Horst.

270. T'reron capelilei (V.).

[Native name "Puni lanquok."]

271. Treron rerniss (L.).

[Very common in Labuan, often congregating in fairly large flocks. It nests in gardens, especially

265. Dendrochelidon comata (T.).

266. Dendrochelidon longipennis (Rafin.).

267. Chatura conacina (S. Müll.).

268. Hirundinapus giganteus (V. Hasselt).

Order COLUMBE.

Family Cypselide. 
in orange-trecs, where it makes a frail nest and lays two white cggs (axis 1.1 inch, diam. 0.85 ) about the middle of May and at other dates.

This specics has a bcautiful cye, the iris being composed of rings of yellow, pink, and bluc; bill green; feet dull pink.]

272. Treron baramexsis (Meyer).

[Apparently only a migrant to Labuan, where it occurs rarely.]

273. Pthlopus jambu (Gm.).

[Native name "Puni Gumballi.]

274. Carpophaga menea ( ( L. $_{\text {. }}$.

[Iris dark lake; tip of bill blue; the rest muddy lake-red, like the feet.

Common in the forests, feeding on fruits high on the tops of the trees, often out of shot. This Pigeon has a loud booming "coo."

Native name "Pergum."]

275. Carpophiga badia (Raffl.).

This fine Pigcon is now recorded from Borneo for the first time.

[Iris pale dull yellow; skin round eye and on the nostrils and feet muddy pink.]

276. Carpophaga bicolor (Scop.).

[Iris black; skin round eye, nostrils, and fect dull slaty blue; rest of bill black.]

277. Chalcophaps indica (L.).

[Common in the S.E. monsoon, when this little Pigeon is caught in hundreds by the natives, who build a small covered place on the ground, round which they place some grain, and then attract the Pigeons with a peculiar banboo calling-instrument, with a booming note like that of the birds (cf. Burbidge, P. Z. S. 1879, p. 347). The Pigeons then settle, and are noosed in numbers by the native only a few fect off. This bird has a tender skin, and is difficult to preserve neatly. The flesh is very sweet and much sought after by all in the East. Where these Pigeons come from, or where they go to, I am unable to say; but I never met with a native who had seen their nest.

Native name "Punei tanah," or "Earth Pigeon."]

278. Macropygia mitliana, Bp.

279. Macropygta RUFtceiss (T.).

This is the first rcally authentic record of its occurrence in Borneo.

280. CaLeenas nicobarica, L.

[A fresh-killed bird is covered with grey powder on the head, breast, and neck, which adds greatly to its beauty.

Native name "Burong Jinguni."”]

Order GALLINÆ⿸

Family Phastantd

281. Argusianus Grayi (Elliot).

[Native name "Burong Krūhi."]

\section{Family Perdicide.}

282. Bambusicota erythrophrys, sp. n., Sharpe.

$\delta$ ad. Similis B. Typerythrce, sed capitis latcribus et facie laterali aurantiaco-rubris distinguenda, gutture nigricante. Long. tot. 10, culm. 95 , alæ 5.8, caudæ 1.8, tarsi 1.85 poll. Angl.

o ad. Mari similis, sed gutture minime nigro.

[This Partridge frequents the thick bamboo-jungle on the stecp slopes of Kina Balu from 2000 to 
4000 feet. It was extremely difficult to obtain specimens owing to the impossibility of getting about in the parts frequented by these birds. Besides, no doubt, the rat-trupping Dusuns have had something to do with their rarity. pink.]

Iris greenish brown; bill blaek; skin round eye dull pink, that on throat brighter; legs salmon-

283. Arbotophila charltont (Eyton).

[Native name "Lenticong."]

284. Rollulus Rouloul (Scop.).

285. Excalfactoria ChINENSis (L.).

[Common in open plains, and found on Kina Balu up to 1000 feet. These birds nest in the "lalang"-grass plains, and lay five or six dark olivc-green eggs, which are speckled all over with black and dark-brown spots; axis 1 inch, diam. $\cdot 85$. I found a nest in the middle of February, and have seen them in other months.

Feet orange-yellow; iris lake-brown; bill black.]

\section{Family Megapodide.}

286. Megapodius cumingi, Dillwyn.

[On most of the small islands round the coast of Borneo this Megapode, of whieh the native name is "Menambun," is very plentiful. It never secms to frequent the country more than a few hundred yards inland, but prefers the loose sandy soil close to the sea, where it can scratch up those huge mounds which so often attraet one's attention when walking near the sea-eoast.

Whilst in Palawan I had a good opportunity of watehing these birds, for they were very plentiful, June to August being their nesting-months. The old birds are difficult to see, owing to their dull brown colour. They are very shy and generally run off long before you are near them. Their note is a most doleful "Mōw," exactly like a cat in distress, and is heard many times towards evening, adding to the melancholy of the forest.

Their nest is a most wonderful structure, and is no doubt built by the labour of several pairs of birds. A Sulu boy eaught seven or eight birds on one heap. The largest nest I have seen was 34 paces round and $5 \frac{1}{2}$ feet high, and the heap must have contained many cartloads of earth, stieks, and stones, and yet the ground round about was apparently untouched. How such a heap is brought together is a mystery; but it is no doubt the gradual work of many birds for several years; for the birds, if not molested, use the same heap many seasons. The eggs are buried so deep that with our small implements (a coeoa-nut shell) we found it impossible to get at them. The eggs are often placed amongst the roots of a tree, and this makes them very difficult to get at. A good many green leaves are plucked and placed in the hole, and amongst these the egg is laid. The leaves would ferment and so assist in hatching the eggs, which arc of a pale salmon-eolour with a chalky surface, which is easily chipped off. The Dusuns make regular egging-expeditions, and often brought the eggs to me, to be exehanged for two or three smokes of tobacco.

The young bird's early life is to me a mystery. It may be dug out of the heap fully fledged and ready to fly. I sent one home with my collection which might pass for an adult bird of another species; but this bird had never seen the daylight until we dug it out; none of the feathers had soft shafts or seemed in any way new. The young are neither fed nor looked after by their parents, which, as they are of all ages, would be difficult. They generally squat until you are within 15 yards or so and then take wing like a Quail, never running out of danger like the old birds.] 


\section{Order GRALL伥. \\ Family Charadrides.}

287. Esacus magnirostris (G. St.-Hil.).

[T'his large Stone Plover is seldom met with on the eonst of Borneo. During my four years' eollecting in the East I only saw three individuals. They frequent the sandy bays, either singly or in pairs. I onee saw one of these Plovers hunting the large sand-crabs whieh abound at low water on the consts. These crabs have wonderful power of dodging, stopping dead, and then rumning at full speed in the opposite direction; so it took the Plover some long time before it eould deal the erab a blow with its powerful beak.]
288. Squatarola helvetica (L.).
289. Charadrius fuluvus (Gm.).
290. \#gialitis PERoNi (T.).
291. Egralitis cantiana (Lath.),
292. Alaialitis dubia (Seop.).
293. Aegialitis georfroyi (Wagl.).
294. Glareola orientalis, Leach.
295. Strepsitas interpres (L.).
303. Scolopax megala, Swinh.

296. Tringa ruficollis (Pall.).

297. Tringa subminuta (Midd.).

298. Tringoides hypoleucus (L.).

299. Totanus glareola (L.).

300. Totanus brevipes (Gm.).

301. Numenius uropigialis (Gould).

302. Scolopax gallinago (L.).

This is the first authentic instance of this speeies having been found in Borneo.

304. Hypotanidia striata (L.).
305. Ralima fasciata (Raff.).

308. Ardea sumatrana, Raffl.

309. Ardea purpurea, L.

310. Demiegretta sacra (Gm.)

313. Ardelala speciosa (Horsf.).

[Only one speeimen met with in Borneo, but in Java, where there is much open riee-land, this species is very common. Often enough, when passing a field, you do not observe this little Heron until suddenly dozens of snow-white wings (the small and dull-eoloured body being diffieult to see) open and slowly flap away.]

314. Butorides javanica (Horsf.).

315. Gorsachius melanolophus (Raft.).

316. Ardetta chnamonea (Gm.).

Family Ciconirde.

319. Leptoptilus javanicus (Horsf.).

320. Mareca penelope (L.).
317. Ardetta sinensis ( $\mathrm{Gm}$. .).

318. Nycticorax manilleasis, Vig.
306. Ortygonetra cinerea (V.).

307. Erythra phenicura (Penn.).

311. Herodias torra, Frankl.

312. Bubulcus coromiandus (Bodd.).

\section{Order ANSERES. \\ Family Anatide.}


321. Fregata minor (Gm.).

\section{Family Pelecanide.}

322. Plotus melanogaster (Penn.).

323. Sterna Bergit, Steph.

Family Larid $x$.

324. Anous leucocapillus, Gould.

It will be seen that Mr. Whitehead's expedition added to the avifauna of Borneo no less than 25 genera, as follows :-1. Heteroscops, 2. Chlamydochara, 3. Hemichelidon, 4. Muscicapula, 5. Tarsiger (vel Nitidula), 6. Cryptolopha, 7. Horomis, 8. Geocichla, 9. Oreoctistes, 10. Henicurus, 11. Phyllergates, 12. Staphidia, 13. Chlorocharis, 14. Brachypteryx, 15. Orthnocichla, 16. Garrulax, 17. Allocotops, 18. Androphilus, 19. Corythocichla, 20. Turdinulus, 21. Pteruthius, 22. Chlorura, 23. Psarisomus, 24. Cyanops, 25. Arborophila.

Moreover, Mr. Whitehead procured examples of 69 species not before known from Borneo:1. Accipiter rufotibialis, 2. Spilornis bacha, 3. Heieroscops lucice, 4. Cissa jefferyi, 5. Oriolus vulneratus, 6. Hemipus picatus, 7. Artamides normani, 8. Chlamydochara jefferyi, 9. Pericrocotus cinereigula, 10. P. montanus, 11. Hemichelidon cinereiceps, 12. Muscicapula hyperythra, 13. M. maculata, 14. Xanthopygia narcissina, 15. Tarsiger hodgsoni, 16. Rhipidura allicollis, 17. Rhinomyias ruficrissa, 18. R. gularis, 19. Cryptolopha trivirgata, 20. C. montis, 21. Stoparola cerviniventris, 22. Horornis oreophila, 23. Geocichla aurata, 24. Merula seebohmi, 25. Erithacus cyaneus, 26. Chloropsis kinabaluensis, 27. Hemixus connectens, 28. Oreoctistes leucops, 29. Henicurus borneensis, 30. Phyllergates cinereicollis, 31. Staphidia everetti, 32. Chlorocharis emilix, 33. Brachypteryx erythrogyna, 34. Orthnocichla whiteheadi, 35. Garrulax schistochlaniys, 36. Allocotops calvus, 37. Stachyris borneensis, 38. Turdinus canicapillus, 39. T. magnirostris, 40. Mixornis montana, 41. Androphilus accentor, 42. Corythocichla crassa, 43. Turdinulus exsul, 44. Iyloterpe hypoxantha, 45. Ptemuthius cralatus, 46. Dendrophita corallipes, 47. Arachnothera julio, 48. Zosterops auriventer, 49. Z. clara, 50. Dicaum monticola, 51. Anthus richardi, 52. Chlorura borneensis, 53. Calyptomena whiteheadi, 54. Psarisomus psittacinus, 55. Harpactes whiteheadi, 56. H. orescius, 57. Cyanops pulcherrima, 58. C. monticola, 59. Hierococcyx nana, 60. H. bocki, 61. Cuculus noliocephalus, 62. Anorrthinus comatus, 63. Carpophaga badia, 64. Macropygia ruficeps, 65. Bambusicola erythrophrys, 66. Arborophila charltoni, 67. Tringa subminuta, 68. Scolopax megala, 69. Arachnothera affinis (var.).

Of the 198 genera and 286 species it will be found that 74 genera and 127 species are, so far as we know, inhabitants of the lowlands of Borneo only, and do not ascend the slopes of Kina Balu at all.

This leaves us a total of 124 genera and 159 species which are known to occur on the mountain. By adding Rallina fasciata and Butorides javanica from the Wading-birds, we have the exact number of species found on Kina Balu by Mr. Whitehead, viz. 161, representing 126 genera. 


\title{
ON THE BIRDS OF PALAWAN.
}

\author{
[From 'The Ibis.']
}

THE following account of the birds found in the Island of Palawan, with descriptions of several new species collected by ne, appeared in 'The Ibis' for 1888, in a paper by Dr. Sharpe. In the same Journal for 1890, I wrote a paper giving any notes I had collected on the ornis of this Island, and described the Buchanga under the name of $B$. palavanensis. I also added to the list the names of any species found by Dr. Platen and not obtained by myself. The present paper is a compilation of the two papers of Dr. Sharpe and myself, the only alteration that $I$ have since made being the separation of the Palawan Cryptolopha as a new specics under the name of $C$. xanthopygia: hitherto this species has been confounded with C. montis of Borneo, from which it is easily distinguished.

I left Labuan on 18th June, 1887, in a small trading-steamer belonging to a Chinaman who had several stores on the southern end of Palawan. The steamer landed us at Taguso, on the S.E. coast (many miles south of Puerto Princesa), promising to return in two and a half months; but as she did not turn up till nearly four, I was unable to change my collecting-ground to the N.W. coast, as I had intended.

I will now give some account of our collecting-grounds. The coast is fringed with high forest, reaching inland about a mile; this fringe is probably left by the natives to break the wind and to shelter their rice-crops. In the forest Megapodes abound, Pittas and Jungle-fowl are plentiful, and, more rarely, that prince of birds, Polyplectron. In the trees above the most numerous birds are the various species of Pigcons and Parrots, but nearly all the small species in the following list may be met with.

Behind this band of forest are plains of coarse grass, inhabited by two species of Turnix; Cisticolce and Centrococcyges and a few white Egrets attend the Sulu cattle. This sort of scenery continues until you reach the foot of the mountains, no great distance from the coast. When the great rush of birds from the north takes place these plains have a much more lively aspect; hundreds of Wagtails, Pipits, Snipes, and other small Waders are continually flying up on your approach.

The swamps at the river-mouths have also their occupants-Sunbirds, Rhipiduras, and several species of Herons and Kingfishers, which are not met with elsewhere.

Towards the middle of September, after we had collected all the resident species within our reach, the sea-coast, with its rocky points and cstuaries, was by far the most attractive hunting-ground; for about that time the great winter migration from the north reaches the coasts and forests of Palawan. Most Waders passed between 5 and 6 P.M., all in one direction, S.W.; if a small flock settled and was disturbed, never did the birds return, but still hurried on their southward course. By continuing this line of flight they would touch Balabac, and then turn due south down to the coast of Borneo, where some remain for the winter, but most seem to travel further still. When the wind was blowing gales from the S.W., bringing up heavy clouds loaded with rain, then was the liveliest time for migrating; on calm, and evcn moderate, days it was seldom worth while to visit the coast. All these great travellers were as fat as butter, and in no state for a bird-collector.

The number of species as yet recorded from the island of Palawan is 157, of which 37 are peculiar to that island, 19 are found only in the Philippines, 36 in the Malayan, but not in the Philippine region, and 13 are common to both regions. Then there are no less than 49 migrants, which distribute themselves over the Eastern Archipelago during the northern winter. One species (Dendrophita frontalis) is Malayan and not Bornean, and one (Agithina viridis) has been hitherto only found in Borneo and Sumatra; lastly Gallus bankira, which is found throughout the Malayan and Philippine regions, but of which I believe no specimens are as yet known from Borneo. 
Of 37 specics peculiar to the island, 4 only have thcir gencric allies confined to the Philippines; 4 others are forms distinct from those of cither the Malayan or Philippine regions.

The Malayan forms predominate by 36 , as against 19 from the Philippines ; but there is a curious absence of several weak-winged Malayan genera, such as Trogons and Barbets, in the list. The Timeliine birds are all peculiar to Palawan, and the two Pittas arrive from the Philippines ; so that if there ever was any connexion betwecn Palawan and Borneo, or with any other Malayan territory now more remote, it must have existed for only a short period of time. As yet, I believe, no species of Merops has been met witl in Palawan, which is curious, as in the large adjacent islands this genus is very plentiful.

The specics in the following list peculiar to Palawan are marked thus $\dagger$.

Migrants $*$.

P. = Philippine region only.

Mi. = Malay region only.

1. Cacatua h matuturopyeia (L. S. Müll.). P.

Common; generally met with in pairs; has a slow flapping flight, and often screams when on the wing. During the heat of the day Cockatoos rest in the shade high up in the trees, where they carry on their flirtations, screaming and erecting their crests and performing many antics. Towards crening they fly in flocks to the rice-ficlds, doing much harm before the harvest.

Eye black, orbit white ; bill pale bluc, white at the tip ; feet dull blue. Sulu, "Agi."

2. Tanygnathus leuconensis (L.). P.

Very common. This Parrot is one of the first birds that attract the traveller's attention in Palawan, as it flics swiftly from forest to forest in small flocks, screaming loudly. In flight the wings are oftcn kept much bclow the level of the body. This species frequents the tops of high trees, feeding on various jungle fruits, but often during the heat of the day they hide amongst thick-foliaged trees only a few fect from the gromul, from which they dash out with loud screams when disturbed.

Bill rosy red ; feet horny green ; the pupil black, with a small black ring round it.

3. Priontturus cyaneiceps, sp. n., Sharpc. †.

Similis $P$. discuro, sed pileo toto ct cervice cum capitis latcribus viridi-cyaneis; gutture toto, pectore ct abdomine viridi-cyaneo lavatis.

Adult male. General colour above grass-grcen, becoming clearer green on the lower back and rump, and decidedly brighter on the upper tail-coverts; curious dusky frecklings are scen on the feathers in a ștrong light; wing-coverts green, the median and greater coverts a little brighter ; bastard-wing and primary-covcrts grcen, with a bluish tinge internally; quills black, externally green, subterminally with a bluc shade, and fringed with yellow, the first primary externally blue; two centre tail-feathers bright green, with a black shaft and racket at the end, which is black edged with green: remainder green, internally blue, and with a broad band of black at the ends ; tail blue underneath ; entire head and nape, as well as thc sides of the face, ear-coverts, cheeks, throat and sides of neck verditer-blue, overspreading the under surface of the body, which is otherwise light green, but yellow towards the vent and under tail-coverts, the latter being yellow washed with green ; under wing-coverts and axillaries bright green ; $l_{\text {ower }}$ primary-coverts and immer web of quills pale blue, blackish externally and at the tips of the primaries. Total length $12 \cdot 4$ inches, culmen $0 \cdot 8$, wing $6 \cdot 1$, tail $2 \cdot 8$, long feathers $5 \cdot 6$, tarsus $0 \cdot 5$.

Young birds differ from the adult in being entirely green, without any of the beautiful verditer-blue shade on the head and ncck; the wing-coverts and secondaries edged with ycllowish green; under surface of body pale green, yellower on the throat, and bright yellow on the under tail-coverts, washed with pale green.

This beautiful little Parrakeet is nearly as common as the last species, but it was some time before I could makc them out to be different birds, owing to the swift flight of both species; then, again, the curious racket tail-feathers were not visible, ncarly all the birds being in full moult. In August, 
however, I collected some beantiful specimens of both sexes whilst they were feeding on some fruit-bearing trees only a few feet from the ground.

The raeket tail-feathers apparently grow without the web on the shaft, as in some immature feathers the stem was still buried in the shell and bare, whilst in the young of both sexes the short shafts are slightly webbed; so that it would seem that the bird does not itself destroy the web of the two eentre tailfeathers, as the Motmots are known to do.

Eye black ; bill dull white ; feet greenish.

4. Astur trivirgatus (T.). M., P.

5. Spizaetus limnaetus (Horsf.). M.

8. Haliaetus ledcogaster (Gm.). M., P.

6. Spizaktus philippinensis (Gurney). P.

9. Spilornis bacha (Daud.). M., P.

7. Butastur indicus (Gm.). *.

10. Pernis ptilonorhynchus (T.). M.

12. Hтpotriorchis severus (Horsf.). *.

I met with this little Hawk several times on the sea-eoast, and often started before daylight to a point on the eoast where it used to pass, but unfortunately never got within shot.

13. Circus spilonotus, Kaup. *.

14. Pandion haliaetus (L.). *.

15. Baza leucopais, sp. n., Sharpe.

Juv. Sinilis $B$. sumatrensi, jr., sed subtus alba ; linea mediana gutturali nulla, abdomine minime transfiaseiato distinguenda.

Adult female. General eolour above brown, with whitish-brown margins to the feathers ; lesser wingcoverts brown, the inner ones rufons, with brown eentres; median and greater eoverts pale rufous, white externally towards the ends and round the tips; bastard-wing dark brown, extemally rufous; primaryeoverts uniform dark brown; quills dark brown, fringed with white round the ends, and crossed with blaekish-brown bars, four in number, one subterminal ; seeondaries paler brown, externally rufous ; upper tail-coverts tawny rufous, edged with white and with dark brown eentres; tail-feathers dark brown, narrowly fringed with white at the ends, and crossed with blackish bands, the subterminal one very broad, but not nearly so wide as the preeeding interspaee; a erest of white feathers, the long ones freckled with brown ; head, nape and hind neek, lores, sides of faee, ear-eoverts, eheeks, sides of neek, and entire under surfaee of body pure white, slightly washed with rufous on the head and hind neck ; the breast, abdomen, and under tail-eoverts washed with ereamy buff; the sides of body and flanks with slight indications of spots of pale tawny buff; under wing-eoverts and axillaries like the breast; quills below ashy grey, with blaekish bars on the primaries. Total length $15 \cdot 5$ inehes, eulmen $1 \cdot 15$, wing $10 \cdot 8$, tail $7 \cdot 0$, tarsus $1 \cdot 4$.

The typical specimen, though manifestly immature, differs thoroughly from the young of $B$. sumatrensis, and I feel sure that the adult bird, when diseovered, will be markedly distinet.

If this speeies is confined to Palawan, it will be interesting to find a strong-winged bird keeping to such a limited area. I rather expect that it will be met with in the Philippines, whieh are so near to the eastern parts of Palawan.

16. Syrnium whiteheadi, sp. n., Sharpe.

S. similis $S$. sinensi, sed suhtus minime albo transfasciatum.

Adult male. General eolour above chocolate-brown, spotted with white, the spots arranged in pairs, the one on the inner web often fulveseent ; seapulars forming a light patch of tawny buff, covered with narrow bars of choeolate-brown; lesser wing-coverts dark ehocolate-brown, with scarcely any white spots; median and greater eoverts more reddish ehoeolate-brown, transversely barred with white, slightly tinged with tawny buff; bastard-wing and primary-eoverts uniform blackish brown ; quills brown, erossed with lighter and more rufous-brown bars, whiter near the edge, espeeially of the seeondaries, which are slightly freckled externally; the innermost seeondaries spotted with white, like the back; upper tail-corerts like the back, but barred with tawny buff or whitish ; tail-feathers dark chocolate-brown, barred with tawny 
buff or creamy white, with which the tail is conspicuously tipped, the light bars, seven in number, on the centre feathers, broader and coalcscing on the remainder; crown of head like the back, thickly spotted with white, the spots arranged in pairs; feathers on the hind neck with concealed bases of tawny buff; the mantle somewhat more uniform brown; sides of face chestnut, deeper about the eyes and on the earcoverts, which arc whiter posteriorly ; ruff dark chocolate-brown, barred across with rufous ; chin rufous, followed by a broad white patch, narrowly barred with black; remainder of under surface of body tawny rufous, narrowly barred across with blackish brown, including the thighs and under tail-coverts; fore neck with broad bands of white and clocolate-brown; under wing-coverts and axillaries like the breast; quills below dusky brown, barred with yellowish buff, these bars broader towards the base of the inner web. Total length $17 \cdot 5$ inches, culmen $1 \cdot 35$, wing 13 , tail $7 \cdot 5$, tarsus $2 \cdot 3$.

Its nearest ally is Syrnium sinense, but it is easily distinguished from that species by its rufescent under surface, with the absence of white bars.

The loud "hoo, hoo," of this fine Owl first attracted my attention, I remember, one evening when returning to the shed under which we lived, being quite startled by the loudness of its note. I scveral times saw these birds during the day in the swamps, but they had probably been disturbed from the forests close at hand. On the mountain inland I heard several.

Orbit pink; eye and bill black.

17. Scops eVEretti, Twedd. $†$.

18. Ninox borneensis (Bp.). *.

19. Thriponax hargitti, Sharpe. $\dagger$.

20. Chrysocolaptes erythrocephalus, Sharpe. + .

21. Tiga everetti, Tweedd. †.

22. Mulleripicus pulverulentus ('Temm.). M.

23. Eurystomus orientalis (L.). M., P.

24. Alcedo bengalensis, Gm. *.

25. Alcedo astatica, Swain. M.

26. Pelargopsis gouldi, Sharpe. P.

27. Chyx rufidorsa, StrickI. M.

28. Halcyon pileata (Bodd.). *.

29. Halcyon coromanda (Lath.). M., P.

30. Halcyon chloris (Bodd.). M., P.

44. Eudynamis mindanensis (L.). P.

The Palawan Cuckoo passes all day in the tops of the high jungle-trees (often quite out of shot), seldom going amongst the outside branches, but preferring to hop about well under shelter from sun and Hawks. This bird is very tenacious of life and requires a severc wound to bring it down. I never heard or shot an adult bird after the middle of August, when perhaps it migrates to Borneo and other islands, as most of the birds in Labuan are seen after Scptember during the N.E. monsoon. (See above, pp. 145, 146.)

45. Dryococcyx harringtoni, Sharpe. $\dagger$.

46. Centrococcyx eurycercus, Cab. \& Hcine. M.

47. Centrococcrx afeinis (Horsf.). M.

48. Ijanius lucionensis (L.). *.

49. Graucalus sumatrensis (S. Müll.). M.
31. Anthracoceros lemprieri, Sharpe. $\dagger$.

32. Chatura gigantea (V. Hasselt). M.

33. Collocalia troglodytes, Wallace. P.

35. Batrachostomus cornutus (Temm.). M.

36. Caprimulgus macrurus (Horsf.). M.

37. Caprimulgus manillensis, G. R. Gray. P.

38. Cuculus sonnerati, Lath. *.

39. Cuculus canoroides (L.). *.

40. Cocomantis merulinds (Scop.). M., P.

41. Hierococcyx strenuus, Gould. *.

42. Chrysococcyx xanthorhynchus, Horsf. M.

43. Surniculus lugubris (Horsf.). M.
34. Collocalia fuciphaga, Thumb. M., P. 
53. Pericrocotus civereus, La Fresn. *.

Eye, fect, and bill black.

54. Hýoterpe whitehead, sp. n., Sharpe.

H. affinis $H$. grisola, sed supra olivascenti-brunnea, pileo dorzoque concoloribus ; tectricibus alarum cinerascenti-brumneis nec rufescenti-brumneis distinguenda.

Adult female. General colour above dingy mouse-brown, the head like the back; wing-coverts rather more ashy than the back; bastard-wing and primary-coverts brown ; quills dark brown, edged with ashy brown, the secondarics margined witl rufous towards the ends; upper tail-coverts and tail-fcathers aslyy brown ; lores and feathers round the eye ashy grey ; ear-coverts brown, like the head ; cheeks ashy grey, as also the throat and hreast, the latter slightly washed with brown ; lower breast and abdomen white ; sides of body and flanlss somewhat washed with ashy; thighs white, with ashy bases; under tail-coverts white; under wing-coverts and axillaries white, with ashy bases ; quills below dusky, ashy along the inner edge. Total length $5 \cdot 7$ inches, culmen $0 \cdot 65$, wing $3 \cdot 15$, tail $2 \cdot 3$, tarsus $0 \cdot 75$.

Scarce ; met with in old forest.

55. Chibia palawanensis (Tweedd.). †.

Fairly common, frequenting the edges of forest.

56. Buchanga Palawanensis, sp. n. (Whitehead). †.

This species is not $B$. leucophcea, being a smaller and much darker bird, and having a jet-black patch of feathers over the nostrils. The eye in $B$. leucophcea is brick-red, and in this new species dark grey, so I venture to describe it under the name of Buchanga palawanensis.

Adult male. General colour above dark steel-grey. Wings darker and with a greenish gloss ; quills black: inner web of primaries sooty black. Tail near the base slightly lighter than the back, but deepening to sooty black at the end, with a slight greenish gloss. Nasal bristles and a small part of the forehead next the bill black ; feathers round eye and ear-coverts sooty black. Under surface dark steelgrey, without much gloss on the throat; under wing-coverts sooty grey, with stecl-grey edgings. Bill and legs black; iris dark grcy. Total length $9 \cdot 5$ inches ; tail to tip of outer feather $4 \cdot 8$; wing $5 \cdot 2$.

Female. Like the male, but slightly smaller.

57. Hemichelidon sibiricus (Gray). *.

58. Rhipidura nigritorquis, Vigors. P.

59. Siphia lemprieri, Sharpe. †.

60. Siphia erithacus, sp. n., Sharpe. $\dagger$.

Adult male. General colour above rufous brown, with a slight olivaceous tinge ; lesser wing-coverts like the back; median coverts, greater coverts, bastard-wing, primary-coverts, and quills blackish brown, more or less broadly edged with the samc colour as the back, a little more rufous on the latter ; upper tailcoverts and tail-feathers bright chestnut ; crown of head like the back, slightly washed with olive ; lores ashy grey ; feathers round the cye dusky ; ear-coverts olive-brown, washed with tawny ; cheeks, throat, and chest orange-rufous ; breast and abdomen pure white, as well as the sides of body and flanks; thighs dusky brown; under tail-coverts pale tawny rufous; under wing-coverts and axillaries white; quills bclow dusky, whitish along their inncr edgc. Total length $4 \cdot 2$ inches, culmen $0 \cdot 55$, wing $2 \cdot 35$, tail $1 \cdot 7$, tarsus $0 \cdot 8$.

Adult female. Similar to the male, but with the lores more tawny. Total length $4 \cdot 2$ inches, culmen $0 \cdot 5$, wing $2 \cdot 25$, tail $1 \cdot 5$, tarsus $0 \cdot 7$.

Fairly common, frequenting the low and tangled growth near the ground in old forest. I found a nest of this species on the lower slopes of one of the mountains; it was placed amongst some dcad palmleaves, about three feet from the ground, and composed of the same leaves, but lined with finc plant-stalks. The cggs were two in number, of a pale blue colour, slightly spotted at the larger end with red.

Eye black ; mandible black, lower light cobalt ; feet whitc. 
61. Xantholestes Pavayensis, Shatpe. P.

62. Cryptolopha xanthopygia, sp. n. (Whitehead).

Similar to C. montis (Sharpe), but differing from that species in baving the entire rump sulluhuryellow and the bill considerably larger.

This, perhaps the most interesting discovery of my expedition to Palawan, throws a light on what may be expected from the highlands of that island, viz. that they will probably be found to have an ornis similar to that of the highlands of Borneo. I discovered a new species on Kina Balu (Borneo), C. montis, and met with this allied form in Palawan, on the top of a small mountain about 2000 feet high, and this is the only highland form as yet procured in Palawan.

63. Muscicapa griseisticta (Swinhoe). *.

68. Hirundo javanica, Sparrm. M., P.

$63 a$. Hemicheitidon Sibirica.

69. Oriolus palawanensis, Sharpe. †.

64. Нуротнтміs azurea, Salrad. M., P.

70. Oriolus xanthonotus, Horsf. M.

65. Zeocepraalus cyanescens, Sharpe. †.

71. Pitta sordida (L. S. Müll.). P.

66. Aurocephaluds orientalis (Bp.). *.

72. Pitt'a erpythrogastra (Temm.). P.

67. Hirundo gutturalis (Scop.). *.

73. Turdinus rufifrons (Tweedd). †.

74. Mixonis woodi, Sharpe. †.

I found a nest of this species, which was placed in a creeping bamboo, about three feet from the ground, and contained two eggs, which were white spotted with red. The nest is a loose ball of leares slightly lined with fine stalks.

75. ANURopsis CINEREICEPS (Tweedd.). †.

Scarce, frequenting the thick tangled masses of jungle. I took a nest of this species on 2nd September, which was placed close to the ground and made of bamboo-leaves; it contained two blue eggs thickly speckled with dark brown.

76. Petilocichla falcata, Sharpe. †.

80. Eigithina viridis (Bp.).

77. Irena tweeddalit, Sharpe. $\dagger$. Borneo and Sumatra only.

78. Pychonotus cinereifruass (Tweedd.). †.

81. Micropus melanocephalus (Gm.). M.

79. Phyliornts palatwanensis, Sharpe. $\dagger$.

82. Iole striaticeps, sp. n., Sharpe.

I. similis $I$. viridescenti, sed magis brunnea, cauda pallide rufezcente, pileo brunnescente, anguste griseo lineato, et dorso vix striolato, facie laterali grisescenti-olivacea, angustissime albiclo striolata distinguenda.

Adult female. General colour above olive-brown, with narrow whitish shaft-streaks to the feathers of the mantle and back ; the lower back and rump uniform, the feathers of the latter very loose and fluffy and with pale tips; lesser wing-coverts brown, with a wash of olive; bastard-wing and primary-coverts dusky brown, with a reddish tinge and washed with olive externally; quills dark brown, externally pale olive-brown, rather more rufous towards the base of the secondaries; upper tail-coverts and tail-feathers light reddish brown, with a slight edging of olive; crown of head brown, slightly contrasting with the back, all the feathers with narrow ashy white shaft-streaks; lores white, with a yellowish tinge ; feathers below the eye and ear-coverts light brown, washed with yellow and having narrow whitish shaft-streaks; cheeks and under surface of body ashy white, with a strong tinge of yellow, the breast, abdomen, and under tail-coverts clearer yellow ; sides of body and flanks washed with olive-brown; thighs pale yellow ; under wing-corerts and axillaries pale yellow; quills below dusky brown, yellowish along the edge of the inner web. Total length $6 \cdot 6$ inches, culmen $0 \cdot 7$, wing $3 \cdot 2$, tail $2 \cdot 75$, tarsus $0 \cdot 75$.

83. Crintger frater, Sharpe. †.

85. Monticola solitaria (P. L. S. Müll.). *.

84. Ćriniger palawanensis, Tweedd. $\dagger$.

86. Cittocincla nigra, Sharpe. †. 
87. Phylloscopus borealis (Blas.). *.

88. Cisticola cisticola (Oates). M.

89. Onthotomus Ruficeps (Less.). M.
90. Motacilla flava, L. *.

91. Anthus gustavi, Swinh. *.

92. Anthus maculatus, Hodgs. *.

93. Parus amabilis, Sharpe. $\dagger$.

This beautiful little Titnouse is fairly common in the forest, frequenting the ligh trees in small parties, probably families. The young were fully fledged in the beginning of September.

The description of the adult female (in B. M. Catalogue, vol. viii. p. 22) from typieal specimens collected by- Professor Steere really applics to the adult male only, so I take it that they were wrongly sexed.

Adult female. Head greenish black, sliglitly greener on throat; a pale yellow eollar at the back of the neck; back olive-green, slightly grey on the rump. Upper tail-coverts greenish black; tail brownish black, tipped and marked as in the male, but to a very muel less degree. Wings dark brown, marked as in the male, but not nearly so pronounced; primaries externally washed with greenish yellow, but quills not tipped with white; rest of the under surfaee slightly duller than in the male.

The young are brown above, more greenish on the lower back, with a distinet yellow collar, as in the female; bencath pale yellow, with a slightly greyislı tinge on the throat. Some young males have the adult plumage on the throat and breast, but the baek is mueh mingled with immature feathers, which have faded into rusty brown. The white spots on the wings and tail often become worn off.

94. Dendrophila frontalis, Horsf. M. (but not Bormean).

This Nuthateh is fairly common in the morc open country, especially amongst the dead trecs, which are left standing, often in numbers, in the rice-fields. This, curiously enough, is not the Bornean speeies, D. corallipes (which has bright-red legs, and is of a richer colour in plumage), but is the true $D$. frontalis of Java, Sumatra, and other islands. Thus it is doubtful whether Dendrophila frontalis reached Palawan viâ Bornco. D. cenochlamys of the Philippines is more like the Bornean species, both being morc brightly coloured than $D$. frontalis, but the Philippinc bird is brown-legged like $D$. frontulis. The orbital skin of the typical D. frontalis is lemon-yellow, that of the Palawan D. frontalis grey.

Sulu, "Baltēlik."

Eye straw-yellow ; bill vermilion ; orbital skin grey ; legs light brown.

95. Mrzanthe PygMeA (Kittlitz). P.

96. Prionochilus johannz, sp. n., Sharpe. †.

$P$. similis $P$. vanthopygio, sed mento et fascia supragenali albis distinguendus.

Adult male. General colour above dark slaty blue, with a broad band of yellow across the rump; wing-eoverts like the back; bastard-wing, primary-eoverts, and quills blackish, edged with slate-blue; upper tail-eoverts slate-blue ; tail-feathers black, with slate-blue margins; crown of head dark slaty blue, with a large patch of scarlet in the centre of the hinder crown; sides of faee, ear-coverts, sides of neck, and sides of upper brcast slate-blue, with a distinct white cheek-stripe, followed by a line of slate-blue along the sides of the throat, and joined to the hinder cheeks and ear-eoverts; ehin whitish; remainder of under surface bright yellow, the chest with a scarlet pateh in the centro; abdomen and sides of vent and under tail-coverts yellowish white; sides of body and flanks yellow, with a greenish tinge ; thighs slate-grey; under wing-coverts and axillaries white; quills below blaek, white along the inner edge. Total length $3 \cdot 4$ inches, culmen $0 \cdot 45$, wing 2 , tail $1 \cdot 05$, tarsus $0 \cdot 55$.

Dr. Sharpe did not describe the female, so I add a description :-General colour above olive-green, with a bright yellow patch on the rump; head slightly grey, with a dull ycllow patch on the crown ; wing-coverts and tail brownish black, edged with greenish yellow; primaries edged with grey ; sides of face and ear-coverts grevish brown, with a distinet white eheek-stripe, followed by a brown line along 
the side of the throat; under surface bright yellow, slightly deeper on the fore neck; throat almost white, slightly mingled with yellow; flanks dull greyish yellow.

This species has a longer bill than $P$. xanthopygius of Borneo, its nearest ally.

97. Cinnyris sperata, L. P.

98. Cinnyris aurora (Tweedd.). †.

On a large plain, studded here and there with clumps of bamboo and low trees, I collected a few pairs, all of which had nests, on the 29th June. The nests hang from the ends of the boughs, often in a very exposed position. The eggs are two in number, and are similar to those of C. pectoralis.

99. Chalcostetha insignis (Jard.). M.

100. Æֶthopyga SHelleyi, Sharpe. $\dagger$.

Fairly common, frequenting the edges of old forest.

The female is, I believe, undescribed, and is above bright olive-green, greyer on head and rump; wings brown outwardly, edged with reddish brown. Two centre tail-feathers olive-green, with a black blotch near the tip, which in certain lights is metallic green; rest of tail black, tipped with olive-yellow, edged outwardly near the base with reddish yellow. Under surface greyish olive on the sides of the face, throat, and breast; abdomen pale yellow, deepening on the under tail-coverts.

Faded females are dull brown above; pale greyish brown on the throat, breast, and flanks.

101. Aлthrepties malaccensis (Scop.). M.

102. Arachnothera dilutior, Sharpe. $\dagger$.

103. Corone pusilla (Tweedd.). †.

Plentiful in all old jungle, feeding entirely on fruit. This species never seems to settle on the ground or to visit the vicinity of native villages, and I never saw it near the Sulu cattle. Here we find in Palawan an interesting member of the (row family which has attained none of the pernicious habits that make his more civilized brethren in other parts of the globe so renowned. It will be interesting to see if, when Palawan becomes opened up for planting and its forcsts destroyed, its Crow will become more civilized too, and change its present mode of life into that of a garbage-eating pilferer. I am afraid civilization will benefit the Crow as little as it does the native, so that our philanthropic European race will improve them both, as it generally does, off the face of the earth.

But to return to the Crow : it is, no doubt, one of the most interesting birds in Palawan, and may often be noticed making flights from forest to forest, with neck outstretched, and uttering a peculiar "Ka-ka-gug-gug" note. During flight the wings are often held below the body, the primary feathers only being used with a quick flittering motion.

104. Sturnia violacha (Bodd.). *.

105. Calornis panayensis (Scop.). P.

106. Eulabes palatanensis, Sharpe. †.

107. Oxycerca everettit, Tweedd. $\dagger$.

108. Munia Jagori, Cab. P.

109. Treron vernans (L.). M.

110. Treron Nasica, Schlegel. M.

111. Carpophaga exne (L.). M.

120. Polyplectron napoleonis, Less. $\dagger$

This splendid little Pheasant is scarce and local, all my specimens having been collected in one forest, and although my men set hundreds of snares in other forests we never met with another during
112. Carpophaga bicolor (Scop.). M.

113. Ptilopus lieclancheri, Bp. $P$.

114. Ptilopus melanocephalus, Forster. M.

115. Turtur dussumieri (Temm.). $\quad P$.

116. Turtur tigrina (Temm.). M.

117. Calienas nicobarica, L. M.

118. Chalcophaps indica (L.). *.

119. Macropygia tenuirostris, G. R. Gray. P. 
three months. One female was eaten by a wild cat in one of the traps, and I rather expect this little tiger destroys numbers of this beatiful bird.

This species, like the Argus Pheasant, has its "showing-off" arena, a neatly-swept patch some three or four feet in diameter; the chosen spot is generally in some unfrequented part of the forest. I often noticed that this ring had a small lump of earth in the middle, where no doubt the male birds show off their splendid plumage and perhaps do battle. Their battles, if they have any, must be very short and decisive, as the double spurs of the cock would be sufficient to cut his adversary into pieces.

I am inclined to think that the birds pair and are not polyganous, as we collected three pairs; but that was not during the nesting-season, which is probably in the months of December and January.

Eyc dark hazel; skin round eye and patch on cheek of the male reddish pink; legs blackish brown.

Mr. A. H. Everett gives the name as "Tandikan"; but the natives of Palawan call it in Sulu "Malāk" and in Dusun "Bertik."

121. Gallus bankiva, Tcmml. M., P.; but, as yet, not found in Borneo.

122. Excalfactoria chinensis (L.). M.

123. Turntx nigrescens, Twcedd. P.

This species is fairly common on the coarse grass plains, espccially in dry localities, where the grass is poor. If flushed more than once it would often fly straight into the forests which bordered these plains, thus rendering further pursuit impossible.

On the 3rd of September I found a nest containing thrce eggs hard set. The birds had made a decided nest of grass-stems amongst some tufts of grass and low-growing shrubs in a stony place. The eggs are of a dull greenish grey, finely speckled all over with black. The male was sitting.

123 a. Megapodus cumingi, Dillwyn.

124. Egialitis geoffroyi (Wagl.). *.

125. \#agalitis dubius (Scop.). *.

126. Egalalitis cantiana (Lath.). *.

127. Tegialitis mongolica (Pall.). *.

128. EGalatitis veredus (Gould). *.

129. Egraltits peroni (T.). M.

130. Charadrius fulvus (Gm.). *.

131. Charadrius helveticus (L.). *.

132. Strepsilas interpres (L.). *.

133. Esacus magnirostris (G. St.-Hil.). *.

134. Glareola orientalis, Leach. *.

135. Limicola platyrhyecha (Temm.). *.

136. Numenuus lineatus, Cur. *.

137. Trivgoides hypoleucus (L.). *.

138. Totanus calidris (L.). *.

139. Totanus brevipes (Gm.). *.

140. Totanus glareola (L.). *.
141. Terekia cinerea (Giild.). *.

142. Tringa ruftcolits (Seebohm). *

143. Gallinago Megala, Swinh. *.

144. Erythra phenicura (Penn.). M.

145. Rallina fasciata (Raffl.). M., P.

146. Herodias intermedia (Wagl.). *.

147. Bubulcus coromandus (Bodd.). *.

148. Demiegretta sacra (Gm.). *.

149. Ardea sumatrana, Raffles. M.

150. Butorides javanica (Horsf.). M., P.

151. Gorsachius melanolophus (Raff.). M.,P.

152. Sterna bergil, Licht. All over the east.

153. Sterna sinensis. *.

154. Sterna melanauchen, Temm. M.

155. Anous stolidus (L.). M.

156. Hydrochelidon hybrida (Pall.). *.

157. Fregata minor (Gm.). *. 


\section{NO'TES ON A COLLECTION OF BIRDS FROM EASTERN JAVA. BY JOHN WHITEHEAD.}

THE following is a list-with a few field-notes-of the birds collected by me during a period of three months spent in the Island of Java. The collection, though small, is sufficiently interesting, beiug chiefly composed of species inhabiting the eastern highlands of the island. Two species proved to be new and worthy of specific distinction ; these have been described by Mr. Seebohm.

As I was unaccompanied by a native collector I was forced to do all the shooting and preparing myself. When in Lawang I employed a Javanese who shot a few birds for me. This man had some curious anecdotes to relate, one of which is worth recounting. I had often noticed a large black Hawk in a forest near Lawang and I offered this man a reward if he could procure it for me. He told me, "Once an Orang Blanda, i. $e$. a Dutchman, asked me for one of these birds; so I went with a friend to a large tree where one often rested. The Hawk was resting, as usual, on the tree, so my friend stalked him from one side, I from the other ; when the Hawk saw that all chance of escape was cut off he began to weep, and I saw his tears fall to the earth." I have heard of "crocodile's tears," but of weeping Hawks on this occasion only.

In conclusion, I may remark that Tosari is a small village situated at an altitude of about 5500 feet on a spur of the Bromo, an active volcano. Lawang is about 1000 feet above the sea-level; the country round about consisting either of rice-land or coffee-plantations, with here and there a clump of old forest.

1. Cettia montana (Horsf.).

I obtained only one specimen of this species, which I met with iu a casuarina-pine forest, on the slopes of the Bromo.

Iris hazel ; upper mandible black, lower yellowish ; feet light brown.

2. Merula whiteheadi, sp. n. (Seebohm, Bulletin B. O. C. no. v.)

"Supra brunnea, capite canescente, abdomine castaneo, veutre medio albo, subcaudalibus albo striatis."

This Blackbird was met with in the cabbage-gardeus on the top of the Bromo spurs. In habits and note it closely resembles our familiar garden friend. This species prefers the few spots left uncleared by the natives, where casuarinas are plentiful and the undergrowth is thick. On the 26 th September I saw a pair of birds witl nesting-materials in their bills.

Eye black; bare skin round eye yellow; bill and feet dull king's yellow.

3. OreoctNcla Horsfieldi (Bonap.).

Only one spccimen seen and obtained of this rare Thrush, not far from Tosari.

Bill and eye black; feet light brown.

4. Geoctchla rubecula, Gould.

Fairly common in the coffee-plantations in the neighbourhood of Lawang. This sp ecies has a most pleasing song.

Bill and eye black; legs dirty flesh-colour. Javan name "Băndās."

5. Cittocincla macrura (Sclater).

Obtained near Lawang.

6. Henicurus leschenaulti (Elwes).

Several were obtained on a stream close to Lawang. This species does not seem to frequent the higher altitudes.

Iris dark brown ; bill black ; feet white. 
7. Hydrocichla velatus (Sharpe).

Several werc obtained in a rocky stream near Tosari.

Iris dark brown; bill black ; fcet white.

8. Prinia polychroa (Gray).

A specimen was obtained near Lawang.

Iris light hazel ; legs pink.

9. Motacilla Flava, L.

Large flocks began to arrive in Tosari on the 23rd October.

10. Anthus rufulus, Vieill.

Fairly common on the ridges of the Bromo and also noticed on the dry sandy desert at the bottom of the extinct crater.

\section{Pomatorhinus montanus, Horsf.}

Fairly common in the mountains, where they frequented the low growth amongst the casuarina trces, a favourite hunting-ground of this bird being the tangled growth which covers the deep gullies cut in the soft volcanic ash by the heavy rains, which are at timcs about eight fect deep. The note of this bird begins with a whistle and finishes with a chatter like that mado by the Fieldfare.

Eye pale straw-yellow; bill brown, yellow underneath; legs greyish green.

12. Megalurus palustris, Horsf.

Met with both in the mountains and in the plains. The great difference in size between individuals of this species is most remarkable. This bird has much the habits of a Pipit; like the Meadow-Pipit, it often flies high in the air and slowly descends to the ground with half-closed wings, attering all the while a pretty song; it often settles on the tops of low trees, but when walking in the grass the long tail seems to cause inconvenience.

Eye hazel ; upper mandible black, lower and feet flesh-colour.

13. Timelia pileata, Horsf.

A small flock was met with in a tangled mass of weeds in a field near Lawang.

Iris lake-red; bill black ; feet horny grey.

14. Turdinus sepiarius, Sharpe.

A few were seen near Lawang. Generally creeping mouse-like amongst the tangled thorny thickets of bamboo, when disturbed flying a short distance, when it is soon lost to sight in the thick undergrowth. On the 5th November I found a nest containing two eggs-much in the position usually selected by a Nightingale; the nest was deep, composed of broad grasses and dead leaves. The eggs were pale salmon coloured, scribbled all over with dark red, after the manner of a Bunting's.

Iris hazcl.

15. Drymocataphus capistratus (Salvad.).

Lawang.

16. Hemixus virescens (Temm.).

Several were obtained in the coffee-plantations near Tosari.

Eye light red; bill and feet leaden blue.

17. Pycnonotus Bimaculatus, Blyth.

Not very common; a few pairs were met with as high as 7000 feet.

Eye, bill, and feet black.

18. Pycnonotus aurigaster, Gray.

One of the commonest of Javan birds from the sea-level up to 5000 feet. 
19. Chloropsis nigricollis (Vieill.).

Obtained in old forest near Lawang.

20. Oriolus maculatus, Vicill.

Fairly common in the vicinity of Tosari.

Eyc and bill black; legs dull cobalt-blue.

21. Parus cinereus (Bonn. \& Vieill.).

Fairly common both in the mountains and the plains. In August these Tits were to be secn witlı their fully fledged young busily hunting for food near the ground in the stubble of the maize-plantations. It was only at the end of October that this Titmouse was in good plumage; many were then again in pairs.

Eye and bill black; feet dull cobalt.

22. Lanius Ben'tet, Horsf.

This Shrike is very common throughout the Island. In Tosari this bird would makc long straight flights from some high elevation, hardly moving the wings, the steering being done by the long narrow tail.

Iris, fcet, and bill black.

23. Hempus obscurus (Horsf.).

Obtained near Tosari.

24. Buchanga cineracea (Sharpe).

Common near Tosari ; always seen in pairs.

Eye brick-red; bill and feet black.

25. Graucalus larvatus (Bp.).

I saw several spccimens of this bird in the neighbourhood of Tosari, where they frequented the scanty bush which is left on the highly cultivated slopes of the Bromo.

Iris dark hazel; feet and bill black.

26. Pericrocotus miniatus, Boie.

This beautiful Flycatcher frequented the maize-plantations near Tosari in large flocks, forming a most beautiful sight when alarmed, when some dozens of fiery-red birds would suddenly fly up into the trees, gencrally settling amongst some bright red flowcrs.

Eyc, bill, and feet black. The "Burong Bromo" of the Tosari villagers.

27. Pericrocotus exsul, Wall.

Common in the coffee-plantations in the vicinity of Lawang.

Eye, bill, and feet black.

28. Campephaga fimbriata (Gray).

Obtained near Lawang.

Iris, feet, and bill black.

29. Pratincola caprata, Blyth.

Common both in the mountains and plains. This Chat nests in the sandy banks on the sides of the roads in the mountains, scooping out a small chamber, in which it builds a neat nest of dry grass; the eggs are invariably three, of a pale blue, thickly spcckled with rusty red. In the plains $I$ have found the nests in the banks in the rice-fields. Eggs wcre taken on 5th September.

Eye, bill, and feet black.

30. Muscicapula hyperythra (Blyth).

Fairly common in the neighbourhood of Tosari.

Eyc and bill black; fect dark brown. 
31. Muscicaplela maculata, Bp.

Fairly common in the neighbourhood of Tosari. I cannot agree with Dr. Sharpe in separating this from the Kina Balu bird under the name of $M$. veestermanni.

Eye, bill, and feet black.

32. Cryptolopha Grammiceps (Verr.).

Only one specimen was obtained in a coffee-plantation, and this in bad plumage.

33. Cryptolopha trivirgata (Temm.).

One specimen was obtained in a coffee-plantation close to Tosari.

It would be interesting to know if this species has a grey phase of plumage like the species found on Kina Balu.

34. Stoparola indigo, Blytli.

Rather scarce, but found in the coffce-plantations below Tosari.

Eye, feet, and bill black.

35. Еthopyga mystaCalis (Licht.).

I obtained only one specimen of this handsome species, in a coffee-plantation close to Lawang.

36. Æthopyga exinia (Cab.).

Several males of this beautiful Sun-bird used to frequent the fuchsias which were planted in the hotcl garden in Tosari. It is, however, rather rare.

Eye black.

37. Arachnothera affinis (Shelley).

Lawang.

38. Zosterops NeGlecta, sp. n. (Seebohm, Bulletin B. O. C. no. v.)

"Similis Z. palpebrosce, sed magis olivascens, et macula anteoculari obscuriore distinguenda."

Common in the neighbourhood of Tosari. In the beginning of October I found a young bird fully fledged.

Iris white ; bill black ; feet dull cobalt.

39. PAdDa ortzivora, L.

Not noticed in the mountains; but immense flocks used to roost every night in some large trees close to the hotel in Solo.

40. Munta nisora (Temm.).

Cominon near Lawang.

41. Mirafra Javanica, Horsf.

Fairly common amongst the rough grassland in the neighbourhood of Lawang.

Iris black.

Javanese "Dranjanan."

42. Acridotheres javanicus (Cab.).

Common in the mountains and plains, where it is decidedly gregarious, flocks of over a hundred being seen together. yellow.

Iris light straw-yellow; bill king's yellow, dcepening into bright orange at the base ; feet king's

43. Gracupica melanoptera (Daud.).

Common in the plains. An odd bird or two were noticed amongst the flocks of the last species in the neighbourhood of 'Tosari.

Iris pale brown; bill dirty brownish white; bare patch on sides of head lemon-yellow; feet dull brown. 
44. Sturnopastor Jalla, Gray.

Fairly eommon in the plains. Not noticed in the mountains near Tosari.

Iris yellow ; bill dirty brownish white ; bare skin round eye orange-yellow ; legs yellow.

45. Eucichla cyanura (Cab.).

Fairly eommon in the eoffee-plantations near Lawang, where the absenee of undergrowtl allows of free morement. The sexes apparently separate during certain seasons, as in one plantation I eould only meet with males, while in another more distant I proeured females in numbers. This speeies takes to the lower branehes of trees when alarmed. The note is "quer-řr-řr- $\breve{r}$," the last r's being sounded quickly. These Pittas, and many other birds shot near Lawang, had numbers of long, flat, white worms under the skin, especially about the thigh-joints; these worms were rolled up in round discs.

Iris and bill black; legs lead-grey.

Javanese " Punglor."

46. Picus analis, Horsf.

Seen several times near Tosari.

Iris dark hazel.

47. Alcedo meninting, Horsf.

Obtained near Lawang.

48. Halcyon omNicolor (Temm.).

Only one speeimen seen and obtained near Lawang.

49. HaLCYon CHLORis, Gray.

Java speeimens are deeidedly bluer than those met with in Borneo. Common in the lowlands.

50. Ceyx rufidorsa (Strickl.).

Lawang.

51. Merops philippinus, L.

Very eommon in the plains.

Eye lake-red.

52. Merops quinticolor, Hodgs.

$\Lambda$ few were obtained near Lawang.

53. Xantholama australis, Horsf.

Obtained in the vieinity of Lawang.

Eye and bill blaek; feet (horny) green.

54. Xantholama rosea, Horsf.

Lawang.

Eye and bill blaek; feet vermilion.

Native name "Koekol."

55. Megalema javanensis, Gray.

A few were seen, in company with $X$. rosea, feeding on the jungle-fruits in the high trees. This Barbet has a loud "booh-booh-booh" note, whieh may be heard all day long in the forest. The Javanese say that it kills small birds, but this is of course most improbable.

Eye and bill blaek; feet olive-green.

56 Chirysococcyx basalis (Shclley).

One specinen obtained near Tosari.

57. Cocomantis merulinus (Scop.).

Near Tosari I obtained a specimen of this species. 


\section{APPENDIX.}

58. Pal fornis Javanica (Sclat.).

Common near Lawang.

Eyes light straw-yellow; bill lake-red.

Javanese "Bĕtet."

59. Astur soloknsis (Lath.).

One specimen was obtained at Lawang.

60. Accipiter virgatus (T.).

Onc, Lawang.

61. Cerchneis moluccensis (Sharpe).

Several were seen in the highlands. The speeimen obtained by me in Tosari was in full moult.

62. Treron nasica, Schleg.

Very common ncar Lawang.

There is a large bare emerald-green patch round the eye of freshly shot specimens, which in skins dries up and disappears, detracting much from its beauty.

Iris yellow ; feet lake-red.

Javanese "Māntan."

63. Macropygia leptogrammica ('Temm.).

Common in the casuarina forests at 7000 feet, and also near Lawang.

Iris, rings of pale pink and yellow ; bill black ; feet dull dark pink.

64. Gallus varius, Shaw.

A few were seen in the cabbage-fields on the spurs of the Bromo; with a good dog this bird would afford capital sport, as it readily takes wing when alarmed. I only procured an immature cock, but saw scveral in full plumage.

In a coffec-plantation I came across a pair of $G$. bangkiva, which were busily engaged in scratching beside a fallen tree; thinking they might be tume birds belonging to the Javanese, I did not shoot at them. My guide was much disgusted at my mistake.

65. Turnix pugsax (Temm.).

Several were shot in the vicinity of Tosari.

Iris pale yellow; bill brownish at tip and yellow at base; feet yellow.

66. Ortigonetra cinerea (V.).

Common in a large tank near Lawang, and one specimen was obtained. I also saw a bird closely resembling our Water-hen, and several Cormorants, which I did not obtain, on the some sheet of water.

67. Totanus glareola (L.)

Common in the rice-fields 


\section{RECHERCHES SUR LA FAUNE HERPÉTOLOGIQUE DES ILES DE BORNÉO ET DE PALAWAN. Par M. F. MOCQUARD.}

[The following interesting Memoir on the Reptiles of Bornco and Palawan appeared in the 'Nouvelles Arehives du Muséum' (Paris, 1890). Dr. Mocquard in this paper gives an account of the Reptiles colleeted by me, and full descriptions of the many ncw spccies diseovercd : since it was pnblished six species have been added to this list, viz.:-1cliopholis collaris, n. g. et sp. (Mocquard) ; Oryglossus lavis (Günther); Chaperina fusca, n. g. et sp. (Mocquard) ; Varanus heteropholis (Boulenger) ; Rhacophorus dulitensis (Boulengcr) ; Nectophryne hosii (Boulenger). I havc curtailed Dr. Mocquard's Memoir considerably, leaving out all his remarlis on species that were not discovered by me.]

On a pu remarqner que toutes ccs collections ont été recueillics soit à l'est, au sud-est, au sud ou à l'ouest de Bornéo, et que le nord de l'île, abstraction faite des recherches de J. Motley à l'île Labuan, ćtait resté complètement inexploré. Cette lacune vient d'être comblée par $\mathbf{M}$. Whitehead, voyageur anglais, qui, pendant l'année 1885, forma dans le nord de Bornéo, principalement au mont Kina Balu, ainsi qu'à l'îlc Palawan, une importante collection de Reptiles et de Batraciens, acquise par le Muséum, et dont l'ćtude fait l'objet du présent mémoire.

Cctte eollection comprend soixante-dix espèces : soixante-scpt proviennent de Bornéo et huit de Palawan; cinq sont communes aux deux îles. Seize espèces, ainsi qu'une variété, nous paraissent nouvelles et seront déerites plus loin. Quarante-six cspèces, dont treize Lacertiens, quinze Ophidiens et dix-huit Batraeiens anoures ont ćté recueillis au mont Kina Balu, pour la plus grande partie à des altitudes comprises entre 1,000 et 4,000 ou même 6000 pieds. Quelques Batraciens proviennent d'une hauteur de 8,000 pieds. Sur ces quarante-six espèces de Kina Balu, dix sont nouvelles, sur lesquelles deux appartiennent à des genres nouveaux.

Dans la liste suivante des Reptiles et des Batraciens de Bornéo, Labuan et Palawan actuellement connus, et que nous nous sommes efforcć de rendrc aussi exacte et aussi complète que possible, en laissant toutefois de côté les Tortues et les Batraciens psendophidiens, les espèees eomposant la collection qui nous occupe sont marquées d'un ou de denx ou de trois astérisques, suivant qu'elles proviennent de Bornéo ou de Palawan, ou qu'elles sont communes aux deux îlcs.

Liste des Crocodiliens, des Lacertiens, des Ophidiens et des Batraciens anoures actuellement connus à Bornéo, Labuan et Palawan.

\section{Crocodiliens.}

* 1. Crocodilus porosus, Schneider. 2. - palustris, Schlegel.

3. Gavialis schlegelii, Müller.

\section{LACERTIENS.}

4. Gymnodactylus consobrinus, Peters.

5. - narmoratus, Dum. Bibr.

* 6. - baluensis, n. sp.

7. Gonatodes kendallii, Gray.

8. Aelurosaurus (Pentadactylus) felinus, Güntlıer.

9. - dorsalis, Peters.

10. Hemidactylus frenatus (Sehlegel), Dum. Bibr.
* 11. Hemidactylus platyurus, Sehneider.

* 12. craspedotus, n. sp.

13. Gecko stentor, Cantor.

** 14. - verticillatus, Laurcnti.

*** 15. - monarchus (Sclilegel), Dum. Bibr.

* 16. Gehyra mutilata, Wiegmann.

17. Ptychozoon homaloceptialum, Creveldt.

** 18. Draco volans, Linné.

* 19. cornutus, Günther. 
?20. Draco rostratus, Giinther.

21. - fimbriatus, Kubl.

22. — cristatellus, Giinther.

* 23. - hamatopogon (Boié), Gray.

24. - teniopterus, Günther.

* 25. - quinquefasciatus, Gray.

* 26. obscurus, Boulenger.

27. Aphaniotis fusca, Peters.

28. Goniocephalus doria, Peters.

29. liogaster, Günther.

* 30. miotympanum, Günther.

* 31. - borneensis, Sehlegel.

32. Japalura nigrilabris, Peters.

** 33. Calotes cristatellus, Kuhl.

* 34. Pelturagonia cephalum, n. g. et sp.

35. Varanus dumerilii (Müller), Sehlegel. 36. — rudicollis, Gray.

53. Typhlops braminus, Daudin.

54. — lineatus, Boié.

55. Cylindrophis rufus, Laurenti.

56. Xenopeltis unicolor, Reinwardt.

* 57. Python reticulatus, Sehneider.

58. _ Ureitensteini, Steindachner.

59. Calamaria flaviceps, Güinther.

60. —_ benjaminsii, Edeling.

61. - martapurensis, Edeling.

62. —— borneensis, Bleeker.

63. Leccarii, Peters.

64. - schlegelii, Dum. Bibr.

? 65. - rolandtii, Blecker.

* 66. - bicolor (Sehlegel), Dum. Bibr.

67. - arcticeps, Günther.

68. — nigro-alba, Günther.

* 69. temminckii, Dum. Bibr.

70. - lowii, Boulenger.

* 71. - grabowskyi, Fischer.

72. - gracillima, Gïnther.

* 73. lateralis, n. sp.

74. Rhabdion torquatum, Dum. Bibr.

* 75. Simotes octolineatus, Sehneider.

76. labuanensis, Günther.

* 77. - vertebralis, Günther.

78. - subcarinatus, Günther.

* 79. Ablabes baliodeirus, Boié.

80. - - immaculatus, Peters.

81. - melanocephalus, Gray.
37. Varanus salvator, Laurenti.

38. Tachydronus sexineatus, Daudin.

39. Lanthanotus borneensis, Steindachncr.

40. Mabuia rugifera, Stoliczka.

* 41. - multicarinata, Gray.

* 4.2. - multifasciata, Kuhl.

* 43. - rudis, Boulenger.

* 44. Lygosoma variegatum, Peters.

* 45. - olivaceum, Gray.

46. - vittatum, Edeling.

47. — nitens, Peters.

48. - parietale, Peters.

* 49. - tenuiculum, n. sp.

* 50. - whiteheadi, n. sp.

* 51. Tropidophorus (Amphixestes) beccarii, Peters.

52. - brookii, Gray.

OPHIDIENS.

82. Ablabes longicaudus, Peters.

83. — periops, Günther.

* 84. - - prafrontalis, var.

85. Enicognatkus (Coronella) ornatus

(Sehlegel), Jan.

86. Elaphis taniurus, Cope.

87. Compsosoma radiatum, Schlegel.

88. — melanurum (Bleeker), Sehlegel.

89. Ptyas (Coryphodon) korros (Reinwardt), Sehlegel.

90. Xenelaphis (Coryphodon) hexagonotus, Cantor.

91. Zaocys (Coryphodon) fuscus, Güntlıer.

92. - (-) carinatus, Güntlıer.

93. Tropidonotus quincunciatus, Schlegel.

94. —— melanozostus, Gravenhorst.

* 95. - sundanensis (Bleeker), Günther.

96. — triangutigerus, Boié.

97. —— - annularis, Fiseher.

* 98. — sarawacensis, Günther.

99. - conspicillatus, Günther.

* 100. - flavifrons, Boulenger.

101. Amphiesna rhodomelas, Boié.

102. - slolatum, Linné.

103. - substolatum (Sehlegel), Jan.

104. - chrysargum, Boié.

105. — flaviceps, Dum. Bibr.

106. —— semifasciatum, Jan.

* 107. Helicopsoides typicus, n. g. et sp. 
108. Cerberus rhynchops, Selnneider.

109. - acutus, Gray.

110. Homalopsis buccata, Linné.

111. Pythonopsis punctata, Gray.

112. Homalophis doria, Peters.

113. Hypsirhina plumbea (Kuhl), Boié.

114. — enhydris, Schneider.

115. Fordonia (Hemiodontus) unicolor, Gray.

116. Miralia (Eurostus) alternans, Reuss.

117. Cyclophis (Liopeltis) tricolor (Boié), Sehlegel.

118. Goniosonı oxycephalum (Reinwardt), Boié.

119. margaritatum, Peters.

* 120. Leptophis (Dendrophis) formosus (Reinwardt), Boié.

121. Dendrophis pictus, Gmelin.

122. - caudolineatus, Gray.

123. Chrysopelea ornata, Shaw.

124. — (Dryophis) rubescens, Gray.

125. Tragops prasinus (Reinwardt), Boié.

126. —— fasciolatus, Peters.

* 127. Psammodynastes pulverulentus, Boié.

128. - pictus, Giinther.

129. Ophites (Sphecodes) subcinctus, Boié.

* 130. — albofuscus, Dum. Bibr.

131. Amblycephalus boa, Boié.
132. Pareas (Leptognathus) carinata (Reinwardt), Wagler.

* 133. Dipsas (Triglyphodon) dendrophila, Reinwardt.

131. - boops, Günther.

135. - cynodon, Cuvier.

136. - multimaculata, Boié.

137. Acrochordus javanicus, Hornstedt.

* 138. Platurus fasciatus, Daudin.

139. Pelamis bicolor, Sehneidcr.

140. Hydrophis schistosus, Daudin.

141. —- brookii, Günther.

142. - loreata, Gray.

143. - anomalus, Sehmidt.

144. - atriceps, Günther.

145. Elaps (Calloplis) intestinalis, Laurenti.

146. - (-) nigrotæuiatus, Peters.

147. — bivirgatus (Boié), Sehlegel.

148. Bungarus (Adeniophis) fasciatus, Sehneider.

149. - flaviceps, Reinhardt.

150. Trimeresurus (Hamadryas) ophiophagus, Cantor.

151. Naja ingens, Van Hasselt.

* 152. - tripudians, Merrem.

* 153. Bothrops gramineus, Shaw.

154. Atropophis borneensis, Pcters.

155. Tropidolcmus wagleri (Boié), Schlegel.
* 156. Rana kuhlii, Schlegel.

157. - tigrina, Daudin.

* 158. - gracilis, Wiegmann.

* 159. - decorata, n. sp.

160. - (Limnodytes) luctuosa, Peters.

161. - (Hylorana) jerboa, Günther.

* 162. - whiteheadi, Boulenger.

163. - (Hyla) erytlirca, Sehlegcl.

164. - (Ixalus) natatrix, Günther.

165. — (Polypedates) signata, Günther.

* 166. obsoleta, n. sp.

167. - (Polypedates) raniceps, Peters.

168. - similis, Günther.

* 169. - everetti, Boulenger.

170. - (Hylorana) longipes, Fischer.

* 171. - paradoxa, n. sp.

*** 172. Rhacopliorus nuaculatus, Gray.

\section{BATRACIENS ANOURES.}

* 173. Rhacophorus leucomystax quadrilineatus, Wiegmanu.

174. - pardalis, Günther.

175. - reinuardtii, Boié.

* 176. - cruciger, Blyth.

* 177. - appendiculatus, Günther.

* 178. - acutiroscris, n. sp.

179. Ixalus pictus, Peters.

180. — aurifasciatus, Sehlegcl.

* 181. latopalmatus.

*** 182. - nubilus, n. sp.

183. Calophrynus pleurostigma, Tschudi.

184. - punctatus, Peters.

185. Callula (Calohyla) pulchra, Gray.

186. Bufo melanostictus, Sehncider.

* 187. - asper, Gravenhorst.

* 188. - biporcatus (Sehlegel), Tschudi. 
** 189. Bufo divergens, Peters.

* 190. fuligincus, n. sp.

* 191. - leptopus, Günther.

192. - borbonicus, Boié.

* 193. - penangensis, Stoliczka.

* 194. - spinulifer, 11. sp.

195. Nectes (Pseudobufo) subasper (Tsehudi).

196. — pleurotania, Bleeker (d'après Fischer).
197. Nectophryne guentheri, Boulenger.

198. - (Calohyla) sundana, Pcters.

* 199. - misera, n. sp.

* 200. - maculata, n. sp.

* 201. Leptobrachium gracile, Günther.

202. - montanum, Fischer.

** 203. Megalophrys montana (Kuhl), Wagler.

* 204. - nasuta, Sclilegel.

A cette liste, qui renfermc certainement encore des doubles emplois, nous aurions pu ajouter plusieurs autres espèces de Batraciens; mais les spécimens qui les représentent sont trop jeunes ou dans un état de conservation trop imparfait pour pouvoir être déterminćs avec certitude autrement que par comparaison.

Reptiles et Batraciens de Bornéo et de Palawan composant la collection recueillie par $M$. Whitehead.

1. Crocodilus Porosus, Schneider.

6. Gymnodactylus baluensis, n. sp.

Cettc espèce, représentée par six spécimens, dont quatre mâles et deux femelles, ne diffère de G. marmoratus que par les particularités suivantes : les granulations dorsales et les tubercules dont elles sont entremĉlées sont de dimensions encore plus réduites que chez ce dernier, et la face ventrale de la queue est garnie d'une série médio-longitudinale d'écailles dilatées transversalement.

Le nombre des pores fémoraux varie de six à neuf et semble être le plus souvent de six de chaque côté ; on compte en outre neuf ou dix pores préanaux rangés sur les côtés d'un angle aigu et sépạrés des premiers par un large intervalle.

Le système de coloration est le même que celui de G. marmoratus.

Cette espèce est originaire de Kina Balu.

11. Hemidatylus Platyurus, Schneider.

12. Hemidactylus CRaspedotus, $\mathrm{n}$. sp.

Le corps tout entier, y compris les membres, est très déprimé. Concave transversalement dans la région frontale, la tête se termine par un museau assez étroit, régulièrement arrondi, sensiblement plus long que la distance qui sćpare l'œil de l'orifice auditif, et égale à une fois et demie le diamètre de l'orbite. La rostrale est rectangulaire, deux fois plus large que haute, avec une courte fissure au milieu de son bord superieur. La narine s'ouvre de chaque côté au-dessus de son angle latérosupérieur, entre cette plaque, la première supéro-labiale et trois nasales. L'orifice auditif est petit, ovalaire, à grand axe presque horizontal, un peu oblique en haut et en arrière. On comptc onze labiales supérieures et huit ou neuf labiales inférieures. La mentonnière est très grande, en forme do triangle à base convexe ; elle est suivie de deux paires de sous-maxillaires dont les antérieures sont les plus grandes et se touchent sur la ligne médiane. La face supérieure du corps est garnie de granulations très petites, plus grandes sur le museau, parsemées, depuis l'extrémité postérieure de la tête, jusqu’à l'origine de la queue, de tubercules inégaux petits et arrondis, distribués sans ordre. On en distingue cependant une ligne régulière à la partie supérieure des flancs et une antre, composée de sept à neuf tubercules, qui part de l'angle postéro-supérieur de l'œil, se dirige en arrière, puis se recourbe en dehors pour se terminer au-dessus du trou auditif. Les écailles abdominales sont petites, cycloïdes, légèrement imbriquées. Les membres sont de grandeur médiocre, les doigts très dilatés et complètement palmés, tous bicn développés. Les lamclles sous-digitales sont au nombre de cinq sous le doigt interne, de huit ou neuf sous le quatrième, et de sept sous le quatrième orteil. On compte, du moins chez le mâle, seize ou dix-sept pores fémoraux de chaque côté, formant deux séries interrompues sur la ligne médianc. La queue est très déprimée, plane en dessous, à bords tranchants et finement denticulés. Elle 
est revêtue, en dessus, d'ćcailles granuleuses, avec quelques séries transversales de petits tubercules dans sa partie antérieure ; inférieurement, elle présente sur la ligne médiane une sćrie de grandes écailles dilatées transversalement.

Un repli cutané très saillant s'ètend de l'aisselle à l'aine. Un second, également très développé, borde en avant et en arrière les deux paires de membres. Enfin, un troisième repli, analogue par sa position à celui que l'on obscrve chez Piychozoon homalocephalum Kuhl, mais beaucoup moins saillant, s'étend, en passant an-dessous du trou auditif, depuis le cou jusque près de la commissure des lèvres.

Un gris de sable forme le fond de la coloration des parties supérieures; il s'y ajoute, sur le dos, cinq taches assez grandes à bords indécis, et sur la queue huit bandes transversales d'un brun très pâle, deux fois plus étroites que les espaces clairs qui les séparent. Quelques marbrures ou barres transversalcs de même teinte s'observent aussi sur les flancs et surtout sur les membres. La face ventrale est uniformément gris jaunâtre.

Le spécimen unique qui sert de type à cette espèce mesure 123 millimètres de longueur totale, dont 64 millimètres, ou un peu plus de la moitié, pour la queue.

Il provient du nord de Bornćo.

La seule espèce avec laquelle on pourrait confondre celle que nous venons de décrire est $H$. platyurus Schneid., dont eile se distingue facilement par ses tubercules dorsanx, ses doigts complètement palmés, les replis cutanés qui bordent ses membres, et l'interruption sur la ligne médiane de ses deux séries de pores fémoraux.

14. Gecko verticillatus, Laurenti.

Quatre exemplaires provenant de Palawan.

15. Gecko morarchus (Schlegel), Dum. Bibr.

Cette espèce est représentée par trois spécimens, dont deux ont été recueillis au nord de Bornéo et le troisième à Palawan.

16. Gehyra mutillata, Wiegmann.

Deux spécimens proviennent du mont Kina Balu.

18. Draco volarss, Linné.

Quatre spécimens du nord de Bornéo et deux de Palawan.

19. Draco cornutus, Günther.

Quatre spéeimens ont été recueillis au nord de Bornéo, dont un à Kina Balu.

23. Draco hematopogon (Boié), Gray.

25. Draco quivquefasciatus, Gray.

26. Draco obscurus, Boulenger.

Head small ; snout as long as the dianteter of the orbit ; nostril directed upwards, perfectly vertical; tympanum naked, smaller than the eye-opening; eleven upper labials. The male's gular appendage as long as the head, covered with large scales. No nuchal fold or crest. Dorsal scales smooth, equal, not larger than ventrals; a lateral series of widely-distant, enlarged, keeled scales. The fore limb stretched forward cxtends considerably beyond the tip of the snout; the hind limb reaches the shoulder. Brown above, with blaek spots on the nape; wing-membranes blackish above, colourless inferiorly; throat brown, with light spots; gular appendage brown, black at the base; lower surface of lateral wattles dark purple.

Total length . . . . $\quad \underset{256}{\operatorname{millim}}$

Head . . . . . . . 17

Width of head . . . . . 11

Body . . . . . . . . 75

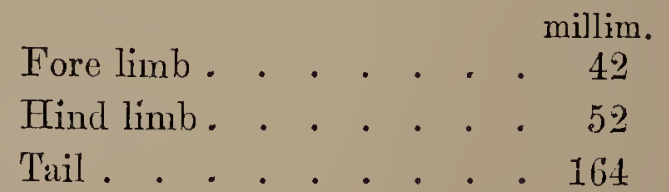

[Dr. Mocquard unites this species with $D$. blanfordii.-J. W.] 
30. Goniocephalus motrmpanum, Günther.

31. Goniocephalus bonneensis, Schlegcl.

33. Calotes cristatellus, Kuhl.

Un spécimen a ćté recueilli à Palawan et six au nord de Bornéo, dont deux au mont Kina Balu.

Outre ces individus, deux œufs en forme de fuseau furcnt trouvés parmi les Reptiles dont nous uous oecupons ici, et la collcetion du Muséum n'en possédant pas de semblables, nous ne sûmes d'abord à quelle espèce les rapporter. Ils renfermaient heureusement des jeunes à peu près arrivés au terme de leur développement et présentant si bien les caractères de l'adulte que nous avons pu les déterminer avec exactitude. Cette détermination a d'ailleurs été confirmée par l'observation directe d'œufs semblables sur des femelles gravides de C. cristatellus.

Ces œufs, sont très allongés, renflés au milieu, atténués aux extrémités, en un mot fusiformes.

\section{Pelturagonia, n. g.}

Nous considérons comme type d'un genre notveau un Agamidé capturé à Kina Balı, remarquable par les écailles en forme de boucliers qui garnissent, chez les mâles, les angles de la base de la queue ct auquel, pour cette raison, nous imposons le nom générique de Pelturagonia*. On peut lui assigner les caractères suivants:

La tête est proportionnellement très grošse chez les mâles; le corps est svelte, comprimé, les menbres bien développés, le tympan caché. Il y a une crête nuchale et le dos est recouvert d'écailles petites, lisses, inćgales. La qucue est longue, comprinéc, et, chez les mâles, la base de eet organe présente le long de ses bords latéro-supérieurs et inférieurs une rangée longitudinale de boucliers fortement carénés. Il n'existe ni repli ni sac gulaire, ni pores préanaux ou fémoraux.

34. Pelturagonia cephalum, $\mathrm{n}$. sp.

Assez courte et petite chez la femelle, où elle est contenue trois fois ct demie dans la distance conıprise entre l'extrémitć du museau et l'anus, la tête est, chez le mâle, proportionnellement beaucoup plus grosse et n'est contenue qu'un peu moins de trois fois dans cette distance. Ellc se fait surtout remarquer chez ce dernier par une convexité de la région nuchale qu'on n'observe pas chez la femelle et par deux gros renflements situés sur les côtés de l'extrćmité postérieure de la tête, en arrière de la commissure des lèvres. Dans les deux sexes, la région frontale est concave transversalement, et le museau, terminé en biseau, est un peu plus court que le diamètre de l'orbite. La narine s'ouvre latéralement près de son extrémitć dans une plaque unique. Le tympan n'est pas distinct. Le canthus rostralis et le bord sourcilier sont formés d'écailles modérément agrandies; lo premier est simplement angulcux, le second saillant et tranchant, suivi d'un tubercule arrondi qui surmonte l'angle postérieur de l'œil.

Les écailles de la face supérieure de la tête sont inégales et carénées, excepté sur le museau. Celles des régions sus-oculaircs sont les plus grandes et vont en augmentant de dimensions de dehors en dedans. De chaque côté de l'occiput est une écaille dilatéc, relevée à son centre d'une pointe conique. Deux ou trois autres ćcailles semblables, dont l'antérieure est un peu au-dessous de la commissure des lèvres, se voient sous l'extrémité postérieure des mandibules; quelques-unes de même forme et moins saillantes s'observent aussi sur la région temporale et sur les côtés de la région gulaire, mais elles ne paraissent pas constantes. La rostrale ne se distingue pas, par ses dimensions, des labiales supérieures, qui sont au nombre de 11 ou 12, de même que les labiales inférieures. La crête nuchale est composée de 6 ou 8 écailles coniques ct comprimées, la plupart séparées par des écailles plus petites ct de forme ordinaire. Il n'existe pas à proprement parler de crête dorsale; toutefois on observe sur la ligne vertébrale une série d'ćcailles plus grandes, allongées, séparées les uns des autres et relevées d'une carène qui se termine en pointe à son extrémité postérieure. Les écailles des régions supérieures sont petites, lisses, inégales, entremêlées de quelques autres plus grandes et carénées, dont on voit une rangée transversale arquée,

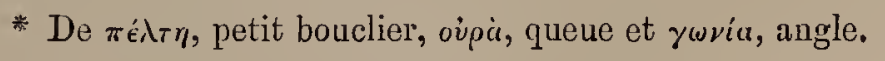


convexe en arrière et interrompue sur la ligne médiane, qui s'étend entre la racine des membres postérieurs. Les ventrales sont plus grandes et pourvues d'une carène qui devient de moins en moins saillante à mesure qu'elles se rapprochent de l'orifice anal.

Les membres sont grêles et allongés; le postérieur dirigé en avant atteint l'œill, et le quatrième doigt est un peu plus long que le troisième. Ils sont garnis en dessus d'écuilles carénées inégales, et sur le bord postérieur de l'avant-bras et de la cuisse on en remarque quelques-unes, quatre au plus, grandes, coniques et comprimées, sćparées les unes des autres.

La queue est comprimée et égale environ une fois trois quarts la longueur de la tête et du trone pris ensemble. Chez les mâles, la forme de la base de la queue, comme celle des écailles qui la garnisscnt, est caractéristique. En section transversale, sur une longueur d'un peu plus de 2 centimètres, cette forme est celle d'un triangle dont lc sommet tourné en bas serait légèrement tronqué, et les écailles qui garnissent les angles de la base ainsi que eeux de cette troncature sont très agrandies, très épaisses, cornées, fortement carénées, surtout celles des rangées supérieures, dont la carène se termine en une pointe relevée. Ces sortes de boucliers sont au nombre de 6 à 8 sur chacune des 4 arêtes de la base de la queue et vont en diminuant de grandeur d'avant en arrière à partir du quatrième ou du einquième. Ils manquent chez la femelle ; mais les écailles qui leur correspondent sont plus grandes et plus fortement carénées que les autres, de sorte que la base de la queue, quoique beaueoup moins renflée que ehez le mâle, offre cependant une forme assez semblable. Au delà de ces boucliers, les écailles de la queue sont de taille médiocre, assez faiblement carénées, à l'exception de celles qui, en dessous, continuent les deux rangées inférieures de boucliers.

La langue est épaisse, papilleuse, à peine échancrée à son extrémité. A chaque mâchoire, il existe de chaque côté une forte canine; les molaires sont simples et les bords des mandibules sont fortement relevés en arric̀re chez les mâles.

La coloration semble très variable. Dans les deux sexes, un bleu de ciel, plus éclatant sur les membres, mais très pâle sur la tête où il est plus ou moins fortement lavé de brun, orne les régions supérieures, coupé sur le dos et les membres par des bandes transversales noires irrégulières et de largeur variable. Le dessous de la gorge est blanc bleuâtre, le ventre blanc jaunâtre, l'un et l'autre tachetés ou marbrés de noir. La queue présente une teinte brune avec des intervalles plus clairs qui, sur le vivant, sont probablement d'un bleu pâle *.

Deux mâles et cinq femelles représentent cette espèce. Les deux mâles sont très sensiblement de même taille et mesurent 80 millimètres de l'extrémitè du museau à l'anus; la longueur de la queue égale 140 millimètres. Les femelles sont notablement plus petites, et les dimensions précédentes se réduisent respectivement, chez elles, à 65 et 111 millimètres.

Tous sont originaires de Kina Balu.

41. Mabuia multicarinata, Gray. Kina Balu.

42. Mabuia multifasciata, Kuhl. Kina Balu.

43. Mabuia rudis, Boulenger. Kina Balu.

44. Lygosoma variegatum, Peters. Kina Balu.

45. Lygosoma olivaceum, Gray. Kina Balu.

49. Lygosoma tenuiculum, n. sp.

Ce Lygosoma est voisin de l'espèce ténue (L. erucata, D. B.). Même pbysionomie, même écaillure de la tête, mêmes proportions relatives des membres. Il s'en distingue toutefois par son tympan situć moins profondément et presque superficiel, par le nombre plus faible des séries longitudinales d'écailles (26 au lieu de 30) au milieu du trone et par les dimensions notablement plus petites des écailles de la

* D'après M. Whitehead, ces Lacertiens étaient de couleur verte à l'état. vivant et ont été capturés sur le sol à une altitude de 6,000 pieds. 
queue. La coloration diffère également, en ce que le dos est presque complètement dépourvu de taches noires, et celles qui occupent les parties latérales, depuis l'œil jusqu'à la racine des membres postérieurs, sont moins confluentes et entremêlées de nombreuses petites taches d'un blanc grisâtre, que l'on observe aussi, associées à de petites taches noires, sur les côtés des deux tiers antérieurs de la queue. La ventre et le dessous de la gorge sont grisâtres, sans aucune tache noire.

Un seul exemplaire, originaire de Kina Balu, représente cette espèce. Il est de petite taille et mesure seulement 45 millimètres de l'extrémitć du museau au cloaque; la longrueur de la queue égale 56 millimètres.

50. Lrgosoma whiteheant, n. sp.

Le corps est peu allongé, les nembres faibles et courts, lia paupière inférieure pourvue d'un disque transparent. Le museau est arrondi et la distance de son extrémité à la racine des membres antérieurs est comprise une fois et deux tiers dans cclle qui sépare l'aisselle de l'aine.

Le narine est percée dans une nasale étroite, surmontée d'une internasale en contact avec sa congénère derrière la rostrale. Deux fois plus large que longue, la fronto-nasale touche par une large suture à l'extrémité antérieure tronquée de la frontale, et les préfrontales sont fort réduites. La frontale est aussi longue que les fronto-pariétales et les pariétales réunies; elle est bordée latéralement par les 2 premières sus-oculaires. Ces dernières plaques sont au nombre de 4 , et on compte 7 surcilières. Il y a 2 frontopariétales distinctes, plus longues que l'interpariétale, en arrière de laquelle les pariétales, bordées en dehors et en arrière par une paire de temporales et une paire de nuchales, forment une courte suture. La frénale antérieure est simple, plus haute que la suivante. Il existe 7 supéro-labiales, dont la cinquième, de beaucoup la plus longue, borde l'œil en dessous. L'orifice anditif est petit, presque circulaire, avec un lobe à son bord antérieur ; le tympan est situé profondćment.

Les écailles sont lisses, hexagonales, plus petites sur les côtés, et forment 30 séries longitndinales au milieu du tronc. Sur la face ventrale, l'une de ces séries contient 33 écailles dans l'intervalle compris entre la racine des membres antérieurs et celle des membres postérieurs. Les préanales sont légèrement dilatées.

Étendus le long du trone à la rencontre l'un de l'autre, les membres n'arrivent pas au contact; l'antérieur dirigé en avant n'attcint pas tout à fait l'œil, et le postérieur mesure un peu plus que la moitié de la distance entre l'aisselle et l'aine. Les doigts sont courts, moins comprimés que les orteils, dont le quatrième dépasse le troisième, et qui sont garnis en dessous d’écailles légèrement unicarénées, au nombre de 11 à 13 sous le quatrième. La quene est mutilée.

Le dos est d'un brun fauve clair, parcourn par 4 lignes longitudinales plus foncées, continues èt parallèles : les 2 moyennes partent de l'extrémité postérieure des pariétales et passent sur le milieu dés deux séries d'écailles en contact sur la ligne médiane; les deux externes se prolongent en avant jusque sur les sus-oculaires et s'étendent sur les écailles de la troisième rangée, àpartir de cette même ligne médiane. La partie supérieure des régions latérales, depnis l'œil jusqu’à la racine de la queue, est également parcourue par une bande d'un brun encore plus sombre, que borde en dessus une teinte claire et au-dessous de laquelle sont disséminées de petites taches brunes entremêlécs de taches ovalaires plus grandes et plus nombreuses d'un blanc grisâtre. La face véntrale est d'un gris fauve uniforme.

L'exemplaire unique qui représente cette espèce est originaire du nord de Borıéo. Il mesure 38 millimètres de l'extrémité du museau au cloaque.

Cette espèce est assez voisine de L. punctatum; elle s'en distingue cependant facilement par son corps moins allongé, par le nombre plus élevé des séries longitudinales d'écailles (30 au lieu de 24 ou 26), et par sa coloration.

51. Tropidophorus beccarit, Peters.

Deux spécimens provenant de Kina Balu ne peuvent être rapportés qu'à cette espèce, dont ils diffèrent cependant par 34 séries d'écailles au lieu de 30. 
57. Pүтhon Reticulates, Schneider.

Un jeune spécimen a été recueilli au nord de Bornéo. L'espèce décrite par Steindachner sous le non de $P$. Ureitensteini a été trouvée à Teweh.

66. Calamaria bicolor (Schlegel), Dum. Bibr. Kina Balu.

69. Calamaria teminuckit, Dum. Bibr. Kina Balu.

71. Calamaria grabowskyi, Fischer. Kina Balu.

73. Calamaria lateralis, n. sp.

Cette espèce a le corps assez grêlc et allongé, la tête un peu plus large que le cou et la queue très courte.

La rostrale est petite, pentagonale, aussi haute que large, non renversée sur le museau. Par ses bords supérieurs elle touche en dehors à la nasale, en dedans aux préfrontales, qui sont grandes et forment sur la ligne médiane unc longue suture, tandis qu'en dehors elles se renversent sur la région frénale pour sc mettre en contact avec les deux premières supéro-labiales. I La frontale est hexagonale, sensiblement plus longue que large ; son angle antérieur est à peu près droit, le postérieur est aigu; sa plus grande largeur siège au niveau des angles latéro-antérieurs. Les sus-oculaires sont courtes, un peu élargies en arrière, et les pariétales ont leur extrémité postérieure tronquée obliquement de dehors en dedans et d'arrière en avant.

La narine est percée dans une très petite nasale quadrangulaire située entre la rostrale, la $1^{\text {re }}$ supérolabiale et la préfrontale. Il n'existe ni frénale ni temporale. L'œil est petit, bordé en avant par une préoculaire, en arrière par la sus-oculaire qui se met en contact avec la quatrième supéro-labiale, en présentant cependant d'un eôté un commencement de division en sus-oculaire et post-oculaire. Les supéro-labiales sont au nombre de 5 ; la troisième et la quatrième touchent à l'œil, et la cinquième, aussi longue que les deuxième, troisième et quatrième réunies, forme une longue suture avec la pariétale correspondante. On compte également 5 inféro-labiales ; celles de la première paire se touchent derrière la mentonnière. Il n'y a pas d'écaille impaire entres les 2 paires de sous-maxillaires.

Le nombre des séries longitudinales d'écailles est de 13 ; celui des gastrostèges, de 146, ct celui des doubles urostèges, de 21. L'anale est entière. Les gastrostèges, à partir de la trente-neuvième inclusivement, présentent un sillon longitudinal médian assez profond, ayant l'aspect d'une suture, qui s'arrête un peu en avant de leur bord postérieur.

D'un brun noirâtre uniforme, un peu moins foncé sous le ventre, avec une bande blanche latérale qui s'étend depuis la cinquième supéro-labiale inclusivement jusqu'à l'extrémité de la queue, en passant sur des deuxième et troisième séries longitudinales d'écailles, la coloration est caractéristique.

Nous ne possédons de cette jolie espèce qu'un seul spécimen originaire de Kina Balu. Il a une longueur totale de 245 millimètres, dans laquelle la quene entre pour $12^{\mathrm{mm}}, 5$.

75. Simotes octolineatus, Schneider. Kina Balu.

77. Simotes vertebralis, Güinther. Kina Balu.

79. Ablabes baliodeirus, Boié. Kina Balu.

84. Ablabes Periops, Günther, var. PR ærrontalis.

Nous croyons devoir rapporter à une variété d'Ablalies periops, espèce caractérisće par un cercle d'écailles entourant l'œil et par le contact de la mentonnière avec les sous-maxillaires de la $1^{\text {re }}$ paire, deux individus originaires de Kina Balu, qui diffèrent des types décrits par Günther par diverses particularités d'ćcaillure et de coloration.

Les préfrontales sont fusionnées, et la nasale est ou simple ou indistinctement divisée; le nombre des séries longitudinales d'écailles est de 15 au lieu de 17 ; enfin, le nombre des gastrostèges égale dans un cas 178, dans l'autre 180, restant ainsi assez éloigné de 209. 
La eoloration, identique ehez nos deux spéeimens, diffère également de eelle d'Ablabes periops. La faee dorsale est brun olive, avee une raie noirâtre qui eommence au cou et s'étend de ehaque eôté jusqu'à l'origine de la queue, en passant sur les parties eontiguës des troisième et quatrième rangées externes d'éeailles. En outre, au-dessus de ehaeune de ees lignes, à une distance égale à deux rangées d'écailles, se trouve une série longitudinale de petits traits de même teinte, longs d'une longueur d'éeaille et séparés entre eux par des intervalles de même étendue. Clineune de ees séries eommenee et se termine sensiblement au même niveau que les lignes auxquelles elles sont parallèles. La faee ventrale tout entière est uniformément gris jaunâtre, à part une ligne étroite d'un brun très pâle, qui, sous le queue, suit la suture médiane des deux rangées d'urostèges.

C'est avee hésitation que nous proposons eette rariété. L'espèce Ablabes periops n'est en effet eonnue que par les deux spéeimens types, qui sont originaires de Matang, et on ignore les limites entre lesquelles elle peut varier. Cependant, les earaetères offerts par les denx spéeimens que nous avons sous les yeux sont tellement identiques, qu'il n'est guère possible de eonsidérer eomme de simples variations individuelles les différenees si tranehées qu'ils présentent avee eeux de l'espèee de Günther. Des observations nltérieures montreront si la var. prrefrontalis est légitime, ou si même ello ne eonstitue pas une raee distinete.

95. Tropidonotus maculatus, Edeling.

Cinq spéeimens, dont 2 adultes et trois jeunes, tous originaires de Kina Balu, représentent eette espèee.

Ils offrent, relativement à la forme un peu boubée de la tête, aux grandes dimensions de l'œil, au nombre et à la disposition des plaques ećplialiques, à la earénation des éeailles du trone, au nombre de séries qu'elles forment, au nombre des gastrostèges et des doubles urostèges, ainsi qu'à la division de l'anale, les mêmes partieularités que Tr. maculatus. De même, les dents maxillaires sont faibles et assez courtes, à l'exeeption des deux ou trois dernières qui sont beaneoup plus fortes et deux à trois fois plus longues que les autres, dont elles sont séparées par une eourte laeune. Mais ils se distinguent de T). maculatus par leur eoloration, et ils nous semblent devoir en être eonsidérés eonme une variété, que lous désignerons sous le nom de torquatus.

Tropidonotus maculatus, var. ToRquatus.

Chez l'adulte, le dessns de la tête et du eorps tout entier est d'un brun noirâtre à peu près uniforme, qui s'étend jusqu'à la partic inférieure des flanes, sur les extrémités des gastrostèges. Sur le eou est un eollier étroit plus ou moins apparent, d'un jaune sale et en forme de fer à eleval, dont les branehes dirigées en avant vont aboutir aux eommissures des lèvres. A la partie supérieure des flanes se trouve, de ehaque eôté, une série de petites taches blanc grisâtre, allongées transversalenıent et situées sur les éeailles de quatrième, einquième et sixième rangées. Elles sont distantes l'une de l'autre, dans ehaque série, d'environ 1 eentimètre ; elles eommeneent un peu en arrière du eou pour se sueeéder jusqu'à l'extrémité de la queue, eelles d'un eôté alternant irrégulièrement avee celles de l'autre. La lèvre inférieure et la face ventrale sont d'un blane jaunâtre; mais à 3 ou 4 centimètres en arrière de la tête, de petites taehes noires, d'abord assez rares, apparaissent sur les parties latérales des gastrostèges, puis sur leur partie mojenne, en devenant plus nombreuses. Dans la partie antérieure du tronc, toutes ees taehes sont irrégulières, quant à leur situation et leur forme, tandis que dans son tiers postérieur et surtout sous la queue où elles existent seules, les taehes latérales se disposent en deux séries longitudinales formant deux larges raies noires, interrompues seulement sur le bord postérieur des gastrostèges et des urostèges.

Il n'existe point de taches noires sur le dos, ni sur les flanes, ni dessin d'aueune sorte sur la tête, ni ligne noire sur la suture médiane des urostèges.

Chez les jeunes̃, la eoloration des parties supérieures est assez différente. Le eou est noir, jusqu'à environ 13 millimètres en arrière des pariétales, et le dessus de la tête d'un brun foneé ; le eollier est d'un blane pur et s'élargit vers les eommissures. Le reste de la faee dorsale, beaueoup moins sombre que ehez 
l'adulte, surtout cn avant, offre l'aspect d'un réseau de bandes brunes encadrant des espaces plus clairs, et les deux séries longitudinales de taches situées à la partie supérieure des flancs sont blanches, comme le collier. La face ventralc offre la même coloration que chez l'adulte.

Le plus grand des deux spécimens adultes mesure 715 millimètres de longueur totale, dans laquelle la queue entre pour 188 millimetres. La longueur des jeunes varie de 23 ì 29 millimètres.

L'absence de taches noires sur le dos et les flancs, l'existence d'un collier blanc chez les jeunes, jaune sale chez les adultes, et celle de deux séries longitudinales de taches latérales blanches ou grises, caractérisent cette variété et la distinguent de $T r$. maculatus.

98. Tropidonotus sarawacerssis, Günther. Kina Balu.

100. Tropidonotus flavifrons, Boulenger.

Dentition syncranterian. Head oval, very distinct from neck; snout short; eyos moderate. Scales in 19 rows, fcebly keeled, of outer row smooth. Ventrals 146 ; anal entire; subcaudals 95 . Internasals truncated in front, about half as large as the præfrontals ; one præ- and two postoculars; loreal as deep as broad; eiglit upper labials, fourth and fifth entering the orbit; two superposed anterior temporals. Olive above, with dark network; two alternating series of white spots along each side, upper on the sixth scale from the ventral, lower larger and on the outer border of the ventral; a large yellow spot covcrs the forehead (prefrontals, loreals, præoculars, and anterior half of frontal); sutures between the labials black; vcntrals whitish, with large black spots; the black predominates on the subcaudals.

Length to vent 300 millim.; tail 153 .

A single specimen.

HeLicopsoides, n. g.

Ce genre, appartenant à la sous-famille des Homalopsince et voisin des Helicops, offre les caractères suivants :

La tête est déprimée, le museau large et arrondi. Il existe deux internasales; la frénale est simple ou divisée, et l'œil, pourvu d'une pupille arrondie, est entouré d'un cercle complet d'écailles. Les labialcs supérieures sont nombreuses, élevées, les postérieures subdivisées. La fente buccale est longue, relevée aux commissures. Les écailles du tronc sont carénées et striées, sans fossette à leur extrémité postérieure. L'anale et les urostèges sont doubles. Les dents maxillaires supérieures sont petites, égales, en sćrie continue, sans crochets sillonnés.

107. Hritcopsoides typicus, n. sp.

Déprimée et terminée par un museau large et arrondi, la tête est bien distincte du cou. Le tronc est court, cylindrique, presque partout d'égale grosseur, un peu plus étroit à ses deux extrémités, et la queue, également courte, s'atténue rapidement et devient très grêle dans sa partie postérieure.

La rostrale est pentagonale, près de deux fois plus large que hante, non renversée sur le museau, à bords latéraux presque parallèles. Allongées, percées en dessus d'une narine en forme de fente et incomplètement divisées, les nasales se rcncontrent derrière la rostrale et séparent cette plaque de deux petites internasales triangulaires. Les préfrontales sont notablement plus larges que longues et présentent cinq côtés, dont l'antérieur et le postérieur, les plus longs, sont transversaux et sensiblement parallèles. Les sus-oculaires sont courtes et très étroites, de sorte que la frontale, qui est rannassée, aussi large que longuc et à bords latéraux presque parallèles, occupe la plus grande partie de l'espace interorbitaire. Cette plaque a la forme d'un pentagone dont la base, tournée en avant, est transversale et dont le sommet, dirigé du côté opposé, forme un angle obtus, peu différent d'un angle droit. Les pariétalcs sont grandes, près de deux fois plus longues que larges; eiles laissent entre elles, en avant, un angle qui reçoit l'extrémité postérieure dc la frontale; leur bord externe est assez régulièrement convexe et leur anglc postérieur ne présente qu'une légère troncature de dehors cn dedans et d'arrière en avant. D'un côté, la frénale très allongée est en partie divisée par une suture verticale, tandis que de l'autre, la division est 
complète. L'oil est petit, à pnpille arrondie, entouré d'un ecrele eomplet d'écailles, dont deux préoenlaires, autant de postoculaires et trois autres plus petites, réduites à deux du côté droit par suite de soudure, qui le séparent inféricurement des supéro-labiales. Ces dernières sont au nombre de 11, les 6 premières sont denx fois plus hautes que longues et les 4 postérieures sont subdivisées elacune en deux parties dont l'inférieure, très petite et formant le bord labial, est le plus souvent située sous la suture qui sépare l'une de l'autre les parties supérieures. Celles des septième et luitième paires correspondent à l'œil. Un sillon assez profond sépare les supéro-labiales des écailles qui leur sont superposées. De forme très irrégulière, les temporales sont rangées suivant la formule $1+1+2$; la première est la plus petite, la deuxième la plus grande. Les labiales inférieures sont au nombre de 10 : eelles de la premièro paire se rencontrent derrière la mentonnière, qui est très courte et affecte la forme d'un eroissant à coneavité peu accusée ; les 3 suivantes touehent aux sons-maxillaires de la première paire, qui sont larges en avant et lancéolées à leur extrémité postérieure. Los sous-maxillaires de la deuxième paire sont courtes et triangulaires, à base tournée en dehor's et sans contact avec les infëro-labiales.

Les écailles du trone sont losangiques, non imbriquées, assez fortement carénées, striées et rangées au milieu du trone suivant 19 séries longitudinales. On compte 3 plaques gulaires, dont l'antérieure seule est paire, 176 gastrostèges dépourvues de earène latérale et 82 doubles urostèges. L'anale est divisée.

Toutes les parties supérieures ont une teinte uniforme brun olivâtre; la face ventrale est d'un jaune sale.

L'unique spécimen qui représente cette espèce est de petite taille et ne mesure que 39 centimètres de longueur totale, celle de la quene étant de $9^{\mathrm{cm}}, 5$, à peu près le quart. Il provient de Kina Balu.

120. Leptophis formosus, Boié.

127. Psammodynastes pulverulentus, Boié. Kina Balu.

130. Ophites albofuscus, Dum. Bib. Kina Balu.

133. Dipsas dendrophila, Reinwarlt.

138. Platurus fasciatus, Schneider.

152. NaJA tripudians, val. Nigra, Günther.

153. Bothrops gramineus, Shaw. Kina Balu.

156. Rana KuHLit, Sehlegel. Kina Balu.

158. RaNa Gracilis, Wiegmann.

159. RaNa DeCorata, u. sp.

La tête est modérément läge et déprimée, le museau obtus, avec un canthus rostralis pen marqué, au-dessous duquel s'ouvrent les narinos, un peu plus près de l'extrénité du museau que du bord antérienr de l'orbite. L'espaee interorbitaire est notablement plus large que la paupière supérieure, et le tympan très distinct a un diamètre presque égal à eelui de l'œil. Les dents vomériennes forment, entre les narines internes, deux groupes dont l'obliquité assez faible est telle que la direction de chacun d'eux passe sur le bord antérieur de la saillie de la voûte palatime eorrespondant à l'œil du côté opposé. Les doigts sont peu allongés, à extrémité obtuse, non dilatée ; le premier est notablement plus long que le second et il dépasse le quatrième autant qu'il est lui-même dépassé par le troisième, dont il diffère peu. Les orteils sont d'une longuenr modérće, moins qu'à moitić palmés et légèrement dilatés à leur extrémité. Les tubercules sous-articulaires sont grands, ovalaires, mais assez peu saillants. Le tuberenle métatarsien interne n'en diffère guère que paree qu’il est un peu plus allongé ; à la base du quatrième orteil on distingue une légère saillie arrondie qui offre plus de netteté ehez de jeunes individus dont les métamorphoses ne sont pas encorc tout à fait acherées. L'articulation tibio-tarsienne atteint la narine lorsque le membre postérieur est dirigé en evant. 
La peau cst lisse sur ses deux faces dorsale et ventrale, et il n'existe aucune trace de repli entre l'œil ct l'épaule, ni sur les flancs.

Le dos, d'un brun olive, est entouré d'une raie blanche (peut-être jaune sur le vivant), qui passe à la limite supérieure des flancs, s'interrompt au niveau du bord libre de la paupière supérieure, suit le canthus rostralis et s'unit à celle du côté opposé à l'cxtrémité du museau. Les flancs ainsi que les côtés de la tête sont d'un brun noirâtre, moins foncé à la partie inférieurc. Une raie blanche naît entre l'œil et la lèvre supéricure, se dirige en arrière en passant au-dessous du tympan et se termine au devant de l'épaule. Le dessus des membres est d'un brun clair, avec quelques marbrures ou taches noires transversales plus on moins étroites, tandis que, les membres postérieurs étant repliés sur eux-mêmes, toutes les faces en contact sont coupées par de larges barres transversales noires assez régulières, séparées par des raies blane jaunâtre étroites sur les cuisses, plus larges sur la jambe et le tarse. Le face inférieure du corps est d'un brun uniforme sous la gorge, plus clair et légèrement tacheté de blanc jaunâtre sous le ventre.

Nous ne possédons de cette belle espèce qu'un seul spécimen adnlte et deux jeunes, tous les trois originaires de Kina Balu.

Les jeunes sont encore assez ćloignés de la forme adulte. En effet, l'appendicc caudal n'est pas complètement résorbé ; la bouche est encore peu fendue ; les dents maxillaires et vomériennes sont à peine visibles et le tympan est encore caché. Ils ont à peu près la coloration de l’adulte, avec cette différence que le dos est brun ardoisé assez clair, sans raie blanche sur les bords, et que le ventre est plus tacheté, principalement sur les côtés.

L'espècc que nons venons de décrire est voisine de $R$. malabarica; elle s'en distingue cependant avec facilité par ses narines moins rapprochées de l'extrémité du museau, par une plus grande largeur de l'espace interorbitaire, par une plus grande longueur du premier doigt et une moindre du troisième, par une légère dilatation des orteils à leur extrémité et la moindre étendue de la membrane interdigitale, par une saillie beaucoup plus faible du tubereule métatarsien externe, par une plus grande longueur du membre postérieur, par l'absence de repli entre l'œil et l'épaule, enfin par la coloration.

162. Rana whiteheadi, Boulenger.

Vomerine teeth in two oblique groups just behind the line of the choanæ. Head large; snout obtusely acuminate, projecting, with angular canthus rostralis and dceply concave loreal region; eyes very large; interorbital space narrower than the upper eyelid; tympanum half or three fifths tha diameter of the eye. Fingers moderate, first extending slightly beyond second; toes moderate, entirely webbed; disks well developed, about two fifths the diameter of the tympanum ; subarticular tubercles small ; a small oval inner metatarsal tubercle. Hind limb very long, the femoro-tibial articulation reaching the shoulder ; tibia as long as the distance between the orbit and the vent. Skin nearly smooth ; an interrupted glandular lateral fold from the eye to the sacrum. Grey-brown above, with rather ill-defined darker cross bands on the limbs; tympanum reddish; upper lip and lower surfaces whitish. Male with an external vocal vesicle on each side of the throat, below the commissure of the jaws; no humeral gland.

From snout to vent 46 millim.

Four male specimens.

The nearest ally of this species is $R$. jerboa, Gthr., which differs in having longer hind limbs, a shorter, blunter, and less projecting snout, smaller eyes, \&c.

166. Rana obsoleta, n. sp.

La tête est assez étroite, déprimée, le museau allongé et arrondi à son extrémité. Le canthus rostralis est bien distinct, la région frénale presque vertieale, concave, et la narine s'ouvre beaneoup plus près de l'extrćmité du museau que de l'œil. L'espace interorbitaire est environ d'un tiers plus large que la paupière supérieure, et le tympan égale les deux tiers du diamètre de l'œil. Les dents vomériennes forment cntre les narines internes deux petits groupes obliques largement espacés. Les doigts sont assez grêles et allongés, et lc premier dépasse à peine le second. Les orteils sont un peu moins qu'aux deux 
tiers palmés, avec des tubercules sous-articulaires courts et bien saillants. Comme les doigts, ils sont légèrement dilatés à leur extrémité. Il existe deux tubercules métatarsiens : l'interne allongé, l'externo court, arrondi et très saillant, à la base du quatrième orteil. Dans l'extension du membre postérieur le long du corps, l'articulation tibio-tarsienne atteint l'extrémité du museau.

La face dorsale est granuleuse et bordée dc chaque côté par un repli glanduleux bien distinct. En arrière de la commissure des lèvres se trouvent également deux saillies glanduleuses situées l'une au devant de l'autre ; mais il n'y a pas de repli entre l'œil et l'épaule.

Le dos est brun marron foncé, parsemé de petites taches plus claires, tandis que les flancs et les parties latérales de la tête sont plus sombres et presque noirs. La lèvre supérieure présente une bordure blanche lavée de brun, que se prolongc au-delà de la commissure sur les saillies glanduleuses signalées en ce point. La face ventrale est d'un gris de sable piqueté de brun. Sur la face inférieure des membres postérieurs sont des taches sombres, presque noires, formant à la jambe des barres transversales peu distinctes.

Un seul spécimen provenant de Kina Balu. Longueur totalc 101 millimètres ; du museau à l'anus, 41 111illimètres.

Cette espèce est très voisine de $R$. signata, Günther, a vec laquelle nous ne pouvons malheureusement la comparer, cette demière ne se trouvant pas dans la collection du Muséum. Elle de s'en distingue guère, en effet, que par le repli glandulaire latéral qui fuit défaut chez $\boldsymbol{R}$. signata, par la plus grande largeur de l'espace interorbitaire, par la brièveté plus grande du premier doigt et quelques détails de coloration.

\section{Rana everetti, Boulenger. Kina Balu.}

171. RANA PARAdOXA, n. sp.

La tête cst déprimée, assez étroite chez les femelles, très large, triangulaire, avec deux renflements sur les côtés de l'occiput chez les mâles. Le museau est court, subanguleux, plus petit que le diamètre de l'orbite et, chez les mâles, recourbé en bas à son extrémité antérieure à la manière d'un bec de tortue, disposition qu'on doit attribuer à une forte saillie des os intermaxillaires et qu'on observe aussi à un certain degré chez les femelles. Le canthus rostralis est nul, la région frénale légèrement concave, le tympan caché, la narine ouverte un peu plus près de l'extrémité du museau que du bord antérieur de l'orbite, et l'espace interorbitaire est beaucoup plus large que la paupière supérieure. Les dents vomériennes forınent deux courtes séries obliques, convergentes, dépassant en arrière le nireau du bord postérieur des narines internes; la mâchoire inférieure porte en avant deux apophyses dentiformes très saillantes.

Les doigts sont modérément allongés, les deux premiers sensiblement égaux. Les orteils sont complètement palmés et terminés par des disques bien développés qui, aux doigts, sont au contraire très petits. Aux doigts comme aux orteils, les tubercules sous-articulaires sont très accusés. Le tubereule métatarsien internc, le seul qui existe, est très allongé ; un repli cutané borde en dehors le métatarsien externe et le cinquième orteil. Le niembre postérieur étant appliqué le long du corps et dirigé en avant, l'articulation tibio-tarsienne atteint l'œil ou un peu au delà.

Les faces dorsale et ventrale sont à peu près lisses, et il n'existe pas de repli distinct allant de l'œil à l'épaule; quelques petits tubercules verruqueux se voient sur les tibias.

Toutes les parties supérieures sont d'un brun sombre. Quelques grandes taches plus foncées nuancent les lèvres supérieure et inférieure. La face ventrale est gris jaunâtre, avec un réseau de taches brun clair sous la gorge.

Deux mâles et quatre femelles, dont deux portent une raie blanche dorsale médiane, provenant tous de Kina Balu, appartiennent à cette espèce.

172. Reacophorus maculatus, Gray.

Un spécimen de Kina Balu et deux de Palawan. 
173. Rhacophords leucomystax, var. quadrilineatus, Wiegmann. Kina Balu.

176. Rhacophorus CRUCiger, Blyth.

Nous rapportons à cette espèce trois Rhacophomus provenant du nord de Bornéo, qui diffèrent manifestement des espèces précédentes. Ainsi, le inembre postérieur est plus long et l'artieulation tibiotarsienne dépasse, eliez deux des spéeimens, l'extrémité du museau du ticrs de la longueur du tibia ; les doigts son libres et leur disque terminal est plus grand et dilaté transversalement; enfin, deux des spéeimens présentent sur leur fice dorsale la grande tache brune en forme de sablier, qui s'étend depuis l'intervalle compris entre les yeux jusqu'au sacrum, et qu'on rencontre habituellement chez $R$. cruciger.

Les fronto-pariétaux sont plus larges en avant qu'en arrière, mais ils n'ont aucune connexion avec le squamosal, et la peau, adhérente chez l'un des spéeimens aux fronto-pariétaux et aux nasaux, n’adhère qu'aux premiers de ces os chez un second, tandis qu'elle est libre partout chez le troisième. Ce dernier caractère ne semble donc avoir qu'une valeur très relatisc.

Le plus grand de ces Rhacophorus mesure 75 millimètres de l'extrémité du museau à l'orifice anal ct 195 millimètres de longueur totale.

Cette espèee n’avait été jusqu'ici recontrée qu’à Ceylan où, d'après Newill, elle est très répandue.

177. Rhacophorus appendiculatus, Güinther.

Cette espèce, dont le type est originaire des îles Philippines, vient, comme la préeédente, s’ajouter à la fiune batrachologique de Bornéo. Elle n'est représentée que par un spécimen femelle de faibles dimensions (38 millimètres de l'extrémité du museau à l'anus), quoique adulte, puisqu'il est chargé d'œufs arrivés à une période de leur développement voisine de la ponte. Elle se distingue donc par la petitesse de sa taille, et il est probable que les deux spécimens considérés par M. Boulenger dans son Catalogue of the Batrachia salientia du British Museum, p. 86, comme incomplètement développés, sont également adultes, si la figure qui en est donnée les représente en grandeur naturelle.

Ajoutons que chez notre spécimen, les tubercules sous-articulaires ne sont doubles que sous le quatrième doigt, et que le membre postérieur étant étendu le long du corps, l'articulation tibio-tarsienne atteint l'œil et non l'extrémité du museau.

Il provient du nord de Bornéo.

178. Rhacophords acutirostris, n. sp.

De forme peu élancée, cette espèce a la tête large, déprimée, le museau anguleux et court, à peinc supérieur au plus grand diamètre de l'œil. Le canthus rostralis est bien marqué, et l'arête qu'il forme se prolonge jusqu'à l'extrémité du museau, où elle se rencontre, après s'être infléchie vers le bas, sous un angle aigu avec celle du eôté opposé, un peu au-dessus du bord labial. De là, la forme anguleuse du museau, et le nom donné à cette espèce. La narine s'ouvre immédintement au-dessous du canthus rostralis, à égale distanee de l'extrémité du museau et de l'œeil. Los yeux sont peu saillants et l'espace intcrorbitaire est plus large que la paupière supérieure. Le tympan est petit, un peu plus grand que le tiers du diamètre de l'œeil, et il est surmonté d'un forte repli qui s'étend de l'œil à l'épaule. Les dents vomériennes forment deux petits groupes largement espacés, dirigés presque transversalement entre les narines internes.

Les doigts sont courts, les cxternes aux deux tiers palmés, tandis que l'interne est presque libre. Les orteils sont aux trois quarts palmés, et leurs disques terminaux, plus petits que ceux des doigts, sont aussi grand que le tympan. Les tubercules sous-articulaires sont bien développés, mais courts et presque circulaires. Il n'y a pas de tubercule métatarsien externe, et l'interne est petit. Le membre postérieur étant dirigé en avant le long du corps, l'articulation tibio-tarsienne atteint l'œil ou un peu au delà.

La peau est lisse en dessus, fortement granuleuse sous le ventre et la face inférieure des cuisses. Le long du bord postérieur de l'avant-bras se trouve une rangée de six ou sept petits tubercules arrondis, qui tranchent par leur teinte blanche sur le fond brun du membre, et sont plus aceusés chez les jeunes que chez les adultes. 
Chez deux spécimens adultes, la ficc dorsale, y compris la lèvre supérieure, est d'un brun ardoisé uniforme plus ou moins foncé, et la face ventrale blanc jaunâtre mouclieté de brun, avee de grandes taches prcsque noircs séparées ou fusionnées sur la partie postéro-inférieure des flancs, ainsi que sur lcs faecs antérieure et postérieurc des cuisses. L'un des deux spécimens présente cn ontre, entre les yeux, une étroite bande transversale plus sombre, que l'on observe également chez quatre autres jeunes individus. Telle est la coloration qu'on doit considérer comme normalc. Mais chez les jeunes individus dont nous venons de parler et dont la longueur, de l'extrémité du musenu à l'orifice anal varie de 33 à 37 millimètres, la faee ventrale a une teinte grise ou blanc jaunâtre sans taehe, et la faee dorsale passe de la teinte ardoisće à une tcinte roussâtre, avce quelques taehes brun sombre qui, dans un cas, forment quatre bandes transversales. Des barres transversales brunes sur fond roussâtre se voient aussi, chez l'un d'eux, aux cuisses et aux jambes. Enfin, me petite tache blanche que l'on observe ehez l'un des deux adultes cn avant du tympin, au-dessous de l'angle postérieur de l'œil, se retrouve chez l'un des jeunes oì clle s'aranee jusqu'au bord libre de la paupière inféricure, et manque chez tous les autres spécimens.

Tous proviennent de Kina Balu. Le plus grand mesure 120 millimètres de longucur totale et 47 millimètres de l'extrémité du muscau à l'orifiee anal.

\section{Ixalus latopalmatus, Boulenger.}

Snout very short, broadly rounded, obliquely truncate at the end, with nearly vertieal, eoncave lores; eyes large; interorbital space as broad as the upper eyelid; tympanum very small, not very distinct. Fingers short, dilated into enormous disks, the width of which equals three fourths the width of the eye ; a broad web, extending nearly to the disks, between the two outer fingers, and a short one between the second and third ; toes very broadly wcbbed, the web enclosing one half of the disks ; latter about lialf the sizc of those of the fingers ; subarticular tubercles oval, flat; no distinct metatarsal tuberele. Hind limb very long and strong; the femoro-tibial articulation reaches the shoulder; tibia as long as the distance between the tympanum and the vent. Skin finely granulate above, snootl inferiorly. Blackish above, with pale brown variegations on the back and whitish dots on the sides; limbs with lighter cross bands ; hinder side of thighs-blackish, speeklcd with whitish; lower surfaees whitish.

From snout to vent 53 millim.

Two specimens, female and half-grown.

\section{Ixalus NuBILUS, n. sp.}

Lo museau est obtus, d'une longueur égale au grand diamètre de l'œil et coupé obliquement cn bas et en arrière à son extrémité. Le canthus rostralis est angulcux, la région frénale verticale, et la distance qui sépare la narine du sommet du museau ćgale la moitié de celle qui la sépare de l'œil. L'espace interorbitaire est un peu plus large que la paupière supérieure. Le tympan est bien distinct et son diamètre exeède légèrement lc ticrs de celui de l’œil. Une papille arrondie et assez saillante s’élère sur le milien de la partie antérieure de la langue.

Les doigts sont libres, les deux internes égaux; les orteils sont complètement palınés, la membrane interdigitale s'étendant même jusqu'aux disques terminaux. Ces derniers sont larges, ceux des doigts plus grands que le tympan. Les tubcrcules sous-articulaires sont bien développés, et il existe un tubereule métatarsien interne étroit, allongé et assez saillant, sans tubercule externe. Dans l'extension du membre postérieur en avant, l'articulation tibio-tarsienne dépasse sensiblement l'extrémité du museau.

Granulense en dessus, la peau est lisse sous le ventre, sans repli entre l'œil et l'épaule, ni repli glanduleux latéral. La face dorsalc est d'un brun sombre uniforme ou avec quelques veines plus claires, la faee ventrale gris jaunâtre ; des bandes transvcrsales plus ou moins distinctes pcuvent exister sur les membres postérieurs.

Trois spéeimens ont été reeueillis à Palawan; le plus grand est une femelle chargée d'œufs qui mcsure 108 millimètres de longueur totale et 45 millimètres du museau à l'orifice anal. 
Cettc espècc, assez voisine de I. saxicola, s'en distingue par sa narine plus rapprochée dc l'extrémité du museau que de l'œil, par son tympan bien visible, par ses orteils complètement palmés, par sa peau granuleuse en dessus, par l'absence de repli entre l'œil ct l'épaule ct par sa coloration.

Ixalus, sp. indet. (Têtards).

Ici se place l'étude des Têtards, au nombrc cle quatre, capturés dans un ruisseau de mont Kina Balu, à une altitude d'environ 3000 pieds, et que j'ai déjà signalés dans une communication au Congrès international de zoologie.

Ccs Têtards offrent cette curieuse particularité qu'ils sont pourvus d'un large disque adhésif qui occupe presque toute la face ventrale et qui est bordé sur tout son pourtour, excepté en avant, par un repli saillant dirigé horizontalcment. La bouche est, sans doute possible, comprise dans ce disque, car la lèvre inférieure, qui mériterait ici le nom de postérieure, est renversée en arrièrc et si étroitcment appliquée sur le disque, dont elle offre d'ailleurs la teinte blanchâtre, qu'on nc la distingue qu'en la soulevant au moyen d'une aiguille ; elle forms le bord postérieur d'une ventouse orale puissamment armée, qui termine en avant le grand disque adhésif ventral. Isa lèvre supérieure (antérieure), saillante, limite en avant cet appareil. Entre ces deux lèvres très écartées l'une de l'autre, se trouve la cavité buccale largement ouverte et pourvue de trois robustes dents cornées de couleur noire, qui rappellent, par lear disposition générale, celles de certains Cyclostomes, en particulier des Mordacia.

L'une de ces dents en forme de $\mathrm{V}$ à pointe tournée en arrière*, est injpaire et inférienrc, à faces externes canelées, et elle est portée sur un gros manıclon charnu qui devient la languc de l'adulte; les deux autres, également portées chacune par un mamelon qui, toutcfois, s'unit à son congénère sur la ligne médianc, sont supérienres, arquées et symétriques, séparécs par un assez large espace, et ont le bord libre denticulé comme celui de la dent inférieure. Chez le plus avancé de ces Têtards, les dents supérieures sont très réduites et semblent en voie de résorption; l'inférieure a nême tout à fait disparu, et le tubercule charnu qui la supportait s'est étalé et bifurqué dans sa portion profonde, de manière à revêtir en partie les caractères de la langue de l'adulte.

Sur les eôtés de ces dents buccales, ainsi qu'en arrière de l'inférieure et en avant de la supérieure, se trouvent une série de replis imbriqués les uns sur les autres, qui garnisscnt ce que l'on doit considérer comme la face interne des deux lèvres, et dont le bord libre porte un petit liséré noir finement denticulé ct de nature cornée, comme les dents. Les replis qui naissent de la lèvre supérieurc ont le bord libre dirigć en avant, tandis que ceux de la lèvre inférieure se dirigcnt en arrière, de sortc que sur l'une et sur l'autre lèvre, les replis les plus rapprochés de l'orifice buccal, considéré comme centrc, recouvrent les autres replis de la série correspondante. La disposition de ces replis indique claircment que leur rôle cst de contribuer à la fermeture de la rentouse orale pendant les mouvenents exécutés par l'appareil dentaire.

La pupille est horizontalc. Los membres postérieurs, chez les Têtards dont le développement est lc plus avancé, sont très allongés, et lorsqu'ils sont dirigés en avant, appliqués contre le corps, l'articulation tibio-tarsienne dépasse notablement l'cxtrénité du museau. Les métatarsicns externes sont séparés par unc membrane. Dilatés cn disque à leur extrémité et d'une longueur modérée, les orteils sont complètement palmés, la membrane intcrdigitale s'étendant jusqu'aux disques inclusivement. Les tubercules sousarticulaires sont bicn dévcloppés, ovalaires, et on distinguc un tubercule métatarsien interne allongé et assez saillant, sans tubcreulc externc.

Chez dcux de nos Têtards, les membres antéricurs sont complètcment développés et on peut constater que les doigts sont modérément allongés, libres, dilatés en un assez large disque à leur extrémité, les dcux internes étant de mêmc longueur.

En dessus, le corps est d'un brun olive uniforme, avec des traces de barres transversales plus foncćes

* C'est par erreur que dans le Compte rendu des séances du Congrès international de zoologie, p. 80, cette dent est dite tourner sa pointe en ayant. 
sur les membres; lc rentre est blanc grisâtre. Chez le plus avancé en développement, la face dorsale est, comme chez Ixalus nulilus, fortement granuleusc, excepté sur les membres.

Quelques autres particularités méritent d'être mentionnécs. Le spiraculum se voit cncore chez l'un de ces Têtards seulement, à l'extrémité d'une courte saillie tubuleuse sur le côté gauche, un peu en arant du niveau du bord postérieur du disque ventral ; et chez un second un peu plus âgé, on voit à gauche au nuême point, et à droite au point correspondant, un orifice arrondi par lequel le membre antérieur contenu dans la cavité branchiale commence à faire saillie. Nous rappellerons enfin que l'existence d'un disque adhésif ventral chez les Batraciens anoures n'a rien qui puisse surprendre, si l'on observe que la plupart des larves de ce groupe, celles des Aglosses exceptées, sont pourvues, pendant une asscz longue période de leur développement, d'une paire (quelquefois même de deux) de petits disques adhćsifs qui, d'abord séparés, se rejoignent ensuite, au moins dans certains cas, derrière la bouche, pour se séparer de nouveau ct s'atrophier. Que ces disques, au lieu de disparaître après s'être réunis, s'étendent de manière à occuper toute la face ventrale, et la disposition observée chez nos Têtarls de Kina Balu se tronvera réalisée.

Balfour * a émis l'opinion que les Têtards des Batraciens anoures et les Cyclostomes descendent d'unc souche commune primitive dont la bouche était disposće en suçoir; la présence, chez les Têtards dont nous venons de parler, d'une bouche semblable à ceḷle des Cyclostomes témoigne en faveur de cette hypothèse.

Ija détermination de ces Têtards d'est pas exempte de difficultés.

Procédons par ćlimination. Les seuls genres de Batraciens anoures actuellement connus à Bornéo sont les suivants: Rana (comprenant les Limnodytes et les Mylorana), Rhacophorus (les Polypedates compris), Ixalus, Calophrynus, Callula, Nectophryne, Bufo, Pseudobufo (Nectes), Leptolrachium et Megalophrys. Or, nous avons vu ci-dessus que, chez nos Têtards, les métatarsiens externes sont séparés par une membrane; ils ne peuvent donc être rapportés à aucun des huit derniers genres, chez lesquels ces métatarsiens sont unis. Il reste donc les trois genres Rana, Rhacophorus et Ixalus.

Ce que l'on sait du développement de divcrses espèces de Rana ne permet guère d'admettre qu'il puisse présenter, dans l'autres espèces du même genre, des particularités telles que celles que l'on observe chez nos Têtards. Nous écartons done aussi le genre Rana.

Jans ma communication au Congrès international de zoologie, j'avais conclu en faveur du genre Rhacophorus, réserve faite du cas où ces Têtards appartiendraicnt à un type générique nouveau ; mais un examen plus approfondi de ces animanx m'a conduit à les considérer plutôt comme des larves d'Taxalus, et voici les raisons de cette nouvelle manière de voir.

On peut remarquer que chez les Rhacophorus, au moins chez la plupart des espèces, les deux doigts extcrnes sont presque d'égale longueur et notablement plus grands que les deux internes. Cette particularité ne s'observe pas chez nos Têtards, où les doigts présentent, en ce qui concerne leur longueur relative, les caractères de ceux des Rana et des Ixales, c'est-à-dire que le quatrième doigt ne diffère pas plus du second qu'il ne diffère lui-même du troisième ; en outre, les doigts sont parfaitement libres, et la phalange terminale n'est pas bifurquée comme on l'obscrve chez $R$. maculatus,-leucomystax,-cruciger,"ppendiculatus,_acutirostris, que l'on rencontre tous à Bornéo. Je rejette donc également le genre Rhacophorus. Reste le genre Ixale.

Trompé par une donnée, sans doute trop généralisée, puisée dans le catalogue des Batrachia salientia du British Museum, par M. Boulenger, page 93, à savoir que chez les Ixales, les phalanges terminales sont obtuses à leur extrćmité (Terminal phalanges oltuse), j'avais de prime abord éliminé ce genre, ces phalanges étant, chez nos Têtards, terminées en T, avcc une barre transversale plus longue que chez les Runa et pointue à ses extrémités. Or, ces caractères de la phalangc terminale, nous les avons retrouvés

* Traité de embryologis, trad. franç, t. II, p. 12S (1SS5). 
chez les Ixales : I. latopalmatus, $I$. nubilus. Nous pouvons aller plus loin et affirmer que les membres, les antérieurs comme les postérieurs, offrent dans tous leurs détails les mêmes caractèrcs que chez I. nubilus, ainsi qu'on peut s'en convaincre en comparant les descriptions qui cn ont ćté données chez cet Ixale et chez les 'lêtards.

Nons concluons donc, tout en faisant les réserves qui s'imposent en pareil cas, que nous avons affaire à des larves d'Ixalus et probablemcnt d'I. nubilus, espèce qui, trouvéc à Palawan, nc peut manquer de se rencontrer dans lc nord de Bornćo.

La détermination exacte de ces Têtards, l'étude de leur développement et l'évolution du disque adhésif ventral ainsi que de la ventouse orale, la connaissance de l'hôtc sur lequel ils vivent en parasites, tclles sont les questions qui restent à résoudrc. Nous ne pouvons que les signaler à l'attention des naturalistes voyageurs.

M. Boulenger a déjà signalé et figuré des Têtards d'anoures pourvus, comme les nôtres, d'un disque adhésif ventral, mais dont la bouche est inerme et qu'il rapporte provisoirement au Rhacophorus reinwardtii. Ces Têtards avaient-ils accidentellement perdu leur armature buccale, ou diffèrent-ils réellement de ceux quc nous venons de décrire? c'cst ce qu'il nous est actuellement impossible de dire.

187. Bufo AsPer, Gravenhorst.

Nous rapportons provisoirement à cette espèce un individu en peau desséchée, sur lequel on peut constatcr les principaux caractc̀res du Bufo asper ; toutefois les parotides, beaucoup plus grosses qu'on ne less rencontre ordinairement et d'une longueur presque ćgale à la distancc qui les sépare de l'extrémité du muscau, sont très renflées et vont en divergeant d'avant en arrière, en devenant plus étroites. Ces dimensions exceptionnclles doivent-elles être attribuées à la grande taille de l'individu, qui mesure 470 millimètres de longueur totale ct cnviron 195 millimètres de l'extrémité du museau à l'anus? Nous cn doutons. Il a été capturé au mont Kina Balu, à une altitude d'environ 1500 pieds.

188. Bufo Biporcatus (Schlegel), Tschudi. Kina Balu.

189. Bufo divergens, Peters.

Trois spécimens proviennent de Palawan. Les types décrits par Peters étaient originaires de Sarawack (Bornéo).

190. Bufo fuligineus, n. sp.

Les formes sont modérément ramassées, les membres assez allongés. Dépourvue de crêtes crâniennes, la tête se termine par un museau arrondi, à canthus rostralis anguleux, limitant une région frénale légèrement oblique et presque verticale. L'espace interorbitaire est sensiblement plus large que la paupière supérieure, et le tympan, très distinct, présente un diamc̀tre égal à la moitié de celui de l'œil.

Scnsiblement plus court que le second, le premier doigt est renflé ct convert, sur sa face supérieure, de petites épines coniques d'aspect corné, dont on observe aussi quelques-unes sur le second doigt, et qui sont sans doute un attribut du sexe mâlc, auquel appartient l'individu que nous décrivons. L'articulation tibio-tarsienne atteint le bord antérieur du tympan, lorsque le membre postérieur est étendu le long du corps. Les orteils sont courts, à moitié palmés, sauf les deux internes qui le sont presque complètement. Dc même que les doigts, ils sont renflés à leur extrémité, mais non dilatés. On ne distingue pas de tubcreules sous-articulaires, ni de tubercule métatarsien interne, l'externe seul était apparent, quoique peu développé.

Dépourvu de parotides, le corps est couvert en dessus de tubercules verruqucux inégaux, qui sont surtout nombreux ct saillants dans la région comprise entre le tympan et l'épaule. Le vontre est simplement granulcux.

La face dorsale est d'un noir de suie uniforme, qui a valu à l'espèce le nom de fulligineus, et qui passe au brun clair sous le ventre et au blanc sale sous les membres.

Un spécimen rrâle a ćté seul capturé ; il provient du nord de Bornéo et mesure 38 millimètres de l'extrémité du museau à l'anus et 80 millininètres de longueur totale. 


\section{Bufo Leptopus, Günther.}

193. Bufo (Ansonia) penangensis, Stoliezka.

Quatre spćcimens de Kina Balu.

Cette espècc n'était jusqu'iei connue, autant du moins que nous sachions, que par les individus types, qui sont originaires de Pinang.

194. Bufo SPINulifer, n. sp.

De forme élancée, cette espèce a les membres grêles et allongés, la tête petite. Le museau, subanguleux et à extrémité oblique en bas et en arrière, a une longueur égale au grand diamètre de l'œil. Le canthus rostralis est relevé par une arête assez saillante qui déborde la région frénale verticale, et il n'existe pas d'autre crête erânienne. L'espace interorbitaire cst presque deux fois aussi large que la paupière supérieure. Très distinct, le tympan égale en diamètre la moitié de l'œil.

La longueur du membre antérieur égale la distanee qui sépare le tympan de l'orifice anal, et le menbre postérieur étant appliqué le long du corps, l'articulation tibio-tarsienne arrive entre l'œil ct l'extrémité du museau. Les doigts sont grêles, le premier un peu plus eourt que le seeond; les orteils sont palmés à la hase et, comme les doigrts, très légèrement dilatés à leur extrémité. Les tubercules sous-articulaires font défaut, tandis qu'il existe deux tubercules métatarsiens, un interne très grand, oralaire et aplati, et un externe petit, un peu plus saillant que le premier.

Los parotides manquent; mais le dessus du corps est eouvert de gros tubercules inégaux, la plupart verruqueux et à orifices excréteurs très visibles, parfois assez régulièrement disposés cn quatre séries longitudinales. Les tubercules latéraux sont surtout développés et, par leur confluence, forment deux gros bourrelets verruqueux sur les bords de la face dorsale. Les flancs et le dessus des membres sont garnis de tubereulcs arrondis, inégaux, distincts entre eux ct terminés pour la plupart, comme eeux du dos, par une petite pointe spiniforme. Toute la face ventrale, même la gorge, est couverte de granulations qui, sous la symphyse du menton et aux angles de la mâchoire inférieure, sc transforment en petits tubercules munis d'une pointe.

Le fond de la coloration est une teinte sombrc, plus foncée et presque noire en dessus, où son uniformité n'cst altérée que par une tache irrégulièrement ovalaire, à grand axe longitudinal, situéc immédiatement cn arrière du niveau de la racine des membres antérieurs, et qui est d'un gris brun, avec des tubercules rosés. Sous le ventre, la teinte est plus claire et présente quelques marbrures blanc jaunâtre. Enfin, sur les membres, on remarque quelques taches ou des barres étroites et irrégulières d'un rouge cerise très pâle.

Trois spécimens ont été reeueillis à Kina Balu. Le plus grand mesure 41 millimètres de l'extrémité du museau à l'orifice anal et 101 millimètres de longueur totale.

\section{NeCtophryne misera, n. sp.}

De taille très réduite et de formes modérément élancées, cette espèce a la tête petite, le museau court, de mềne longueur que l'œil, et légèrement anguleux. Le canthus rostralis est distinct et la région frénale presque verticale. La narine s'ouvre près de l'extrémité du museau. L'espace interorbitaire est un peu plus large que la paupière supérieure, et le tympan, très apparent, égale en diamètre à peu près les deux ticrs de l'œil.

Complètement palmés, à l'exception du troisième qui ne l'est qu'à moitié, les loigts sont fortement déprimés et très courts, le premier même étant presque rudimentaire. Dans l'extension du membre postérieur en avant, l'articulation tibio-tarsienne atteint le tympan ou un peu au delà. Les orteils sont très courts, les trois internes palmés jusqu'à leur extrémité. De même que les doigts, ils sont terminés par un petit disque sans dilatation sensible. Il n'existe pas de tubercules sous-articulaires; lc tubercule métatarsien interne manque également, mais il y cn a un externe arrondi, relativement large, quoique peu saillant. Pas de repli le long du tarse. 
Le corps tout entier, à l'exception des trois quarts antérieurs de la face ventrale, où il est lisse ou légèrement granuleux, est couvert de tubercules verruqueux inégaux ; les plus gros sont situés sur la région moyenne de la face dorsale et surtout sur ses bords, où ils sont rangés suivant deux lignes, une de chaque côté, allant de l'œil aux apophyses sacrées.

La face dorsale est d'un brun olive uniforme plus ou moins foncé. Quant à la face ventrale, ou bicn ellc cst seulement d'une nuance plus claire que le dos, ou bien, ce qui paraît être le cas le plus fréquent, elle présente, de l’origine des membres antérieurs à celle des postérieurs, une teinte noire piquetéc ou vcinéc de blanc grisâtre.

Trois spécimens, dont un en assez mauvais état, ont été recueillis dans le nord de Bornéo. Ils sont de taille très faible et d'aspect chétif-d'où leur nom spécifique-le plus grand mesurant 43 millimètres de longueur totale et 23 millimètres de l'extrćmité du museau à l'orifice anal.

200. Nectophryne maculata, n. sp.

Le corps est svelte, les membres très allongés. La tête est courte, terminée par un museau tronqué, coupé obliquement en bas et en arrière et dont la longucur égale celle de l’œil. Limitće en haut par un canthus rostralis anguleux, la région frénale est verticale et la narine s'y ouvre tout près de l'extrémité du museau. L'espace interorbitaire a la largeur de la paupière supérieure ; le tympan n'est pas distinct.

Les membres sont très grêles et très allongćs. Les orteils sont aux dcux tiers palmés, les doigts, à la base seulement. Ceux-ci sont déprimés et terminés par un élargissement tronqué qui est beaucoup' plus faible aux orteils. Les tubercules sous-articulaires sont à peine visibles, mais les tubercules métatarsiens sont bien distincts, et l'externe est le plus saillant. Les membres. postérieurs étant appliqués le long du corps, l'articulation tibio-tarsienne dépasse notablement l'extrémité du musenu.

Le corps est couvert de grosses granulations, sur la face ventrale aussi bien que sur la face dorsale. La coloration des parties supérieures est un gris brunâtre parsemé de petites taches noires irrégulières, isolées ou confluentes, réunies en bandes transversales plus ou moins distinctes sur les inembres. Ce fond gris brunâtre se retrouve, mais un peu plus clair, sur la face ventrale.

Trois spécimens ont été rccueillis à Kina Balu. Le plus grand nesure 51 millimètres du museau à l'orifice anal et 134 millimètres de longueur totale.

\section{Leptobrachium gracile, Günther.}

203. Megalophrys montana (Kuhl), Wagler.

Trois spécimens, dont un de très petite taille, ont été capturés à Palawan. Cette espèce, dont la collection du Muséum renferme des spécimens de Java, de Mindanao et de Ceylan, n’a pas encore été rencontrée à Bornéo ; mais sa présence à Palawan fait supposer qu'elle habite également cette île.

204. Megalophris nasuta, Schlegel. Kina Balu. 


\section{ON COLLECTIONS OF REPTILES AND FRESHIVATER FISHES COLLECTED BY Mr. JOHN WHITEHEAD.}

[Two papers read before the "Congrès International de Zoologie."]

\section{SUR UNE COLLECTION DE REPTILES ET DE BATRACIENS DES ILES BORNÉO ET PALAWAN. PAR F. MOCQUARD.}

Une importante collection de Reptiles ct de Batraciens, recueillie dans le nord de Bornéo; pour la plus grande partie an mont Kina Balu, et à Palawan, a été récemment acquise de M. Whitehead par le Muséum d'histoire naturelle. Elle comprend environ soixanto-dix espèces, dont plusieurs sont nouvelles. Parmi ces dernières, quelques-unes ont déjà été décrites par M. Boulenger*; les autres feront l'objet d'un mémoirc spécial qui paraîtra ultérieurement et contiendra en même temps la listc complète de toutes ces espèces.

L'étude de cette collection ne fait que confirmer les données que l’on l'ossédait déjà sur l'extension géographique de la faunc herpétologique de Bornéo. Abstraction faite des espèces nouvelles qu'clle renfermc, et d'un certain nombre d'autres déjà connues, qui, jusqu'à présent, peuvent aussi être considérées commc particulières à cette faune, la plupart des espèces de Lacertiens, d'Ophidiens ct de Batraciens de Bornéo se retrouvent dans les autres îles du grand archipel indien, Java, Sumatra, ctc., dans la presqu'île dc Malacca et dans l'Indo-Chine, sans modifications appréciables. L'airc occupée par chacune do ces espèces n’a pas encore été rigoureusement déterminée; mais un résultat qui paraît aujourd'hui bien acquis et qui ressort de la comparaison des divcrses faunes des îles de l'Archipel indien avec celles de la presqu'île de Malacca et de l'Indo-Chine, c'est que, à une époque relativement peu éloignée, toutes ces îles étaient rattachées au continent asiatique.

Un autre fait fort intéressant à signaler est la présence, parni les Batraciens anoures recueillis au mont Kina Balu, de quatre Têtards pourvus d'un large disque adhésif ventral. M. Boulenger $†$ a déjà fait une observation scmblable sur des Têtards originaires de Posata et de Bantam, qu'il rapporte avec doute au Rhacophorus reinwardti, Wagler ; mais nos Têtards diffèrcnt de ceux de M. Boulenger par cette importante particularité, que la bouche est comprise dans le disque adhésif et qu'elle est armée, au lieu d'un bec corné comme chez les Têtards de Grenouille, de trois robustes dents cornées, qui rappellent, par leur disposition générale, celles de certaines Cyclostomes, en particulier des Mordacia. L'une de ces dents, en forme dc $V$ à pointe tournée en avant, est inférieure et portée par un gros mamelon charnu, qui devicnt sans doute la langue de l'adulte; les deux autres, également portées chacune par un mamelon, sont supérieures, arquées, séparées sur la ligne médiane par un assez large espace, et ont le bord libre denticulé, comme celui de la dent inférieure. La bouche de ces Têtards est ainsi disposée en suçoir comme celle des Cyclostomes, avec cette différence que la ventouse orale s'étend sur toute la face ventralc.

Il importait de déterminer ces Têtards, au moins génériquement. Chez deux d'entre eux, les membres, aussi bien les antérieurs que les postérieurs, sont complètement développés et offrent les caractères de ceux des Rhacophorus. Ces Têtards ne pcuvcnt d'ailleurs être rapportés à aucun des autres genres de Batraciens anoures actuellement connus à Bornéo, et à moins qu'ils n'appartiennent à un type générique nouveau, on doit les considércr comme des larves de Rhacophorus.

Quelque exceptionnelle quc soit, chez les Batraciens anoures, l'existence d'un disque adhésif ventral, elle n'a rien cependant qui puisse surprendre, si l'on observe que la plupart des larves de ce groupc de Batraciens, les Aglosses exceptés, sont pourvues, pendant une assez longue période ce leur développement, de deux petits disques adhésifs d'abord distincts, qui se rejoignent ensuite derrière la bouche, pour sc

* Ann. \&. Mag. Nat. Hist. xx. p. 95, 1887.

+ Catal. Batr. Sal. p. 89, 1882. 
séparer de nouvcau et s'atrophier. Que ces disques, au lieu de disparâtre après s'être réunis, s'étendent de manière à occuper tonte la face ventrale, et la disposition obscrrée chez nos Têtards de Kina Balu se trouvera réalisée.

On ne saurait méconnaitre que l'observation que nous venons de rapporter ne rienne à l'appui de l'hypothèse d'après laquelle les Batraciens anoures et les Cyclostomes dérivcraient d'une souche commune primitivc dont la bouche était disposée en suçoir.

La détermination exacte de nos Têtards, l'étude de leur développement et de l'évolution du disque adleésif ventral, la connaissance de l'hôte sur lequel ils vivent en parasites, telles sont les questions qui seraient à résoudre. Nous ne pouvons que les indiquer et les signaler à l'attention des naturalistes voyageurs que leur bonne étoile conduira à Bornéo.

\section{SUR LES POISSONS DES EAUX DOUCES DE BORNEOO. PAR M. LEEON VAILLANT.}

Le Muséum d'Histoire naturelle a pu acquérir les collections de Reptiles et de Poissons recueillies à Bornéo par M. Whitehead. Les premiers de ces animaux sont entre les mains de M. Mocquard, qui s'occupe actuellement de leur ધtude. Quant aux seconds, ils proviennent de trois localités, l'île Palawan, le nord dc Bornéo même, enfin la montagne de Kina Balu. Ceux pris sur ce dernier point, dont seuls il sera question dans cette note préliminaire, offrent, malgré leur petit nombre, un intérêt très particulier colume appartenant aux caux dcuces de cctte région.

Quatre espèces seulement ont été récoltées. Un Mastacembelus, qui pourrait bien êtrc nouveau, ì cn juger par le nombre relatirement peu considérable (XXVIl) de ses épines dorsales, malheureusement l'individu unique est de petite taille et en médiocre état de conservation pour quelques parties importantes, ainsi le museau. Deux autres Poissons se rapportent à des espèces connues : Barbus maculatus, Kuhl et van Hasselt, Clarias tysmanni, Bleeker ; l'un et l'autre de la faune insulindienne. Quoique représentés chacun par un seul spécimen, leur détermination ne peut guère laisser de doute.

L'animal le plus intéressant est toutefois un autre Silure, d'un type nouveau et présentant une. particularité jusqu'ici inconnue dans ce groupe. Il apparticnt, suivant la classification proposée par M. Günther, aux Protéropodes liypostomatinés et présente absolument l'aspect d'un Hypostoma, avec une tête aplatie, demi-circulaire, et un corps en triangle isocèle allongé, ayant comme base le diamètre de ce demi-cercle, mais là s'arrête la ressemblance. Les nageoires pcctorales en cffet, étendués sur les côtés, se prolongent en s'étalant sous l'abdomen, il en est de même des ventralcs, aussi lorsqu'on regarde la partie inférieure, l'enscmble de ces quatre nageoires, complétées par un prolongement latéral, donne une large surface aplatie susceptible d’agir comme ventousc. On est de suite frappé de l'analogie à établir sous ce rapport avec le genre Chimurvichtys, créé par mon excellent collègne M. Sauvage en 1874, ponr un Siluroïde des hautes montagnes du Thibct, cette disposition particulière s'explique d'ailleurs dans l'un et l'autre cas par la nécessité dans laquelle se trouvent ces Poissons, pour résister au courant impétueux des torrents qu'ils habitent, de se fixer solidement aux pierres et autres corps solides submergćs.

Mais le caractère le plus spécial de cet être, c'est que son tégnment est couvert de petites écailles cycloïdes comparables à celles de ccrtains CyPRINid plus curieux qu'aucun Siluroïde jusqu'ici ne présentait quelque chose d'analogue et l'on pouvait donncr comme caractère général du groupe une peau soit nue, soit munie de boucliers osseux ou dentineux, n'offrant jamais de réritables écailles, ce qui avait engagé Agassiz à les mettre dans son groupe des Ganoïdes. Le tcrme de Lepidoglanis, que je propose pour ce nouveau genre, fait allusion à cette disposition particulière.

Les individus recueillis par M. Whitehead, au nombre d'une dizaine ct de tailles très variées, les plus grands mesurant $80^{\mathrm{mm}} \grave{a ̀} 100^{\mathrm{mm}}$, les plus petits $30^{\mathrm{mm}} \grave{a} 40^{\mathrm{mm}}$, paraissent se rapporter à une seule espècc, le Lepidoqlanis monticola. 


\title{
DESCRIPTIONS OF SOME NEW SPECIES OF LAND-SHELLS FROM BORNEO. BY EDGAR A. SMITH.
}

\author{
[From the 'Annals and Magazine of Natural History.']
}

1, Nanina regalis, Benson ; 2, N. subconsul, sp. n. ; 3, Trochomorpha metcalfei, Benson ; 4, T.planorbis, Lcsson ; 5, T. conicoides, Metcalfe, var. parva ; 6, Leptopoma undatum, Metcalfe ; 7, L. sericatum, Pfr. ; 8, L. whiteheadi, sp. n.; 9, Opisthoporus pterocycloides, Pfr.

\section{Nanina subconsul.}

Testa $N$. consuli simillima, superne tamen minus nitida ; anfractibus paulo planioribus instructa, sculptura minutissime rugulosa supernc ornata, inferne spiraliter microscopice striata.

Diam. maj. 19, min. 17 ; alt. $10 \frac{1}{2}$ mill.

Hab. North Borneo.

This species is very closely related to $N$. consul, and is only distinguished from that species by its duller upper surface, resulting from a different microscopic sculptnre, and its slightly less convex whorls. The spiral striæ on the base are visible under an ordinary lens, but the minute rugulose lines of the upper surface are discernible only under a stronger magnifier.

Helix (Trochomorpha) conicoides, Metcalfe, var. parva.

Two specimens collected in Northern Borneo by Mr. John Whitehead are cxceptionally small and depressed, and remarkable also on account of the basal margin of the peristome being slightly thickened, narrowly expanded, and reflexed, a feature which does not occur in ordinary examples. In colour, texture, and sculpture they offer no differences. Although consisting of seven whorls, the greatest diameter is only 11 millimetres.

\section{LEPTOPOMA WHITEHEADI.}

Testa conica, umbilicata, mediocriter tenuis, purpurasccnti- vel fuscescenti-cornea, maculis rufis sutura radiantibus picta, epidermide tenui sublamellata amicta; anfractus 6 , convexi, carinis tenuibus 2-3 instructi, incrementi lineis striisque spiralibus inconspicuis sculpti, sutura subprofunda sejuncti, ultimis carinis ad 6 ornatus; apertura modice magna ; peristoma anguste reflexum, bimarginatum.

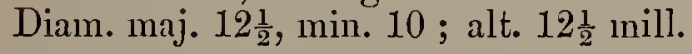

IIab. Northern Borneo.

This intercsting speeies was collected by Mr. John Whitehead, with whose name I have associated it. It is peeuliar on aceount of the epidermis, which upon the keels is produced into very short tufts. The operculum is very thin, yellowish, and consists of about eight whorls.

Lieut.-Col. Godwin-Austex describes the following new species in the 'Proceedings of the Zoological Society,' for January 6, 1891 :-

Helicarion (?) whiteheadi, n. sp.

Shell depressedly globose, tumid, slight subangulation on periphery, not perforate ; sculpture coarse, a peeuliarly wrinkled surface, the lines having a very oblique transverse direction; colour rich umberbrown, pale purple and iridescent within the aperture ; spire low, rounded on apex; suture impressed ; whorls $3 \frac{1}{2}$, rapidly increasing, the last much expanded ; aperture widely ovate, oblique ; pcristome thin, not reflected at all on columellar margin, which is subvertical.

Size : maj. diam. $35 \cdot 0$, min. $28 \cdot 0$; alt. axis $12 \cdot 0$; breadth of aperturc $20 \cdot 0$ millin.

Hab. Kina Balu Mountain, altitude not known.

I place this next to Helicarion borneensis, not that $I$ think it has any affinity to that genus as restricted, but only in its widest sense; the animal would be a most interesting one to examine, and will 
probably be found allied to local races, and not having anything in common with forms such as Girasia of the Indian Region, with which the shell outwardly has resemblance. Only two specimens wcre brought home by Mr. Whitehead.

\section{LIST OF THE LAND-MOLLUSCA COLLECTED BY Mr. JOHN WHITEHEAD IN PALAWAN DURING 188i. BY LieUT.-Col. H. H. GODIVIN-AUSTEN, F.R.S., \&c.}

Hemiplecta densa, var. schumacheriana, Pfr.

Trochomorpha metcalfei, Pfr.

Helix (Hadra) traillit, Pfr.

Helix (Hadra) monochroa, Sowerby, var. palawanensis, Pfr.

Cochlostyla satyrus, Brod.

Amphidromus quadrasi, Hidalgo.

Leptopoma undatum, Metcalfe.

Leptopoma sericatum, Pfr., largc var.

Lagocheilus smirurs, Edgar Smith, 1893.

This species has been lately describcd by Mr. Edgar Smith from specimens collected by Mr. Ererett, which were old. When in perfect preservation, like those found by Mr. Whitehead, it is covered with a brown epidermis, having well-displayed transverse regular fine liration and the periphery adorned with a strong hairy fringe. The largest specimen measures : maj. diam. $18 \cdot 75$, min. diam. $15 \cdot 0$, alt. axis $7 \cdot 5 \mathrm{~mm}$.

Rhiostoma boxalli, n. sp. (Dr. Hungerford, MS.)

Shell discoid, widely and perspectively umbilicated; sculpture smooth, being covered with a strong epidermis; colour dark madder-brown, with a few white splotches on the second and third whorls; spire scarcely raised above the last whorl; apex rounded; suture deep; whorls 4, round, rapidly increasing, the last scparated for a short distance from the pcnultimate whorl; the sutural tube short, horizontal; aperturc oblique, circular; peristome double, continuous, the inner simple, the outer expanded at right angles to the body-whorl, curved slightly backward on the outer margin," and with a slight nick near the sutural tube. Size : major diam. 24, minor diam. 16.25 , alt. axis $5.75 \mathrm{~mm}$.

This species, which is the first of the genus from this island, was among the Palawan shells. The type was obtained by Mr. Boxall near Kina Balu and was given by him to Dr. Hungerford; being a MS. name I retain it. Its ncarest ally is R. iris, Godw.-Aust., of Borneo (described in the P. Z. S. June 1889, p. 343), as regards the expanded peristome; but the gcneral form differs, it is not so turbinate or streakcd with zigzag markings as seen in iris.

The total number of specics recorded by Edgar Smith from Palawan (vide the List by the Rev. A. H. Cooke, P.Z.S. May 1892, and Edgar Smith, A.M.N. H. May 1893) is thirty, which is now increased by three more. It is quite evident that many genera and species still remain to be discovered.

\section{LIST OF FRESHWATER AND BRACKISH-WATER SHELLS COLLECIED BY Mr. JOHN WHITEHEAD IN THE ISLAND OF PALAWAN IN 1887. By Lieut.-Cor. H. H. GODWIN-AUSTEN, F.R.S., F.Z.S., \&c.}

Melanta (Pachychilus) testudinaria, v. d. Busch, var. olivacea.

This is ncarcst to the figure of the above species given by Brot in the Conch. Cab. pl. vi. f. 3 b, p. 49, in the smooth character of the surface of the shell; it, however, differs very much in coloration, being of an olive tint, fading into pale ochre just below the suture, in evcry whorl. Mr. testudinaria is recorded from Java, Madras, and India. 
Melania (Striatella) crepidinata, Reeve.

Found in Java and Borneo (Geale).

Mrlania (Striatella) tuberculata, Müll.

Melanta turris?, Geale.

The spccimens are very young and aciculate, therefore not to be easily identified. 1 . turris is from Bornco.

The following spccies, except one which may be new, have a wide distribution:-

Neritisa dubia, Chemin.

Neritina turtoni.

Neritina soverbir, Récluz.

Neritina diadema, Récluz.

Pythia undata, Lesson.

Cassidula mustelina, Desh.

Cassidula bicolor, n. sp.

This is a smaller shell than sulculosa, Mouss., to which it is nearest as regards the form of the aperture, but it is not so strongly formed. The body-whorl is crossed by shallow longitudinal plications. The colour is a very dark sepia-brown, with two broad parallel very white bands, which extend to the outer margin of the peristome. I could find nothing like it in the British Museum collection.

Melampus fasciatus, Desh.

Auricula AURIS-JUd $\mathbb{x}$, Linn.

\section{TWO PAPERS ON A PORTION OF THE COLLECTION OF COLEOPTERA MADE BY Mr. JOHN WHITEHEAD IN NORTH BORNEO.}

[From the ' Proceedings of the Zoological Society of London.']

\section{ON NEW GENERA AND SPECIES OF COLEOPTEROUS INSECTS FROM MOUNT KINA BALU, NORTH BORNEO. BY H. W. BATES, F.R.S., F.Z.S.}

THE following descriptions contain the results of the examination of a portion only of the collection of Coleoptera made by Mr. J. Whitehead during his recont visit to Kina Balu. The Coleoptera comprise an unusual proportion of new and remarkable forms.

Therates WHiteheadi.

\section{Family Cictndelid 2.}

Th. spectabili (Schaum) similis et affinis, sed differt, inter alia, oculorum pedunculis fere verticalibus fronteque angustiore. E majoribus, nigro-viridis, elytris viridioribus : thorace angusto, lateribus medio minime rotundatis : elytris apice longe spinosis, spinis divaricatis et obliquc elevatis, margine exteriore versus spinam continuo nec emarginato, angulo suturali distincto etsi rotundato, deinde margine usque ad spinæ basin minus obliquo : dorso sicut in Th. spectabili multituberoso, vittula humerali calloque obliquo discoidali albo-testaceis : pedibus nigris, coxis fcmoribusque basi ct subtus albo-testaceis : abdominis margine et apice rufo-testaceis. Labrum margine antice of 8-, o 6-denticulatum. Long. 16 millim.

This beautiful species differs from Th. spectabilis (Schaum) and princeps (Bates) in the more vertically clevated peduncles of the eyes, which position perceptibly narrows and deepens the forchead between them. It also differs in the outline of the apical margin of the elytra, the suture forming a distinct though rounded angle, whence to the base of the spine the apical margin is not continuous with the 
spinc, as it is very nearly in the two other species. The inequalities of the surface are the same in allthe common basal elevation being quadrate and plane ahove, tuberculated on its margin, and the disk having a rounded tubercle before and an oblique elongated callus behind the middle.

Mr. Whitehead obtained also examples of the following species of Cicindelidx:-Cicindela crespignyi (Bates, since redescribed as $C$. borneeana, Dokhtouroff) in a distinct colour variety, the broad orangecoloured belt and stripe of the type-form (from near Labuan) bcing replaced by white; the rare Heptadonta tricondyloïdes (Gestro); Therates punctipennis (Bates), many examples, all alike in the uniform pale colour of the elytra, but still little more than a colour variety of T. schaumi (Chaud.); and Tricondyla beccarii (Gestro).

OODES (Simous) BORneEnsis.

\section{Family Carabider.}

O. aneo (Laferté) proxime affinis, sed differt corpore an gustiore supra multo minus polito, præetcrea colore violaceo vel viridi-cyaneo etc. Anguste elongato-oblongus; palpis, antemnis tarsisque (vel pedibus totis) picescenti-rufis : thorace post inedium latiore, antice valde angustato, supra lævi, puncto setifero ad angulum posticum : elytris tenuiter sed acute crenulato-striatis, margine ante apicem sat fortiter sinuato, interstitiis planis, $3^{\text {io }}$ longe post medium unipunctato : subtus niger, nitidus. Long. $15-16$ millim. $\delta$ o .

Two examples. Found also in South-eastern Borneo. The genus Simous was separated from Oodes by Chaudoir chiefly on account of the extremely short six-punctate labrum and the setiferons puncture close to the hind angles of the thorax. It forms a perfectly natural group, of which five species are now known, peculiar to Indo-China and the neighbouring islands.

COLPODES FRYI.

Species inagna clongataque C. parallelo (Chaud.) affinis. Valde elongatus relative angustus, elytris lateribus parum rotundatis; nigro-æneus, elytris lætius cuprascenti-æneis : capite pone oculos gradatim recte angustato, collo supra transversim depresso : thorace subquadrato, capite paullo angustiore, lateribus paullo ante medium leviter rotundatis rersus basin sinuatis, angulis posticis obtusis, margine anguste explanato-reflexo: elytris simpliciter acute striatis, interstitiis usque ad apiecm planis, $3^{\text {io }}$ punctis magnis tribus, versus apicem oblique sintratis, juxta suturam breviter sinuato-truncatis et utrinque bidentatis : tarsis robustis, subtus dense pilosis, 4 posterioribus supra valde bisuleatis medioque carinatis, articulo $4^{\text {to }}$ extus lobato. Palpi, antennæ ct pedes rufescenti-picei. Long. 17 millim. $q$.

One (femalc) example. The species belongs to the numerous group of the genus distributed through South-eastern Asia and its islands, in which the metathoracic epimera are long and narrow, the fourth joint of the hinder tarsi strongly unilobular, and the sutural apex of the elytra briefly truncated and more or less spined or toothed.

Euplyanes auro-cinctius.

Breviter oblongus, subdepressus, piceo-niger, politus; elytris splendide viridi-reneis, lateribus late auratis ; antennis (scapo obscuriore), mandibulis et palpis apice tarsisque rufescentibus : capite brevi mox pone oculos magnos subito angustato, supra planato lavi, sulcis frontalibus flexuosis postice versus oculos curvatis : thorace lato et brevi, angulis anticis rotundatis, posticis fere rectis, lateribus medio rotundatis postice usque ad angulum leviter sinuatis, nrargine basali utringue ad angulum ascendenti, foveis basalibus latis sat profundis punctulatis : elytris humeris valde rotundatis, apice sinuatis, versus suturam conjunctinn obtuse rotundatis, acute punctulato-striatis, interstitiis planis, striis $\partial^{\mathrm{a}}-7^{\mathrm{m}}$ versus basin valde curvatis, ibique interstitio $5^{\circ}$ fovea magna oblonga. Tarsi subtus dense pilosi, articulo $4^{\circ}$ (sicut in Euplyni) longe bilobato. Long. 8 millim.

This interesting species has also been met with in Sumatra by Dr. Beceari.

Dinopelma, nov. gen.

Genus anomalum, facie Platyni vel Colpodis sed tarsis sicut in Hexagonia; subfam. Ctenodactyline referendum. Caput subovatum, post oculos rectilineatim oblique angustatum, foveis frontalibus maximis fundo inzequalibus, collo sat angusto supra transverse depresso $:$ nnandibula elongata sat recta robusta; maxillæe (?) ; mentum medio late obtuse dentatum, lobis latis extus et apice rotundatis; ligula cornea, antice lata integra bisetosa, paraglossis temuibus liberis; palpi (desunt); labrum recte truncatum. Antennæ mediocres, articulis $3^{\circ}-10^{\mathrm{m}}$ subæequalibus, $1^{\circ}-3^{\mathrm{mi}}$ et $4^{\text {ti }}$ basi 
glabris. Thorax capite multo latior, quadratus, angulis anticis obtusissimis posticis rectis, lateribus explanato-reflexis, ante medium perparum rotundatis et postice leviter sinuatis. Elytra thorace plusquam duplo latiora, oblongo-ovata, basi utrinque emarginata, humeris acutis et mox pone humeros rotundato-dilatatis deinde margine sat cxplanato, prope apicem valde emarginato, ibique epipleuris margine inferiore sicut in Pterostichince, Ctenodactylinae et Hexagoniince interrupto. Tibic pluricarinate. Tarsi breves, maxime dilatati, subtus dense breviter pilosi, articulo $1^{\mathrm{mo}}$ magno triangulari angulis rotundatis, $2^{\text {ndo }}$ breviore, paullo latiore angulis acutis, $3^{\text {io }}$ multo angustiore, brevissimo, $4^{\text {to }}$ iterum latiore, triangulari haud bilobato. Ungues sinplices. Metathoracis episterna elongata, angusta.

Dinopelma plantigradum.

Nigrum politissimum, elytris vix renesentibus ; capite lævi, epistomate 4-foveato ; thorace impunctato, foveis basalibus prope angulos postieos latis sat profundis, sulculo abbreviato intra marginem lateralem ; elytris paullo convexis, striis acutis et crcnulatis utrinque novem xqualiter distantibus et impressis, interstitiis planis, $3^{\text {io }}$ tripunctato, striola scutellari mediocriter elongata. Long. 12 millim.

One example, apparently a female. The form of the tarsi, and especially the dilated and cntire fourth joint, resembles still more closely that of the genus Calophcena; and in spite of the latter belonging to the Truncatipennes division of the Carabidx, there may be a real affinity between the two genera.

\section{Prigenia viridiaurata.}

\section{Family Cetonidos.}

․ Quoad forman1 P. vollenhoreni (Mohn.) simillima, differt colore supra et subtus viridi-aurato, tibiis tarsisque igneo-cupreis : sat nitida, supra glabra, capite grossissime crebre punctato, vertice rrofunde concaro, fronte earina lata olstusa antice declive et postice verticaliter truncata: thorace punetis umbilicatis annuliformibus medio distantibus, lateribus densis et subconfluentibus, linea dorsali areaque basali impunctatis: scutello subtilissime striguloso-punctulato : elytris planatis, paullo subtilius quam thorace annulato-punctatis, lateribus post medium apiceque dense strigulosis : pygidium strigis eoncentricis densissime impressum, erectc fulvo-pilosum : eorpore subtus pedibusque (lateribus densius) fulvo-pilosis. Long. 26 millim.

Although the female only is in the collection, and of that a single example, the differences in eolour and seulpture from the same sex in $P$. vollenhoveni seem to indicate a distinct species and to justify its description as such.

\section{Mroteristes (Theodosta) Telifer.}

Elongato-oblongus, aurescenti-viridis, elytris planatis flavescentibus.

б. Caput et thorax passin densissime confluenter punctulata subopaca, hoc dorso subnitens punctulis subdiscretis ; scutello et elytris, pygidio, corpore subtus ct pedibus subtilissime dense punctulatis, sericeo-nitentibus : capite cornu sat brevi curvato, apice profunde bitido parum dilatato, frontis margine supra antennarum basin angulatim producto; thorace dorso oblique valde elevato et in cornu porrectum elongatum robustum apice emarginatum (sub-bificlum) producto ; cornu dimidio apicali fronteque igneo-cupreis : pedibus anticis, præcipue tarsis, valde elongatis, tibiis extus acute et breviter bidentatis (apicali incluso), tarsis glabris.

․ Caput densissime ruguloso-punctatum, clypeo sparsim grosse punctato, margine ante oeulum indentato deinde antice flexuoso, clypeo angustato apice lidentato : thorace disco sparsim grosse umbilicato-punetato inter puncta subtilissime punctulato, lateribus densissime rugoso-punctato: seutello punctis nonnullis grossis : elytris punctis umbilicatis, versus basin seriatis, versus latera et postice densius vel confusis : pygidio coneentricaliter dense strigoso : tibiis antieis tridentatis. Long. 20-28 millim.

Aceording to the praciiee of recent systematists a new genus should be instituted for this species on account of the peculiar shape of the horns in the male; but the abrupt modifications in these fcatures presented in the known species allicd to Mycteristes seem to show that they form spccific and not generic claracters, just as they do in such genera as Onthophagus, Phanceus, and Copris. Of the numerous genera proposed, the present species approaches nearest to Theodosia, Thoms.

Coryphocera borneensis, Wall. Tr. Ent. Soe. (3) ir. p. 528, t. xi. f. 2 ( $q$ ).

One (male) example, which I refer to this spccies on account of its perfect agreement, in form and eolour, with Wallaec's deseription and figure. From the armature of the head of the male the species 
belongs undoubtedly to the genus Coryplocera and not to Diceros, as Mohnike supposed would be found to be the case when the male was known.

Xenoloba, nov. gen.

Genus inter subfam. Gymnetinee et Macronotinne collocandum. Corpus postice gradatim angustatum, supra deplanatum, velutino-opacum. Clypens antice sensim dilatatus, apice medio anguste sinuato angulisque late rotundatis ; fronte medio obtuse carinata. Antennæ clava valde elongata. Palpi elongati, gracillimi. Thorax trapezoideus, sed ad basin elytris multo angustior margineque laterali ante basin breviter sinuato: supra æqualis disco postice vix lineatim impresso, lobo basali magno postice vix angustato apiceque late rotundato. Scutellum mediocre, apice acutum. Elytra sicut in Macronotis ad lrumeros dilatata deinde usque ad apicem angustata abdominisque latera haud tegentia. Processus sternalis sat elongatus, paullo oblique dependens, subcompressus, apice superiore paulo acuto. Tibiæ anticæ acute tridentatæ, posticæ extus læves apice longe bispinosæ.

The very beautiful Cetonid which constitutes this genus connects in some measure the two large groups Gymnetince and Macronotince. The thorax is nearly cvenly convex, and its posterior lobe and its relations to the scutellum are not widely different from the same in the genus Desicasta.

XENOLOBA SPECIOSA.

Saturate viridis, sericeo-opaca, elytris fulvis plaga magna communi trilobata (utrinque albo trimaculata) fere nigra : capite antice flavo-metallico glabro grosse punctato, postice viridi-velutino, vittis duabus flavo-tomentosis: thorace sparse setifero-punctato immarginato, sed lateribus antice intra marginem depressiusculis et flavo-tomentosis : elytris utrinque haud profunde bisulcatis, sulcis interiore tri- exteriore subtiliter bi-striatis striaque simili suturali, alteris $2-\ddot{z}$ propinquis, versus apicem. Pygidium longe erecte pilosum, nigrum, opacum, utrinque macula magna ochracea. Pedes fulvo-testacei, reneo-tincti. Subtus viridi-velutina, erecte fulvopilosa, abdomine utrinquc fasciis 4 , metasterno fasciis 2 , episternis anterioribus et maculis variis, ochraceis. Long. 18 millim.

Chalcothea (Plectrone) auripes, Westw. Tr. Ent. Soc. 1874, p. 474, t. vii. fig. 2 (q); Ritsema, Midden-Sumatra, Col. t. ii. figs. $6,6 b^{\prime}, 6 c^{\prime}, 6 d^{\prime}, \dot{b}^{\prime}(q)$.

3. A fœmina differt solum tibiis anticis angustis extus inermibus, intermediis intus medio incurvatis, posticis intus usque post medium dilatatis, ibique subito angustatis et lobo acutissimo unciformi armatis : ventro medio depresso, apice impunctato.

The female only was known to Westwood and Ritsema. Our examples agree exactly witl the characters given by the latter to distinguish the species from $C$. virens, which was also apparently known only in the female. I find the inner spur of the hind tibia in the male only a little obtuse at the apex, not obtusely truncated as figured by Ritsema.

Chalcothea (Plectrones) viridipts.

$P$. auripedi quoad formam simillima. Supra cum antennis et palpis saturate viridis submetallica, subtus pedibusque subæneo-viridis: clypeo profunde fisso, capite utrinque marginato et punctato: thorace lateribus punctatis et marginatis ante medium perparum angulatis deinde usque ad angulos posticos acutis fere rectis, medio cum scutello et elytrorum sutura late depresso : elytris prope marginem et apicem punctulatis sub callo apicali strigulosis. Processus mesosternalis æquilaterali-triangularis.

§. Tibir anticæ graciles, extus incrmes; postice intus longe ante medium lobum elongatum tenuem apice triangulariter spathulatum emittentes. Ventris segmentum apicale apicc modio emarginatün. Pygidium transversim striatulum, apice convesum ct medio sulcatun.

q. Tibiæ anticæ latæ, tridentatæ; postice inermes, calcari interiore elongato apice emarginato. Ventris segmentum apicale scmicirculare, toto transversim striolatum. Pygidium striatum, apice parum convexum, æquale. Long. 34 millim.

This specics is similar in colour to Clerota brama (Gestro), to which I should have been inclined to refer it, if the mesosternal process had not been so different in form. In C. brama it is prolonged (as figured in 'Midden-Sumatra,' iv. 6, pl. ii. fig. 5ל) into an acute point; in C. viridipes it forms a rather short subequilateral triangle. The lind legs and tarsi, judging from the figure, are also much shorter in C. Irama than in C. viridipes. 


\section{Chalcothea (Plectrone) spathulifera.}

Priecedentibus differt thorace scutello basique clytrorum parum depressis his post medium planis: supra saturate ancscenti-viridis, antennis et palpis castaneo-cupreis clava obscura, corpore subtus femoribusque cupreo-auratis, tibiis, tarsis clypeoque apice igneo-cupreis; supra toto sat dense punctata, elytris basi sparsius et seriatim, lateribus et apicc conflucnter et rugose, punctatis, interstitiis subtilissime punctatis. Oculi magni et prominentes, capite anto oculos angusto antice dilatato, clypeo triangulariter emarginato lobisque minus acuminatis, to to crebre punctato carinisque submarginalibus angustis. Thorax angustior longe ante medium subangulato, deinde postice margine usque ad angulos posticos acutos valde sinuato: scutello lævi : elytris disco utrinque vix convexis. Subtus et pedes sat dense punctata, medio fere lævis. Pygidium dense transversim rugulatum. Processus mesosternalis mediocris, apice obtuse acuminatus.

ธิ. Tibiæ antice extus inermes, intermediæ intus valde sinuatæ apiceque dilatatæ, posticæ intus longe ante medium lobo longissimo tenui apice spathuliformi (ovato) armatis : venter disperse punctulatus parum depressus, segmento apicali apice valde et late sinuato. Pygidium apice breviter bilobatum.

q. Tibiæ antice tridentatæ, intermediæ rectæ calcaribus acutis, posticæ reetæ calcari interiore elongato, apice emarginato. Pygidium apicc planum. Ventris segmentum apicale apice obtuse rotundatum, strigosum. Long. 32 millim.

Chalcothea Affinis, Vollcnh. Tijdschr. Nederl. Ent. Ver. i. p. 23, t. ii. fig. 2 ( $ð$ ).

Mr. Whitehead obtained female examples only, in which the mesosternal process is extremely short and far from scmicircular as described by Vollenhoven. I have, however, seen another examiple $(q)$, from Borneo (probably Sarawak), differing in 110 other respect from these two than in the mesostcrnal process being nearly semicircular. The sides of the thorax are immarginate.

\section{Chalcothea pomacea.}

q. C. resplendenti quoad formam similis, paullo robustior, toto pomaceo-viridis subargenteo-relucens, subtus medio tantum subflavescens, tarsis chalybeis; supra medio fere a collo usque apicem latius et profundius quam in C. resplendente concava ; supra et subtus lævissima, capite thoracisque lateribus parce punctatis, elytrisque propc marginem et apicem plagis duabus strigosis, callo humerali valde convexo nigro, callo apicali parum elevato : capite elongato, angusto, antice parum dilatato, apice triangulariter fisso: thorace elongato et angusto, ante medium perparum et haud angulaim dilatato, postice minus oblique sinuato-dilatato, angulis posticis perparum extus productis, margine laterali integro. Processus mesosternalis brevis, rotundato-subacuminatus vel semiovatus. Ventris segmentum apicale apice medio obtuse rotundatum, strigulatum et setifero-punctatum. Tibiæ postice calcari interiorc apice oblique truncato. Long. 30 millim.

A single female example. May possibly bc found to belong to the section Plectrone when the male is known. The margined sides of the thorax would bring it, like the following, within the definition of Ritsema's genus Pseudochalcothea, which appears to be synonymous with Plectrone, all the species of which that I have seen have the thorax similarly margined.

\section{Chalcothea planiuscula.}

ๆ. Dilutius pomaceo-viridis, submetallico-nitens, capite viridi-æneo, antennis palpisque rufis, tibiis et tarsis fulvis lete aureo- vel cupreo-metallicis : capite ante oculos sat brevi, quadrato, apice minus angulatim profunde emarginato, passim punctato ; thorace, scutello et elytris medio late et parum profunde depressis, his longe ante apicem fere planis; thorace anguste trapezoidali, angulis posticis parum productis, lateribus paullulnm flexuosis fere rectis, sulco marginali profundo passim minutissime dense punctulato, punctis paullo majoribus consperso, lobo basali minus producto, scutelloque elongato: elytris lateribus et apice sat dense punctatis, disco utrinque convexo lævi. Pygidium dense transversim striatum. Processus mesosternalis brevissimus, antice rotundatus. Subtus medio lavis, lateribus et pedibus disperse punctatis. Ventris segmentum apicale strigulosum, apice rotundatum. Tibiæ postice calcari intcriore apicc emarginato-truncato. Long. 30 millim.

A single (female) examplc.

\section{Glyptothes, nov. gen.}

A gen. Chalcothea differt clypeo apice verticaliter reflexo integro. Oblongus ; thorace postice, scutello elytrisque medio profunde depressis, his disco postcriore lateribusque plurisulcatis: 
tibiæ 4 postica calcaribus longitudine valde inæqualibus. Antennarum clava cateris articulis conjunctis dinidio longior. Processus mesosternalis brevis, apice rotundatus. $\delta$.

\section{GLyptothea Whiteheadi.}

§. Supra obscure viridescenti-fulva, elytrorum lateribus obscure viridi-æneis, capite et tibiis viridi-reneis, tarsis chalybeis, corpore subtus femoribusque splendide auratis, antennis castancis scapo viridi-æneo: capite grosse sparsim punctato, ante oculos oblongo, lateribus elcratis obtusis: thorace anguste trapezoidali, longe ante medium paullulum angulato-dilatato, deinde usque ad basin parum ampliato, lateribus leviter sinuatis, angulis posticis paullulum productis subacutis, lateribus ante dilatationem deflexis immarginatis, post dilatationem marginatis, lobo basali mediocriter producto, supra passim discrete punctato: scutello elongato, lateribus postice sinuatis : elytris utrinque disco convexo, versus basin lævi post medium in costas duas læres diviso, costaque $3^{\text {ia }}$ lævi submarginali, interstitiis depressis punctato- vel ruguloso-striatis : pygidio convexo, dense et profunde transvcrsim striato, medio postice sulcato. Subtus fere lævis, segmento apicali apice latc sinnato. Tibiæ anticœ extus inermes, 4 posticæ apice valde inæqualiter bidentatæe, calcaribus longitudine inæqualibus, posticarum calcari interiorc elongatissimo unciformi. Isong. 19 millim.

A single (malc) example.

TzNIODERA DITISSIMA.

In hoc genere magna et robusta ; supra nigra, opaca, capite vittis duabus latis, thorace utrinque vitta lata latcrali postice angustata et ante basin tcrminata; scapulis, scutello (et margine elytrorum contiguo) elytrisque guttulis lineolisque transversis, ochraceo-tomentosis, disco elytrorum utrinque macula elongata alteraque lumerali purpureo-sanguineis ; subtus ochraceotomentosa (ventre pallidiore) et pilosa, medio anguste nigro-æenea, polita, abdominisque segmentis dorsalibus ad marginem singulis macula magna sericeo-nigra; pygidio nigro, macula mediana ochraceo-tomentosa.

Clypeus grosse punctatus, glaber, apice sat profunde emarginatus. Thorax sicut in 'T'. egregia, postice lateribus parallelis angulisque posticis paullo obtusis, lobo mediano mediocriter producto late rotundato, dorso æquali disperse curvatim striguloso, lateribus tomentosis undulato-strigulosis. Scutellum elongato-triangulare. Elytra medio late depressa, in depressione postice striis 5 undulatis, disco utrinque longitudinaliter elevato obtuse unicarinato, limbo transversim rugulato. Pedes nigro-nitidi, femoribus anticis ochraceis, tibiis 4 posticis extus medio unispinosis. Processus mesosternalis tuberculiformis.

$\delta$ ? 'Tibiæ anticæ acutc tridentatæ; intermediæ rectæ, apice cxtus unispinosæ; posticæ apice extus sat longe laminato-productæ, laminæ apice recurrato dilatato angu!isque dentatis, calcari interiore curvato ct late ensiformi. Long. 20 millim.

Two examples of the same sex, apparently males.

\section{ON G I C O R I A.}

KinabaLua, nov. gen.

๙. Gen. Dorycerce (White) et Ommatomeno (Higgins) proxime affinis. Corpus mediocriter elongatum, subtiliter sericeo-pubescens. Oculi maxini, supra fere contigui (linea impressa solum separati), subtus approximati. Mandibulæ sicut in Dorycera, sed apice subito curratr ; palpi ariiculo apicali cylindroido, obtuse truncato. Antenuæ corpori longitudine subæquales, scapo curvato-clavato, articulis $3^{\circ}-9^{\mathrm{m}}$ (cæeteris desunt) valde compressis, angulis apicalibus acutis intus productis, subtus planis opacis, supra intus paullo dilatatis ibique late haud profunde sulcatis, subtiliter porosis, opacis. Thorax latissimus et brevissimus, utrinque valde tridentatus, dentibus 2 anterioribus basi conjunctis, $2^{\text {do }}$ retrorsun curvato. Elytra lateribus paullulum rotundatis. Tibiæ sat tenues, compressæ, apice extus acutæ productæ. Prosternum apice parum productum, conicum. Mctastcrni episterna postice haud angustata.

The only Malayan genus of Prionidæ of the subgroup to which the present specics belongs is Empliesmenus (Lansberge), founded on a Sumatran species, and differing from Kinabalua essentially in the structure of the antennæ, which in our genus closely resembles that of the West-African genera Dorycera and Ommatomenus. In these latter, however, thc scape is quite different in form, being rery short, thick, quadrate (subglobular in Dorycera), as in Acanthophorus, whilst that of our new genus is more elongate aud curved. In this respect it resembles the South Chinese genus Cnethocerus, belonging to the same subgroup. 


\section{Kinabalua Megalops.}

Cinnamomeo-fusca, supra dense breviter fulvo-pubesccns, pectore densius et longius vulpino-rufo piloso; thoracc supra inequali : elytris subtiliter crebre punctulatis, lateribus longitudinaliter parum distincte sulcatis, apice late rotundatis, angulo suturali breviter dentiformi : ventro glabro, polito. Long. 30 millim. $\delta$.

A single (male) example.

\section{ZONOPTERUS MAGNIFICUS.}

Nigro-velutinus, elytris fascia lata flava, antennis articulis $4^{\circ}-11^{\mathrm{m}}$ et $3^{\circ}$ apice aurantiaco-flavis, abdomine chalybeo-nigro, segmentis $1^{\circ}-4^{\text {nt }}$ apice fascia pubescenti argentea ornatis, coxis metasternoquc apice argenteo-maeulatis. Antennæ dimidio corporis fere æequales: thorax antice et postice constrictus, medio transversim qnadratus et convexus : elytra basi thorace fere duplo latiora, postice gradatim leviter angustata, costis utrinque tenuissimis et parum clevatis duabus, fascia flava nuda sed opaca vage rugosa: tibiæ posticæ subrectæ, compressæ, gradatim leviter dilatatæ. Lung. 37 millim. $\nsucceq$.

\section{Gauresthes, nov. gen.}

Gen. Helymao (Thoms.) affinis. Corpus elongatum, elytris supra subplanatis, post medium paullo dehiscentibus. Caput antice sat elongatum, mandibulæ clongatæ, reetæ; maxillæ exsertæ. Antennæ ( $\sigma^{*}$ ?) dimidio corporis paullo longiore, ante apicem gradatim incrassatæ, articulis $8^{\circ}-$ $11^{\mathrm{m}}$ iterum angustatis, seapo curvato articulo $3^{\mathrm{o}}$ valde elongato. Thorax breviter subcylindricus, lateribus utrinque tuberculo lato conico. Elytra thorace dimidio latiora elongata fere parallela, apice latissime rotundata, supra utrinque tenuiter bicostulata. Femora clavati, postica elongata (elytrorum apicem perparum longiora) ; tibiæ posticæ post medium paullulum curvatæ compressæ, mediocriter dilatatæ; tarsi articulo basali duobus sequentibus conjunctis subæquali. Scutellum apiee acutum, prolongatum.

Among the few genera of Callichromince with clavate and petiolated femora this new form approaches the African and Arabian Helymceus mueh nearer than the Malayan Ipothalia. It differs from Helymaus in the three apical joints of the antennæ being gradually narrower with the terminal one obtusely acuminated, in the long straight mandibles, and in the different form and punctuation of the thorax.

\section{GaUREsthes Rufipes.}

Nigro-violaceus, subnitidus, cum pligis opacis, pedibus (tibiis posticis cyaneo-violaceis exceptis) rufis : thorace disco antico basique medio impunctato polito, cæetera superficie creberrime subtiliter scabrosa et nigro-opaca, lateribus argenteo-sericeis : scutello subtiliter scabroso viridescente opaco, linea medio polita: elytris subtilissime punctulato-scabrosis, opacis, sicut velutinis, humeris faseiaquc lata ante-mediana sparsius punctato-scabrosis, subnitidis : subtus chalybeus, argenteo-sericeus. Long. 28 millin. ơ?

\section{Eusyntheta, nov. gen.}

Gen. Achthophor certe affinis, sed valde differt antennis brevibus, robustis, articulis $4^{\circ}-11^{\mathrm{m}}$ brevissimis. Breviter oblongo-ovata. Frons trapezoidalis, oculis nullo modo prominentibus. Tuberes antenniferi approximati, paullulum divergentes nec armati. Antennæ ( $q$ ?) robusti, capitc cun thorace paullo longiores, subtus sparsim breviter ciliatæ; scapo clongato-conico, cicatrice lata scabrosa incompleta, articulo $3^{\text {io }}$ quam seapo dimidio breviore, $4^{\text {to }}$ adhuc breviore, cxteris brevissimis. Thorax post medium tuberculo aeuto armatus. Elytra thorace fere duplo latiora, absque cristis, apicc rotundata. Mesosternum productum, conicum. Tibiæ intermedix extus oblique sulcatæ. Ungues parum divaricati.

The incompleteness of the ridge limiting the cicatrice of the scape (it is, in fact, very short) would rcmove this genus from the group to which Achthophora belongs, but in all its other characters it agrees with the group. The claws in threc species of Achthophora which I have examined are as fcebly divaricated as in the new genus.

\section{EUSYNTHETA BREVICORNIS.}

Supra fuliginco-nigra, vertice vittis duabus latis, thorace lineis duabus dorsalibus, scutello, elytris fascia lata mediana et macula magna apicali, cinereo-albo tomentosis: antennis articulis nonnullis basi, fronte genisque, corpore subtus et pedibus cinercis. Thorax grosse rugulosopunctatus. Elytra basi late grosse ct aspere, versus apicem sparsim grosse, punctata. Long. 16-20 millin. 


\section{DESCRIPTIONS OF COLEOPTERA COLLECTED BY Mr. JOHN WHITEHEAD ON KINA BALU, BORNEO. BY the REv. H. S. GORHAM, F.Z.S.}

THF Coleoptera of which it is the purpose of this paper to give an account were collected by Mr. J. Whitehend during his residence from 1886 to the middle of 1887 in the neighbourhood of Kina Balu, and for the most part in the early months of those years.

\section{HISPID $x$.}

Prionispa, Chapuis.

Prionispa pulchra, n. sp.

Rufa, supra metallico-viridis, prothorace elytrisque subopacis, rufo-marginatis, grosse punctatis, his tuberculis tribus conicis; humeris costatis, et angulo posteriore spiniformi. Long. 6 nillim.

Hal. Borneo, Kina Balu.

Body beneath and legs red ; head red except the crown ; antennæ blackish, their basal joint sometimes wholly red; the front produced and with a carina between the bases of the antennie; thorax subquadrate, coarscly punctured at the sides, obsoletcly so in the middle, green above and opaque, red beneath. Elytra with the shoulders elevated, with a double costate elevation in addition to the costate submarginal interstice, and three conical clevations, of which the middle is the larger and which on its cxterior side is excavated, and mctallic and not green in that part; the spine-like production of the hind angle is large and sharp and compressed horizontally, it is green in the middle but fiery copper at its apex; the sutural angle is yellow, and the margins of the elytra external to the humeral callus are brownish with a coppery or purple reflexion. The apical margin is not toothed, but there are one or two minute serrations at the base of the spine.

Hispopria grandis.

$$
\text { HisPopria, Baly. }
$$

Hispopria grandis, Baly, Cat. of Hisp. in Coll. Brit. Mus. 1858, p. 95.

Kina Balu.

ANISODERA, sp. n. (a).

$$
\text { Anisodera (Chevr.), Baly. }
$$

Kina Balu. A dull red species apparently belonging to Sect. A. $b$ of Baly's Catalogue. The species of Anisodera are so difficult to distinguish, that I do not feel disposed to describe this till I have further acquaintanec with them.

ANISODERA, sp. n. (b).

Kina Balu.

A single specimen of a smaller species with black legs and antennæ, and much rougher clytra and coarsely punctured thorax.

\section{ERotyLid ж.}

Tetralanguria splendens, Wied. Kina Balu.

Triplatona attendata. Kina Balu.

Triplatoma attenuata, Crotch, Cist. Ent. 1876, p. 405.

Nesites attenuata, Bedel, Rev. Triplatoma, Ann. Mus. Civ. Gen. 1882, p. 10, t. x. f. 5.

Triplatouia geströ̈.

Triplatoma geströi, Bedel, l. c. p. 440, t. x. f. 4 ; Gorlam, P. Z. S. 1883, p. 80, t. 18 . f. 1.

Excaustes marginalis.

Encaustes marginalis, Crotch, Cist. Ent. 1876, p. 477. Kina Balu. 
Asmonax, gen. nov.

Characteres plerumque sicut in Encauste; differt antennarum articulo tertio vix longiore quam secundus, prothoracis latcribus compressis, sinuatis, angulis anticis depressis, disco inaquali, bicostato, elytris interstitiis alternis costato-clevatis.

This new genus is nearly allied to Encanstes, but has a very different facies owing to the form of the thorax, and the costæ on it and on the elytra. The front of the prosternum is plain as in Encaustes, that is to say, not elevated nor brought into a point in front as in Micrencaustes.

Asmonax whitehead, n. sp. Kina Balu.

Anthracinus, niger, nitidus; antennis articulis octo globuliformibus, tertio vix elongato, tribus ultimis transverso-compressis, pubescentibus ; capité opaculo, fere lævi, inter antennas transverse impresso; prothorace transverso-subquadrato, ad angulos posticos parum angustato, levi, in medio nitidulo, obsolete haud acute bicostulato, ad margines subopaco, antice posticeque obsolete fossulato, punctis nommullis hic illic dispersis, margine laterali tenuiter elevato ; ely tris tenuiter punctato-striatis, costis tribus elevatis, quarta etiam externa cum suturali ad apicem conjuncta, sericbus duobus inter costas singulas. Abdomen fortiter sparse punctatum. Long. 18-19 millim.

Wholly black and shining, subopaque in places, as the sides and lateral reflexed underside of the thorax. Owing to the form of the thorax, which has the sides sinuate, turied in and downward at the front angles, and the strong double ridge on the centre of the thorax, this spccies has a rcmarkable and Endomychid appearance; the costate elytra are an exaggeration of what takes place in such species as E. opaca, Crotch. The shortening of the third joint of the antennæe and their bead-shaped appearance show this to be a strongly modified form. The fcmora are compressed and sinuous just as in Encaustes; the middle tibiæ have a tooth-like projection externally, just above the insertion of the tarsi, and are pubescent internally at their apices. The elytral epipleura are pitchy brown, but not noticeably so, and have obsolete transverse wrinkles.

I have only secn four cxamples of this species, viz. those obtained by Mr. Whitehead. I cannot distinguish the sexes.

\section{ENDOMYCHID E.}

Amphisternus armatus, 11. sp. Kina Balu.

Niger, opacus, obsolete varioloso-punctatus; thorace subquadrato, angulis anticis acutis, valde productis ; elytris spinis duabus acutis æneo-micantibus, nna subhumerali, altera conoidea in medio, apice acute mucronato, tuberculisque duobus nigris nitidis, mo basali uno apicali ; femoribus clavatis, apicibus piceis. Long. 8 millim.

Rather larger than A. spinicollis; and at once distinguished from both the described species of spinous Amphisterni by the two black tubercles, the produced front angles of the thorax, which are like those of $A$. auriculatus but not reflexed, and by the fiery coppery or aneous colour which is seen on the shining parts. The head is thickly punctured, rather shining, and the antennæ have all the joints from the third to the eighth elongate, the third longer than the two following united; the sides of the thorax are slightly angulate in the middle and narrow a little to the base; the disk is quite opaque, with coarse confluent large punctures. Of the elytra the anterior tubercle has a pitchy tint, the humeral angle is reflexed and smooth, as is the basal margin; the first lateral spine is a little below the shoulder, very long and acute, wide at its base, but compressed if viewed from behind, brassy black; the middlc spine more upright but still divaricating, conoidal at its base ; both spincs punctured at their basc, as the elytra are. The postcrior tubercle is bluish black and smooth; the apical production of the elytra is external to and independent of the sutural angle, which is itself quite distinct-it is in fact part of the margin itself, the epipleural fold being continued along it as a groove. The legs are brassy black, the club of the femora distinctly pitchy.

Several specimens of this interesting new species were obtained by Mr. Whitehead.

Eumorphus tumescens, n. sp. Kina Balu.

E. marginati statura et similitudine; niger, clytris nigro-cæruleis, late (humeris minus) narginatis, apicibus subacutis, maculis quatuor magnis aurantiacis. Long. 17, lat. 13 millinı. $\delta$. 
Mas, clytris in medio conjunctim altc ct acute elevatis, prothoracis angulis posticis acutis, haud longc productis; tibiis anticis infra medium dente acuto valde distante armatis; haud compressosinuatis.

Antennæ longer than in $E$. marginatus, all the joints from the third, and the club, being longer. The thorax is not so broad, especially at the base, the hind angies in the male not being nearly so much produced, but still thcy are acute; its disk is more uneven, there being in the single male before me an impressed pit on each side of the centre; the elytra have the expanded margin more gradually widened, so that it is narrower at the shoulders than in E. marginatus. The four spots are larger in proportion, and placed nearer together than in that species, and they are more acuminate at the apex, and the middle of their disk is much more acutely raised, the summit of this raised part being conical and nearer the two anterior spots than the corresponding part in $E$. marginatus. The front tibiæ in the male are nearly straight, not strongly sinuous nor distorted as in E. marginatus, but a little compressed laterally with a short cxternal groove at their apices (for the reception of the tarsi), but not grooved along their whole length.

This insect has also some analogy with E. turritus; but the larger yellow spots and the dark blue colour of the elytra, as well as the structure of the tibiæ, will at once distinguish it.

One specimen, a male, obtained by Mr. Whitehead.

Eumorphus costatus.

Eumorplus coslatus, Gorham, Endom. Rec. p. 34.

Mas, tibiis anticis dente acuto valde distante in medio armatis; tibiis intermediis ct posticis mediocritcr curvatis, his intus ciliatis.

I.believe a single male and female from Kina Balu to be identical with the species described by myself from two female specimens from Celebes. The male has the elytra shining, and with an indistinct violet tint, while the fenale is subopaque and is distinguished by a short keel on the elytra at their base near the scutellum. The yellow spots are large, and causc the speeies to recall E. quedrinotatus. The male has the hind angles of the thorax acutely produced, by which it is at once separated from E. quadrinotatus.

Eumorphus GUERINI.

Eumorphus guerini, Gorham, Endom. Rec. p. 33.

Many specimens of this were obtained by Mr. Whitehead; all I have yet seen are males. Hitherto only seen from the Malay peninsula.

Eujorphus lucidus, n. sp. Kina Balu.

Nigro-subviolaceus, nitidus ; elytris ovatis, apice acuminatis, maculis duobus rotundatis aurantiacis nitidis, anteriore parum tumida; thorace (feninæ) subopaco. Long. 9 millim. $q$.

It is difficult to compare this species with any other of the genus; the elytra are very slightly margined, but are acuminate at their apex, and not very strongly convex. It is entirely black, with the exccption that the elytra have a faintly violct tinge and are very smooth and shining, the four. spots are moderate in sizc, and round, very smooth, but not raised; the thorax (of the female) is opaque, with two rather obsolete basal impressions and a central channel, its sides are a little angular in the middle, contractcd to the front angles. The antennæ are of moderate length, the fourth to the eighth joints a little longer than wide, the three club-joints subequal, transverse, not much compressed.

Four specimens were found by Mr. Whitehcad. This species may be placed after E. guerini, Gorh.

Metriorrhynchus, sp. inc. Kina Balu.

\section{IXCID \&.}

A single cxample ( $q$ ) of a Metriorrlyynchus allied to $M$. geometricus, but larger, and precisely similar in colour to Xylobanus reticulatus, Gorl., of which there is an example from the same region. It is also very close to Mr. infuscatus, Gorh., Notes from Leyd. Mus. iv. 1882, p. 96.

Metriorrhynchus, sp. inc. Kina Balu.

A single spccimen of a species allied to M. sericeus, but with much brightcr red elytra, apical half black. 
Metriorrhyschus, sp. inc. Kina Balu.

Unfortunatcly also a single specimen only of a species with the doublc rows of cells distinct and wide, black with red clytra, of which the apical quarter is black, and black marks at their base. Allied to M. cinnabarinus, Gorh.

Xylobanus neticulatus. Kina Balu.

Tylobanus reticulatus, Gorh., Notes from Leyd. Mus. 1882, p. 96.

A single specimen, apparently of this spccies.

Telephorus viridanus. Kina Balu.

Telephorus viridanus, Gorh., Notes from Leyd. Mus. vol. iv. 1882, p. 105.

Lrnopzus, n. sp. Kina Balu.

Vesta aunastiaca. Kina Balu.

\section{LAMPYRID $\boldsymbol{\text { I. }}$}

Vesta aurantiaca, Ern. Oliv., Notes from Leyd. Mus. vol. viii. 1886, p. 192.

M. Ernest Olivier has separatcd under this name specimens of a Vesta referred by me to Vesta urens, described by myself from Borneo ( $c f$. Notes from Leyd. Mus. vol. v. 1883, p. 3). Three specimens collected by Mr. Whitehead on Kina Balu agree precisoly with one of thesc specimens from Sumatra in my possession. As the specimen which M. E. Olivier redescribes as the type of my $V$. urens is now at Leyden, I have no means of forming an opinion on the specific distinction of $V$. aurantiaca, but it certainly occurs in Borneo, as these specimens prove.

\section{Prrocelia, Gorham.}

Pyrocalia collaris, n. sp. Kina Balu.

Oblonga, subparallela, opace nigro-fumosa ; prothorace brevi, transverso, flavo, distincte at tenuiter carinato, margine antico late et alte reflexo, basi recte truucato, angulis posticis subrectis, nullo modo productis; pygidio flavo. Long. 20 millim.

Head black, eyes moderate; antenna long and thin for this genus, nearly as in $P$. fumigata, the joints much longer than wide and not serrate; thorax almost semicircular, with the margins much reflexed, the diaphanous lunules not very transluccnt. Elytra cntirely smoky black, two costules moderatcly distinct for about two thirds of the length of the elytra, the intermediate one vcry obsolete ; scutellum, head, legs, and body entirely dull black, with the exception of the apical ventral segment and pygidium and of the two luminous patches.

This insect is apparently allied to $P$. opaca, Bourg., described and figured in the 'Annali del Museo Civico di Storia Naturale di Genova,' vol. ii. 1855, p. 349, t. v. f. 2, from which, however, it differs by the scutellum being black, by the entirely black legs and body, and by the absence of the pubescencc, and (judging by the figure) by the thinner and not serrate antennæ.

Diaphanes, Motschulsky.

Diaphanes apicalis, n. sp. Kina Balu.

Breviter oblongus, subopacus, ochraceus ; prothorace brevi, marginc antico elevato, lunulis duabus translucidis ; disco antice tenuissime carinato ; clytrorum apicibus, antennis, palpis, pedibus, abdomineque (apice excepto) nigris. Long. 14 millim.

This species resembles rather closely Pyroccelia terminta, Gorh., but from the thin antenuæ and the size of the eyes and the clear translucent spaces of the thorax it ought rather to be placed in the genus Diaphanes. The thorax is shorter and has the hind angles less produced than is usual in this genus ; the apical ventral plate and the pygidium are yellow; the head, breast, and the extreme base of the legs are yellow, but clouded in parts with fuscous. 


\title{
JESCRIPTIONS OF SIX'TEEN NEW BUTTERFLIES FROM KINA BALU. BY H. GROSE SMITH.
}

\author{
[From the 'Annals and Magazine of Natural History.']
}

\section{Papilio acheron.}

Male.-Upperside. Both wings bluish black, slightly suffused with purple; margins between the ncrvures narrowly white; the posterior wings slightly irroratcd with grey in the anal area.

Underside. Both wings with markings as in my $P$.forbesi, except that the grey rays between the nervules on the anterior wings are less marked, the ochraceous band on the postcrior wings does not extend beyond the upper median nervule, and the three blue spots near the extcrior margin between the costal nervure and the discoidal nervule are less distinct; the white spots on the margins between the nervules are much narrower.

Expanse of wings 4 inches.

Nearest to $P$. forbesi.

\section{Papilio stratiotes.}

Male.-Upperside. White, tinged at the base with pale greenish yellow. Anterior wings with the costal margin and cell crossed by four black fascix ; the basal fascia narrow, the second, third, and fourth wedge-shaped, the fourth extending beyond the discocellular nervules; beyond the fourth fascia is a semitransparent space divided by the discoidal nervules, which are black; apex broadly black, centred with another transparcnt space, divided by the black nervules. Posterior wings with exterior margins narrowly black and three black lunate spots near the anal angle; anal area grey, a long bright, quadrangular, carmine spot at the anal angle, bordered on the upperside with black and on the inside on the inner margin with a white linear spot. Tails narrow and black, with white margins.

Underside. Anterior wings as above, tinged at the basc with yellowish brown. Posterior wings ochraceous, crossed at the middle and near the base by two black bands, slightly convergent towards the anal angle and cxtending as far as the greyish-black space above the anal carmine spot; the exterior margin and anal arca broadly black, irrorated towards the anal angle with grey, the carmine spot as above, the discocellular and median nervules black; two small black spots below the former.

Expanse of wings $3 \frac{3}{4}$ inches.

This insect appears to be intermediate betwecn $P$. antiphates, Cramer, and $P$. agetes, Westwood; in shape and markings of the upperside it approaches $P$. agetes, on the underside it bears a superficial rescmblance to $P$. antiphates.

\section{Papilio procles.}

Near to P. bathycles, Zink., but differs from it in the following respects :-Anterior wings : upperside, four spots only in the cell, the second and third being almost obsoletc; the threc lowest spots of the discal row of spots confluent and broader than in $P$. bathycles. On the posterior wings the three discal spots are larger and confluent, instead of being distinct, and the wings are more deeply emarginate. On the underside of posterior wings the large silvery patch is not traversed near the centre by a concave brown fascia, as in P. bathycles, but in lieu of it there is a short, narrow, brown fascia from the costa nearly as far as the subcostal nervure, almost divided on the costal nervure by a small orange-red spot, and thcre is a small triangular silvery spot next the cell between the upper and second discocellular ncrvulcs. The dark brown area in which the series of orangc-red spots towards the anal angle is situaterl is broader than in $P$. bathycles, and the submarginal row of spots is further from the margin.

Expanse of wings $2 \frac{1}{2}$ inches.

4. Papilio macaristus.

Near to P. macareus, Godart, but differs from it in the following respects :-Anterior wings : upperside, in place of the double row of three spots and three short bars in the space between the end of the 
cell and the upper part of the submarginal row of spots, there are three elongated strcaks, slightly clavate at the ends nearest the cell. On the posterior wings the streaks in the area between the cell and the exterior margin are very short and narrow. Underneath, all the streaks on the posterior wings are very indistinct, some being almost obsolcte, while in $P$. macareus they are quite as large and distinct as on the upperside; the body is black, with a narrow grey stripe on each sidc. Two specimens of $P$. macareus in my collection from Sumatra have bright brown bodies, and two others from Darjeeling have black bodies broadly striped with grey.

I should have been disposed to look upon this insect as a variety only of $P$. macareus if there had not becn in the collection a uniform series of it from the same locality.

Expanse of wings $3 \frac{1}{2}$ inches.

5. Appias whiteheadi.

Male. Above, approximates to $A$. pandione, Hübn., but on the anterior wings the apical area is more extensively black, and in place of the large subquadrate black spot at the cnd of the ccll of $A$. pandione, which is contiguous with the greyish-black costal area, there is a small black spot quite distinct. The second submarginal white spot in the middle of the apical area is almost obsolcte. On the posterior wings the black margin is double the width of that of $A$. pandione, extending over the cxterior third of the wings. Below, it differs from $A$. pandione on the anterior wings in the spot at the end of the ccll being rery small and distinct, and the apex being pinkish grey. On the posterior wings the basal third is light ochraceous, very slightly irrorated with grey towards the base; the remainder of the wings pinkish grey, crossed with an indistinct irregular dark band, bordered externally towards the apex with pale pinkish grcy; the spot at the end of the cell is bright ochraceous.

Expanse of wings $2 \frac{5}{5}$ inches.

6. Ragadia anNulata.

Upperside. Both wings stramineous, with the band, costal margin of anterior wings, and exterior margin of both wings broadly ashy brown, crossed near the apex as far as the first median nervulc by an ashy-brown bar; beyond that nervule the bar is discontinued on the upperside, but it shows through from the underside, where it is prolonged across both wings to the inner margin.

Lnderside. Anterior wings crossed by three ashy-brown bands, the submarginal band having eight ocelli ; costal and outer margins ashy brown. Posterior wings with three bands, the middle band concave and the outer one with six occlli, the second, third, and fourth being the largest. All the ocelli are black, with silver pupils, the iris ochraceous, the second and third on the posterior wing enclosed in one iris.

Expanse of wings $1 \frac{1}{2}$ inch.

7. Detias eumolpe.

Male.-Upperside. Both wings purc white.-Anterior wings with the apical third, costa, and base greyish black, the apical black area indented inwardly and with three minute greyish-white spots between the discoidal and two upper median nervules. Posterior wings with the outer margins and ends of the veins narrowly black.

Underside. Anterior wings greyish black except on the inner margin, which is white, and the area below and extending somewhat beyond the cell, which is irrorated with white scales; a large, oblong, oblique, greyish-white spot at the end of and extending slightly above and beyond the cell, broadest at the upper cnd; near the apex a curved row of five conical spots, the four upper spots yellow, the fifth ycllowish white, the first spot below the subcostal nervule, the sccond minute, the third the largest, the fourth about the same size as the first, the fifth the smallest, followed near the margin by two short white lincs betwcen the two lowest median nervules, and two similar lines on the margin close together above the submedian nervure. Posterior wings bright yellow, with a broad marginal black band and black veins; in the band is a submarginal row of six red triangular spots between the veins, the uppermost 
situate below the first subcostal nervure; a basal, broad, elongated red patch below the costal nervure; the costa at the base irrorated with yelluw.

Expanse of wings $3 \frac{1}{8}$ inches.

Nearest to $D$. descombesi, Boisd., and $D$. leelisama, Cr.

\section{Cyrestis sejinjgra.}

Upperside. Both wings whitc, with black veins, and crossed with brown-black bands. Anterior wings with a small brown spot near the outer angle narrowly bordered internally with white, and with one small black spot a little above its centre; at the top of the brown spot is a larger black spot narrowly edged with white, and above this spot between the two lowest median nervules, each of which it touches, is an elongate quadrate spot narrowly edged with white. Posterior wings with a brown patch at the anal angle in which are several black spots; an oval black spot narrowly surrounded with white on the abdominal fold above the brown patch.

Underside as above, but paler.

Near to C. mcenalis, Erichs., and irma, Forbes, but differs from both chiefly in being white and black instead of stramineous and brown; the transverse bands are broader, and in the brown spot at outer angle of anterior wings, which is smaller than in either of those species, there is only one instead of two black spots. Mr. Forbes, in describing C. irmae ('A Naturalist's Wanderings in Sumatra,' p. 274), appears to have transposed the description of this butterfly with the description of Cethosia carolince; his description of the latter applies to Cyrestis irma, and the description of Cyrestis irma applies to Cethosia carolince.

Expanse of wings $1 \frac{7}{8}$ inch.

9. Euthalia Whiteheadi.

Male.-Upperside. Anterior wings dark brown, the costal margin, apex, and a rather broad outer marginal space tinged with olivaceous green, slightly iridescent, cspecially towards the outer angle; three dark brown bars across the cell, a small oblong white spot between the basal and middle bar on the subcostal nervure, a narrow, oblong, slightly curved, greyish-white spot immediately beyond the third bar, a fourth bar on the discocellular nervule, and a fifth beyond, the space between the fourth and fifth slightly iridescent olive-green; two rows of three white spots each beyond, converging above the upper median nervule; near the costal margin, between the rows, is one white spot; in the disk, on each side of the lowest median nervule, is a curved, rather narrow, indistinct, whitish-brown marking. Posterior wings : basal three fourths dark brown, outer fourth iridescent dark olivaceous green, in the middle of which is a row of seven black conical spots, the anal spot double, the three upper spots edged externally with three carmine spots; three larger carmine spots towards the middle, the uppermost below the costal nervure, the other two below the first and second subcostal nervules; an indistinct small red spot near the anal angle.

Underside. Both wings paler and greener above. Anterior wings with the bars across and beyond the cell as above, the space between the second and third and fourth and fifth bars carmine, the white spots as above; two greyish-white patches, edged internally witl brownish black on each side of the lowest median nervule; a rather broad whitish-green space on the outer margin, lightest towards the outer angle, becoming obsolete towards the apex, edged internally with brownish black. Posterior wings with the red spots as above; the submarginal row of black conical spots almost obsolete; across the disk below the lowest red discal spot is a double row of lunular brown markings, the usual basal markings centred with carminc; base of the costa narrowly carmine.

Female.-Upperside. Palcr than the male. Anterior wings crossed about the middle with an oblique white band of four spots: the uppermost crosses the cell, indented on each side; the second at the junction of the middle median nervule with the mcdian nervure, minute; the third between the second and lowest median nervules, narrowly elongated outwardly at its lower end along the latter; the fourth below it smaller and lunulate. Instead of the two converging rows of three white spots in the apical portion of the male wing, the outer row has two spots only, and there is one spot on the costa. 
Underside as above, but paler ; the anterior wings lave a small annular spot below the celi, which is absent in the male. Posterior wings : the two lowcst discal carmine spots are represented by two pale whitish-pink patches, edged internally with dark brown, beneath which, bending towards the anal angle, is a double row of lunular markings; the carmine spots within the basal markings are smaller, several being nearly obsolete.

Expanse of wings, $\delta 3 \frac{1}{4}$, $q 3 \frac{1}{2}$ inches.

The male is in the collections of Mr. Whitehead and Mr. Grose Sinith, the female is in the collection of Mr. Whitehead only.

Nearest to E. lubentina, Cramer, but in the shape of the wings, the position and number of the white markings on the anterior wings of both sexes, and the size differing from that species. It also differs from $E$. djata, Distant, with the types of which it has been compared and in which the white spots in the apical portion of the anterior wings are absent; and in the female $E$. djata the white band of spots on the anterior wings is transverse and different in numerous respects. In E. whiteheadi there are no red lines or markings on the abdominal margin of the posterior wings of eitler sex.

\section{TANXCIA AMISA.}

Male.-Upperside. Both wings dark velvety brown, crossed in the middle by a pure white band. On the anterior wings the band on the costa is only represented by a narrow short linc; thence to the inner margin the band gradually widens, the veins across the band brown; a very indistinct, somewhat curved, white line between the subcostal nervules halfway between the band and the apex; the cell is crossed by five black lines, the two outermost nearly joining each other on the median nervure; between the lowest median nervule and the submedian nervure, near the base, touching the cell at their upper ends, are two transverse black lines crossed at their lower ends hy a similar line; a small black spot below the cell between the lowest and middle median nervule; a submarginal row of indistinct, rather large, black spots. On the posterior wings the band gradually tapers towards the anal angle, where it slightly curves outwardly; the onter edge of the band is slightly indentated; an indistinct submarginal row of round black spots.

Underside. The band as above; pale brown inside the band, darker beyond it; the band is edged on both sides with dark brown markings ; the subapical, indistinct, curved white line on the upperside is represented by two white spots near the costa and indistinct whitish-brown markings inside the submarginal row of dark brown spots, the lines across the cell and beneath it as above. Posterior wings brownish grey between the band and the base, with numerous brown markings; the area beyond the band is palc brown, with a submarginal row of dark brown spots capped with whitish lunules, above which is a series of lunular brown markings; the outer portion of the band above the latter narrowly grey.

Expanse of wings $3 \frac{1}{4}$ inches.

Nearest to $T$. cibaritis and $T$. acontias of Hewitson.

\section{Tanacia carulescens.}

Male.-Upperside. Both wings brown, with dark markings in the cell and basal area. Anterior wings with a greyish-blue marginal band intersected by the brown nervules, commencing narrowly below the upper median nervule, gradually widening towards the posterior angle. Posterior wings broadly margined with a band of the same colour, dentated on the inner edge; above the middle of the band is a row of small spots between the veins as far as the lowest median nervule, the two uppermost becoming larger and hastate.

Underside. Anterior wings pale brown at the base, gradually becoming darker towards the middle, whence to the outer margin the wings are suffused with bluish grey, tinged with pink and slightly iridescent; a submarginal row of hastate dark markings commencing below the costa, larger towards the posterior angle; inside the submarginal row is another row of lunular spots capped with dark markings ; the usual markings across and beneath the cell. Posterior wings : basal third pale brown tinged with bluish grey, the rest of the wings bluish grey, more iridescent than the anterior wings; a submarginal 
row of hastate markings, inside which, a little beyond the middle, is a row of lunular markings ; the usual spots and markings towards the base.

Expanse of wings $2 \frac{1}{4}$ inches.

Nearest to $T$. supercilia, Butler.

12. Tenaris occulta.

This species is near T. horsfieldii, Swainson, but differs from it iu the following respects :-

Male.-Upperside. The anal third of the posterior wings is wholly pale brownish white, instead of being margined with the same colour as the rest of the wings, the basal area being darker than in T. horsfieldii.

Underside. The outer half of the posterior wings, in which the ocelli are situated, is pale brownish white, except a space near the apcx, which is irrorated with dusky brown; the rest of the posterior wings is dark brown, the outer edge of which colour does not extend to the ocelli, but forms two distinct curves partially round them, leaving on the inner side of the upper ocellus a narrow, and of the lower ocellus a broadcr area of the same colour as the outer portion of the wings.

Female.-Upperside paler than in the male, and the lower ocellus on the postcrior wings is entirely surrounded by the brownish-white colour of the anal aren.

Underside. The outer two thirds of the posterior wings is pale brownish white, the basal third dusky brown, which colour does not extend as far towards the ocelli as it extends in the malc. The posterior wings are narrower than in the male.

Expanse of wings, o $3 \frac{1}{8}$, 우 $2 \frac{7}{8}$ inches.

13. Elymintas konga.

Male.-Upperside. Both wings dull bluish slate-colour, changing to dull brown on the margins; outer margins cinarginate.

Underside. Both wings dull brown, darker towards the base and mottled with brownish-grcy markings. Anterior wings with several light grey markings on the costal margin towards the apex and an indistinct light grey area from the apex to ncar the middle. Posterior wings with a rather sunall white spot a little bclow the costal margin near the middle, halfway between which and the base is an indistinct rufous patch, the apex slightly rufous.

Expanse of wings $2 \frac{3}{4}$ inches.

Near to E. penanga, Hewitson, and E. sumatrana, Wallace; but, besides other differences, the apex of the anterior wings is less acute; it has a subcostal white spot on the underside of the posterior wings which is absent in those species, and the outer margins are emarginate.

\section{Sithon teunga.}

Male.-Upperside. Anterior wings dull brown, with the inner margin projecting; a round, depressed, sericeous spot above the submedian nervure about the middle. Posterior wings: anal third white, the vcins across the white area black, rather broadly tipped with black on the margin ; the upper half smooth, devoid of scales ; two tails, that nearest the anal angle the longest.

Underside. Both wings dull pale brown, darker towards the apex and almost white at the anal angle; the inner marginal third of the anterior wings smooth, with a tuft of pale brown hairs. Posterior wings : outer margin narrowly black, a black round spot at the anal angle, another and two black bars in a row above it, and inside these is another row of three sinuate black elongated spots.

Expanse of wings $1 \frac{1}{2}$ inch.

Somewhat resembles $S$. amrita, Feld., on the underside.

15. Sithon KIANA.

Male-Upperside. Anterior wings dark brown. Posterior wings : basal and costal third dark brown, the remaining part light blue, shading to white towards the anal angle, at which there is a black 
spot; an oval black spot between the lowest and middle medimn nervule; one white tail, margin narrowly black; eilia white, spotted with black at the tips of the veins.

Underside. Anterior wings rufous-orange, a rather broad rufous band on the outer margin ; inner margin narrowly grey; an indistinct short white line, edged externally with brown near the outer angle at the inner edge of the rufous band; an indistinct, interrupted, transvorse grey line beyond tle middle, becoming obsolete towards the costa. Posterior wings rufous-orange, the apical third of the margin rather broadly rufous, below which to the anal angle there is a rather broad marginal white band, narrowly black on the margin, in which, at the anal angle, is a black spot; beyond the tail is another black spot crowned with a brown bar, and conneeted with the anal spot by two narrow dark brown bars, and two smaller blaek spots beyond, the first of which has a narrow brown bar above it ; above the spots and bars and extending nearly to the apex are a row of lunular white markings, edged narrowly with brown, and towards the middle an indistinct $\mathrm{V}$-shaped white line.

Female.-Upperside as in the male, but paler; the blue area on the posterior wings is narrower and greyer, with a submarginal row of five ill-defined black spots, the middle and anal spots being the largest.

Underside as in the male, but posterior wings paler and yellower.

Expanse of wings, of $1 \frac{1}{3}$, ㅇ $1 \frac{1}{4}$ ineh.

Nearest to S. tharis, Hübn., and S. meduana, Hew.

16. Sithon Cineas.

Male.-Upperside. Anterior wings dark blue, base and eosta narrowly, outer margin broadly, black, the inner margin towards the base projecting. Posterior wings rather brighter blue, the lower part of the outer margin strongly emarginate, with three black tails tipped with white, the middle tail mueh the longest; a black band on the margins, broadest above the tails; a narrow white line between the two lowest tails, and above it and the blaek land is a rather broad brownish-white spot, broadest next the abdominal fold; a faint indication across the middle of the black line on the underside; on the costal margin a broad shiny patch devoid of scales.

Underside. Anterior wings dull brownish white at the base, gradually becoming greyish brown at the apex and outer margin. Posterior wings brownish white, with a submarginal band from the apex to the anal angle, brown at the apex, changing to black above the tails, and at the anal angle centred with a thin metallic blue line ; above the submarginal band is a second slightly irregular band, brown and linear near the apex, changing to blaek and broader towards the anal angle; eilia white.

Female.-Upperside. Both wings entirely brown except the narrow white line between the two tails on the posterior wings and a small white s of above the anal angle.

Underside as in the male.

Expanse of wings, o $1 \frac{1}{4}$, 우 $\frac{7}{8}$ inch.

Nearest to S. cinesia and S. maneia, Hewitsoll.

The female is smaller than the male, a peculiarity noted by Mr. Hewitson with regard to S. cinesiu. 


\title{
DESCRIPTIONS OF NEW SPECIES OF RHYNCHOTA. BY W. L. DISTANT.
}

\author{
[From the 'Annals and Magazine of Natural History.']
}

\section{HETEROPTERA.}

\section{Family Coreides.}

Prionolomia nigrovittata, n. sp.

Cinnamomeous; antennæe, a central longitudinal line to pronotum, nnargins of scutellum (narrowly), outer margins of clavus (broadly), sternal sutures, lateral margins of inesonotum, metanotum, and abdomen, and the prosterior tibix blackish ; membrane dark brown.

Antennæ with a little less than the apical half of fourth joint ochraceous; first and fourth joints subequal in lengtl, second joint a little longer than thirl. Pronotal angles strongly, upwardly, and sublunately produced, their apices subacute, thcir margins finely serrate. Rostrum reaching the intermediate coxæ.

o. Posterior femora strongly incrassated, with three small but distinct black tubercles above, a strong black spine beneath at about centre and two smaller subapical spines of the same colour; tibite flattened and channelled, and inwardly toothed at about one third from apex.

Long. 27 millim., exp. pronot. angul. 13 millim.

\section{HOMOPTERA.}

\section{Family Cicadide.}

Leptopsaltria mascula, $11 . \mathrm{sp}$.

o. Heal, pronotum, and mesonotum greenish ochraceous ; head with the margins of front, antcrior margins of vertex, inner margins of eyes, and the area of the ocelli black; pronotum and mesonotum with the following black markings :-pronotum with two central longitudinal fascix, widened anteriorly and rounded and united posteriorly, the incisures, a large spot on lateral margins and three spots on posterior margin, the central one smallest and linear; mesonotum with five fascix, one central, widened and somewliat cordate posteriorly, an abbreviated one on each side, followed by another completely crossing disk, two small spots in front of the crueiform elevation. Abdomen castaneous, the segmental margins pitchy and a spot of the same colour at base. Head and thorax beneatl, legs and opercula greenish ochraceous, face with black strix, head spotted with black, apiccs of the tibiæ and tarsi blackish. Abdomen beneath castancous, with the tubercles and apex black. Teginina and wings pale lyyaline, the venation ochraceous; tegmina with the apex slightly infuscated, a small black and ochraceous spot at base of upper ulnar area and the transverse veins at bases of second and third apical areas darkly infuscated.

The rostrum reaches the posterior coxre, the opercula are angulated, the outcr and posterior margins nearly straight.

o. Long. excl. tegm. 28 millim., exp. tegm. 78 millim.

Allied to L. samia, Walk.

Cosmopsaltria montivaga, n. sp.

Allied to $C$. lauta, Dist., but differing by its larger size, broader and more robust body, the absence of the sublateral fascia of the pronotum, and the presence of an oblique black pronotal spot behind the eyes; the markings of the mesonotum smaller and the sublateral fascia curved and not extending to anterior margin. Opercula broader at base, not so concave intcrually, much more narrowly black at apex and imner margin, and crossed at ecutre by a transverse dark castaneous fascia.

Long. 40 millim., exp. tegin. 120 millim. 
Pomponia viridimaculata, $11 . \mathrm{sp}$.

5. Body above castancous ; occli, oyes, and posterior margin of pronotum ochraceous; mesonotum very dark castancous, with two obscure contiguous obconical spots at anterior margin; face, anterior margins of head bencath, and legs blackish ; apices of the femora ochraccous, posterior tibir castancous, their bases and apices blackish.

Tegmina and wings pale hyaline, the rcnation brownish ochraceous; tegmina with the costal membrane palc castaneous, the transverse veins at the bases of the second and third apical areas, and the apex of the longitudinal vein defining the upper apical area, broadly and darkly infuscated, and a distinct bright green basal streak; wings with the inner claval margin green, with a fuscous streak, the outer claval margin fuscous.

Body elongate, the face very robust and rounded; the rostrum reaching the posterior coxæ; opercula short, obliqucly rounded outwardly, obliquely straight inwardly.

Long. o $52-55$ millim., cxp. tegm. 135 millim.

POMIPONIA GR ELINA, I1. sp.

ㅇ․ Allied to $P$. fusca, Oliv., but differing by having the two central fascix of the pronotum much more diverted anteriorly, the two central obconical spots on the mesonotum much more contiguous, and all the tegminal macular markings on the transverse veins at bases of apical areas and at the apices of the longitudinal veins of the apical areas larger and more infuscated. The rudimentary opercula, as compared with those of the same sex of $P$. fusca, are convex and rounded extcrnally and not moderately angulated.

ㅇ. Tong. 31 millim., exp. tegm. 110 millim. 



\section{INDEX}

\section{OF SCIENTIFIC NA M ES.}

Ablabes baliodeirus, 265, 272 . immaculatus, 265 . longicaudus, 265.

melanocephalus, 265. periops, 265, $27 \%$. præfrontalis, 265,272 .

Acanthophorus, 294.

Accipiter manillensis, 201. 248.

- virgatus, 200, 263.

Accipitres, 200.

Achthophora, 295.

Acridotheres javanicus, 261.

Acrocephalus orientalis, 216, 254.

Acrochordus javanicus, 266 .

Egialitis cantiana, 247,257 .

- dubia, 247 .

- dubius, 257.

- geoffroyi, 247,257 .

- mongolica, 257 .

- peroni, 54, 247,257 .

- veredus, 257.

Egithina viridis, 219, 249, 254.

- viridissima, 219.

Aelurosaurus dorsalis, 264.

- (Pentadactylus) felinus, 264.

Ethopyga eximia, 90, 261.

- mystacalis, 261.

— shelleyi, 256.

- siparaja, 54, 232.

- temmincki, 115, 231, 232.

Aicedinidæ, 243.

Alcedo asiatica, 47, 252.

— bengalensis, $243,252$.

- euryzona, 120, 243.

- meninting, 243, 262.

Alcippe cinerea, 224.

Alectris, 163.

Allocotops, 226, 248.
Allocotops calvus, 180, 226, 248. Alophonerpes pulverulentus, 241.

Alseonax latirostris, 211.

Amathusia phidippus, 10 .

Amblycephalus boa, 266 .

Amphidromus quadrasi, 288.

Amphiesma chrysargum, 265.

- flaviceps, 265. - semifasciatum, 265 .

-_ rhodomelas, 265.

- stolatum, 265.

- substolatum, 265.

Amphisternus armatus, 297.

- auriculatus, 297. spinicollis, 297.

Anatidæ, $2+7$.

Androphilus, 225, 229, 248.

- accentor, 164, 177, 229, 248.

Anisodera, 296.

Anorrhinus comatus, 243,248 .

- galeritus, 50, 213.

Anous leucocapillus, 248.

$\longleftarrow$ stolidus, 257 .

Anseres, 247.

Anthothreptes malaccensis, 54, 233.

— phœnicotis, 233.

Anthracoceros convexus, 243.

- lemprieri, 252.

- malayanus, 243.

Anthrepetes malaccensis, 256.

Anthus gustavi, 235, 255.

- maculatus, 255.

— richardi, 235,248 .

— rufulus, 92, 259.

Anuropsis cinereiceps, 254.

- malaccensis, 230.

Aplianiotis fusca, 265 .

Appias nero, 141, 142.

- pandione, 301 . whiteheadi, 11s, 301.
Arachnothera, 125.

- affinis, 233, 248, 261.

- chrysogenys, 233.

dilutior, 256.

— juliæ, 116, 232, 248.

- longirostris, 233.

modesta, 54 .

Arachnotheræ, 53.

Arborophila, 248.

- charltoni, 43, 246, 248.

Ardea purpurea, 247.

- sumatrana, $247,257$.

Ardeidæ, 247.

Ardeola speciosa, 247.

Ardetta cinnamomea, 247.

- sinensis, 15, 247.

Argus grayi, 43.

Argusianus grayi, 245.

Argynnis niphe, 89.

Artamides concretus, 208.

—- melanocephalus, 208.

- normani, $120,248$.

- sumatrensis, 208.

Artamus leucorhynchus, 2t, 54,236 , 252.

Asmonax, 297.

- whiteleadi, 297.

Astur soloensis, 200, 263.

- trivirgatus, 200, 251.

Atherura macrura, 199.

Atropophis borneensis, 266.

Auricula auris-judæ, 289.

Bambusicola erythrophrys, 120, 245, 248.

- hyperythra, 245.

Barbus maculatus, 286 .

Batrachostomus cornutus, 252.

Baza leucopais, 251. sumatrensis, 251. 
Begonia, 163.

Bothrops gramineus, 266, 275.

Brachypteryx, 229, 248.

- cruralis, 225.

- erytlırogyna, 164, 224, 248.

Bubo orientalis, 203.

Bubonidæ, 202.

Bubulcus coromandus, 247,257 .

Buceros rhinoceros, $43,243$.

Bucerotidæ, 54, 243.

Buchanga cineracea, 260.

- leucogenys, 8.

—_ leucophæa, 253.

— palawanensis, $249,253$.

— stigmatops, 54, 103, 184, 207.

Bufo, 281.

- asper, 266, 282.

—_ biporcatus, $266,282$.

— borbonicus, 267 .

- divergens, 267, 282.

_- fuligineus, $267,282$.

- ]cptopus, 121, 267, 293.

- melanostictus, 266.

- penangensis, 267, 282.

- spinulifer, $267,282,283$.

- (Ansonia) penangensis, 283.

Bungarus flaviceps, 266.

- (Adeniophis) fasciatus, 266.

Burnesia supercilinris, 222.

Butastur indicus, 202, 251.

Butorides javanica, 247, 248, 257.

Cacatua hæmaturopygia, 250.

Cacomantis meruliuus, 242.

Caladium esculentum, 107.

Calamaria arcticeps, 265.

-__ beccarii, 265.

— benjaminsii, 265.

— bicolor, 265, 2 ¿2.

borneensis, 265 .

- flariceps, 265.

- grabowskyi, 265, 272.

_._ gracillima, 265.

- lateralis, 205,2 , 2 .

- Iowii, 265.

- martapurensis, 265.

- nigro-alba, 265.

- _ rœlandtii, 265.

— schlegelii, 265.

- temminckii, 265, 272 .

Callichrominæ, 295.

Callula, $2 s 1$.

- (Calohyla) pulchra, 266.

Calonas nicobarica, $245,256$. ophæna, 291.
Calophrynus, 281.

-_ pleurostigma, 266.

punctatus, 266.

Calorhamphus fuliginosus, 241 .

Calornis chalybxa, 235.

- panayensis, 256.

Calotes cristatellus, 265, 269.

Calyptomena, 118, 125, 182, 184.

- viridis, 23, 237.

- whiteheadi, $54,117,182,237$, 248.

Campephaga fimbriata, 260.

Campophagidx, 208.

Capitonidx, 240.

Caprimulgidæ, 244.

Caprimu!gus, 244.

- macrurus, 54, 244, 252.

_ manillensis, 252.

Carabidæ, 290.

Carcineutes melanops, 244.

Carpophaga ænea, 24, 135, 245, 256.

— badia, 53, 158, 182, 245, 248. bicolor, 24, 80, 245,256 .

Carpophagidæ, 122.

Cassidula bicolor, 289.

- mustelina, 289.

- sulculosa, 289.

Casuarina, 90, 163, 209.

Centrococcyges, 249.

Centrococcyx affiuis, 25.2.

- eurycercus, 242,252 .

- javanensis, 243.

Cerberus acutus, 266.

- rhynchops, 266.

Cerchueis moluceensis, 263.

- tinnunculus, 202.

Certhiidæ, 231.

Cervidæ, 45.

Cethosia carolinx, 302.

Cetonia, 184.

Cetoniidæ, 291.

Cettia, 170, 172, 217.

- fortipes, 217 .

- montana, 258 .

- oreophila, 165, 177, 216

Ceyx dillwynni, 54, 74, $2+3$.

- rufidorsa, 252, 262.

— tridactyla, 72 .

Chætura coracina, 244.

- gigantea, 252.

Chalcophaps indica, 245, 256.

Chalcostetha insignis, 54, 232, 256.

Chalcothea affinis, 293.

— planiuscula, 293.
Chalcothea pomacea, 293.

— resplendens, 293.

virens, 292.

(Plectrone) auripes, 292.

- (-) spathulifera, 293.

- (-) viridipes, 292.

Chaperina fusca, 264.

Charadriidæ, 247.

Charadrius fulvus, $247,257$. helveticus, 257.

Chibia borneensis, 54, 113, 207.

- palawamensis, 253.

Climarriclitys, 286.

Chimarrogale himalayica, 195.

Chiropodomys gliroides, 199.

Cllam rdochæra, 209, 248. jefferyi, 122, 209, 248.

Chlorocharis, 170, 172, 224, 248.

-_ emilix, 161, 177, 224, 248.

Chlorocharites, 175 .

Chloropsis, 220.

- cyanopogon, 219.

- kinabaluensis, $219,248$.

nigricollis, 260.

viridinucha, 219.

zosterops, 219

Chlorura, 153, 248.

- borneensis, 124, 168, 236, 248.

Chrysococcyx basalis, 262.

- xanthorhynchus, 242, 252.

Chrysocolaptes erythrocephalus, 252.

Chrysopelea ornata, 266.

- (Dryophis) rubescens, 266.

Chrysophlegma humii, 241.

- malaccense, 241.

Cicadidæ, 306.

Cicindela borneeana, 290.

- crespignyi, 290.

Ciconiidæ, 247.

Cinnyris aurora, 54, 256.

- hasselti, 232.

- pectoralis, 54, 232, 233, 256.

sperata, 256.

Circus spilonotus, $64,200,251$.

Cissa, 164, 184.

— jefferyi, 165, 168, 205, 206, 248.

- minor, 54, 113, 164, 205, 206.

Cisticola cisticola, 255.

Cisticolæ, 249.

Cittocincla macruxa, 258. 
Cittocincla nigra, 137, 254.

- stricklandi, 219.

Clarias tysmanni, 286.

Clerota brama, 292.

— viridipes, 292.

Cnethocerus, 294.

Coccystes coromandus, 242.

Cochlostyla satyrus, 288.

Cocomantis merulinus, 252, 262.

Coix lachryma, 156.

Collocalia, 237.

- fuciphaga, 244, 252.

- linchi, 5t, 7t, 122, $24 t$.

- troglodytes, 252.

Colpodes fryi, 290.

- parallelus, 290 .

Columbæ, 244.

Compsosoma melanurum, 265.

- radiatum, 265.

Conus suratensis, 66 .

Copris, 291.

Copsychus amœuus, 38, 54, 218.

Coraciidæ, $2+4$.

Coreidæ, 306.

Corone pusilla, 256. tenuirostris, 205.

Corvidæ, 205.

Corydon sumatranus, 238 .

Coryphocera, 292.

borneensis, 291 .

Corythocichla, 248.

crassa, 168, 177, 230, 248. epilopidota, 230 .

Cosmopsaltria lauta, 306.

- montivaga, 306.

Criniger frater, 136, 254.

- palawanensis, 254.

— phæocephalus, 221.

ruficrissus, 153, 220, 221.

Crocidura fuliginosa, 195.

- (Crocidura) sp. inc., 195.

Crocodilus palustris, 264. porosus, $264,267$.

Cryptolopha, 175, 248.

- castaneiceps, 215. grammiceps, 261.

montis, $140,165,215,248$,

249, 254.

— schwaneri, 191, 214.

- trivirgata, $165,177,214,248$,

261.

_ xanthopygia, 140, 249, 254.

Cuculidæ, 242.

Cuculus canoroides, 252.

- micropterus, 242.
Cuculus poliocephalus, 177, 242, 248.

- sonmerati, 252.

Culicicapa ceylonensis, 54, 214, 242.

Curculigo, 180.

Cyanoderma, 22t.

— bicolor, 223 .

Cyanops, 248.

— incognita, 241.

- monticola, $241,2+8$.

- pulcherrima, 240, 242, 248.

Cyciophis (Liopeltis) tricolor, 266.

Cylindrophis rufus, 265.

Cymbirhynchus macrorhynchus, 238.

Cynopterus ecaudatus, 194.

- lucnsi, 194.

Cypripedium, 116.

rothschildianum, 116.

Cypselidx, 244.

Cypselus infumatus, 122, 244.

Cyrestis irmæ, 302.

- mænalis, 302 .

— seminigra, 302.

Dacrydium elatum, 163.

Danainæ, 142, 143.

Dallais, 142, 143, 168.

Delias belisama, 302 .

— descombesi, 302.

- eumolpe, 301.

- orphne, 16.

Demiegretta sacra, $247,257$.

Dendrochelidon comata, 74, 244.

- longipennis, $2+4$.

Dendrocitta cinerascens, 54,124 , 205.

Dendrophila, 231.

— wnochlanıss, 255.

- corallipes, 36, 231, 248, 255.

-_ frontalis, 36, 231, 249, 255 .

Dendrophis caudolineatus, 266.

— pictus, 266.

Desicasta, 292.

Diaphanes, 299.

— apicalis, 299.

Dicæidæ, 234.

Dicæum, 115.

— celebicum, 234.

__ chrysorrhæum, 235.

- monticola, 115, 234, 248 .

- nigrimentum, 54, 235.

—_ sulaense, 234 .

- trigonustigma, 235.

Diceros, 292.
Dicrurid 207.

Dinopelma, 290.

— plantigradum, 291.

Dipsas. boops, 266.

- cynodon, 266.

- dendrophila, $266,275$.

- multimaculata, 266 .

Dipteris, 169.

Dissemurus brachyphorus, 207.

Doryceræ, 294.

Draco? sp., 13.

— blanfordii, 268.

- cornutus, $264,268$.

_ cristatellus, 265 .

— hæinatopogon, 265, 268.

- fimbriatus, 265.

- obscurus, $186,265,268$.

- quinquefasciatus, $265,268$.

- rostratus, 265.

- tæniopterus, 265.

- volans, 264, 268.

Drymocataphus capistratoides, 228.

—_ capistratus, 259.

Dryococcyx harringtoni, 252.

Elaphis tæniurus, 265.

Elaphrornis, 229.

Elaps bivirgatus, 266.

- (Callophis) intestinalis. 266.

- (—) nigrotæniatus, 266.

Elymuias, 143.

- discrepans, 143.

— konga, 304 .

__ lais, 143.

- penanga, 304 .

_- sumatrana, 304.

Empliesmenus, 294.

Encrustes, 297.

—_ marginalis, 296.

- opaca, 297.

Endomychidæ, 297.

Enicognathus (Coronella) ornatus, 265.

Eria, 170.

Ericaulon, 163.

Erithacus cyaneus, 218, 248.

Erotylidx, 296.

Erythra phœinicura, 247, 25\%.

Erythrocichla bicolor, 228.

Erythrura prasina, 107, 153, 237.

Esacus magnirostris, 247,257 .

Eucichla cyanura, 93, 262.

Eudynamis, 146.

- malayana, 242.

- $\cdot$ mindaveusis, $145,252$. 
Eulabes palawanensis, $145,256$. Eumorphus costatus, 298.

- guerini, 298.

lucidus, 298.

marginatus, 297, 298.

quadrinotatus, 298.

tumescens, 297.

turritus, 298.

Euploa, 142, 143.

- ledereri, 143.

- midamus, $1+2,143$.

Euplœas, 55.

Euplynes auro-cinctus, 290.

Euripus, 143.

— euplooides, $1+3$.

halitherses, 143.

Eurylæmidæ, 121, 237.

Eurylæmus javanicus, 238.

- ochromelas, 238.

Eurystomus orientalis, 244, 252.

Eusyntheta, 295.

- brevicornis, 295.

Euthalia djata, 303.

__ lubentina, 303.

- whiteheadi, 302, 303.

Excalfactoria chinensis, 54, 246, 257 .

Fulco communis, 202, 251.

Falcones, 200.

Falconidæ, 200.

Fordonia (Hemiodontus) unicolor, 266.

Fregata minor, 14 $7,248,257$.

Gahnea javanica, 163.

Gallinæ, 245.

Gallinago megala, 257.

Gallus bangliiva, 263.

- bankiva, 138, 249,257 .

- varius, $91,263$.

Garrulax, 248.

- schistochlamys, 188, 226, 248.

Gauresthes, 295.

- rufipes, 295.

Gauropicoides rafflesii, 241.

Gavialis schlegelii, 264.

Gecinus puniceus, $2+1$.

Gecko monarchus, 264, 268.

- stentol, 264.

- verticillatus, 264, 268.

Gehyra mutilata, 264, 268.

Gentiana pedicellata, 163.

Geocichla, 248.

-_- aurata, 188, 217, 248 .

- citrina, 217.
Geocichla horsfieldi, 90. rubecula, 217, 258 .

Girasia, 288.

Glareola orientalis, $247,257$.

Glyptothen, 293.

whiteheadi, 294.

Gonatodes kendallii, 264.

Goniocephalus borneensis, 265, 269. doriæ, 265.

liogaster, 265.

miotympanum, 265, 269.

Goniosoma margaritaturn, 266.

- oxycephalum, 266.

Gorsachius melanolophus, 54, 247, 257.

Gracula javanensis, 235.

Gracupica melanoptera, 261.

Grallæ, 247.

Grincalus larvatus, 260.

—_ normani, 208.

- sumatrensis, 252.

Gymnetinæ, 292.

Gymnodactylus baluensis, 264, 267 .

- consobrinus, 264. marmoratus, 264, 267.

Halcyon chloris, 24t, 252, 262.

- concreta, 244.

- coromanda, 244, 252.

- omnicolor, 262.

- pileata, 244, 252.

Haliaëtus leucogaster, 5t, 202, 251.

Haliastur intermedius, 202.

Harpactes, 180, 182.

- diardi, 8, 240.

- duvaucelli, 8, 240 .

- hodgsoni, 240.

-_ liasumba, 240.

— orescius, $124,240,248$.

-_ orrhophæus, 240.

— vidua, 124, 126, 185, 240.

whiteheadi, 239, 248.

Helicarion borneensis, 287.

whiteheadi, 287.

Heliconidæ, 143.

IIelicops, 27 .

Helicopsoides, 274.

- typicus, 265, 27 .

Helix (Hadra) monochroa, var. palawanensis, 288.

$-(-)$ traillii, 288.

- (Trochomorpha) conicoides, var. parva, 287.

Helymæus, 295.

Hemicercus sordidus, $2+1$.
Hemichelidon, 248.

- cinereiceps, 210,248 .

ferruginea, 210.

sibirica, 253, 254.

Hemidactylus craspedotus, 56, 26t, 267.

- frenatus, 264. platyurus, 264, 267, 268 .

Hemiplecta densa, var. schumacheriana, 288.

Hemipus obscurus, 208, 260.

- picatus, 116, 208, 248 .

Hemixus cinereus, 16, 220.

- connectens, 115, 220, 248.

flavala, 220.

— malaccensis, 220.

—_ virescens, 259.

Henicuridæ, 222.

Henicurus, 248.

- borneensis, 120, 222, 248.

leschenaulti, 222, 258.

sinensis, 222.

Heptadonta tricondyloïdes, 290.

Herodias intermedia, 257.

- torra, 247.

Herpornis brunnescens, 223.

Hestia, 142, 143.

- daos, 143.

leuconoë, 142 .

Heteroptera, 306.

Heteroscops, 203, 248. - luciæ, 169, 203, 204, 248 .

Hierococcyx bocki, 242, 248 .

— fugax, 214, $2+2$.

- nana, 242, 248.

- sparverioides, 242.

- strenuus, 252.

Hirundinapus giganteus, 12, 244.

Hirundinidæ, 235.

Hirundo gutturalis, 254.

- jaranica, 54, 235, 254.

Hispidæ, 296.

Hispopria, 296.

- grandis, 296.

Homalopsinæ, 274

Homalopsis buccata, 266.

— doriæ, 266.

Homoptera, 306.

Horornis, 248.

—— oreophila, 217, 248.

Hotinus, 15.

Hydrochelidon hybrida, 257 .

Hydrocichla frontalis, 222.

— velatus, 259.

Hydrophis anomalus, 266. 
Hydrophis atriceps, 266.

brookii, 266.

- loreata, 266.

- schistosus, 266 .

Hylomys, 177.

__ suillus, 169, 195.

- - dorsalis, 194.

Hylorana, 281.

Hyloterpe grisola, 231, 253.

-_ bypoxantba, 117, 230, 248.

—_ philippinensis, 231 .

_- sulfuriventer, 231.

- whiteheadi, 253.

Hypostoma, 286.

Hypotænidia striata, 247.

Hypothymis azurea, 254.

- occipitalis, 54, 212.

Hypotriorchis severus, 251.

Hypsirhina enhydris, 266.

- - plumber, 266.

Hystrix fasciculata, 199.

Ianthocincla treacheri, 103, 113, 161, 181, 207.

Icaria, sp.?

Idiophotis collaris, 264.

Indicator archipelagicus, 242.

Indicatoridæ, 242.

Iole striaticeps, 254.

- viridcscens, 254.

Ipothalia, 295.

Irena, 136.

- crinigera, 222.

- tweeddalii, 136, 254 .

Iris, 162.

Ischnogaster, sp. ?, 119.

Ismenaria, 168.

Ixalus, 281.

__ aurifasciatus, 266.

— latopalmatus, 121, 266, 279, 282.

— nubilus, 266, 279, 281, 282.

- pictus, 266 .

Iyngipicus aurantiiventris, 241.

_ auritus, 54, 241.

Japalura nigrilabris, 265.

Juniperus, 163.

Kaladium, 180.

Kallima buxtoni, 144.

- paralekta, 144.

Kelaartia, 221, 222.

Kenopia striata, 228.

Ketupa ketupa, 74, 202.
Kinabalua, 294

- megalops, 295.

Lagocheilus similis, 288.

Lalage culminata, 210.

- dominica, $25 \%$.

- terat, 210.

Lampyridœ, 299.

Laniidæ, 230.

Lavius bentet, 91, 260. Iucionensis, 230, 252.

Lanthanotus borneensis, 265 .

Laridæ, 248.

Lepidoglanis monticola, 286.

Lepocestes porphyromelas, 241 .

Leptobrachium, 281.

- gracile, 267, 284.

- montanum, 267.

Leptophis (Dendrophis) formosus, $266,275$.

Leptopoma sericatum, 287, 288.

- undatum, 287, 288.

whiteheadi, 287.

Leptopsaltria mascula, 306.

- samia, 306.

Lcptoptilus javanicus, 64, 247.

Leucocerca albicollis, 115, 165.

__ javanica, 38.

Lencocercæ, 175.

Leucopogon, 173.

Limicola platyrhyucha, 257.

Limicolæ, 52.

Limnodytes, 281.

Locustella ochotensis, 216.

Longicornia, 294.

Lophotriorchis kieneri, 201.

Loriculus galgulus, 237, 239.

Lycidæ, 298.

Lycopodium cernuum, 162.

Lygosoma, 270.

- erucata, 270 .

— nitens, 265.

- olivaceum, $265,270$.

- parietale, 265.

- punctatum, 270.

- tenuiculum, 265, 270.

— variegatum, 265, 270.

— vittatum, 265.

- whiteheadi, 265, 271.

Lyncornis temmincki, 10, 244.

Lyropæus, n. sp., 299.

Mabuia multicarinata, 265, 270.

- multifasciata, 265, 270 .

rudis, 265,270 .

rugifera, 265 .
Macronotinæ, 29\%.

Macronus ptilosus, 54, 224.

Macropygia, 53.

- emiliana, 54, 102, 245.

- leptogrammica, 263.

— ruficeps, 54, 245, 248.

— tenuirostris, 256.

Malacopterum affine, 228.

- cinereum, 228.

Mareca penelope, 247.

Mastacembelus, 286.

Medinilla, 163.

Megalæma chrysopsis, 240.

- jaranensis, 262.

- mystacophanes, 240, 241.

- pulcherrima, 161.

- versicolor, 240.

Megalophrys, 281.

- montana, 267, 284.

- nasuta, 267, 284.

Megalurus palustris, 259 .

Megapodiidæ, 246.

Megapodius cumingi, 141, 246, 257.

Melampus fasciatus, 289.

Melania testudinaria, 288.

- turris ?, 289.

- (Pachychilus) testudinaria,

var. olivacea, 288.

- (Striatella) crepidinata, 289.

- (- ) tuberculata, 289.

Melanitis ismene, 144.

Melanocichla, 226.

Meropidæ, 243.

Merops, 250.

— philippinus, 262.

— quinticolor, 262.

- sumatranus, 54, 243.

Merula javauica, 164, 217 .

- obscura, 218.

seebohmii, 164, 177, 191, 217,

248.

—— whiteheadi, 90, 258.

Metriorrhynchus, 298, 299.

- cinnabarinus, 299.

- geometricus, 298.

- infuscatus, 298.

___ sericeus, 298.

Micrencaustcs, 297.

Microhiemx latifrons, 202.

Micropternus badiosus, 241.

Micropus melanocephalus, 221, 254.

- melanoleucus, 220.

Miglyptes grammithorax, 241 .

— tukki, 241.

Mirafra javanica, 90, 261. 
Miralia (Eurostus) alteruans, 266. Mixornis borneensis, 153, 228, 229.

- montana, 54, 153, 228, 248. woodi, 54, 136, 254 .

Monticola solitaria, 218, 254.

Mordacia, 285.

Morphinæ, 55.

Motacilla flava, 93, 235, 255, 259 .

- melanope, 153, 235.

Motacillidæ, 235.

Mulleripicus pulverulentus, 252.

Munia brunneiceps, 37, 38, 54, 236.

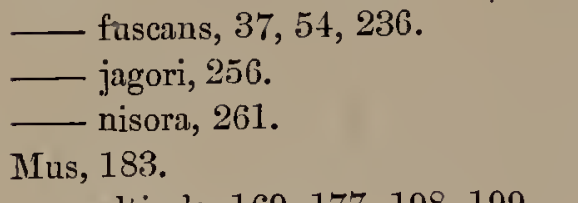

__ alticola, 169, 177, 198, 199.

- concolor, 199.

— coxingi, 198.

—_ decumanus', 198.

— edwardsi, 198.

- ephippium, 199.

— hellwaldi, 198.

_ infraluteus, 183,197 .

—_ jerdoni, 197, 198.

— lepturus, 198.

— muelleri, 198.

_ musschenbroecki, 199.

__ niveiventer, 198, 199.

-_ rattus, $169,197$.

—_ sabanus, 182, 197, 198.

Muscicapa griseisticta, 254.

Muscicapidæ, 210.

Muscicapula, 248.

- hyperythra, 54, 91, 211, 248, 260.

_- maculata, 91, 158, 211, 248, 261.

— westermanni, 211, 261.

Mycteristes, 291.

- (Theodosia) telifer, 291.

Myiophoneus borneensis, 218.

Myzanthe pygmæa, 255.

Naja ingens, 266.

tripudians, 266, 275.

Nanina regalis, 287.

- subconsul, 287.

Narathuræ, 55.

Nectarinia, 232.

- pectoralis, 38 .

Nectariniidæ, 231.

Nectes, 281.
Nectes pleurotænia, 267.

- (Pseudobufo) subasper, 267.

Nectophryne, 281.

- guentheri, 267.

- hosii, 264.

- maoulata, 267, 284.

misera, 177, 267, 283.

- (Calohyla) sundana, 267.

Neopus malayensis, 201.

Nepenthes, 16, 116, 180.

— albo-marginata, 16.

- ampullaria, 16.

— lowii, 162, 166.

_ phyllamphora, 167.

— rafflesiana, 16, 166.

- sanguinea, 16. villosa, 162, 166, 167, 170 .

Nepheronia, 143.

- Iutescens, 141, 143, 144.

Neritina diadema, 141, 289.

— dubia, 289.

- soverbii, 289.

- turtoni, 289.

Nesites attenuata, 296.

Nesokia, 197.

Ninox borneensis, 204, 252.

— japonicus, 204.

Nipa fruticans, 31 .

Nitidula, 248.

Numenius lineatus, $25 \%$.

- uropygialis, 247.

Nycticebus tardigradus, 45.

Nycticorax manillensis, 247.

Nyctiornis amicta, 243.

Nymphalidæ, 142.

Ommatomenus, 294.

Onthophagus, 291.

Oodes, 290.

— æneus, 290.

- (Simous) borneensis, 290 .

Ophites (Sphecodes) albofuscus, $266,275$.

$-(-)$ subcinctus, 266.

Opisthoporus pterocycloides, 287.

Oreocincla horsfieldi, 258.

Oreoctistes, 221, 248.

leucops, 165, 177, 221, 248.

Oriolidæ, 206.

Oriolus consanguineus, 206.

- maculatus, 91, 260 .

- palawanensis, 254 .

- sanguinolentus, 206.

— vulneratus, 118, 206, 248.

xanthonotus, 206, 254.
Ornithoptera brookiana, 119

Orthnocichla, 248.

- subulata, 22j. whitehendi, $175,225,248$.

Orthotomus cineraceus, 222.

- ruficeps, 222, 255.

Ortygometra cinerea, $24 \bar{\gamma}, 263$.

Oxycerca everetti, 256.

Oxyglossus lævis, 264.

Padda oryzivora, 38, 236, 261.

Palæornis javanica, 263.

longicauda, 33, 239.

Pandion haliaetus, 202, 251.

Pandiones, 202.

Panicum, 163.

Papilio, 143.

- acheron, 300

agetes, 300 .

- antiphates, 300 .

- arjuma, 36.

- bathycles, 300 .

- brama, 51, 90.

- delesserti, 143.

- demolion, 142.

- evemon, 142.

- forbesi, 300 .

- helenus, 142.

— idæoides, 143.

- macareus, $300,301$.

- macarist us, 143,300 .

— paris, 90.

— procles, 300 .

- sarpedon, 142.

— stratiotes, 118,300 . zanoa, 143.

Papiïionidx, 141, 142.

Pareas (Leptognathus) carinata, 266.

Parus amabilis, 135, 255.

- cinereus, 90, 260.

Passeriformes, 205.

Patersonia, 163.

- glabrata, 162 .

Pelamis bicolor, 266.

Pelargopsis gouldi, 252.

- leucocephala, 243.

Pelecanidæ, 248.

Pelturagonia, 269.

- cephalum, 183, 265, 269.

Penthoceryx pravatus, 242.

Perdicidæ, 245.

Pericrocotus, 175.

— cinereigula, 209, 210, 248.

- cinereus, 253.

- exsul, 260. 
Pericrocotus igneus, 209, 252.

- miniatus, 91, 260.

- montanus, 116, 161, 209, 210, 248.

- xanthogaster, 209, 210.

Periophthalmus kœlreuteri, 31.

Pernis ptilonorhynchus, 202, 251.

Phanæus, 291.

Phasianidx, 245.

Philentoma pyrrhopterum, 213.

Phyllergates, 248.

- cinereicollis, $115,179,223$,

248.

- cucullatus, 223.

Phyllornis kinabaluensis, $11 \%$.

- palawanensis, 254 .

Phylloseopus borealis, 255.

xanthodrvas, 216.

Picariæ, 239.

Pjcidæ, 241.

Picus analis, 262.

Pierinæ, 141, 142.

Pitta arcuata, 124, 238.

-_- baudi, 44, 238.

cyanoptera, 80, 238.

cyanura, 188.

erythrogastra, 137, 254.

- muelleri, 80, 136, 238, 239.

schwareri, 188, 238.

sordida, 136, 254

ussheri, 44, 238.

Platurus fasciatus, 266, 275.

Platylophus coronatus, 208.

Platysmurus aterrimus, 206.

Plectrone, 293.

- auripes, 292.

Ploceidæ, 236.

Plotus melanogaster, 32, 54, 248.

Polioaëtus ichthyaëtus, 45, 202.

Poliococcyx sumatranus, 242.

Poliomyias luteola, 211.

Polypedates, 281.

Polyplectron, 249.

- napoleonis, 137, 256.

Polypodium dipteris, 162, 166.

Pomatorhinus borneensis, 54, 225.

- montanus, 259.

Pomponia fusca, 307.

—_ græcina, 307.

- viridimaculata, 307 .

Potentilla, 173.

- peduncularis, 173 .

Pratincola caprata, 54, 90, 93, 260.

Prigenia viridiaurata, 291.
Prigenia rollenhoveni, 291.

Prinia polychroa, 259.

Prionispa, 296.

— pulchra, 296.

Prioniturus cyaneiceps, $147,250$.

- - discurus, 250.

Prionochilus johanuæ, 136, 255.

— thoracicus, 235.

- xanthopygius, 235, 255, 256.

Prionolomia nigrovittata, 306 .

Prionopidæ, 207.

Prothoe uniformis, 51.

Psammodynastes pictus, 266.

- pulverulentus, $266,275$.

Psarisomus, 121, 248.

— psittacinus, 121, 238, 248.

Pseudobufo, 281.

Pseudochalcothea, 293.

Psittaci, 239.

Pteromys melanotis, 13. nitidus, 195.

Pteropus, 10, 32.

Pteruthius, 248.

- æralatus, 122, 161, 231, 248.

Ptilocichla falcata, 254.

Ptilopus jambu, 245.

— leclancheri, 256.

- melanocephalus, 256.

Ptyas (Coryphodon) korros, 265.

Ptychozoon homalocephalum, 264, 267.

Pycnonotidæ, 219.

Pycnonotus analis, 54, 221.

- aurigaster, 259.

- bimaculatus, 259 .

- cinereifrons, 254 .

- simplex, 221.

Pyrocœlia, 299.

— collaris, 299.

_- fumigata, 299.

— opaca, 299.

- terminata, 299.

Pythia undata, 289.

Python breitensteini, 265.

— reticulatus, 265, 272.

Pythonopsis punctata, 266.

Radena vulgaris, 142, 143.

Ragadia annulata, 301 .

Rallidæ, 247.

Rallina fasciata, 247, 248, 257.

Rana, 281.

- decorata, 266, 275 .

- everetti, 266,277 .
Raua gracilis, 266, 275 .

- jerboa, 276 .

kuhlii, 266, 275 .

malabarica, 276.

obsoleta, 266,276 .

paradoxa, 266, 27\%.

signata, 277.

similis, 266 .

tigrina, 266.

whiteheadi, 121, 266, 276 .

(Hyla) erythræa, 266.

(Hylorana) jerboa, 266.

(-) longipes, 266.

(Ixalus) natatrix, 266.

(Limnodytes) luctuosa, 266.

(Polypedates) raniceps, 266.

- (-) signata, 266.

Regulus, 214.

Rhabdion torquatum, 265.

Rhacophorus, 281, 285.

- acutirostris, 266, 278, 281.

- appendiculatus, $266,278,281$.

- cruciger, 266, 278, 281.

-. dulitensis, 264.

- leucomystax, 281.

- quadrilineatus, 266, 278. maculatus, 266, 277, 281. pardalis, 266.

— reinwardtii, 266, 285.

Rheithrosciurus macrotis, 197.

Rhinocichla treacheri, $226,227$.

Rhinomyias gularis, $54,161,213$, 248.

- pectoralis, 54, 213, 214.

- ruficauda, 213.

ruficrissa, 213, 248.

Rbinoplax vigil, 43, 243.

Rhinortha chlorophæa, 242.

Rhiostoma boxalli, 288 .

- iris, 288.

Rhipidura albicollis, 212, 248.

- javanica, 54, 212, 242.

- nigritorquis, 253.

- perlata, 212.

Rhizophora, 31.

Rhopodytes erythrognathus, 242.

Rollulus rouloul, 23, 246.

Rubigula montis, 124, 221.

Rubus rosæfolius, 157.

Sasia abnormis, 241.

Satyrinæ, 142.

Scirpus, 173.

Sciurus badjing, 196 :

_ bicolor ephippium, 195. 
Sciurus concinnus, 196. exilis, 33, 196, 197. jentinki, 115, 195, 196. - melanotis, 196.

notatus, 196. plantani, 196. pluto, 195.

prevostii, 195. tenuis, 195, 196. whiteheadi, 117, 196, 197.

Scolopax gallinago, 247.

— major, 150.

- megala, 64, 247, 248.

Scops, 203.

— balli, 204.

everetti, 252.

lempiji, 204.

luciæ, 204.

— rufescens, 204.

Semnopithecus hosei, 183, 194.

Simotes labuanensis, 265.

— octolineatus, 265, 272.

subcarinatus, 265.

— vertebralis, 265, 272.

Simous, 290.

Siphị banyumas, $2 \mathbf{I} 6$.

- elegans, 216.

- erithacus, 54, 136, 253 .

lemprieri, 253.

Sithon amrita, 304.

— cineas, 305 .

— cinesia, 305.

-_ kjana, 184, 304.

- maneia, 305 .

- meduana, 305 .

_ teunga, 304 .

- tharis, 305 .

Spilornis, 201.

- bacha, 181, 201, 207, 248, 251.

- pallidus, 201

Spizaëtus limnaëtıs, 54, 201, 251.

- philippinensis, 251.

Squatarola lielvetica, 247.

Stachyris borneensis, 54, 227,

248.

-_- maculata, 224, 227 . nigriceps, 227. poliocepbala, 124,227 .

Staphidia, 223, 248.

- castaneiceps, 223.

- everetti, 54, 115, 203, 223, 248

Sterna bergii, 248,257 .
Sterna melanauchen, 257 .

- sinensis, 257 .

Stoparola cerviniventris, 120,215 , $216,248$.

—- indigo, 216, 261.

— ruficrissa, 216.

—_thalassinoides, 216.

Strepsilas interpres, $247,257$.

Striges, 202, 203.

Sturnia violacea, 235, 256.

Sturnidæ, 235.

Sturnopastor jalla, 262.

Surniculus lugubris, 242, 252.

Sus barbatus, 46 .

Symphædra dirtea, 51 .

Syrnium leptogrammicum, 204.

- sinense, $251,252$.

- whiteheadi, 141, 251.

Tachydromus sexlineatus, 265 .

Tæniodera ditissima, 294.

__ egregia, 294.

Tanæcia acontias, 303 .

- amisa, 303.

— cærulescens, 303.

— cibaritis, 303 .

— supercilia, 304.

Tanygnathus leuconensis, 250 .

- luzoniensis, 66 .

Tarsiger, 248.

- hodgsoni, 122, 212, 248.

Telephorus viridanus, 299.

Tenaris horsfieldii, 304.

- occulta, 304.

Tephrodornis, 208.

- gularis, 54, 207.

Terekia cinerea, 257.

Terpsiphone affinis, 23, 213.

Tetralanguria splendens, 296.

Thaumantis noureddin, 144.

Theodosia, 291.

Therates princeps, 289.

- punctipennis, 290.

- schaumi, 290.

- spectabilis, 289.

whiteheadi, 289.

Thriponax hargitti, 252.

- juvensis, 241.

Tiga everetti, 252.

— javanensis, 241.

Timelia pileata, 259 .

Tiuneliidæ, 22\%.

Totanus brevipes, 247, 257.

- calidris, 257.
Totanus glareola, 247, 257, 263.

Trachycomus ochrocephalus, 221. Trachymene saniculafolia, 163.

Tragops prasinus, 266. fasciolatus, 266.

Tragulus javanicus, 45 .

Treron baramensis, 245 .

- capellei, 244.

— nasica, 256, 263.

- vernans, 38, 54, 244, 256.

Trichixus pyrrhopygus, 218.

Tricholestes criniger, 221.

Trichostoma rostratum, 228.

Trichys guentheri, 199.

— lipura, 184, 199.

Tricondyla beccarii, 290 .

Trigonopteryx obliqua, 74 .

Trimeresurus (Hamadryas) ophiophagus, 266.

Tringa ruficollis, 247,257 .

- subminuta, $247,248$.

Tringoides hypoleucus, $247,257$.

Triplatoma attenuata, 296. geströi, 296.

Trochomorpha conicoides, 287.

— metcalfei, 287, 288.

_- planorbis, 287.

Trogonidæ, 54, 239.

Tropidolæmus wagleri, 266.

Tropidonotus conspicillatus, 265.

- flavifrons, 265, 274.

- maculatus, 273.

- quincunciatus, 265.

- melanozostus, 265 .

sarawacensis, 265,274 .

sundanensis, 265.

trinnguligerus, 265. annularis, 265.

Tropidophorus brookii, 265.

(Amphixestes) beccarii, 265, 271.

Truncatipennes, 291.

Tupaia ferruginea, 194.

- montana, 167, 193, 194.

Turdidæ, 216.

Turdiformes, 208.

Turdinulus, 248.

- exsul, 188, 230, 248.

roberti, 230 .

Turdinus atrigularis, 227.

— canicapillus, 22 $7,248$.

— míagnirostris, $228,248$.

- rufifrons, 254 .

—_ sepiarius, 54, 228, 259. 
Turdus obscurus, 153.

Turnix, 249.

- nigrescens, 54, 257. pugnax, 263.

Turtur dussumieri, 256.

— tigrina, 38, 256.

Typhlops braminus, 265.

- lineatus, 265.

Utricularia, 163.

Tanessa cardui, 89. perakana, 168 .

Varanus sp. ?, 14.

_ dumerilii, 265.

— heteropholis, 264.
Varanus rudicollis, 265.

- salvator, 265.

Vesta aurantiaca, 299.

- urens, 299.

Xantholæma australis, 262.

- duvauceli, 241.

- rosea, 262.

Xantholestes panayensis, 254.

Xanthopygia cyanomelæna, 211.

- narcissina, 211, 248.

Xenelaphis (Coryphodon) hexagonotus, 265.

Xenoloba, 292.

- speciosa, 292.

Xenopeltis unicolor, 265.
Xylobanus reticulatus, 298, 299.

Xylolepes validus, 241.

Xyris schœnoides, 163.

Zanclostomus javanicus, 16, 242.

Zaocys (Coryphodon) carinatus, 265.

(-) fuscus, 265.

Zeocephalus cyanescens, 254 .

Zonopterus magnificus, 295.

Zosterops, 91, 179.

— auriventer, 234, 248. clara, 54, 179, 234, 248. neglecta, 91, 261. - palpebrosa, 261. 



$$
\text { , }
$$


